UNIVERSIDADE FEDERAL DE JUIZ DE FORA

INSTITUTO DE CIÊNCIAS HUMANAS- ICH

PROGRAMA DE PÓS GRADUAÇÃO EM GEOGRAFIA- PPGEO

O CLIMA URBANO COMO RISCO CLIMÁTICO: OS IMPACTOS DAS CHUVAS EM JUIZ DE FORA- no período de 1980-2018

Thiago Alves de Oliveira

Juiz de Fora

Março de 2021 
Thiago Alves de Oliveira

\title{
O CLIMA URBANO COMO RISCO CLIMÁTICO: OS IMPACTOS DAS CHUVAS EM JUIZ DE FORA- no período de 1980-2018
}

\begin{abstract}
Dissertação de mestrado apresentada ao Programa de Pós-Graduação em Geografia, área de concentração em Dinâmicas espaciais e linha de pesquisa: Planejamento e gestão espacial e ambiental, como requisito parcial para a obtenção do título de Mestre em Geografia.
\end{abstract}

Orientadora: Profa. Dra. Cássia de Castro Martins Ferreira 
Ficha catalográfica elaborada através do programa de geraçáo automática da Biblioteca Universitária da UFJF. com os dados fornecidos pelo(a) autor(a)

Oliveira, Thiago Alves de.

O CLIMA URBANO COMO RISCO CLIMÁTICO : OS IMPACTOS

DAS CHUVAS EM JUIZ DE FORA- no periodo de 1980-2018 /

Thiago Alves de Oliveira. - 2021.

$312 \mathrm{f}$.

Orientador: Cassia de Castro Martins Ferreira

Dissertaçăo (mestrado academico) - Universidade Federal de Juiz de Fora, Instituto de Ciencias Humanas. Programa de Pos-Graduação em Geografia, 2021.

1. Risco Climatico. 2. Eventos Extremos. 3. Impactos Pluviometricos. 4. Clima Urbano. 1. Ferreira, Cassia de Castro Martins, orient. II. Titulo. 


\section{THIAGO ALVES DE OLIVEIRA}

\section{O CLIMA URBANO COMO RISCO CLIMÁTICO: OS IMPACTOS DAS CHUVAS EM JUIZ DE FORA- no período de 1980-2018}

Dissertação apresentada ao Programa de PósGraduação em Geografia da Universidade Federal de Juiz de Fora como requisito parcial à obtenção do grau de Mestre em Geografia.

Dissertação defendida e aprovada em 03 de março de 2021.
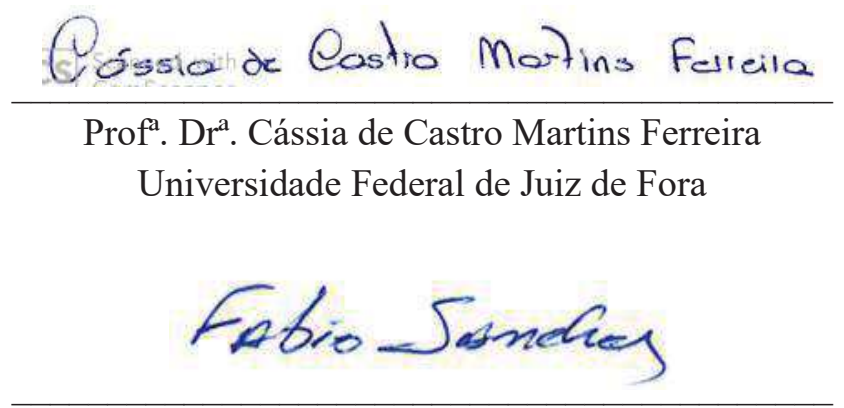

Prof. Dr. Fabio de Oliveira Sanches

Universidade Federal de Juiz de Fora

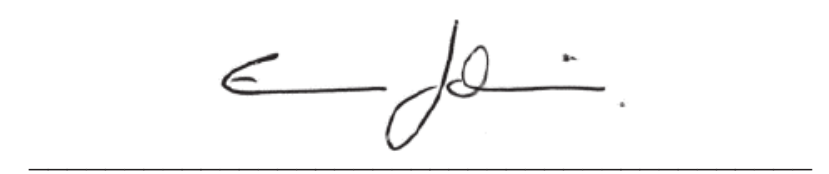

Prof. Dr. Emerson Galvani

Universidade de São Paulo 
Dedicatória

Dedico aos meus pais, pelo incentivo de sempre

E à toda população de Juiz de Fora- $M G$ 


\section{Agradecimentos}

Primeiramente, agradeço a meus pais Marluce e Waltencir pelo apoio incondicional e por sempre acreditarem e incentivarem os meus estudos.

A minha madrinha Lúcia, também por me incentivar e além de ter sido minha professora na educação básica, sempre me aconselhou sobre a licenciatura e à docência.

Agradeço a Cássia de Castro Martins Ferreira, minha orientadora desde o segundo período da faculdade, em 2014, quando ingressei como bolsista no Laboratório de Climatologia e Análise Ambiental- LabCAA, pelas dicas, conselhos, ajudas, correções, questões que sempre me faziam pensar sobre os caminhos deste trabalho e por ser muito mais que orientadora, uma pessoa profissional, ética e responsável.

Agradeço aos meus irmãos Gustavo (Gu), Wanessa (Nê), Nathália.

Agradeço ao Yan, funcionário do Laboratório, colega de trabalho no Lab desde 2014, sempre disposto a ajudar, e ajudou bastante, sobretudo com o Arc Gis. Além dos inúmeros cafés no Laboratório

Ao professor Fabio (Fabião) pelos muitos cafés, bons papos, excelentes dicas, caronas, pela parceria de sempre, saibam que aprendi muito desde que chegou a Juiz de Fora, você acompanhou este trabalho desde o projeto e suas dicas foram de enorme valia para o desenvolvimento do trabalho. Agradeço também por acompanhar e avaliar este trabalho no Seminário de Dissertação, no Exame de Qualificação e também na defesa final.

Agradeço a todas as professoras e professores da educação básica, que me formaram e sempre incentivaram a buscar o ensino superior.

Um agradecimento especial à Camila Tavares e Michaela Campos pelas muitas conversas, viagens, rolês, boas risadas, muitos memes, e pela parceria de sempre. Muito Obrigado !!! 
Aos meus tios pelo apoio e as palavras de incentivo sempre, tio José Carlos (Quinha), tio Marco (que tão cedo nos deixou, e não pôde ver este trabalho concluído), João, Lindaura, Marli, Célia, Celi, Roberto, Maria Elena, Juliana.

Agradeço ao professor Emerso Galvani, por aceitar avaliar o meu trabalho no Exame de Qualificação e na Defesa Final, suas considerações foram sempre muito pertinentes e auxiliaram bastante a construção dessa dissertação.

Agradeço ao professor Vicente Paulo dos Santos Pinto pela avaliação do trabalho no Seminário de Dissertação, com suas considerações sempre muito instigantes e importantes.

Agradeço aos funcionários da Divisão de Arquivo Histórico da Prefeitura de Juiz de Fora, Poliana Anacleto, Igor Sampaio, Jéssica Alves e Angélica Bitencourt pelo atendimento sempre solícito que muito auxiliaram o levantamento de dados.

Um agradecimento especial à Heliane Casarim funcionária do setor de memória da Biblioteca Municipal Murilo Mendes por me atender em tempo integral no longo período de levantamento de dados, com boas dicas e sempre auxiliando. 0 seu trabalho é fundamental para o desenvolvimento de Juiz de Fora e para a preservação de sua história. Muito Obrigado!!! Assim como agradeço ao bolsista Geovani e ao sr. Nilo que estiveram por lá ao longo do período sempre auxiliando.

Aos colegas de mestrado pelas ajudas de sempre, muito obrigado!

Aos colegas de LabCAA pelo ambiente sempre de muito trabalho e parcerias, Camila Teixeira, Thamires Gatti, Edinaldo Lumonte, Bruno Brito, Pâmela Martins. Agradeço ao Victor de Paula (Vitão) pelo auxílio no levantamento de dados em campo, o que otimizou bastante o trabalho.

Ao amigo de longa data Lucas Padovani, parceiro desde a educação básica e também da Geografia. Abraço !!

Aos amigos que a Geografia/2014 me proporcionou Guilherme Gaio, Flávio Halfeld e Caio César. 
Aos professores do Departamento de Geociências pelas disciplinas ministradas ao longo da graduação, em especial Roberto Marques, Pedro Machado e Vicente Pinto pela excelência das discussões observadas nas suas disciplinas.

Agradeço também à CAPES pela bolsa de mestrado, bem como à Universidade Federal de Juiz de Fora ambiente que frequentei desde 2014, pelas bolsas de iniciação científica, tendo inúmeras possiblidades de crescimento para além do conhecimento geográfico, mas também pessoal. E que a Universidade pública, siga gratuita e de qualidade. 


\section{Epígrafe}

Um dia me disseram Que as nuvens não eram de algodão Um dia me disseram Que os ventos às vezes erram a direção ("Somos Quem Podemos Ser"- Engenheiros do Hawaii)

Oh! Chuva Eu peço que caia devagar Só molhe esse povo de alegria Para nunca mais chorar ("Oh Chuva"; Falamansa) 


\section{Resumo:}

As discussões acerca do clima urbano no Brasil avançaram, a partir dos anos de 1970, quando o país registrava um intenso processo de urbanização, levando a indagações dentre os estudiosos acerca desse novo quadro ambiental que se observava nas cidades. Dentro das investigações do clima urbano, a abordagem de Carlos Augusto de Figueiredo Monteiro com o Sistema Clima Urbano- SCU (1976) se consolidou como referencial teórico-metodológico dos estudos, no entanto, atualmente outras abordagens são possíveis e complementares a esta, dentre elas a discussão do clima urbano a partir da proposta da Geografia do Clima proposta por Sant'Anna Neto (2001, 2007), no qual o Clima urbano passa a ser analisado a partir do Risco Climático, de acordo com Nascimento Júnior (2018) e Goudard (2019). Dessa forma apreender o clima urbano a partir do risco é entender o impacto das chuvas a partir de uma visada que leve em conta a precipitação como elemento fundamental, mas também a forma como o espaço urbano é ocupado e produzido, em relação a suas susceptibilidades ambientais, à vulnerabilidade social visando perceber os impactos, a partir de uma perspectiva também social. Do ponto de vista metodológico este trabalho valerá do levantamento e aplicação de técnicas estatísticas nos dados diários de precipitação; levantamento de informações acerca da suscetibilidade ambiental a ocorrência de movimentos de massa e inundações; aplicação de um índice de vulnerabilidade social e de um levantamento documental acerca dos impactos das chuvas na cidade, valendose de informações obtidas através dos jornais de mídia impressa da cidade. Por fim, foi utilizada uma integração nos dados, utilizando a técnica de AHP (Analytic. Hierarchy Process), o mapeamento do risco climático a partir das informações de vulnerabilidade, suscetibilidade e histórico de ocorrências associados à precipitação (perigo). Os resultados demonstraram tendência significativa de aumento das chuvas no mês de Novembro nos eventos superiores ao percentil 90. Nos outros meses as tendências não foram significativas. O mapeamento dos impactos revelou que as Regiões de Planejamento mais impactadas são as RP Centro e Leste, sendo que no Centro predominam os impactos hidrológicos (enchentes, inundações, alagamentos, enxurradas). A partir da técnica AHP foi mapeado o risco climático a impactos geomorfológicos (deslizamentos e desabamentos), sendo que as regiões com maior percentagem de área com as classes de altíssimo e alto risco foram a Leste e Sudeste, além disso, as áreas de alto e altíssimo risco foram as mais impactadas pela ocorrência dos deslizamentos e desabamentos na cidade. Com base na discussão do risco climático concluiuse que a ocorrência dos impactos, sejam eles hidrológicos (enchentes, inundações, alagamentos, enxurradas) ou geomorfológicos (deslizamentos e desabamentos), ocorre de maneira desigual na cidade, na medida em que se relacionam com os elementos vulnerabilidade e suscetibilidade, sendo que os episódios extremos de precipitação repercutem de maneira diferenciada nos bairros da cidade.

Palavras- chave: Risco Climático; Eventos Extremos; Impactos Pluviométricos; Clima Urbano 


\begin{abstract}
Discussions about the urban climate in Brazil have advanced since the 1970s, when the country registered an intense process of urbanization, leading to inquiries among scholars about this new environmental picture that was observed in cities. Within the investigations of the urban climate, Carlos Augusto de Figueiredo Monteiro's approach with the Urban Climate SystemSCU (1976) has consolidated itself as a theoretical-methodological reference of the studies, however, currently other approaches are possible and complementary to this, among them the discussion of urban climate based on the proposal of Geography of Climate proposed by Sant'Anna Neto $(2001,2007)$, in which urban climate starts to be analyzed based on Climate Risk, according to Nascimento Júnior (2018) and Goudard (2019). Thus, to apprehend the urban climate from the risk is to understand the impact of the rains from a view that takes into account precipitation as a fundamental element, but also the way in which the urban space is occupied and produced, in relation to its environmental susceptibilities, to social vulnerability with a view to perceiving impacts, from a social perspective as well. From a methodological point of view, this work will rely on the survey and application of statistical techniques in the daily precipitation data; gathering information about environmental susceptibility to the occurrence of mass movements and floods; application of a social vulnerability index and a documentary survey about the impacts of rainfall in the city, using information obtained from the city's printed media newspapers, finally an integration was used in the data, using the AHP technique ( Analytic Hierarchy Process), the mapping of climatic risk based on information on vulnerability, susceptibility and history of occurrences associated with precipitation (hazards). The results showed a significant trend of increasing rainfall in November in events above the 90th percentile. In other months, the trends were not significant. The mapping of the impacts revealed that the Planning Regions most impacted are the Central and Eastern RP, with the hydrological impacts predominating in the Center (floods,). Using the AHP technique, the climatic risk was mapped to geomorphological impacts (landslides and landslides), and the regions with the highest percentage of areas with the very high and high risk classes were in the East and Southeast, in addition, the areas of high and extremely high risk were the most impacted by the occurrence of landslides and landslides in the city. Based on the discussion of climate risk, it was concluded that the occurrence of impacts, whether hydrological (floods) or geomorphological (landslides), occurs unevenly in the city, as they relate to the elements of vulnerability and susceptibility, with the extreme episodes of precipitation having a different impact on neighborhoods in the city.
\end{abstract}

Key Words: Climatic Risk; Extreme Events; Rainfall Impacts; Urban Climate 


\section{Lista de Figuras}

Figura $01 \quad$ Diagrama básico do Sistema Clima Urbano- SCU 36

Figura 02 Canal III- Impacto Meteórico (Subsistema Hidrodinâmico). 42

Figura 03 Noção de hierarquia proposta por Koestler, utilizada por Monteiro 45 (1976).

Figura 04 Estrutura do clima urbano como risco climático. 55

Figura 05 Tipos de chuva em função de sua gênese ou mecanismo de ascensão 59 do ar.

Figura 06 Hidrograma hipotético comparando os picos de vazão em áreas rurais e urbanizadas.

Figura 07 Perfil esquemático mostrando os processos de inundação e enchente.

Figura 08 Evolução da população e da mancha urbana de Juiz de Fora-MG

Figura 09 Evolução da mancha urbana em Juiz de Fora de 1963 a 2010.

Figura $10 \quad$ Juiz de Fora no contexto regional. $\quad 84$

$\begin{array}{lll}\text { Figura } 11 & \text { Juiz de Fora e seus distritos. } & 85\end{array}$

Figura 12 Regiões urbanas do município de Juiz de Fora 88

$\begin{array}{ll}\text { Figura 13 Quadro físico regional de Juiz de Fora. } & 90\end{array}$

Figura 14 Mapa hipsométrico do município de Juiz de Fora- MG 91

Figura 15 Rede de drenagem no Município de Juiz de Fora- MG 92

Figura 16 Carta de declividade do município de Juiz de Fora- MG 94

Figura 17 Rede hidrográfica no perímetro urbano do município de Juiz de 95 Fora.

Figura 18 Climograma de Juiz de Fora- MG 96

Figura 19 Box plot trimestral para os dados de Juiz de Fora (MG) 98

Figura 20 Participação mensal dos sistemas atmosféricos na bacia do Rio 100 Preto.

Figura 21 Tendência mensal dos dados de precipitação em Juiz de Fora 101

$\begin{array}{lll}\text { Figura } 22 & \text { Organização da metodologia de trabalho. } & 103\end{array}$

Figura 23 Pontos de coleta de dados de precipitação na área urbana de Juiz 105 de Fora.

Figura 24 Representação dos elementos do gráfico Box Plot 107

$\begin{array}{lll}\text { Figura } 25 & \text { Pontos utilizados para correlação entre os dados observados e } & 113\end{array}$

$\begin{array}{lll}\text { Figura } 26 & \text { Organização metodológica da primeira etapa. } & 114\end{array}$

$\begin{array}{lll}\text { Figura } 27 & \text { Organização metodológica da segunda etapa. } & 115\end{array}$

Figura 28 Fluxograma das etapas e processamento das informações para o 117 mapeamento

$\begin{array}{lll}\text { Figura } 29 & \text { Sequência de procedimentos no modelo HAND } & 118\end{array}$

$\begin{array}{lll}\text { Figura } 30 & \text { Classes de suscetibilidade utilizadas no modelo HAND } & 119\end{array}$

$\begin{array}{lll}\text { Figura } 31 \text { Correlação entre os parâmetros quantitativos e qualitativos para a } & 120\end{array}$ suscetibilidade a inundação 
Figura 32 Organização metodológica da terceira etapa.

Figura 33 Setores censitários no perímetro urbano de Juiz de Fora. 123

$\begin{array}{lll}\text { Figura } 34 & \text { Primeira planilha: para levantamento de dados em campo. } & 131\end{array}$

$\begin{array}{lll}\text { Figura } 35 \text { Segunda planilha: para organização dos dados levantados, } & 131\end{array}$ exemplo de janeiro de 1980.

Figura 36 Terceira planilha: para organização dos dados organizados por tipo 132 de impacto, exemplo de 1981

$\begin{array}{lll}\text { Figura } 37 & \text { Organização metodológica da quarta etapa. } & 133\end{array}$

Figura 38 Comparação entre os dados CEMADEN e INMET no posto Cidade 140 Universitária.

$\begin{array}{lll}\text { Figura } 39 \text { Correlação entre os dados observados nos pluviômetros do } & 141\end{array}$ CEMADEN x INMET

Figura 40 Comparação dos dados mensais de precipitação em 2016.

Figura 41 Correlação linear entre os dados diários e agrupados em pêntadas: 143 CEMADEN x CHIRPS

Figura 42 Frequência de ocorrência de meses secos, chuvosos e habituais nos 145 meses da estação chuvosa

Figura 43 Frequência do número de dias de chuva no período de 1980-2018 149

Figura 44 Frequência média do número de dias de chuva mensal no período 149 de 1980-2018

Figura 45 Frequência anual de dias de chuva a partir dos percentis 15, 35, 65, 151 $85,95,99$.

Figura 46 Precipitação máxima em 24horas, por mês, no período de 19802018.

Figura 47 Precipitação total diária e as faixas dos percentis 90, 95 e 99

$\begin{array}{lll}\text { Figura } 48 & \text { Total de eventos superiores ao Percentil 90, por mês. } & 155\end{array}$

Figura 49 Total de eventos superiores ao Percentil 95, por mês. 155

Figura $50 \quad$ Total de eventos superiores ao Percentil 99, por mês. 156

Figura 51 Gráficos de tendência mensal para os dados a partir do Percentil 90, 157 na estação chuvosa

Figura 52 Gráficos de tendência mensal para os dados a partir do Percentil 95, 158 na estação chuvosa

Figura 53 Gráficos de tendência mensal para os dados a partir do Percentil 99, 160 na estação chuvosa

$\begin{array}{lll}\text { Figura } 54 \text { Frequência anual de pêntadas pluviométricas superiores ao P90 } & 162\end{array}$

Figura 55 Precipitação agrupada em pêntadas e as faixas dos percentis 90, $95 \quad 163$ e 99

Figura 56 Frequência anual das pêntadas pluviométricas nas classes do 164 percentil 90, 95 e 99 
Figura 57 Índices de extremos climáticos aplicados aos dados de precipitação 168 de Juiz de Fora.

Figura 58 Carta de suscetibilidade a inundação no perímetro urbano de Juiz 172 de Fora

$\begin{array}{lll}\text { Figura } 59 \text { Carta de suscetibilidade a movimentos de massa no perímetro } & 175\end{array}$ urbano de Juiz de Fora.

Figura 60 Taxa de crescimento populacional (\%) no período de 1991-2010. 178

$\begin{array}{lll}\text { Figura } 61 & \text { Vetores de crescimento disposto no Plano Diretor } & 178\end{array}$

Figura 62 População total em Juiz de Fora- 1991-2010 e taxa de crescimento 180 nesse período

Figura 63 Percentual de setores por classe de vulnerabilidade social nas 183 regiões de planejamento

Figura 64 Índice de vulnerabilidade social no perímetro urbano de Juiz de 183 Fora.

Figura 65 Bairro Santa Luzia em dois momentos, durante o loteamento na 185 década de 1950 (a) e na atualidade (b)

$\begin{array}{lll}\text { Figura } 66 & \text { População total na RP Sul- 1991-2010. } & 186\end{array}$

Figura 67 Carta de suscetibilidade a movimentos de massa e inundações, 188 com base na CPRM (2014) na RP Sul

Figura 68 Comparativo da ocupação no bairro Santa Luzia, às margens do 189 córrego Ipiranga, em 1980-2020

Figura 69 População total na RP Centro- 1991-2010. 190

Figura 70 Área de alta suscetibilidade a movimentos de massa na RP Centro, 192 localizada no setor limítrofe à RP Oeste

Figura 71 Carta de suscetibilidade a movimentos de massa e inundações, 192 com base na CPRM (2014), na RP Centro.

Figura 72 Avenida Independência (atual Itamar Franco) em dois momentos.

Figura 73 População total na RP Leste- 1991-2010. 195

Figura 74 Carta de suscetibilidade a movimentos de massa e inundações, com 196 base na CPRM (2014), na RP Leste

$\begin{array}{lll}\text { Figura } 75 & \text { População total na RP Oeste- 1991-2010. } 198\end{array}$

Figura 76 Carta de suscetibilidade a movimentos de massa e inundações, 199 com base na CPRM (2014), na RP Oeste.

Figura 77 População total na RP Sudeste- 1991-2010. 201

Figura 78 Vista da RU Vila Olavo Costa- Juiz de Fora. 201

Figura 79 Carta de suscetibilidade a movimentos de massa e inundações, 203 com base na CPRM (2014), na RP Sudeste

Figura 80 População total na RP Centro Oeste- 1991-2010. 204

Figura 81 Conjunto habitacional localizado na RU Monte Castelo- RP Centro- 205 Oeste

Figura 82 Carta de suscetibilidade a movimentos de massa e inundações, 206 com base na CPRM (2014), na RP Centro-Oeste. 
$\begin{array}{lll}\text { Figura } 84 & \text { População total na RP Nordeste- 1991-2010. } & 207\end{array}$

Figura 85 Carta de suscetibilidade a movimentos de massa e inundações, com 210 base na CPRM (2014), na RP Nordeste.

Figura 86 Córregos da Tapera e Ribeirão das Rosas na RP Nordeste. 211

$\begin{array}{lll}\text { Figura } 87 & \text { População total na RP Norte- 1991-2010 } 212\end{array}$

Figura 88 Carta de suscetibilidade a movimentos de massa e inundações, $\quad 214$ com base na CPRM (2014), na RP Norte.

Figura 89 Frequência anual de episódios extremos em Juiz de Fora- MG. 216

Figura 90 Média mensal de episódios extremos em Juiz de Fora. 216

Figura 91 Variabilidade mensal da ocorrência de episódios extremos em Juiz 217 de Fora

Figura 92 Frequência anual de impactos registrados em Juiz de Fora 218

Figura 93 Somatório de impactos por período- 1980-89;1990-99;2000-18. 218

Figura 94 Box plot mensal dos impactos registrados em Juiz de Fora. 219

Figura 95 Distribuição dos impactos por região de planejamento e por $\quad 220$ período analisado.

Figura 96 Variação no número de impactos entre o período 2000-18 e 1980- 221 89.

Figura 97 Dez regiões urbanas mais citadas por impactos associados a chuva 221 em Juiz de Fora

Figura 98 Distribuição por região urbana dos impactos associados a chuvas 224 em Juiz de Fora

Figura 99 Frequência anual dos impactos geomorfológicos em Juiz de Fora.

Figura 100 Somatório por décadas dos impactos geomorfológicos em Juiz de 225 Fora.

Figura 101 Distribuição dos impactos geomorfológicos por região de 226 planejamento e por período analisado.

Figura 102 Variação no número de impactos geomorfológicos entre o período 226 2000-18 e 1980-89.

Figura 103 Dez regiões urbanas mais citadas por impactos geomorfológicos em 227 Juiz de Fora

Figura 104 Distribuição por região urbana dos impactos geomorfológicos em 228 Juiz de Fora

Figura 105 Distribuição por região urbana dos impactos geomorfológicos em 229 Juiz de Fora, a partir dos pontos

Figura 106 Indicador de densidade de Kernel aplicado aos impactos 230 geomorfológicos

Figura 107 Frequência anual dos impactos hidrológicos em Juiz de Fora 231

Figura 108 Somatório por décadas dos impactos hidrológicos em Juiz de Fora 232 
Figura 109 Distribuição dos impactos hidrológicos por região de

planejamentos e por período analisado

Figura 110 Variação no número de impactos hidrológicos entre o período 2000- 233 18 e $1980-89$.

Figura 111 Ocorrência de impacto hidrológico na RP Centro 233

Figura 112 Dez regiões urbanas mais citadas por impactos hidrológicos em Juiz 234 de Fora

Figura 113 Distribuição por região urbana dos impactos hidrológicos em Juiz 235 de Fora

Figura 114 Distribuição por região urbana dos impactos hidrológicos em Juiz 236 de Fora, a partir dos pontos.

Figura 115 Indicador de densidade de Kernel aplicado aos impactos 238 hidrológicos

Figura 116 Risco climático a impactos geomorfológicos no perímetro urbano 241 de Juiz de Fora.

Figura 117 Percentagem de área por região de planejamento. 242

Figura 118 Ocorrência de deslizamento na Vila Esperança, RU Benfica (3) 243

Figura 119 Desabamento registrado na RU Jardim Natal em 25/12/2013 243

$\begin{array}{lll}\text { Figura } 120 & \text { Ocorrência de deslizamentos na RU Esplanada. } & 244\end{array}$

Figura 121 Ocorrência de deslizamento na RU Borboleta 244

Figura 122 Risco climático a ocorrência de impactos geomorfológicos no setor 245 "a" do perímetro urbano.

Figura 123 Desabamento ocorrido na RU Santa Cecília vitimando uma 246 criança

Figura 124 Risco climático a ocorrência de impactos geomorfológicos no $\quad 247$ setor "b" do perímetro urbano

Figura 125 Deslizamento ameaça famílias na Vila Olavo Costa 248

Figura 126 Ocorrência de desabamento no Graminha, com três vítimas fatais 248

Figura 127 Ocorrência de deslizamento no bairro Três Moinhos- RU Linhares 249

Figura 128 Ocorrência de deslizamento na RU Bom Pastor. 250

Figura 129 Condições de suscetibilidade a inundação e vulnerabilidade social 252 na RP Centro- Oeste.

Figura 130 Inundação no bairro Industrial em 11/03/2018 252

Figura 131 Condições de suscetibilidade a inundação e vulnerabilidade social 253 na RP Centro- Oeste/ Norte.

$\begin{array}{lll}\text { Figura } 132 & \text { Bairro Parque das Torres } & 254\end{array}$

Figura 133 Condições de suscetibilidade a inundação e vulnerabilidade social 254 na RP Oeste.

Figura 134 Trecho canalizado do córrego São Pedro em um setor de alta 255 vulnerabilidade social na RU Martelos

Figura 135 Condições de suscetibilidade a inundação e vulnerabilidade social na RP Sul. 
Figura 136 Diferenças nos tipos de uso e na vulnerabilidade social em relação 256 à suscetibilidade a inundação na RU Santa Luzia

Figura 137 Condições de suscetibilidade a inundação e vulnerabilidade social 257 na RP Leste

Figura 138 Impactos hidrológicos na RU Vitorino Braga em Dezembro de 2018

$\begin{array}{lll}\text { Figura } 139 & \text { Vista do bairro Vitorino Braga em } 1971 & 258\end{array}$

$\begin{array}{lll}\text { Figura } 140 & \text { Inundação no bairro Linhares } & 258\end{array}$

Figura 141 Condições de suscetibilidade a inundação e vulnerabilidade social 259

Figura 142 Impactos hidrológicos nas regiões urbanas Fábrica e Santa 259

$\begin{array}{lll}\text { Figura } 143 \text { Carta sinótica de 15/01/1985. } & 260\end{array}$

Figura 144 Comparativo da atuação dos sistemas atmosféricos nos meses 261 analisados

Figura 145 Precipitação na América do Sul nas pêntadas 1 e 2 de Janeiro de 262 1985, estimados pelo CHIRPS.

Figura 146 Precipitação na América do Sul nas pêntadas 3 e 4 de Janeiro de 263 1985 estimados pelo CHIRPS.

Figura 147 Cartas sinóticas nos dias 18 e 24 de Janeiro de 1985.

Figura 148 Precipitação na América do Sul nas pêntadas 5 e 6 de Janeiro de 264 1985 estimados pelo CHIRPS.

Figura 149 Dados de precipitação total diária de Janeiro de 1985 e número de 266 impactos

Figura 150 Total de impactos por região urbana em Janeiro de $1985 \quad 268$

Figura 151 Impactos geomorfológicos registrados em Janeiro de 1985.

Figura 152 Ocorrências registradas em Janeiro de 1985.

Figura 153 Impactos na região urbana Centro 270

Figura 154 Impactos hidrológicos registrados em Janeiro de 1985.

Figura 155 Inundação do Paraibuna na Favela do Rato 272

Figura 156 Precipitação na América do Sul nas pêntadas 1 e 2 de Janeiro de 273 1990, estimados pelo CHIRPS.

Figura 157 Cartas sinóticas de 07 e 10 de Janeiro de 1990.

Figura 158 Precipitação na América do Sul nas pêntadas 3 e 4 de Janeiro de 274 1990 estimadas pelo CHIRPS

Figura 159 Cartas sinóticas de 20 e 24 de Janeiro de 1990.

Figura 160 Precipitação na América do Sul nas pêntadas 5 e 6 de Janeiro de 275 1990 estimadas pelo CHIRPS

$\begin{array}{lll}\text { Figura } 161 & \text { Impactos registrados no dia 05/01/1990 } & 276\end{array}$

Figura 162 Dados de precipitação total diária de Janeiro de 1990 e número de 277

$\begin{array}{lll}\text { Figura } 163 & \text { Impactos geomorfológicos em Janeiro de } 1990 & 278\end{array}$

Figura 164 Precipitação na América do Sul nas pêntadas 1 e 2 de Janeiro de 279 2012 estimadas pelo CHIRPS 
$\begin{array}{lll}\text { Figura } 165 \text { Carta sinótica de 14/01/2012 } & 280\end{array}$

Figura 166 Precipitação na América do Sul nas pêntadas 3 e 4 de Janeiro de 280 2012 estimadas pelo CHIRPS

Figura 167 Cartas sinóticas de 23 e 26 de Janeiro de 2012

Figura 168 Precipitação na América do Sul nas pêntadas 5 e 6 de Janeiro de 281 2012 estimadas pelo CHIRPS

Figura 169 Dados de precipitação total diária de Janeiro de 2012 e número de 283 impactos

Figura 170 Reportagem no site do Jornal Tribuna de Minas- 30/01/2012 284

Figura 171 Total de registros de impactos em janeiro de $2012 \quad 285$

Figura 172 Impactos geomorfológicos registrados em Janeiro de $2012 \quad 286$

Figura 173 Impactos hidrológicos registrados em Janeiro de $2012 \quad 287$ 
Quadro 01 Comparação entre os canais de percepção do Sistema Clima 38 Urbano-SCU.

Quadro 02 Categorias taxonômicas e organização geográfica do clima

Quadro 03 Conceituação de inundação, enchente e alagamento a partir do Ministério das Cidades (2007).

Quadro 04 Registros históricos de Juiz de Fora, do início, passando pelas plantas até as transformações do século XX

Quadro 05 Regiões de planejamento; regiões urbanas, número de ordem e bairros de Juiz de Fora.MG.

Quadro 06 Resultados da análise de tendência das precipitações mensais e anual, segundo o Teste Mann-Kendall

Quadro 07 Intervalos de classificação do box plot.

Quadro 08 Fórmulas para determinação dos níveis de intensidade de precipitação.

Quadro 09 Interpretação dos valores para o valor de r

Quadro 10 Variáveis utilizadas para o Índice de Vulnerabilidade Social-IVS

Quadro 11 Fórmulas para normalização e padronização das informações

Quadro 12 Estrutura do Índice de Vulnerabilidade Social-IVS

Quadro 14 Variáveis para o zoneamento do risco climático

Quadro 16 Pesos aplicados ao índice de vulnerabilidade social

Quadro 17 Pesos aplicados ao histórico de ocorrências dos impactos geomorfológicos

Quadro 18 Classificação do risco climático aos impactos geomorfológicos

Quadro 19 Etapas metodológicas e objetivos

Quadro 20 Correlação dos dados diários CEMADEN- CHIRPS

Quadro 21 Correlação de dados agrupados em pêntadas: CEMADEN-

\section{CHIRPS}

Quadro 22 Classificação dos dados de precipitação a partir da técnica do box 146 plot

Quadro 23 Legenda da classificação dos dados a partir do box plot 
Quadro 24 Classes do percentil para os dados diários de precipitação.

Quadro 25 Síntese dos dados da avaliação de tendência dos dados diários de 151 precipitação.

Quadro 26 Frequência e tempo de retorno para as classes do percentil diários. 153

Quadro 27 Estatística de tendência para os dados mensais da estação chuvosa 157 a partir do percentil 90.

Quadro 28 Estatística de Mann-Kendall aplicado ao percentil 90.

Quadro 29 Estatística de tendência para os dados mensais da estação chuvosa a partir do percentil 95

Quadro 30 Estatística de Mann-Kendall aplicado ao percentil 95

Quadro 31 Estatística de tendência para os dados mensais da estação chuvosa a partir do percentil 99.

Quadro 32 Classes do percentil calculados para as pêntadas pluviométricas

Quadro 33 Estatísticas de tendência aplicada aos percentis 90, 95 e 99 dos 164 dados agrupados em pêntadas

Quadro 34 Frequência e tempo de retorno para os dados agrupados em pêntadas

Quadro 35 Frequência e tempo de retorno para os dados em pêntadas superiores ao P99

Quadro 36 Maiores totais de pêntadas pluviométricas em Juiz de Fora

Quadro 37 Intensidades da precipitação diária calculada pela técnica dos máximos de precipitação.

Quadro 38 Frequência e tempo de retorno para as classes dos máximos de precipitação

Quadro 39 Estatísticas de tendência aplicadas aos índices de extremos climáticos do ETCCDI.

Quadro 40 Frequência e tempo de retorno por classes de intensidade diária

Quadro 41 Suscetibilidade a inundação por classe, no perímetro urbano de Juiz de Fora

Quadro 42 Suscetibilidade a movimentos de massa, por classe, no perímetro urbano de Juiz de Fora.

Quadro 43 Percentagem de área edificada por classe de suscetibilidade aos movimentos de massa, por região de planejamento

Quadro 44 Percentagem de área edificada por classe de suscetibilidade à inundação, por região de planejamento 
Quadro 45 Suscetibilidade a movimentos de massa, por classe, na região de planejamento Sul.

Quadro 46 Percentagem das áreas suscetíveis a movimentos de massa 187 ocupadas.

Quadro 47 Suscetibilidade a inundação por classe, na região de planejamento Sul

Quadro 48 Porcentagem das áreas suscetíveis a inundação, ocupadas

Quadro 49 Suscetibilidade a movimentos de massa, por classe, na região de planejamento Centro.

Quadro 50 Porcentagem das áreas suscetíveis a movimentos de massa 191 ocupadas, na RP Centro.

Quadro 51 Suscetibilidade a inundação por classe, na região de planejamento Centro

Quadro 52 Porcentagem das áreas suscetíveis a inundação, ocupadas, na RP Centro.

Quadro 53 Suscetibilidade a movimentos de massa, por classe, na região de planejamento Leste.

Quadro 54 Porcentagem das áreas suscetíveis a movimentos de massa 195 ocupadas, na RP Leste.

Quadro 55 Suscetibilidade a inundação por classe, na região de planejamento Leste

Quadro 56 Porcentagem das áreas suscetíveis a inundação, ocupadas, na RP Leste.

Quadro 57 Suscetibilidade a movimentos de massa, por classe, na região de planejamento Oeste.

Quadro 58 Porcentagem das áreas suscetíveis a movimentos de massa 199 ocupadas, na RP Oeste.

Quadro 59 Suscetibilidade a inundação por classe, na região de planejamento 200 Oeste

Quadro 60 Porcentagem das áreas suscetíveis a inundação, ocupadas, na RP 200 Oeste.

Quadro 61 Suscetibilidade a movimentos de massa, por classe, na região de planejamento Sudeste.

Quadro 62 Porcentagem das áreas suscetíveis aos movimentos de massa ocupadas, na RP Sudeste

Quadro 63 Suscetibilidade à inundação por classe, na região de planejamento Sudeste

Quadro 64 Percentagem das áreas suscetíveis a inundação, ocupadas, na RP Sudeste.

Quadro 65 Suscetibilidade a movimentos de massa, por classe, na região de planejamento Centro-Oeste

Quadro 66 Percentagem das áreas suscetíveis a movimentos de massa ocupadas, na RP Centro-Oeste. 
Quadro 67 Suscetibilidade a inundação por classe, na região de planejamento 207 Centro-oeste

Quadro 68 Percentagem das áreas suscetíveis a inundação, ocupadas, na RP 207 Centro-Oeste.

Quadro 69 Suscetibilidade aos movimentos de massa, por classe, na região de 209 planejamento Nordeste.

Quadro 70 Percentagem das áreas suscetíveis a movimentos de massa 209 ocupadas, na RP Nordeste.

Quadro 71 Suscetibilidade a inundação por classe, na região de planejamento 210 Nordeste

Quadro 72 Percentagem das áreas suscetíveis a inundação, ocupadas, na RP 211 Nordeste.

Quadro 73 Suscetibilidade a movimentos de massa, por classe, na região de 213 planejamento Norte

Quadro 74 Percentagem das áreas suscetíveis a movimentos de massa 213 ocupadas, na RP Norte.

Quadro 75 Suscetibilidade a inundação por classe, na região de planejamento 215 Norte

Quadro 76 Percentagem das áreas suscetíveis a inundação, ocupadas, na RP 215 Norte.

Quadro 77 Percentagem do tipo de impacto por região urbana

Quadro 78 Classes de risco a impactos geomorfológicos no perímetro urbano 239 de Juiz de Fora

Quadro 79 Distribuição dos pontos por classe de risco no perímetro urbano de 240 Juiz de Fora 
Tabela 01 Intervalo das 73 pêntadas pluviométricas

Tabela 02 Índices de extremos precipitação utilizados no estudo Parâmetros utilizados para a avaliação quantitativa da suscetibilidade a inundações

\section{Lista de Siglas}

$\begin{array}{ll}\text { ANA } & \text { Agência Nacional de Águas } \\ \text { INMET } & \text { Instituto Nacional de Meteorologia } \\ \text { CEMADEN } & \text { Centro Nacional de Monitoramento e Alertas de Desastres Naturais } \\ \text { CPRM } & \text { Companhia de Pesquisa de Recursos Minerais } \\ \text { LabCAA } & \text { Laboratório de Climatologia e Análise Ambiental } \\ \text { IGAM } & \text { Instituto Mineiro de Gestão das Águas } \\ \text { PJF } & \text { Prefeitura de Juiz de Fora } \\ & \text { Shuttle Radar Topography Mission (Missão Topográfica de Radar } \\ \text { SRTM } & \text { Embarcado) } \\ \text { SCU } & \text { Sistema Clima Urbano }\end{array}$




\section{Sumário}

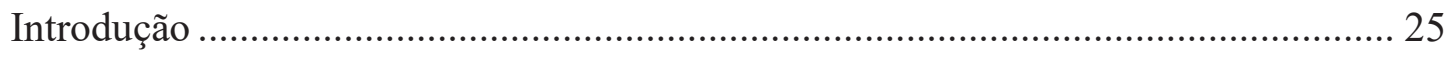

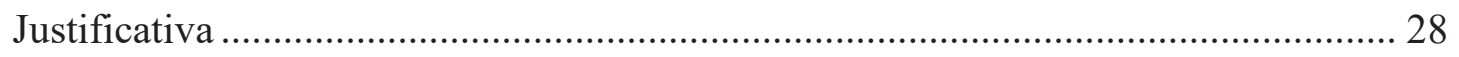

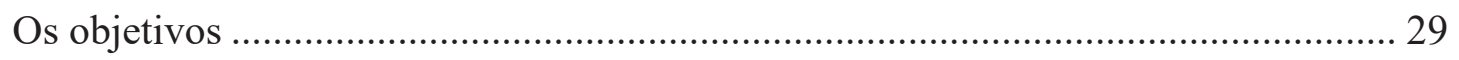

Capítulo 1 - O REFERENCIAL TEÓRICO: O clima urbano como objeto de estudo

O Sistema Clima Urbano de Carlos Augusto de Figueiredo Monteiro (1976)........... 31

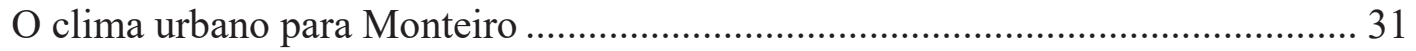

O Sistema Clima Urbano- SCU e seus enunciados básicos ................................... 32

Os canais de percepção: os subsistemas do Clima Urbano ...................................... 38

O subsistema Hidrometeórico: Os impactos pluviométricos .................................. 40

O clima urbano e a necessidade de uma abordagem interescalar .......................... 43

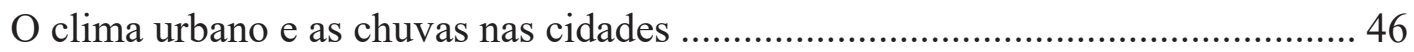

Por uma Geografia do Clima de João Lima Sant'Anna Neto: a necessidade de uma

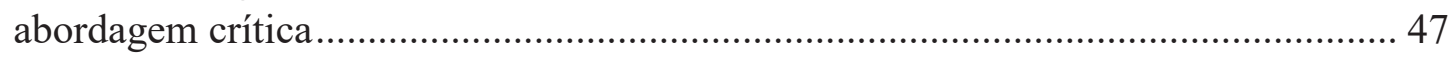

Do Sistema Clima Urbano à Geografia do Clima...................................................... 49

De Monteiro a Sant'Anna Neto: o que mudou no estudo das cidades para a climatologia

Capítulo 2: O clima urbano como risco climático 54

As chuvas e suas técnicas de investigação: a perigosidade ........................................ 56

A chuva como elemento em análise .................................................................... 56

Os eventos extremos pluviométricos e suas técnicas de investigação .....................5 59

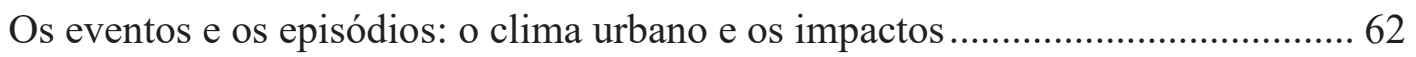

A suscetibilidade ambiental: os sistemas naturais e o sítio urbano ............................ 64

Os movimentos de massa e as relações com a precipitação..................................... 65

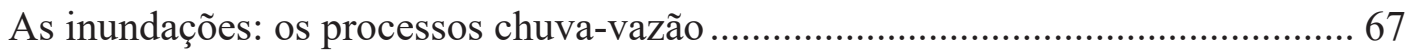

A vulnerabilidade social e a produção desigual do espaço.......................................... 70

Capítulo 3: Caracterização da área de estudo ............................................................. 75

Juiz de Fora: dos primórdios ao século XXI: Aspectos históricos e econômicos ...... 75

A expansão da mancha urbana e o crescimento populacional ................................ 82

A legislação e o planejamento urbano em Juiz de Fora .......................................... 86

Caracterização das regiões de planejamento de Juiz de Fora................................... 87

Dinâmica Físico Ambiental da Cidade ........................................................................ 90

Juiz de Fora e sua rede hidrográfica urbana .......................................................... 95

A Dinâmica Climática de Juiz de Fora........................................................................ 96 
A Climatologia das chuvas na cidade de Juiz De Fora 97

Capítulo 4: Materiais e métodos 103

$1^{\circ}$ etapa: As precipitações em Juiz de Fora: dados e técnicas empregadas 105

As técnicas empregadas 106

Análise mensal..... 106

Análise diária 107

$2^{\circ}$ etapa: O sítio urbano de Juiz de Fora e suas suscetibilidades ...... 115

$3^{\circ}$ etapa: O espaço urbano de Juiz de Fora e sua vulnerabilidade social. 120

$4^{\circ}$ etapa: Os impactos das chuvas e o levantamento das informações. 128

A Integralização dos elementos e o Risco Climático.

Capítulo 5- Os dados de precipitação: das técnicas aos eventos extremos 140

A correlação e avaliação dos dados CHIRPS 140

Correlação dos dados do CEMADEN e os dados do INMET . 140

A correlação entre os dados diários e agrupados em pêntadas 142

As Chuvas em Juiz De Fora: Da Variabilidade Mensal Aos Eventos Extremos...... 145

A variabilidade mensal dos dados de precipitação. 145

Os dados diários de precipitação: Variabilidades e Tendências ............................... 148

Os totais diários de precipitação: a técnica dos percentis .................................. 150

Os Extremos Em Juiz De Fora: Sua Distribuição Mensal ................................... 155

Técnicas Para A Identificação De Eventos Intensos e Extremos........................ 161

Tendências dos dados a partir dos Índices de Extremos Climáticos-ETCDDI..... 167

Capítulo 6: Entre os elementos do risco: a suscetibilidade ambiental; vulnerabilidade social e os impactos das chuvas

A produção do espaço e a vulnerabilidade social em Juiz de Fora 177

A suscetibilidade ambiental e as regiões de planejamento 185

A região de planejamento Sul 185

A região de planejamento Centro. 189

A região de planejamento leste 194

A região de planejamento Oeste. 197

A região de planejamento Sudeste 200

A região de planejamento Centro-Oeste ............................................................. 204

A região de planejamento Nordeste ..................................................................... 208

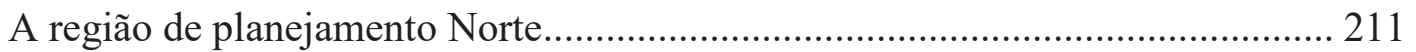

Os episódios extremos e os impactos das chuvas em Juiz de Fora........................... 215

Os impactos das chuvas em Juiz de Fora: e a sua espacialização no perímetro urbano 
Capítulo 7: O Clima Urbano como risco climático e os episódios extremos em Juiz de

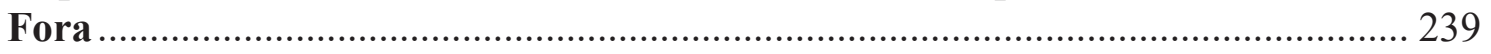

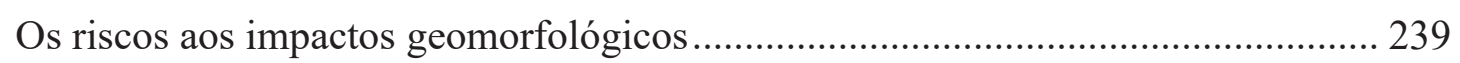

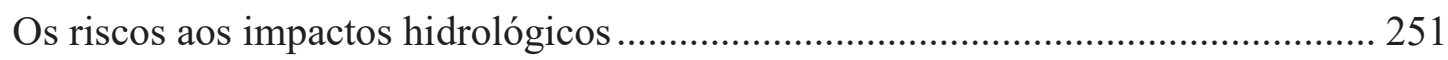

Os impactos hidrológicos associados aos canais fluviais.................................. 251

Os eventos/episódios extremos em Juiz de Fora e os meses padrão.......................... 260

O mês padrão chuvoso de Janeiro 1985 ............................................................... 261

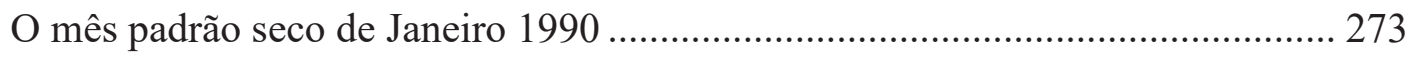

O mês padrão habitual de Janeiro 2012 .......................................................... 279

Os episódios extremos: gênese, impactos e riscos na cidade de Juiz de Fora. .......... 288

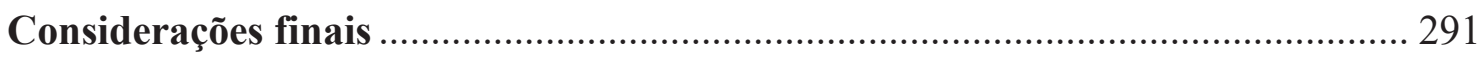

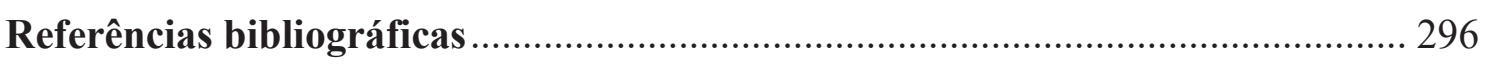




\section{Introdução}

Com a crescente urbanização nas cidades brasileiras, sobretudo a partir da segunda metade do século $\mathrm{XX}$, diversos aspectos relacionados à qualidade ambiental urbana foram negligenciados em detrimento do "progresso" econômico-industrial característico do período. Essa perda de qualidade ambiental foi mais acentuada nas aglomerações urbanas, pois, como coloca Mendonça (2004a), as cidades são palco de diversas relações sociais e econômicas geradoras de profundas desigualdades sociais, e segundo Souza (2015), “o ambiente urbano, não é apenas a natureza alterada pela cidade, [...], o ambiente urbano é fruto ou materialização de um modelo de sociedade" (SOUZA, 2015, p. 2015).

O crescimento demográfico nas cidades aconteceu sobre um espaço, que passou a ser transformado de acordo com os interesses do homem, como aponta Santos (2012a, p. 42) "o fenômeno humano é dinâmico, e uma das formas de revelação desse dinamismo está, exatamente, na transformação qualitativa e quantitativa do espaço habitado".

As modificações processadas no espaço pelo homem podem potencializar os eventos naturais, sendo assim, se tivessem como palco um espaço menos alterado, não causariam tantos problemas à população, acredita Gonçalves (2013). As ações antrópicas que alteram o ambiente de forma negativa provocam maior vulnerabilidade à população, frente aos eventos, que não necessariamente são de grande intensidade. Dessa forma, os impactos gerados por eventos de precipitação têm se tornado a cada dia mais prejudiciais à população, tanto no ponto de vista econômico, como também social.

Lave et al (2019) ao defender uma abordagem da Geografia Física Crítica (GFC), considera que "as paisagens sócio-biofísicas são o resultado de fatores sociais de poder, do legado histórico do colonialismo e das disparidades raciais e de gênero, quanto fatores físicos como a hidrologia, ecologia e alterações climáticas" (LAVE, et al, 2019, p. 78).

No meio tropical, não é incomum nos períodos chuvosos, a ocorrência de eventos de precipitação que associados ao uso e ocupação do espaço causam inúmeros problemas à população, estes são rotineiramente divulgados pelos meios de comunicação, que trazem diversas manchetes relacionadas às inundações urbanas, movimentos de massa, etc.

Com isso a ocorrência dos eventos extremos nas cidades produzidas de maneira desigual, engendram a consubstanciação dos riscos na medida em que a vulnerabilidade demarca a desigualdade inerente ao espaço. "Dessa forma, a sociedade torna-se cada vez mais desigual e a natureza, externa ao processo produtivo, se transfigura-se ou degrada-se" (SUERTEGARAY, 2014, p. 4). 
A questão que se coloca então, segundo Rodrigues (1998), é que para além de uma questão ambiental deve-se atentar para a questão social por detrás dos impactos ambientais nas cidades. A autora acrescenta ainda que

É preciso, assim, ter cuidado para não ocultar a existência e as contradições de classes sociais para compreender a problemática ambiental em sua complexidade, pois os problemas ambientais dizem respeito às formas como o homem em sociedade apropria-se da natureza (RODRIGUES, 1998, p. 8).

Com isso a abordagem do risco permite vislumbrar uma relação entre a dinâmica dos fenômenos naturais, e a forma com a qual os espaços sentem os seus impactos, Sant' Anna Neto $(2001,2008)$ argumenta que um evento pluviométrico de mesma intensidade em uma cidade produz impactos que são sentidos de maneira distinta nos diferentes espaços e pelos diferentes sujeitos.

Os eventos extremos de precipitação podem estar associados à variabilidade normal do clima, assim as cidades não deveriam já estar preparadas? Por que então ainda são presentes uma série de desastres advindos desses eventos, e principalmente porque a população mais vulnerável a estes são normalmente as que possuem suas habitações nas margens de cursos d'água, ou em vertentes íngremes? (MENDONÇA, 2004).

Essas questões apontam a inter-relação entre os três componentes principais para a abordagem do risco. A perigosidade expressa pelos eventos extremos, a suscetibilidade marcada pelo sítio urbano e a vulnerabilidade das populações que ocupam os diferentes espaços. Com isso a ideia do risco, no caso o climático, pode auxiliar na compreensão dos impactos associados aos elementos do clima no espaço urbano.

Dentre os principais problemas associados às chuvas nas cidades brasileiras, sobretudo no Sudeste, estão as inundações e os movimentos de massa (MONTEIRO, 1976; VICENTE, 2005; ARMOND, 2014; NUNES, 2015). De acordo com Nunes (2015) às inundações figuram como um dos desastres naturais mais comuns no mundo, e ocorrem em locais que não necessariamente sofreram alguma elevação nos totais pluviométricos, destacando o impacto que as formas de uso e ocupação da terra assumem na ocorrência desses eventos.

O outro elemento destacado por Nunes (2015) são os movimentos de massa, eventos comuns no meio tropical, os escorregamentos normalmente estão associados a eventos pluviais concentrados (GONÇALVES e GUERRA, 2006). Nas cidades, como as encostas estão sendo amplamente ocupadas a ocorrência de movimentos de massa se torna mais danosa, seja pelo aumento no número de habitantes ocupando estes espaços como também pela alteração da dinâmica e dos processos geomorfológicos inerentes à vertente (NUNES, 2015). 
Estes eventos ocorrem de maneira recorrente no Brasil e no Mundo. Segundo o Índice Global de Risco Climático, publicado em 2019 pela ONG GermanWatch, em 2017 o Brasil estava na $79^{\circ}$ posição no ranking global, tendo registrado 30 óbitos associados a eventos climáticos extremos.

É necessário colocar que, com o desenvolvimento tecnológico existente na atualidade e o conhecimento adquirido acerca dos fenômenos naturais, revela uma "inabilidade crescente do ser humano em conviver com fenômenos que sempre aconteceram e o distanciamento entre as conquistas científicas e tecnológicas dos reais problemas que afligem a sociedade" (NUNES, 2015, p. 14).

Com esses elementos postos, busca-se com esse trabalho investigar sobre os problemas enfrentados pela cidade de Juiz de Fora com relação às chuvas e seus respectivos impactos, sobretudo na sua área urbana, no período de 1980-2018. Dessa forma, particularmente, é necessário indagar:

- As chuvas têm ficado mais intensas em Juiz de Fora?

- O processo de ocupação da cidade fez com que um maior número de impactos ocorresse e em maior intensidade ao longo dos anos?

-O crescimento urbano tem relação com o número de impactos pluviométricos?

- Quais são as áreas mais afetadas pelas chuvas? Quais são as condicionantes naturais e/ou socioeconômicas?

Essa pesquisa se dividiu em seis capítulos. No primeiro capítulo foram discutidos os referenciais teóricos que norteiam o estudo do clima urbano no Brasil, a partir de Monteiro (1976) com Sistema Clima Urbano, bem como pelas considerações levadas a efeito por Sant'Anna Neto $(2001 ; 2008)$ e a Geografia do Clima.

No segundo capítulo foi analisado o clima urbano a partir da perspectiva do risco climático, desenvolvida por Nascimento Júnior (2018); Goudard (2019), baseados na tríade vulnerabilidade social $\mathrm{x}$ suscetibilidade ambiental $\mathrm{x}$ perigos. No terceiro capítulo foi apresentada a área de estudo, no caso o perímetro urbano de Juiz de Fora, a partir de suas características históricas, bem como físico-ambientais.

No quarto capítulo foi alocado os materiais e métodos do trabalho, que se basearam em 4 etapas. A primeira etapa versou sobre o levantamento, organização e aplicação das técnicas estatísticas nos dados de precipitação; a segunda etapa buscou o levantamento das informações sobre a suscetibilidade ambiental em Juiz de Fora; na terceira etapa foi realizada a aplicação de um índice de vulnerabilidade social-IVS; e na quarta e última etapa foi realizado o levantamento 
das informações acerca dos impactos associados à chuva na cidade, a partir das notícias veiculadas nos jornais de mídia impressa e /ou digital, bem como a aplicação de uma modelagem, baseada em AHP (Analytic Hierarchy Process) para a integralização dos elementos e mapeamento dos riscos.

No quinto capítulo encontram-se os principais resultados relacionados aos dados de chuva, as características e os eventos intensos e extremos, que foram divididos em duas partes. Na primeira etapa foi avaliada a partir da correlação os dados modelados CHIRPS, utilizados para a espacialização das chuvas. Na segunda etapa foi discutido a partir dos dados de precipitação diária, avaliando a distribuição mensal, bem com as tendências dos eventos intensos e extremos de precipitação.

No sexto capítulo foram discutidos os elementos de caracterização do risco para cada região de planejamento da cidade, a suscetibilidade ambiental, bem como a vulnerabilidade social e a distribuição espacial dos impactos no perímetro urbano de Juiz de Fora.

No sétimo capítulo, quarta etapa dos resultados foram discutidas as considerações acerca do risco climático em Juiz de Fora, a partir do mapeamento e a avaliação comparativa dos impactos das chuvas em três meses padrão distintos, um seco, um habitual e outro chuvoso.

A partir disso foram contempladas, as considerações finais da pesquisa.

\section{Justificativa}

A proposta desse trabalho sinaliza uma preocupação acerca das relações entre a elevação da ocupação na área urbana de Juiz de Fora e os impactos associados à ocorrência de eventos pluviométricos intensos e concentrados. Lima (2012, p. 635) coloca que "estudos de Clima Urbano tiveram, em sua grande maioria, foco em grandes cidades e em regiões metropolitanas". Sobre isso, Collischonn (2014) destaca que o crescimento populacional observado nas cidades de porte médio e pequeno fizeram com que os impactos de ordem ambiental associados às grandes metrópoles passassem a serem visualizados também nesses contextos, necessitando assim de investigações nesse sentido. Essa constatação dos autores reforçam a necessidade das discussões sobre o clima urbano nas cidades de porte médio, como é o caso de Juiz de Fora.

Ademais, o Painel Intergovernamental para as Mudanças Climáticas (IPCC, sigla em Inglês) aponta que o número de eventos extremos de precipitação tem aumentado em frequência e os modelos de projeção climática também apontam para a intensificação desses eventos em cenários futuros (IPCC, 2015). No Brasil, Marengo (2009) destacou uma intensificação nos 
eventos extremos para a região sudeste. Sendo assim, é necessário entender o comportamento das chuvas, também a partir de uma perspectiva local, do urbano, no caso Juiz de Fora.

Faz-se necessário também intensificar as investigações acerca dos impactos relacionados às chuvas, conforme já identificado em várias cidades brasileiras, Salvador (GONÇALVES, 2003); Curitiba (ZANELLA, 2006); Rio de Janeiro (ARMOND, 2014); São Carlos (LIMA; 2014); Campinas (VICENTE, 2005). Além disso, a cidade de Juiz de Fora que vem se caracterizando por um notável crescimento demográfico dentre as cidades médias mineiras (IBGE, 2010), associado ao modo de uso e ocupação do seu sítio urbano, merece um olhar específico sobre as precipitações e seus impactos, em função dos riscos associados a estes eventos.

\section{Os objetivos}

O objetivo geral do trabalho foi investigar os impactos deflagrados pelas chuvas na área urbana de Juiz de Fora-MG e suas relações com os condicionantes naturais e urbanos da cidade, no período de 1980 a 2018.

Complementarmente ao objetivo central, cumpre destacar os objetivos específicos direcionados a obtenção de elementos e discussões fundamentais para a compreensão do objetivo geral, são eles:

- Analisar o comportamento das chuvas historicamente e suas intensidades diárias;

- Identificar as áreas propensas à ocorrência de inundações, enchentes e alagamentos e movimentos de massa;

- Caracterizar a partir do Índice de Vulnerabilidade Social, a áreas com maior vulnerabilidade social na cidade;

- Realizar estudos de caso em alguns eventos extremos localizados na série histórica;

- Realizar uma análise documental no arquivo histórico da Prefeitura, relacionadas a impactos pluviométricos em Juiz de Fora, no período de 1980 a 2018.

- Investigar quais eventos extremos foram considerados episódios extremos e qual técnica melhor os representa. 


\section{Capítulo 1 - O REFERENCIAL TEÓRICO: O clima urbano como objeto de estudo}

Discutir as influências da cidade nas condições de tempo e clima são indagações levadas a efeito desde os meados do século XVII, segundo Monteiro (1976) ainda anterior ao período da Revolução Industrial e a ampliação do crescimento das cidades no ocidente que se iniciam as investigações acerca do clima das cidades. Para ele (MONTEIRO, 1976) seria o trabalho de Evelyn intitulado Fumifugium de 1661 o estudo mais antigo realizado na temática para a cidade de Londres.

Com a Revolução Industrial e a alteração do espaço urbano a necessidade de investigar as alterações climáticas nesses espaços levariam a Luke Howard em 1883 com o trabalho The climate of London, como sendo o primeiro estudo já na era industrial (MONTEIRO, 1976), também para a cidade de Londres. Estes estudos já demonstravam a necessidade de investigação do clima nas cidades, sobretudo a partir do amplo processo de urbanização visualizado com a Revolução Industrial.

Como salienta Monteiro (1976, p.55) “daí pra cá as preocupações e os estudos se multiplicaram, a princípio nas cidades industrializadas da Europa ocidental, passando depois à América do Norte". Desse modo, algumas sínteses já puderam ser feitas a respeito da influência das cidades no clima a partir dos anos de 1960, destacando os trabalhos de Chandler (1965), Oke (1979) e Landsberg (1981). Oke (1979) destaca que em termos do clima urbano, existem três principais preocupações: a liberação antropogênica de gases, a alteração dos processos de evapotranspiração superficial e os efeitos sobre a precipitação, ocasionando o aumento desta em intensidade.

No entanto, é a partir da Segunda Guerra Mundial, na virada da década de 1960 para a de 70, que no Brasil, em franco processo de urbanização, começaram a despontar as discussões acerca da questão ambiental urbana (LUCENA, 2005). O crescimento das cidades se dava de forma que "o improvisado (ilegal) superava, de muito o planejado (legal). Em termos genéricos, o caos superava a ordem" (MONTEIRO, 2013, p.10). Com isso, alguns estudiosos na área da Geografia Física, passaram a se interessar pelas questões associadas ao sítio urbano e o crescimento urbano.

No Brasil, os estudos de clima urbano passaram a ser desenvolvidos sobretudo a partir da década de 1980, após a publicação da Tese de Livre Docência do professor Carlos Augusto de Figueiredo Monteiro (Teoria e Clima Urbano), no ano de 1976, estabelece o que Mendonça 
(2003) chamou de "escola brasileira de climatologia urbana", segundo Lima et al (2012) entre 1991 e 2010 "cerca de 137 estudos de Clima Urbano foram elaborados, grande parte utilizando o Sistema Clima Urbano (S.C.U.) na íntegra ou parte dele” (LIMA, 2012, p. 634).

\section{O Sistema Clima Urbano de Carlos Augusto de Figueiredo Monteiro (1976)}

Dentro dessa perspectiva, Monteiro, visando entender o clima das cidades, parte inicialmente de uma diferenciação entre o que seriam os propósitos da Meteorologia e da Climatologia, destacando que a primeira estaria interessada no "air over city" enquanto que a segunda, no "air within the city", logo a Climatologia Urbana necessitaria de um levantamento de dados fora da área urbana para entender as dinâmicas microclimáticas geradas e influenciadas pelo desenvolvimento da cidade.

Além disso, destaca-se a necessidade de entender o clima a partir de sua complexidade, associado a uma circulação atmosférica regional e como esses processos desencadeiam a sucessão dos tipos de tempo. Para auxiliar na montagem do sistema, Monteiro utilizou-se da Teoria Geral dos Sistemas de Ludwig Von Bertalanffy, como um encaminhamento teórico e técnico.

\section{O clima urbano para Monteiro}

Introduzindo os elementos para a montagem do Sistema Clima Urbano (SCU), Monteiro (1976) coloca que no urbano ocorre a mais efetiva interação entre Homem e Natureza, havendo assim uma coparticipação e não um antagonismo. Para visualizar essas interações, Monteiro utiliza como suporte a Teoria Geral dos Sistemas pois estaria justamente associada à visão organísmica, auxiliando na compreensão do funcionamento, do desempenho e da organização do sistema.

Dentro da proposta do Sistema Clima Urbano, Monteiro (1976) ressalta que essa se enquadra nos termos mais despretensiosos e simples da teoria sistêmica, sendo então, uma

\footnotetext{
${ }^{1}$ Air over city- Dessa forma o interesse da Meteorologia estaria associado ao ar sobre a cidade;

2 Air within the city- seria o objeto de interesse da Climatologia Geográfica e por conseguinte da Climatologia Urbana que seria o ar dentro da cidade e as transformações que esta provoca na dinâmica dos elementos climáticos;
} 
hipótese de trabalho, como modelo teórico, de explicação, previsão e controle dos fenômenos, podendo dessa forma entender a essência do fenômeno.

Inicialmente são colocados cinco critérios de escolha, que Monteiro (1976) coloca como elementos fundamentais que direcionam os objetivos da montagem do Sistema Clima Urbano (SCU).

- Pragmatismo: Monteiro (1976) destaca que a proposta teórica deve ter objetivos definidos, dessa forma, o autor considera como pragmático, a capacidade de estabelecer perguntas e emitir respostas, possibilidade inerente à Teoria Geral dos Sistemas (TGS).

- Dinamismo: no qual estabelece-se como conceituação climática a proposta Sorreana, entendendo o clima como a sucessão dos tipos de tempo, dessa forma "exige uma moldura teórica capaz de revelar esses dinamismos em graus diferentes, mas peculiares" (MONTEIRO, 1976, p. 114).

- Consistência destaca que a proposta teórica deve tratar de forma efetiva as diversas escalas da complexidade urbana, "a consistência da análise deverá manter a conjunção entre o nomotético (assegurado pela ossatura, ou andaime teórico) e pelo ideográfico (expressão dos resultados de cada realidade urbana específica)" (MONTEIRO, 2013, p.18), além da possibilidade de aplicação em diferentes realidades, atendendo do mais amplo ao mais peculiar.

- Empirismo, no qual Monteiro discute que a "moldura teórica escolhida deve ser suscetível e mesmo orientada à observação empírica" (MONTEIRO, 2013, p.18). Nesse contexto, a TGS permite uma observação tanto indutiva como hipotético dedutiva.

- Modelismo, destacando que o clima urbano necessita continuamente de mapeamento e diagramação, que podem ser aprofundados a partir dos Sistemas de Informação GeográficaSIG, para além da simples soma de partes.

\section{O Sistema Clima Urbano- SCU e seus enunciados básicos}

Monteiro (1976) nesse ponto destaca que os enunciados seriam tratados como ideias reguladoras, destacando-se não como regras, mas com um caráter informativo. Dessa forma o S.C.U. foi construído a partir de dez (10) enunciados básicos:

O primeiro enunciado trata que "O clima urbano é um sistema que abrange o clima de um dado espaço terrestre e sua urbanização” (MONTEIRO, 1976, p. 116)

Não se deve entender esse primeiro enunciado como uma definição, mas ele responde à questão de se trabalhar com elementos sociais e naturais. Além disso, não se faz necessário estabelecer qual será o grau de urbanização bem como as características ambientais locais são 
responsáveis pelo clima urbano. Para isso, a TGS não necessita de um rigor na ordem de grandeza, mas deve-se construir o sistema em função dos objetivos (MONTEIRO, 1976).

Dito isso, diversos trabalhos investigando a temperatura do ar em cidades pequenas e médias visualizaram a formação de ilhas de calor, como em Ugeda Júnior (2011), Vianna (2018) e Alves (2019), dentre outros. Com relação à precipitação, apesar de Oke (1979) e Landsberg (1981) apontarem uma elevação da precipitação em áreas urbanas, essa relação ainda não é tão latente nos trabalhos da área, sobretudo em cidades de porte médio e pequeno.

Landsberg (1981) a esse respeito, destaca que a cidade pode influenciar de três formas para uma elevação nas precipitações, primeiro pelo efeito da ilha de calor e a intensificação dos processos de convecção, o segundo efeito seria pelo barramento ao deslocamento da massa de ar através da estrutura urbana e o terceiro fator seria a poluição que em função de uma maior disponibilidade de núcleos de condensação, fomentaria a formação de nuvens. No entanto, o mesmo autor (LANDSBERG, 1981) considera que essas relações seriam um grande quebracabeças de necessária investigação.

O segundo enunciado destaca que "O espaço urbanizado, que se identifica a partir do sítio, constitui o núcleo do sistema que mantém relações íntimas com o ambiente regional imediato em que se insere" (MONTEIRO, 1976, p. 117).

Esse enunciado trata da investigação interescalar inerente à abordagem climática, e preconizada na TGS, "pois que o sistema se projeta tanto em escala ascendente para um número infinito de interações em sistemas superiores, quanto se fraciona, também infinitamente, em sistemas inferiores" (MONTEIRO, 2013, p.20) visualizando a articulação necessária entre o local e o regional, pois a circulação atmosférica regional estará intimamente associada aos desdobramentos dos elementos climáticos em microescala (UGEDA JÚNIOR e AMORIM, 2016).

O terceiro enunciado destaca que "O S. C. U. importa energia através do seu ambiente, é sede de uma sucessão de eventos que articulam diferenças de estados, mudanças e transformações internas, a ponto de gerar produtos que se incorporam ao núcleo elou são exportados para o ambiente, configurando-se como um todo de organização complexa que se pode enquadrar na categoria dos sistemas abertos" (MONTEIRO, 1976, p. 118).

$\mathrm{Na}$ cidade os elementos do clima sofrem transformações, sendo processos que não podem ser definidos pelas condições iniciais do sistema, logo, deve-se considerar o clima urbano como um sistema aberto (MONTEIRO, 1976). Além disso, Monteiro (1976) assevera que não se deve confundir a complexidade inerente à cidade, que gera um sistema em si mesma, com a montagem do SCU. 
O SCU objetiva compreender as peculiaridades do clima das cidades, para isso este estará centrado na atmosfera e entendendo-a como o operador do sistema, com isso, o que se materializa no urbano constituiria o operando do sistema, sendo que este operando não se comporta de maneira estática e muito menos passiva (MONTEIRO, 1976). Dito isso, alguns processos de ordem econômica e sociais contribuem para aumentar o dinamismo e a complexidade da cidade, dessa forma estes interagem de forma indireta na estrutura do sistema, pois estão atrelados à própria aglomeração urbana.

Deve-se então entender que a entrada de energia no sistema se dá pela atmosfera urbana, no entanto as atividades humanas impactam na estrutura interna, atuando no sentido de transformar essa energia.

Contudo nesse enunciado Monteiro deixa claro o foco na atmosfera urbana, quando a chama de operador do sistema, o que se diferencia da abordagem proposta posteriormente pelo Sant'Anna Neto (2001, 2008), denominada Geografia do Clima, pois para este último existe uma necessidade fundamental de investigação a partir da superfície, focada na produção do espaço urbano capitalista e os reflexos disso em termos ambientais, sendo esta condição sine qua non para uma abordagem geográfica do clima.

No enunciado quatro (4): “As entradas de energia no S.C.U são de natureza térmica (oriundas da fonte primária de energia de toda a Terra- o Sol), implicando componentes dinâmicas inequívocas determinadas pela circulação atmosférica, e decisivas para a componente hídrica englobada nesse conjunto" (MONTEIRO, 1976, p.120).

No quarto enunciado o destaque é dado para a fonte de energia do sistema, fundamentalmente de natureza térmica, proveniente da radiação solar. No entanto esta energia influenciará nas dinâmicas da circulação geral da atmosfera, sendo que nesse contexto deve-se atentar para o fato de que o organismo urbano será o receptáculo dessa energia. Esse organismo "através das diferentes formas de uso do solo e estrutura urbana, que passa a exercer os efeitos decisivos de reflexão, absorção e armazenamento térmico; efeitos de atrito na ventilação etc." (MONTEIRO, 2013, p. 22).

Deve-se então abstrair que todos esses processos se passam de maneira instantânea e ininterrupta. Pode-se colocar que a circulação atmosférica predominante sobre a cidade acaba sendo, nesse ponto de vista, mais eficiente que o próprio Sol para o SCU. Dessa forma, as condições atmosféricas são fundamentais para a conformação dos tipos de tempo e a dinâmica dos elementos climáticos na cidade.

Do ponto de vista da temperatura do ar, Monteiro (1991) coloca que as coletas deveriam ser realizadas em períodos de estabilidade atmosférica, com a atuação de sistemas de alta 
pressão. Obviamente que as investigações sobre os impactos meteóricos demandariam um entendimento sobre os sistemas atmosféricos geradores de instabilidade atmosférica, que gerariam os eventos pluviométricos concentrados. Exemplificando a importância da circulação atmosférica para o entendimento do clima urbano.

No quinto enunciado, Monteiro aponta que “A avaliação dessa entrada de energia no S. C. U. deve ser observada tanto em termos quantitativos como, especialmente, em relação ao seu modo de transmissão" (MONTEIRO, 1976, p. 121).

Ressalta-se que nesse enunciado a preocupação se volta para o entendimento da complexidade do sistema, para isso, Monteiro traz a ideia "de diferença, que se avalia através daquele de estado, que conduz àquele de mudança e, finalmente, chega-se à transformação e ou mudança repetida" (MONTEIRO, 2013, p. 22).

Nesse contexto, deve-se entender o clima a partir da sucessão dos tipos de tempo (que definem o clima do ponto de vista geográfico) necessitando de um entendimento dos modos de transmissão, entrada e fluxo de energia através do sistema. Dessa forma a compreensão da dinâmica climática estará além dos valores médios.

Segundo Ugeda Júnior (2011), nesse ponto é necessário entender os fluxos de energia no sistema, "uma vez que, esse trânsito pressupõe um ritmo, e as alterações na forma e nos tipos de materiais causados pela urbanização vão alterar com maior ou menor intensidade todo o modo e ritmo como a energia e transmitida no SCU” (UGEDA JÚNIOR, 2011, p. 72)

No sexto enunciado, “A estrutura interna do S. C. U. não pode ser definido pela simples superposição ou adição de suas partes (compartimentação ecológica, morfológica ou funcional urbana) mas somente por meio da íntima conexão entre elas" (MONTEIRO, 1976, p. 122).

Esta prática é fundamental na abordagem sistêmica, a busca pelas tramas internas dos sistemas, em alguns casos é possível identificar as entradas e saídas, sem que se consiga decifrar o funcionamento do mesmo (black box).

Com isso, Monteiro (1976) revela que o Sistema Clima Urbano necessita de "integração entre os diferentes elementos, aglutinando-se em partes, caracterizando atributos que cujas relações dependem do desempenho e organização funcional do sistema" (MONTEIRO, 1976, p. 123). Desse modo a questão está voltada para a integração entre os elementos do sítio urbano com as diversas formas de uso e ocupação da terra, Pimentel (2016) nesse ponto, destaca as possibilidades trazidas pelos softwares de Geoprocessamento e as modelagens matemáticas, permitindo ampliar o conhecimento das relações dentro do Sistema Clima Urbano.

No sétimo enunciado, “o conjunto- produto do S. C. U. pressupõe vários elementos que caracterizam a participação urbana no desempenho do sistema. Sendo variada e heterogênea 
essa produção, faz-se mister uma simplificação classificadora que deve ser constituída através de canais de percepção humana” (MONTEIRO, 1976, p.24).

Monteiro apresenta que os produtos do SCU, são variados e produzidos de forma heterogênea, nesse momento o autor irá apontar os canais de percepção humana como uma forma de classificação (Figura 01). O canal de percepção de conforto térmico estará associado aos processos termodinâmicos. O canal qualidade do ar reflete os impactos da poluição na qualidade ambiental urbana. E o terceiro canal, denominado Meteoros do Impacto, congrega os eventos de ordem hídrica, que ao atingirem determinada intensidade, provocam impactos no meio urbano.

Figura 01: Diagrama básico do Sistema Clima Urbano- SCU.

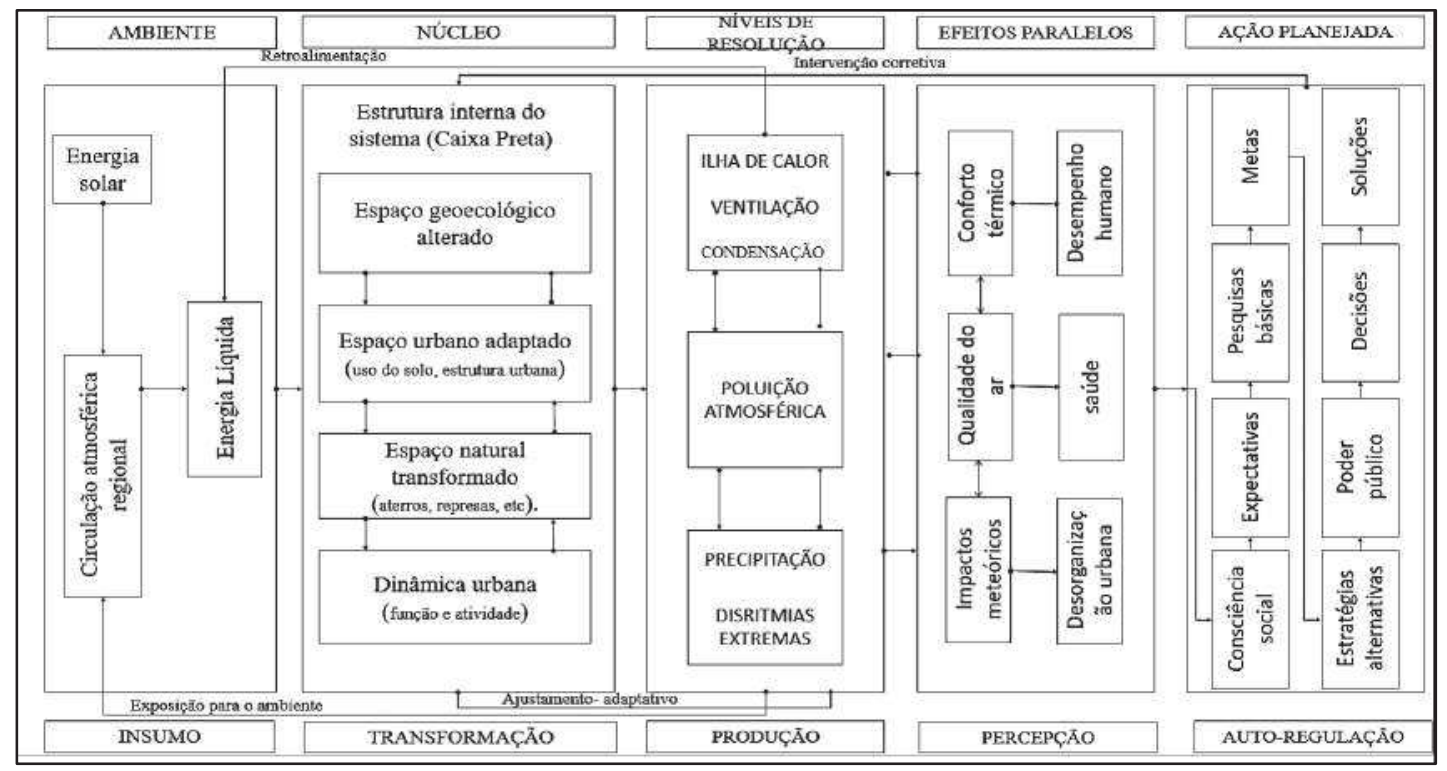

Fonte: Adaptado de Monteiro (1976).

Dessa forma, fica claro que a partir dos insumos atmosféricos, desencadeados inicialmente pela radiação solar e consequentemente a circulação atmosférica, diversos produtos são gerados na forma de efeitos, a partir da transformação dessa energia no núcleo do sistema, que é o espaço urbano, onde as atividades humanas com suas múltiplas formas de uso e ocupação da terra, compondo o operando do sistema.

No oitavo enunciado "a natureza urbana do S. C. U, implica em condições especiais de dinamismo interno consoante o processo evolutivo do crescimento e desenvolvimento urbano, uma vez que várias tendências ou expressões formais de estrutura se sucedem ao longo do processo de urbanização" (MONTEIRO, 1976, p.125).

Nesse ponto, diz respeito aos processos de evolução e crescimento urbano, enquanto um operando do sistema, "será muito importante para o SCU dispor de formas de expressão 
quantitativa de sua estrutura em segmentos temporais sequentes para que seja possível avaliar os graus de desenvolvimento de sua estrutura" (MONTEIRO, 2013, p.25). Sendo assim, se tornam importantes os levantamentos associados à própria evolução da mancha urbana investigada, se tratando de uma complexidade inerente os operando do sistema.

Além de considerar a velocidade desse processo, uma vez que em cidades de porte médio esse crescimento se deu de modo rápido, sem que houvesse propostas efetivas de planejamento, reduzindo a qualidade ambiental e de vida, nesses espaços. (PIMENTEL, 2018; UGEDA JÚNIOR e AMORIM, 2016).

O nono enunciado "o S. C. U. é admitido como passível de autorregulação, função essa conferida ao elemento homem urbano que, na medida em que o conhece e é capaz de detectar suas disfunções, pode, através do poder de decisão, intervir e adaptar o funcionamento do mesmo, recorrendo a dispositivos de reciclagem elou circuitos de retroalimentação capazes de conduzir o desenvolvimento e crescimento seguindo metas preestabelecidas" (MONTEIRO, 1976, p. 126).

Este enunciado destaca as possibilidades de autorregulação do sistema e as possibilidades de mitigação e reciclagem. Nesse sentido, o homem deve assumir essa função, principalmente os tomadores de decisão, pois a pesquisa científica dará os subsídios que poderão ser utilizados na reciclagem do sistema.

Nesse sentido é importante chamar a atenção para a necessidade de incorporar o clima ao planejamento urbano, com isso, “faz-se necessário a identificação de metodologias capazes de contemplar os elementos da natureza nos processos de planejamento, com a finalidade de minimizar os impactos ambientais inerentes ao processo de urbanização" (UGEDA JÚNIOR e AMORIM, 2016, p. 168).

Souza (2015) apresenta uma outra perspectiva, atentando para o fato de que no momento atual atuações efetivas de planejamento seriam pouco prováveis, uma vez que os interesses econômicos têm dominado a produção do espaço urbano. "Sendo assim, os critérios de ordem técnica e ambiental permanecem obscurecidos em face de critérios mercantis capazes de intervir no planejamento e na gestão das cidades” (SOUZA, 2015, p. 170).

O décimo e último enunciado "pela possibilidade de interferência autoreguladora, acrescentam-se ao S. C. U., como um sistema aberto, aquelas propriedades de entropia negativa pela sua própria capacidade de especialização dentro do crescimento através de processos adaptativos, podendo ser qualificado, assim, como um sistema morfogenético" (MONTEIRO, 1976, p.127). 
Nesse ponto Monteiro acrescenta aspectos relacionados às propriedades de entropia negativa, destaca que o sistema caminharia para uma entropia, que pode ser entendida como estado de desordem (UGEDA JÚNIOR e AMORIM, 2016) caso fossem mantidas as formas de uso e ocupação da terra e os modos de expansão urbana, no entanto, mesmo que de forma utópica, o homem a partir de suas ações ainda é capaz de reverter e elaborar reciclagens para o sistema.

Nesse enunciado o autor destaca que a visão de uma possível revitalização do SCU poderia ser encarada de forma utópica, mas que essa alteração caberá aos tomadores de decisão. O SCU será designado como um sistema morfogênico pois "poderá gerar, continuamente, variedade de forma e comportamento por meio de dinamismo peculiar de inter-relação com as partes que o constituem" (MONTEIRO, 2013, p.26). Dessa forma poderá o SCU ser direcionado de forma contrária aos impactos gerados pela atmosfera, bem como contra o aumento na transformação interna.

\section{Os canais de percepção: os subsistemas do Clima Urbano}

Dentro da construção do Sistema Clima Urbano, Monteiro (1976) assevera que o SCU admite vários níveis de entendimento e resolução em função da complexidade dos processos a ele associados, dessa forma, estabelece-se uma decomposição que visa favorecer a capacidade explicativa

Não se trata, aqui, de uma redução ao nível de elementos, mas uma aglutinação em conjuntos que, mantendo associação intrinsecamente atmosféricacomposição, comportamento e produção meteórica- são dirigidos à percepção sensorial e comportamental do habitante da cidade. (MONTEIRO, 1976, p. 161).

Entende assim como uma possibilidade operacional para a discussão geográfica do clima. O Quadro 01 permite visualizar a organização dos subsistemas a partir de suas características, favorecendo os paralelos entre os canais de percepção, com isso ficam estabelecidos alguns aspectos relacionados aos subsistemas termodinâmico, físico químico e o hidrometeórico.

Quadro 01: Comparação entre os canais de percepção do Sistema Clima Urbano-SCU.

\begin{tabular}{|c|c|c|c|}
\hline $\begin{array}{r}\text { Subsistemas } \\
\text { Canais }\end{array}$ & $\begin{array}{c}\text { I } \\
\text { Termodinâmico } \\
\text { (Conforto Térmico) }\end{array}$ & $\begin{array}{c}\text { II } \\
\text { Físico- Químico } \\
\text { (Qualidade do ar) }\end{array}$ & $\begin{array}{c}\text { III } \\
\text { Hidrometeórico } \\
\text { (Impacto Meteórico) }\end{array}$ \\
\hline
\end{tabular}




\begin{tabular}{|c|c|c|c|}
\hline Fonte & $\begin{array}{l}\text { Atmosfera, radiação, } \\
\text { circulação horizontal }\end{array}$ & $\begin{array}{c}\text { Atividade urbana, } \\
\text { veículos automotores } \\
\text { Indústrias, Obras- } \\
\text { Limpeza }\end{array}$ & $\begin{array}{l}\text { Atmosfera; estados } \\
\text { especiais (Desvios } \\
\text { rítmicos). }\end{array}$ \\
\hline Trânsito no sistema & $\begin{array}{c}\text { Intercâmbio operador e } \\
\text { operando }\end{array}$ & De operando a operador & Do operador ao operando \\
\hline Mecanismo de ação & Transformação no sistema & $\begin{array}{c}\text { Difusão através do } \\
\text { sistema }\end{array}$ & Concentração no sistema \\
\hline Projeção & $\begin{array}{l}\text { Interação Núcleo e } \\
\text { ambiente }\end{array}$ & Do núcleo ao ambiente & Do ambiente ao núcleo \\
\hline Desenvolvimento & Contínuo (permanente) & Cumulativo (renovável) & Episódico (eventual) \\
\hline Observação & $\begin{array}{l}\text { Meteorológica especial ( } \mathrm{T} \text {. } \\
\text { de campo) }\end{array}$ & $\begin{array}{c}\text { Sanitária e meteorológica } \\
\text { especial }\end{array}$ & $\begin{array}{c}\text { Meteorológica e } \\
\text { hidrológica (T. de } \\
\text { Campo) }\end{array}$ \\
\hline $\begin{array}{c}\text { Correlações disciplinares } \\
\text { e tecnológicas }\end{array}$ & $\begin{array}{c}\text { Bioclimatologia, } \\
\text { Arquitetura e Urbanismo }\end{array}$ & Engenharia Sanitária & $\begin{array}{l}\text { Engenharia Sanitária e } \\
\text { infraestrutura urbana }\end{array}$ \\
\hline Produtos & $\begin{array}{l}\text { "Ilhas de Calor" Ventilação, } \\
\text { Aumento de precipitação }\end{array}$ & Poluição do Ar & $\begin{array}{c}\text { Ataques à integridade } \\
\text { urbana }\end{array}$ \\
\hline Efeitos diretos & $\begin{array}{l}\text { Desconforto e redução do } \\
\text { desempenho humano }\end{array}$ & $\begin{array}{c}\text { Problemas sanitários, } \\
\text { doenças respiratórias e } \\
\text { oftalmológicas }\end{array}$ & $\begin{array}{l}\text { Problemas de circulação e } \\
\text { comunicação urbana }\end{array}$ \\
\hline Reciclagem adaptativa & $\begin{array}{l}\text { Controle do uso do solo, } \\
\text { tecnologia de conforto } \\
\text { habitacional }\end{array}$ & $\begin{array}{l}\text { Vigilância e controles dos } \\
\text { agentes de poluição }\end{array}$ & $\begin{array}{l}\text { Aperfeiçoamento da } \\
\text { infraestrutura urbana e } \\
\text { regularização fluvial, uso } \\
\text { do solo }\end{array}$ \\
\hline Responsabilidade & Natureza e Homem & Homem & Natureza \\
\hline
\end{tabular}

Fonte: Adaptado de Monteiro, 1976.

O subsistema I- Termodinâmico, está associado a questões relacionadas ao conforto térmico e todos os processos relacionados às variações da temperatura no espaço urbano, tendo na coparticipação entre o homem e a natureza os seus responsáveis.

O subsistema II- Físico- Químico envolve os processos relacionados à qualidade do ar e a poluição urbana, visando seus reflexos na saúde humana, tendo nas atividades humanas o seu principal responsável.

Por fim, o subsistema III- Hidrometeórico, relacionado aos impactos meteóricos, visa compreender os impactos das chuvas nas cidades e como estas podem interferir nas atividades humanas, através dos alagamentos, inundações, enchentes e movimentos de massa. Nesse subsistema, Monteiro destaca o papel de responsabilidade da Natureza, através da circulação atmosférica, nos impactos gerados na cidade. 
Alguns autores como Mendonça (2003, 2004b), Sant'Anna Neto (2001, 2008), Romero e Mendonça (2012), Armond (2014, 2018), Murara (2016) e Nascimento Júnior (2018, 2019) chamam a atenção para o fato de que os modos de produção desigual do espaço poderiam figurar como elementos responsáveis pelos impactos gerados nas cidades. Pautando-se numa abordagem de "desnaturalização" dos impactos buscando uma visão crítica acerca da produção do espaço, se comportando como pontos divergentes à proposta de Monteiro. Esses pontos serão levantados com mais detalhe posteriormente.

\section{O subsistema Hidrometeórico: Os impactos pluviométricos}

O subsistema hidrometeórico diferencia-se dos outros subsistemas, o termodinâmico e o físico-químico, do ponto de vista da responsabilidade. Nesse sentido a ação da natureza assume o papel de destaque uma vez que estes eventos se originam de insumos inerentes à circulação atmosférica regional, repercutindo assim como impactos no espaço urbano das cidades.

Os eventos causadores dos impactos irão representar os desvios em relação aos padrões de circulação atmosférica habituais e, consequentemente, os impactos meteóricos serão variáveis ao redor da terra em função das dinâmicas climáticas locais (MONTEIRO, 2003). Monteiro (1976) destaca ainda que dificilmente há um ano em que diversas cidades brasileiras não são impactadas por eventos pluviométricos extremos, destacando ainda a incapacidade por parte dos tomadores de decisão em propor medidas que realmente visem a mitigação desses impactos.

Além disso, Monteiro (1976) acrescenta que estudos acerca desse subsistema (Figura 02) devem estar associados à investigação das gêneses dos eventos, bem como as possibilidades e os mecanismos de defesa. No sudeste do Brasil, como exemplifica Monteiro, algumas configurações atmosféricas associadas à dinâmica das frentes frias ocasionam e provocam a ocorrência dos aguaceiros intensos, principalmente na primavera e no verão.

Do ponto de vista das possibilidades de mitigação dos impactos, deve-se atentar para uma análise da drenagem, entendendo que o núcleo do sistema é o ambiente que o integra. Além disso, revela-se importante uma análise do sítio urbano, e as suas relações com as formas de uso e ocupação da terra. "Ninguém poderá impedir que chova violenta e concentradamente. As medidas de reação têm sido incipientes, paliativas e mal planejadas" (MONTEIRO, 1976, p. 174). 
As medidas de planejamento das cidades devem partir de ações atreladas à racionalização do uso do solo urbano, além de atividades voltadas ao aperfeiçoamento das estruturas de drenagem urbana. Salienta ainda a importância das áreas verdes no processo de mitigação dos impactos do clima urbano, seja qual for o subsistema a vegetação terá um aspecto fundamental na qualidade do ambiente. As áreas verdes "constituem verdadeiras válvulas reguladoras do escoamento, pela possibilidade de infiltração em meio a massa de edificações e ruas pavimentadas" (MONTEIRO, 1976, p. 175).

Nesse subsistema a entrada de energia será dada pela própria sucessão dos tipos de tempo e os sistemas atmosféricos associados, cabendo destacar aspectos como frequência, intensidade e duração dos eventos, o operando do sistema, no caso a cidade e sua massa construída de edificações irá transformar essa energia dentro do sistema, e com isso podemos destacar os aspectos relacionados à drenagem urbana, ao uso e ocupação da terra, fazendo com que as precipitações se tornem elementos danosos à organização urbana (Figura 02).

Produz-se então ocorrências como inundações, alagamentos, enchentes, movimentos de massa, acúmulo de detritos, que serão percebidos pela população na forma de transtornos à circulação de bens e serviços, à própria circulação diária da cidade. Estas ocorrências podem causar mortes em função da exposição dos citadinos a esses impactos, sejam por movimentos de massa, deslizamentos, ou mesmo afogamentos, e problemas de saúde ocasionados por doenças de veiculação hídrica.

Desse modo, os eventos concentrados de precipitação têm tido uma capacidade deveras danosa nos espaços urbanos, em função das alterações humanas neles processados, e com isso as chuvas obstruem sobremaneira o desenvolvimento habitual das atividades humanas. Cabe então reforçar pesquisas nesse sentido, conforme colocado no enunciado dez, citado anteriormente, para buscar possibilidades de adaptação a estes eventos extremos. 
Figura 02: Canal III- Impacto Meteórico (Subsistema Hidrodinâmico).

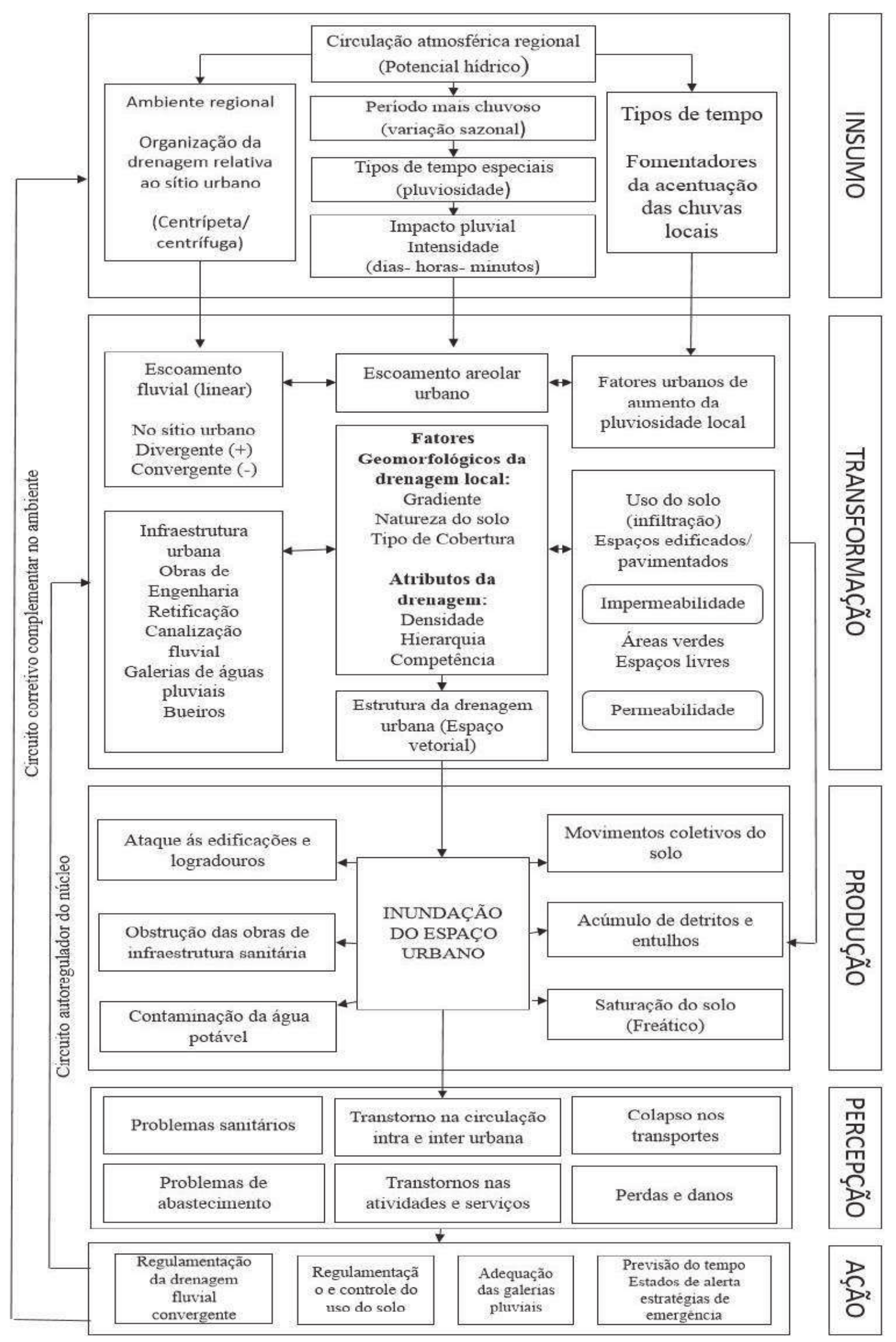

Fonte: Adaptado de Monteiro (1976). 


\section{O clima urbano e a necessidade de uma abordagem interescalar}

Dentro das questões apontadas na construção do Sistema Clima Urbano, Monteiro (1976), demonstra uma preocupação com as escalas, indicando sempre uma inter-relação entre processos que se manifestam a partir de diversos níveis. A preocupação, dessa forma, não deve se direcionar ao estabelecimento de limites escalares rígidos, mas sim, de buscar respostas para as perguntas “Que está dentro de quê? Quais são os elementos que compõem o conjunto? Em que níveis escalares os elementos podem ser posicionados?" (MONTEIRO, 1976, p.132). Pois para ele, seguindo a abordagem sistêmica, "o que importa são as relações entre elas (as partes), liames esses que conduzem à organização funcional” (MONTEIRO, 1976, p. 131).

Inicialmente Monteiro utiliza como base o quadro taxonômico proposto por Tricart e Cailleux (1956) como inspiração para a proposição das unidades climáticas (Quadro 02), uma vez que estas estariam, em certa medida, próximas às estabelecidas pela Geomorfologia. No entanto, é necessário destacar que estas serviriam apenas como uma referência, e não como limites rígidos.

Quadro 02: Categorias taxonômicas e organização geográfica do clima.

\begin{tabular}{|c|c|c|c|c|c|c|c|}
\hline \multirow{2}{*}{$\begin{array}{c}\text { Ordens de } \\
\text { grandeza }\end{array}$} & \multirow{2}{*}{$\begin{array}{l}\text { Unidades } \\
\text { de } \\
\text { Superfície }\end{array}$} & \multirow{2}{*}{$\begin{array}{c}\text { Escalas } \\
\text { cartográficas } \\
\text { de tratamento }\end{array}$} & \multirow{2}{*}{$\begin{array}{l}\text { Espaços } \\
\text { climáticos }\end{array}$} & \multirow{2}{*}{$\begin{array}{l}\text { Espaços } \\
\text { Urbanos }\end{array}$} & \multicolumn{3}{|c|}{ Estratégias de abordagem } \\
\hline & & & & & $\begin{array}{c}\text { Meios de } \\
\text { observação }\end{array}$ & $\begin{array}{c}\text { Fatores de } \\
\text { organização }\end{array}$ & $\begin{array}{l}\text { Técnica de } \\
\text { análise }\end{array}$ \\
\hline II & $\begin{array}{c}10^{6} \\
\text { milhões } \\
\text { de Km }\end{array}$ & $\begin{array}{l}1: 45.000 .000 \\
1: 10.000 .000\end{array}$ & Zonal & - & $\begin{array}{c}\text { Satélites } \\
\text { Nefanálises }^{3}\end{array}$ & $\begin{array}{c}\text { Latitude } \\
\text { Centros de ação } \\
\text { atmosférica }\end{array}$ & $\begin{array}{c}\text { Caracterizaçã } \\
\text { o geral } \\
\text { Comparativa }\end{array}$ \\
\hline III & $\begin{array}{c}10^{4} \\
\text { milhares } \\
\text { de } \mathrm{Km}\end{array}$ & $\begin{array}{l}1: 5.000 .000 \\
1: 2.000 .000\end{array}$ & Regional & - & \multirow{2}{*}{$\begin{array}{c}\text { Cartas } \\
\text { sinóticas } \\
\text { Sondagens } \\
\text { Aerológicas } \\
\text { Rede } \\
\text { meteorológi } \\
\text { ca de } \\
\text { superfície }\end{array}$} & $\begin{array}{c}\text { Sistemas } \\
\text { meteorológicos } \\
\text { (Circulação } \\
\text { secundária) }\end{array}$ & $\begin{array}{l}\text { Redes } \\
\text { Transectos }\end{array}$ \\
\hline IV & $\begin{array}{l}10^{2} \text { centen } \\
\text { as de } \mathrm{Km}\end{array}$ & $\begin{array}{c}1: 1.000 .000 \\
1: 500.000\end{array}$ & $\begin{array}{c}\text { Sub- } \\
\text { Regional } \\
\text { (Fácies) }\end{array}$ & $\begin{array}{l}\text { Megalópole } \\
\text { Grande área } \\
\text { Metropolitana }\end{array}$ & & $\begin{array}{l}\text { Fatores } \\
\text { geográficos } \\
\text { regionais }\end{array}$ & $\begin{array}{l}\text { Mapeamento } \\
\text { sistemático }\end{array}$ \\
\hline V & $\begin{array}{c}10 \\
\text { dezenas } \\
\text { de } \mathrm{Km}\end{array}$ & $\begin{array}{l}1: 250.000 \\
1: 100.000\end{array}$ & Local & $\begin{array}{c}\text { Área } \\
\text { metropolitana } \\
\text { Metrópole }\end{array}$ & $\begin{array}{c}\text { Posto } \\
\text { meteorológi } \\
\text { co } \\
\text { Rede } \\
\text { complement } \\
\text { ar }\end{array}$ & $\begin{array}{c}\text { Interação } \\
\text { geoecológica } \\
\text { Ação antrópica }\end{array}$ & $\begin{array}{l}\text { Análise } \\
\text { espacial }\end{array}$ \\
\hline VI & $\begin{array}{c}10^{-2} \\
\text { centenas } \\
\text { de } \mathrm{km}\end{array}$ & $\begin{array}{l}1: 50.000 \\
1: 25.000\end{array}$ & $\begin{array}{c}\text { Mesoclim } \\
\text { a }\end{array}$ & $\begin{array}{l}\text { Cidade grande } \\
\text { Bairro ou } \\
\text { subúrbio de } \\
\text { metrópole }\end{array}$ & $\begin{array}{l}\text { Registros } \\
\text { móveis } \\
\text { (Episódios) }\end{array}$ & Urbanismo & \multirow{3}{*}{ Especiais } \\
\hline- & $\begin{array}{l}\text { Dezenas } \\
\text { de metros }\end{array}$ & $\begin{array}{c}1: 10.000 \\
1: 5.000\end{array}$ & $\begin{array}{c}\text { Topoclim } \\
\text { a }\end{array}$ & $\begin{array}{l}\text { Pequena } \\
\text { cidade } \\
\text { Fácies de } \\
\text { bairro/subúrbi } \\
\text { o de cidade }\end{array}$ & (Detalhe) & Arquitetura & \\
\hline- & Metros & $1: 2.000$ & $\begin{array}{c}\text { Microclim } \\
\text { a }\end{array}$ & $\begin{array}{c}\text { Grande } \\
\text { edificação } \\
\text { Habitação }\end{array}$ & $\begin{array}{l}\text { Baterias de } \\
\text { instrumento } \\
\mathrm{s} \text { especiais }\end{array}$ & Habitação & \\
\hline
\end{tabular}

\footnotetext{
${ }^{3}$ Nefanálise: Investigação sinótica a partir do mapa meteorológico.
} 


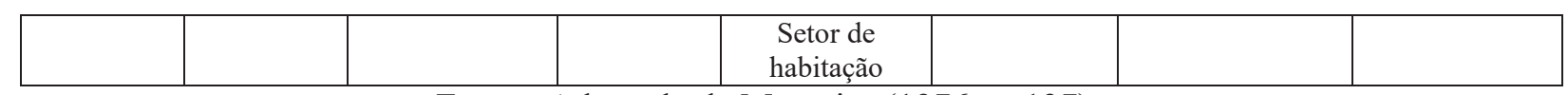

Fonte: Adaptado de Monteiro (1976, p. 137).

Nesse ínterim Monteiro (1999) chamando a atenção para os problemas das escalas geográficas do clima, assevera que

Quando enunciamos o clima de um lugar (espaço) é a resultante do comportamento dinâmico mais habitual ou recorrente da atmosfera, cronologicamente desenvolvido (tempo) sobre aquele dado lugar, teremos que definir que lugar é este. Ele pode variar desde o globo terrestre, passando pelos continentes, regiões países até atingir um dado lugar (ponto) que pode ser uma pequena ilha, uma grande, média ou pequena cidade que por sua vez, poderá ser subdividida em bairros, setores, ruas, etc. (MONTEIRO, 1999, p.10).

Visando uma abordagem a partir dos níveis de organização, Monteiro (1976) utiliza a ideia de hierarquia, desenvolvida por Koestler na qual o autor estabelece uma relação entre hierarquia e uma árvore viva (Figura 03), esclarecendo que "fazendo um corte transversal e projetando-o no plano horizontal, a visão dinâmica da arborescência transforma-se na visão estética do reticulado, reveladora da estrutura, em termos do embutimento das partes em dado conjunto" (MONTEIRO, 2013, p. 31), esta ideia se apresenta de forma mais dinâmica "por revelar as relações entre as partes e, sobretudo por admitir implicitamente a noção de crescimento e evolução do sistema” (MONTEIRO, 1976, p. 141).

A figura 03 permite visualizar o escalonamento entre as unidades, desde o nível zonal ao local, "Do tronco inicial da superfície (nível 1), passam a desdobrar-se os grandes galhos da organização zonal (nível 2), dos quais emergem os galhos regionais (nível 3) até os ramos locais (nível 4) " (MONTEIRO, 1976, p. 143), assim sendo, o processo pode ser repetido partindo do nível local para as inúmeras relações meso, topo e microclimáticas, como representado na parte esquerda da figura.

Essa proposição revela que no nível zonal há uma diversificação a partir de um todo, orquestrada pelo fator latitude, definindo as células de circulação. A partir disso se organizaria numa posição macrorregional os centros de ação e os sistemas atmosféricos zonais, levando a uma organização climática (MONTEIRO, 1976).

A sucessão dos sistemas atmosféricos seria responsável pela organização climática regional, "os elos e afinidades espaciais estariam para ser encontrados, portanto, no ritmo, no modo de variação e no quantum expresso pelos elementos discretos em que se pode reduzir o tempo ou condições atmosféricas" (MONTEIRO, 1976, p. 144). 
Figura 03: Noção de hierarquia proposta por Koestler, utilizada por Monteiro (1976).

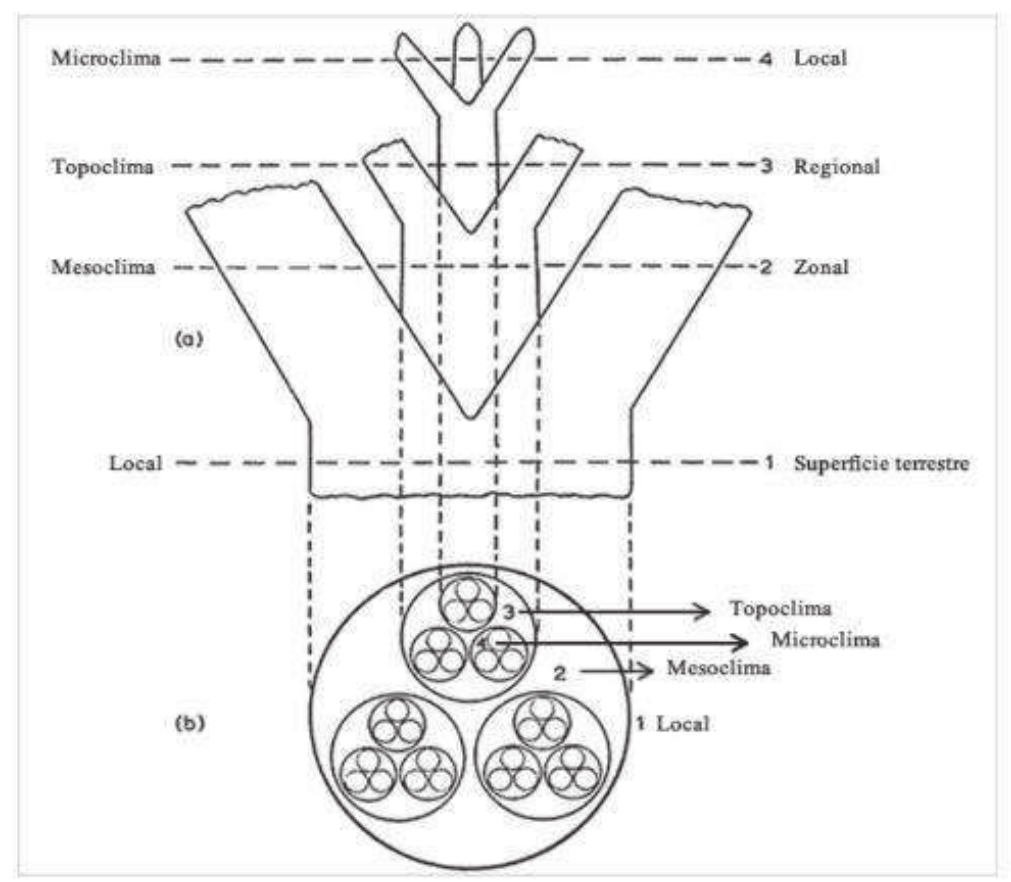

Fonte: Adaptado por Vianna (2018).

Assim seria possível o entendimento da “organização dos sistemas climáticos regionais, de vez que a solidariedade espacial é mantida através do próprio comportamento atmosférico e suas propriedades mais intensivas” (MONTEIRO, 1976, p. 144), e na sequência, a relação entre os fatores geográficos definiria uma "nova gama de diversificações secundárias e intermediárias (variações rítmicas associadas a grandes expressões quantitativas) até atingir os climas locais" (MONTEIRO, 1976, p.145).

A diversificação do clima local está associada "inicialmente ao nível de sua compartimentação geoecológica, base mesma da identificação dos mesoclimas, passando a organizar-se no nível dos topoclimas e especializar-se nos microclimas" (MONTEIRO, 2013, p. 35).

Monteiro (1999, p. 27) coloca que

Se um clima urbano é um ponto dentro do regional onde a conjugação de fatores "especializa" uma certa definição climática, nos locais ocupados por cidades, a ocorrência destes fatores constitui um espectro bem mais amplo pelas grandes derivações introduzidas pelo homem na edificação urbana.

Dito isso, devemos considerar que do ponto de vista regional, se tratando do contexto tropical, seria comum a ocorrência de elevados totais pluviométricos, no entanto a multiplicidade de formas de uso e ocupação da terra fazem com que os elementos climáticos produzam efeitos danosos para as organizações humanas. 
Assim, com a crescente impermeabilização do solo, as alterações nos sistemas de drenagem e as construções em locais susceptíveis a movimentos de massa tem agravado os impactos associados às chuvas intensas, principalmente se entendermos a cidade, núcleo do sistema, e como produtora de espaços desiguais, direcionando as pessoas com menor poder econômico para as áreas desprovidas de condições de habitação, e mais susceptíveis aos impactos climáticos.

Entender os extremos pluviométricos a partir das diversas escalas, revela que desde a gênese do fenômeno até os impactos gerados na cidade, existe uma gama de interações complexas que necessitam ser investigadas, principalmente, se tratando das mudanças climáticas globais e os possíveis impactos dela no nível local, no urbano.

\section{O clima urbano e as chuvas nas cidades}

Gonçalves (2013) pesquisa os impactos pluviais e a desorganização no espaço urbano de Salvador. Do ponto de vista metodológico utiliza-se dos dados de precipitação oriundos de dados do INMET e as ocorrências de problemas socioespaciais foram coletados junto a levantamento documental nos jornais, além das bases de dados da Defesa Civil. Além disso aponta para uma investigação acerca da gênese dos eventos extremos pluviométricos, respeitando "a necessária articulação geográfica entre o local e o regional” (GONÇALVES, 2013, p. 79).

Os impactos na cidade foram espacializados e analisados em função das condições de sítio e da ocupação, sendo que "as variáveis topografia, morfologia, declividade, drenagem natural, uso do solo e infraestrutura urbana de macro e microdrenagem foram, evidentemente, consideradas, numa tentativa de integração ecológico- urbana" (GONÇALVES, 2013, p. 79), além disso, os eventos extremos foram categorizados em função da sua intensidade a partir de $60 \mathrm{~mm} / 24 \mathrm{~h}$.

(GONÇALVES, 2013) observa uma recorrência nos eventos, no período de outonoinverno, período de chuvas mais concentradas em Salvador, bem como uma elevação no número de impactos ao longo do período investigado (de 1904-1989). Estabelece ainda uma cartografia de localização dos impactos, com base na carta topográfica e termina destacando que a ampliação da mancha urbana de modo desordenado estaria levando a uma ampliação na ocorrência dos impactos, uma vez que, cada vez mais, as pessoas estariam ocupando áreas de risco. Apesar de avançar nas discussões sobre a vulnerabilidade social, seu trabalho utiliza-se da teoria de Monteiro. 
Souza (2003) avalia a relação entre chuva e deslizamentos na região Noroeste da cidade de Juiz de Fora, destacando a ocorrência dos eventos a partir de uma abordagem genética. Destaca que a passagem de sistemas frontais foi capaz de desencadear eventos pluviométricos causadores de deslizamentos, além disso destaca que "os escorregamentos nas encostas, muito mais do que meros fenômenos de ordem físico-natural, envolvem outros importantes aspectos, como a exclusão e a segregação socioespacial” (SOUZA, 2003, p. 98).

Lucas (2007) analisou os impactos das chuvas em Belo Horizonte - MG, utilizando-se da análise rítmica para a identificação de eventos com atuação da Zona de Convergência do Atlântico Sul (ZCAS) destaca a interação entre o escoamento em baixos níveis e os sistemas frontais na gênese de eventos extremos na área estudada.

Lima (2012) buscou investigar os impactos das chuvas no espaço urbano de São CarlosSP, destacou que o aumento da impermeabilização do solo decorrente do crescimento urbano da cidade, repercutiu em um aumento das inundações, alagamentos e enchentes na cidade. Colocou ainda que o acervo histórico da mídia impressa forneceu subsídios para o entendimento histórico e espacial dos impactos no espaço urbano.

Destaca-se a partir dos trabalhos de Gonçalves (1992), Souza (2003), Lima (2012) um interesse pelos impactos da chuva na cidade, a partir de uma visão de gênese, aspectos geomorfológicos e a localização desses impactos na cidade. No entanto, pouco aprofundam acerca de quem são os sujeitos impactados por estes eventos extremos.

Para além das questões levantadas por Monteiro, Sant'Anna Neto (2001;2008) propõe uma visada dentro da proposta do Sistema Clima Urbano voltada para um olhar social e crítico, discutindo a necessidade de um tratamento eminentemente geográfico ao clima. Com isso pretende-se traçar os elementos fundamentais por trás dessa construção teórica, trazendo as questões primordiais para a investigação do clima urbano.

\section{Por uma Geografia do Clima de João Lima Sant'Anna Neto: a necessidade de uma abordagem crítica}

Sant'Anna Neto (2001) entende que a superfície terrestre, dominada pelo modo de produção capitalista, inicia um processo de produção de ambientes diferenciados e, nesse sentido, a superfície alterada de forma desigual, levaria a uma diferenciação na repercussão dos eventos climáticos, em função das diferentes possibilidades de construção.

Dessa forma o conhecimento climático deve ir além da abordagem já realizada por outras ciências, como a Meteorologia, destacando esta como um elemento fundamental de 
diálogo, sobretudo aprimorando técnicas amplamente utilizadas no bojo da Climatologia, no entanto, é necessário encarnar um componente social, partindo para uma abordagem eminentemente geográfica do clima, e

Isso significa, necessariamente, compreender que a repercussão dos fenômenos atmosféricos na superfície terrestre se dá num território, em grande parte, transformado e produzido pela sociedade de maneira desigual e apropriado segundo os interesses dos agentes sociais (SANT'ANNA NETO, 2001, p. 58).

Com isso, "o efeito dos tipos de tempo sobre um espaço construído de maneira desigual gera problemas de origem climática também desiguais" (SANT’ ANNA NETO, 2001, p. 58), Nascimento Júnior (2018) coloca que a cidade deixa de ser apenas o receptáculo dos eventos pluviométricos e passa-se a compreendê-los como produtos da própria desigualdade inerente à cidade.

Armond (2014) destaca a necessidade da abordagem rítmica para o entendimento da gênese dos fenômenos atmosféricos e a partir disso entender os seus reflexos no espaço geográfico da cidade. A autora destaca, ainda, que a guinada em direção a uma abordagem crítica da produção do espaço marca a ideia de uma Geografia do Clima a partir de Sant'Anna Neto $(2001,2008)$.

Dentro dessa perspectiva, Armond (2014) coloca em seu estudo sobre as inundações na cidade do Rio de Janeiro-RJ e suas repercussões no urbano, que as inundações e os alagamentos estão muito atrelados a alterações históricas de produção desigual do espaço urbano da cidade. Além disso, como elemento metodológico a autora explorou a localização dos eventos extremos e suas relações com a produção daquele espaço impactado.

Murara (2016) estudando as inundações na bacia do rio Itajaí-SC, parte da consideração de que a população de menor renda se estabelece nas porções mais próximas ao rio e, por conseguinte, estão mais vulneráveis aos impactos das inundações. Destaca que "embora as forçantes socionaturais que impulsionam a gênese dos desastres, abarcam escalas diversas, local, regional e/ou global. Os impactos serão vivenciados principalmente na escala local, repercutindo no cotidiano dos indivíduos" (MURARA, 2016, p. 58).

Nascimento Júnior (2018) investiga o clima urbano a partir de cidades litorâneas de clima tropical, em três países distintos: Santos (Brasil), Maputo (Moçambique) e Brisbane (Austrália). O autor constrói sua investigação do clima urbano nessas cidades a partir de uma noção de risco, o risco climático, aponta a vulnerabilidade social como um elemento importante para a análise das chuvas nas cidades e complementa que 
A composição de diferentes níveis de vulnerabilidade, então, será a condição que expressa a experiência historicamente produzida na apropriação da natureza. Este elemento faz com que o espaço urbano seja o plano de fundo para a construção social do clima urbano, que em última instância constitui com o perigo é relativizado, os impactos tornam-se seletivos, a vulnerabilidade seja latente e o risco imanente. (NASCIMENTO JÚNIOR, 2018, p. 158).

Tavares (2010) Tavares e Mendonça (2014) analisaram a relação entre impactos pluviais e deslizamentos de terra na Serra do Mar no Estado de São Paulo, colocam que a partir de uma análise do ritmo climático e do ritmo do crescimento urbano, ou seja, uma imbricação entre esses fatores. Conclui que o crescimento urbano se prolonga para áreas naturalmente susceptíveis a desastres, elevando "o grau de vulnerabilidade da população a esses processos" (TAVARES e MENDONÇA,2014, p.111).

\section{Do Sistema Clima Urbano à Geografia do Clima}

A partir dessas duas colocações teóricas, Monteiro visando aprimorar e desenvolver o estudo do clima urbano ainda na década de 1970 e Sant'Anna Neto com as discussões acerca de uma abordagem crítica do clima urbano, sobretudo a partir dos anos 2000, apresentam algumas convergências, mas também algumas reflexões, que devem ser pontuados.

A necessidade de uma acurada investigação da circulação atmosférica através de seus ritmos e padrões extremos segue sendo ponto comum nas duas abordagens, ou seja, a busca pelo entendimento da atmosfera e seus processos é defendida por ambos.

Entretanto, uma diferenciação importante e talvez central nas duas abordagens esteja associado ao respectivo arcabouço teórico, pois Monteiro (1976) apoia o estudo do clima urbano em uma abordagem sistêmica, acoplada à Teoria Geral dos Sistemas de Ludwig Von Bertallanfy. Sant'Anna Neto irá se basear em leituras crítico-marxistas dos modos de produção da sociedade no capitalismo e na produção desigual do espaço urbano.

Dentro da abordagem sistêmica que Monteiro muito se apropria, considera o estudo do "ser humano" através de uma visão como elemento "antrópico" e com isso visa entender a partir de uma perspectiva organísmica como este interfere nos fatos naturais, entendendo de forma "biologizada" o homem, como coloca Ferreira et al (2012).

Rodrigues e Silva (2019, p. 33) destacam que

O foco central da teoria dos Geossistemas (discutindo a abordagem de Sochava) é o estudo da dinâmica do meio natural, que abre caminhos diretos para a compreensão científica da influência do ser humano sobre a estrutura e 
o funcionamento dos Geossistemas, ajudando a descobrir o mecanismo dos impactos antropogênicos sobre a natureza (RODRIGUES e SILVA, 2019, p.33).

Desse modo, ainda que vise uma abordagem integrada e sistêmica, ao longo da montagem do Sistema Clima Urbano, em seus enunciados, Monteiro coloca que a circulação atmosférica regularia como "operadora" do sistema, determinando a entrada de energia, desse modo o espaço construído da cidade, viria a ser um receptáculo dessa energia, ou o que chama de operando do sistema, seja em seus estados habituais, como também durante os eventos extremos. Observando comparativamente com a leitura de Sant'Anna Neto essa ideia estaria relativizando a lógica de produção do espaço e levando a uma naturalização dos processos.

Dentro dos subsistemas de Monteiro (1976), como já apresentado no quadro 01, no caso do hidrometeórico é dada a responsabilidade dos eventos para a NATUREZA, sendo que estes estariam associados à dinâmica e ao ritmo climático dos eventos extremos. Essa consideração talvez seja o ponto de maior diferença entre as abordagens de Monteiro e Sant'Anna Neto, pois é justamente para este espaço construído que o segundo irá desenvolver e defender argumentos que advogam para a necessidade de um aprofundamento no olhar para esse espaço.

Sant'Anna Neto (2001) com uma abordagem crítico-marxista da produção do espaço irá defender que a produção do espaço urbano através do modo capitalista engendra uma seletividade espacial, capaz de gerar um quadro em que as condições de vulnerabilidade social se tornem elemento importante na consubstanciação espacial dos impactos decorrentes dos elementos climáticos. Com isso, no caso da precipitação, esta poderá impactar de forma mais profunda aqueles sujeitos que já vivem em uma condição de vulnerabilidade social.

A partir disso, considera-se que a abordagem de Monteiro será importante no sentido de trazer os elementos teórico-metodológicos para uma leitura da atmosfera a partir do ritmo climático e da sucessão dos tipos de tempo, geradores das excepcionalidades e dos eventos extremos, ou seja para um olhar da atmosfera para a superfície. No entanto, essa superfície socialmente produzida, necessita de caminhos teóricos para um melhor desvelamento de seus processos e para isso as colocações de Sant'Anna Neto se fazem importantes e necessárias.

No presente trabalho visualiza-se duas necessidades de investigação, uma primeira endereçada à atmosfera e a gênese dos eventos extremos e suas considerações em termos atmosféricos, mas também vislumbra-se que a investigação acerca da produção daquele espaço construído se fará importante no sentido de visualizar que para além da ocorrência dos eventos extremos, existem outros atores e processos que interferem na localização e ocorrência dos impactos ocasionados pelas chuvas. 


\section{De Monteiro a Sant'Anna Neto: o que mudou no estudo das cidades para a climatologia}

No início dos anos de 1960, a Geografia e a Geografia Urbana passavam a deixar de lado as leituras "empírico-naturalistas", como coloca Barcelos (2010, p.18), e ocorre um direcionamento das investigações discutindo sobretudo na perspectiva econômica. Daí em diante a utilização das técnicas matemático-estatísticas passam a se fazer mais constantes, culminando no que a partir de 1968 seria chamado de a nova Geografia (New Geography) (BARCELOS, 2010).

Para a Nova Geografia ou Geografia Neopositivista ou revolução quantitativa, que se desenvolveu na década de 1970, a cidade passa a ser visualizada de forma neutra, de acordo com Corrêa (1989, p. 121) "a geografia teórico-quantitativa introduziu nos estudos interurbanos uma perspectiva que considera a cidade e suas relações socioespaciais como "coisas"”, dessa forma os estudos estavam interessados nos aspectos da forma e dos padrões espaciais da cidade, sem que visualizassem os processos e os interesses por detrás da produção do espaço urbano.

A tese de Livre docência- Teoria e Clima Urbano, de Monteiro (1976), se inscreve em um momento em que a geografia urbana discutia formas de empreender avanços nos estudos das cidades. Sendo que, ainda nesse período, se baseava em estudos quantitativos que visavam investigar os padrões espaciais da cidade.

A construção de Monteiro (1976), se baseia então nesses referenciais, que visualizavam a cidade a partir dos padrões e das formas espaciais, pouco investigando os processos por trás da produção do espaço urbano. Monteiro (1976) defende ainda que nesse momento a geografia urbana Brasileira havia deixado de lado as investigações sobre a questão ambiental urbana e passado a se interessar sobremaneira pelas abordagens associadas em questões socioeconômicas, com isso ele estaria buscando uma forma de retomar os estudos das cidades com base em uma profunda relação entre sociedade e natureza.

Assim, toda construção teórica baseada em abordagens críticas do espaço urbano iriam ocorrer posteriormente à construção da Teoria e Clima Urbano. É nesse cenário que desponta para o estudo do clima das cidades a proposta teórica de Sant'Anna Neto, vislumbrando o seu olhar para o que chamou de Geografia do Clima, onde justamente busca integrar a leitura do clima urbano a uma abordagem crítica acerca da produção do espaço. 
As críticas viriam ao longo do $3^{\circ}$ Encontro Nacional dos Geógrafos, em 1978, de acordo com Barcelos (2010) se discutia a necessidade de uma abordagem mais profunda acerca dos processos, que resultariam nas formas urbanas.

É nesse período que, segundo Barcelos (2010, p. 20) “procura-se romper o isolamento do geógrafo aceitando as contribuições de autores não-geógrafos como Castells, Lefébvre, Lojikne e Topalov, que junto com o geógrafo David Harvey formavam a 'frente ampla'" e nesse contexto a geografia urbana, baseada numa perspectiva crítica iria se interessar pela "utilização do espaço desigual e os confrontos de interesse; urbanização e as relações de dominação; políticas urbanas; processos de produção do espaço urbano, movimentos sociais e a questão da moradia" (BARCELOS, 2010, p. 20).

A esse respeito Carlos (2011, p. 64) destaca que

$\mathrm{Na}$ construção do pensamento geográfico é possível perceber uma nítida inflexão, senão ruptura, que se estabelece nos anos 1970 a partir do questionamento sobre a elaboração do pensamento constituído até então, problematizando sua potência explicativa sobre o mundo e, nessa direção, permitindo construir os fundamentos da noção de produção do espaço sob a orientação do materialismo histórico.

Logo, existe uma produção na área de geografia urbana interessada nos processos, “o materialismo histórico permitiu pensar as contradições do processo e, com isso, situar o lugar e o papel dessa produção na totalidade da produção social capitalista" (CARLOS, 2011, p.64), e dessa forma, indo além da discussão a partir das formas urbanas.

Segundo Miyazaki (2013) "preocupar-se demasiadamente com a análise da forma a partir de fenômenos biológicos pode reduzir a ideia de morfologia apenas à forma em si, excluindo-se os processos históricos, sociais, políticos e econômicos” (MIYAZAKI, 2013, p. 27).

As proposições colocadas por Sant'Anna Neto, então, são leituras de uma nova abordagem para os processos inerentes à produção do espaço urbano que ainda nem sequer haviam sido profundamente debatidos quando Monteiro, em 1976, publica sua tese Teoria e Clima Urbano. Nesse contexto o olhar para os processos urbanos, trazidos por Sant'Anna Neto, irão ampliar a abordagem de Monteiro, que visualizava a cidade a partir do sítio e de sua forma, em diversos pontos da mesma forma que a geografia urbana avançou com relação aos referenciais teóricos e procedimentos metodológicos disponíveis naquela época.

Com isso não cumpre aqui pontuar que a evolução do conhecimento e das formas com as quais se visualiza determinados fenômenos vão caracterizar profundamente as diferenças de abordagens entre os dois autores. Desse modo, permitindo então visualizar o clima, nesse caso 
urbano, sob diferentes perspectivas, Monteiro com uma leitura a partir da atmosfera e sua relação com os impactos na superfície urbana, enquanto uma forma espacial e Sant'Anna Neto com um olhar a partir da superfície, vislumbrando como os diferentes sujeitos são impactados pelos elementos do clima, em função de condições distintas de vulnerabilidade dentro do espaço urbano produzido e mediado por relações de classe. 


\section{Capítulo 2: O clima urbano como risco climático}

Os riscos são inerentes à vida humana e variáveis no tempo e no espaço. Segundo Almeida (2010, p. 88) “é incontestável a onipresença do risco”, ou como coloca Veyret (2019, p. 13) "o risco está em toda parte", no entanto "nos tornamos incapazes de lidar com eles, tanto por nos proteger quanto por minimizar seus danos" (MARANDOLA JÚNIOR e HOGAN, 2004, p. 27).

O termo risco admite múltiplas acepções e entendimentos em função de sua capilaridade nos diversos campos do conhecimento, sendo então considerado um termo polissêmico e multidisciplinar (ALMEIDA, 2010; NASCIMENTO JR., 2018). Com isso, é comum que o termo risco seja acompanhado por um adjetivo que defina a sua natureza, podendo ser natural/ambiental; social; tecnológico; industrial; econômico, etc.

Diversas são as concepções de risco nos diversos campos do conhecimento, no entanto, do ponto de vista geográfico é comum considerar que só há risco com a presença humana, sendo assim, o risco deve ser entendido como uma construção social, na medida em que se relaciona com a vulnerabilidade de pessoas e suas consequências sempre desembocam na sociedade (NASCIMENTO JÚNIOR, 2018).

Por ser eminentemente social,

O risco é a percepção de um indivíduo ou grupo de indivíduos da probabilidade de ocorrência de um evento potencialmente perigoso e causador de danos, cujas consequências são uma função da vulnerabilidade intrínseca desse indivíduo ou grupo (ALMEIDA, 2010, p. 99.

Os riscos sempre existiram, Almeida (2010) destaca que estes se exacerbaram na modernidade. Com as aglomerações humanas nas cidades, aumentam a exposição social aos riscos e perigos, uma vez que o crescimento urbano se dá até áreas suscetíveis aos perigos, bem como vulneráveis à ocorrência dos impactos.

Considerando que o século XXI seja o "século das cidades" (MENDONÇA, 2010), a concentração e a intensificação dos fluxos revelam que "a cidade adquire, assim, o patamar ou nódulo central dos processos gerais derivados da sociedade humana sobre o espaço terrestre" (MENDONÇA, 2010, p. 154).

Mendonça (2010) defende que os riscos ambientais se tornaram um novo paradigma

Na medida em que muda o foco da compreensão da lógica de produção e reprodução socioespacial; ou seja, ela atesta a inserção de uma nova base de análise na relação sociedade - natureza, pois salta de uma base de certeza e estabilidade para uma outra de incerteza e de instabilidade quanto à 
repercussão dos processos naturais e sociais do espaço geográfico (MENDONÇA, 2010, p. 155).

A ocorrência dos eventos extremos de precipitação e seus impactos nas cidades revela que a precipitação, enquanto fenômeno natural, ocasiona outros eventos, como as inundações e movimentos de massa, que impactam os sujeitos de forma diferenciada nas cidades. Dessa forma, os riscos "definem-se como a percepção do perigo, de uma catástrofe possível" (VEYRET, 2019, p. 11).

Sendo assim, o risco natural e no caso o climático, ocorre na medida em que a precipitação assume a condição de perigo, com isso os eventos extremos de precipitação tem a capacidade de dinamizar os riscos, porém este também está associado à suscetibilidade ambiental e à vulnerabilidade social (GIRÃO et al, 2018).

Monteiro (2009, p. 9), a esse respeito, salienta que "a tolerância e a elasticidade social, econômica e política a um episódio climático extremo condicionam a gravidade do risco já que ele é a função multiplicativa do episódio pela vulnerabilidade". Com isso direcionamos o olhar para o clima urbano enquanto risco climático (Figura 04), como defende Nascimento Júnior (2018), "trazendo o risco definido pela triangulação entre perigo-suscetibilidadevulnerabilidade" (NASCIMENTO JÚNIOR, 2018, p. 74).

Figura 04: Estrutura do clima urbano como risco climático.

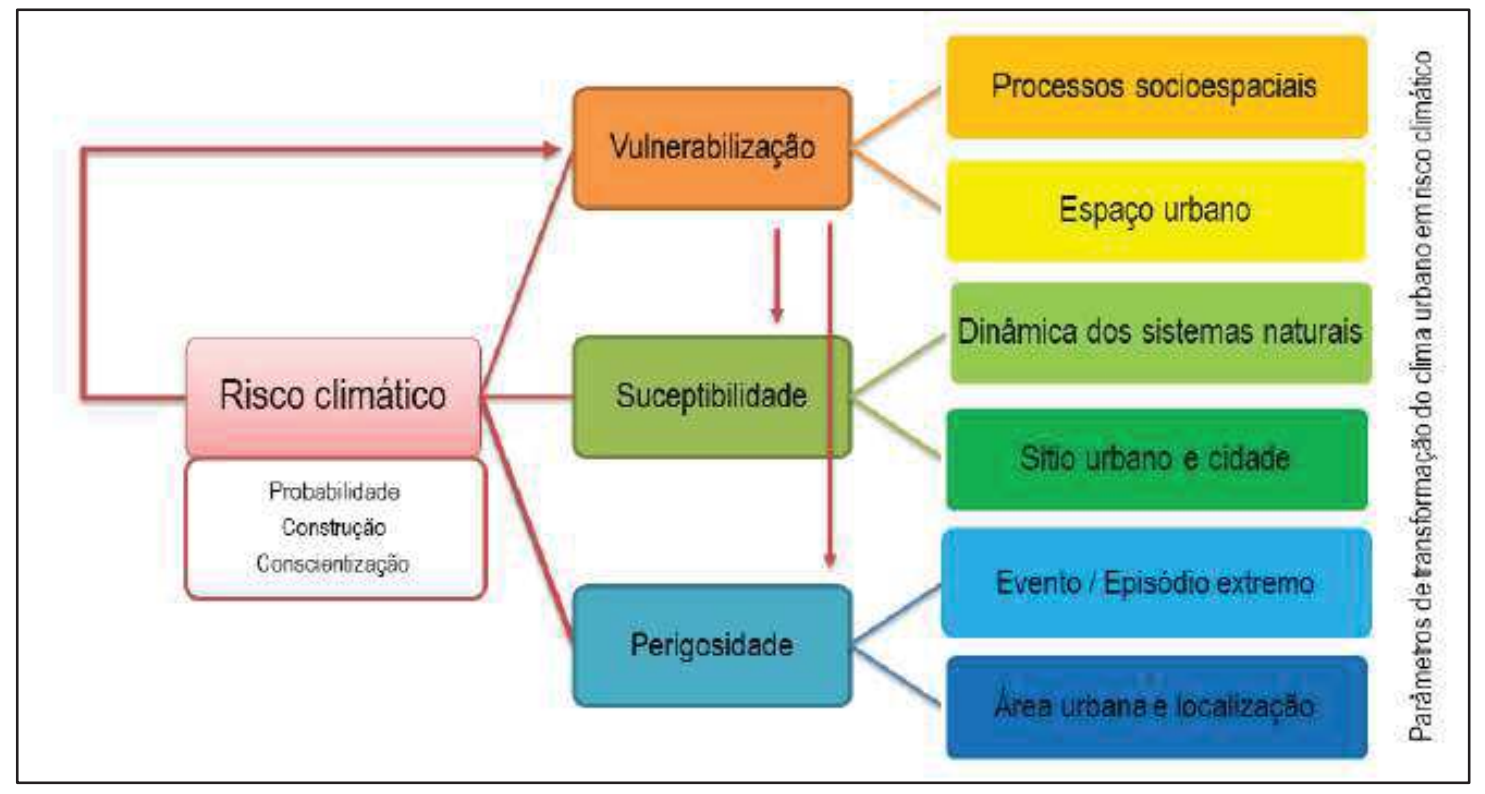

Fonte: Nascimento Júnior, 2018, p. 75. 
Dentro dessa perspectiva, o risco climático estará associado a três elementos: ao (1) perigo ou ameaças, como coloca Goudard (2019) ocasionado pelos eventos extremos, no caso as precipitações intensas, ocorrendo sobre um sítio que apresenta ou não uma (2) suscetibilidade natural a estes eventos, sendo estes influenciados pela (3) vulnerabilidade representando a “exposição e a fragilidade dos grupos sociais perante aos riscos” (GOUDARD, 2019, p. 46).

\section{As chuvas e suas técnicas de investigação: a perigosidade}

A precipitação, enquanto elemento deflagrador dos impactos, assume uma condição de perigo, ameaça, álea (em língua Francesa), hazard (em língua Inglesa), mas que definem um evento, que pode ser natural, social, econômico etc., cuja ocorrência é aleatória no tempo e no espaço, assumindo uma condição de desvio a uma habitualidade, ou seja, uma excepcionalidade (MONTEIRO, 1992).

Veyret (2019) utiliza o termo álea, definido como "um evento possível; pode ser um processo natural, tecnológico, social, econômico, e sua probabilidade de realização. O equivalente em inglês é "hazard" (para definir álea natural). Alguns autores utilizam o termo “perigo" (VEYRET, 2019, p. 24). Nascimento Júnior (2018) considera o perigo como “o fenômeno natural que deve ser entendido em sua provável capacidade de catalisar danos, prejuízos, destruição, vítimas etc.

Marandola Júnior e Hogan (2004, p. 98) destacam que "um hazard não é natural em si, mas trata-se de um evento que ocorre na interface sociedade-natureza". No caso da precipitação, esta assume a condição de hazard/ perigo/ álea na medida em que ocorre de maneira desigual no tempo e no espaço, bem como é capaz de desencadear processos que impactam a população, seja ela urbana ou rural.

Monteiro (1992) destaca que os eventos extremos são considerados um hazard na medida em que não permitem uma acurada previsão, dessa forma os hazards são assim considerados em função da frequência, intensidade e duração dos eventos naturais extremos e o ajustamento das organizações humanas, no caso a cidade.

\section{A chuva como elemento em análise}

Para a ocorrência das chuvas, no seu processo de formação, inicialmente é necessário a formação das nuvens. De acordo com Nery e Carfan (2013, p. 262) "nuvem é uma massa visível de gotas de líquido ou cristais congelados suspensos na atmosfera”. A formação das nuvens 
está associada à condensação de gotículas de água, que ocorre através das superfícies dos núcleos de condensação ${ }^{4}$ (NERY e CARFAN, 2013, p.262). Ynoue et al (2017) acrescenta que “as gotículas d'água, também chamada gotículas de nuvem, possuem diâmetro médio de 0,02mm. A união de várias dessas gotículas forma a gota de chuva” (YNOUE et al, 2017, p. $55)$.

Existem casos em que a condensação de uma nuvem não é capaz de gerar precipitação, formando gotículas minúsculas que flutuam na forma de nuvem na atmosfera, dessa forma, para a formação das chuvas existem duas teorias que explicam a agregação das gotículas a um tamanho que ultrapasse a força de flutuação (YNOUE, 2017). A primeira associada às nuvens frias (com temperatura inferior a $0^{\circ} \mathrm{C}$ ) e a outra apontada para as nuvens quentes (com temperatura superior a $0^{\circ} \mathrm{C}$ ).

A primeira teoria foi desenvolvida por T. Bergeron e aprimorada por F. Findeisen (VAREJÃO-SILVA, 2006). A teoria de Bergeron-Findeisen

Se fundamenta no fato da pressão de saturação sobre o gelo ser menor que sobre a água sobrefundida. Assim, em uma nuvem fria, onde coexistem gotas d'água e cristais de gelo a temperaturas bem abaixo de $0^{\circ} \mathrm{C}$, estes crescem às custas daquelas. Atingindo um tamanho suficiente, o cristal de gelo iniciaria sua queda em direção à superfície (VAREJÃO-SILVA, 2006, p. 356).

Nas nuvens quentes (com temperatura $>0^{\circ} \mathrm{C}$ ) a formação da precipitação está associada aos processos de colisão e coalescência. "As gotas dentro de uma nuvem têm tamanhos distintos e, portanto, diferentes velocidades terminais (velocidades de queda) " (YNOUE et al, 2017, p. 56). Com isso as gotas maiores tem maior velocidade, quando colidem com as gotas menores coalescem formando uma gota ainda maior.

A precipitação pode também ser classificada em três tipos, em função de sua gênese, sendo eles: a chuva convectiva, frontal e a orográfica/de relevo.

As chuvas convectivas estão associadas às nuvens do tipo torre (cumulus congestus e cumulonimbus), (BARRY e CHORLEY, 2013),

Também chamada de chuva de verão, o ar próximo à superfície, desenvolve no movimento vertical quando a temperatura está elevada. O movimento ascendente do vento carrega o vapor para as camadas superiores da atmosfera acarretando o resfriamento, esse vapor se condensa em gotículas tão pequenas que permanecem em suspensão, assim produzindo a precipitação, após essas gotículas crescerem. Esse tipo de chuva é considerado de grande turbulência e têm características de serem rápidas e de grandes volumes (OLIVEIRA, 2014, p. 54).

\footnotetext{
${ }^{4}$ De acordo com Almeida (2016, p. 268) "Núcleos de condensação são partículas higroscópicas em torno das quais o vapor d'água se condensa".
} 
As chuvas de origem orográfica ou de relevo, segundo Mendonça e Danni-Oliveira (2007, p. 71):

Ocorrem por ação física do relevo, que atua como uma barreira à advecção
livre do ar, forçando-o a ascender. O ar úmido e quente, ao ascender próximo
às encostas, resfria-se adiabaticamente devido à descompressão promovida
pela menor densidade do ar nos níveis mais elevados. O resfriamento conduz
à saturação do vapor, possibilitando a formação de nuvens estratiformes e
cumuliformes, que, com a continuidade do processo de ascensão, tendem a
produzir chuva (MENDONÇA e DANNI-OLIVEIRA, 2007, p. 71).

As chuvas frontais, de acordo com Nery e Carfan (2013) são "um tipo de precipitação que ocorre quando uma massa de ar quente e uma massa de ar frio se encontram. Chuvas frontais são provocadas, geralmente, por forçantes térmicas" (NERY e CARFAN, 2013, p. 70).

Nas chuvas de origem frontal

A intensidade das chuvas nelas geradas, bem como sua duração, será influenciada pelo tempo de permanência da frente no local, pelo teor de umidade contido nas massas de ar que formam, pelos contrastes de temperatura entre as massas e pela velocidade de deslocamento da frente (MENDONÇA e DANNI-OLIVEIRA, 2007, p. 71).

A figura 05, demonstra esquematicamente os três tipos de chuvas, a primeira, convectiva, está associada à ascensão de ar úmido em condições de temperatura do ar elevada. A segunda, chuva frontal, é marcada pelo encontro de duas massas de ar, com temperatura distinta, sendo que o ar frio, mais denso e pesado, força a ascensão do ar mais aquecido e menos denso, formando as nuvens de chuva. Já o terceiro tipo, chuva orográfica, acontece quando o ar é forçado a ascender em função de um elemento topográfico, resfriando-se adiabaticamente gerando a condensação das nuvens. Com isso, as vertentes a barlavento serão normalmente mais chuvosas que as vertentes a sotavento (MENDONÇA e DANNI-OLIVEIRA, 2007; OLIVEIRA, 2014; YNOUE et al., 2017). 
Figura 05: Tipos de chuva em função de sua gênese ou mecanismo de ascensão do ar.

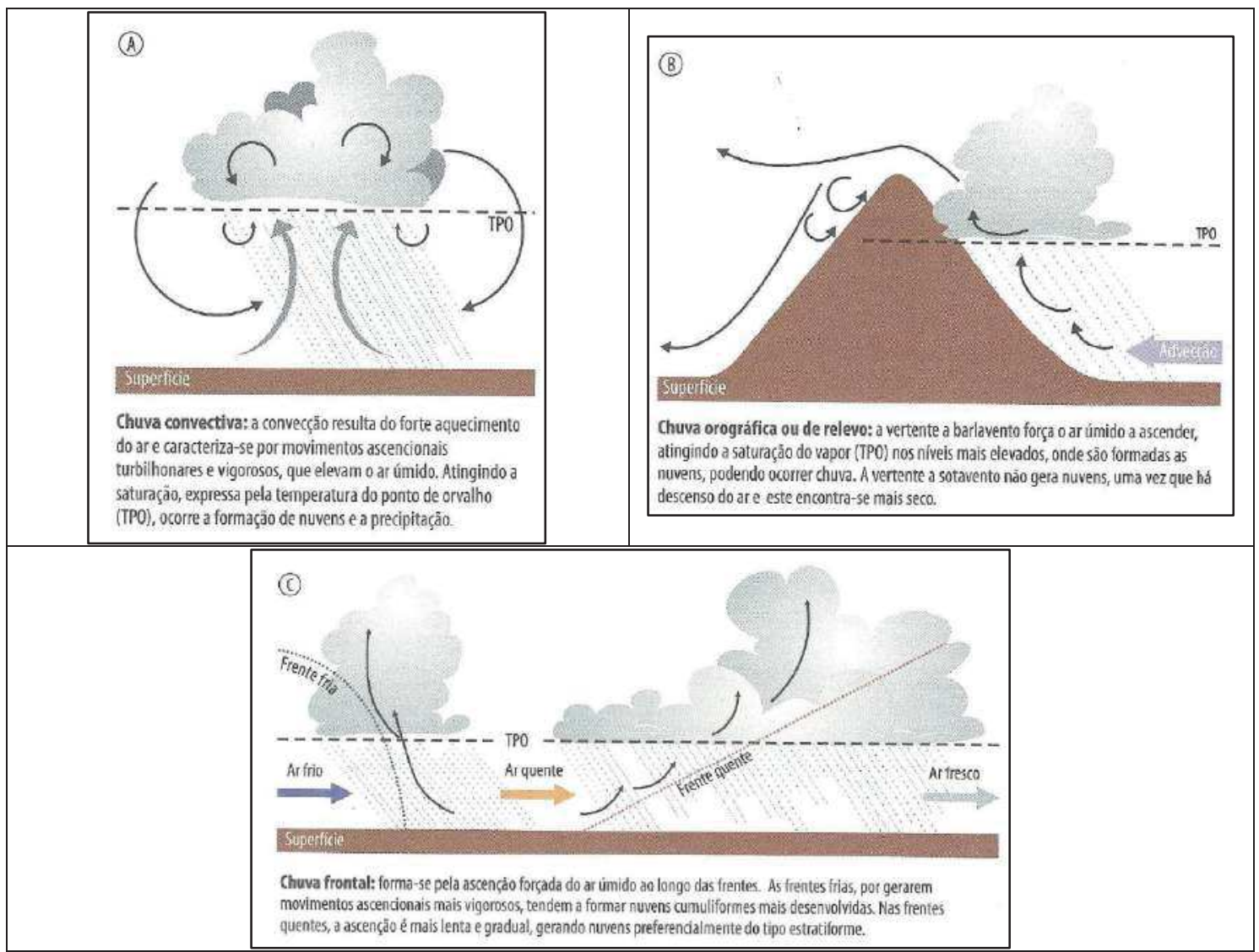

Fonte: Adaptado de Mendonça e Danni-Oliveira (2007, p. 72).

\section{Os eventos extremos pluviométricos e suas técnicas de investigação}

Os eventos naturais extremos ocorrem de maneira copiosa nos sistemas ambientais, podendo ser geológicos, geomorfológicos, hidrológicos e também meteorológicos ou climáticos (VICENTE, 2005; MONTEIRO, 2016). São considerados extremos, em função de seu afastamento das condições habituais e por ocorrerem com uma baixa frequência, porém com elevada capacidade de causar danos à sociedade (GONÇALVES, 1992; VICENTE, 2005; STHEPHENSON, 2009; PINHEIRO, 2016; MONTEIRO, 2016; GOUDARD, 2019).

Para Goudard (2019, p. 32) “do ponto de vista específico das chuvas, os extremos podem ser considerados aqueles cujo total anual, sazonal ou diário demonstram desvios de valores superiores ou inferiores à apresentação dos habituais da área no período analisado".

Monteiro (1991) revela que estes eventos extremos "encontram-se entre os mais importantes, seja pela complexidade e diversidade de fenômenos quanto pela frequência e variação de intensidade dos impactos causados" (MONTEIRO, 1991, p. 8). Dito isso, já se pode extrair algumas características fundamentais na investigação dos extremos: sua frequência, intensidade e a repercussão espacial (GOUDARD, 2019). Marengo (2009) acrescenta que os 
eventos extremos fazem parte da própria variabilidade do clima, "e sua frequência e intensidade podem variar de acordo com a mudança climática" (MARENGO, 2009, p. 6).

Diversas são as parametrizações para os eventos extremos pluviométricos, por vezes podem ser caracterizados a partir de valores estabelecidos, fixados, como Gonçalves (1992, 2003) com 60mm para a cidade de Salvador- BA, Zanella (2006) também aplicou os 40mm para a cidade de Curitiba-PR. Vicente (2005) adotou o limiar de $50 \mathrm{~mm}$, como precipitação capaz de gerar impactos na região metropolitana de Campinas, Vieira (2018) utilizou o valor de $40 \mathrm{~mm}$ para investigar os impactos das chuvas em Belo Horizonte e Zanella et al (2009) que utilizaram o limiar de $60 \mathrm{~mm}$ para definir os eventos extremos em Fortaleza, Maranguape e Pacatuba- CE,

Há que se considerar que no Brasil, em função da intensa variabilidade climática deveria ser complicado utilizar parâmetros já fixados, sem que houvesse uma visualização a partir do comportamento dos dados numa perspectiva local, por isso além da utilização de valores predeterminados, diversas técnicas estatísticas podem ser utilizadas para a caracterização dos eventos extremos. Dentre elas despontam a utilização dos percentis 95 e 99 (LOUREIRO, 2014; PRISTO et al, 2018; GOUDARD, 2019; PAZ et al, 2019), dos quantis (MONTEIRO, 2016; WANDERLEI et al, 2018), a técnica do decil (CAMPOS et al, 2015) às técnicas dos máximos de precipitação (MONTEIRO e ZANELLA, 2017), além dos índices de extremos climáticos do ETCCDI $^{5}$ (FEITOSA, 2014; PINHEIRO, 2016; VALVERDE, 2018; MARENGO et al, 2020).

Loureiro et al (2014) utilizaram o valor de $25 \mathrm{~mm}$ como parâmetro para definir os eventos extremos e a partir desse valor aplicou a técnica dos percentis para classificar os eventos, chegando a um valor de $48 \mathrm{~mm}$ para eventos extremamente intensos, em estudo no estado do Pará. Pristo et al (2018) avaliando as chuvas intensas na cidade do Rio de Janeiro, utiliza o valor estabelecido pelo percentil 95 como determinante para a localização dos eventos intensos na série de dados. Goudard (2019) estudando os eventos pluviais intensos na bacia do alto Iguaçu no Paraná, utiliza os percentis 90, 95 e 99 para avaliar os valores extremos de precipitação. Paz et al (2019) utilizaram o percentil 99 para a definição dos eventos extremos em Uberaba-MG.

\footnotetext{
${ }^{5}$ Dentro do universo de técnicas utilizadas para a observação de variações e ou tendências climáticas o Expert Team on Climate Change Monitoring and Índices (ETCCDI), vinculado à Comissão de Climatologia da Organização Meteorológica Mundial (OMM) e o Climate Variability and Predictability Project (CLIVAR) sugerem a utilização de 27 índices de extremos climáticos, sendo que 16 deles são relacionados à temperatura do ar e 11 índices à precipitação (ZHANG e YANG, 2004).
} 
Monteiro (2016) aplicou a técnica dos quantis para os dados de precipitação no estado do Ceará e colocou que os quantis 0,05 e 0,95 são representativos para a investigação de eventos raros. Wanderlei et al (2018) utilizaram os quantis para analisar as precipitações diárias em Recife-PE;

Campos et al (2015) utiliza a técnica do decil para definir os eventos extremos, sendo que o nono decil corresponderia aos eventos extremos, com isso utilizaram o valor de $24 \mathrm{~mm}$ como evento extremo na cidade de Belém-PA.

Monteiro e Zanella (2017) utilizaram a técnica dos máximos de precipitação aplicada aos municípios de Fortaleza, Sobral e Crato, partindo de um limiar de $50 \mathrm{~mm}$, a aplicação da técnica consiste em dividir os valores superiores a este limiar em classes de intensidade, "permitiu definir um limiar de chuva para caracterizar diferentes níveis de eventos extremos nas localidades supracitadas, além de permitir a identificação do número de episódios de grande magnitude" (MONTEIRO e ZANELLA, 2017, p. 137).

A técnica do RClindex também é amplamente utilizada para a avaliação de tendência a partir das classes de intensidade de precipitação, desenvolvida pelo grupo de pesquisadores do ETCCDI (ZHANG e YANG, 2004), no qual sugerem onze (11) índices para o estudo da precipitação. Dessa forma sugerem que o percentil 95 seria considerado como dia muito chuvoso e o percentil 99 como dia extremamente chuvoso.

Os índices dos extremos climáticos propostos pelo ETCDDI têm sido amplamente utilizados, exemplo disso New et al. (2006) investigaram os índices de extremos climáticos na região Sudeste do continente Africano; Sun et al (2016) estudaram as tendências nos índices de temperatura e precipitação na região do Loess Plateau na China; Popov et al (2018) que avaliaram as chuvas na região de Peripannonian, na Bósnia, a partir dos índices sugeridos pelo ETCCDI; Alvarez et. al. (2019) também buscaram analisar os índices de extremos climáticos no estado de Aguascalientes no México, dentre outros.

No Brasil alguns autores também já utilizaram dos índices de extremos climáticos do ETCCDI, para a avaliação de tendências em dados climáticos, como Sanches (2013b) avaliando os extremos pluviométricos no sudoeste do Rio Grande do Sul; Óscar Júnior (2015) investigou as chuvas no município de Duque de Caxias; Ferreira et al (2017) também trabalharam os índices de extremos de precipitação região Semiárida do estado de Pernambuco; Souza et al (2018) estudaram os índices de extremos de precipitação no município de AlfenasMG; Santos et al (2019) aplicaram a técnica para os dados pluviométricos na porção CentroLeste do estado de São Paulo, Marengo (2020) avaliou as tendências nos eventos extremos na 
cidade de São Paulo, identificando uma tendência de elevação na frequência dos eventos do percentil 95 e 99.

Valverde et al (2018) dentre os índices estabelecidos pelo ETCCDI, utilizam o valor do percentil 95 como definidor dos eventos extremos no ABC Paulista. Pinheiro (2016), da mesma forma, utiliza como evento extremo os valores estabelecidos a partir do percentil 95, considerando que um dia chuvoso é aquele em que a precipitação ultrapassa $1 \mathrm{~mm}$. Marengo et al (2020) aplicaram os índices do ETCCDI para os dados do município de São Paulo, e concluíram com uma elevação na frequência dos eventos classes de R80mm e R100m, nos últimos anos.

Com isso, observa-se que são inúmeras as possibilidades de estudo dos eventos extremos de precipitação, bem como são diversas as técnicas utilizadas, seja para a identificação dos eventos, bem como como para a avaliação de sua frequência e tendências a partir das séries históricas.

\section{Os eventos e os episódios: o clima urbano e os impactos}

Buscando vislumbrar a ideia de "impacto", a princípio procuramos entender etimologicamente o significado dessa expressão, utilizada por diversas vezes no presente trabalho. Segundo o dicionário Michaelis (2019) oriunda do latim Impactus, pode ser apreendida a partir de alguns significados dignos de nota, como: impelido contra, choque ou encontro impetuoso, efeito que, por sua força, impede ou acarreta mudanças.

Além disso, na palavra impacto observa-se que o prefixo "Im" tem como princípio a negação, a contrariedade; completado pela palavra "pacto" que reserva um caráter de contrato e de reciprocidade entre partes, segundo o dicionário Michaelis (2019).

Diante desses significados, pode-se vislumbrar que em todas as acepções a palavra impacto esteve associada a algum embate, ou choque entre partes, a uma ruptura entre uma relação amistosa. Com isso os citados: movimentos de massa, inundações, enchentes, alagamentos, podem ser considerados momentos de choque entre o elemento climático, no caso a precipitação, e a cidade.

Mendonça (2004b) salienta que

Os problemas e questões enfocados na perspectiva ambiental são, sobretudo, de ordem social, dados que a noção de problema é uma abstração exclusivamente humana, o que reforça a ideia de que não existe problema na e para a Natureza; quando colocados não passam das leituras possíveis do homem sobre a Natureza, da maneira humana de compreendê-los, de uma certa humanização dela (MENDONÇA, 2004b, p. 188) 
Monteiro (1992) aponta que as chuvas extremas poderiam trazer aspectos positivos para, por exemplo, reduzir a concentração de poluentes na atmosfera, melhoria na capacidade dos sistemas de abastecimento urbano, dentre outras. No entanto, em função do ajustamento humano, desencadeiam o que chamou de consequências calamitosas (MONTEIRO, 1976).

É nesse momento que o clima, e no caso as chuvas extremas, assumem a condição de perigo, pois na sua interface com a sociedade irão consubstanciar os impactos e constituir o risco, no caso o risco climático (NASCIMENTO JÚNIOR, 2019). Gonçalves (2013) argumenta que em função dos graus de vulnerabilidade social, eventos considerados "normais" serão capazes de desencadear impactos à sociedade. A autora complementa ainda que "um evento extremo torna-se risco quando supera a capacidade material de determinada organização social para absorver, amortizar ou evitar seus efeitos negativos" (GONÇALVES, 1992, p. 19).

Além disso, Armond (2014) faz uma importante diferenciação entre os critérios de ordem quantitativa e estatística, trazendo a ideia de eventos extremos, como "aqueles que ultrapassam os valores habituais meteorológicos" (ARMOND, 2014, p. 77) e os episódios extremos "aqueles que causaram impactos" (ARMOND, 2014, p. 77). Essa diferenciação se faz importante pois nem todo evento extremo necessariamente se consubstancia como um episódio extremo, ou seja não produz impactos no espaço urbano, e por vezes, um total pluviométrico inferior a marca de evento extremo pode produzir diversos impactos no espaço urbano.

Com isso, as chuvas, como insumo da atmosfera, "assume a condição de impacto na medida em que atua sobre um espaço mais adaptado pelo homem, nele interferindo com diversos graus de significância, em função da vulnerabilidade” (GONÇALVES, 1992, p. 18). Nascimento Júnior (2013) coloca que para além de critérios matemático-estatísticos os eventos (ou episódios) extremos também "são resultado da produção desigual do espaço geográfico em níveis de vulnerabilidade ao ritmo climático” (NASCIMENTO JÚNIOR, 2013, p. 48). É nesse ponto que se assenta a perspectiva de Sant'Anna Neto (2001, 2008) da Geografia do Clima, pois "a população vulnerável sofre consequências que podem variar em grau de intensidade, em função de sua capacidade em enfrentar os desastres” (SANT’ ANNA NETO, 2011, p.48).

Os impactos ocorrem e se localizam no espaço também em função da capacidade que o sujeito tem de se proteger diante de um evento pluviométrico, sendo que mesmo que estes sejam fomentados pela dinâmica atmosférica, "suas ações e percepções serão resultados das transformações e produções antrópicas no espaço" (MURARA, 2016, p. 61).

É necessário pontuar que a ideia de impacto deve também assumir um componente social, pois para além da relação entre o evento pluviométrico intenso e a cidade, existem dentro 
da própria cidade possibilidades diferentes de contato entre o evento pluviométrico e a superfície, uma vez que o espaço produzido tende a oferecer maior exposição a esses episódios a determinados grupos sociais.

Dessa forma, para Murara (2016) é necessária uma abordagem socionatural dos impactos decorrentes do clima, justamente chamando a atenção para os processos de vulnerabilidade social que exercem influência na consubstanciação de determinado impacto no espaço urbano da cidade (ROMERO e MENDONÇA, 2012). Com isso, visa-se um olhar de coparticipação entre Sociedade e Natureza, preconizada por Monteiro na construção do Sistema Clima Urbano (SCU).

\section{A suscetibilidade ambiental: os sistemas naturais e o sítio urbano}

A suscetibilidade ambiental, considerada segundo Girão et al (2018) como o quão provável um determinado fenômeno pode ocorrer independente dos fatores sociais, mas tendo a sociedade como elemento de interferência que acelera ou retarda. A suscetibilidade exprime a predisposição ambiental à ocorrência de determinado evento, no caso, seja ele a inundação ou os movimentos de massa. O CPRM em sua nota técnica considera a suscetibilidade como “propensão à ocorrência de algum fenômeno ou processo sobre determinada área” (Bitar, 2014, p.4).

Fell et al (2008) entende a suscetibilidade a movimentos de massa como a investigação qualitativa ou quantitativa da classificação, área e distribuição dos movimentos de massa, levando em conta aspectos como intensidade e frequência. Zezerê et al (2005) destaca que a suscetibilidade irá responder a possibilidade de ocorrência de um evento, seja ele inundação ou movimento de massa, sob determinadas condições.

Incorporando à ideia do risco climático, a suscetibilidade estará relacionada a como o sítio da cidade apresenta diferentes características físico-naturais, que produzem condições distintas de propensão a eventos de inundação ou movimentos de massa. Sendo que além dessas características físicas, estes também se relacionam com a precipitação, no caso das inundações nos processos chuva-vazão e no caso dos movimentos de massa atuam alterando as condições de estabilidade da encosta, dinamizando esses eventos.

É necessário, inicialmente, colocar que todos esses processos são conspícuos no meio tropical, seja ele urbanizado ou não, ocorrendo de maneira recorrente. No domínio tropical atlântico eles assumem um caráter "danoso" em função de relevos mais movimentados e de 
uma densidade de drenagem mais elevada, associado a uma franca ocupação humana neste domínio.

Ab’ Sáber (2003) destaca que no contexto do "Domínio dos Mares de Morros Florestados" é o meio físico, ecológico e paisagístico mais difícil do país em relação às ações antrópicas. No seu interior tem sido difícil encontrar sítios para centros urbanos de uma certa proporção" (AB'SÁBER, 2003, p. 17), em função de uma topografia de morros, nos quais a ação do intemperismo químico, principalmente, desenvolveu profundos mantos de alteração, suscetíveis a movimentos de massa, bem como a alta densidade de drenagem nesse domínio, engendram a ocorrência de inundações periódicas (AB'SÁBER, 2003).

As inundações e os movimentos de massa figuram como os eventos que mais causam mortes e desabrigados, perdendo apenas paras os terremotos. Segundo Nunes (2015) os eventos hidrometeorológicos e climáticos representaram 78,4\% dos eventos de desastres naturais na América do Sul entre 1960 e 2000, ocasionando 32,3\% das mortes, $88 \%$ dos afetados e 78,4\% dos prejuízos. Isso revela a expressão que estes eventos assumem.

A abordagem dos temas relacionados às inundações, enchentes, alagamentos e os movimentos de massa podem ser levados a efeito a partir de diversas perspectivas e não é objetivo deste trabalho discutir a temática dentro de sua profundidade cabível, mas fazer o diálogo entre estes eventos e processos e suas relações com o elemento climático em tela, no caso a precipitação.

\section{Os movimentos de massa e as relações com a precipitação}

Sendo comuns tanto em áreas urbanas e rurais, é na primeira que os movimentos de massas desencadeiam, com frequência, episódios danosos e por vezes com desfechos trágicos à população (FERNANDES et al, 2001; TORRES et al, 2012). O movimento de massa, no entanto, é

O movimento do solo, rocha e/ou vegetação ao longo da vertente sob a ação direta da gravidade. A contribuição de outro meio, como água ou gelo se dá pela redução da resistência dos materiais de vertente e/ou pela indução do comportamento plástico e fluido dos solos. (TOMINAGA, 2015, p.27).

Os movimentos de massa ocorrem quando a resistência ao cisalhamento do material é alterada, principalmente pela elevação da tensão cisalhante ou pela diminuição na resistência ao cisalhamento (CASTRO, 2006). A elevação da tensão cisalhante pode ser dar pela "remoção de suporte lateral ou subjacente, sobrecarga, solicitações dinâmicas e pressões laterais" 
(CASTRO, 2006, p. 21), já a redução na resistência ao cisalhamento pode se dar pelas "propriedades inerentes do material (composição, textura; descontinuidades, orientação do talude); e propriedades que variam com o tempo (ação do intemperismo, causando diminuição da coesão e atrito, elevação do nível d'água, mudanças na estrutura)” (CASTRO, 2006, p. 21). Dessa forma o movimento ocorre quando a "força gravitacional vence o atrito interno das partículas, responsável pela estabilidade, a massa de solo movimenta-se" (TOMINAGA, 2015, p. 28).

Colângelo (2005) salienta que há

Uma série de fatores intervêm sobre estas variáveis, ora favorecendo a tensão de resistência ao cisalhamento, ora favorecendo a tensão cisalhante. Intensa pluviosidade e consequente escoamento superficial e hipodérmico promovem periodicamente a queda da resistência dos materiais superficiais suporte do sistema geomórfico. O abatimento da resistência pode chegar a níveis extremos, atingindo valores críticos, abaixo dos limiares, podendo, neste caso, gerar superfícies de ruptura com desencadeamento de movimentos de massa (COLÂNGELO, 2005, p. 16).

Com isso, os movimentos de massa correspondem a uma busca por um novo equilíbrio na encosta (COLÂNGELO, 2005). Dentre os mais importantes causadores de impactos nas cidades estão os escorregamentos (FERNANDES e AMARAL, 2000), que se dividem em translacionais ou planares; rotacionais ou circulares e os escorregamentos em cunha. Os escorregamentos translacionais ou planares, estão entre os mais frequentes. Podem ser classificados a partir do material transportado, podendo ser apenas solo, rochas ou ainda com solo e rocha, concomitantemente. Estes quando ocorrem com solos, têm uma elevada velocidade são potenciais causadores de destruição, ocorrendo normalmente após chuvas intensas (FERNANDES e AMARAL, 2000; TOMINAGA, 2015).

Os escorregamentos rotacionais ou circulares estão associados a locais com mantos de alteração espessos, oriundos de materiais argilosos (TOMINAGA, 2015), estão entre os mais comuns no sudeste do Brasil e ocorrem normalmente associados a cortes na base do talude, sendo tanto naturais como artificiais (FERNANDES e AMARAL, 2000). Os escorregamentos em cunha deste último tipo demanda normalmente a ocorrência de controles estruturais, na medida em que vão ocorrer no contato entre duas estruturas com resistências distintas (TOMINAGA, 2015).

Apesar da discussão levantada acerca dos movimentos de massa e suas características, não é objeto deste trabalho discutir suas ocorrências a partir desse detalhamento, uma vez que, com base nas informações da mídia impressa não seria possível alcançar esta classificação no presente trabalho. 
Diversos trabalhos se interessaram em definir limiares e parâmetros com relação à precipitação e sua capacidade de desencadear os movimentos de massa. Stabile e Colângelo (2017) apontam que "a chuva pode ser considerada como o principal fator deflagrador de escorregamentos, principalmente em locais de relativa estabilidade tectônica" (STABILE e COLÂNGELO, 2017, p. 3878), ainda segundo os mesmos autores é comum que os eventos de escorregamentos estejam associados a chuvas excepcionais, "de modo que tanto a chuva antecedente como a intensidade do evento pluviométrico deflagrador são descritos como significativos na geração de escorregamentos nas encostas"( STABILE e COLÂNGELO, 2017, p. 3878).

Santos et al (2019) apontam que diversos estudos têm se interessado em investigar os limiares de precipitação capazes de deflagrar movimentos de massa, estes afirmam que normalmente se investiga as intensidades diárias de precipitação e os acumulados em quatro dias. Em seu estudo para a cidade de Maceió- AL revelam que eventos de precipitação superiores a $40 \mathrm{~mm}$ em cinco horas, são potencialmente geradores de movimentos de massa, além de que totais pluviométricos superiores a 100mm em 15 dias podem gerar deslizamento a qualquer momento.

Em Juiz de Fora, Fonseca et al (2017) avaliaram a relação entre a precipitação e os deslizamentos na cidade e destacam que, para o período estudado, "o evento de chuva diário superior a $100 \mathrm{~mm}$ apresenta $100 \%$ de probabilidade de haver ocorrência de deslizamento" (FONSECA et al, 2017, p. 189), bem como "verifica-se 74\% de probabilidade de deslizamento a partir de dados acumulados de chuva de 10 dias para a precipitação igual ou acima de 150 mm. Os dados acumulados de chuva igual ou acima de $200 \mathrm{~mm}$ em 15 dias de observações resultaram em 67\% de probabilidade de ocorrências" (FONSECA et al, 2017, p. 190).

Dessa forma destaca-se o papel da precipitação para a ocorrência dos movimentos de massa, atuando no comportamento físico do perfil de solo, alterando a resistência e a agregação das partículas, dinamizando os movimentos de massa. Quando associados a uma ocupação sem o aparato técnico construtivo para essas condições, figuram como impactos para a cidade e os sujeitos que nela habitam.

\section{As inundações: os processos chuva-vazão}

A água do ponto de vista geomorfológico representa um dos principais agentes modeladores da paisagem (BOTELHO, 2011). Em se tratando do ambiente tropical, onde a densidade de drenagem é elevada, é comum a presença de riachos, córregos e rios. Se torna 
então importante visualizar a relação destes com a sociedade, sobretudo nas áreas urbanas. Nesses ambientes, alterados por uma sociedade capitalista, a dinâmica hídrica assume a forma, na maioria dos casos, de problema ambiental, seja pela poluição, como também pelas inundações, enchentes e alagamentos, comuns nesses espaços.

Segundo Tucci (2003, p. 45)

A inundação ocorre quando as águas dos rios, riachos, galerias pluviais saem do leito de escoamento devido à falta de capacidade de transporte de um destes sistemas e ocupa áreas onde a população utiliza para moradia, transporte (ruas, rodovias e passeios), recreação, comércio, indústria, entre outros.

Esses eventos ocorrem tanto por vias naturais, como também podem ser intensificadas pelas atividades humanas, pois "na medida que a população impermeabiliza o solo e acelera o escoamento através de condutos e canais a quantidade de água que chega ao mesmo tempo no sistema de drenagem aumenta produzindo inundações mais frequentes" (TUCCI, 2003, p. 45).

Após precipitada, a água em áreas de cobertura vegetal poderia ser direcionada de diversas formas (BOTELHO, 2011), seja pela interceptação pela vegetação, infiltração, armazenamento na serapilheira, dentre outros, quando visualizamos esse processo nas áreas urbanas, a infiltração e o escoamento assumem condição prioritária, sendo que o escoamento superficial a partir das superfícies impermeabilizadas se torna predominante (BOTELHO, 2011).

Com isso, a figura 06 demonstra que em áreas urbanizadas o pico da vazão ocorre de forma mais acelerada em função da rapidez com que as águas atingem o canal, velocidade proporcionada pela impermeabilização nas áreas de captação. Segundo Botelho (2011) "o pico de cheia numa bacia hidrográfica urbana pode chegar a seis vezes mais do que o pico dessa mesma bacia em condições naturais" (BOTELHO, 2011, p. 73). 
Figura 06: Hidrograma hipotético comparando os picos de vazão em áreas rurais e urbanizadas.

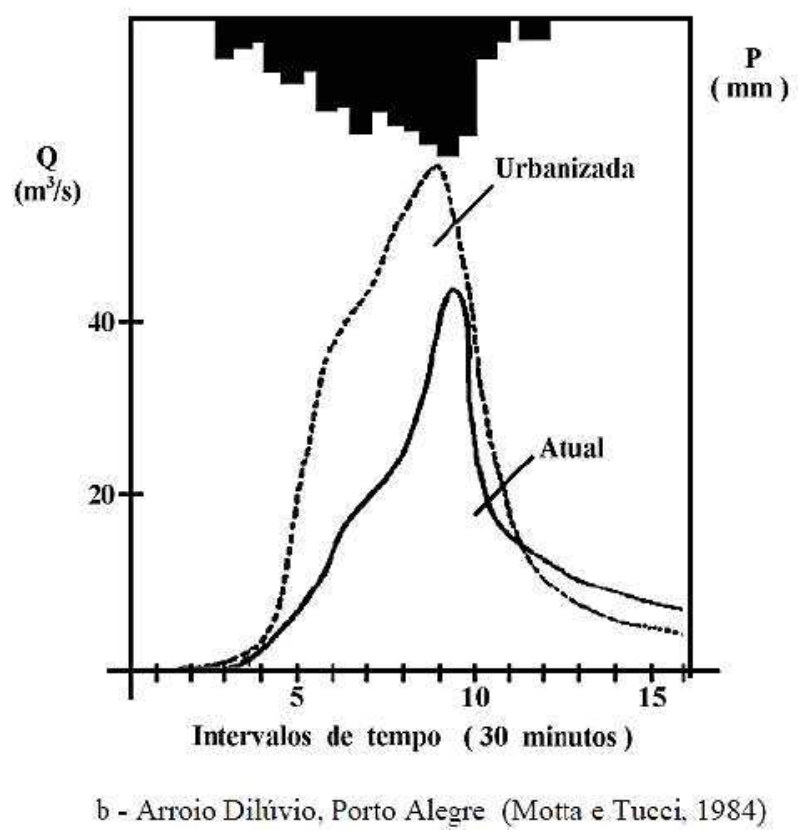

Fonte: Adaptado de TUCCI (2003).

Dentro da abordagem da drenagem urbana, diversos processos, que por vezes são utilizados como sinônimos, necessitam de uma demarcação conceitual mais rígida, dessa forma, com base no Ministério das Cidades (2007), estabelece-se os conceitos de inundação, enchente, alagamento e enxurrada, comumente utilizados (Quadro 03).

Quadro 03: Conceituação de inundação, enchente e alagamento a partir do Ministério das Cidades (2007).

\begin{tabular}{|c|l|}
\hline Nome do processo & \multicolumn{1}{|c|}{ Características } \\
\hline Inundação & $\begin{array}{l}\text { Processo de extravasamento das águas do canal de drenagem para } \\
\text { as áreas marginais (planície de inundação, várzea ou leito maior } \\
\text { do rio) quando a enchente atinge cota acima do nível máximo da } \\
\text { calha principal do rio. }\end{array}$ \\
\hline Enchente & $\begin{array}{l}\text { Elevação temporária do nível d'água em um canal de drenagem } \\
\text { devida ao aumento da vazão ou descarga, sem que haja } \\
\text { extravasamento. }\end{array}$ \\
\hline Alagamento & $\begin{array}{l}\text { Acúmulo momentâneo de águas em uma dada área por problemas } \\
\text { no sistema de drenagem, podendo ter ou não relação com } \\
\text { processos de natureza fluvial }\end{array}$ \\
\hline
\end{tabular}




\begin{tabular}{|l|l|}
\hline Enxurrada & $\begin{array}{l}\text { Escoamento superficial concentrado e com alta energia de } \\
\text { transporte. }\end{array}$ \\
\hline
\end{tabular}

Fonte: Ministério das Cidades, 2007.

Além disso, na figura 07, observa-se um perfil hipotético, no qual visualiza-se a diferenciação entre enchente e inundação, estes normalmente são tratados como sinônimos, no entanto, a inundação é caracterizada pelo extravasamento das águas a partir do seu leito, atingindo a planície de inundação, que no caso de áreas urbanas, é comumente ocupada.

Figura 07: Perfil esquemático mostrando os processos de inundação e enchente.

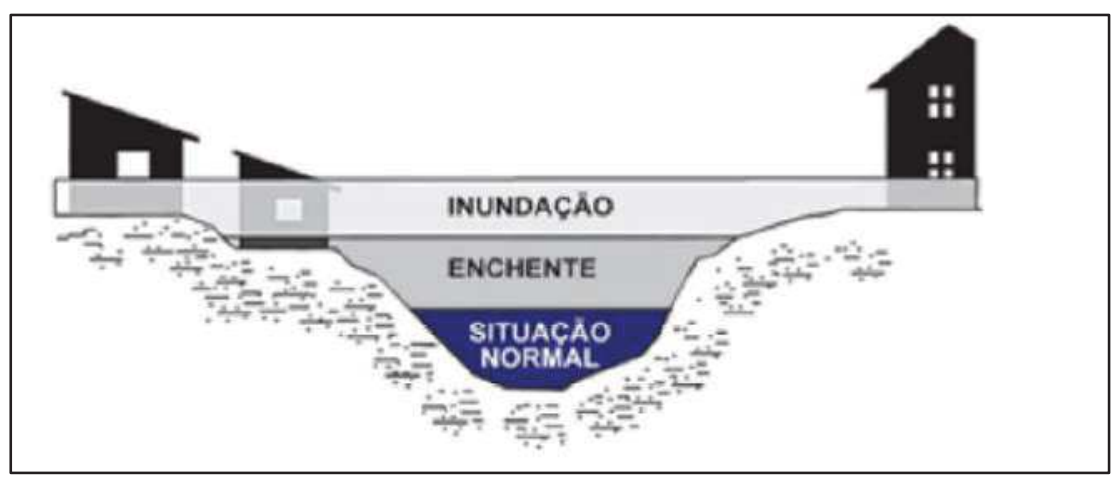

Fonte: Ministério das Cidades (2007, p. 92).

\section{A vulnerabilidade social e a produção desigual do espaço}

Quando a precipitação, ou outro elemento climático, ocorre de maneira extrema nas cidades, deve-se considerar que aquele espaço, assim como apresenta condições distintas de suscetibilidade ambiental, é ocupado e vivenciado de maneira distinta pelos sujeitos na cidade.

No Brasil,

Cujo processo de urbanização se deu maneira muito rápida, desigual, bem como destituído de perspectivas de planejamento, o desenvolvimento das cidades resultou na formação de espaços eivados de consideráveis disparidades socioeconômicas e de elevada degradação socioambiental; nestes, a deterioração da atmosfera é, de maneira geral, apenas mais um testemunho da relação predatória entre a sociedade e a natureza (MENDONÇA, 2003, p. 179).

Mendonça (2010) complementa argumentando que os interesses econômicos e políticos comandaram o desenvolvimento da urbanização nos países ocidentais, como Santos (2018) destaca, "a ideologia desenvolvimentista dos anos de 1950 e a posterior ideologia do crescimento e do Brasil-Potência justificavam e legitimavam a orientação do gasto público em benefício de grandes empresas" (SANTOS, 2018, p. 113), desta forma os investimentos 
municipais atendiam e atendem aos interesses de empresas, "em lugar de canalizar os dinheiros obtidos para dar respostas aos reclamos sociais" (SANTOS, 2018, p. 113).

Nesse contexto são implementados equipamentos, principalmente nas cidades, com o intuito de favorecer e desenvolver a circulação do capital, gerando um processo antagônico de produção: para alguns de riquezas e para outros de pobreza (SANTOS, 2018).

A urbanização corporativa (SANTOS, 2018), direcionada aos interesses das grandes corporações e empresas, revela uma série de problemas que se repetem em todas as cidades, mudando apenas o nível em função de seu tamanho, "problemas como os do emprego, da habitação, dos transportes, do lazer, da água, dos esgotos, da educação e saúde" (SANTOS, 2018, p. 105) estão em todas elas.

A especulação e a escassez de serviços levam a uma valorização diferenciada do espaço, “a organização dos transportes obedece a essa lógica e torna ainda mais pobres os que devem viver longe dos centros, não apenas porque devem pagar caro seus deslocamentos, como porque bens e serviços são mais dispendiosos nas periferias" (SANTOS, 2018, p. 106) e o espraiamento da mancha urbana se configura.

Havendo especulação, há criação mercantil da escassez e acentua-se o problema do acesso à terra e à habitação. Mas o déficit de residências também leva à especulação, e os dois juntos conduzem à periferização da população mais pobre e, de novo, o aumento do tamanho urbano (SANTOS, 2018, p. 106).

Ainda segundo Santos (2018) há uma “conjugação de dois movimentos convergentes: a superposição de um sítio social ao sítio natural; e a disputa entre atividades e pessoas por dada localização" (SANTOS, 2018, p. 106), com isso a especulação atua e reforça a seletividade dos espaços, portanto

Criam-se sítios sociais, uma vez que o funcionamento da sociedade urbana transforma seletivamente os lugares, afeiçoando-os às suas exigências funcionais. É assim que certos pontos se tornam mais acessíveis, certas artérias mais atrativas e também uns e outras, mais valorizados. Por isso, são as atividades mais dinâmicas que se instalam nessas áreas mais privilegiadas; quanto aos lugares de residência, a lógica é a mesma, com as pessoas de maiores recursos buscando alojar-se onde lhes pareça mais conveniente, segundo os cânones de cada época, o que inclui também a moda. É desse modo que as diversas parcelas da cidade ganham ou perdem valor ao longo do tempo (SANTOS, 2018, p. 106).

Esse cenário revela o contraditório processo de produção do espaço capitalista, e a cidade nesse contexto "é cada vez mais produzida como mercadoria, em fragmentos, por meio 
do trabalho nela cristalizado, que contém em si valor (valor de uso e de troca) e também como meio de circulação do capital permitindo que ele se realize propriamente" (ALVAREZ, 2018, p. 66). A propriedade da terra é, dessa maneira, um elemento importante para a reprodução do capital e, com isso, a localização se torna um elemento fundamental para a atribuição do valor de troca.

De tal forma que em função da própria divisão do trabalho e a organização de uma sociedade em classes, influenciará a ocupação de uso residencial na cidade (SOUZA, 2016), “o tipo, local, tamanho e forma de moradia vão depender e expressar o modo como cada indivíduo se insere dentro do processo de produção material geral da sociedade" (CARLOS, 2013, p. 54).

A incorporação da terra como mercadoria se coloca como um elemento para a reprodução do capital de tal forma que morar na cidade tem um preço, que é elevado (ALVAREZ, 2018). Souza (2016) complementa afirmando que "embora morar seja um ato necessário a todas as pessoas, ele é vivenciado de forma diferente por cada classe social" (SOUZA, 2016, p. 78).

Assim, a produção desigual do espaço engendra o desenvolvimento de uma vulnerabilidade social aos sujeitos, nesses termos Cunico (2013) afirma que a "vulnerabilidade está relacionada às desvantagens sociais que são reflexos e produtos da pobreza, que por sua vez é assimilada como condição social que afeta de maneira restritiva indivíduos, grupos sociais e lugares" (CUNICO, 2013, p. 15). Dessa forma, ao incorporá-la ao estudo dos eventos climáticos, esta "possibilita a compreensão analítica das condições sociais a que a população está submetida, bem como das condições ambientais presentes no espaço geográfíco" (CUNICO, 2013, p. 15).

A ideia de vulnerabilidade se assenta na necessidade de buscar possibilidade para o entendimento dos "fatores que influenciam as capacidades locais (definidas aqui como subnacionais) na preparação para, resposta e recuperação de desastres” (CUTTER, 2011, p. 60). Ainda segundo a autora é necessário ampliar o entendimento dos fenômenos naturais em seu contato com a sociedade, em função das diferentes condições de vulnerabilidade. Nascimento Júnior (2018) frisa que deve-se entender a vulnerabilidade "como resultado das condições de desigualdade social precedentes à ocorrência de processos perigosos" (NASCIMENTO JÚNIOR, 2018, p. 62).

O entendimento na vulnerabilidade deve perpassar a visualização desta enquanto um processo, que se desdobra em função da própria produção do espaço. Sendo assim, a vulnerabilidade não é um elemento cristalizado, mas sim em constante movimento, num processo de vulnerabilização (NASCIMENTO JÚNIOR, 2018). 
A vulnerabilização entendida como um processo permite um entendimento da vulnerabilidade para além de uma condição registrada pelo recenseamento, sendo assim a vulnerabilidade está associada ao próprio processo de urbanização que engendrou aquela condição, e "é também produção, um produto, produtor das concepções e das ideias de sociedade, de natureza, de espaço e de tempo" (NASCIMENTO JÚNIOR, 2018, p. 68).

A vulnerabilidade então deixa de ser uma condição visualizada isoladamente quando da ocorrência de um evento extremo ou qualquer outra manifestação de perigo e assume uma condição de resultado de dinâmicas e processos sociais que se materializam no espaço, mas que refletem um modelo econômico e social em escala superior.

Com isso visualizar a vulnerabilidade para além de uma condição já posta, é deixar de culpabilizar os sujeitos que sofrem os impactos de determinado evento perigoso e apontar "para o entendimento das circunstâncias que põem as pessoas sob risco e das condicionantes que reduzem a habilidade com que as pessoas e os lugares respondem às ameaças ambientais" (ALMEIDA, 2012, p. 104). Sendo assim a vulnerabilidade deve "compreender as características de uma pessoa ou grupo no que concerne à sua capacidade para antecipar, sobreviver, resistir e recuperar-se do impacto de uma ameaça ou perigo natural" (ALMEIDA, 2012, p. 106).

A partir dessas considerações era necessário buscar caminhos para avaliar e estimar as condições de vulnerabilidade, conforme Cunico (2013), a vulnerabilidade pode ser estimada a partir de um conjunto de variáveis socioeconômicas, no entanto, esta não deve ser apenas uma mensuração da pobreza, mas deve avaliar a "insegurança e exposição a riscos e perturbações provocadas por eventos ou mudanças, inclusive econômicas, para possibilitar uma ampliação da compreensão das condições de vida dos grupos sociais mais pobres" (CUNICO, 2013, p. 19).

De acordo com Almeida (2012) alguns elementos podem ser indicadores da vulnerabilidade social, como renda, idade, gênero, etnia, dentre outras. Essas condições "podem indicar se determinados grupos da sociedade são mais propensos do que outros ao dano, à perda e ao sofrimento no contexto das diferentes ameaças" (ALMEIDA, 2012, p. 107).

Para Nascimento Júnior (2018) a incorporação da vulnerabilidade como elemento na construção do risco climático, marca um novo olhar para o clima urbano, pois "é só no momento da vulnerabilização que a relativização da suscetibilidade e do perigo ocorre, e o risco acontece" (NASCIMENTO JÚNIOR, 2018, p. 74). Ou seja, ao acrescentar a vulnerabilidade como um dos processos intervenientes incorpora o olhar para as relações entre o espaço socialmente produzido e os impactos relacionados ao clima, ou melhor, "comporta a relação humana, física 
e social, assumindo assim, uma perspectiva holística e eminentemente complexa" (CUNICO, 2013, p. 17). 


\section{Capítulo 3: Caracterização da área de estudo}

\section{Juiz de Fora: dos primórdios ao século XXI: Aspectos históricos e econômicos}

Remontando a história do município de Juiz de Fora, retomamos aos idos do século XVII, período em que a extração de Ouro e de outras pedras preciosas davam a tônica do contexto econômico regional. Dessa forma se fazia necessário o transporte principalmente do Ouro para a capital, Rio de Janeiro (OLIVEIRA, 1994).

Ainda na segunda metade século XVII foi construída a estrada denominada "Caminho Novo", com o intuito de ligar a então Vila Rica (atual Ouro Preto) à capital nacional- Rio de Janeiro, sendo assim uma nova via de acesso, uma vez que o chamado "Caminho Velho", utilizado até então, ligava a cidade de Paraty-RJ à Vila Rica, passando pelo Sul de Minas e o Campo das Vertentes.

Deslocando-se pela Zona da Mata Mineira o Caminho Novo impulsionou a instalação de povoamentos ao longo da estrada, associados a paradas de suprimentos das tropas e suporte para os transeuntes (OLIVEIRA, 1994). Dentre os vários núcleos de povoamento ao longo do Caminho Novo, estava o povoado de Santo Antônio do Paraibuna, atualmente chamada de Juiz de Fora (Quadro 04).

Garcia Rodrigues Paes Leme, o incumbido pela feitura do caminho e filho do conhecido Bandeirante Fernão Dias Paes Leme, tinha o poder sobre as terras ao longo do Caminho Novo, com isso ele demarcou diversas Sesmarias ao longo do Caminho, sendo uma delas para o seu Genro Tomé Correia Vasques, na altura de uma planície pantanosa, como coloca Barbosa (2017), as margens de um rio que os indígenas chamavam de "Para-y-buna" ou Rio de Barro, (LESSA, 1985; BARBOSA, 2017).

Pires (1993) destaca que desde o Caminho Novo, os aglomerados populacionais que se desenvolveram, onde hoje se encontra a cidade de Juiz de Fora, muito se deram em função de sua condição de entreposto comercial no período da extração do ouro, que serviu de parada para aqueles que trafegavam em direção ao Rio de Janeiro, o desenvolvimento urbano que se processou era "rural, pontual, disperso e sem contiguidade espacial" (MACHADO, 2018, p. 26)

Até a primeira metade do século XIX, as atividades econômicas fundamentais que vão sustentar a pequena aglomeração populacional que futuramente vai se definir, paulatinamente, como núcleo urbano vão se basear na produção de alimentos para suprir o intenso tráfego da estrada, haja vista o posicionamento estratégico do lugarejo frente ao Rio de Janeiro, 
ponto de destino fundamental para toda a movimentação de cargas e pessoas (PIRES, 1993, p. 110).

Segundo Machado (2018) "até o final da década de 1830, Juiz de Fora não reunia suficiente consolidação econômica, demográfica ou urbana capaz de fazê-la figurar entre as localidades mais importantes do período. Pelo contrário” (MACHADO, 2018, p. 26), ao longo dessa primeira metade do século XIX o povoado de Santo Antônio do Paraibuna esteve vinculado à freguesia de Simão Pereira, sendo que, é a partir de 1840 que a cidade passará a desenvolver sua urbanização (MACHADO, 2018)

Dentre os fatores responsáveis pela urbanização em Juiz de Fora, Machado (2018) coloca a consolidação do café na região, e o desenvolvimento de uma elite cafeicultora, além da construção da Estrada Nova do Paraibuna, pelo engenheiro alemão Heinrich Wilhelm Ferdinand Halfeld, aberta a partir de 1836, (Quadro 04), com o objetivo de construir um caminho possível à passagem de carroças, entre a Vila Rica e a divisa do Estado do Rio de Janeiro, foi aí que o mesmo, na região de Juiz de Fora, muda o traçado do Caminho Novo, atravessa o Paraibuna na região de Benfica e estabelece o novo caminho, agora pela margem direita do Paraibuna, até então pouco ocupada.

A partir disso, Lessa (1985) coloca que Antônio Dias Tostes, importante proprietário de terras e figura da época, fez a primeira casa na margem direita do Paraibuna, ao longo da estrada nova de Halfeld, além disso doou uma porção do terreno para a construção de uma igreja, atual Catedral Metropolitana de Juiz de Fora, impulsionando a ocupação na margem direita do rio. Desse período em diante, diversas casas começam a se instalar ao longo da estrada do Halfeld.

No período da virada entre a primeira e a segunda metade do século XIX o café começa a despontar na região (PIRES, 1993), ultrapassando rapidamente a produção de alimentos, para o abastecimento das tropas, até então dominante. Segundo Machado (2018) enquanto o café foi a principal atividade na região, Juiz de Fora foi assumindo uma condição de centralidade e diversos investimentos foram realizados na cidade e região.

São grandes os investimentos desse período: em transportes (Estrada União \& Indústria, Ferrovia D. Pedro II, sistema de bondes urbanos de Juiz de Fora, elétricos a partir de 1906); em infraestrutura (abertura de ruas, ampliação da construção civil, hospital, abastecimento público de água); no desenvolvimento do comércio e da prestação de serviços (lojas, hotéis, profissionais liberais); no sistema de educação e cultura (escolas, teatros, revistas, jornais); na rede bancária (criação do Banco Territorial e Mercantil de Minas Gerais e do Banco de Crédito Real de Minas Gerais, ambos com sede em Juiz de Fora); nos sistemas de telefonia e telégrafo; nas indústrias diversas (com destaque para o ramo têxtil). Tudo isso impulsionado por um sistema gerador próprio, fruto do pioneirismo da instalação da primeira usina hidrelétrica da América do Sul, inaugurada em 5 de setembro de 1889 (MACHADO, 2018, p. 295). 
Nesse contexto o arraial passa a condição de Vila de Santo Antônio do Paraibuna em 1850, em 1856 passa a cidade do Paraibuna e mais tarde em 1865 torna-se cidade do Juiz de Fora (ABDALLA, 2000). Juiz de Fora, segundo Lessa (1985, p. 27), era "Luís Fortes Bustamante e Sá, que na data de 18 de março de 1711 havia sido nomeado juiz de fora da cidade do Rio de Janeiro. Bustamante era fidalgo português, prestigiado e audacioso", que adquiriu uma légua de terra no Caminho Novo.

Em 1860, é contratado outro alemão, o Gustavo Dodt, sob supervisão de Halfeld, para a proposição de uma planta com o desenho de algumas ruas perpendiculares à rua da Direita (Atual avenida Barão do Rio Branco) propondo um traçado (Quadro 04) para o que se consolidava como o centro da então Vila de Santo Antônio do Paraibuna e posteriormente Juiz de Fora (ABDALLA, 2000).

É a partir desse momento que vai se modernizando o sistema de transporte rodoferroviário-; que se inicia o desenvolvimento de nucleamentos urbanos naquela região; onde Juiz de Fora desponta-se como principal entreposto comercial e logístico, em que parte da acumulação do capital cafeeiro será reinvestida; e com isso, pari passo, o setor urbano e industrial vai se constituindo lócus por excelência para o deslocamento do capital agrário em direção ao comércio, à indústria de transformação, às atividades financeiras (PAULA, 2008, p. 83).

Sendo que a produção de café, se desenvolveu sobretudo na Zona da Mata Mineira, no contato com o estado do Rio de Janeiro. Nesse cenário, Juiz de Fora desponta como um elo entre as cidades produtoras em Minas e o Rio de Janeiro, onde seria exportado.

Em 1861 concluem-se os trabalhos de construção da rodovia União e Indústria, verdadeiro ponto de inflexão no processo histórico de desenvolvimento de Juiz de Fora. Por um lado, a construção da rodovia, pela melhoria do sistema viário local, até esta época extremamente precário e constituindo um óbice para o desenvolvimento econômico da Zona da Mata, provoca um grande impulso no processo da expansão cafeeira que vinha ocorrendo até então, consolidando definitivamente a economia agroexportadora na região (PIRES, 1993, 121).

Ademais, com a chegada de imigrantes na cidade, sobretudo no período de construção da rodovia União e Indústria, estes influenciaram e diversificaram as atividades urbanas nesse período. Com “a chegada das ferrovias em meados da década de 1870, só fez impulsionar ainda mais o crescimento urbano e as atividades assalariadas, consolidando, desse modo, a cidade de 
Juiz de Fora, como o principal entreposto comercial e logístico de Minas Gerais" (PAULA, 2008, p. 84).

Desse modo, ainda que fosse um centro da circulação do café na região, passa-se nesse período da segunda metade do século XIX, haver investimentos em atividades fabris na cidade, "ou seja, por um lado, na esteira das inversões de capital do núcleo agroexportador; de outro, incentivada pelo processo de transição das relações de trabalho, impulsionada pela abolição da escravidão" (PAULA, 2008, p. 83).

Segundo Machado (2018) “em 50 anos o município passou da condição de recém-criado - emancipado de Barbacena - em 1850, para a condição de mais rico, desenvolvido e populoso do Estado de Minas, em 1900" (MACHADO, 2018, p. 294), e com isso, ocorre um franco processo de urbanização e de desenvolvimento urbano, influenciado, também, pela chegada dos imigrantes na cidade, Machado (2018, p. 295) coloca “entre os anos de 1855 e 1920 a população municipal cresce $325,18 \%$, tornando Juiz de Fora, na virada do século, o município mais

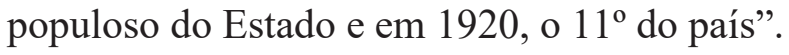

Conforme Paula (2008) Juiz de Fora foi a primeira cidade de Minas Gerais a se industrializar, ainda no final do século XIX e início do século XX. Paula (2006) estabelece dois momentos da industrialização na cidade, um primeiro que se desdobra até a década de 1880 , associado às condições urbanas trazidas no bojo da produção cafeeira, e um segundo momento a partir do final do século XIX e início do século XX.

Essa primeira onda de industrialização ficou conhecida por uma "fase proto-industrial" (PAULA, 2006, p. 238). Nesse contexto, fora "marcada pelo baixo índice de capital investido, baixo volume de mão de obra e pela presença dos proprietários dos meios de produção como produtores diretos do processo" (BARBOSA, 2017, p. 59)

Nas palavras de Paula (2006, p. 177) a segunda fase, desenvolveu-se principalmente a partir do início do século XX.

A dinâmica agroexportadora cafeeira será importante para que a partir do final
da década de 1880 surja na cidade de Juiz de Fora unidades fabris de grande
porte, desenvolvendo assim, de acordo com o autor, um processo de
industrialização que entra em estagnação e, mesmo em declínio, a partir da
década de 1930 .

Com a crise de 1929 e por conseguinte a queda na exportação do café, a economia de Juiz de Fora, que havia se industrializado em grande medida associada ao setor têxtil, sofre com a baixa diversificação industrial. Segundo Paula (2008) nesse período, com o advento do desenvolvimento de indústrias de base, desponta o setor do minério de Ferro, na porção central 
do estado, fazendo com que o prestígio alcançado por Juiz de Fora no início do século, fosse se perdendo em detrimento da mineração.

A esse respeito, Rodrigues (2013, p. 111) explica que

No final da década de 1930, a economia da cidade apresenta nítidos sinais de desaceleração industrial e declínio econômico. Acrescenta-se que, posteriormente, ocorreu tanto a transferência da capital do país, Rio de Janeiro, situada próxima a Juiz de Fora, para Brasília, em 1960, quanto a migração dos novos investimentos do governo, voltados para as indústrias de bens de capital e bens de consumo duráveis para a região metropolitana de São Paulo, contemplando também regiões como o Vale do Aço em Minas Gerais (RODRIGUES, 2013, p. 111).

Juiz de Fora que havia despontado como produtora de bens de consumo (indústrias têxteis, bebidas e alimentos) acabou perdendo competitividade (MENEZES, 2004), além de atrair poucos empreendimentos nesse período.

Juiz de Fora esteve ausente dos grandes projetos de investimentos idealizados pelo Plano de Metas, tendo apenas sido beneficiada marginalmente com a instalação da Facit S.A. Máquinas de Escritório e da empresa Beckton Dickinson Indústrias Cirúrgicas Ltda., de capital internacional, que em nada alteraram a tendência de decadência industrial da cidade. Acrescenta ainda que inúmeras indústrias tradicionais decretaram falência, razão pela qual não ocorreu nenhum processo de dinamização da economia local (RODRIGUES, 2013, p. 112).

Dessa forma, de acordo com Rodrigues (2013), o período de 1930 a 1960 fora marcado pela decadência da Zona da Mata, em função da derrocada na produção do café e da baixa representatividade da indústria têxtil e de alimentos nesse período em que o foco da industrialização nacional já mudara.

Na década de 1970 com a implementação do II Plano Nacional do Desenvolvimento (II PND), financiado por capitais estrangeiros e empresas estatais, visando diminuir as disparidades regionais e arrefecer as dinâmicas migratórias para os grandes centros (RODRIGUES, 2013), cria-se com o financiamento emprestado ao Banco Mundial o Projeto Cidade de Porte Médio (CPM/BIRD), “o acordo objetivava promover o crescimento da atividade econômica e a melhoria da infraestrutura física, serviços urbanos e administração municipal" (RODRIGUES, 2013, p. 114) atuando nos centros considerados de porte médio, como era o caso de Juiz de Fora. De acordo com Rodrigues (2013)

Negociações políticas reforçadas por maior volume de recursos, incentivos fiscais e creditícios foram importantes ainda para a atração de dois investimentos de peso do setor metalúrgico para a cidade: a Siderúrgica Mendes Júnior, hoje Arcelor Mittal e a Cia Paraibuna de Metais, hoje Votorantim Metais e que entraram em funcionamento em 1984 e 1980, respectivamente (RODRIGUES, 2013, p. 115). 
Entretanto, mesmo com este movimento, a cidade não buscou alternativas de integração desses empreendimentos, sendo considerados apenas fatos isolados. Dessa forma a partir de então Juiz de Fora se estabelece após a década de 1990 como um centro de prestação de serviços e do comércio varejista (TASCA, 2010), nesse período "atividades terciárias que se tornaram tradicionais, como os serviços de educação e saúde, que se ampliaram atendendo não somente à população da Zona da Mata, mas também, outras cidades mineiras e do Estado do Rio de Janeiro" (TASCA, 2010, p. 109). 


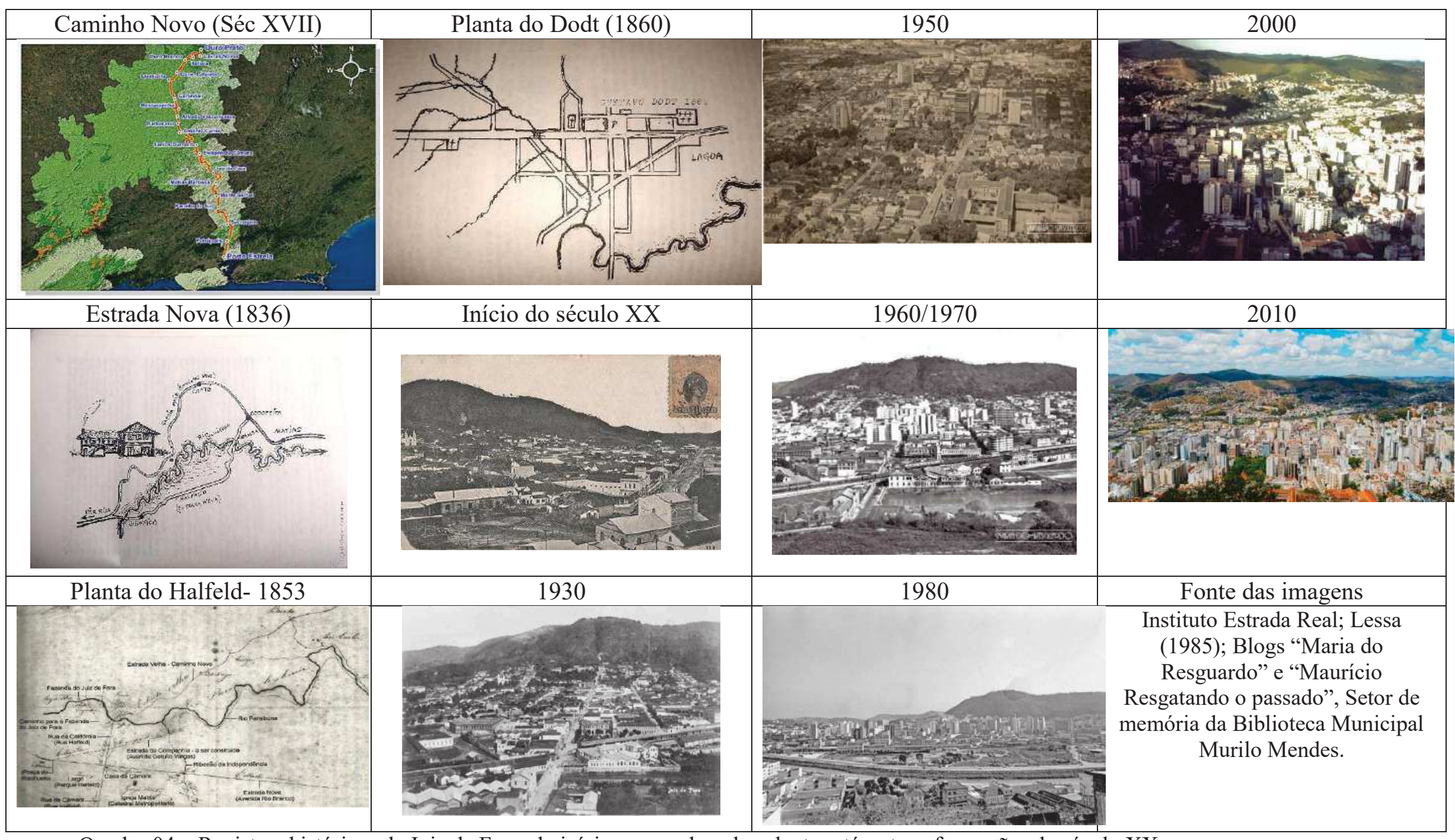

Quadro 04: Registros históricos de Juiz de Fora, do início, passando pelas plantas até as transformações do século XX. 


\section{A expansão da mancha urbana e o crescimento populacional}

A cidade de Juiz de Fora seguiu o ritmo da urbanização brasileira, com um processo intenso na segunda metade do século XX, marcado pela elevação na população total do município, bem como o crescimento da população urbana, que atingiu $92 \%$ na década de 1970 (PJF, 2020) influenciando assim para o crescimento da mancha urbana, figura 08, sendo que em 1950 a área urbana era de $19,3 \mathrm{Km}^{2}$, chegando a $130,8 \mathrm{Km}^{2}$ em 2010 , quando a população urbana atingiu 98,9\% (PJF, 2020).

Figura 08: Evolução da população e da mancha urbana de Juiz de Fora- MG

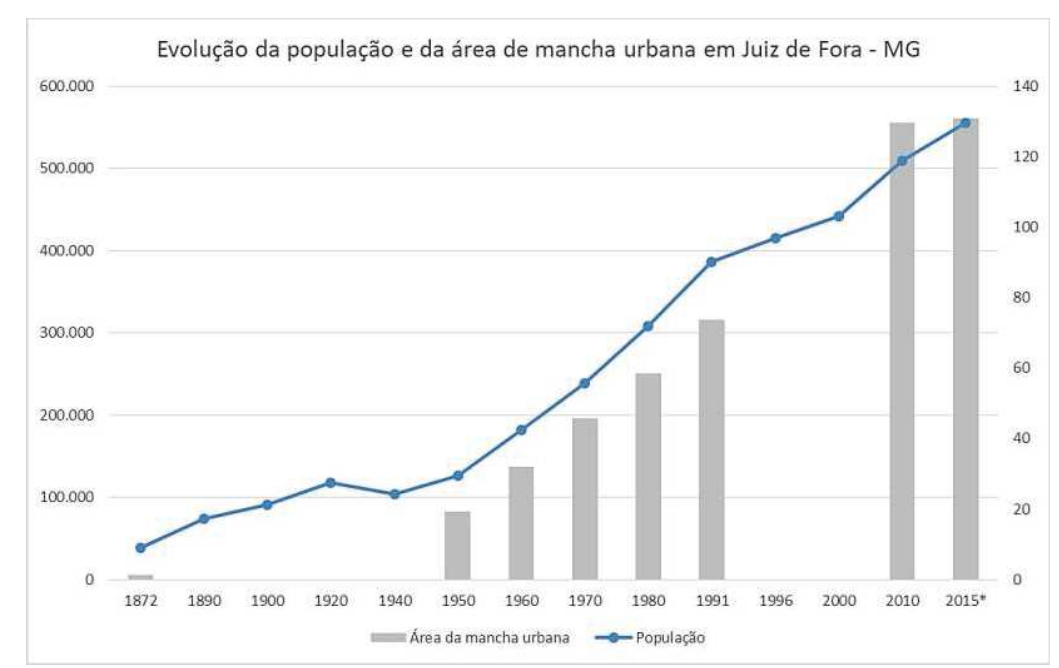

Fonte dos dados: IBGE; Prefeitura de Juiz de Fora-PJF. Organizado pelo autor.

A mancha urbana de Juiz de Fora se desenvolveu a princípio no centro da cidade e às margens do Rio Paraibuna, principalmente a partir da estrada nova do Halfeld, além disso a instalação da ferrovia no mesmo eixo (Figura 09; Quadro 04), fez com que se desenvolvesse essa ocupação marginal, ao rio, a estrada e a linha férrea (SOUZA, 2006; GERALDO, 2014).

Com o crescimento populacional e da mancha urbana esta ocupação passou a ocupar outros setores do município, e subiu as encostas, bem como ocupou as subbacias do rio Paraibuna (Young, Tapera, Matirumbide, Ipiranga, Humaitá, entre outros) a partir dessa ocupação e o crescimento da mancha urbana, as porções mais declivosas passaram a ser ocupadas, com a retirada da vegetação o que altera o quadro ambiental dessas áreas.

Segundo Geraldo (2014), a partir da década de 1980 "houve a tendência à concentração de equipamentos atrativos nas regiões noroeste e sudoeste da cidade. $O$ fator de maior evidência é a presença da BR-040 e recentemente dos acessos Norte e Sul, compondo o Cinturão da BR040" (GERALDO, 2014, p. 123). A região Oeste da cidade, conhecida como cidade alta, apesar de ter uma ocupação antiga (associada a imigração alemã), foi a partir da década de 1980 que 
esta região teve um crescimento elevado (GERALDO, 2014). De acordo com Rodrigues (2005) as regiões Oeste e Noroeste representaram no período de 1991 a 2000 os maiores incrementos populacionais do município.

Figura 09: Evolução da mancha urbana em Juiz de Fora de 1963 a 2010.

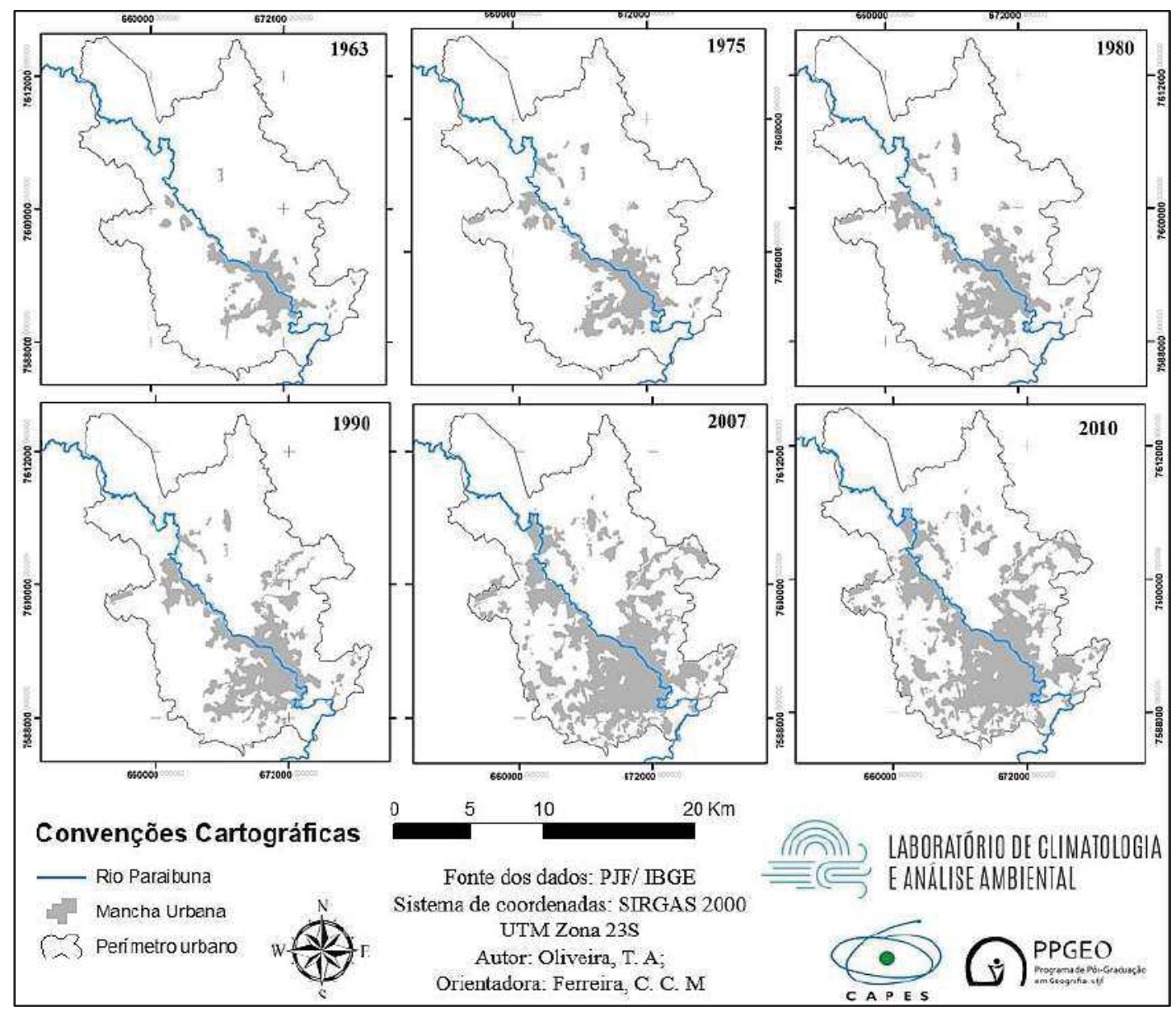

Fonte: Organizado pelo autor.

A expansão do crescimento para essa região se deu muito em função da instalação do campus da Universidade Federal de Juiz de Fora- UFJF no bairro Martelos, a criação de vias de acesso, como a avenida Presidente Itamar Franco (Antiga Av. Independência), a construção da BR 040, (ALBERTONI, 2014) e daí em diante este será o setor com o maior crescimento populacional nesse período. Além disso, nos últimos anos esta região recebeu diversos empreendimentos habitacionais, tanto de alto padrão, como os loteamentos fechados, tanto os conjuntos habitacionais do Minha Casa Minha Vida (MCMV), (GERALDO, 2011). 
Figura 10: Juiz de Fora no contexto regional.

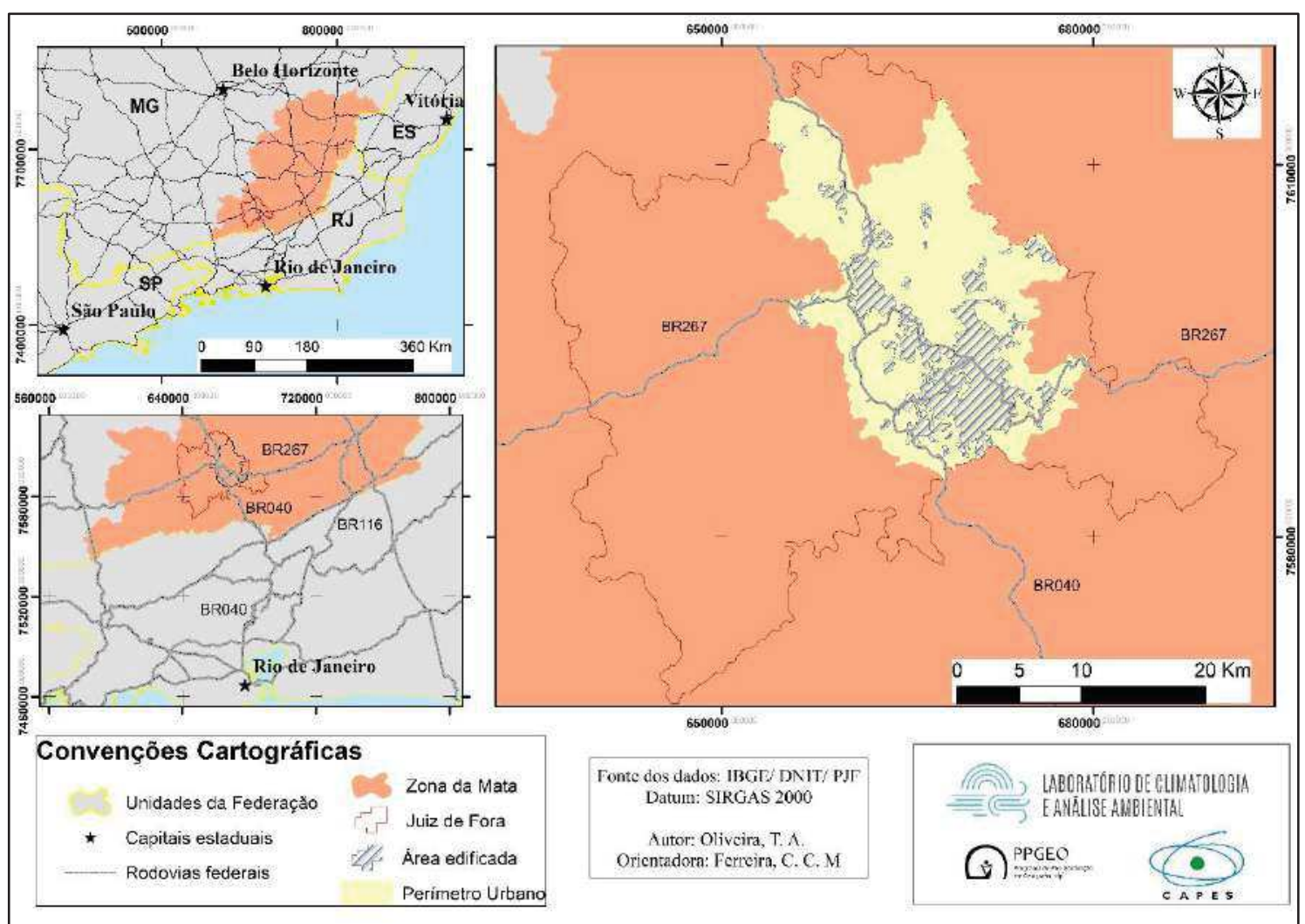

Fonte: Organizado pelo autor.

Isso posto, até 2010 Juiz de Fora contava com 516247 habitantes, segundo estimativas, em 2019 contava com 568873 habitantes (IBGE, 2020), isso representa que a cidade é a $36^{\circ}$ mais populosa do país, a $4^{\circ} \mathrm{em}$ Minas Gerais e a $1^{\circ}$ na Zona da Mata Mineira (Figura 10). O município atualmente conta com uma área de $1429875 \mathrm{~km}^{2}$, com nove distritos: Juiz de Fora (sede), Sarandira, Torreões, Rosário de Minas, e os criados pela lei ${ }^{\circ} 13.769$, de 25 de outubro de 2018: Valadares, Penido, Humaitá, Monte Verde de Minas e Caetés de Minas, bem como redelimitou os outros distritos (Figura 11). 
Figura 11: Juiz de Fora e seus distritos.

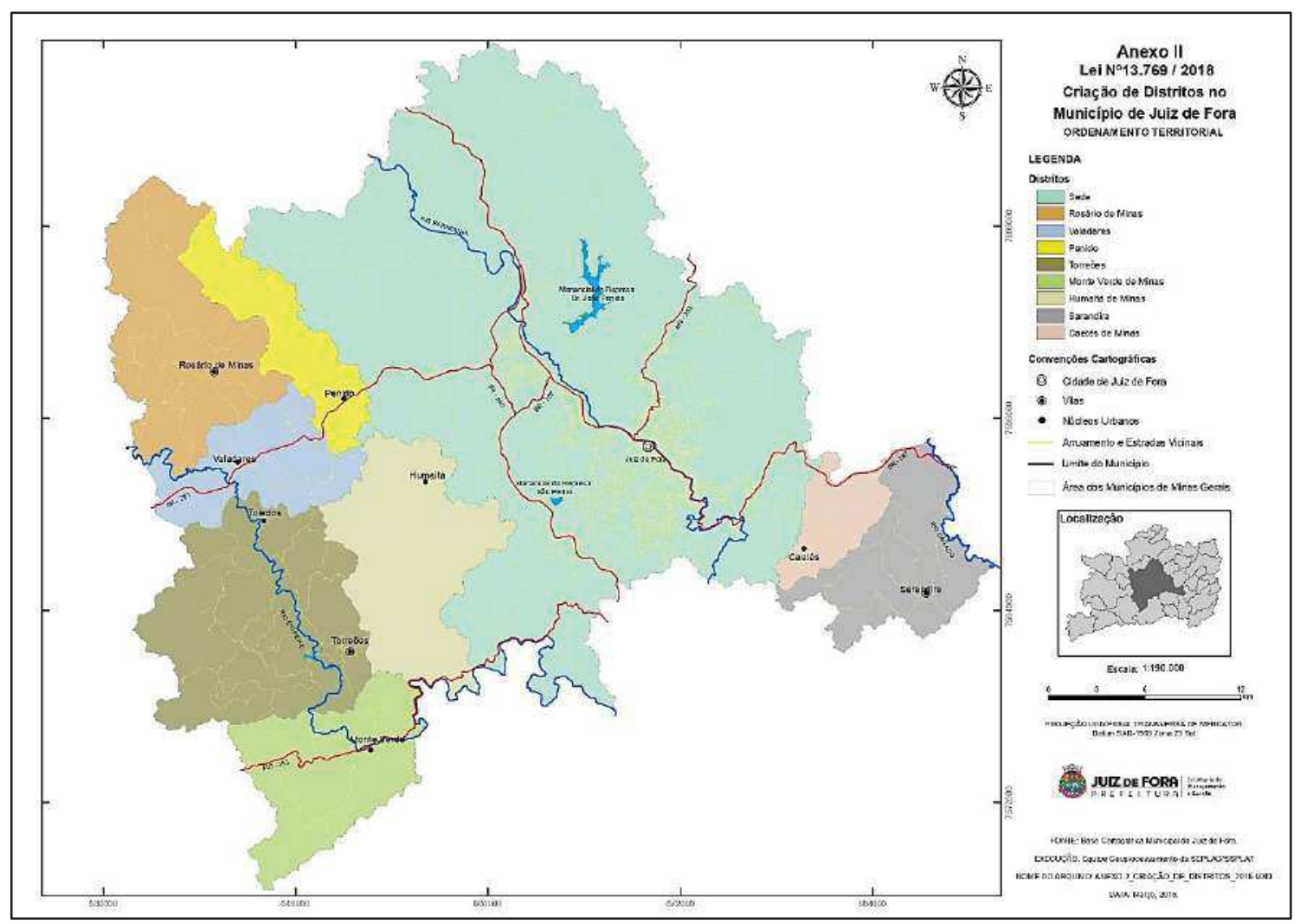

Fonte: Plano Diretor Participativo, PREFEITURA DE JUIZ DE FORA, 2018, Art. 38. 


\section{A legislação e o planejamento urbano em Juiz de Fora}

Do ponto de vista urbanístico, até a década de 1980, a cidade era regida pelo código de obras de (1938), (TASCA, 2010), sendo que com o advento do Projeto CPM, a cidade institui o IPPLAN (Instituto de Pesquisa e Planejamento) e com isso algumas leis urbanísticas foram criadas. Segundo Souza (2016, p. 58).

A cidade, que foi uma das primeiras a integrar o projeto CPM, teve como ação do poder público municipal a criação do Instituto de Pesquisa e Planejamento (Ipplan) em 1977, cuja função era institucionalizar o planejamento urbano local. Para isso, uma equipe especializada coordenou a implantação de mecanismos modernizadores, tais como o controle orçamentário, a proteção ambiental, o assessoramento técnico e a política de transporte e trânsito, entre outros. Sob a coordenação do Ipplan, três leis entraram em vigor: a Lei n. 6.908, de 31 de maio de 1986, dispondo sobre o Parcelamento do Solo; a Lei n. 6.909, de 31 de maio de 1986 sobre o Código de Edificações e a Lei n. 6.910, de 31 de maio de 1986, sobre o Ordenamento do Uso e Ocupação do Solo (SOUZA, 2016, p. 58).

Esses instrumentos de legislação viriam com o intuito de ordenar e controlar o crescimento urbano da cidade, para mais tarde iniciar-se a discussão no sentido de construir um Plano Diretor, que, começadas as discussões em 1996, e se arrastando com várias alterações no texto, foi instituído e publicado no início dos anos 2000.

O projeto do Plano Diretor foi iniciado em 1995, com organização técnica do IPPLAN, no final do mandato do então prefeito Custódio Mattos, que até então, segundo Tasca (2010) demonstrava um interesse da prefeitura pelo planejamento urbano da cidade. No entanto, com seu sucessor no cargo, Tarcísio Delgado, assumindo a prefeitura em 1997, o plano voltou à discussão, dispositivos que tratavam do parcelamento do solo foram retirados e o plano seguiu para aprovação em " 27 de junho de 2000. Juiz de Fora passa a ter, finalmente, seu Plano Diretor de Desenvolvimento Urbano, um elaborado diagnóstico físico-territorial, porém, sem o conteúdo fundamental das leis de parcelamento e de uso e ocupação do solo" (TASCA, 2010, p. 125).

Dentre as proposições estava a ideia de reduzir a fragmentação da mancha urbana do município; intensificar a ocupação nas margens do rio Paraibuna, "as proposições orientavam para a descompressão da Área Central, sem, contudo, retirar seu papel dinamizador da cidade e da região" (TASCA, 2010, p. 126), além de fomentar a ocupação no setor noroeste da cidade (TASCA, 2010) e desestimular a ocupação nos setores Oeste, Nordeste e Sudeste.

Destaca-se que o setor Noroeste é a região da cidade caracterizada por um forte vetor de crescimento, haja vista os distritos industriais e os bairros operários que surgem ao redor das indústrias. Além disso, é porta de entrada/saída da cidade através da rodovia BR-040, ligando Juiz de Fora ao 
interior de Minas Gerais, Espírito Santo, São Paulo, Rio de Janeiro, entre outras cidades. Já os setores Oeste, Sudeste e Nordeste, são os bairros da chamada Cidade Alta, cujo impedimento à construção se dá por ser área de preservação ambiental aos pés do Morro do Imperador. Existem ainda aqueles que fazem divisa com outros municípios, como os setores Leste e Sul, que já possuem ocupação acentuada (TASCA, 2010, p. 129).

Dessa forma era instituído o plano diretor de Juiz de Fora PDDU/JF, com vias de ser revisto e atualizado a cada 10 anos, apenas em Novembro de 2013 fora instituído o Grupo de Trabalho para "acompanhar a elaboração da primeira revisão do Plano Diretor de Desenvolvimento Urbano de Juiz de Fora - PDDU/JF” (PREFEITURA DE JUIZ DE FORA, 2013, art. 1), passando então a denominação de Plano Diretor Participativo, cumprindo a obrigatoriedade da participação popular no processo construtivo do mesmo. Após a construção do material diagnóstico no período de 2013 a 2015, o Plano Diretor Participativo de Juiz de Fora foi sancionado em 3 de Julho de 2018.

\section{Caracterização das regiões de planejamento de Juiz de Fora}

Ao longo do trabalho serão utilizados os limites estabelecidos pela Prefeitura de Juiz de Fora, através das Regiões Urbanas e Regiões de Planejamento. As regiões urbanas foram instituídas através de decreto municipal de número 4219 de 1989, no qual ficaram estabelecidas as 81 regiões urbanas da cidade, que por sua vez agrupam um ou mais bairros (Figura 12).

As regiões de planejamento foram utilizadas no âmbito do Plano Diretor de 1996, no entanto, inicialmente foram constituídas 12 regiões de planejamento baseadas em características espaciais das regiões urbanas, e passaram a 8 regiões de planejamento a partir do Plano Diretor Participativo aprovado em 2018.

Na figura 12 estão localizadas as 81 regiões urbanas e suas respectivas regiões de planejamento, bem como no quadro 05 , estão todas as regiões urbanas, com as regiões de planejamento e seus números de ordem, utilizados para a identificação das RUs ao longo do trabalho. 
Figura 12: Regiões urbanas do município de Juiz de Fora

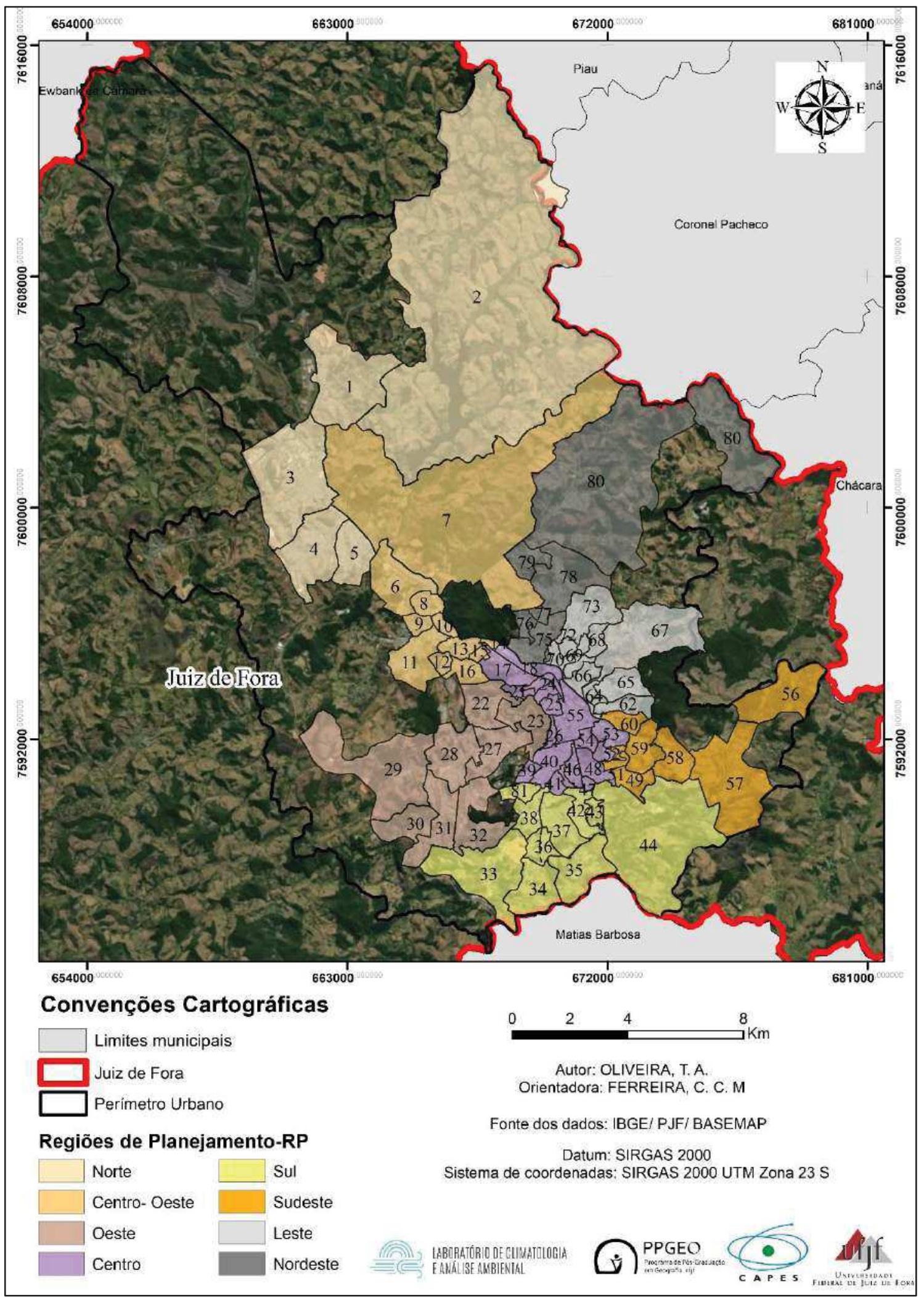

Fonte: Organizado pelo autor. 
Quadro 05: Regiões de planejamento; regiões urbanas, número de ordem e bairros de Juiz de Fora.MG.

\begin{tabular}{|c|c|c|c|c|c|c|c|}
\hline RP & Número & $\frac{\mathrm{RU}}{\mathrm{RU}}$ & Bairros e loteamentos & $\frac{R P}{R P}$ & Nümero & $\mathrm{RU}$ & Bairos eloteamentos \\
\hline \multirow{5}{*}{ Norte } & 1 & Barreira & Barreira do Triunfo, Novo Triunfo, Aldeia, Volta Grande & \multirow{13}{*}{ Leste } & 61 & Botanágua & Botanágua \\
\hline & 2 & Represa & $\begin{array}{l}\text { Represa, Nauttico, Taboporanga, Jardim Paraisos, Ensseada Parque } \\
\text { Feclogico }\end{array}$ & & 62 & São Bemardo & São Bemardo, Jardim do Sol, Bosque dos Pinheiros, Belvedere \\
\hline & 3 & Benfica & $\begin{array}{l}\text { Benfica, Disitio Industrial, Säo Damiäo, Araújo, Ponte Preta, Vila do } \\
\text { Sape, Nova Benfica, Vila Esperança I e II }\end{array}$ & & 63 & Cesário Alvim & Cesário Alvim \\
\hline & 4 & Santa Cruz & $\begin{array}{l}\text { Santa Cruz, Vila Melo Reis, São Judas Tadeu, São Francisco de Paula, } \\
\text { Verbo Divino, Jardim dos Alfineiros, Oswaldo Cruz, Santa Clara, Morada } \\
\text { Novaa a }\end{array}$ & & 64 & Vitorino Braga & Vitorino Braga, Santos Anjos, Jardim Vitorino, Ladeira \\
\hline & 5 & Nova Era & Nova Era, Nova Era I II, Santa Lúcia, Jardim Santa Isabel & & 65 & Santa Candida & Săo Bene dito, Vila Alpina, Santa Cândida, São Sebastião, Parque ABC \\
\hline \multirow{11}{*}{ Centro Oeste } & 6 & Barbosa Lage & $\begin{array}{l}\text { Barbosa Lage, Cidade do Sol, Parque das Torres, Santa Amélia, Joquie } \\
\text { clube II Santa Maria Recanto da Mata }\end{array}$ & & 66 & Grajaú & Grajaú, Alto Grajaú, Săo Tarcisio \\
\hline & 7 & Remonta & $\begin{array}{l}\text { Remonta, Joquei II IIII, Miguel Mararinho, Jardim LEmitage, Parque das } \\
\text { Torres }\end{array}$ & & 67 & Linhares & $\begin{array}{l}\text { Linhares, Bom Jardim, Trés Moinhos, Yung, Residencial Jardim das } \\
\text { Flores, Recanto das Pedras }\end{array}$ \\
\hline & 8 & Joquei Clube & Jóquei Clube, Vila Vidal & & 68 & Santa Rita de Cássia & \\
\hline & 9 & Jardim Natal & Jardim Natal & & 69 & Nossa Senhora de Aparecida & N. S. Aparecida \\
\hline & 10 & B. Industrial & Industrial & & 70 & Manoel Honório & Manoel Honório \\
\hline & 11 & Francisco Bemardino & $\begin{array}{l}\text { Francisco Bemardino, Miliho Branco, Amazónia, Encosta do sol, Realeza, } \\
\text { Parcue Bemadino }\end{array}$ & & 71 & Bonfim & Bonfim \\
\hline & 12 & Cartos Chagas & Carlos Chagas & & 72 & Bairu & Bairú, Alto Bairú, Vila Sozzi \\
\hline & 13 & Ceràmica & Cerâmica, Parque Bemardino & & 73 & Progresso & Progresso, Marumbi, Santa Paula \\
\hline & 14 & Săo Dimas & São Dimas & \multirow{8}{*}{ Oeste } & 22 & Borboleta & Borboleta, Residencial Pinheerios \\
\hline & 15 & Esplanada & Esplanada & & 23 & Morro do Imperador & 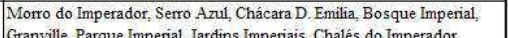 \\
\hline & 16 & Monte Castelo & Monte Castelo, Jardim da Cachoeira, Monteville & & 27 & Martelos & $\begin{array}{l}\text { Martelos, Jardim Casablanca, Adolfo Vireque, N. Sta de Fátima, São } \\
\text { Luca }\end{array}$ \\
\hline \multirow{7}{*}{ Nordeste } & 74 & Cenjtenário & Centenário & & 28 & São Pedro & 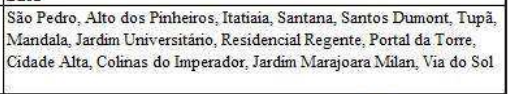 \\
\hline & 75 & Santa Terezinha & Santa Therezinha, N. Srr das Gragas, Quintas da Avenida & & 29 & Cruzeiro do Santo Antônio & Cruzeiro Santo Antônio, Bosque do Imperador, Viñ̃a del Mar \\
\hline & 76 & Eldorado & Eldorado, Alto Eldorado & & 30 & Nova Califómia & Nova Califónnia \\
\hline & 77 & Bom Clima & Bom Clima & & 31 & Novo Horizonte & Novo Horizonte, São Clemente, Martiândia, Jardian da Serra, Spinavilie \\
\hline & 78 & Banderantes & Banderiantes, Parque Guarani, Vivendas da Serta & & 32 & Aeroporto & Aeroporto, Jardim Guadalajara \\
\hline & 79 & Granjas Bethânea & Granjas Betànea & \multirow{8}{*}{ Sudeste } & 49 & Vila Ideat & Vila Ideal Solidariedade, Parque Attanta \\
\hline & 80 & Grama & \multirow{2}{*}{ 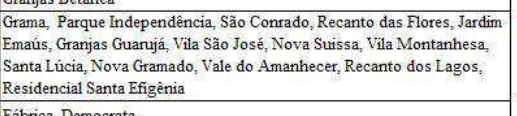 } & & 50 & Vila Olavo Costa & Vila Olavo Costa \\
\hline \multirow{19}{*}{ Centro } & 17 & Fábrica & & & 51 & Furtado de Menezes & $\begin{array}{l}\text { Vila Furtado de Menezes } \\
\end{array}$ \\
\hline & 18 & Mariano Procópio & Mariano Procópio & & 56 & Floresta & $\begin{array}{l}\text { Floresta, Forestinha } \\
\text { Retita }\end{array}$ \\
\hline & 19 & Morro da Glória & Morro da Glónia & & 57 & Retiro & 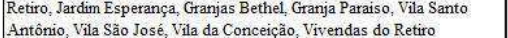 \\
\hline & 20 & Santa Catarina & Santa Catarina & & 58 & Santo Antônio do Paraibuna & Santo Antonionio, Parque Serra Verde \\
\hline & 21 & Vale do Ipê & Vale do Ipế & & 59 & B. Loudes & Lourdes, Tiguera \\
\hline & 24 & Jardim Glöria & Jardim Glória & & 60 & Costa Carvalho & Costa Carvalho, Bairro Aracy, Bairro JK, Jardin da Lua, Porto do Sol \\
\hline & 25 & Santa Helena & Santa Helena & \multirow{10}{*}{ Sul } & 33 & Salvaterra & Salvaterra, Portal do Aeroporto \\
\hline & 26 & Paineiras & Paineiras, Redentor & & 34 & Sagrado Coração de Jesus & Sagrado Corą̧ão de Jesus \\
\hline & 39 & Dom Bosco & Dom Bosco & & 35 & São Geraldo & $\begin{array}{l}\text { Săo Geraldo, Vale Verde, Jardim Unuarama, Previdenciärios, Residencial } \\
\text { Renascenca. Terra Nostra Fazen dinha do Ipiranga }\end{array}$ \\
\hline & 40 & São Mateus & Săo Mateus & & 38 & Teiverias & 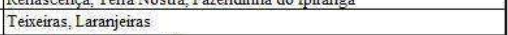 \\
\hline & 41 & Santa Cecilia & Santa Cecilita & & 42 & Santa Luzia & Santa luzia, Jardim de Alá \\
\hline & 45 & Mundo Novo & Mundo Nove & & 43 & Cruzeiro do Sul & Bomba de Fogo, Cruzeiro do Sul \\
\hline & 46 & Alto dos Passos & Alto dos Passos & & 44 & Graminha & Graminha, Granjas Bethel, Parque das Palmeiras \\
\hline & 47 & Boa Vista & Boa Vista, Cidade Jardim & & 81 & Cascatinha & Cascatinha \\
\hline & 48 & Bom Pastor & Bom Pastor, $\mathrm{Pa}$ & & 36 & Santa Efigènia & Santa Efrigênia, Jardim Gaúcho, Cidade Nova, Cidade Nova II, \\
\hline & 52 & Vila Ozanan & Vila Ozanan & & 37 & Ipiranga & $\begin{array}{l}\text { Ippranga, Ipiranguinha, Jardim Bela Aurora, Estrela Sul, Alta Vista, Arco- } \\
\text { fris }\end{array}$ \\
\hline & 53 & Pọ̧o Rico & Poço Rico, Santa Tereza & \multirow{3}{*}{\multicolumn{4}{|c|}{ feitura de Juiz de Fora-PJF }} \\
\hline & 54 & Grambery & chenter & & & & \\
\hline & 55 & Centro & Centro & & & & \\
\hline
\end{tabular}

Fonte: Prefeitura de Juiz de Fora. Organizado pelo autor. 


\section{Dinâmica Físico Ambiental da Cidade}

Juiz de Fora está localizada no domínio morfoclimático dos "Mares de Morros", segundo Ab'Sáber (2003), na região que considerou ser caracterizada pela morraria arredondada (AB'SÁBER, 2007) fruto da intensa atuação do intemperismo químico. A cidade de Juiz de Fora encontra-se na bacia do Rio Preto, tributário do rio Paraíba do Sul (Figura 13).

Figura 13: Quadro físico regional de Juiz de Fora.

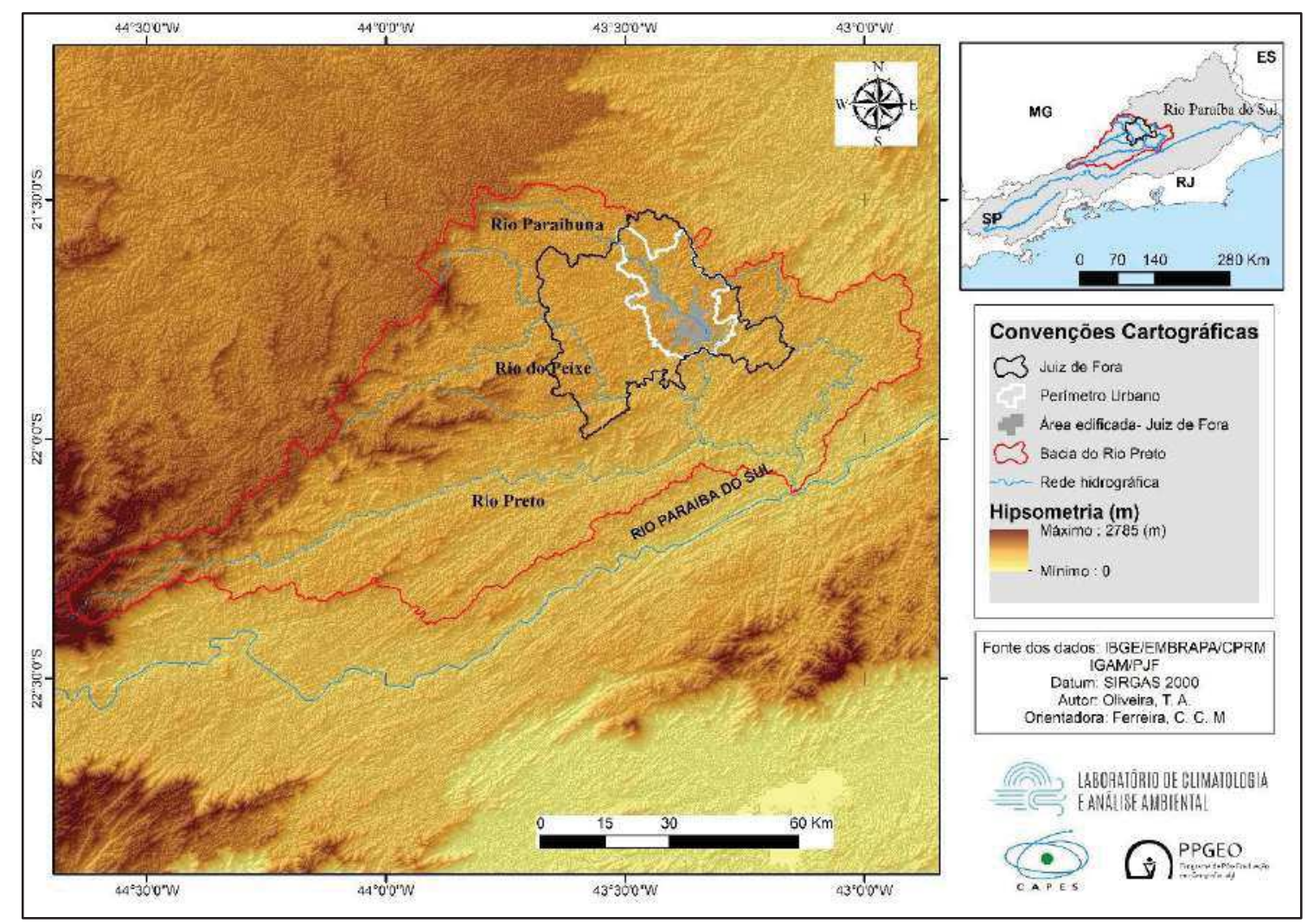

Fonte: Organizado pelo autor.

Ainda no século passado, quando Ab'Sáber desenvolveu sua tese de doutorado, o mesmo esteve em Juiz de Fora e apontou aquele sítio como indicado para as aglomerações urbanas, quando comparada a outros contextos do Brasil Sudeste. Ab'Sáber (1956) discutiu que:

Quem demanda aquela cidade de Minas Gerais, vindo de sul ou de sudeste, percebe logo a grande dificuldade existente para a localização de núcleos no meio da morraria arredondada que caracteriza a Zona da Mata mineira. Bruscamente, entretanto, entrasse em contato com uma larga planície situada a montante de uma resistente soleira rochosa, que faz parte de um pequeno maciço residual a SE da cidade. Trata-se do único compartimento de relevo relativamente plano que se pode encontrar, desde as raias de Minas Gerais com o Estado do Rio de Janeiro, passível de asilar uma aglomeração urbana da importância de Juiz de Fora (AB' SÁBER, 1956, p. 41). 
Entretanto naquele período a ocupação da cidade estava consolidada na planície do Paraibuna, como os anos se passaram, a ocupação demandou outros compartimentos do relevo para ocupar, atingindo as porções mais elevadas e as vertentes declivosas e suscetíveis a movimentos coletivos do solo. Marques Neto et al (2017) afirmam que a partir de então a ocupação se torna descontínua quando ultrapassa o gráben do Paraibuna, encontrando declividades desafiadoras à instalação humana.

Eduardo (2018) realizou o mapeamento geomorfológico do município de Juiz de Fora e destacou que este "possui feições de relevo em declividades majoritariamente elevadas, estabelecendo setores de encostas do relevo como áreas suscetíveis a escorregamentos" (EDUARDO, 2018, p. 81).

As regiões de planejamento (RP) Norte, Centro-Oeste, Centro e Sudeste estão alojadas em altitudes mais baixas e próximas à calha do Paraibuna, já as RP's Noroeste, Leste, Oeste e Sul estão nas áreas mais elevadas, sendo que a porção sul da RP Sul encontra-se mais rebaixada, pois drena para outra bacia, a bacia do Rio do Peixe (Figuras 13 e 14).

Figura 14: Mapa hipsométrico do município de Juiz de Fora-MG

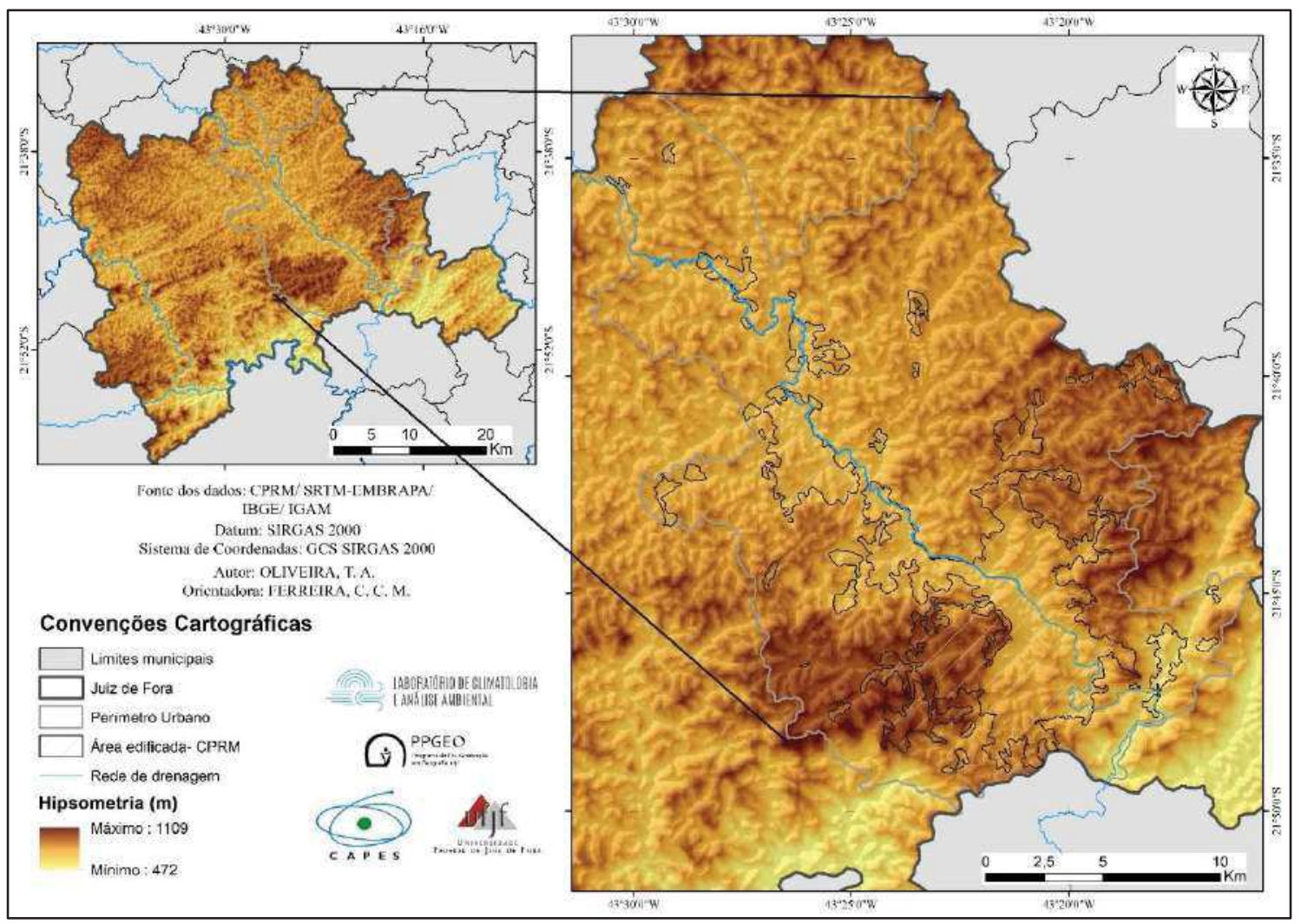

Fonte: Organizado pelo autor.

No mapeamento realizado por Eduardo (2018) verifica-se as que Regiões de planejamento se distribuem em morros, morrotes e colinas, sendo que predominam os morros 
na área urbana de Juiz de Fora (EDUARDO, 2018). Apenas a porção leste e sudeste que se posiciona em cristas reafeiçoadas, denotando relevo de maior energia. Já na porção nordeste predominam os morrotes e colinas, com topografias mais planas (Figura 14).

O município é drenado por dois rios o rio do Peixe e o rio Paraibuna tributários na Bacia do Rio Preto e posteriormente do Paraíba do Sul, sendo que o perímetro urbano de Juiz de Fora se assenta na bacia do Rio Paraibuna, Figura 15, além de uma rica rede de drenagem de subbacias dos rios já citados.

Figura 15: Rede de drenagem no Município de Juiz de Fora-MG

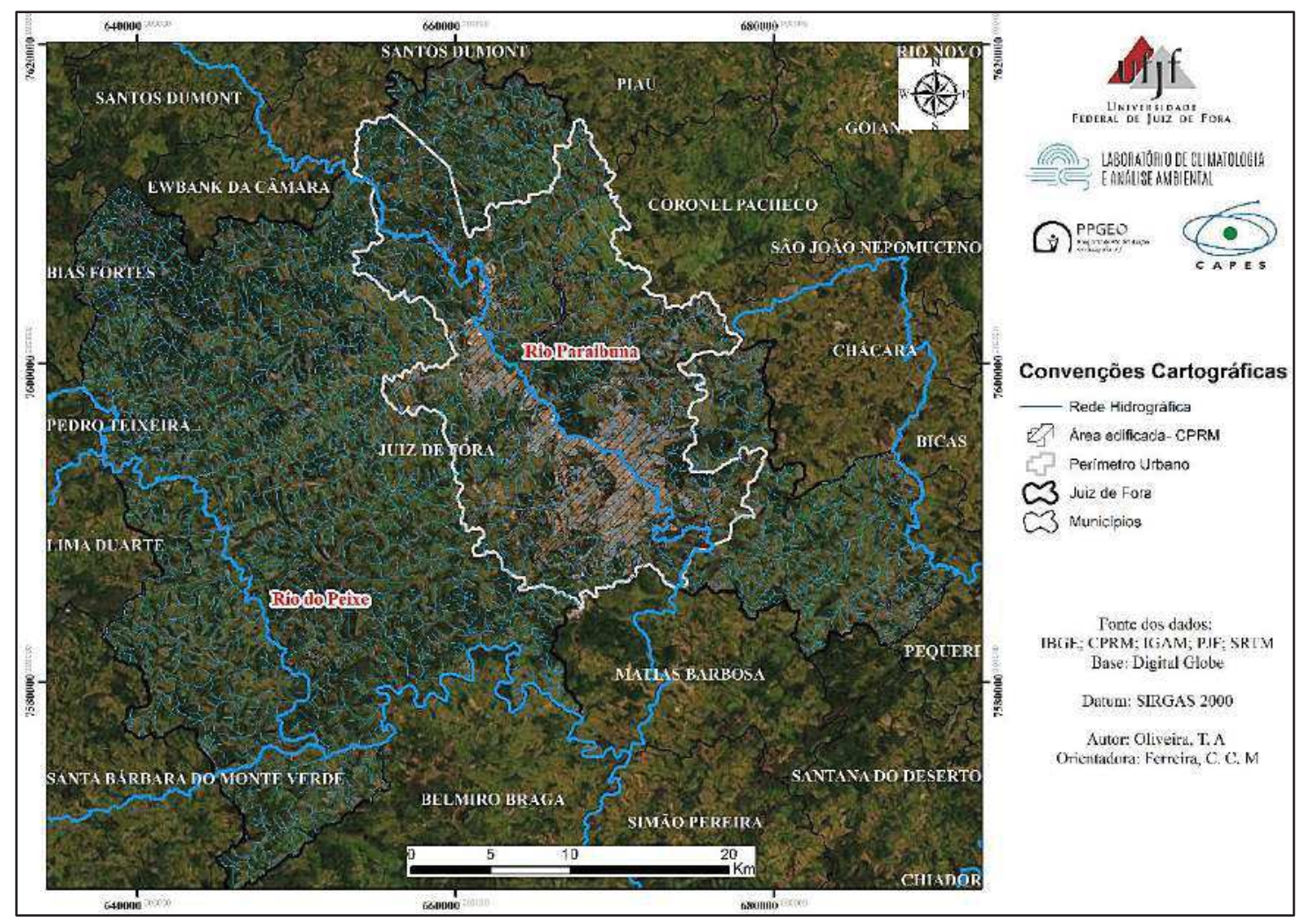

Fonte: Organizado pelo autor.

Do ponto de vista Geológico a cidade está assentada sobre o "Complexo Juiz de Fora" (ROCHA et. al., 2003), “ao sul, formado principalmente por charnockitos e kinsigitos, e o Gnaisse Piedade, ao norte, caracterizado por migmatitos variados, gnaisses e intercalações de quartzitos" (ROCHA et. al., 2003, p. 510). Associadas a diversos planos de falhas précambrianas em rochas metamórficas que "serão responsáveis pela significativa fragilidade geológica que se observa na região, definindo um ambiente de alta energia atestado pelos constantes movimentos de massa" (ROCHA et. al., 2003, p. 510).

A pedologia da área foi identificada com solos do tipo latossolo vermelho amarelo, cambissolos e neossolos litólicos, "geotecnicamente citam-se os solos de alteração, de composição areno-siltosa a argilo-arenosa, os quais caracterizam-se por apresentar estruturas 
reliquiares das rochas locais e elevada propensão à erodibilidade. (ROCHA et. al., 2003, p. 511).

Em uma análise geomorfológica, a cidade está situada na região da Mantiqueira Setentrional, na unidade das Serranias da Zona da Mata Mineira (EDUARDO, 2018). O perímetro urbano de Juiz de Fora está posicionado em altitudes que variam dos 472m atingindo os 1109m (Figura 13), no contexto geomorfológico se observa um relevo controlado pela tectônica, no qual o rio Paraibuna se posicionou em um minigráben, enquanto que dois horts, acomodam as regiões Oeste e Leste (EDUARDO, 2018).

Na figura 16 apresenta-se o mapa de declividade para o município de Juiz de Fora-MG, predominam as classes entre 6 e $30^{\circ}$ de declividade, no perímetro urbano as declividades mais elevadas estão nas regiões Oeste, Sul e Leste, onde atingem em alguns pontos os $45^{\circ}$ de declive, porções bastante ocupadas pela população. Na área urbana de Juiz de Fora, as RP's Leste e Oeste apresentam as maiores declividades da área, sendo necessário investigações a respeito da suscetibilidade à ocorrência de escorregamentos nessas áreas (EDUARDO, 2018). 
Figura 16: Carta de declividade do município de Juiz de Fora-MG

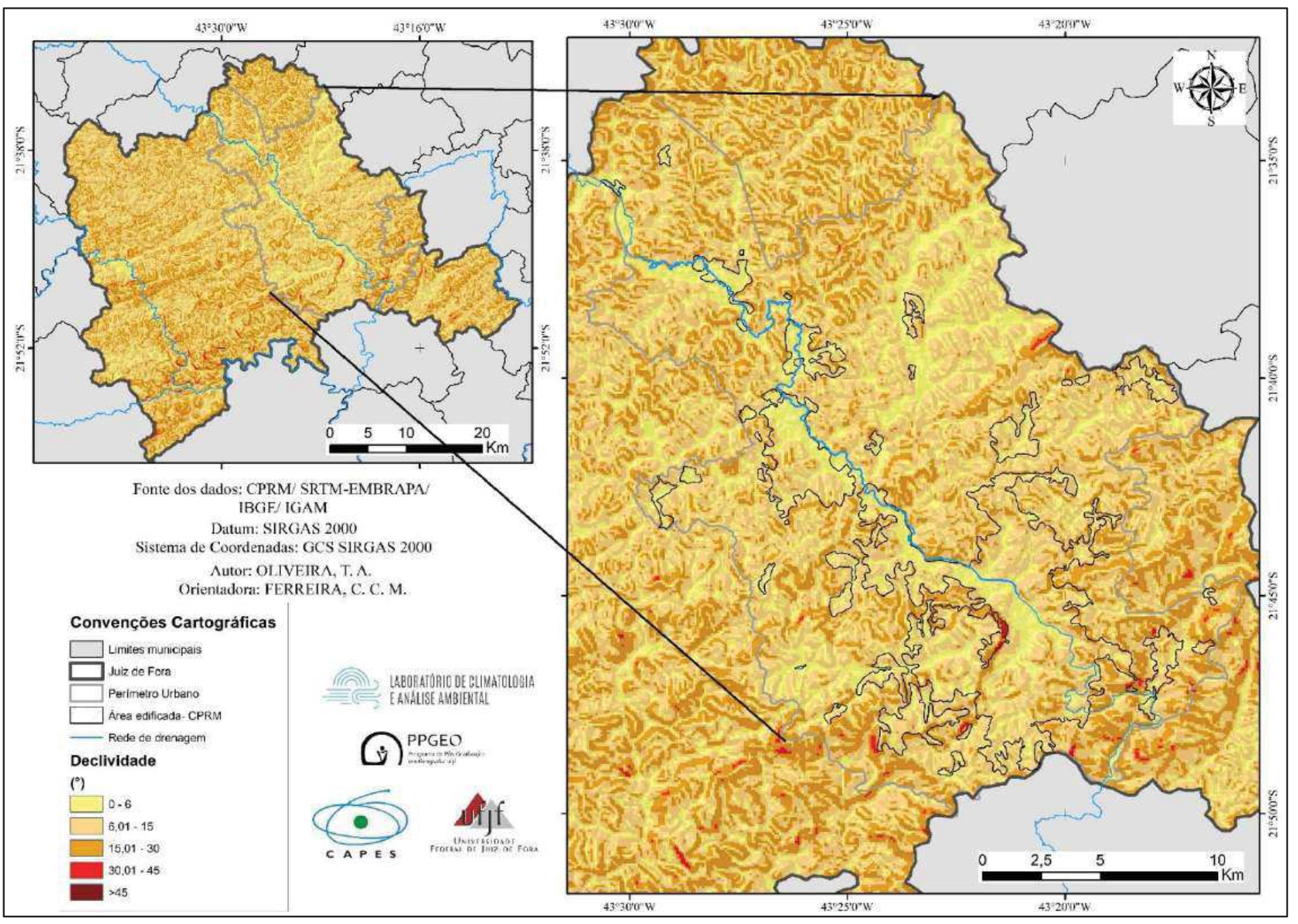

Fonte: Organizado pelo autor. 


\section{Juiz de Fora e sua rede hidrográfica urbana}

No trecho urbano inúmeros rios drenam as subbacias do Paraibuna, e que por vezes figuram nos cenários das inundações urbanas na cidade. Dentre os principais rios nos trechos urbanizados da cidade temos as bacias dos córregos Tapera, Matirumbide, Young na margem esquerda e Igrejinha, Humaitá, São Pedro, Independência, Ipiranga na margem direita (Figura 17). Diversos estudos avaliaram as inundações nas bacias desses córregos, como Gerheim (2016) estudou as bacias do córrego Ipiranga e São Pedro, no córrego São Pedro (ROCHA, 2019), Machado (2016) investigou o córrego Independência e no próprio rio Paraibuna que nos anos de 1906 e 1940 encenou grandes inundações que atingiram o centro da cidade e incentivou diversas obras de contenção (MACHADO et al, 2016).

Figura 17: Rede hidrográfica no perímetro urbano do município de Juiz de Fora.

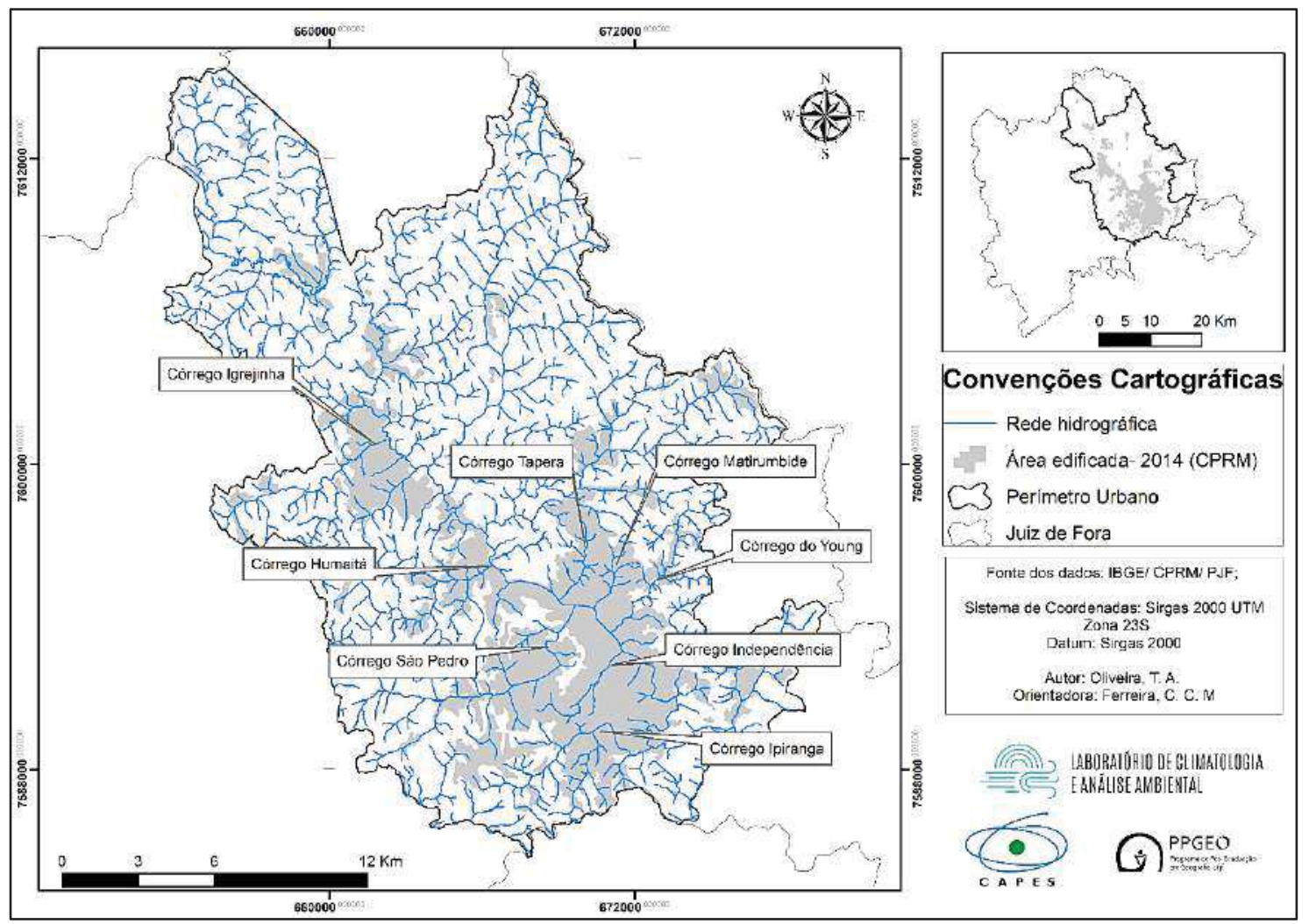

Fonte: Organizado pelo autor, 2020.

Esses córregos foram ao longo dos anos sofrendo com diversas obras e alterações na calha, sendo comum a utilização das retificações e canalizações, em função da ocupação de suas margens e da expansão da mancha urbana em suas bacias. Dentre as obras, pode-se destacar a retificação do rio Paraibuna na década de 1940, a canalização do córrego 
independência, na década de 1960 a retificação do córrego Santa Luzia na década de 1970, bem como as obras nos córregos Tapera, Matirumbide e Young que ocorreram a partir da década de 1980 e as obras de retificação e canalização que ainda hoje são realizadas no córrego São Pedro.

\section{A Dinâmica Climática de Juiz de Fora}

Juiz de Fora apresenta uma dinâmica climática com duas estações bem definidas, uma estação quente e chuvosa que vai de Outubro a Março, e uma estação fria e seca que vai de Abril a Setembro (Figura 18). Conferindo à cidade uma condição de clima tropical de altitude (ASSIS, 2016; PIMENTEL, 2017), influenciado "pelas características do relevo regional, de altitudes médias elevadas, que produzem um substancial arrefecimento das temperaturas" (ASSIS, 2016, p. 88).

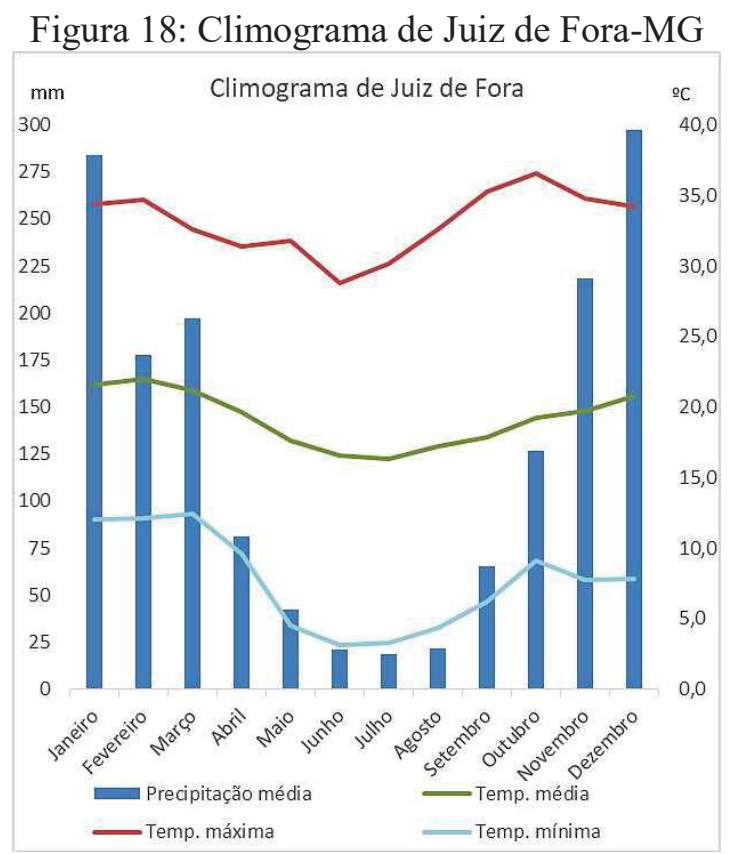

Fonte dos dados: Laboratório de Climatologia e Análise Ambiental-LabCAA.

Como coloca Abreu (1998), a localização do estado de Minas Gerais, faz com que o mesmo sofra interferência tanto de fenômenos meteorológicos tropicais como aqueles advindos das latitudes médias. Sant'Anna Neto (2005) acredita que as variações temporais irregulares de precipitação na região sudeste, estejam atreladas à dinâmica atmosférica e associadas à disposição do relevo, bem como outros fatores climáticos como a continentalidade e a altitude.

Dentre os principais sistemas atmosféricos atuantes, podemos apontar a Massa Tropical Atlântica (mTa), a Massa Polar Atlântica $(\mathrm{mPa})$ e, consequentemente, os sistemas frontais, além da participação da Zona de Convergência do Atlântico Sul (ZCAS) e da Zona de Convergência 
de Umidade (ZCOU) na dinâmica principalmente do período chuvoso na região de estudo (CAVALCANTI et al, 2009).

A Massa Tropical Atlântica (mTa), originada no Anticiclone Subtropical do Atlântico Sul (ASAS), possui características atmosféricas quente e seca, tendo uma maior atuação na estação fria, pois durante o inverno esse centro ciclônico aproxima-se do continente sulamericano intensificando sua influência no Brasil (BORSATO, 2016,) e diminuindo a sua atuação no verão, período no qual o anticiclone se afasta do continente e perde abrangência.

Por se tratar de um sistema originado em um anticiclone, as suas características durante o período de atuação, principalmente no inverno, são de atmosfera estável. Essa dinâmica dificulta os movimentos ascendentes do ar promovendo, consequentemente, baixos totais pluviométricos, exceto em áreas de influência orográfica (REBOITA et al 2015; BORSATO, 2016).

Os sistemas frontais estão associados à atuação da Massa Polar Atlântica $(\mathrm{mPa})$ pois "em sua borda, no contato com os sistemas atmosféricos tropicais, configuram-se extensas zonas de pressão relativamente baixa e intensa convergência, usualmente chamada de frente polar" (GALVANI e AZEVEDO, 2012, p.7). Em função dessa convergência do ar mais quente observa-se a ocorrência de chuvas frontais na vanguarda da massa Polar atlântica (mPa).

Já a Massa Polar Atlântica (mPa), consiste em um sistema de alta pressão, gerador de estabilidade atmosférica, com exceção à sua zona frontal, que avança pelo território brasileiro impondo suas características físicas. Durante o período do inverno, sua atuação é mais intensa pelo interior do continente (BORSATO, 2016).

Nos períodos de primavera e verão, parte da umidade produzida na região Amazônica é transportada para o sul e o sudeste através dos Jatos de Baixos Níveis (JBN) a leste dos Andes. Estas condições, associadas a sistemas frontais localizados no Atlântico, favorecem a formação das Zonas de Convergência do Atlântico Sul (ZCAS) que aparecem como uma das principais fontes de umidade e, consequentemente, precipitação que atinge principalmente a região Sudeste do Brasil (REBOITA et al, 2015; SANTOS e FIALHO, 2016; OLIVEIRA, 2016).

\section{A Climatologia das chuvas na cidade de Juiz De Fora}

De acordo com Reboita et al (2015) o estado de Minas Gerais se insere em um clima de monção, uma vez que as chuvas se concentram em mais de $70 \%$ no período do verão austral, pois nessa época do ano “os sistemas atmosféricos migram para sul e com isso há uma 
intensificação da temperatura do ar e da atividade convectiva nas cercanias do Trópico de Capricórnio" (REBOITA et al., 2015, p.207).

Oliveira et al (2020) avaliaram a variabilidade das precipitações em Juiz de Fora no período de 1910 a 2018 e destacaram que a precipitação na cidade ocorre, em média, 44,4\% no verão e 40,6\% na primavera, definindo uma estação marcadamente chuvosa que vai de outubro a março. No outono chove $8,8 \%$ do total anual, e esse valor cai para $6,1 \%$ no inverno, sendo esta a estação seca, no período de abril a setembro. Ferreira (2012, p. 959) considera que "que os meses de abril e setembro se comportam como um período de transição entre a estação seca e a chuvosa e o contrário", observando-se a atuação de sistemas atmosféricos que promovem tanto precipitações, como períodos de seca durante esses dois meses. Dessa forma, de acordo com Oliveira et al (2020) é comum que no período da primavera e verão chova mais de $1000 \mathrm{~m}$ em Juiz de Fora, figura 19.

Figura 19: Box plot trimestral para os dados de Juiz de Fora (MG)

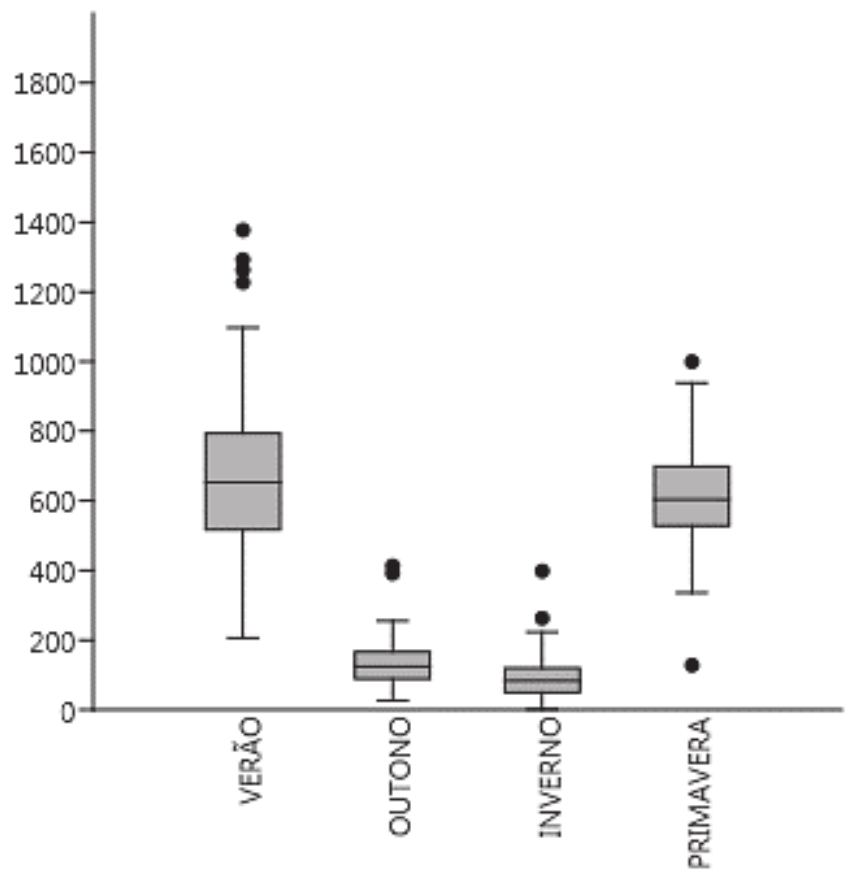

Fonte: Adaptado de Oliveira et al, 2020.

No período de verão, com o aumento da temperatura no continente Sul Americano os sistemas quentes e úmidos equatoriais migram para sul, abastecendo de umidade os setores mais austrais, assim, “o transporte de umidade do oceano Atlântico, associado à sua reciclagem sobre a floresta tropical, mantém a precipitação máxima sobre o Brasil Central, favorecendo a formação da Zona de Convergência do Atlântico Sul (ZCAS) ” (GAN et al, 2009, p. 298). 
No caminhar do outono para o inverno, os sistemas convectivos migram para Norte, em função das diferenças de temperatura e do deslocamento da Zona de Convergência Intertropical (ZCIT) dessa forma "o transporte de umidade em baixos níveis, proveniente do oeste da Amazônia, enfraquece devido às frequentes incursões de ar seco e frio proveniente das latitudes médias sobre o interior da região subtropical da América do sul” (GAN et al, 2009, p. 298).

Oliveira (2016) estudou a gênese e o ritmo das chuvas na bacia do Rio Preto a partir dos anos padrão, habitual (2007), seco (2006) e chuvoso (2008). A partir da figura 20 a autora esclarece a participação dos sistemas atmosféricos na bacia, na qual se localiza Juiz de Fora.

Nota-se que a Massa de ar Tropical Atlântica (mTa) aparece como a principal massa de ar atuante no sudeste brasileiro ao longo do ano, figura 20, porém, com maior atuação nos meses de inverno, sendo a responsável pela estabilidade atmosférica e os baixos totais pluviométricos do período seco (BORSATO, 2016; OLIVEIRA, 2016).

De acordo com Oliveira (2016) os sistemas frontais atuaram durante todo o ano, sendo que atuaram em um maior número de dias no verão, em mais de 75\% dos dias representaram precipitação na região (Figura 20). Na estação seca os sistemas frontais são responsáveis pelo pouco volume de chuva precipitado na cidade, conforme observado por Oliveira et al (2016).

Segundo Oliveira (2016) a ZCAS (Zona de Convergência do Atlântico Sul) atua no verão, durante os dias que esta atua na região, em mais de $90 \%$ do tempo chuvas foram registradas, sendo normalmente intensas e duradouras (Figura 20). Cavalcanti (2012) destaca que esse sistema atmosférico está associado a eventos de precipitação diária intensa e caracterizados pelos eventos extremos de precipitação, demandando atenção para os possíveis impactos na cidade. 
Figura 20: Participação mensal dos sistemas atmosféricos na bacia do Rio Preto.

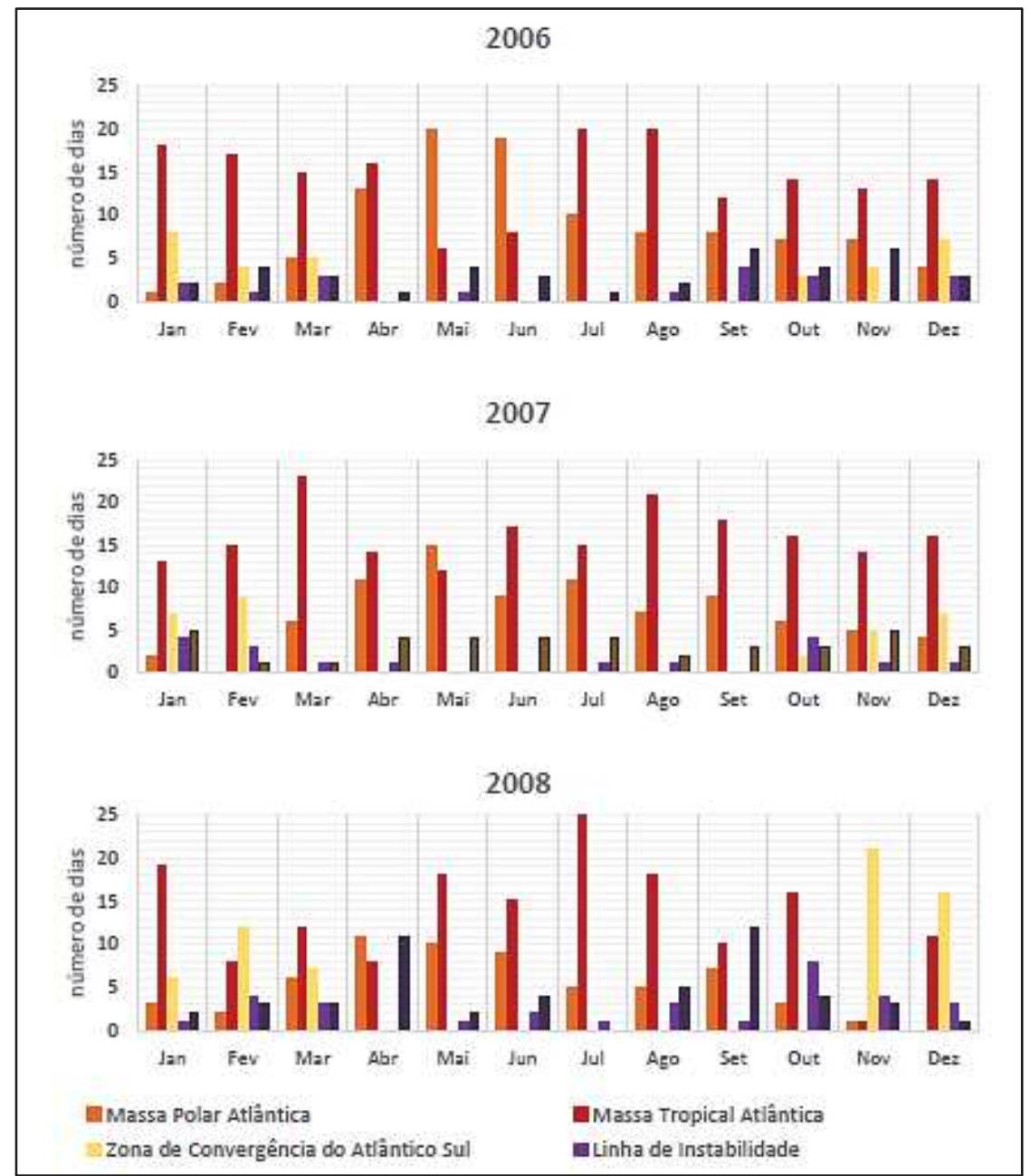

Fonte: Oliveira, 2016, p. 85. Adaptado pelo autor.

Avaliando a tendência dos dados totais mensais, quadro 06 e figura 21, observa-se, que admitindo-se uma significância de 90\% no teste Mann-Kendall, tendências de redução das chuvas no mês de Fevereiro; tendência de aumento das chuvas para os meses de maio, novembro e dezembro. Para a confiança de $95 \%$ o mês de novembro apresenta tendência de aumento das chuvas mensais, sendo no entanto, o único mês que efetivamente tem apresentado tendência de mudança de comportamento, para os métodos estatísticos utilizados (OLIVEIRA et al, 2016).

Quadro 06: Resultados da análise de tendência das precipitações mensais e anual, segundo o Teste Mann-Kendall.

\begin{tabular}{|c|c|c|c|}
\hline Mês/ ano & $Z$ calculado & Tendência $\propto=0,05$ & Tendência $\propto=0,10$ \\
\hline Janeiro & 0,31 & -NS & -NS \\
\hline
\end{tabular}




\begin{tabular}{|c|c|c|c|}
\hline Fevereiro & 1,67 & $-\mathrm{NS}$ & $-\mathrm{S}$ \\
\hline Março & 0,26 & $+\mathrm{NS}$ & $+\mathrm{NS}$ \\
\hline Abril & 0,014 & $+\mathrm{NS}$ & $+\mathrm{NS}$ \\
\hline Maio & 1,81 & $+\mathrm{NS}$ & $+\mathrm{S}$ \\
\hline Junho & 0,76 & $-\mathrm{NS}$ & $-\mathrm{NS}$ \\
\hline Julho & 1,52 & $+\mathrm{NS}$ & $+\mathrm{NS}$ \\
\hline Agosto & 0,2 & $-\mathrm{NS}$ & $+\mathrm{NS}$ \\
\hline Setembro & 0,95 & $+\mathrm{NS}$ & $-\mathrm{NS}$ \\
\hline Outubro & 1,13 & $-\mathrm{NS}$ & $+\mathrm{S}$ \\
\hline Novembro & 2,09 & $+\mathrm{S}$ & $+\mathrm{S}$ \\
\hline Dezembro & 1,74 & $+\mathrm{NS}$ & $+2016)$ \\
\hline
\end{tabular}

Fonte: Adaptado de Oliveira et al (2016).

Além disso, alguns meses como abril e agosto que apresentaram tanto coeficiente de determinação baixos $(0,001$ e 0,004 respectivamente), bem como valores $Z$ calculados bem baixos, 0,01 e 0,02 respectivamente, demonstrando não haver alteração do comportamento desses dados (OLIVEIRA et al, 2016).

Figura 21: Tendência mensal dos dados de precipitação em Juiz de Fora.

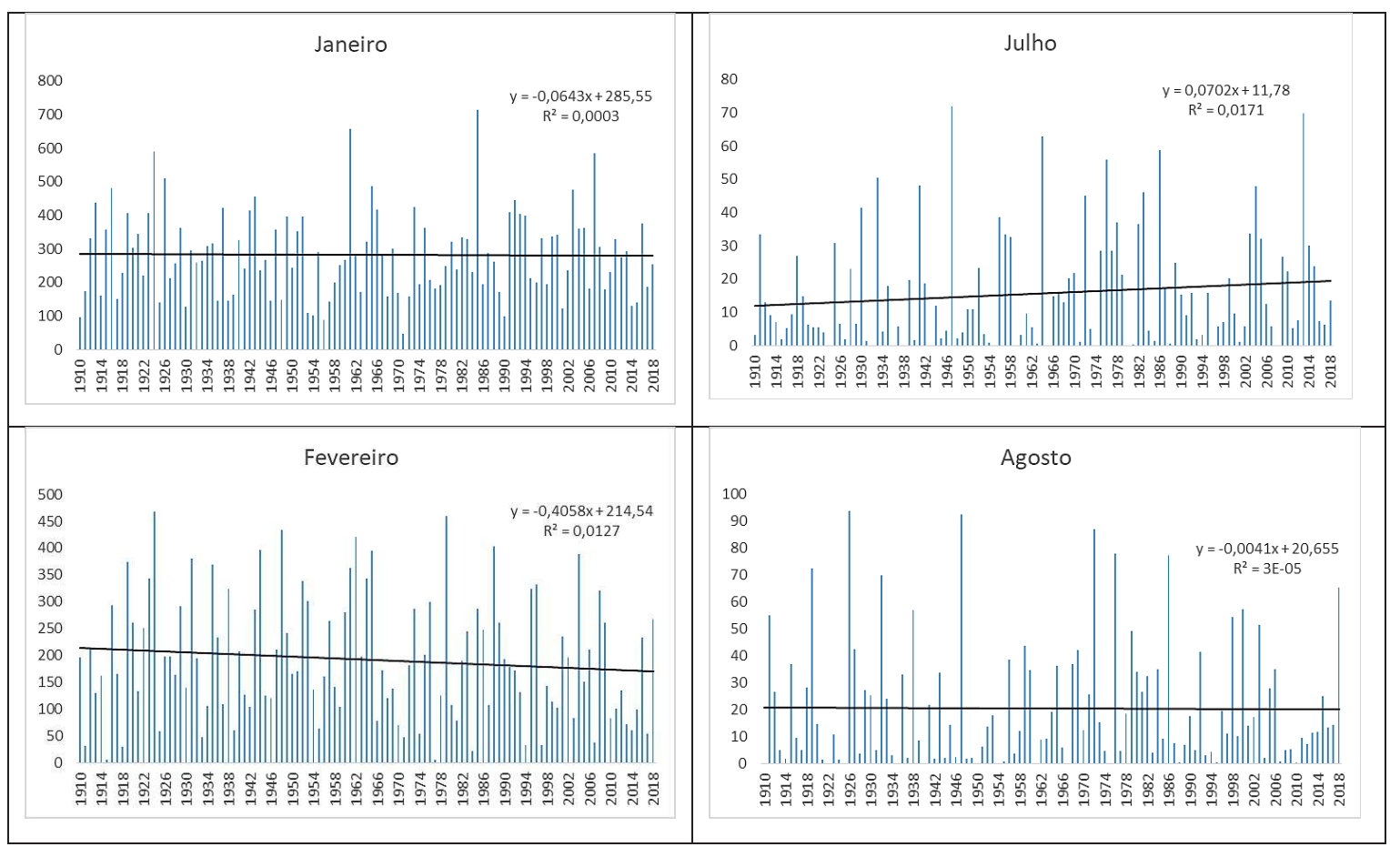




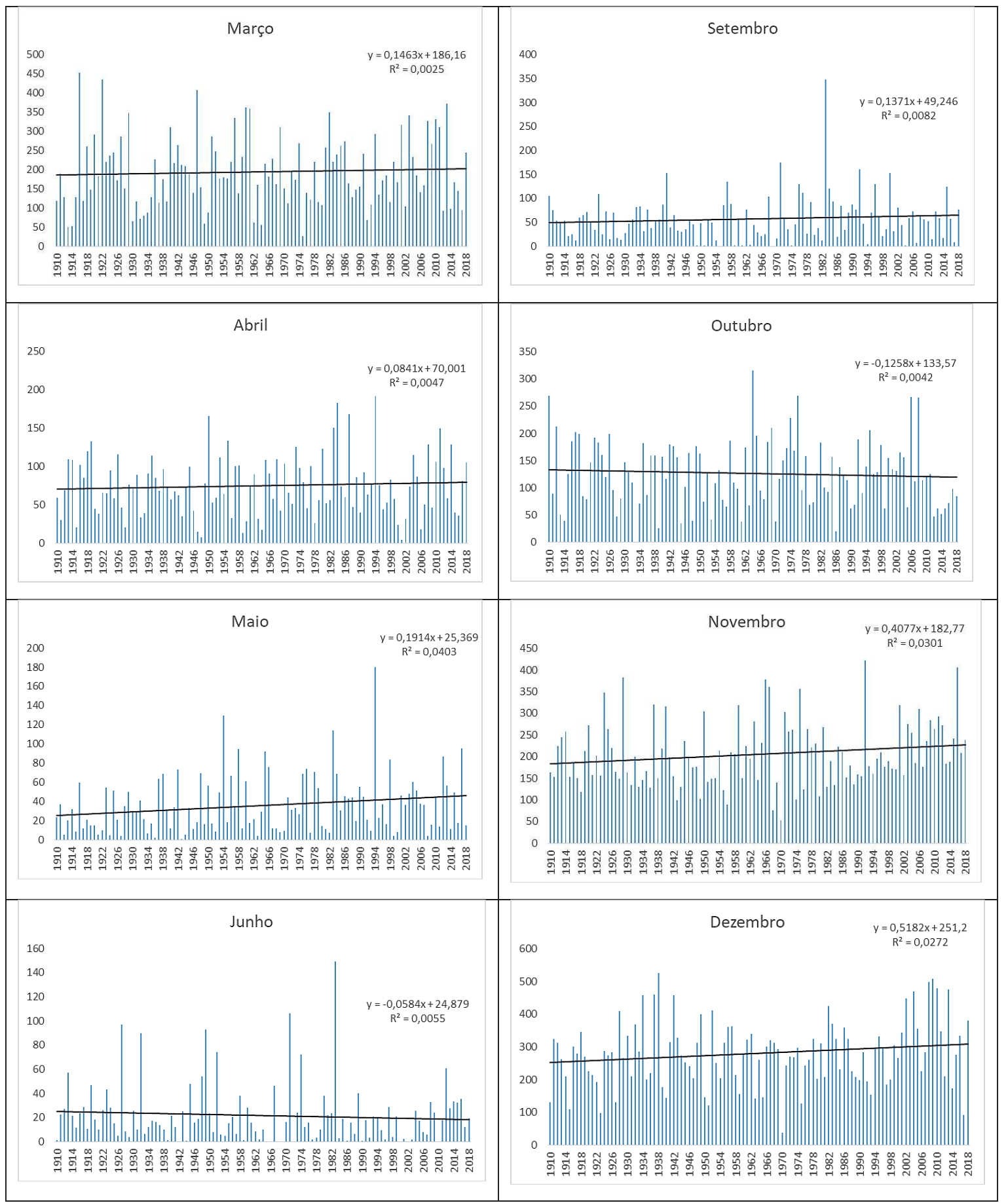

Fonte: Adaptado de Oliveira et al 2016. 


\section{Capítulo 4: Materiais e métodos}

A metodologia do trabalho baseou-se em quatro grandes etapas de levantamento das informações, aplicação das técnicas estatísticas, com suas respectivas técnicas aplicadas que serão aqui apresentadas (Figura 22). A primeira etapa consistiu no levantamento dos dados pluviométricos, a segunda etapa versou sobre as informações sobre o sítio urbano de Juiz de Fora e suas suscetibilidades e a terceira etapa compreendeu no levantamento das informações sobre o espaço urbano e a vulnerabilidade social a ele inerente, a quarta e última etapa foi composta do levantamento sobre os impactos das chuvas, e sua espacialização.

Figura 22: Organização da metodologia de trabalho. 


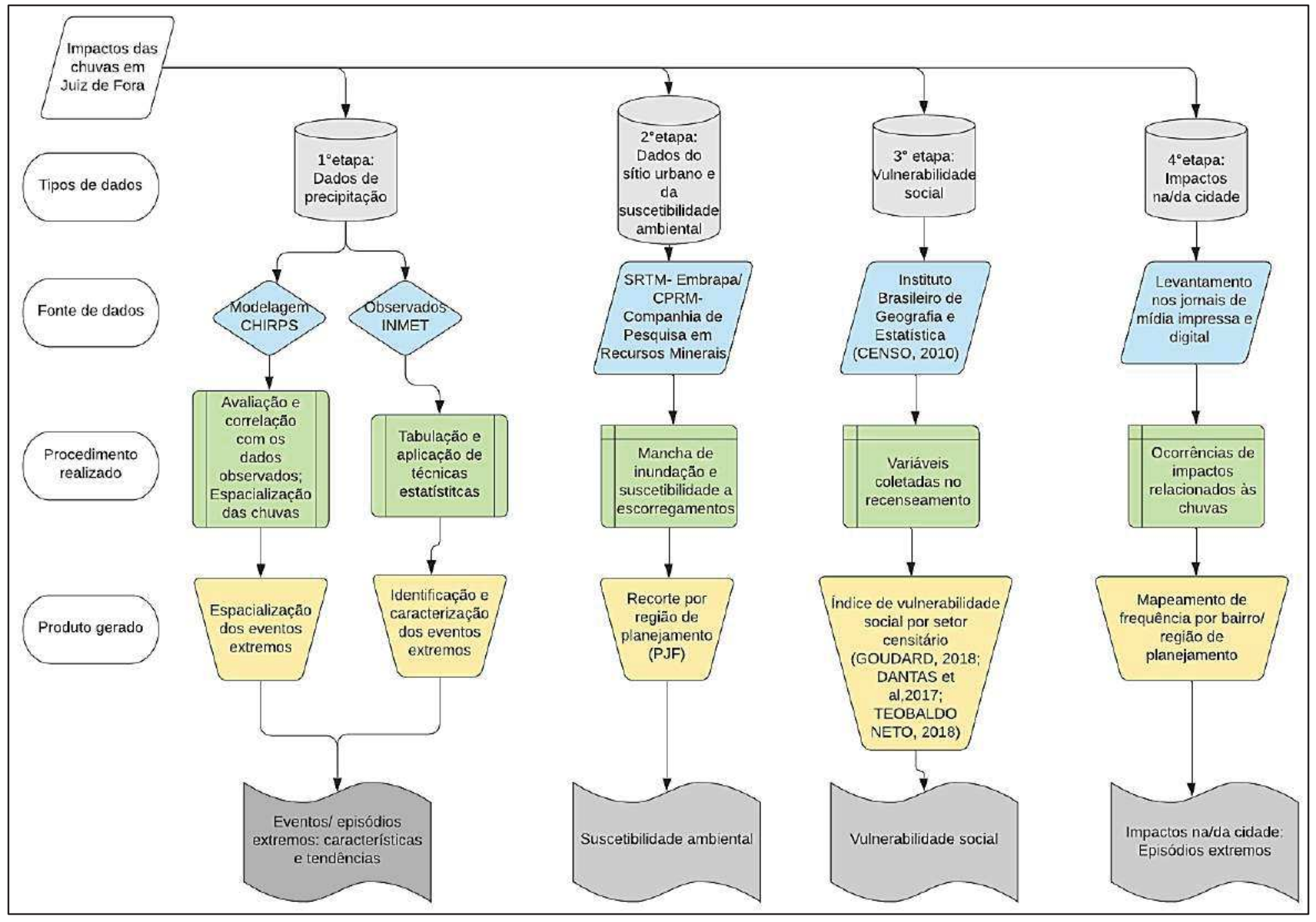

Fonte: Organizado pelo autor. 


\section{$1^{\circ}$ etapa: As precipitações em Juiz de Fora: dados e técnicas empregadas}

Neste item se dividem as duas fontes de dados de precipitação utilizados: os dados observados em superfície e os dados oriundos de sistemas orbitais.

O levantamento dos dados pluviométricos observados se deu junto ao Laboratório de Climatologia e Análise Ambiental- LabCAA, no qual compreende os dados diários de precipitação desde 1972, quando a estação meteorológica foi instalada no Campus da Universidade Federal de Juiz de Fora - UFJF, vinculada ao Instituto Nacional de MeteorologiaINMET. Os dados utilizados no presente trabalho se referem as informações de precipitação total diária, no período de 1980-2018.

Além disso, pode-se levantar os dados armazenados junto à Agência Nacional das Águas- ANA, através do portal Hidroweb (http://www.snirh.gov.br/hidroweb/mapa). Nesse ambiente estão disponíveis os dados de outras estações pluviométricas vinculadas a outras instituições, como o CPRM, Grupo Votorantim, entre outros. Além destes, os dados CEMADEN foram baixados junto ao site (http:/www.cemaden.gov.br/mapainterativo/\#) e foram todos organizados em totais diários e mensais a partir do software Microsoft Excel 2013, figura 23.

Figura 23: Pontos de coleta de dados de precipitação na área urbana de Juiz de Fora.

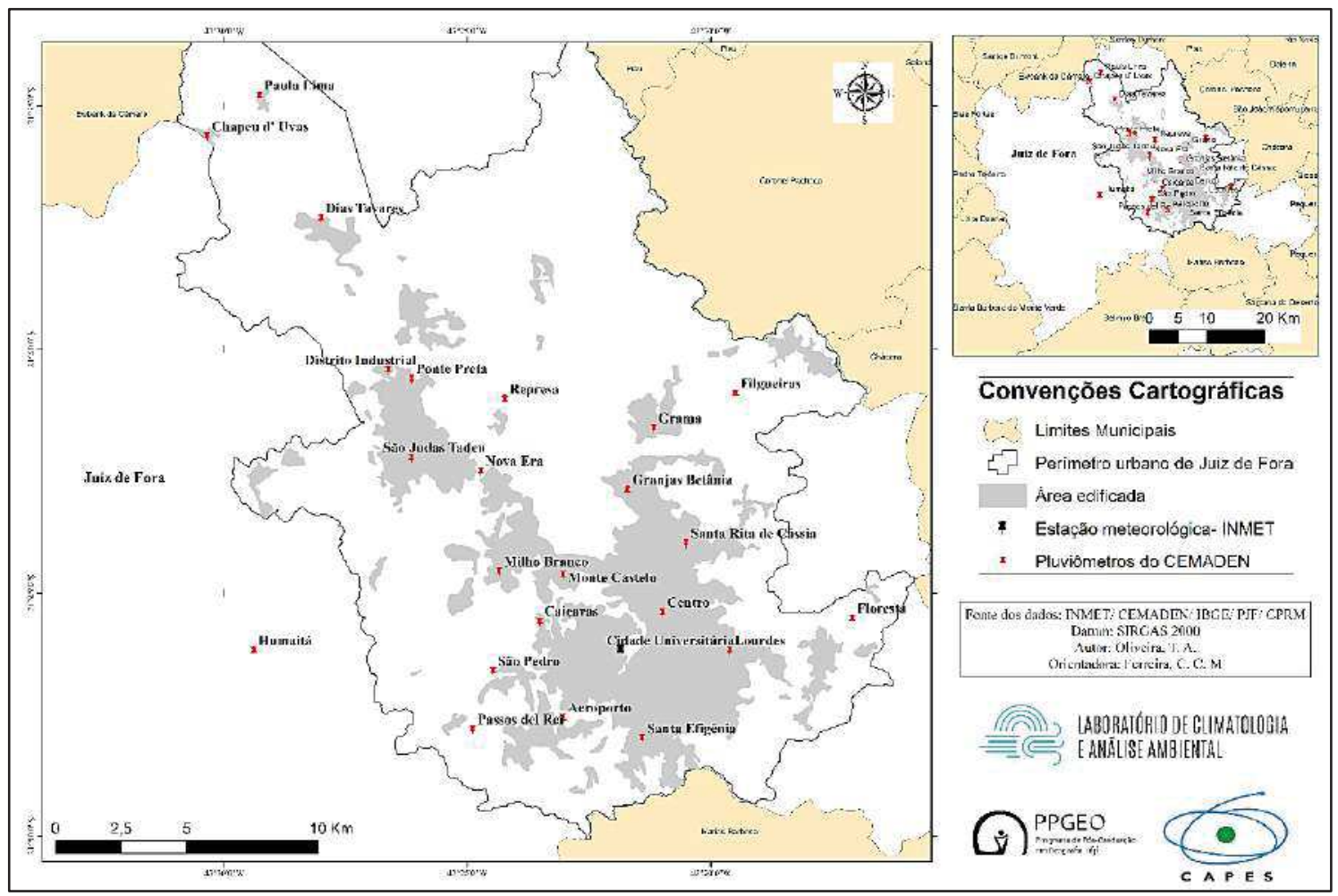


Fonte: Organizado pelo autor.

Os dados do sistema CHIRPS (Climate Hazards Group InfraRed Precipitation with Station) foram inicialmente avaliados, em função de sua confiabilidade, para a investigação das precipitações no município. Estes dados possuem uma série disponibilizada desde 1981 com resolução espacial de $5 \mathrm{Km} \times 5 \mathrm{Km}$, disponíveis em escala de tempo diária, por pêntadas, decendais, mensais e anuais. Os produtos são disponibilizados para o intervalo de latitudes $50^{\circ} \mathrm{N}$ e $50^{\circ} \mathrm{S}$ e em todas as Longitudes. Além disso, dispõem de saídas em diversos formatos, como o net.cdf, e o .tiff, possibilitando os trabalhos em ambiente SIG (FUNK et al, 2015).

As cartas sinóticas foram acessadas e baixadas junto ao site da Marinha do Brasil (https://www.marinha.mil.br/chm/dados-do-smm-cartas-sinoticas/cartas-sinoticas).

\section{As técnicas empregadas}

Para a análise dos dados, aplicação e verificação dos testes estatísticos utilizou-se como ambientes os softwares Microsoft Excel 2013, o PAST 3 (HAMMER et al., 2001), e para a espacialização dos resultados, análise da forma urbana de Juiz de Fora empregou-se o software de Geoprocessamento Arc Gis C 10.2.2.

\section{Análise mensal}

Em um primeiro momento foi realizada uma análise mensal dos dados pluviométricos de Juiz de Fora, a partir de técnicas estatísticas com o box plot. Segundo Silvestre (2016, p.97) "a técnica do Boxplot consiste em utilizar a divisão dos dados de acordo com os quartis. Os quartis dividem o conjunto de dados em quatro partes".

O box plot ou diagrama de caixa permite a divisão do conjunto de dados em quatro partes (Figura 24), a partir do cálculo dos quartis, dessa forma, cada uma dessas partes representa $25 \%$ do conjunto de dados. Com isso a caixa do box plot representa $50 \%$ dos dados que mais se aproximam da mediana, os primeiros $25 \%$ maiores e menores que ela. A partir disso calcula-se o alcance do "bigode" do gráfico com as equações dois (1) e três (2). A partir disso os valores que ultrapassarem os limites superior e inferior são considerados "outliers", os chamados "pontos fora da curva".

Limite inferior: $\max \left\{\min (\right.$ dados $\left.) ; Q_{1}-1,5\left(Q_{3}-Q_{1}\right)\right\}$

Limite superior: $\min \left\{\max (\right.$ dados $\left.) ; Q_{3}+1,5\left(Q_{3}-Q_{1}\right)\right\}$ 
Figura 24: Representação dos elementos do gráfico Box Plot

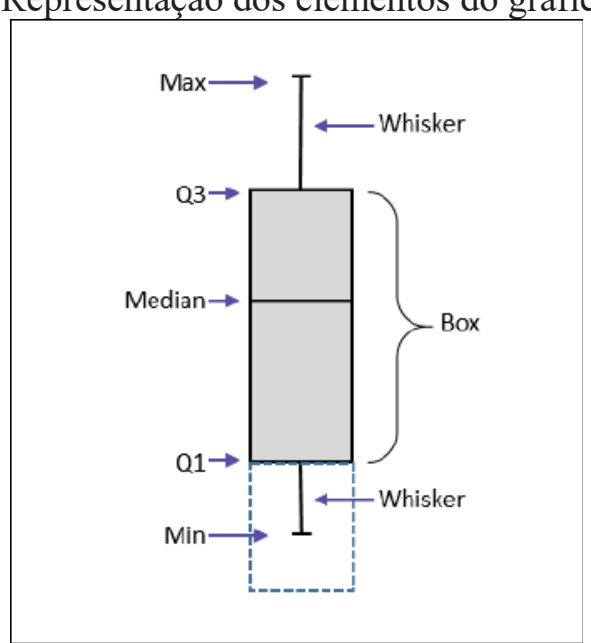

Fonte: contextures.com

Segundo a metodologia proposta por Galvani e Luchiari (2004), a distribuição dos dados como seco, normal, chuvoso se daria a partir da posição dos valores no gráfico. Primeiramente, os valores compreendidos entre o valor mínimo e o primeiro quartil são considerados como meses secos, já os compreendidos dentro da caixa do box plot, ou seja, entre o quartil 1 (Q1) e o quartil 3 (Q3), são considerados normais ou habituais, e os meses classificados como maiores que o terceiro quartil (Q3), foram considerados chuvosos.

Ainda conforme Galvani e Luchiari (2004), os valores 5\% menores e maiores do conjunto de dados foram, respectivamente, considerados como super-secos e super-chuvosos, quadro 07.

Quadro 07: Intervalos de classificação.

\begin{tabular}{|c|c|}
\hline Precipitação mensal (mm) & Classificação \\
\hline $5 \%$ menores da série & Super secos \\
\hline $5 \%$ maiores da série & Super úmidos \\
\hline Entre V min e $1^{\circ}$ quartil & Secos \\
\hline Entre $1^{\circ}$ quartil e $3^{\circ}$ quartil & Normais/habituais \\
\hline Entre $3^{\circ}$ quartil e V máx. & Úmidos \\
\hline
\end{tabular}

Fonte: Galvani e Luchiari (2004)

Adaptado pelo autor.

\section{Análise diária}

As técnicas empregadas na análise diária da precipitação visavam estabelecer os limiares para o entendimento dos eventos extremos, com isso foram aplicadas as técnicas dos percentis, máximos de precipitação, agrupamento em pêntadas e os índices do ETCCDI. 


\section{A técnica dos percentis}

A técnica dos percentis consiste em dividir o conjunto de dados em 100 partes e a partir disso, pode-se estabelecer os intervalos de interesse. No caso das precipitações, o percentil 95 representa que 5\% dos valores estão acima deste e apontando os eventos de elevada intensidade, já o percentil 99 representa que apenas $1 \%$ dos dados ultrapassam este valor, sendo então eventos extremos ao longo da série.

Pretende-se com o auxílio da técnica dos percentis investigar o comportamento das chuvas do ponto de vista histórico, a partir das classes de intensidade estabelecidas por esta técnica. Para a categorização da precipitação diária, os percentis 95 (P95) e o 99 (P99) são considerados como eventos intensos e extremos, respectivamente, sendo calculados a partir dos dados de precipitação em 24 horas, desconsiderando os totais inferiores a $1 \mathrm{~mm}$, no software EXCEL 2013.

\section{A técnica dos máximos de precipitação}

Outra técnica utilizada para a categorização dos eventos extremos foi a dos máximos de precipitação, aplicada por Monteiro (2016) e Monteiro e Zanella (2017), "tal metodologia apresenta mais coerência no tratamento de eventos extremos de chuva, uma vez que trabalha com um limiar de chuva e classes de intensidade de chuva" (MONTEIRO, 2016, p. 70), definindo classes de intensidade em função da magnitude do evento.

Para a aplicação da técnica, é indicado o levantamento de todos os eventos pluviométricos iguais e superiores a $50 \mathrm{~mm} / 24 \mathrm{~h}$, após esse levantamento são extraídas duas medidas de tendência central para esses dados, a média e o desvio padrão, no entanto o valor de $50 \mathrm{~mm}$ foi substituído pelo valor do percentil 95. Após a seleção dos dados, estes são aplicados às condições conforme o quadro 08:

Quadro 08: Fórmulas para determinação dos níveis de intensidade de precipitação.

\begin{tabular}{|c|c|}
\hline Normal & $\mathrm{P}<\bar{M}$ máx. \\
\hline Nível I & $\bar{M}$ máx. $\leq \mathrm{P} \leq \bar{M}$ máx. $+1 \sigma$ \\
\hline Nível II & $\bar{M}$ máx. $+1 \sigma \leq \mathrm{P} \leq \bar{M}$ máx. $+2 \sigma$ \\
\hline Nível III & $\bar{M}$ máx. $+2 \sigma \leq \mathrm{P} \leq \bar{M}$ máx. $+3 \sigma$ \\
\hline Nível IV & $\bar{M}$ máx. $+3 \sigma \leq \mathrm{P}$ \\
\hline
\end{tabular}

Fonte: Adaptado de Monteiro e Zanella (2017).

Onde: $\bar{M}$ máx.: Média dos Máximos; $\sigma=$ Desvio Padrão; $\mathrm{P}=$ Evento pluviométrico. 


\section{A técnica das pêntadas}

Além da investigação diária dos dados, foram investigados os concentrados em 5 dias, chamados de Pêntadas (FISCH, 1999), "uma pêntada constitui o acumulado das precipitações de cinco dias consecutivos, levando ao conjunto anual de 73 pêntadas, Tabela 01. Durante os anos bissextos, a 12 "pêntada foi considerada como o somatório de seis dias, ao invés de cinco" (SANCHES et al, 2014, p. 147). Assim como nos dados de precipitação diária, serão calculados os percentis 95 e 99 para as pêntadas, buscando visualizar as maiores concentrações em cinco dias na série de dados, da mesma forma que os percentis diários.

Tabela 01: Intervalo das 73 pêntadas pluviométricas

\begin{tabular}{|c|c|c|c|c|c|c|c|}
\hline $\begin{array}{l}\text { Número } \\
\text { da } \\
\text { Pentada }\end{array}$ & $\begin{array}{l}\text { Datas de } \\
\text { calendário }\end{array}$ & $\begin{array}{l}\text { Número } \\
\text { da } \\
\text { Pentada }\end{array}$ & $\begin{array}{l}\text { Datas de } \\
\text { calendário }\end{array}$ & $\begin{array}{l}\text { Número } \\
\text { da } \\
\text { Pentada }\end{array}$ & $\begin{array}{l}\text { Datas de } \\
\text { calendário }\end{array}$ & $\begin{array}{l}\text { Número } \\
\text { da } \\
\text { Pentada }\end{array}$ & $\begin{array}{l}\text { Datas de } \\
\text { calendário }\end{array}$ \\
\hline 1 & 1-5 de janeiro & 21 & 11-15 de abril & 41 & 20-24 de julho & 61 & 28Out. - INov. \\
\hline 2 & $6-10$ de janeiro & 22 & 16-20 de abril & 42 & $25-29$ de julho & 62 & 2- 6 de novembro \\
\hline 3 & 11-15 de janeiro & 23 & 21-25 de abril & 43 & 30Jul. - 3 Ago. & 63 & 7-11 de novembro \\
\hline 4 & 16-20 de janeiro & 24 & 26-30 de abril & 44 & 4-8 de agosto & 64 & 12-16 de novembro \\
\hline 5 & $21-25$ de janeiro & 25 & $1-5$ de maio & 45 & 9-13 de agosto & 65 & $17-21$ de novembro \\
\hline 6 & 26-30 de janeiro & 26 & $6-10$ de maio & 46 & $14-18$ de agosto & 66 & $22-26$ de novembro \\
\hline 7 & 31Jan. - 4Fev. & 27 & $11-15$ de maio & 47 & 19-23 de agosto & 67 & 27Nov. - IDez. \\
\hline 8 & 5-9 de fevereiro & 28 & $16-20$ de maio & 48 & $24-28$ de agosto & 68 & 2- 6 de dezembro \\
\hline 9 & 10-14 de fevereiro & 29 & 21-25 de maio & 49 & 29 Ago. - 2 Set. & 69 & 7-11 de dezembro \\
\hline 10 & $15-19$ de fevereiro & 30 & $26-30$ de maio & 50 & 3-7 de setembro & 70 & $12-16$ de dezembro \\
\hline 11 & 20-24 de fevereiro & 31 & 31Mai. - 4Jun. & 51 & 8-12 de setembro & 71 & 17-21 de dezembro \\
\hline 12 & 25Fev. - 1Mar. & 32 & 5-9 de junho & 52 & $13-17$ de setembro & 72 & $22-26$ de dezembro \\
\hline 13 & 2-6 de março & 33 & 10-14 de junho & 53 & $18-22$ de setembro & 73 & 27-31 de dezembro \\
\hline 14 & 7-11 de março & 34 & 15-19 de junho & 54 & $23-27$ de setembro & & \\
\hline 15 & $12-16$ de março & 35 & 20-24 de junho & 55 & 28Set. - 2Out. & & \\
\hline 16 & 17-21 de março & 36 & $25-29$ de junho & 56 & 3-7 de outubro & & \\
\hline 17 & $22-26$ de março & 37 & 30Jun. - 4 Jul. & 57 & $8-12$ de outubro & & \\
\hline 18 & 27-31 de março & 38 & 5-9 de julho & 58 & 13-17 de outubro & & \\
\hline 19 & 1-5 de abril & 39 & 10-14 de julho & 59 & $18-22$ de outubro & & \\
\hline 20 & 6-10 de abril & 40 & 15-19 de julho & 60 & 23-27 de outubro & & \\
\hline
\end{tabular}

Fonte: Adaptado de Souza e Ambrizzi, 2002.

\section{Os índices de extremos climáticos do ETCCDI}

Dentro do universo de técnicas utilizadas para a observação de variações e ou tendências climáticas o Expert Team on Climate Change Monitoring and Índices (ETCCDI), vinculado à Comissão de Climatologia da Organização Meteorológica Mundial (OMM) e o Climate Variability and Predictability Project (CLIVAR) sugerem a utilização de 27 índices de extremos climáticos, sendo que 16 deles são relacionados à temperatura do ar e 11 índices à precipitação (ZHANG e YANG, 2004).

Dessa forma foram aplicados dez índices relacionados à precipitação, para os dados de Juiz de Fora, os índices foram calculados pelo software Excel e estão descritos na Tabela 02, abaixo. 
Tabela 02: Índices de extremos de precipitação utilizados no estudo

\begin{tabular}{|c|c|c|c|}
\hline ID & Nome do Índice & Definição & Unidade \\
\hline CWD & $\begin{array}{ll}\text { Dias } & \text { chuvosos } \\
\text { consecutivos } & \end{array}$ & $\begin{array}{l}\text { Número máximo de dias consecutivos com } \\
\text { precipitação } \geq 1 \mathrm{~mm} \text {. }\end{array}$ & Dias \\
\hline CDD & Dias secos consecutivos & $\begin{array}{l}\text { Número máximo de dias consecutivos com } \\
\text { precipitação }<1 \mathrm{~mm} \text {. }\end{array}$ & Dias \\
\hline Rx1Day & $\begin{array}{l}\text { Quantidade máxima de } \\
\text { precipitação em } 1 \text { dia }\end{array}$ & Máximo de precipitação em 1 dia. & $\mathrm{mm}$ \\
\hline SDII & $\begin{array}{l}\text { Índice simples de } \\
\text { intensidade diária }\end{array}$ & $\begin{array}{l}\text { Total anual de precipitação dividido pelo } \\
\text { número de dias chuvosos (prec. } \geq 1 \mathrm{~mm} \text { ). }\end{array}$ & $\mathrm{mm} / \mathrm{dia}$ \\
\hline $\mathrm{R} 10$ & $\begin{array}{l}\text { Precipitação de um dia } \\
\text { superior a } 10 \mathrm{~mm}\end{array}$ & $\begin{array}{l}\text { Número de dias com precipitação maior que } \\
10 \mathrm{~mm}\end{array}$ & Dias \\
\hline $\mathrm{R} 20$ & $\begin{array}{l}\text { Precipitação de um dia } \\
\text { superior a } 20 \mathrm{~mm}\end{array}$ & $\begin{array}{l}\text { Número de dias com precipitação maior que } \\
20 \mathrm{~mm}\end{array}$ & Dias \\
\hline $\mathrm{R} 50$ & $\begin{array}{l}\text { Precipitação de um dia } \\
\text { superior a } 50 \mathrm{~mm}\end{array}$ & $\begin{array}{l}\text { Número de dias do ano com precipitação maior } \\
\text { que } 50 \mathrm{~mm} \text {. }\end{array}$ & Dias \\
\hline R95p & Dias muito chuvosos & $\begin{array}{l}\text { Precipitação total anual nos dias que superem o } \\
\text { percentil } 95\end{array}$ & $\mathrm{~mm}$ \\
\hline R99p & $\begin{array}{l}\text { Dias extremamente } \\
\text { chuvosos }\end{array}$ & $\begin{array}{l}\text { Precipitação total anual nos dias que superem o } \\
\text { percentil } 99\end{array}$ & $\mathrm{~mm}$ \\
\hline PRPCTOT & $\begin{array}{l}\text { Precipitação total anual } \\
\text { em dias úmidos }\end{array}$ & $\begin{array}{l}\text { Total anual em dias com precipitação maior que } \\
1 \mathrm{~mm}\end{array}$ & $\mathrm{~mm}$ \\
\hline
\end{tabular}

Fonte: Adaptado de Zhang e Yang (2004).

\section{A análise de frequência e o tempo de retorno}

De posse dos dados dos eventos intensos e extremos, de precipitação diária e pentadal, foram aplicadas as técnicas de frequência e tempo de retorno desses eventos. Calculados a partir das equações 3 e 4 apresentadas abaixo.

Equação 1: Frequência relativa

$$
F r=n a / n
$$

Onde: na= quantidade de eventos ocorridos ao longo da série (n).

Equação 2: Tempo de retorno 


$$
T=1 / F r
$$

O tempo de retorno é calculado a partir do inverso da frequência relativa (Fr). Com isso avaliar as ocorrências desses eventos ao longo da série histórica de dados.

\section{Análise de tendência}

Todos os índices calculados apresentam uma frequência ao longo da série de dados, e para avaliar a tendência desses valores, foi aplicado o teste Mann-Kendall para visualizar possíveis alterações no comportamento dos dados. O teste não paramétrico Mann- Kendall, foi calculado por meio do software Past, a partir do conjunto de testes estatísticos (incluindo o Mann-Kendall) alocados na ferramenta timeseries. Este teste tem por objetivo identificar se em determinada série de dados analisados existe tendência temporal de alteração estatisticamente significativa (SALVIANO et al, 2016). Nesse sentido, são testadas duas hipóteses:

$H_{0}$ : Onde as observações da série são independentes e igualmente distribuídas (Não há tendência)

$H_{I}$ : As observações da série possuem tendência monótona no tempo (Há tendência)

Nesse caso a estatística de teste é dada pela equação 5 :

$$
S=\sum_{k=1}^{n-1} \sum_{j=k+1}^{n} \operatorname{sign}\left(x_{j}-x_{k}\right)
$$

Onde:

$$
\operatorname{sign}(x)=\left\{\begin{aligned}
1, & \text { se } x>0 \\
0, & \text { se } x=0 \\
-1, & \text { se } x<0
\end{aligned}\right.
$$

É possível mostrar que S é normalmente distribuída, ou seja, $S \sim N\left(\mu, \sigma^{2}\right) \operatorname{com} \mu=0$;

$$
\sigma^{2}=\frac{n(n-1)(2 n+5)-\sum_{j=1}^{P} t_{j}\left(t_{j}-1\right)\left(2 t_{j}+5\right)}{18}
$$

Em que n é o número de observações e, considerando o caso em que a série pode ter grupos com observações iguais, $\mathrm{P}$ é o número de grupos com observações iguais e t $\mathrm{t}_{\mathrm{j}}$ é o número 
de observações iguais no grupo j. No caso em que o número de observações é superior a 30, a estatística do teste é calculada pela equação 7.

$$
Z=\left\{\begin{array}{cc}
\frac{S-1}{\sigma}, & \text { se } S>0 \\
0, & \text { se } S=0 \\
\frac{S+1}{\sigma}, & \text { se } S<0
\end{array}\right.
$$

Em um teste bilateral, não rejeitamos a hipótese nula $\mathrm{H}_{0}$ para um dado nível de significância $\alpha$, se para o quantil $Z_{\alpha / 2}$ de uma distribuição normal padrão temos $|Z| \leq Z_{\alpha / 2}$. Em estudos voltados para a climatologia, é utilizado uma confiança de 95\%, no entanto a estatística $H_{0}$ é rejeitada quando o $Z$ encontrado estiver sob esta condição, $-1,96<Z<1,96$ (MARENGO et al., 2007; BLAIN, 2010; SANCHES et al, 2013a),

\section{Os dados da modelagem CHIRPS}

Os dados CHIRPS são disponibilizados em formato raster com uma extensão territorial de $50^{\circ} \mathrm{N}$ e $50^{\circ} \mathrm{S}$ para todas as longitudes e foram baixados em formato tiff junto ao site (https://chc.ucsb.edu/data/chirps). Para a extração dos dados a partir dos pontos, o procedimento foi realizado junto ao software Arc gis 10.2.2.

A partir de um shape de pontos, correspondentes às coordenadas das estações alocadas no perímetro urbano de Juiz de Fora, sejam do INMET ou CEMADEN (FIGURA 25) estes dados foram extraídos e alocados em planilhas também no software Microsoft Excel 2013.

A partir da organização dos dados estes foram organizados lado a lado (CEMADEN e CHIRPS) para cada estação, na sequência foram feitas a correlação a partir de duas formas: uma primeira levando em conta os dados diários, e a segunda utilizando os dados agrupados em forma de pêntadas.

Apesar dos dados CHIRPS já serem disponibilizados também em pêntadas, utilizou-se a soma dos dados diários para o formato de pêntadas, tal como utilizado por Fisch (1995 e 1999) e Sanches et al (2014) utilizando as somas em sequência, independente do mês, diferentemente das pêntadas CHIRPS são formadas também pela soma de cinco dias, porém elas são "fechadas" a cada mês somando seis pêntadas, sendo que a última varia em função do número de dias do mês (FUNK et al, 2015). 
A correlação foi realizada para os dados diários e agrupados em pêntadas do ano de 2016, ano considerado chuvoso na cidade, segundo Oliveira et al (2020), e com isso permitiria avaliar o modelo a partir de um maior número de dias de chuva na cidade, além de que os dados da rede do CEMADEN foram instalados na cidade no final de 2013, sendo assim utilizados para a comparação com os dados do modelo CHIRPS.

Figura 25: Pontos utilizados para correlação entre os dados observados e estimados

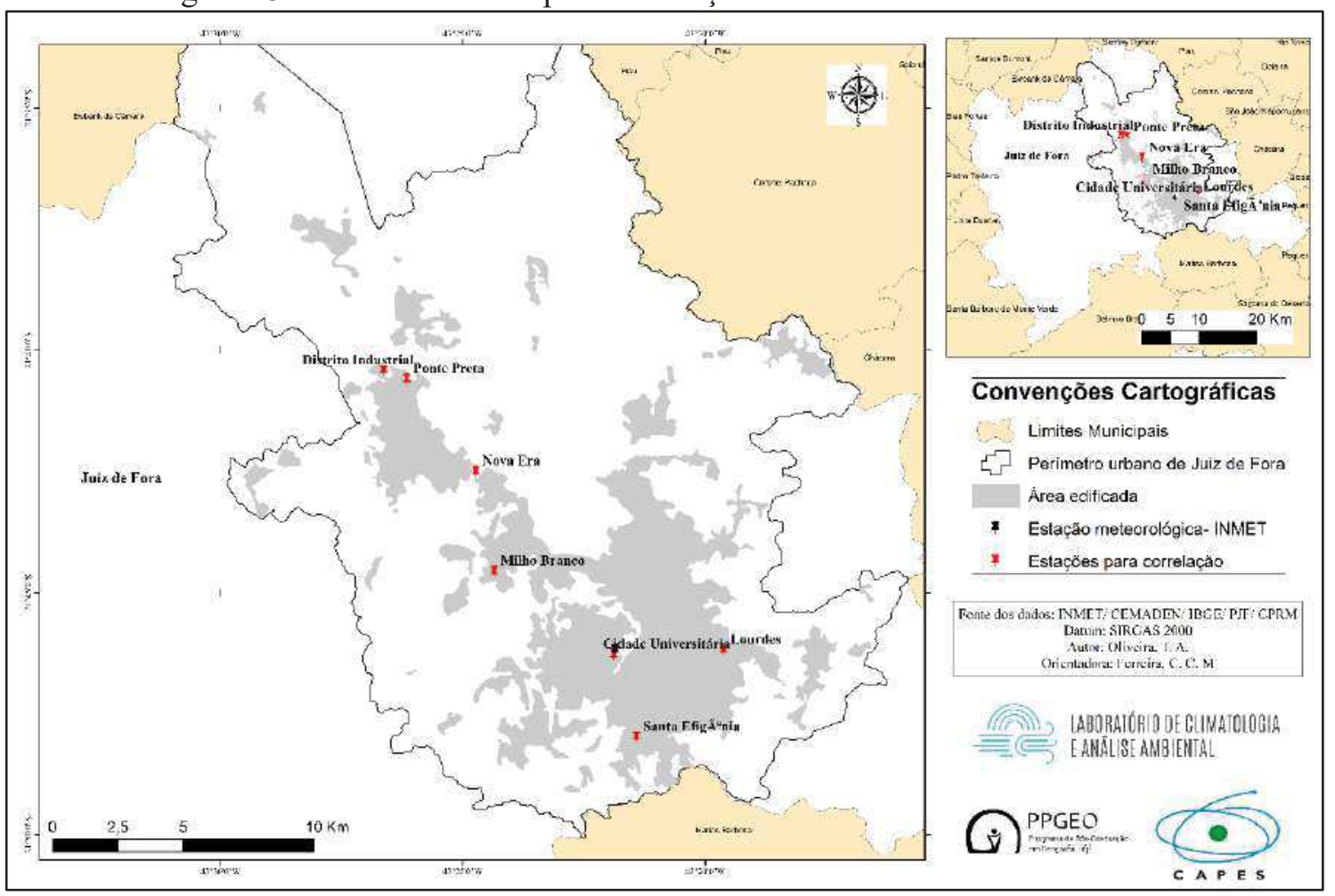

Fonte: Organizado pelo autor.

Os dados diários e agrupados em pêntadas foram comparados aos dados observados, visando avaliar sua viabilidade, sendo assim foram realizados testes de correlação linear de Pearson (r) representada pela equação 8:

$$
\mathrm{r}=\sum\left(\mathrm{xi}^{-} \overline{\mathrm{x}}\right)(\mathrm{yi}-\bar{y}) / \sqrt{\sum(\mathrm{xi}-\overline{\mathrm{x}})^{2}\left(\sum(\mathrm{yi}-\bar{y})^{2}\right.}
$$

Sejam xi e yi os valores das variáveis $\mathrm{X}$ e $\mathrm{Y}$. e são respectivamente as médias dos valores xi e yi. Assim para a sua interpretação os valores de $r$ quanto mais próximos forem de 1 e -1 indicaram uma correlação muito forte, seja ela positiva ou negativa. E quanto mais próximo ao 0 menor será a correlação entre as variáveis estudadas (Quadro 09). 
Quadro 09: Interpretação dos valores para o valor de r

\begin{tabular}{|c|c|}
\hline \multicolumn{2}{|c|}{ Correlação linear de Pearson } \\
\hline$>0,9$ & Correlação muito forte \\
\hline $0,7-0,9$ & Correlação forte \\
\hline $0,5-0,7$ & Correlação moderada \\
\hline $0,3-0,5$ & Correlação fraca \\
\hline$<0,3$ & Correlação desprezível \\
\hline
\end{tabular}

Fonte: Mukaka, 2012 (Adaptado de HINKLE, 2003).

Contudo, a primeira etapa foi endereçada ao levantamento dos dados de precipitação, bem como a aplicação das técnicas estatísticas com o intuito de identificar as porções do município com maiores totais pluviométricos, analisar o comportamento das chuvas historicamente e suas intensidades diárias e avaliar a acuraria de dados de satélite para a espacialização das chuvas em Juiz de Fora, figura 26.

Figura 26: Organização metodológica da primeira etapa.

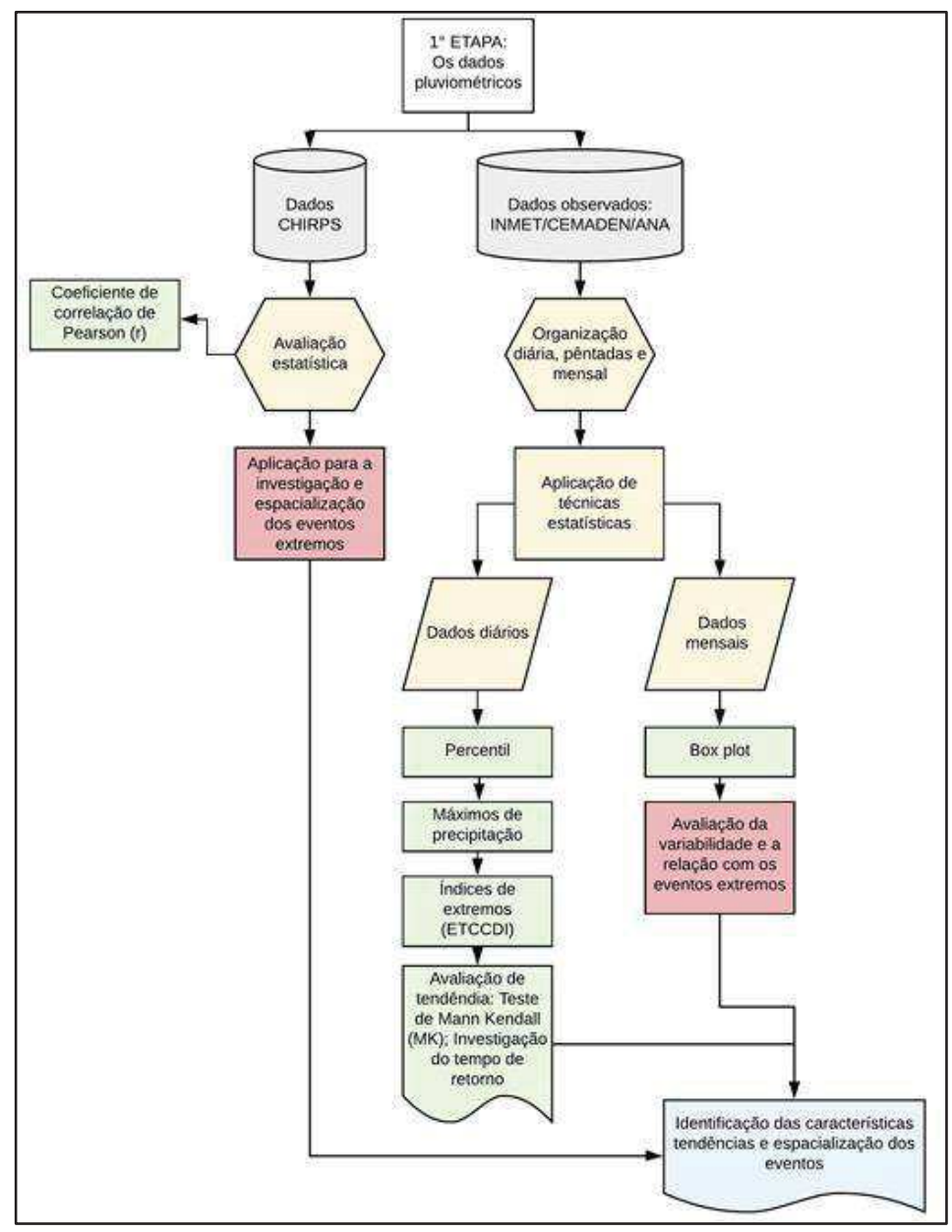


Fonte: Organizado pelo autor.

\section{$2 \circ$ etapa: O sítio urbano de Juiz de Fora e suas suscetibilidades}

O segundo grupo de informações consistiu no levantamento de informações sobre o quadro físico de Juiz de Fora, relevo, declividade, corpos hídricos, bem como suas suscetibilidades à ocorrência de inundações e movimentos de massa. Esse mapeamento foi feito a partir do perímetro urbano, como também por região de planejamento, unidade estabelecida pela Prefeitura de Juiz de Fora através de seu Plano Diretor Participativo (2018).

Os mapas hipsométrico e de declividade foram gerados a partir de produtos SRTM. O procedimento para a obtenção da declividade foi realizado no software Arc Gis 10.2.2, a partir da ferramenta hillshade. A base hidrográfica foi acessada a partir do Instituto Mineiro de Gestão das Águas (IGAM).

As cartas de suscetibilidade à ocorrência dos eventos de movimentos de massa e inundação, bem como a área edificada são oriundas da carta de Suscetibilidade desenvolvida pela Companhia de Pesquisa de Recursos Minerais (CPRM). Os produtos dividem a suscetibilidade à inundação em baixa, média e alta. Os dados correspondem a todo o município de Juiz de Fora e foram recortados em ambiente SIG a partir das regiões de planejamento da Prefeitura de Juiz de Fora (Figura 27).

Figura 27: Organização metodológica da segunda etapa.

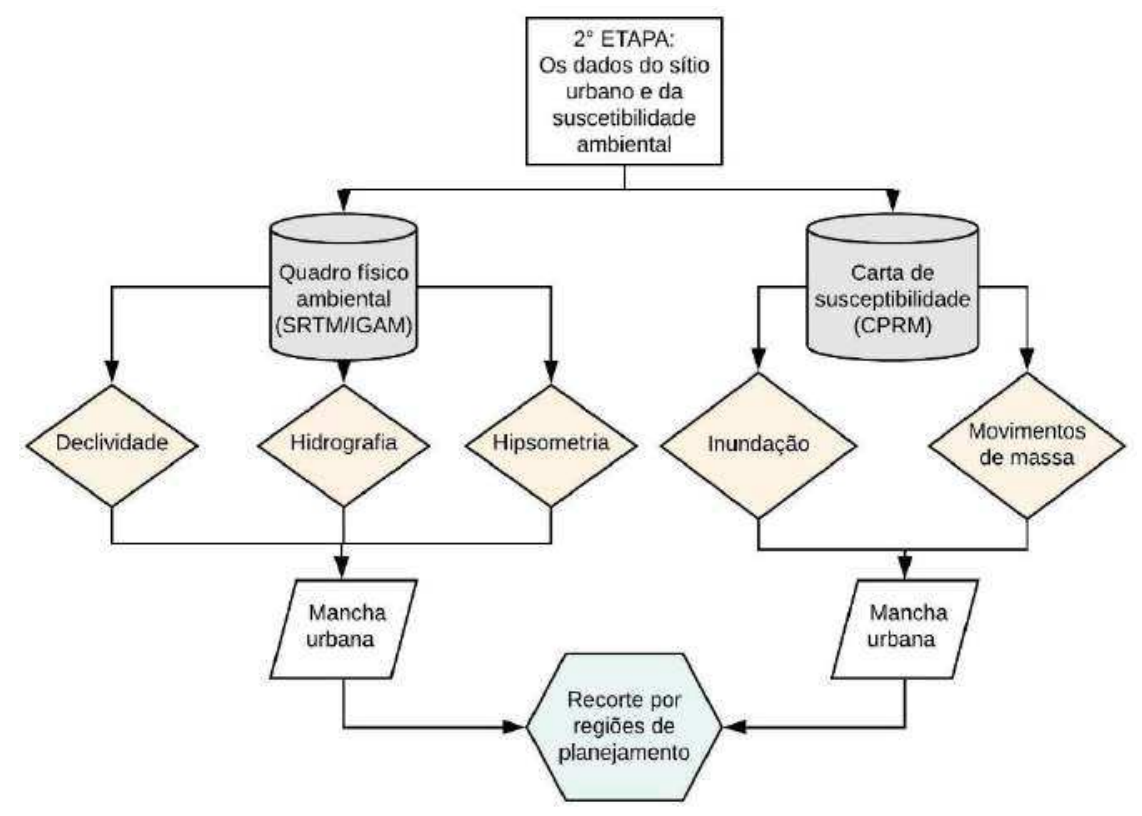

Fonte: Organizado pelo autor 
As cartas de suscetibilidade, segundo consta na nota técnica do CPRM (BITAR. 2014), foram baseadas em modelagem estatística, conjugando fatores predisponentes à ocorrência dos eventos, efetuadas em ambiente SIG:

A modelagem dos movimentos de massa: A modelagem para a carta de suscetibilidade a movimentos de massa, baseia-se em três principais fatores: declividade, curvatura da encosta e densidade de lineamentos estruturais, sendo que a declividade e a curvatura da encosta são oriundas de um modelo digital de elevação e a densidade de lineamentos estruturais foram gerados a partir de ortofotos (BITAR, 2014).

Para cada município foi escolhida uma área piloto, para a verificação da modelagem, essas áreas foram coletadas em função da ocorrência de cicatrizes de escorregamento mapeáveis. Com isso, em função da densidade de cicatrizes ocorreu a avaliação da modelagem empregada (BITAR, 2014).

A delimitação das áreas com alta, média e baixa suscetibilidade se deu em função da frequência de ocorrências, enquanto mais de $90 \%$ dos escorregamentos ocorreram nas áreas de alta suscetibilidade, nas áreas de baixa suscetibilidade a ocorrência é desprezível (BITAR, 2014). Destaca-se ainda que "a resolução do MDE e a extrapolação dos resultados da modelagem a partir das áreas piloto podem interferir nos resultados obtidos" (BITAR, 2014, p. 17).

Suscetibilidade a inundação: A abordagem utilizada para a modelagem de suscetibilidade a inundação empregada pelo CPRM,

Apoia-se nos fatores permanentes, ou seja, nas condições predisponentes dos terrenos, principalmente nas características geológicas, topográficas e morfológicas das bacias que tendem a favorecer o transbordamento do nível d'água, por ocasião de chuvas intensas (BITAR, 2014, p.18).

O mapeamento e a classificação das áreas não estão associados ao tempo de retorno das precipitações, o levantamento está pautado em uma modelagem hidrológica-geomorfológica (BITAR, 2014). Assim, a carta suscetibilidade a inundações da CPRM é construída em três fases, figura 28, a primeira de caracterização morfométrica da bacia, a segunda, de aplicação do modelo HAND (Height Above Nearest Drainage), e a terceira etapa de integração entre dos dados das primeiras duas, gerando o mapeamento da suscetibilidade a inundação nas classes baixa, média e alta (BITTAR, 2014). 
Figura 28: Fluxograma das etapas e processamento das informações para o mapeamento

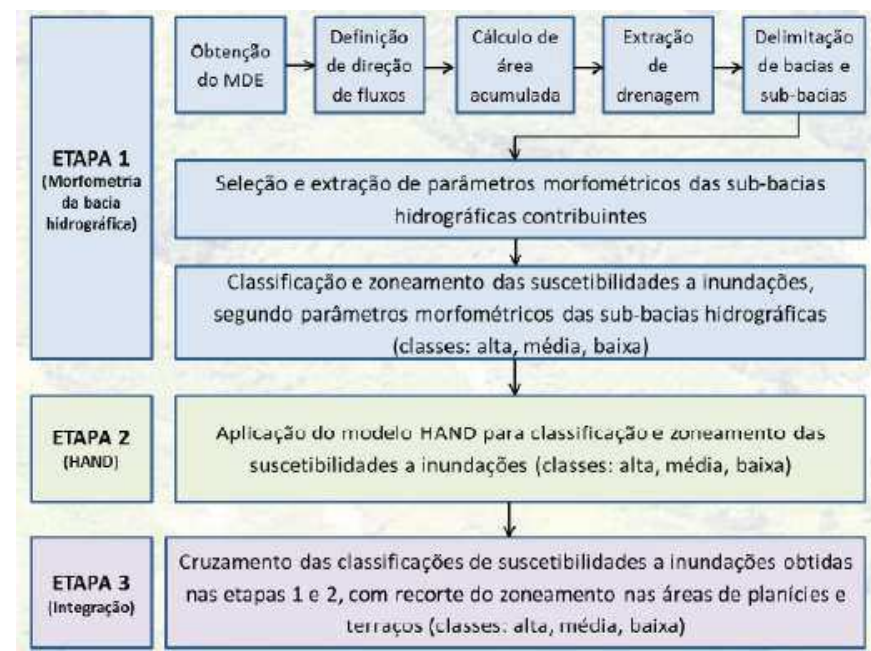

Fonte: Adaptado de Bitar (2014, p. 19).

As etapas do mapeamento da suscetibilidade a inundação:

$1^{\circ}$ etapa: Levantamento da morfometria das bacias hidrográficas

$\mathrm{Na}$ primeira etapa da modelagem de suscetibilidade a inundação, são levantadas as condições morfométricas de cada bacia, expressando uma "análise quantitativa das interações entre a fisiografia e a sua dinâmica hidrológica" (BITAR, 2014, p. 19). Com isso, estabelecese relações entre a dinâmica dos canais fluviais e a morfologia do terreno.

De acordo com Bitar (2014, p. 19)

As características morfométricas do padrão de drenagem e do relevo refletem algumas propriedades do terreno, como infiltração e deflúvio das águas das chuvas, e expressam estreita correlação com a litologia, estrutura geológica e formação superficial dos elementos que compõem a superfície terrestre (BITAR, 2014, p.19).

Na modelagem utilizada pela CPRM, cinco parâmetros morfométricos são calculados com o intuito de investigar as condições da bacia hidrográfica em relação à ocorrência de extravasamento do canal fluvial. E com isso, estima-se a partir de parâmetros quantitativos a suscetibilidade à ocorrência de inundações, tabela 03 . 
Tabela 03: Parâmetros utilizados para a avaliação quantitativa da suscetibilidade a inundações

\begin{tabular}{|c|c|c|}
\hline Parâmetro/índice & Cálculo & Influência \\
\hline Área de contribuição (Ac) & Extração automática em SIG & $\begin{array}{l}\text { Associa-se ao volume de água que atinge o rio } \\
\text { principal. Quanto maior Ac, maior tende a ser a } \\
\text { suscetibilidade }\end{array}$ \\
\hline $\begin{array}{l}\text { Relação de relevo (Rr) } \\
\text { (SCHUMM, 1956) }\end{array}$ & $\begin{array}{l}\text { Relação entre amplitude }(\Delta a) \text { e comprimento } \\
\text { do rio principal da sub-bacia (L); } R r=\Delta a / L\end{array}$ & $\begin{array}{l}\text { Indica velocidade de escoamento. Quanto } \\
\text { maior } \mathrm{Rr} \text {, mais rápido tende a ser o fluxo, } \\
\text { reduzindo o acúmulo de água na sub-bacia }\end{array}$ \\
\hline $\begin{array}{l}\text { Densidade de drenagem (Dd) } \\
\qquad \text { (HORTON, 1945) }\end{array}$ & $\begin{array}{c}\text { Relação entre comprimento da drenagem }(\mathrm{C}) \\
\mathrm{C} \text { / área da sub-bacia }(\mathrm{A}) ; \mathrm{Dd}=\mathrm{C} / \mathrm{A}\end{array}$ & $\begin{array}{c}\text { Quanto maior Dd, menor é infiltração de água } \\
\text { no solo e maior tende a ser a velocidade com } \\
\text { que a água atinge o rio }\end{array}$ \\
\hline $\begin{array}{l}\text { Índice de circularidade (Ic) } \\
\text { (MÜLLER, 1953) }\end{array}$ & $\begin{array}{l}\text { Relação entre a área da sub-bacia }(\mathrm{A}) \text { e a de } \\
\text { um círculo de mesmo perímetro (Ac); Ic = } \\
\qquad \mathrm{A} / \mathrm{AC}\end{array}$ & $\begin{array}{l}\text { Quanto maior é o lc, maior tende a ser a } \\
\text { retenção de água na sub-bacia, reduzindo a } \\
\text { velocidade de chegada da água no rio }\end{array}$ \\
\hline $\begin{array}{l}\text { Índice de sinuosidade (1s) } \\
\text { (SCHUMM, 1963) }\end{array}$ & $\begin{array}{c}\text { Relação entre o comprimento do canal } \\
\text { principal }(L) \text { com a distância vetorial entre os } \\
\text { extremos do canal }(\mathrm{dv}) ; \mathrm{I}=\mathrm{L}=\mathrm{dv}\end{array}$ & $\begin{array}{c}\text { Quanto maior o is, menor tende a ser a } \\
\text { velocidade do escoamento e chegada da água } \\
\text { no rio }\end{array}$ \\
\hline
\end{tabular}

Fonte: Adaptado de Bitar (2014, p. 20).

$2^{\circ}$ etapa: Aplicação do modelo HAND

O segundo procedimento utilizado para a modelagem da suscetibilidade a inundação consiste da aplicação do modelo HAND (Height Above Nearest Drainage). O modelo trabalha a partir de um modelo digital de elevação (MDE) do terreno, com base nessa informação são estimadas a áreas suscetíveis a inundação em função da proximidade de um canal fluvial, figura 29.

\section{O modelo HAND}

Mede a diferença altimétrica entre qualquer ponto da grade do MDE e o respectivo ponto de escoamento na drenagem mais próxima, considerando a trajetória superficial de fluxo (flowpath) que liga topologicamente os pontos da superfície com a rede de drenagem (BITAR, 2014, p. 21).

O MDE utilizado para a modelagem pode ser um SRTM, ASTER ou outro produto, mapeando-se a superfície do terreno, em função de uma drenagem mais próxima. Na figura 29, estão apontadas as etapas para o processamento do modelo HAND.

Figura 29: Sequência de procedimentos no modelo HAND 


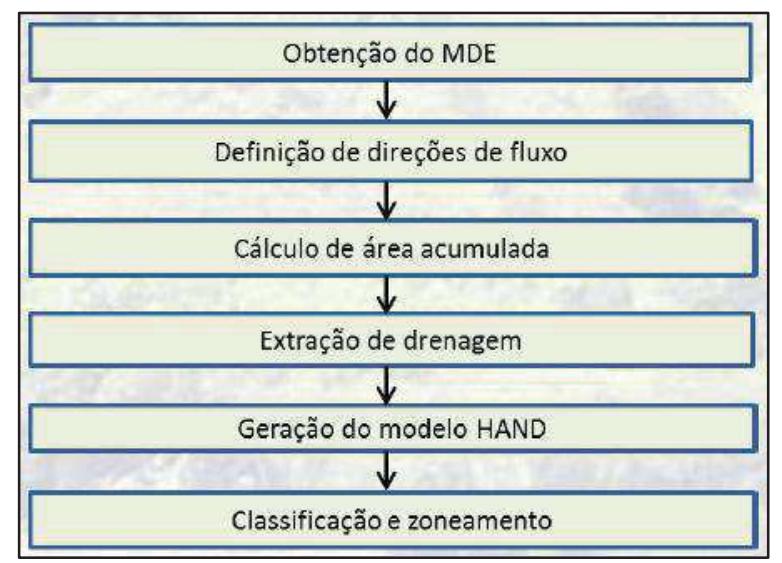

Fonte: Adaptado de Bitar (2014, p. 21).

A partir da geração do modelo HAND são definidas as alturas a partir da cota do canal fluvial (Figura 30), para o estabelecimento das classes. "Com base nas condições geomorfológicas e pedológicas dos terrenos atribuem-se as seguintes classes" (BITAR, 2014, p. 22).

Figura 30: Classes de suscetibilidade utilizadas no modelo HAND

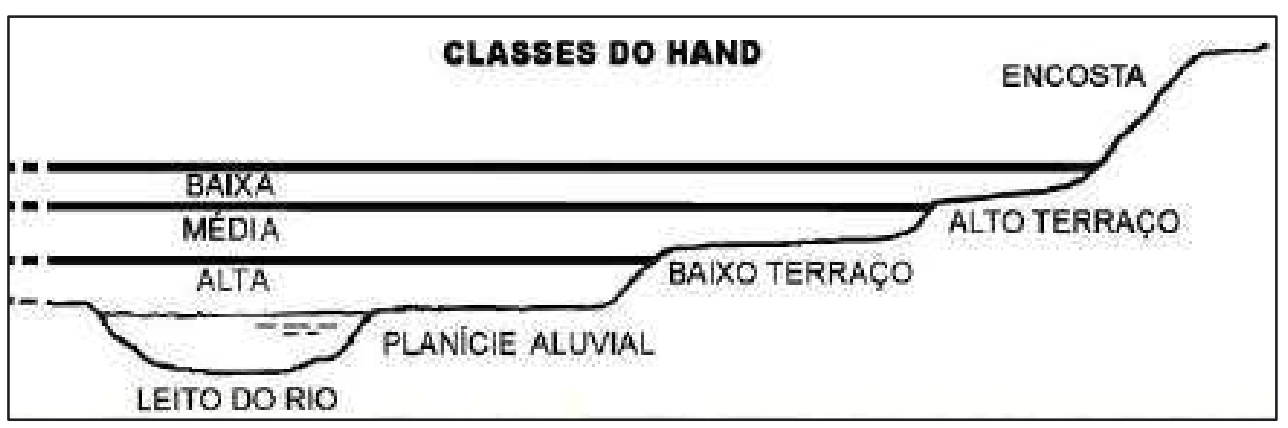

Fonte: Adaptado de Bitar (2014, p. 22).

A classe alta está associada à planície aluvial, enquanto que as classes média e baixa compreendem os terraços, sendo o baixo terraço com média suscetibilidade e o terraço alto como baixa suscetibilidade (BITAR, 2014).

$3^{\circ}$ etapa: Integração entre os dados morfométricos e modelados:

$\mathrm{Na}$ terceira etapa da modelagem ocorre a junção dos dados gerados nas etapas 1 e 2 , na qual são integradas informações de origem morfométricas e as informações obtidas pela modelagem do HAND. Com isso, é utilizada, conforme figura 31, uma matriz de correlação baseada na lógica booleana em que "comumente utilizada para a identificação de relações entre distintos tipos de dados geográficos (identificadas por meio de sobreposição de temas ou de mapas temáticos)” (BITAR, 2014, p. 22). 
Figura 31: Correlação entre os parâmetros quantitativos e qualitativos para a suscetibilidade a inundação

\begin{tabular}{|c|c|c|c||}
\hline $\begin{array}{l}\text { Índices } \\
\text { Morfométricos }\end{array}$ & Alta & Média & Baixa \\
\hline Alta & Alta & Alta & Média \\
\hline Média & Alta & Média & Baixa \\
\hline Baixa & Média & Baixa & Baixa \\
\hline
\end{tabular}

Fonte: Adaptado de Bitar (2014, p. 22).

Cabe ainda destacar que imprecisões podem ocorrer na modelagem disponibilizada pela CPRM, em função da resolução do MDE e da qualidade das informações obtidas para cada bacia hidrográfica.

\section{$3^{\circ}$ etapa: $O$ espaço urbano de Juiz de Fora e sua vulnerabilidade social}

Com base no levantamento do Censo Demográfico (IBGE, 2010) foram selecionadas variáveis, com base nos trabalhos de Goudard (2019) e Teobaldo Neto (2019) para avaliar a vulnerabilidade social em Juiz de Fora. A partir do levantamento das variáveis, agrupadas em setores censitários, foi calculado o índice de vulnerabilidade social, a partir da integração das variáveis (Figura 32).

Figura 32: Organização metodológica da terceira etapa. 


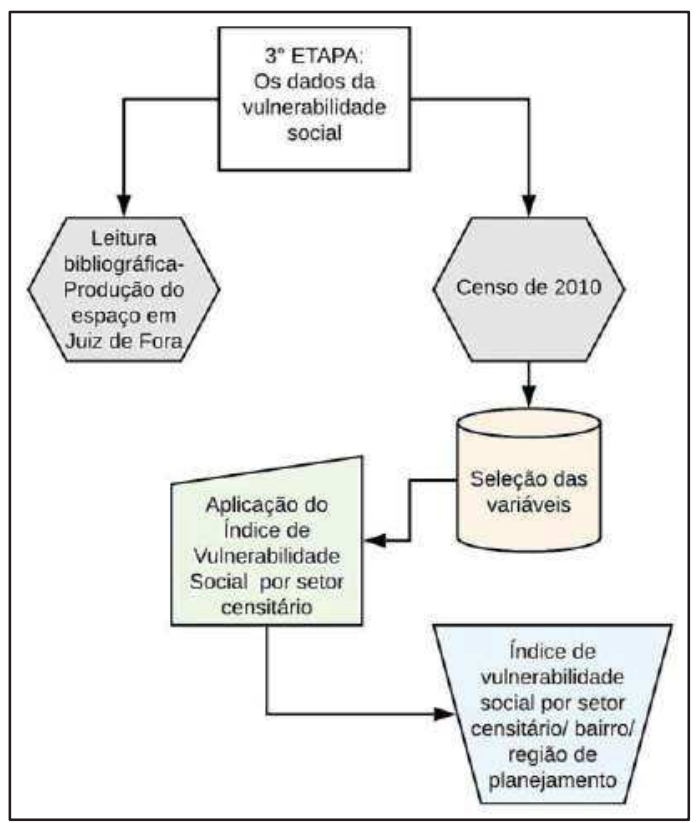

Fonte: Organizado pelo autor

A partir desse levantamento os dados foram espacializados no perímetro urbano do município, com base nos setores censitários e posteriormente foram recortados de acordo com as regiões de planejamento do Prefeitura de Juiz de Fora (PJF), figura 32. Os procedimentos foram realizados no software Excel 2013 e Arc Gis 10.3.3.

As informações do censo demográfico do IBGE são dispostas em planilhas agrupadas por estado, ou no caso da cidade de São Paulo, agrupadas a partir do município. A unidade espacial utilizada é o setor censitário "é a unidade territorial estabelecida para fins de controle cadastral, formado por área contínua, situada em um único quadro urbano ou rural, com dimensão e número de domicílios que permitam o levantamento por um recenseador" (IBGE, 2012, n. p.).

O perímetro urbano de Juiz de Fora apresenta 701 setores censitários, sendo que 25 deles não apresentam informações disponíveis, figura 33.

O cálculo do índice de vulnerabilidade social (IVS) constitui-se de nove variáveis integradas que se consubstanciam no índice, adaptadas de Teobaldo Neto (2019). As variáveis versam sobre a estrutura familiar (1); cor/etnia (2); faixa etária (3); renda (4) habitação e condições de moradia (5); saneamento básico (6); estrutura urbana (7); gênero (8) e educação (9). Para cada indicador, do 1 ao 9, foram selecionadas variáveis para a primeira etapa, a partir da base dados do IBGE, no censo demográfico de 2010.

Para integralizar o Índice de Vulnerabilidade Social (IVS), foram selecionadas 34 subvariáveis que agregadas formavam as nove variáveis utilizadas. As variáveis estrutura 
familiar, cor/etnia, renda e educação são formadas por apenas uma subvariável. Outras variáveis apresentam mais de uma subvariável, como faixa etária (3); habitação e condição da moradia (8); saneamento básico (4); estrutura urbana (10) e gênero (5). 
Figura 33: Setores censitários no perímetro urbano de Juiz de Fora.

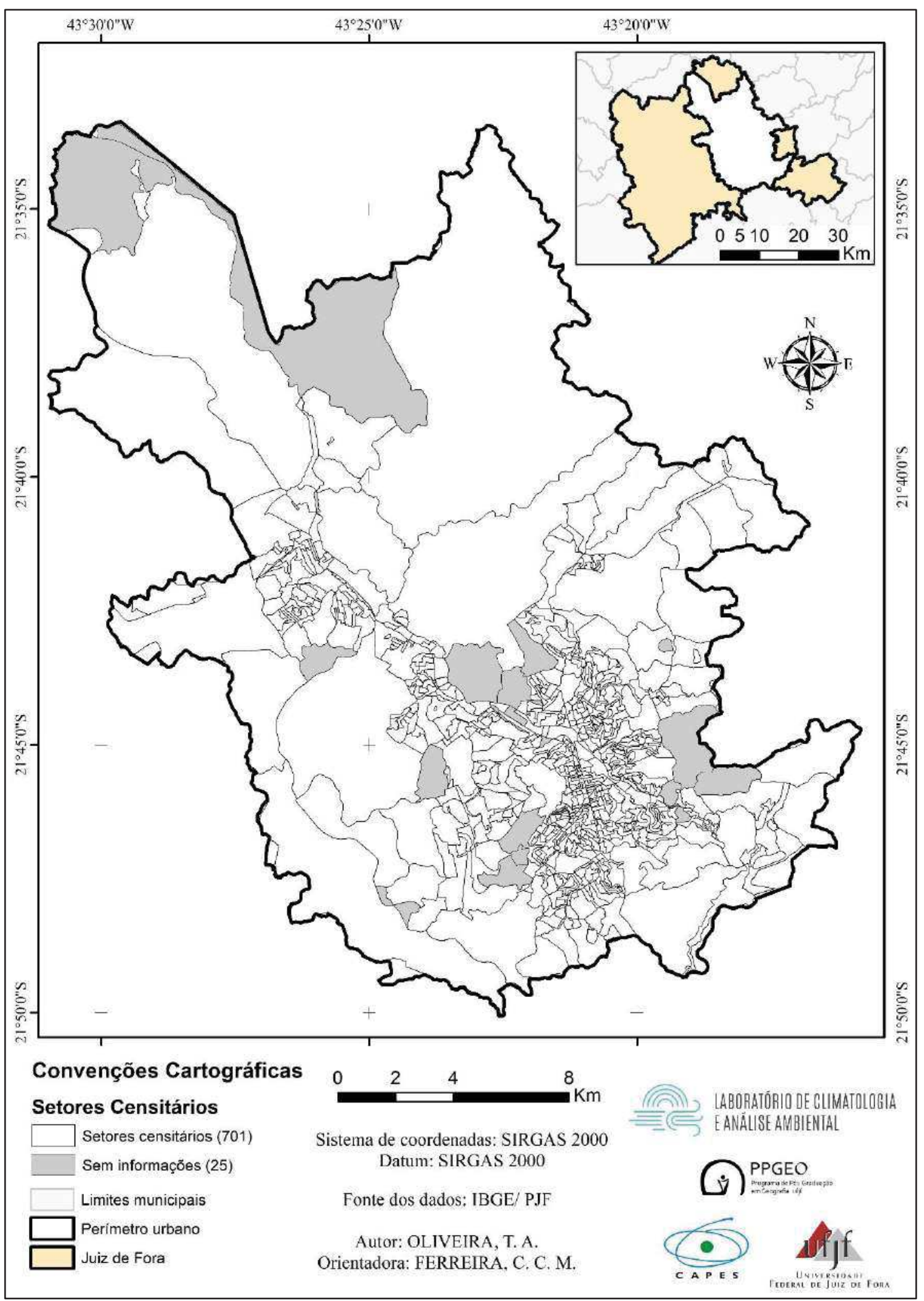

Fonte: Organizado pelo autor.

Quadro 10: Variáveis utilizadas para o Índice de Vulnerabilidade Social-IVS 


\begin{tabular}{|c|c|c|c|c|c|}
\hline Ordem & Variáveis & Varíaveis agregadas & Cód IBGE & Descrição original das variáveis (Censo Demográfico IBGE/2010 & Arquivo fonte \\
\hline \multirow{4}{*}{ v001 } & \multirow{4}{*}{ Estrutura familiar } & \multirow{4}{*}{ Domicilios com 7 ou mais moradores } & V056 & Domicilios particulares permanentes com 7 moradores & \multirow{4}{*}{ Domicilio01 } \\
\hline & & & V057 & Domicilios particulares permanentes com 8 moradores & \\
\hline & & & V058 & Domicilios particulares permanentes com 9 moradores & \\
\hline & & & V059 & Domicilios particulares permanentes com 10 ou mais moradores & \\
\hline \multirow{3}{*}{ V002 } & \multirow{3}{*}{ Cor/ etnia } & \multirow{3}{*}{ Pessoas de cor preta, parda e indigena } & V003 & Pessoas residentes e cor ou raça - preta & \multirow[b]{3}{*}{ Pessoa03 } \\
\hline & & & V005 & Pessoas residentes e cor ou raça - parda & \\
\hline & & & V006 & Pessoas residentes e cor ou raça - indigena & \\
\hline \multirow{5}{*}{ v003 } & \multirow{5}{*}{ Faixa etária } & \multirow{3}{*}{ Pessoas de 0 a 18 anos* } & V022 & Pessoas com menos de 1 ano de idade & \multirow{4}{*}{$\frac{\text { Pessoa13 }}{\text { Pessoa13 }}$} \\
\hline & & & V035 & Pessoas de 1 ano de idade & \\
\hline & & & V036 a V05: & 2Pessoas com 2 anos de idade a Pessoas com 18 anos de idade & \\
\hline & & Pessoas de 60 anos ou mais de idade & V094 a V13 & 4 Pessoas com 60 anos de idade a Pessoas com 60 anos ou mais de idade & \\
\hline & & Pessoas responsáveis por domicilio (com mais de 60 anos) & V052 a s & $\begin{array}{l}\text { Pessoas Responsáveis com } 60 \text { anos de idade a Pessoas Responsáveis com } 100 \text { ou mais anos de } \\
\text { 2iddade }\end{array}$ & Responsavel02 \\
\hline \multirow{4}{*}{ v004 } & \multirow{4}{*}{ Renda } & \multirow{4}{*}{$\begin{array}{l}\text { Domicílios com rendimento mensal domiciliar per capita de até } 1 \\
\text { salário mínimo (SM) }\end{array}$} & v005 & $\begin{array}{l}\text { Domicílios particulares com rendimento nominal mensal domiciliar per capita de até } 1 / 8 \text { salário } \\
\text { minimo }\end{array}$ & \multirow{4}{*}{ DomicilioRenda } \\
\hline & & & v006 & $\begin{array}{l}\text { Domicílios particulares com rendimento nominal mensal domiciliar per capita de mais de } 1 / 8 \text { a } \\
1 / 4 \text { salário mínimo }\end{array}$ & \\
\hline & & & v007 & $\begin{array}{l}\text { Domicilios particulares com rendimento nominal mensal domiciliar per capita de mais de } 1 / 4 \text { a } \\
1 / 2 \text { salario minimo }\end{array}$ & \\
\hline & & & v008 & $\begin{array}{l}\text { Domicilios particulares com rendimento nominal mensal domiciliar per capita de mais de } 1 / 2 \text { a } \\
1 \text { salário minimo }\end{array}$ & \\
\hline \multirow{10}{*}{ v005 } & \multirow{10}{*}{$\begin{array}{c}\text { Habitação e } \\
\text { condiç̃̃es da } \\
\text { moradia }\end{array}$} & Total de domicílios particulares improvisados & V001 & Total de domicilios particulares improvisados & DomicílioRenda \\
\hline & & Domicílios próprios em aquisição & V007 & Domicilios particulares permanentes próprios em aquisição & Domicilio01 \\
\hline & & Domicilios cedidos por empregador & V009 & Domicilios particulares permanentes cedidos por empregador & Domicilio01 \\
\hline & & Domicilios cedidos de outra forma & V010 & Domicilios particulares permanente cedidos de outra forma & Domicilio01 \\
\hline & & $\begin{array}{c}\text { Domicilios em outra condição de ocupação (não são próprios, } \\
\text { alugados, nem cedidos) }\end{array}$ & v011 & $\begin{array}{l}\text { Domicilios particulares permanentes em outra condição de ocupação (não são próprios, } \\
\text { alugados, nem cedidos) }\end{array}$ & Domicilio01 \\
\hline & & Domicilios sem energia elétrica & V046 & Domicilios particulares permanentes sem energia elétrica & Domicilio01 \\
\hline & & \multirow{2}{*}{ Domicilios com moradia semi-adequada } & V204 & $\begin{array}{l}\text { Domicilios particulares permanentes com moradia semi-adequada- Existe identificcação do } \\
\text { logradouro }\end{array}$ & \multirow{2}{*}{ Entorno02 } \\
\hline & & & V205 & $\begin{array}{l}\text { Domicilios particulares permanentes com moradia semi-adequada- Não existe identificação do } \\
\text { logradouro }\end{array}$ & \\
\hline & & \multirow{2}{*}{ Domicílios com moradia inadequada } & V206 & $\begin{array}{l}\text { Domicilios particulares permanentes com moradia inadequada- Existe identificação do } \\
\text { logradouro }\end{array}$ & \multirow{2}{*}{ Entorno02 } \\
\hline & & & V207 & $\begin{array}{l}\text { Domicilios particulares permanentes com moradia inadequada- Não existe identificação do } \\
\text { logradouro }\end{array}$ & \\
\hline \multirow{13}{*}{ v006 } & \multirow{13}{*}{ pameamento básic } & \multirow{3}{*}{ Domicilios SEM abastecimento de água da rede geral } & V013 & $\begin{array}{l}\text { Domicilios particulares permanentes com abastecimento de água de poço ou nascente na } \\
\text { propriedade }\end{array}$ & \multirow{3}{*}{ Domicílio01 } \\
\hline & & & V014 & $\begin{array}{l}\text { Domicilios particulares permanentes com abastecimento de água da chuva armazenada em } \\
\text { cisterna }\end{array}$ & \\
\hline & & & V015 & Domicilios particulares permanentes com outra forma de abastecimento de água & \\
\hline & & & V019 & $\begin{array}{l}\text { Domicilios particulares permanentes com banheiro de uso exclusivo dos moradores ou sanitário } \\
\text { e esgotamento sanitário via fossa rudimentar }\end{array}$ & \\
\hline & & $\begin{array}{l}\text { Domicílios com banheiro de uso exclusivo dos moradores ou } \\
\text { saniário SFM esgotamento sanitáric yiarede geral de esgoto ou }\end{array}$ & v020 & $\begin{array}{l}\text { Domicilios particulares permanentes com banheiro de uso exclusivo dos moradores ou sanitário } \\
\text { e esgotamento sanitário via vala }\end{array}$ & \\
\hline & & $\begin{array}{l}\text { saniário SEM esgotamento sanitário via rede geral de esgoto ou } \\
\text { fossa septica }\end{array}$ & V021 & $\begin{array}{l}\text { Domicilios particulares permanentes, com banheiro de uso exclusivo dos moradores ou } \\
\text { sanitário e esgotamento sanitário via rio, lago ou mar }\end{array}$ & Domicilio01 \\
\hline & & & V022 & $\begin{array}{l}\text { Domicilios particulares permanentes com banheiro de uso exclusivo dos moradores ou sanitário } \\
\text { e esgotamento sanitário via outro escoadouro }\end{array}$ & \\
\hline & & $\begin{array}{c}\text { Domicilios particulares permanentes sem banheiro de uso exclusivo } \\
\text { dos moradores e nem sanitário }\end{array}$ & V023 & $\begin{array}{l}\text { Domicílios particulares permanentes sem banheiro de uso exclusivo dos moradores e nem } \\
\text { sanitário }\end{array}$ & Domicilio01 \\
\hline & & & V038 & Domicilios particulares permanentes com lixo queimado na propriedade & \\
\hline & & & V039 & Domicilios particulares pe & \\
\hline & & Domicílios com lixo não coletado & V040 & Domicilios particulares permanentes com lixo jogado em terreno baldio ou logradouro & Domicilio01 \\
\hline & & & V041 & Domicilios particulares permanentes com lixo jogado em rio, lago ou mar & \\
\hline & & & V042 & Domicilios particulares permanentes com outro destino do lixo & \\
\hline
\end{tabular}




\begin{tabular}{|c|c|c|c|c|c|}
\hline \multirow{28}{*}{ V007 } & \multirow{28}{*}{ Estrutura urbana } & \multirow{3}{*}{ Domicílios sem Identificação de Logradouros (na rua) } & V003 & Domicílios particulares permanentes próprios - Não existe identificação do logradouro & \multirow{3}{*}{ Entorno01 } \\
\hline & & & V005 & Domicílios particulares permanentes alugados - Não existe identificação do logradouro & \\
\hline & & & V007 & Domicílios particulares permanentes cedidos - Não existe identificação do logradouro & \\
\hline & & \multirow{3}{*}{ Domicílios sem Iluminação Pública (na rua) } & V009 & Domicílios particulares permanentes próprios - Não existe iluminação pública & \multirow{3}{*}{ Entorno01 } \\
\hline & & & V011 & Domicílios particulares permanentes alugados - Não existe iluminação pública & \\
\hline & & & V013 & Domicílios particulares permanentes cedidos - Não existe iluminação pública & \\
\hline & & \multirow{3}{*}{ Domicílios sem Pavimentação (na rua) } & V015 & Domicílios particulares permanentes próprios - Não existe pavimentação & \multirow{3}{*}{ Entorno01 } \\
\hline & & & V017 & Domicílios particulares permanentes alugados -Não existe pavimentação & \\
\hline & & & V019 & Domicílios particulares permanentes cedidos - Não existe pavimentação & \\
\hline & & \multirow[b]{2}{*}{ Domicílios sem Calçada (na rua) } & V021 & Domicílios particulares permanentes próprios - Não existe calçada & \multirow[b]{2}{*}{ Entorno01 } \\
\hline & & & V023 & Domicílios particulares permanentes alugados - Não existe calçada & \\
\hline & & \multirow{3}{*}{ Domicílios sem Meio fio Guia (na rua) } & V027 & Domicílios particulares permanentes próprios - Não existe meio-fio/guia & \multirow{3}{*}{ Entorno01 } \\
\hline & & & V029 & Domicílios particulares permanentes alugados - Não existe meio-fio/guia & \\
\hline & & & V031 & Domicílios particulares permanentes cedidos - Não existe meio-fio/guia & \\
\hline & & \multirow{3}{*}{ Domić́lios sem Bueiro/boca de lobo (na rua) } & V033 & Domicílios particulares permanentes próprios - Não existe bueiro/boca-de-lobo & \multirow{3}{*}{ Entorno01 } \\
\hline & & & V035 & Domicílios particulares permanentes alugados -Não existe bueiro/boca-de-lobo & \\
\hline & & & V037 & Domicílios particulares permanentes cedidos - Não existe bueiro/boca-de-lobo & \\
\hline & & \multirow{3}{*}{ Domicílios sem Rampa para cadeirante (na calçada) } & V039 & Domicílios particulares permanentes próprios - Não existe rampa para cadeirante & \multirow{3}{*}{ Entorno01 } \\
\hline & & & V041 & Domicílios particulares permanentes alugados - Não existe rampa para cadeirante & \\
\hline & & & V043 & Domicílios particulares permanentes cedidos - Não existe rampa para cadeirante & \\
\hline & & \multirow[b]{2}{*}{ Domicílios sem Arborização (na calçada) } & V045 & Domicílios particulares permanentes próprios - Não existe arborização & \multirow[b]{2}{*}{ Entorno01 } \\
\hline & & & V047 & Domicílios particulares permanentes alugados - Não existe arborização & \\
\hline & & \multirow{3}{*}{ Esgoto a Céu Aberto } & V050 & Domicílios particulares permanentes próprios - Existe esgoto a céu aberto & \multirow{3}{*}{ Entorno01 } \\
\hline & & & V052 & Domicílios particulares permanentes alugados - Existe esgoto a céu aberto & \\
\hline & & & V054 & Domicílios particulares permanentes cedidos - Existe esgoto a céu aberto & \\
\hline & & \multirow{3}{*}{ Lixo acumulado nos logradouros } & V056 & Domicílios particulares permanentes próprios - Existe lixo acumulado nos logradouros & \multirow{3}{*}{ Entorno01 } \\
\hline & & & V058 & Domicílios particulares permanentes alugados - Existe lixo acumulado nos logradouros & \\
\hline & & & V060 & Domicílios particulares permanentes cedidos - Existe lixo acumulado nos logradouros & \\
\hline \multirow{12}{*}{ v008 } & \multirow{12}{*}{ Gênero } & Domicílios com moradoras do sexo feminino. & V060 & Domicílios particulares permanentes sem morador do sexo masculino & Domicilio01 \\
\hline & & Pessoas responsáveis do sexo feminino & V001 & Pessoas responsáveis, do sexo feminino & Responsável 01 \\
\hline & & \multirow{3}{*}{ Crianças responsáveis pelo domicílio, do sexo feminino } & V002 & Pessoas responsáveis com 10 anos de idade, do sexo feminino & \\
\hline & & & V003 & Pessoas responsáveis com 11 anos de idade, do sexo feminino & \\
\hline & & & V004 & Pessoas responsáveis com 12 anos de idade, do sexo feminino & Responsável 01 \\
\hline & & & V005 & Pessoas responsáveis com 13 anos de idade, do sexo feminino & \\
\hline & & & V006 & Pessoas responsáveis com 14 anos de idade, do sexo feminino & \\
\hline & & 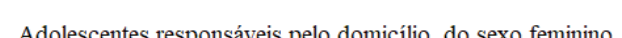 & V007 & Pessoas responsáveis com 15 anos de idade, do sexo feminino & \\
\hline & & Adolescentes responsáveis pelo domicilio, do sexo feminino & V008 & Pessoas responsáveis com 16 anos de idade, do sexo feminino & \\
\hline & & & V009 & Pessoas responsáveis com 17 anos de idade, do sexo feminino & \\
\hline & & & V010 & Pessoas responsáveis com 18 anos de idade, do sexo feminino & Responsável 01 \\
\hline & & Idosas responsáveis por domicilios particulares & V052 a v092 & $\begin{array}{l}\text { Pessoas responsáveis com } 60 \text { anos de idade, do sexo feminino a Pessoas responsáveis com } \\
100 \text { ou mais anos de idade, do sexo femenino }\end{array}$ & Responsável 01 \\
\hline v009 & Educação & Pessoas NÃO alfabetizadas com 7 ou mais anos de idade & V009-V011 & $\begin{array}{l}\text { Pessoas com } 7 \text { ou mais anos de idade (T9) - Pessoas alfabetizadas com } 7 \text { ou mais anos de } \\
\text { idade (T11) }\end{array}$ & Ponderação \\
\hline
\end{tabular}


Fonte: Adaptado de Teobaldo Neto (2019).

Com base nos dados coletados, a primeira etapa após o levantamento das informações consistiu na normalização da variável, permitindo uma comparação dentro do conjunto de dados de cada variável. De acordo com Sampaio (2012) a partir da normalização "um dado é considerado, a partir de sua importância relativa, no conjunto dos dados analisados ou a partir de sua relação com uma segunda variável" (SAMPAIO, 2012, p. 123).

Um exemplo de normalização pode ser ilustrado com o indicador 1- estrutura familiarem foram identificados por setor censitário o número de domicílios com sete ou mais moradores, com isso a variável normalizadora foi o número total de domicílios daquele setor.

$\mathrm{Na}$ sequência a padronização é necessária quando o procedimento necessita integrar mais de uma variável, e com isso este procedimento adequa todos os indicadores a uma escala de 0 a 1 (SAMPAIO, 2012). Após a padronização é possível comparar as variáveis de natureza distinta.

Quadro 11: Fórmulas para normalização e padronização das informações

\begin{tabular}{|l|c|}
\hline \multicolumn{1}{|c|}{ Normalização } & Padronização \\
\hline \multicolumn{1}{|c|}{$V n=\frac{V 1}{V 2}$} & $V p=\frac{V n-V \min }{V \max -V \min }$ \\
Vn= variável normalizada; & $\mathrm{Vp}=$ Variável padronizada; \\
V1: Variável a ser normalizada; & Vn= Variável normalizada; \\
V2: Variável normalizadora. & V min: Valor mínimo da variável normalizada; \\
& V max: valor máximo da variável normalizada \\
\hline
\end{tabular}

Fonte: Sampaio, 2012.

Com isso foi gerado um valor entre 0 e 1 para cada uma das 34 subvariáveis que posteriormente foram agrupadas totalizando as nove variáveis finais que compõem o índice de vulnerabilidade social. Assim, quando o valor se aproxima de 0 melhor é a condição daquele setor censitário atrelada à variável em questão, e quanto mais próximo de 1 pior é a condição do setor censitário para a variável.

Após a normalização e a padronização, algumas variáveis por serem baseadas em mais de uma ou um conjunto de subvariáveis, foi necessário ajustar o conjunto de dados para a integralização de um valor entre 0 e 1 para cada uma das nove variáveis. Sendo assim, cada uma das 34 subvariáveis foram relativizadas com o intuito de agregá-las à variável de referência. 
Quadro 12: Estrutura do Índice de Vulnerabilidade Social-IVS

\begin{tabular}{|c|c|c|c|}
\hline \multicolumn{4}{|c|}{ Esturutura do Índice de Vulnerabilidade Social-IVS } \\
\hline Variável & Subvariáveis & Peso & Total \\
\hline V001 & Domicilios com 7 ou mais moradores & 1 & 1 \\
\hline V002 & Pessoas de cor preta, parda e indigena & 1 & 1 \\
\hline \multirow{3}{*}{ V003 } & Pessoas de 0 a 18 anos & 0,4 & \multirow{3}{*}{1} \\
\hline & Pessoas de 60 anos ou mais de idade & 0,3 & \\
\hline & Pessoas responsáveis por domicilio (com mais de 60 anos) & 0,3 & \\
\hline V004 & Domicilios com rendimento mensal domiciliar per capita de até 1 salário minimo (SM) & 1 & 1 \\
\hline \multirow{8}{*}{ V005 } & Total de domicilios particulares improvisados & 0,2 & \multirow{8}{*}{1} \\
\hline & Domicilios próprios em aquisição & \multirow{4}{*}{0,2} & \\
\hline & Domicilios cedidos por empregador & & \\
\hline & Domicilios cedidos de outra forma & & \\
\hline & Domicilios em outra condição de ocupação (não são próprios, alugados, nem cedidos) & & \\
\hline & Domicilios sem energia elétrica & 0,2 & \\
\hline & Domicilios com moradia semi-adequada & 0,2 & \\
\hline & Domicilios com moradia inadequada & 0,2 & \\
\hline \multirow{4}{*}{ V006 } & Domicilios SEM abastecimento de água da rede geral & 0,25 & \multirow{4}{*}{1} \\
\hline & $\begin{array}{l}\text { Domicilios com banheiro de uso exclusivo dos moradores ou saniário SEM esgotamento } \\
\text { sanitário via rede geral de esgoto ou fossa septica }\end{array}$ & 0,25 & \\
\hline & $\begin{array}{l}\text { Domicilios particulares permanentes sem banheiro de uso exclusivo dos moradores e nem } \\
\text { sanitário }\end{array}$ & 0,25 & \\
\hline & Domicilios com lixo não coletado & 0,25 & \\
\hline \multirow{10}{*}{ V007 } & Domicilios sem Identificação de Logradouros (na rua) & 0,1 & \multirow{10}{*}{1} \\
\hline & Domicilios sem Iluminação Pública (na rua) & 0,1 & \\
\hline & Domicilios sem Pavimentação (na rua) & 0,1 & \\
\hline & Domicilios sem Calçada (na rua) & 0,1 & \\
\hline & Domicilios sem Meio fio Guia (na rua) & 0,1 & \\
\hline & Domicilios sem Bueiro/boca de lobo (na rua) & 0,1 & \\
\hline & Domicilios sem Rampa para cadeirante (na calçada) & 0,1 & \\
\hline & Domicilios sem Arborização (na calçada) & 0,1 & \\
\hline & Esgoto a Céu Aberto & 0,1 & \\
\hline & Lixo acumulado nos logradouros & 0,1 & \\
\hline \multirow{5}{*}{ V008 } & Domicilios com moradoras do sexo feminino. & 0,2 & \multirow{5}{*}{1} \\
\hline & Pessoas responsáveis do sexo feminino & 0,25 & \\
\hline & Crianças responsáveis pelo domicilio, do sexo feminino & 0,15 & \\
\hline & Adolescentes responsáveis pelo domicilio, do sexo feminino & 0,2 & \\
\hline & Idosas responsáveis por domicilios particulares & 0,2 & \\
\hline V009 & Pessoas NÃO alfabetizadas com 7 ou mais anos de idade & 1 & 1 \\
\hline
\end{tabular}

Fonte: Organizado pelo autor.

De posse dos indicadores das nove variáveis para cada setor censitário foi extraída uma média entre os valores oriundos das variáveis, conforme procedimento realizado por Dantas et al. (2017). Assim, o resultado final também esteve entre 0 e 1, mantendo a condição de: quanto mais próximo de 0 menor a vulnerabilidade social e quanto mais próximo de 1 maior a vulnerabilidade social do setor censitário.

$$
\text { IVS = Média }(V 001 ; V 002 ; V 003 ; V 004 ; V 005 ; V 006 ; V 007 ; V 008 ; V 009)
$$


Após a integralização do índice, calculado em planilhas do Microsoft Excel 2013, os valores foram adicionados à tabela de atributos do shape de setores censitários, através da ferramenta "ligar e relacionar" e com isso foi extraído um novo arquivo vetorial com as informações já anexadas. Por fim foi gerado o mapa com o Índice e vulnerabilidade social para o perímetro urbano de Juiz de Fora, em que foram definidas cinco classes (Quadro 13), com base na técnica de quebras naturais (Jenks).

Quadro 13: Classes estabelecidas para o Índice de Vulnerabilidade Social-IVS

\begin{tabular}{|c|c|}
\hline Classe & Intervalo \\
\hline Sem informação & Setores com inexistência de dados \\
\hline Baixíssima vulnerabilidade & $0,08665-0,167656$ \\
\hline Baixa vulnerabilidade & $0,167657-0,227115$ \\
\hline Média vulnerabilidade & $0,227116-0,281506$ \\
\hline Alta vulnerabilidade & $0,281507-0,350617$ \\
\hline Altíssima vulnerabilidade & $0,350618-0,547277$ \\
\hline
\end{tabular}

Fonte: Organizado pelo autor.

\section{$4^{\circ}$ etapa: Os impactos das chuvas e o levantamento das informações}

A utilização dos registros de mídia para a análise dos eventos climáticos é importante na medida em que auxilia no entendimento espacial e na relação dos elementos climáticos com a sociedade, sobretudo quando se trata de eventos extremos, sejam eles de seca (FONTÃO, 2018) ou de chuva intensa (VICENTE, 2005; CASTELLANO, 2010; LIMA, 2012).

Dessa forma a utilização da mídia se dá “devido à abrangência que os meios de comunicação alcançam, além de serem, muitas vezes, a única fonte de informações disponível para determinadas pesquisas" (CASTELLANO, 2010, p.12), relatando os fatos de uma forma espacialmente localizada, e com informações relevantes aos estudos climáticos. A esse respeito Ely (2008) apontou que a mídia impressa:

Por meio do registro e da divulgação que realiza compõe um veículo de comunicação cuja forma de (re) apresentação da realidade pode ser compreendida em uma perspectiva geográfica, pois é considerada um instrumento de registro e construção da memória de determinadas geograficidades por abordar fatos sempre localizados espaço-temporalmente (ELY, 2008, p. 139). 
É necessário, apesar disso, apontar algumas questões relacionadas à utilização da mídia como fonte de dados, mesmo que apresentem informações relevantes, estas são escritas por um jornalista que, em função de sua formação, irá se posicionar ou mesmo definir as palavras para a escrita do texto (CERIGATTO e CASARIM, 2017), dessa forma as notícias são investidas de ideologias, crenças e opiniões e que podem direcionar o texto a um caminho escolhido pelo autor.

Nunes (2007 destaca que

A imprensa intermedia a informação entre a sua origem (que pode ser diversa, de acordo com a natureza da informação) e a sociedade, e nesse processo podem ocorrer, mesmo que não deliberadamente, distorções, simplificações, inconsistências e erros, comprometendo o seu uso adequado por quem poderia dela se beneficiar (NUNES, 2007, p. 30).

Vicente (2005) utilizou os jornais para analisar os impactos das chuvas na Região Metropolitana de Campinas (RMC), e argumenta que "muitos pesquisadores fazem uso desses elementos em suas pesquisas, pelo fato de serem acessíveis e trazerem uma cobertura temporal relativamente satisfatória" (VICENTE, 2005, p. 46).

Vicente (2005) considera ainda que "os registros devem ser analisados criticamente, pois podem ocorrer imprecisões devido a questões de ordem conjuntural" (VICENTE, 2005, p. 46), a mídia seleciona o que publicar e como publicar, de forma que privilegia ou dá destaque a ocorrências que sucedem em regiões ou bairros da cidade.

Castellano (2010) utilizou os veículos de mídia para a identificação dos impactos das chuvas em Campinas-SP, diversos outros trabalhos têm os veículos de mídia como fonte de informação sobre os impactos das chuvas, Lima (2012) utilizou em São Carlos-SP; Simas (2013) em São Paulo-SP; Goudard (2019) em Curitiba-PR.

Os impactos gerados pelas chuvas na cidade podem ser identificados a partir de dados oficiais, como Corpo de Bombeiro e Defesa Civil, bem como pela análise documental de documentos de mídia impressa, eletrônica (pelos portais de notícias) e por telejornais.

Em Juiz de Fora as reportagens e notícias mais recentes (a partir de 2012) estão disponíveis diretamente por busca na internet, nos portais de notícia e nos telejornais. No entanto, para recortes mais pretéritos o levantamento foi realizado junto ao arquivo histórico da Prefeitura de Juiz de Fora- PJF, no qual estão armazenados os jornais de mídia impressa, com exemplares que datam desde o início do século XX, congregando o intervalo de tempo que foi investigado.

Esses levantamentos foram realizados a partir das datas em que foram registrados os totais pluviométricos na cidade, sendo visualizadas todas as datas em que os totais 
pluviométricos ultrapassaram $1 \mathrm{~mm}$, registrado na estação climatológica convencional do INMET, localizada no campus da UFJF.

O levantamento de informações sobre os impactos das chuvas na cidade foi realizado no período de 1980-2004 junto ao arquivo histórico municipal, nos jornais Diário da Tarde (1980-1983) e Tribuna de Minas/Tribuna da Tarde (1983 a 2004). Em função da pandemia da COVID-19, declarada pela Organização Mundial da Saúde (OMS) em 11/03/2020, os levantamentos de campo foram interrompidos e não puderam ser retomados, sendo assim o levantamento de dados se encerrou no ano de 2004.

O levantamento de informações reiniciou no ano de 2012, com base em informações/notícias disponibilizadas online, a partir das datas em que foi registrado precipitação na cidade, bem como por palavras chave, como: inundação, deslizamento, desabamento, temporal, chuva, alagamento, Defesa Civil, Meteorologia, enxurrada.

No período entre 2012 a 2018 as informações foram coletadas a partir de notícias publicadas na internet, mantendo-se a Tribuna de Minas como base de dados, mas acrescentando o G1-Zona da Mata, setor de notícias da Rede Globo direcionado à Zona da Mata Mineira, além de outros sites como o Acessa.com.

A partir de 2013 o site do G1-Zona da Mata disponibiliza a gravação dos telejornais locais, apresentados pela TV Integração (afiliada da Rede Globo), essa fonte de informação também foi utilizada com base no registro de dados de precipitação. Além disso, a partir do final de 2016 o jornal Tribuna de Minas disponibiliza uma versão do jornal em ambiente online para assinantes, que também foi utilizada.

O levantamento de dados com relação aos impactos foi realizado para os meses de Outubro a Março, correspondentes à estação chuvosa em Juiz de Fora e consiste no período que um maior número de impactos é registrado na cidade.

Todas as notícias que expressam alguma relação com a precipitação na cidade de Juiz de Fora foram registradas em fotografias ou baixadas em formato. pdf, e catalogadas a partir da planilha, figura 34, sobre data, manchete, página, jornal e alguma observação que se julgue necessário ao longo do campo. 
Figura 34: $1^{\circ}$ planilha para levantamento de dados em campo.

\begin{tabular}{|c|c|c|c|c|}
\hline \multirow{2}{*}{\begin{tabular}{|l|} 
Jomal: \\
Inicio da busca:
\end{tabular}} & \multirow{2}{*}{\begin{tabular}{|c} 
Data da visita: \\
Término da busca:
\end{tabular}} & \multicolumn{2}{|l|}{ Mês analisado: } & \multirow[t]{2}{*}{ Ano: } \\
\hline & & & & \\
\hline $\begin{array}{l}\text { Data da } \\
\text { noticia }\end{array}$ & Manchete & & Página & Observação \\
\hline & & & & \\
\hline & & & & \\
\hline & & & & \\
\hline & & & & \\
\hline & & & & \\
\hline & & & & \\
\hline & & & & \\
\hline & & & & \\
\hline & & & & \\
\hline & & & & \\
\hline & & & & \\
\hline & & & & \\
\hline & & & & \\
\hline & & & & \\
\hline & & & & \\
\hline & & & & \\
\hline
\end{tabular}

Fonte: Organizado pelo autor.

Posteriormente as notícias foram filtradas em função do caráter e do tipo de conteúdo, dentre estes destacam-se: a própria ocorrência de impactos decorrentes das precipitações, problemas de infraestrutura dos bairros, notícias de previsão do tempo, relações com a produtividade agrícola e preço de alimentos, dentre outros. Nesse momento foi gerada uma segunda planilha (Figura 35) com as informações filtradas, na qual já se consegue visualizar quais foram de fato os impactos das precipitações na cidade.

Figura 35: Segunda planilha para organização dos dados levantados, exemplo de janeiro de 1980.

\begin{tabular}{|c|c|c|c|}
\hline IOANAL & - $\mid$ DATL $=1$ & BAIRAOS ATINGIDOS & Tipo de Noticla \\
\hline Diário de Tarde & O2/jan Projeto BIRD é conquista do planejamento & & Planejamento \\
\hline Diâria da Tarde & 02/jan Nos Bairros o entusiasmo pelas obras & & Obras \\
\hline Diário de Tarde & $14 / j$ an $A$ Agua e esgoto e o que querem os moradores do Vila Alpina & & Problema social \\
\hline Diárío da Tarde & $16 /$ an Moradores do bairro brigem por ponte & & Probleme social \\
\hline Diário da Tarde & 16/:an Moredores reclamam do desvio do córego e obras do canal & & Problema social \\
\hline Dlario de Tarce & 17//an Tratego na rua ja esta impossivel & Santo António & Lama \\
\hline Diário da Tarde & 17//jan Moradores reclamam do barro, lixo e mato: Santo António & Santo Antönio & Lama \\
\hline Diánio da Tarde & $18 /$ an Vitimas das chuvas sobem para $15 \mathrm{em}$ todo estado & & Problema no estado \\
\hline Diärio da Tarde & 19/ian com chuva medo voita aos bairros & Santa Terezinha & Perigo de desabamento \\
\hline Diário da Tarde & 19//an Enxurrada e obra inacabada podem provocar desabamento & Santa Terezinha & Perigo de desabamento \\
\hline Diario da Tarde & 19/lan Chuvas alarmam a cidade & & Alerta/previsäo \\
\hline Diário da Tarde & 19//an Chuvas matam dois em Minas. & & Problema no Estado \\
\hline Diário da Tarde & 21//an cerámica um bairro com problemas & & Problema social \\
\hline Dläria da Tarde & 23/jan Violêncla das äguas arrascu Leopoldina & & Problemas em leopoldina \\
\hline Diário da Tarde & 23//an Chuva e desabamentos provocam expectativa & Grajaú & Deslizamento \\
\hline Diania da Tarde & 23/jan Tromba dágua em Leopoldina & & Problema no Estado \\
\hline Diario da Tarde & 23f/an lpiranga: ainda o problema da leta d'ägua na cabeça & & Problema social \\
\hline Diarrio da Tarde & 30/jan Enchentes deixam 12 mil desabrigados em todo o Estado & & Problema no Estado \\
\hline Diàno da Tarde & 04/fev falta de calsamento provora queixas no bairro $\mathrm{V}$. dos Bande & & Problema social \\
\hline
\end{tabular}

Fonte: Organizado pelo autor.

De posse dos dias específicos e das notícias referentes propriamente aos impactos, uma terceira planilha foi gerada (Figura 36). Nesse momento as notícias foram lidas na íntegra e 
delas foram retiradas as informações para o mapeamento dos impactos, dessa forma, caracterizou-se o tipo de impacto como: (1) inundação; (2) alagamento; (3) deslizamento; (4) desabamento.

Além disso buscou-se a localização do ocorrido, esta localização pode aparecer de duas formas: uma primeira com a localização precisa do caso, com rua e número da residência, e uma segunda forma, na qual cita-se apenas o nome do bairro.

Em função da imprecisão observada ao longo da organização dos dados, viu-se a necessidade de agregar as informações em dois grupos: impactos hidrológicos (agregando as inundações; alagamentos; enxurradas) e impactos geomorfológicos (que totalizam os deslizamentos e os desabamentos) uma vez que as terminologias técnicas nem sempre foram adotadas de maneira precisa nos materiais consultados, inviabilizando uma investigação mais apurada.

Figura 36: Terceira planilha: para organização dos dados organizados por tipo de impacto, exemplo de 1981

\begin{tabular}{|c|c|c|c|c|}
\hline JORNAL $\quad \nabla$ & DATA $=$ & MANCHETE & BAIRROS ATINGIDOS & TIPO DE OCORRENCIA \\
\hline DIÁRIO DA TARDE & $03 / \mathrm{jan}$ & Em Linhares barranco desaba & Linhares & Deslizamento \\
\hline DIÁRIO DA TARDE & $07 / \mathrm{fev}$ & Bairro fica alagado com chuva forte & Bandeirantes & INUNDAÇÃO \\
\hline DIÁRIO DA TARDE & $07 / \mathrm{fev}$ & Chuva causa estragos em toda a cidade & Manoel Honório & Queda de árvore \\
\hline DIÁRIO DA TARDE & $07 / \mathrm{fev}$ & Chuva causa estragos em toda a cidade & Manoel Honório & Inundação \\
\hline DIÁRIO DA TARDE & 10/fev & Chuva causa estragos em toda a cidade & Grajaú & Apenas citado na notícia \\
\hline DIÁRIO DA TARDE & $07 / \mathrm{mar}$ & Bairro Grambrey protesta & Grambery & Lama \\
\hline DIÁRIO DA TARDE & $09 / \mathrm{mar}$ & Chuva forte prejudica transito nas principais ruas da cidade & Centro & Alagamentos \\
\hline DIÁRIO DA TARDE & $10 / \operatorname{mar}$ & Chuvas aumentam problemas em bairros periféricos & São Judas Tadeu & Alagamentos \\
\hline DIÁRIO DA TARDE & $10 /$ mar & As chuvas que castigaram a cidade. & Centro & Problemas de circulação \\
\hline DIÁRIO DA TARDE & $10 / \mathrm{mar}$ & Chuvas aumentam problemas em bairros periféricos & Bandeirantes & Lama; Alagamento \\
\hline DIÁRIO DA TARDE & $11 / \mathrm{mar}$ & Chuvas causa problemas e enche a cidade & Centro & Alagamento \\
\hline DIÁRIO DA TARDE & $11 / \mathrm{mar}$ & Chuvas voltam a inundar a cidade & Manoel Honório & Problema na drenagem \\
\hline DIÁRIO DA TARDE & $11 / \operatorname{mar}$ & Chuvas voltam a inundar a cidade & Santa Terezinha & Inundação \\
\hline DIÁRIO DA TARDE & $11 / \mathrm{mar}$ & Chuvas voltam a inundar a cidade & Santa Luzia & \\
\hline DIÁRIO DA TARDE & $11 / \operatorname{mar}$ & Chuvas voltam a inundar a cidade & Poço Rico & Alagamento, detritos \\
\hline DIÁRIO DA TARDE & $11 / \mathrm{mar}$ & Chuvas voltam a inundar a cidade & Ipiranga & \\
\hline DIÁRIO DA TARDE & $11 / \mathrm{mar}$ & Chuvas voltam a inundar a cidade & Viturino Braga & Alagamento \\
\hline DIÁRIO DA TARDE & $11 / \mathrm{mar}$ & Chuvas voltam a inundar a cidade & Bairro de Lourdes & alagamento \\
\hline
\end{tabular}

Fonte: Organizado pelo autor.

Para o presente trabalho o mapeamento se deu em função das ocorrências de impactos hidrológicos e impactos geomorfológicos, uma vez que estes se associam de forma mais concreta à ideia dos riscos climáticos. Diferentemente de ocorrências de quedas de árvore, destelhamentos, queda de energia que estão relacionados a ventos fortes e descargas elétricas, auxiliam no entendimento da intensidade do evento, mas não estão necessariamente associados à chuva.

Com base nessas informações dois tipos de mapeamentos foram gerados, um primeiro com a localização pontual dos impactos, com base nas notícias que trazem a localização precisa das ocorrências, e um segundo mapeamento que consta o número de citações por bairro no noticiário, porém sem a precisão pontual do anterior (Figura 37). 
Figura 37: Organização metodológica da quarta etapa.

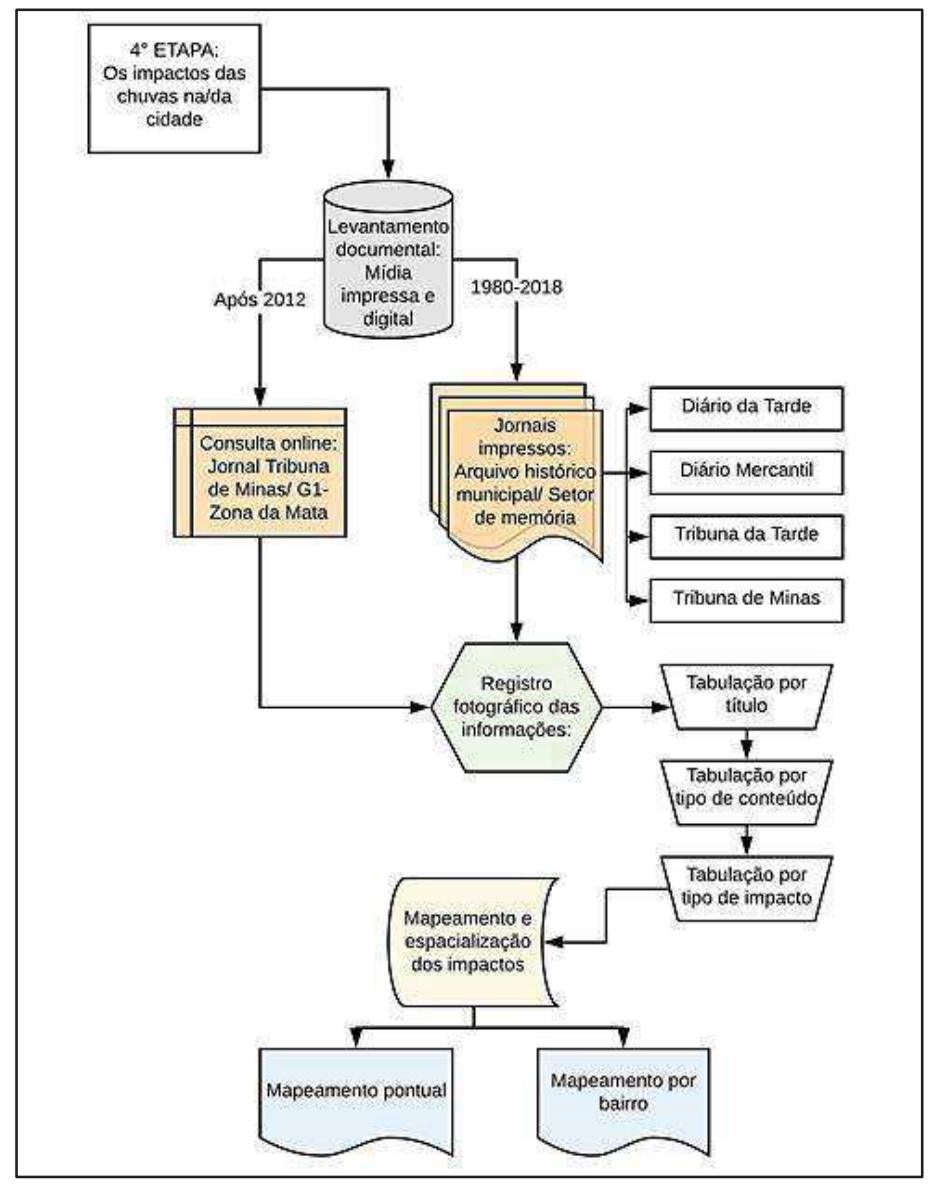

Fonte: Organizado pelo autor.

Com isso, algumas bases de dados foram levantadas nessa etapa do trabalho. A primeira delas consiste do somatório de citações que as regiões urbanas obtiveram nas duas variáveis levantadas, impacto hidrológico e impacto geomorfológico, bem como uma terceira que consiste da soma dessas duas variáveis permitindo visualizar a totalidade dos impactos por região urbana.

A segunda base de dados congrega os impactos na sua forma pontual ao longo do perímetro urbano, sendo apenas duas, referentes às duas modalidades de impactos. Cabe destacar que esta base de dados representa apenas as informações que dispunham da localização do impacto, sendo possível que determinado impacto tenha sido computado na primeira base de dados e se ausente na segunda, em função da imprecisão da localização observada, nesses casos foi possível apenas apontar o bairro/ região urbana ao qual ele se inscreve.

Para a avaliação da concentração dos pontos referentes aos impactos, foi utilizada a técnica de análise de Densidade de Kernel. Coelho e Ferreira (2016, p. 2) destacam que "os parâmetros utilizados são o raio de influência para definir a vizinhança do ponto a ser 
interpolado e controlar o alisamento da superfície, e uma função de estimação". A partir da equação 9.

$$
\hat{\lambda}_{\tau}(u)=\frac{1}{\tau^{2}} \sum_{i=1}^{n} k\left(\frac{d\left(u_{i}, u\right)}{\tau}\right), d\left(u_{i}, u\right) \leq \tau
$$

Onde: (ui...ui+ m-1) são pontos localizados dentro de um raio $\tau$ situado em torno do ponto ui e d é a distância entre a posição e a i-ésima amostra.

Com isso, pretende-se com a metodologia colocada discutir os episódios extremos de precipitação na cidade a partir de uma abordagem que integre as chuvas e os seus impactos, ou seja, os episódios extremos, correlacionando com o quadro físico ambiental e as condições sociais dos sujeitos daquele setor censitário/ bairro impactado ou não.

\section{A Integralização dos elementos e o Risco Climático}

A técnica empregada para integralização do mapa de risco climático esteve associada a uma análise multicritério, sendo baseada em uma análise hierárquica de pesos (AHP). Nesse cenário são atribuídos pesos em função do relacionamento entre as variáveis e o resultado que este processo pode revelar no entendimento de determinado fenômeno.

O método AHP,

Desenvolvido pelo Prof. Thomas Saaty em 1978, na Universidade da Pensilvânia. Ele auxilia na atribuição dos pesos dos planos de informação, para determinar a contribuição relativa de cada um, mas ainda assim o especialista ainda deve definir a hierarquia entre as variáveis e os pesos de cada componente de legenda das variáveis (MOURA, 2007, p. 2903).

Nesse contexto, o pesquisador irá avaliar as suas variáveis par a par e estabelecer quais as relações estabelecidas entre elas. No método AHP ainda que as variáveis sejam coletadas por técnicas distintas é o pesquisador que avalia e atribui os pesos para as variáveis, e com isso, "não existe pesquisa sem um pequeno traço de subjetividade, pois a própria escolha de um modelo já é a opinião de um especialista segundo um olhar sobre a realidade espacial" (MOURA, 2007, p. 2904).

No estabelecimento dos critérios utilizados, algumas perguntas precisam ser respondidas para cada variável. Qual a importância dessa variável para o fenômeno utilizado? Quais as relações entre as variáveis utilizadas? Com isso vislumbra-se os caminhos para a atribuição de pesos entre as variáveis. 
A técnica de análise multicritério baseia-se no estabelecimento de hierarquias que se estruturam em determinado período de tempo e em determinado espaço. Com isso, ao atualizar as informações, é importante reavaliar os critérios empregados na modelagem. De acordo com Moura (2007, p. 2901) “Cada nova análise irá exigir nova escolha de conjunto de variáveis e o peso que cada uma delas terá no resultado final está relacionado ao contexto da análise".

Os três planos de informação utilizados versam sobre os elementos para a análise do risco (Quadro 14). A princípio a suscetibilidade ambiental denotando as diferenças de sítio urbano e das condições ambientais, no caso a cidade. A segunda variável é a vulnerabilidade social entendida a partir da lógica de produção do espaço como um processo produto das desigualdades sociais (NASCIMENTO JÚNIOR, 2018, p. 70). Enquanto que o histórico de ocorrências reflete a materialização dos impactos no espaço, no período investigado, bem como a sua relação com os eventos de precipitação, uma vez que foram coletados a partir dessas informações.

Quadro 14: Variáveis para o zoneamento do risco climático

\begin{tabular}{|c|c|c|c|}
\hline Material cartográfico & Fonte & Mapa temático & Mapa síntese final \\
\hline $\begin{array}{c}\text { Suscetibilidade } \\
\text { ambiental }\end{array}$ & (CPRM, 2014) & $\begin{array}{c}\text { 1- Carta de } \\
\text { Suscetibilidade a } \\
\text { movimentos de } \\
\text { massa; }\end{array}$ & \multirow{3}{*}{$\begin{array}{c}\text { Mapa de risco } \\
\text { climático a } \\
\text { impactos } \\
\text { geomorfológicos; }\end{array}$} \\
\hline $\begin{array}{c}\text { Índice de } \\
\text { vulnerabilidade } \\
\text { social-IVS }\end{array}$ & $\begin{array}{c}\text { Adaptado de } \\
\text { Teobaldo Neto } \\
\text { (2019) e } \\
\text { Goudard (2019) }\end{array}$ & $\begin{array}{c}\text { Mapa de } \\
\text { vulnerabilidade } \\
\text { social }\end{array}$ & \\
\hline $\begin{array}{l}\text { Histórico de } \\
\text { ocorrências dos } \\
\text { impactos }\end{array}$ & $\begin{array}{l}\text { Levantamento } \\
\text { documental nas } \\
\text { informações de } \\
\text { mídia impressa e } \\
\text { digital. }\end{array}$ & $\begin{array}{c}\text { Histórico de } \\
\text { ocorrências de } \\
\text { impactos } \\
\text { geomorfológicos }\end{array}$ & \\
\hline
\end{tabular}

Fonte: Organizado pelo autor.

No mapa utilizado foram utilizadas três variáveis que compuseram o mapa de risco climático. A primeira variável, de ordem qualitativa foi a suscetibilidade aos movimentos de massa, a informação nessa variável, conforme já apresentado, variava entre baixa, média e alta, 
sendo assim estas informações foram reclassificadas a partir do peso que representam para a ocorrência dos impactos (Quadro 15).

Quadro 15: Pesos aplicados às cartas de suscetibilidade ambiental

\begin{tabular}{|c|c|}
\hline Suscetibilidade a inundação/movimentos de massa & Peso \\
\hline Baixa & 1 \\
\hline Média & 3 \\
\hline Alta & 5 \\
\hline
\end{tabular}

Fonte: Organizado pelo autor.

A segunda variável utilizada, também de ordem qualitativa, está associada à vulnerabilidade social, que também foi reclassificada a partir dos pesos. A vulnerabilidade social demonstra quais as condições sociais sobre as quais os espaços impactados por impactos pluviométricos ocorrem (Quadro 16).

Quadro 16: Pesos aplicados ao índice de vulnerabilidade social

\begin{tabular}{|c|c|}
\hline Índice de Vulnerabilidade social-IVS & Peso \\
\hline Baixíssima vulnerabilidade social & 1 \\
\hline Baixa vulnerabilidade social & 2 \\
\hline Média vulnerabilidade social & 3 \\
\hline Alta vulnerabilidade social & 4 \\
\hline Altíssima vulnerabilidade social & 5 \\
\hline
\end{tabular}

Fonte: Organizado pelo autor.

Na medida em que a vulnerabilidade social traz aspectos como a exposição, e as capacidades de resposta a determinado evento perigoso, no caso a precipitação, e como aquele indivíduo ou grupo poderá reestabelecer as suas condições de vida após a ocorrência de um impacto. Assim, quanto mais vulnerável o indivíduo ou o grupo mais difíceis serão as condições de enfrentamento a determinado impacto, entendendo a vulnerabilidade social como elemento que antecede o evento perigoso.

A terceira e última variável, de ordem quantitativa, revela o histórico de ocorrências para cada região urbana, o que traz uma noção já de integração entre os eventos perigosos (a precipitação) e a sua consubstanciação no espaço, na forma de impactos.

Assim, quanto mais vezes a região urbana foi citada com relação aos impactos geomorfológicos (Quadro 17), reflete a recorrência desse tipo de impacto naquela RU. Por se 
tratar de informações de natureza quantitativa, a distribuição dos intervalos de classe se deu em função da técnica de quebras naturais (Jenks) e quanto mais ocorrências registradas, maior o peso atribuído à área.

Quadro 17: Pesos aplicados ao histórico de ocorrências dos impactos geomorfológicos

\begin{tabular}{|c|c|}
\hline $\begin{array}{c}\text { Citações em impactos } \\
\text { geomorfológicos }\end{array}$ & Peso \\
\hline $1-8$ & 1 \\
\hline $9-15$ & 2 \\
\hline $16-27$ & 3 \\
\hline $28-41$ & 4 \\
\hline $42-63$ & 5 \\
\hline
\end{tabular}

Fonte: Organizado pelo autor.

Este mapeamento foi realizado apenas para as informações de impactos geomorfológicos em função dos dados disponíveis, sendo que os impactos hidrológicos representam várias tipologias de ocorrências (alagamentos, enxurradas) que ultrapassam o alcance da carta de suscetibilidade a inundação.

O procedimento foi realizado em ambiente SIG, no Arc Gis 10. 2.2 respeitando-se alguns procedimentos, como fora descrito por Vianna (2018), quando utilizou a modelagem proposta por Ferreira (2014) para a identificação de campos térmicos. Os procedimentos necessários demandam a transformação das informações vetoriais e arquivos raster (1), para que numa segunda etapa seja feita a reclassificação (2) e no terceiro momento ocorra a integração das variáveis (3).

A primeira etapa consistiu de transformar os arquivos vetoriais em arquivos raster, para este procedimento foi utilizada a ferramenta de conversão, polígono para raster (polygon to raster), com isso os arquivos em formato shapefile foram transformados em arquivos em formato .tiff. O tamanho da célula do pixel empregada foi de $1 \mathrm{~m}$.

$\mathrm{Na}$ segunda etapa os arquivos raster foram reclassificados em função dos pesos atribuídos para cada variável, conforme quadros 15,16 e 17, através da ferramenta reclassify. Além disso, os pixels sem informação foram reclassificados com o valor 0 , caso contrário, poderiam inviabilizar o procedimento de soma das variáveis, realizado na terceira etapa. A integração final das variáveis no mapa síntese foi realizada a partir da ferramenta calculadora 
de raster (raster calculator), na qual os três arquivos raster foram somados gerando o mapa síntese de risco climático.

Ao utilizar três variáveis de características distintas, há que se considerar a diversidade de escalas nas bases de dados. No caso utilizado a carta de suscetibilidade da CPRM foi gerada a partir de uma escala de 1:25000 (BITAR, 2014). Enquanto que o Índice de vulnerabilidade social, seguiu os setores censitários e o histórico de ocorrências foi realizado a partir das regiões urbanas.

Após a soma das variáveis, utilizando a mesma lógica aplicada por Ferreira (2014), é gerado um mapa síntese, quanto maior o resultado da soma, maiores serão as repercussões dos impactos naquele ponto. Exemplo disso, o pixel que totalizou 15 pontos, representa uma área com alta suscetibilidade, altíssima vulnerabilidade social e elevada recorrência de impactos.

A avaliação do mapeamento do risco foi realizada a partir dos mapas de pontos, que representam os impactos que tiveram a sua localização descrita de forma mais precisa nas notícias.

Quadro 18: Classificação do risco climático aos impactos geomorfológicos

\begin{tabular}{|c|c|}
\hline Categoria de risco & Intervalo da soma \\
\hline Baixíssimo risco & $1-3$ \\
\hline Baixo risco & $4-6$ \\
\hline Médio risco & $7-9$ \\
\hline Alto risco & $10-12$ \\
\hline Altíssimo risco & $13-15$ \\
\hline
\end{tabular}

Fonte: Organizado pelo autor.

O quadro 19 demonstra a relação entre as etapas metodológicas e os objetivos, que darão subsídios para o objetivo principal investigar os impactos deflagrados pelas chuvas na área urbana de Juiz de Fora-MG, entendendo o clima urbano a partir da perspectiva do risco climático.

Quadro 19: Etapas metodológicas e objetivos 


\begin{tabular}{|c|c|}
\hline $1^{\circ}$ etapa: Dados pluviométricos & $\begin{array}{l}\text { - Analisar o comportamento das } \\
\text { chuvas historicamente e suas } \\
\text { intensidades diárias; } \\
\text { - Avaliar a acurácia de dados de } \\
\text { satélite para a espacialização das } \\
\text { chuvas em Juiz de Fora; } \\
\text { - Investigar quais eventos intensos } \\
\text { extremos foram considerados } \\
\text { episódios extremos e qual técnica } \\
\text { melhor os representa. }\end{array}$ \\
\hline $\begin{array}{l}2^{\circ} \text { etapa: Sítio urbano e } \\
\text { suscetibilidade ambiental }\end{array}$ & $\begin{array}{l}\text {-Investigar as áreas propensas à } \\
\text { ocorrência dos impactos hidrológicos e } \\
\text { geomorfológicos }\end{array}$ \\
\hline $\begin{array}{c}3^{\circ} \text { etapa: Vulnerabilidade social e a } \\
\text { produção do espaço }\end{array}$ & $\begin{array}{l}\text { - Identificar as áreas com maior } \\
\text { vulnerabilidade social na cidade; }\end{array}$ \\
\hline $\begin{array}{l}4^{\circ} \text { etapa: Os impactos na cidade: } \\
\text { levantamento documental }\end{array}$ & 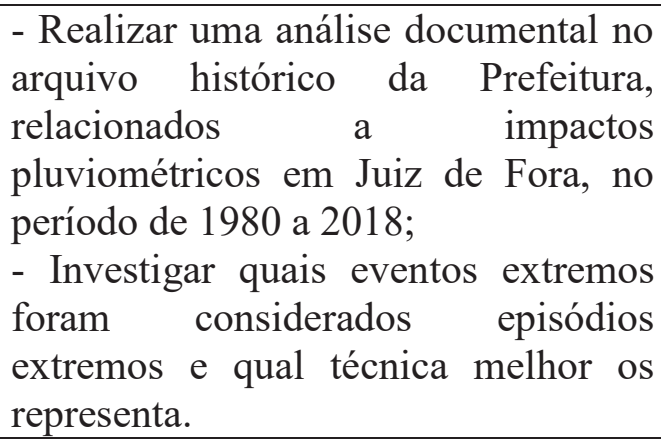 \\
\hline
\end{tabular}

Fonte: Organizado pelo autor. 


\section{Capítulo 5- Os dados de precipitação: das técnicas aos eventos extremos}

\section{A correlação e avaliação dos dados CHIRPS}

\section{Correlação dos dados do CEMADEN e os dados do INMET}

Iniciando pela comparação entre os dados do pluviômetro do CEMADEN localizado ao lado da estação do INMET no campus da UFJF, observa-se uma correspondência entre os dados mensais, exceto nos meses de Janeiro e Fevereiro em que a estação CEMADEN registra valores de 161,9 mm e 131,6mm, respectivamente, inferiores à estação do INMET (Figura 38). Isso pode se justificar pela ocorrência de falhas nas leituras dos pluviômetros do CEMADEN, que ficam com sua área de captação obstruídos por detritos que ali se alojam e comprometem a leituras dos dados até que a manutenção e limpeza seja realizada.

Figura 38: Comparação entre os dados CEMADEN e INMET no posto Cidade Universitária.

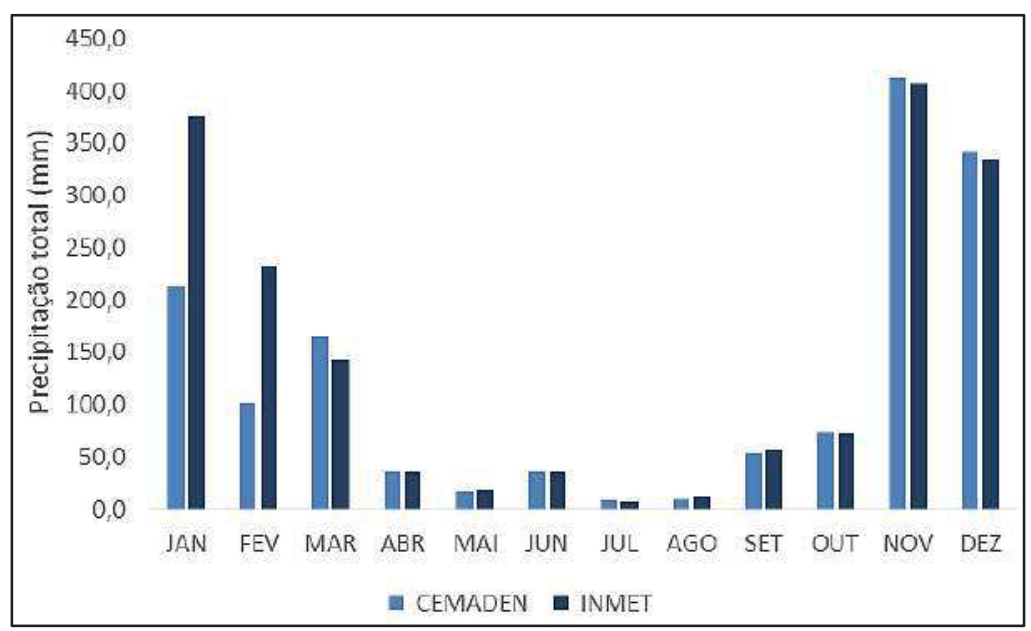

Fonte: Organizado pelo autor.

Com isso, pode-se constatar que os dados CEMADEN, por vezes podem apresentar erros em função de operarem com uma leitura remota, e qualquer obstrução na área de captação compromete a leitura dos dados naquele período entre as visitas de manutenção. Ainda assim, conforme figura 39, os dados ainda apresentam uma boa relação, quando observados os totais diários, com um coeficiente de determinação de $\mathrm{r}^{2}=0,9796$. 
Figura 39: Correlação entre os dados observados nos pluviômetros do CEMADEN x INMET

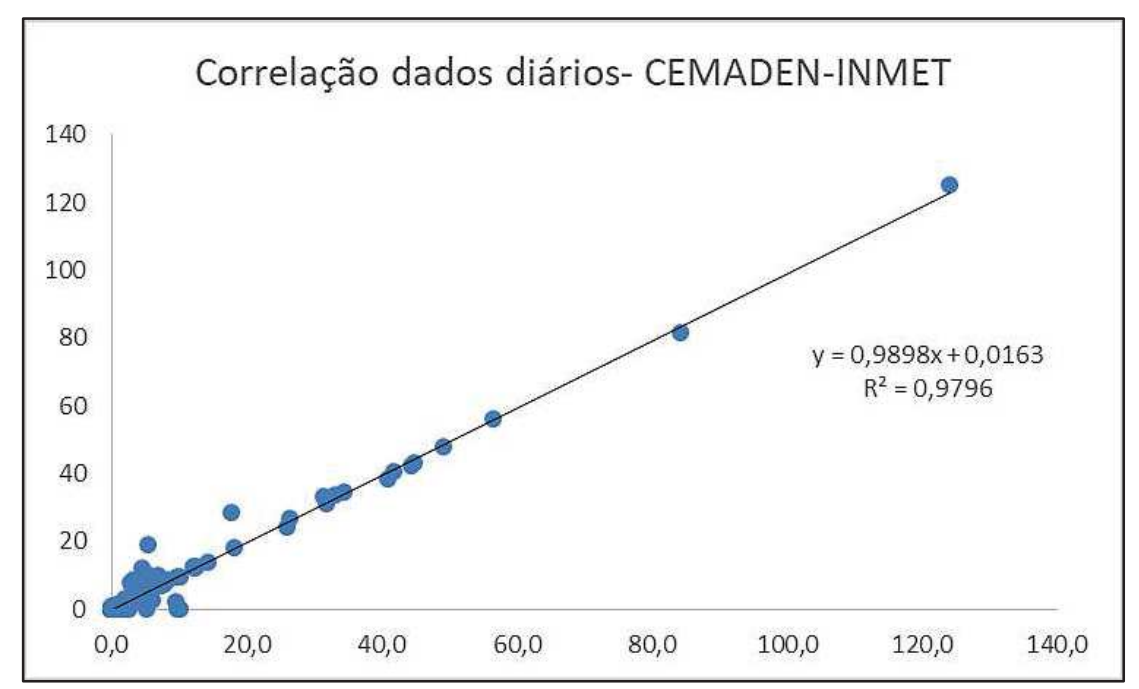

Fonte: Organizado pelo autor.

Comparando os dados CEMADEN, INMET e CHIRPS é possível visualizar que nos totais mensais os dados CHIRPS apresentam uma boa correspondência com os dados observados, Figura 40, fato também destacado por Silva et al (2019). No entanto o mês de março foi o único que apresentou um maior afastamento entre os conjuntos de dados, com uma diferença de 149,7 mm com os dados do CEMADEN e 171,3mm com os dados INMET.

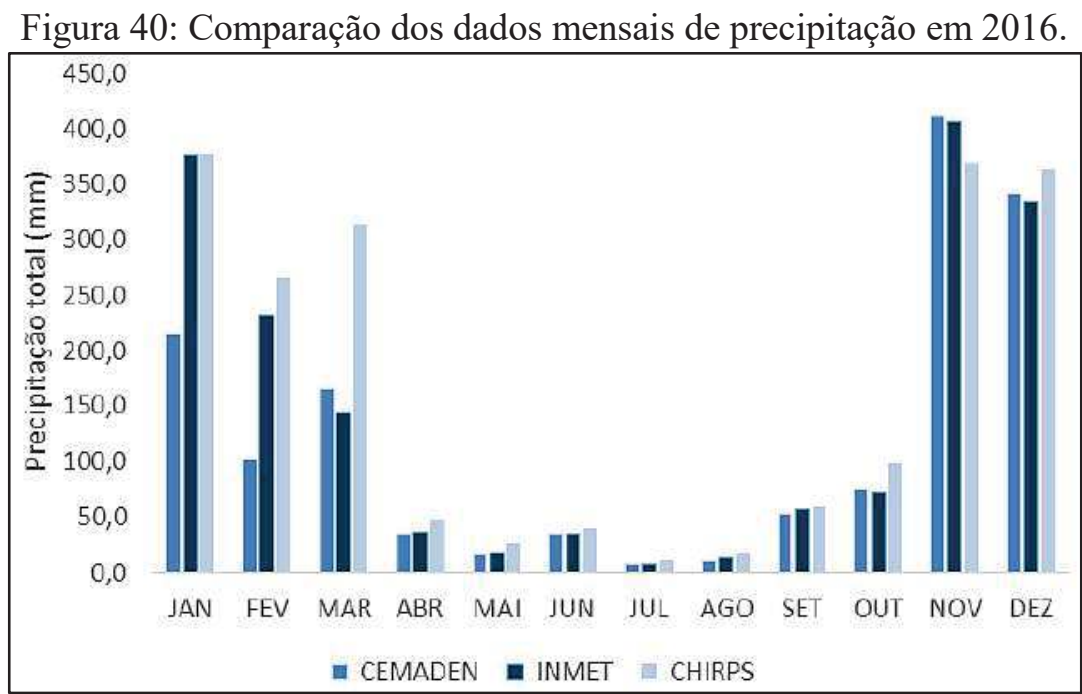

Fonte: Organizado pelos autores.

A correlação entre os dados CHIRPS e CEMADEN no posto Cidade Universitária será discutido adiante, de maneira conjunta aos outros pontos utilizados para esta correlação, distribuídos pela cidade. 


\section{A correlação entre os dados diários e agrupados em pêntadas}

A correlação dos dados diários, quadro 20, demonstra que estes apresentam uma correlação fraca a moderada com os dados do CEMADEN na área urbana de Juiz de Fora. Os dados do coeficiente de correlação de Pearson foram maiores no ponto do Distrito Industrial com um $\mathrm{r}$ de 0,64 , com uma correlação moderada.

Enquanto que uma correlação fraca foi observada no ponto do Santa Efigênia com $r$ de 0,45 . Os valores de $r$ quando no intervalo de 0,5 a 0,7 correspondem a uma correlação moderada, enquanto que no intervalo de 0,3 a menos que 0,5 são considerados como uma correlação fraca (MUKAKA, 2012).

Quadro 20: Correlação dos dados diários CEMADEN- CHIRPS

\begin{tabular}{|c|c|c|}
\hline \multicolumn{2}{|c|}{ Correlação de dados diários- CEMADEN-CHIRPS- 2016 } \\
\hline Estação & $\begin{array}{c}\text { Coeficiente de determinação } \\
\left(\mathrm{r}^{2}\right)\end{array}$ & $\begin{array}{c}\text { Coeficiente de correlação } \\
(\mathrm{r})\end{array}$ \\
\hline Distrito Industrial & 0,3952 & 0,6497 \\
\hline Bairro de Lourdes & 0,2704 & 0,52 \\
\hline Milho Branco & 0,3924 & 0,6264 \\
\hline Nova Era & 0,3801 & 0,62 \\
\hline Santa Efigênia & 0,2113 & 0,458 \\
\hline Ponte Preta & 0,3492 & 0,5909 \\
\hline Cidade Universitária & 0,2194 & 0,468 \\
\hline
\end{tabular}

Fonte: Organizado pelo autor.

Os dados agrupados em pêntadas, quadro 21, demonstraram melhor correlação entre os observados e os CHIRPS, atingindo uma correlação forte em todos os pontos de coleta analisados, com base em Mukaka (2012) os valores de $r$ entre 0,7 e 0,9 correspondem a uma correlação forte. Sendo que os pontos do Milho Branco e Nova Era obtiveram os melhores resultados com coeficiente de correlação (r) de 0,88 e os pontos Ponte Preta e Cidade Universitária apresentam uma correlação de 0,8 .

Quadro 21: Correlação de dados agrupados em pêntadas: CEMADEN-CHIRPS

\begin{tabular}{|c|c|c|}
\hline \multicolumn{2}{|c|}{ Correlação de dados em pêntadas- CEMADEN-CHIRPS- 2016 } \\
\hline Estação & $\begin{array}{c}\text { Coeficiente de determinação } \\
\left(\mathrm{r}^{2}\right)\end{array}$ & $\begin{array}{c}\text { Coeficiente de correlação } \\
(\mathrm{r})\end{array}$ \\
\hline Distrito Industrial & 0,7325 & 0,856 \\
\hline Bairro de Lourdes & 0,7669 & 0,8757 \\
\hline Milho Branco & 0,7804 & 0,8834 \\
\hline Nova Era & 0,7838 & 0,8853 \\
\hline Santa Efigênia & 0,7237 & 0,851 \\
\hline Ponte Preta & 0,6462 & 0,8039 \\
\hline
\end{tabular}




\begin{tabular}{|l|c|c|}
\hline Cidade Universitária & 0,648 & 0,805 \\
\hline
\end{tabular}

$$
\text { Fonte: Organizado pelo autor. }
$$

Silva et al (2019) avaliaram os dados obtidos por sistemas orbitais (TRMM, GPCP e CHIRPS) e sua representatividade para os dados observados em estações automáticas, apontaram que, para sua utilização na escala diária, é necessário um critério maior, devido a uma correlação mais baixa, contudo na escala das pêntadas a correlação é melhor (Quadros 20 e 21 e figura 41 ).

Figura 41: Correlação linear entre os dados diários e agrupados em pêntadas: CEMADEN x CHIRPS

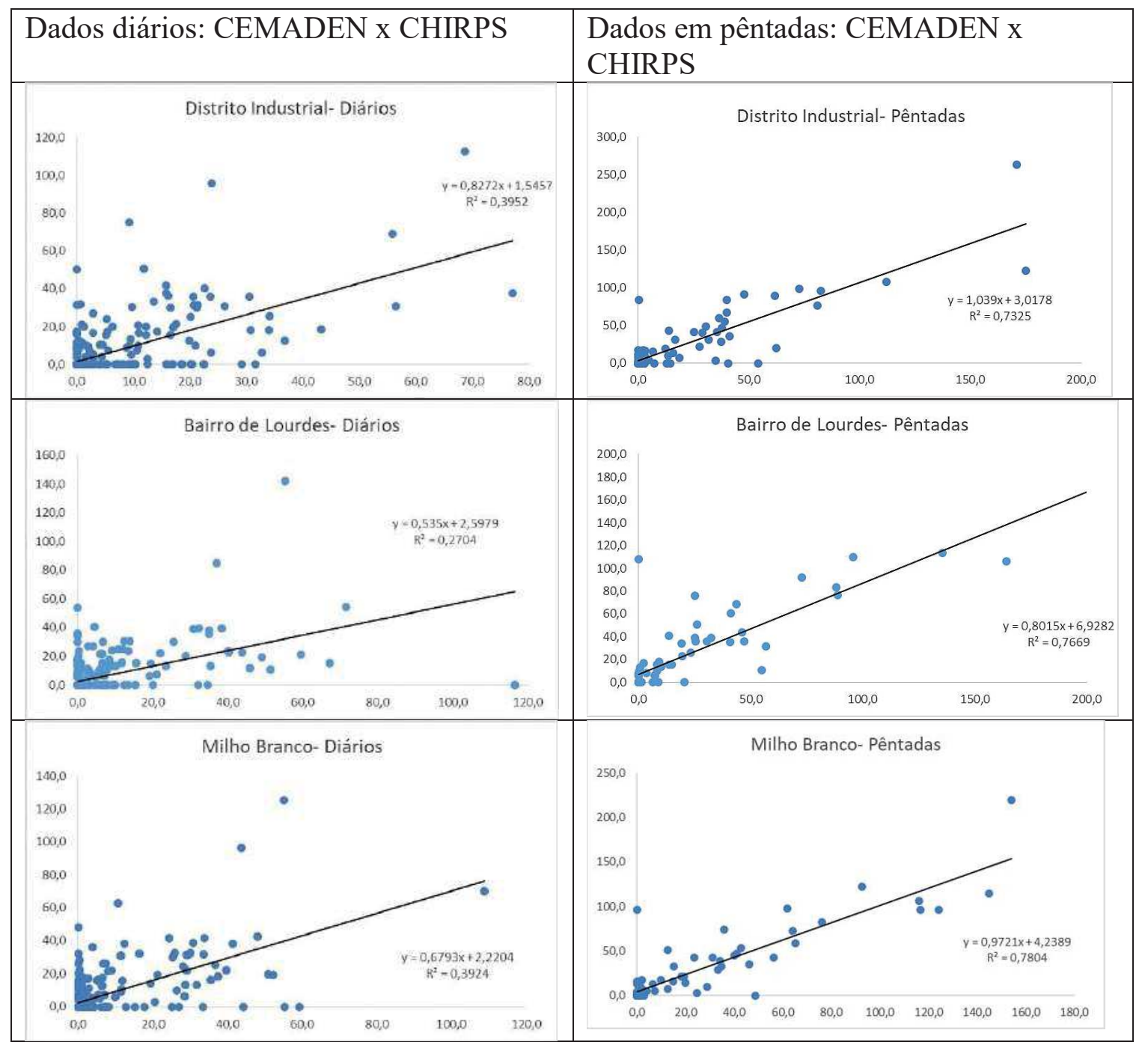




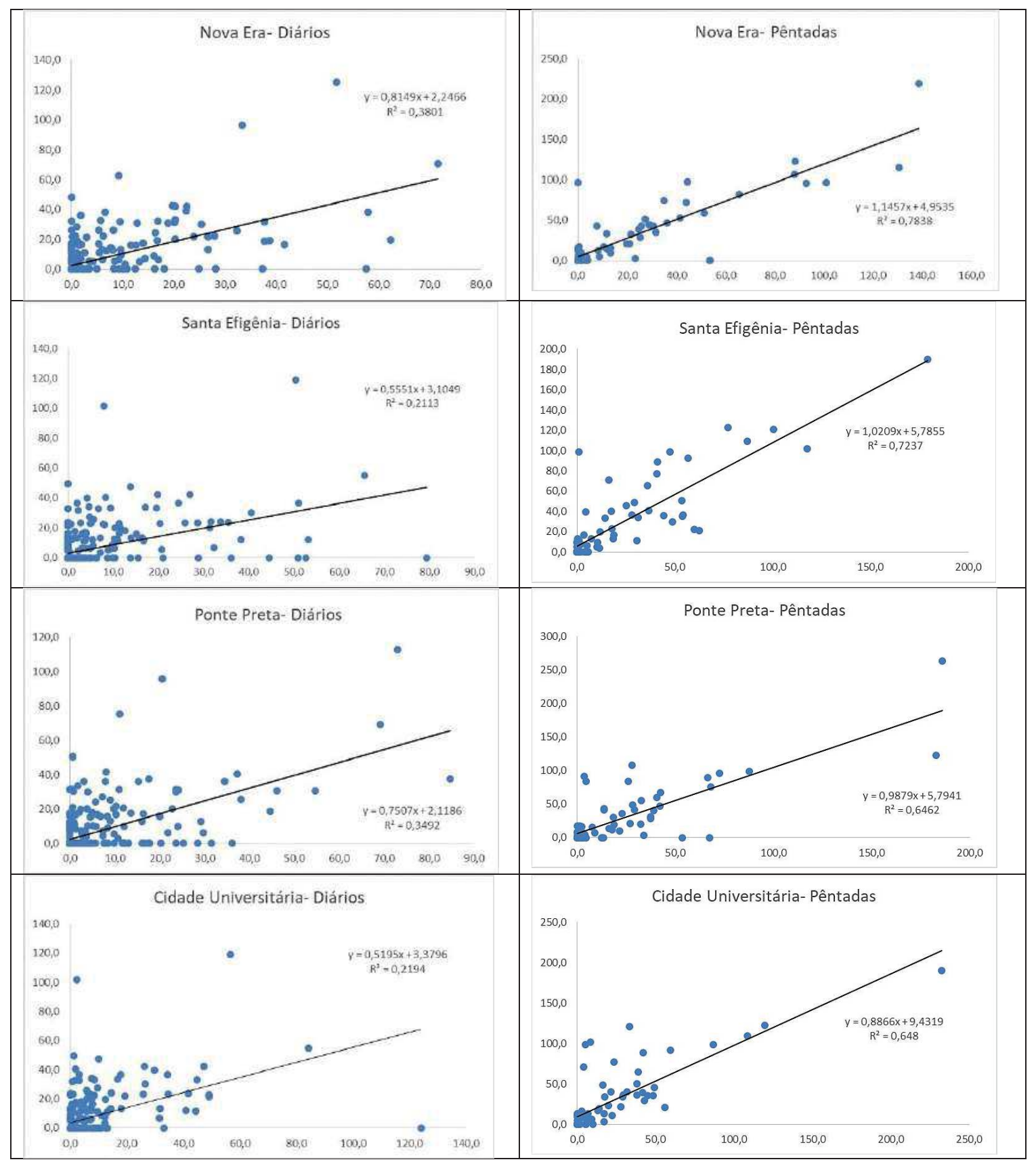

Fonte: Organizado pelo autor.

Observou-se nos pontos analisados uma correlação fraca a moderada com os dados diários de precipitação, enquanto que nos dados agrupados em pêntadas a correlação foi forte nos postos pluviométricos selecionados. Dessa forma, considera-se que os dados agrupados em pêntadas representam melhor dados observados. 


\section{As Chuvas em Juiz De Fora: Da Variabilidade Mensal Aos Eventos Extremos}

\section{A variabilidade mensal dos dados de precipitação}

A variabilidade mensal dos dados precipitação foi calculada para os dados de 19102018, estabelecendo-se o recorte para o período de 1980-2018, período de estudo do presente trabalho. Os dados serão mostrados em detalhe para o período da estação chuvosa, uma vez que os impactos decorrentes dos eventos pluviométricos extremos foram computados apenas no período de Outubro a Março, em função das limitações impostas pela pandemia do Coronavírus.

No período de 1980-2018 foi possível notar uma recorrência de meses habituais e chuvosos, se comparados aos meses secos. Principalmente os meses de Novembro, Dezembro e Janeiro que em média contribuíram com maior volume pluviométrico na cidade e apresentaram uma menor frequência de meses secos nesse período, 4, 9 e 7, respectivamente. Enquanto que os chuvosos ocorreram 10, 15 e 10 vezes, respectivamente, no período de 1980 e 2018 (Figura 42).

Figura 42: Frequência de ocorrência de meses secos, chuvosos e habituais nos meses da estação chuvosa.

\begin{tabular}{|c|c|c|c|c|c|c|}
\hline \multicolumn{7}{|c|}{40} \\
\hline 35 & & & & & & \\
\hline 30 & & & & & & \\
\hline 25 & & & & & & \\
\hline 20 & & & & & & \\
\hline 15 & & & & & & \\
\hline \multicolumn{7}{|l|}{10} \\
\hline \multicolumn{7}{|l|}{5} \\
\hline \multicolumn{7}{|l|}{0} \\
\hline JAN & FEV & MAR & $\mathrm{OU}$ & & Nov & DEZ \\
\hline = Super-Seco & Seco & -Normal/H & vitual = & Chuvoso & - Super- $\mathrm{Cl}$ & \\
\hline & JAN & FEV & MAR & OUT & NOV & $\overline{\mathrm{DEZ}}$ \\
\hline Super-Chuvoso & 1 & 0 & 0 & 0 & 2 & 2 \\
\hline Chuvoso & 9 & 6 & 12 & 6 & 8 & 13 \\
\hline Normal/Habitual & 22 & 20 & 19 & 22 & 25 & 15 \\
\hline Seco & 7 & 12 & 8 & 10 & 4 & 8 \\
\hline Super-Seco & 0 & 1 & 0 & 1 & 0 & 1 \\
\hline
\end{tabular}

Fonte: Organizado pelo autor.

Quadro 22: Classificação dos dados de precipitação a partir da técnica do box plot 


\begin{tabular}{|c|c|c|c|c|c|c|c|c|c|c|c|c|c|}
\hline & JANEIRO & FEVEREIRO & MARÇO & ABRIL & MAIO & JUNHO & \begin{tabular}{|l|} 
JULHO \\
\end{tabular} & AGOSTO & SETEMBRO & OUTUBRO & NOVEMBRO & DEZEMBRO & TOTAL ANUAL \\
\hline 1980 & 321,9 & 107,7 & 106,5 & 123 & 14,2 & 38 & 0 & 34 & 23,8 & 73,3 & 108,2 & 310,3 & 1260,9 \\
\hline 1981 & 237,1 & 77,3 & 257,6 & 51,5 & 11 & 21,8 & 0,1 & 26,4 & 38,2 & 126,5 & 267,1 & 207,2 & 1321,8 \\
\hline 1982 & 334,6 & 189,3 & 349 & 55,7 & 7,3 & 23,2 & 36,6 & 32,4 & 12,3 & 182,9 & 129,2 & 424,8 & 1777,3 \\
\hline 1983 & 328,9 & 245,3 & 220,1 & 150,1 & 113,9 & 148,9 & 46,1 & 3,8 & 348,4 & 100,6 & 189,2 & 370,2 & 2265,5 \\
\hline 1984 & 229,2 & 22,1 & 239,7 & 183 & 68,8 & 2,9 & 4,4 & 34,9 & 120 & 93 & 133,7 & 324,3 & 1456,0 \\
\hline 1985 & 715 & 286,6 & 261,7 & 74 & 30,8 & 19 & 1,4 & 9 & 93,4 & 157,4 & 222,5 & 231,8 & 2102,6 \\
\hline 1986 & 194,7 & 248,5 & 274,1 & 59,9 & 45,3 & 0,5 & 58,8 & 77,2 & 19,2 & 20,1 & 210,7 & 358,1 & 1567,1 \\
\hline 1987 & 287,6 & 107,7 & 163,2 & 168,4 & 43,1 & 15,8 & 17,2 & 7,6 & 84,2 & 138,2 & 152,1 & 324 & 1509,1 \\
\hline 1988 & 261,1 & 403,1 & 127,5 & 47 & 44,4 & 6,5 & 0,5 & 0,2 & 33,5 & 123,7 & 178,9 & 225,7 & 1452,1 \\
\hline 1989 & 170,3 & 260,1 & 146,8 & 85,4 & 19,8 & 40,1 & 24,9 & 6,8 & 70,1 & 113,8 & 135,3 & 207,7 & 1281,1 \\
\hline 1990 & 97,7 & 192,1 & 155,9 & 40 & 55,1 & 0,7 & 15,2 & 17,6 & 86,4 & 62,5 & 159,2 & 197,1 & 1079,5 \\
\hline 1991 & 407,7 & 178,1 & 240,8 & 92,5 & 44,6 & 17,9 & 9,1 & 4,9 & 76,5 & 68,7 & 154,6 & 284,1 & 1579,5 \\
\hline 1992 & 445,9 & 171,8 & 67,3 & 62,9 & 21,1 & 3,2 & 15,8 & 41,3 & 160,7 & 188,6 & 422,2 & 193,2 & 1794,0 \\
\hline 1993 & 402,5 & 131,1 & 108,7 & 75,8 & 9,4 & 20,7 & 1,8 & 2,9 & 47 & 90,7 & 178,1 & 152,5 & 1221,2 \\
\hline 1994 & 398,9 & 33,1 & 293,3 & 191,3 & 180,2 & 20,2 & 3,1 & 4,2 & 4,5 & 138,8 & 159,6 & 295,3 & 1722,5 \\
\hline 1995 & 211,8 & 324 & 134,8 & 75,5 & 23 & 9,5 & 15,7 & 0,4 & 69,6 & 205,2 & 194,9 & 332,2 & 1596,6 \\
\hline 1996 & 198,4 & 332 & 171,7 & 43,5 & 36,9 & 1,5 & 0 & 19,3 & 129,1 & 125,2 & 209,5 & 298,9 & 1566,0 \\
\hline 1997 & 330 & 32,2 & 184,7 & 52,8 & 16,4 & 28,6 & 5,6 & 11,1 & 61,6 & 128,9 & 175,7 & 184,2 & 1211,8 \\
\hline 1998 & 194,2 & 143,3 & 115,2 & 82,8 & 83,8 & 4 & 7 & 54,2 & 21,1 & 179,1 & 189,7 & 199,6 & 1274,0 \\
\hline 1999 & 335,3 & 113,6 & 220,6 & 57,8 & 4 & 21 & 20,1 & 9,9 & 34,8 & 61,8 & 172,3 & 304,9 & 1356,1 \\
\hline 2000 & 340,7 & 102,2 & 166,3 & 23,5 & 8,1 & 0 & 9,5 & 57,2 & 152,7 & 154,3 & 171 & 265,7 & 1451,2 \\
\hline 2001 & 120,5 & 234,3 & 317,2 & 3,8 & 46,2 & 2 & 1 & 13,8 & 31,6 & 134,1 & 318 & 342,7 & 1565,2 \\
\hline 2002 & 236,5 & 196,6 & 104,2 & 31,7 & 36,3 & 0 & 5,6 & 17,3 & 79,8 & 131,5 & 156,7 & 448,4 & 1444,6 \\
\hline 2003 & 477,2 & 82,6 & 340,8 & 73,7 & 48 & 1,6 & 33,6 & 51,3 & 43,7 & 165,5 & 274,8 & 299,5 & 1892,3 \\
\hline 2004 & 358,7 & 388,9 & 233,4 & 114,5 & 60,2 & 25,4 & 47,8 & 2 & 1,3 & 156,3 & 254,6 & 469,3 & 2112,4 \\
\hline 2005 & 362,6 & 151,6 & 184,4 & 86,4 & 51,2 & 17,4 & 32,1 & 27,8 & 57,7 & 64,2 & 185,1 & 355,2 & 1575,7 \\
\hline 2006 & 181,4 & 211,4 & 140,4 & 17,8 & 37,8 & 7,8 & 12,5 & 35 & 72,2 & 267,1 & 309,9 & 224,5 & 1517,8 \\
\hline 2007 & 584,1 & 37 & 159,2 & 50 & 36,5 & 5,6 & 5,8 & 0,8 & 6,4 & 111,7 & 176,4 & 284,2 & 1457,7 \\
\hline 2008 & 304,3 & 320,8 & 326,6 & 128,2 & 4 & 32,6 & 0 & 4,8 & 64,7 & 266,1 & 235,1 & 498,5 & 2185,7 \\
\hline 2009 & 177,3 & 261,3 & 267,6 & 46,5 & 15,8 & 24,1 & 26,6 & 5,1 & 55,7 & 114,2 & 283,5 & 508,8 & 1786,5 \\
\hline 2010 & 229,4 & 83,3 & 330,9 & 106,3 & 44,2 & 0 & 22,2 & 0,4 & 51,4 & 121 & 263,3 & 479,3 & 1731,7 \\
\hline 2011 & 328,3 & 101,4 & 311,2 & 149,7 & 13,9 & 17,5 & 5,2 & 9,3 & 13,7 & 125,6 & 292,7 & 346,5 & 1715,0 \\
\hline 2012 & 275 & 134,4 & 92,6 & 98 & 87 & 60,8 & 7,4 & 7 & 72,7 & 46,8 & 272,8 & 209,2 & 1363,7 \\
\hline 2013 & 291,7 & 71,6 & 372,5 & 57,9 & 56,5 & 27,7 & 69,9 & 11,4 & 58 & 61,9 & 182,9 & 475,4 & 1737,4 \\
\hline 2014 & 130,5 & 60,2 & 96,8 & 128,4 & 11,1 & 33,5 & 30,1 & 11,6 & 16,5 & 51,5 & 187,1 & 173,1 & 930,4 \\
\hline 2015 & 140,4 & 99,9 & 167,1 & 39,7 & 49,6 & 32,2 & 23,8 & 24,8 & 124 & 62,5 & 241,3 & 275,7 & 1281,0 \\
\hline 2016 & 375,8 & 232,7 & 143,6 & 35,8 & 17,9 & 35,2 & 7,3 & 13,2 & 57,2 & 72,3 & 406,5 & 334,4 & 1731,9 \\
\hline 2017 & 185,4 & 54,1 & 93,8 & 80,7 & 95,3 & 11,9 & 6,2 & 14,4 & 7,7 & 98,1 & 208,8 & 90,5 & 946,9 \\
\hline 2018 & 254,1 & 266,6 & 244,7 & 105,2 & 14,9 & 19,2 & 13,5 & 65,4 & 76,7 & 84,7 & 238,7 & 380,6 & 1764,3 \\
\hline
\end{tabular}


Quadro 23: Legenda da classificação dos dados a partir do box plot.

\begin{tabular}{|c|c|}
\hline \multicolumn{2}{|c|}{ Legenda } \\
\hline Cor & Classe \\
\hline & Super-Chuvoso \\
\hline & Chuvoso \\
\hline & Habitual \\
\hline & Seco \\
\hline & Super- Seco \\
\hline
\end{tabular}

Fonte: Organizado pelo autor.

A partir dos dados do quadro 22 verifica-se a variabilidade dos totais mensais e anual de precipitação. Nos totais anuais verifica-se que no período de 1980-2018 ocorreram quatorze anos chuvosos, sendo dois super-chuvosos (1983 e 2008), dezessete anos normais-habituais e oito anos secos, sendo um super-seco em 2014. Sendo assim, 36\% dos anos foram chuvosos, $44 \%$ normais/habituais e $20 \%$ secos.

O mês de Janeiro, conforme quadro 22, apresentou vinte e dois meses habituais, sete secos, nove chuvosos e um super chuvoso. O mês super-chuvoso foi registrado em 1985, com $715 \mathrm{~mm}$ nos 31 dias, sendo este o maior total mensal de todos os meses ao longo de toda a série histórica.

O mês de Fevereiro observou vinte vezes habituais, treze vezes seco e seis chuvosos, sendo uma vez super-seco no ano de 1984. O mês de fevereiro não apresentou nenhum episódio super-chuvoso, no entanto manifestou o dobro de vezes seco, se comparado aos chuvosos e uma vez super-seco (Quadro 22).

No mês de Março foram observados dezenove meses habituais, doze chuvosos e oito secos, sendo que nenhum dos meses atingiu a condição de extremo, seco ou chuvoso. No mês de Outubro ocorreram vinte e dois anos habituais, onze secos e seis chuvosos, sendo apenas um super-seco em 1986 (Quadro 22).

No mês de Novembro vinte e cinco ocorrências foram habituais, dez chuvosos e apenas quatro secos, sendo que ocorreram meses super chuvosos em 1992 e 2016 . O mês de Novembro tem apresentado tendência significativa de elevação dos totais pluviométricos, de acordo com Oliveira et al (2018). O último Novembro considerado seco foi em 1989, desde então todos os anos tiveram o Novembro dentro da habitualidade ou chuvoso (Quadro 22).

O mês de Dezembro, dentre os meses da estação chuvosa, é o que menos possui ocorrência de meses habituais, com quinze dos trinta e nove anos. Além disso, outros quinze foram chuvosos e nove secos, sendo dois super chuvosos, em 2008 e 2009, e um super seco em 
2017 (Quadro 22). Assim como o Novembro apresentou tendência de elevação, no entanto com menos intensidade que Novembro, de acordo com Oliveira et al (2018).

De acordo com Oliveira et al (2020) em testes comparativos com as informações do fenômeno ENOS, segundo os autores não é possível estabelecer relações entre a variabilidade pluviométrica e a ocorrência de eventos El Niño/La Niña. Alguns anos foram identificadas relações entre a ocorrência de El-Niños fortes e totais pluviométricos acima da habitualidade, como 1983 e 2016, no entanto em outros casos, como 1997-98, a relação não foi observada.

Oliveira e Ely (2018) avaliaram a correlação entre os dados pluviométricos e os índices do fenômeno ENOS nas regiões 1+2 e 3.4, para a bacia do rio Preto, e destacaram uma variabilidade espacial das correlações dentro da bacia, na qual Juiz de Fora se inscreve. Destacaram ainda que o fator orográfico regional poderia acentuar a influência do ENOS em alguns setores da bacia e em outros atenuar possíveis reflexos na variabilidade pluviométrica.

Segundo Oliveira e Ely (2019), estudando as relações entre as TSM (Temperatura da superfície do mar) no atlântico Norte e Sul, as autoras observaram que anomalias positivas de TSM no atlântico sul responderam com correlação positiva aos anos mais chuvosos, enquanto que nos anos secos a correlação foi negativa com as anomalias de TSM, na bacia do rio Preto, ainda assim as autoras argumentam que

Por meio das análises apresentadas constata-se que os índices de teleconexões têm um papel secundário na gênese da variabilidade das chuvas na bacia, pois em escala local é o relevo que promove a intensificação, a restrição e o direcionamento dos sistemas atmosféricos (OLIVEIRA e ELY, 2019, p. 11).

Com isso, é possível destacar que muitos fatores podem influenciar na variabilidade pluviométrica na região e, consequentemente, em Juiz de Fora. Sejam fenômenos de larga escala, como o fenômeno ENOS e os outros modos de variabilidade, até os fatores geográficos, como o relevo, que interagem com os sistemas atmosféricos e influenciam para a ocorrência da variabilidade pluviométrica.

\section{Os dados diários de precipitação: Variabilidades e Tendências}

Iniciando uma investigação a partir dos dados pluviométricos diários na cidade de Juiz de Fora-MG, no período de 1980-2018, observa-se que existe uma leve tendência de redução para o número de dias de chuva ao longo do ano, sendo que habitualmente este valor encontrase entre 100 e 120 dias de chuva (Figura 43). 
Entendeu-se dia de chuva os que apresentavam total pluviométrico igual ou maior que 1mm, além disso os anos de 1991,1992 e 1998 foram desconsiderados em função de falhas dos dados de precipitação que ultrapassaram sessenta dias no ano (Figura 43).

Figura 43: Frequência do número de dias de chuva no período de 1980-2018

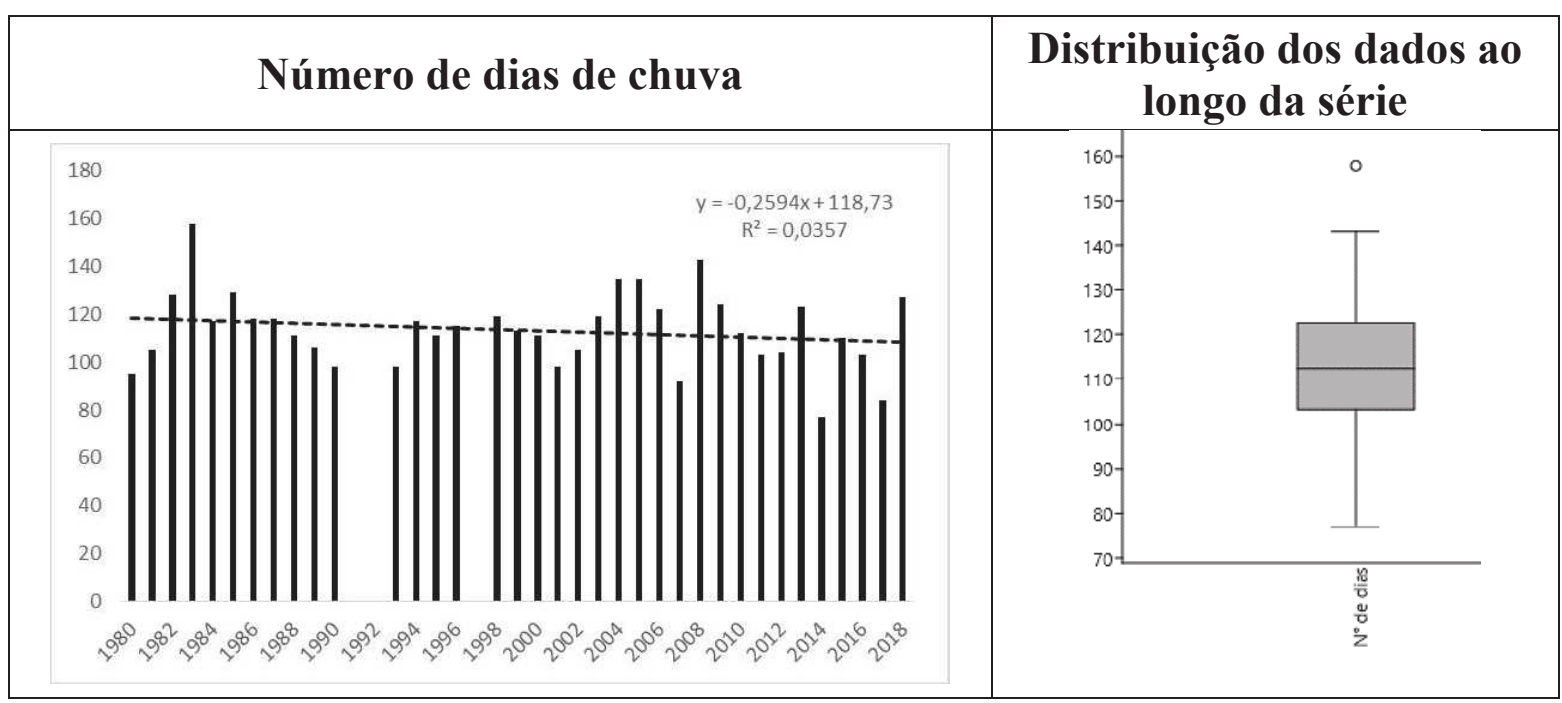

Fonte: Organizado pelo autor.

O número de dias de chuva mensal expressa a variabilidade anual da ocorrência de precipitação na cidade, na média os meses de Outubro a Março apresentaram uma média igual ou superior a 10 dias de chuva, enquanto que nos meses da estação seca o valor foi inferior, sobretudo nos meses de junho a agosto em que a média é inferior a 5 dias de chuva na cidade (Figura 43).

Ao longo da série histórica é comum que haja uma variabilidade nesse número de dias com chuva, sendo que em alguns casos o valor ultrapasse os vinte dias com precipitação, nos meses de dezembro, janeiro, fevereiro e março, e no mês de setembro essa condição foi excepcional (Figura 44).

Figura 44: Frequência média do número de dias de chuva mensal no período de 1980-2018 


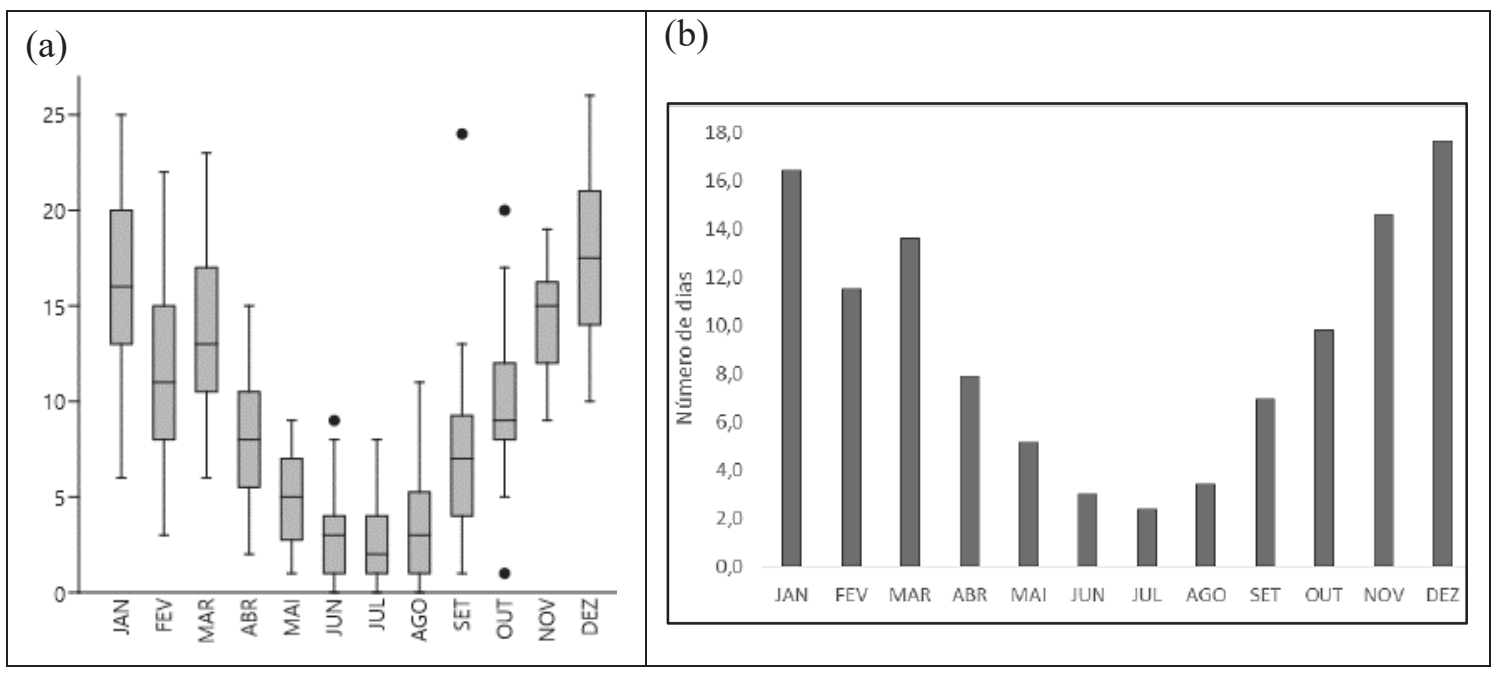

Fonte: Organizado pelo autor

Conforme já colocado, a precipitação em Juiz de Fora se concentra em mais de $80 \%$ dos totais anuais nos meses de outubro a março, no entanto os meses que apresentam, em média, o maior número de dias com chuva são Novembro, Dezembro e Janeiro, concentrando 48\% dos dias com chuva no ano.

\section{Os totais diários de precipitação: a técnica dos percentis}

A técnica dos percentis, utilizada de maneira central no presente trabalho permitiu visualizar os dados a partir de intervalos de classe, dessa forma foram contabilizados a frequência anual de eventos em função dos dados totais diários, com isso foram estabelecidos sete intervalos de intensidade, conforme o quadro 24.

Quadro 24: Classes do percentil para os dados diários de precipitação.

\begin{tabular}{|c|c|c|}
\hline Percentil & Classe & Intervalo \\
\hline P15 & $2 \mathrm{~mm}$ & $2-4,6 \mathrm{~mm}$ \\
\hline P35 & $4,7 \mathrm{~mm}$ & $4,7-13,1 \mathrm{~mm}$ \\
\hline P65 & $13,2 \mathrm{~mm}$ & $13,2-26,6 \mathrm{~mm}$ \\
\hline P85 & $26,7 \mathrm{~mm}$ & $26,7-33 \mathrm{~mm}$ \\
\hline P90 & $33,1 \mathrm{~mm}$ & $33,1-45,5 \mathrm{~mm}$ \\
\hline P95 & $45,6 \mathrm{~mm}$ & $45,6-73,4 \mathrm{~mm}$ \\
\hline P99 & $73,5 \mathrm{~mm}$ & $>73,5 \mathrm{~mm}$ \\
\hline
\end{tabular}

Fonte: Organizado pelo autor

Os eventos referentes ao intervalo do percentil 15, 35, 65 apresentaram uma tendência de redução, sendo que os percentis 15 e 35 tiveram a maior redução, com 7,7 e 4,3 eventos a menos, ao longo do período. O percentil 85 teve uma leve tendência de aumento na frequência ao longo da série, com uma elevação de 0,4 eventos (Quadros 25 e Figura 44). 
Passando para os totais diários de maior intensidade, os percentis 90, 95 e 99, sendo que estes possuem uma maior capacidade de deflagrarem impactos na cidade. Os percentis 90 e 95 apresentaram uma tendência de aumento na sua frequência ao longo da série, com uma variação de 1,4 e 0,2, respectivamente, eventos a mais no período. Enquanto que o percentil 99 apresentaram tendência de redução, a um nível de 0,1 evento (Quadros 25 e Figura 45).

A avaliação a partir do teste de Mann-Kendall revelou que o score z para os dados foram muito baixos, o que significa pouca consistência estatística para as alterações nos conjuntos de dados (Quadro 25). Dessa forma as alterações demonstradas não possuem uma significância estatística.

Quadro 25: Síntese dos dados da avaliação de tendência dos dados diários de precipitação.

\begin{tabular}{|c|c|c|c|c|c|}
\hline Intervalo & Tendência & Equação da reta & $\mathrm{R}^{2}$ & $\begin{array}{c}\text { Variação } \\
\text { em } \\
\text { função } \\
\text { da reta }\end{array}$ & $\mathrm{MK}$ \\
\hline P15 & - & $-0,202 \mathrm{x}+98,682$ & 0,0187 & $-7,7$ & 0,73 \\
\hline P35 & - & $-0,1121 \mathrm{x}+74,32$ & 0,0091 & $-4,3$ & 0,30 \\
\hline P65 & - & $-0,004 \mathrm{x}+39,184$ & $3 \mathrm{E}-05$ & $-0,2$ & 0,36 \\
\hline P85 & + & $0,0101 \mathrm{x}+16,464$ & 0,0004 & 0,4 & 0,07 \\
\hline P90 & + & $0,0375 \mathrm{x}+10,347$ & 0,0074 & 1,4 & 0,63 \\
\hline P95 & + & $0,0043 \mathrm{x}+5,4791$ & 0,0003 & 0,2 & 0,01 \\
\hline P99 & - & $-0,0038 \mathrm{x}+1,2051$ & 0,0015 & $-0,1$ & 0,25 \\
\hline
\end{tabular}

Fonte: Organizado pelo autor.

Figura 45: Frequência anual de dias de chuva a partir dos percentis 15, 35, 65, 85, 95, 99.

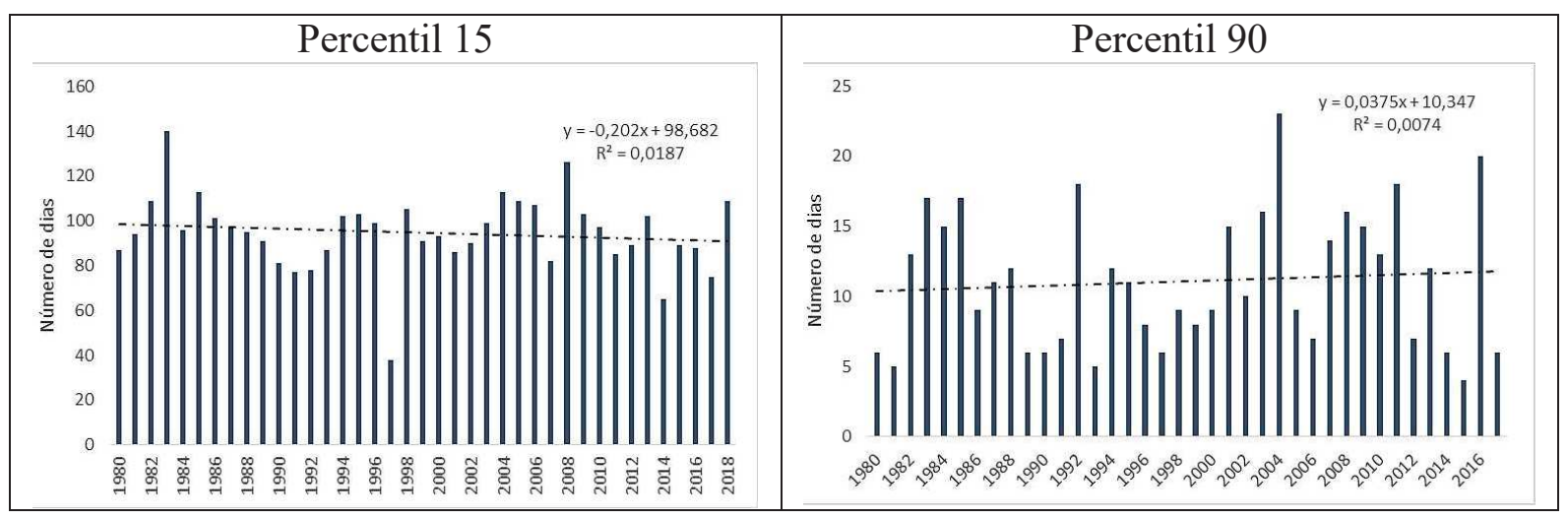




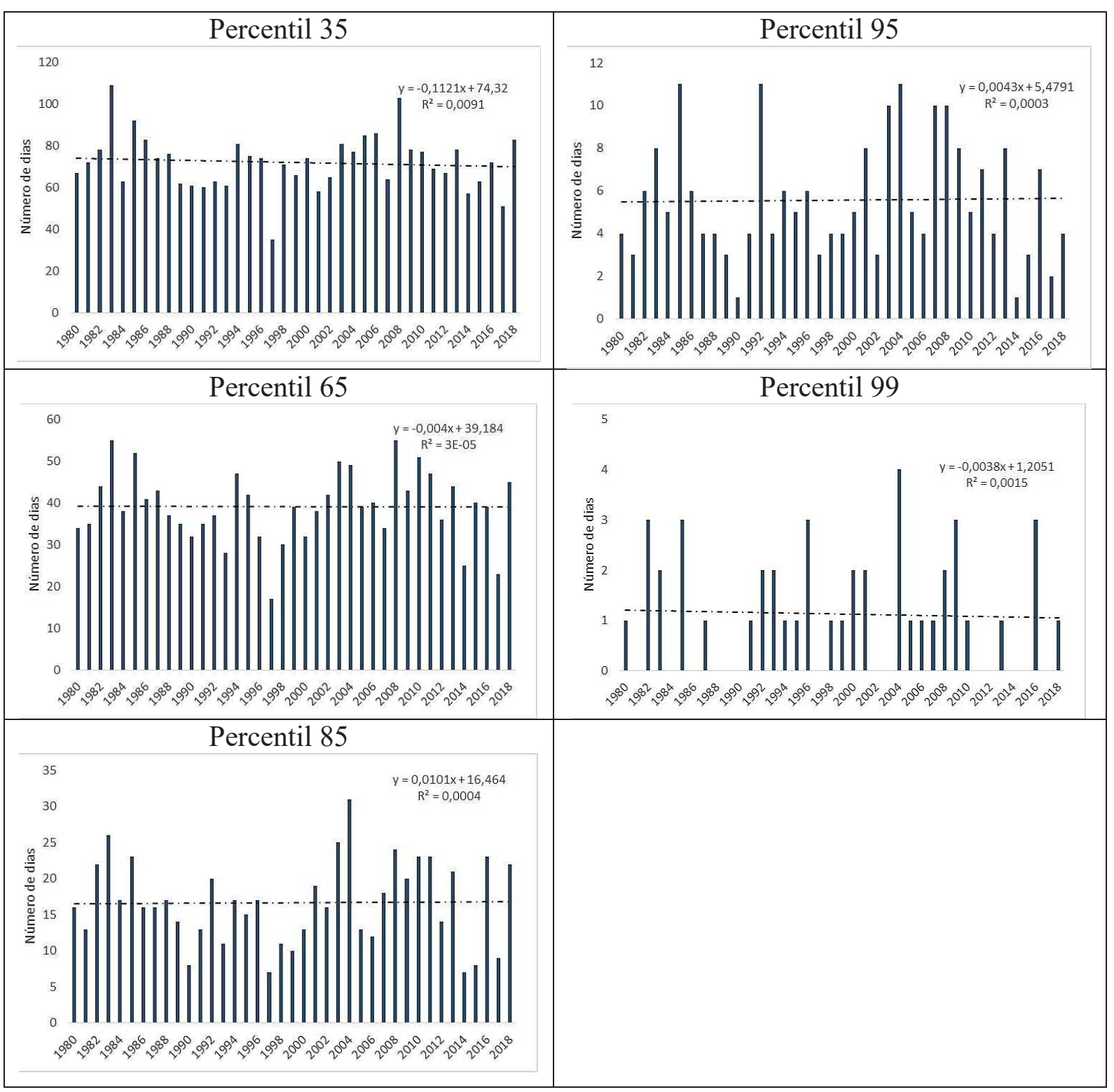

Fonte: Organizado pelo autor.

O cálculo da frequência e do tempo de retorno, quadro 26, para as classes do percentil indica que todas as classes ocorrem pelo menos uma vez por ano, inclusive os eventos superiores ao percentil 99. Dessa forma, apesar de estatisticamente apresentarem como excepcionalidades, é estatisticamente comum que em todos os anos haja um evento que alcance ou ultrapasse o valor de 73,4mm (Percentil 99), sobretudo nas estações chuvosas, visto que o tempo de retorno foi de 10 meses para esses eventos. 
Quadro 26: Frequência e tempo de retorno para as classes do percentil diários.

\begin{tabular}{|c|c|c|c|c|}
\hline \multicolumn{5}{|c|}{ Cálculo da Frequência e Tempo de Retorno } \\
\hline Intervalo (mm) & Frequência & Frequência relativa (\%) & Tempo de retorno (anos) & Tempo de retorno (Meses/dias) \\
\hline $1-2 \mathrm{~mm}$ & 623,0 & 0,0 & 0,1 & $0,7(22$ dias) \\
\hline $2-4,6 \mathrm{~mm}$ & 880,0 & 0,1 & 0,0 & $0,5(16$ dias) \\
\hline $4,7-13,2 \mathrm{~mm}$ & 1302,0 & 0,1 & 0,0 & $0,3(11$ dias) \\
\hline $13,3-26,6 \mathrm{~mm}$ & 859,0 & 0,1 & 0,0 & $0,5(16$ dias) \\
\hline $26,7-33$ & 214,0 & 0,0 & 0,2 & $2,16(65$ dias $)$ \\
\hline $33,1-45,6$ & 223,0 & 0,0 & 0,2 & $2,07(62$ dias $)$ \\
\hline $45,7-73,4$ & 169,0 & 0,0 & 0,2 & $2,73(82$ dias $)$ \\
\hline$>73,4$ & 44,0 & 0,0 & 0,9 & $10,5(315$ dias $)$ \\
\hline
\end{tabular}

Fonte: Organizado pelo autor.

Na figura 46 estão plotados na forma de box plot os maiores totais pluviométricos diários para cada mês, ao longo da série. Cabe destacar que nos meses Novembro, Dezembro e Janeiro, em $25 \%$ da série, os maiores totais pluviométricos diários foram superiores a $70 \mathrm{~mm}$. Além disso, $75 \%$ dos dados para estes meses foram superiores a $40 \mathrm{~mm}$, chamando a atenção para a recorrência de eventos intensos nesses meses do ano.

Figura 46: Precipitação máxima em 24 horas, por mês, no período de 1980-2018.

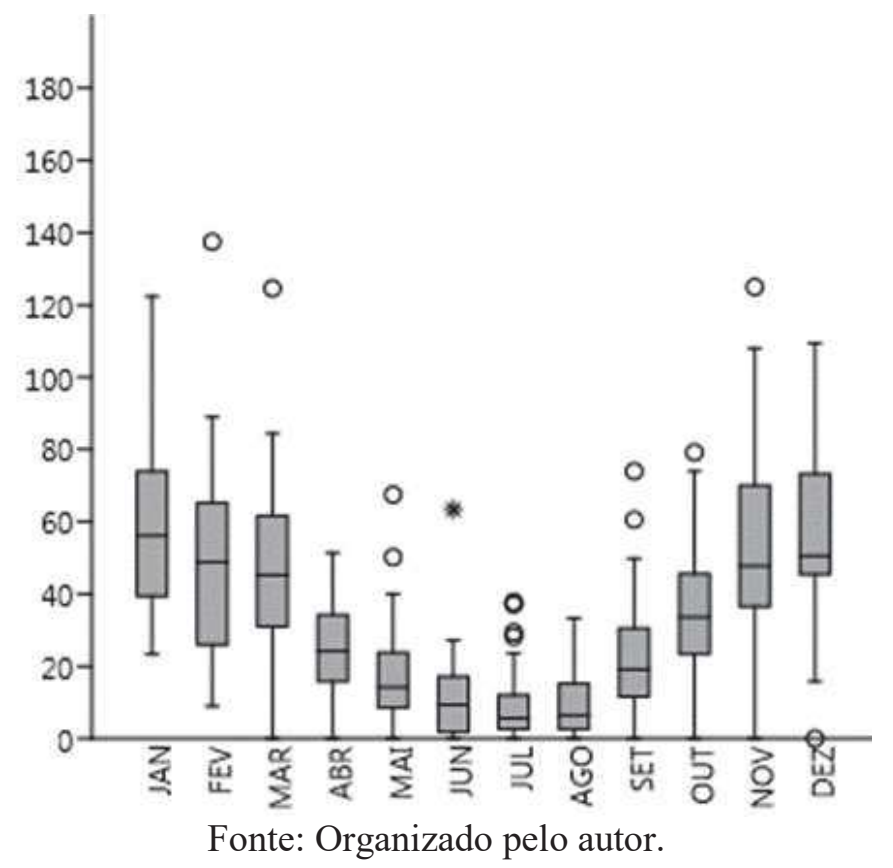

$\mathrm{Na}$ figura 47, a partir dos dados diários de precipitação é possível observar a sazonalidade bem marcada da precipitação, sendo que ao longo da estação chuvosa, entre Outubro e Março, é comum a ocorrência de eventos de intensidade elevada na cidade, demonstrado pelo tempo de retorno do percentil 99 em dez meses. 
Precipitação total diária - Juiz de Fora

140

120

100

80

60

40

20

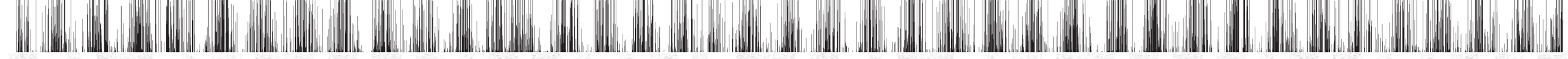

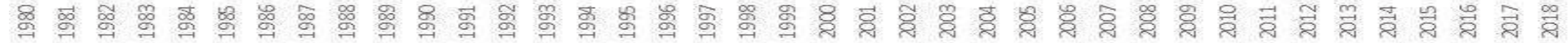

- Precipitação diária (24h)

Percentil $99 \longrightarrow$ Percentil 95

Percentil 90

Figura 47: Precipitação total diária e as faixas dos percentis 90, 95 e 99. Fonte: Organizado pelo autor. 


\section{Os Extremos Em Juiz De Fora: Sua Distribuição Mensal}

A distribuição mensal dos eventos pluviométricos de maior intensidade, em Juiz de Fora, também segue a distribuição mensal da precipitação. A estação chuvosa (Outubro a Março), dessa forma, congrega 92\% dos eventos superiores ao percentil 90 no período de 1980 a 2018, sendo que os meses de Janeiro e Dezembro apresentam uma maior percentagem, com $22,4 \%$ e $24,8 \%$, respectivamente (Figura 48 ).

Figura 48: Total de eventos superiores ao Percentil 90, por mês.

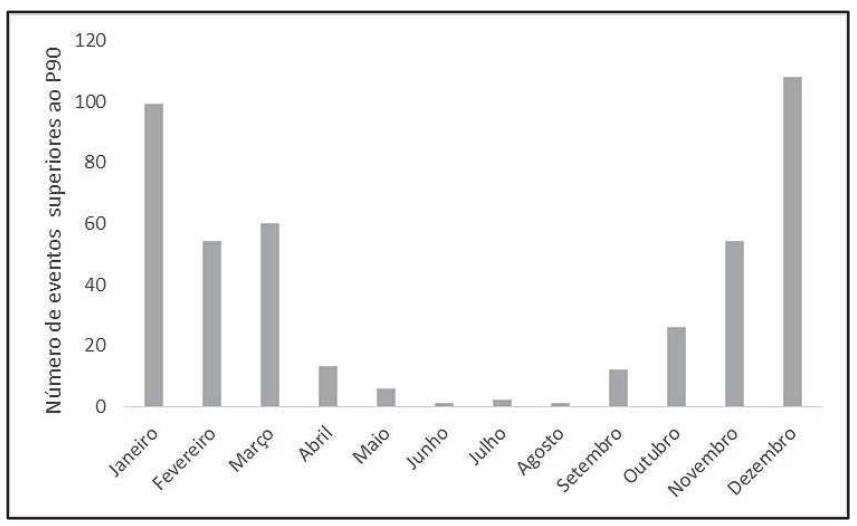

Fonte: Organizado pelo autor

No caso do percentil 95, a distribuição mensal se assemelha, com 95,4\% dos eventos ocorrendo na estação chuvosa, sendo que os meses de Janeiro e Dezembro apresentaram 24,9\% e 23,5\% de ocorrência, respectivamente. Nos meses de Julho e Agosto não foi registrado nenhum evento nessa classe, durante o período analisado (Figura 49).

Figura 49: Total de eventos superiores ao Percentil 95, por mês.

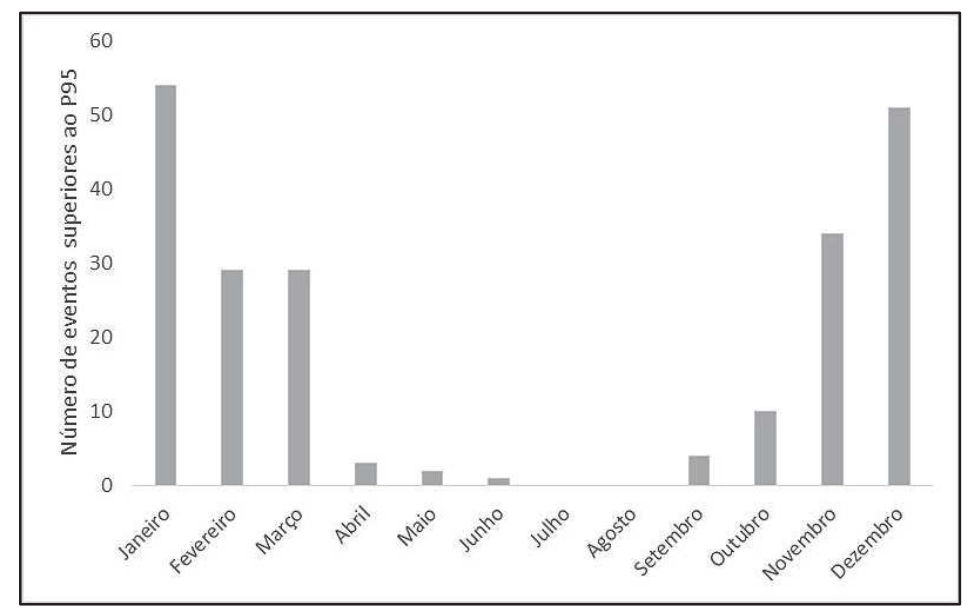

Fonte: Organizado pelo autor 
O percentil 99, representa a classe de maior intensidade, congregando apenas $1 \%$ dos dados diários de precipitação. A distribuição mensal revela que apenas uma vez, no período de 1980-2018, ocorreu um evento superior ao percentil 99 durante a estação seca, sendo observado no mês de Setembro, considerado já um mês de transição para a estação chuvosa, segundo Ferreira (2012). Da mesma forma que nas outras classes, os meses de Janeiro e Dezembro congregam a maior parte dos eventos, com $29,5 \%$ e $20,5 \%$ das ocorrências, respectivamente (Figura 50).

Figura 50: Total de eventos superiores ao Percentil 99, por mês.

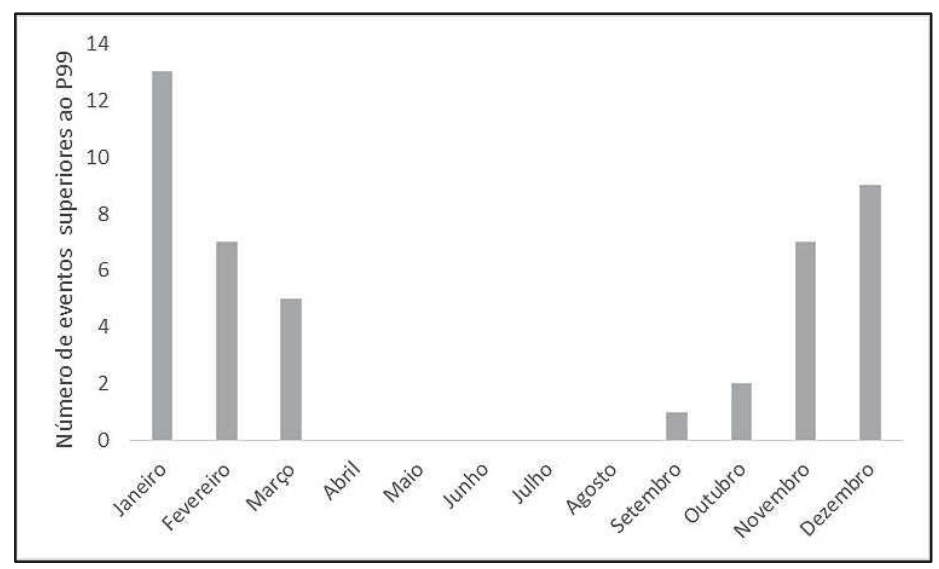

Fonte: Organizado pelo autor

Em função dessa distribuição dos eventos intensos e extremos em Juiz de Fora, é possível destacar que um número muito reduzido de impactos pluviométricos seja deflagrado ao longo da estação seca.

\section{O percentil 90: a investigação mensal}

Para a investigação mensal da frequência dos percentis, foi utilizado apenas os dados da estação chuvosa, uma vez que nos meses secos (Abril a Setembro) a frequência de ocorrência desses eventos é baixa. Durante a estação chuvosa (Outubro a Março) a frequência dos percentis mensal demonstrou uma variabilidade, sendo que três meses apresentaram tendência de aumento na frequência dos eventos dessa classe, enquanto três apresentaram tendência de redução (Figura 51 e quadro 27).

As tendências de elevação foram observadas nos meses de Março, Novembro e Dezembro, sendo que estes dois últimos com maior intensidade. O Novembro apresentou maior elevação na frequência de eventos do percentil 90 da estação chuvosa, segundo o coeficiente de determinação $\left(\mathrm{R}^{2}\right)$, com aumento de 1,3 eventos ao longo da série, seguido pelo mês de 
Dezembro e, em menor intensidade, o mês de março, com uma elevação de 1,5 e 0,5 eventos, respectivamente, ao longo da série. No caso dos meses com tendência de redução, estes foram os meses de Janeiro, Fevereiro e Outubro, sendo este último, o que apresentou maior coeficiente de determinação $\left(\mathrm{R}^{2}\right)$, ainda que, no entanto, sejam tendências de baixa intensidade. A variação da reta esteve inferior a 0,5 eventos para os meses que apresentaram tendência de redução (Figura 51 e Quadro 27).

Figura 51: Gráficos de tendência mensal para os dados a partir do Percentil 90, na estação chuvosa

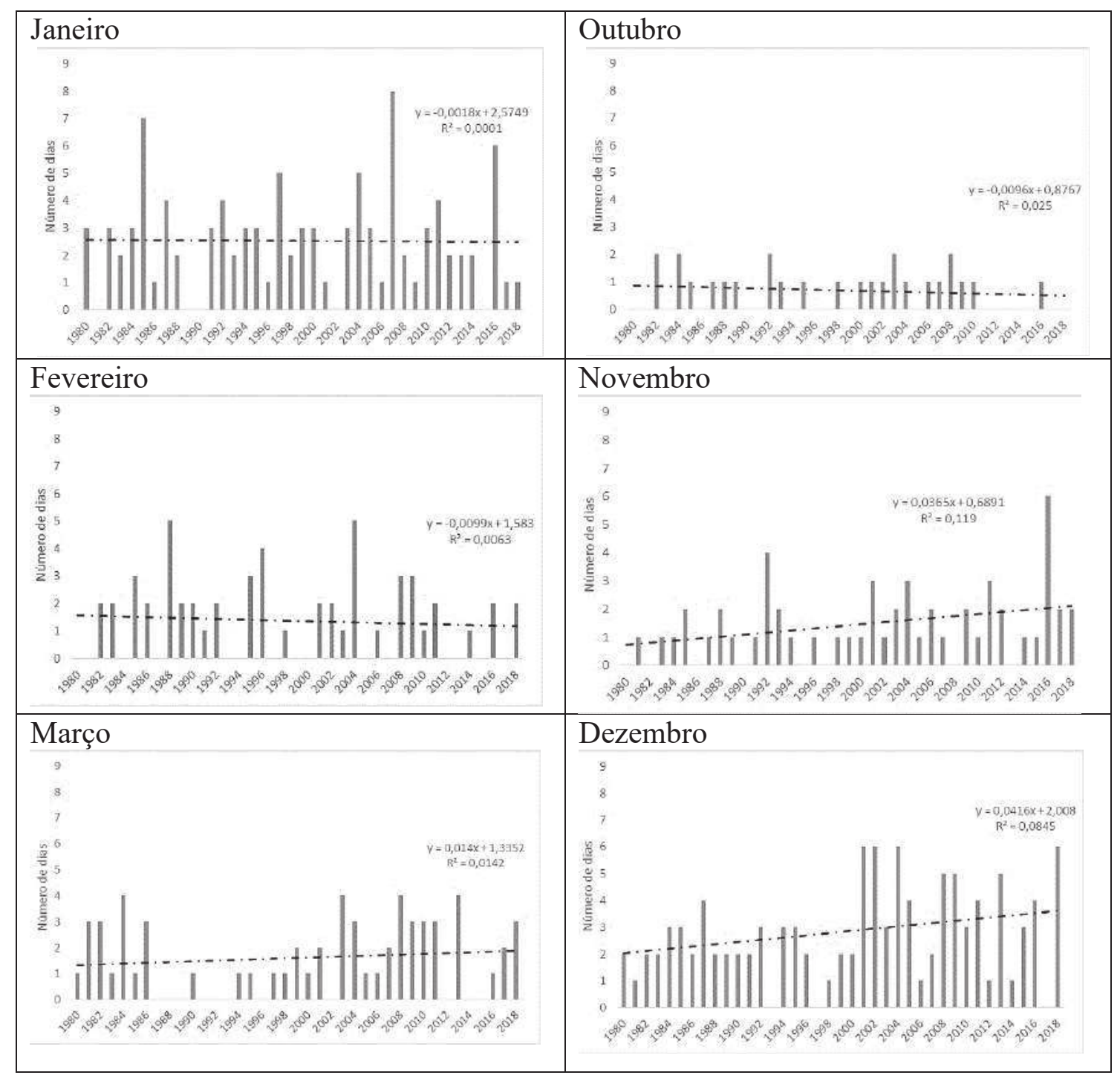

Fonte: Organizado pelo autor.

Quadro 27: Estatística de tendência para os dados mensais da estação chuvosa a partir do percentil 90.

\begin{tabular}{|c|c|c|c|c|}
\hline Mês & Tendência & Equação & $\mathrm{R}^{2}$ & Variação \\
\hline Janeiro & - & $-0,0018 \mathrm{x}+2,5749$ & 0,0001 & $-0,07$ \\
\hline
\end{tabular}




\begin{tabular}{|c|c|c|c|c|}
\hline Fevereiro & - & $-0,0099 \mathrm{x}+1,583$ & 0,0063 & $-0,38$ \\
\hline Março & + & $0,014 \mathrm{x}+1,3352$ & 0,0142 & 0,52 \\
\hline Outubro & - & $-0,0096 \mathrm{x}+0,8767$ & 0,025 & $-0,36$ \\
\hline Novembro & + & $0,0365 \mathrm{x}+0,6891$ & 0,119 & 1,35 \\
\hline Dezembro & + & $0,0416 \mathrm{x}+2,008$ & 0,0845 & 1,54 \\
\hline
\end{tabular}

Fonte: Organizado pelo autor

A avaliação do teste de Mann-Kendall (Quadro 28) revelou valores baixos do score z para quatro dos seis meses (Janeiro, Fevereiro, Março e Outubro), indicando que são tendências de baixo significado estatístico. Já os meses de Novembro e Dezembro, indicaram tendências de maior intensidade, sobretudo em Novembro que os resultados revelam uma tendência significativa com $95 \%$ de confiança estatística.

Quadro 28: Estatística de Mann-Kendall aplicado ao percentil 90.

\begin{tabular}{|c|c|c|c|c|c|c|}
\hline \multicolumn{7}{|c|}{ Teste Mann-Kendall } \\
\hline MK & Janeiro & Fevereiro & Março & Outubro & Novembro & Dezembro \\
\hline Z & $-0,42$ & $-0,40$ & 0,87 & $-0,94$ & $\mathbf{2 , 1 4}$ & 1,59 \\
\hline
\end{tabular}

Fonte: Organizado pelo autor.

\section{O percentil 95: a investigação mensal}

Para o percentil 95 o padrão se repetiu, sendo que os meses Janeiro, Fevereiro e Outubro com tendências de redução na frequência dos eventos, e os meses de Março, Novembro e Dezembro, com tendência de elevação na frequência (Figura 52). No caso da tendência de redução, Fevereiro apresentou o maior coeficiente de determinação $\left(\mathrm{R}^{2}\right)$, com 0,030 . Dentre os casos das tendências de elevação os meses de Novembro e Dezembro demonstraram os maiores coeficientes de determinação $\left(\mathrm{R}^{2}\right)$, com 0,0618 e 0,0548, respectivamente (Quadro 29).

Figura 52: Gráficos de tendência mensal para os dados a partir do Percentil 95, na estação chuvosa

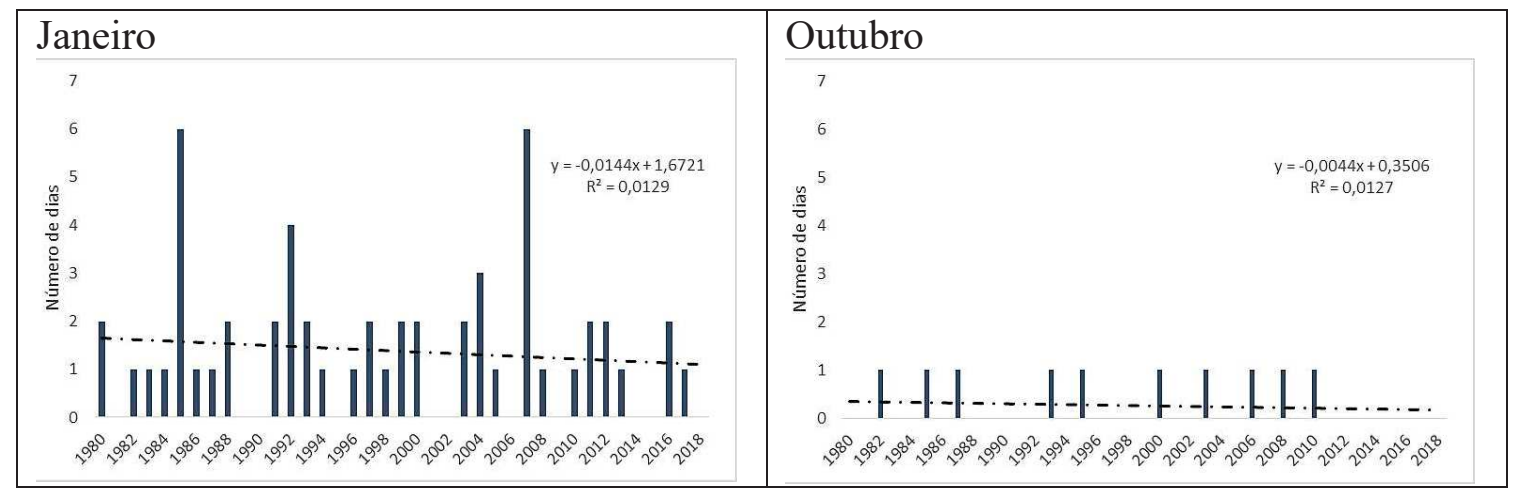




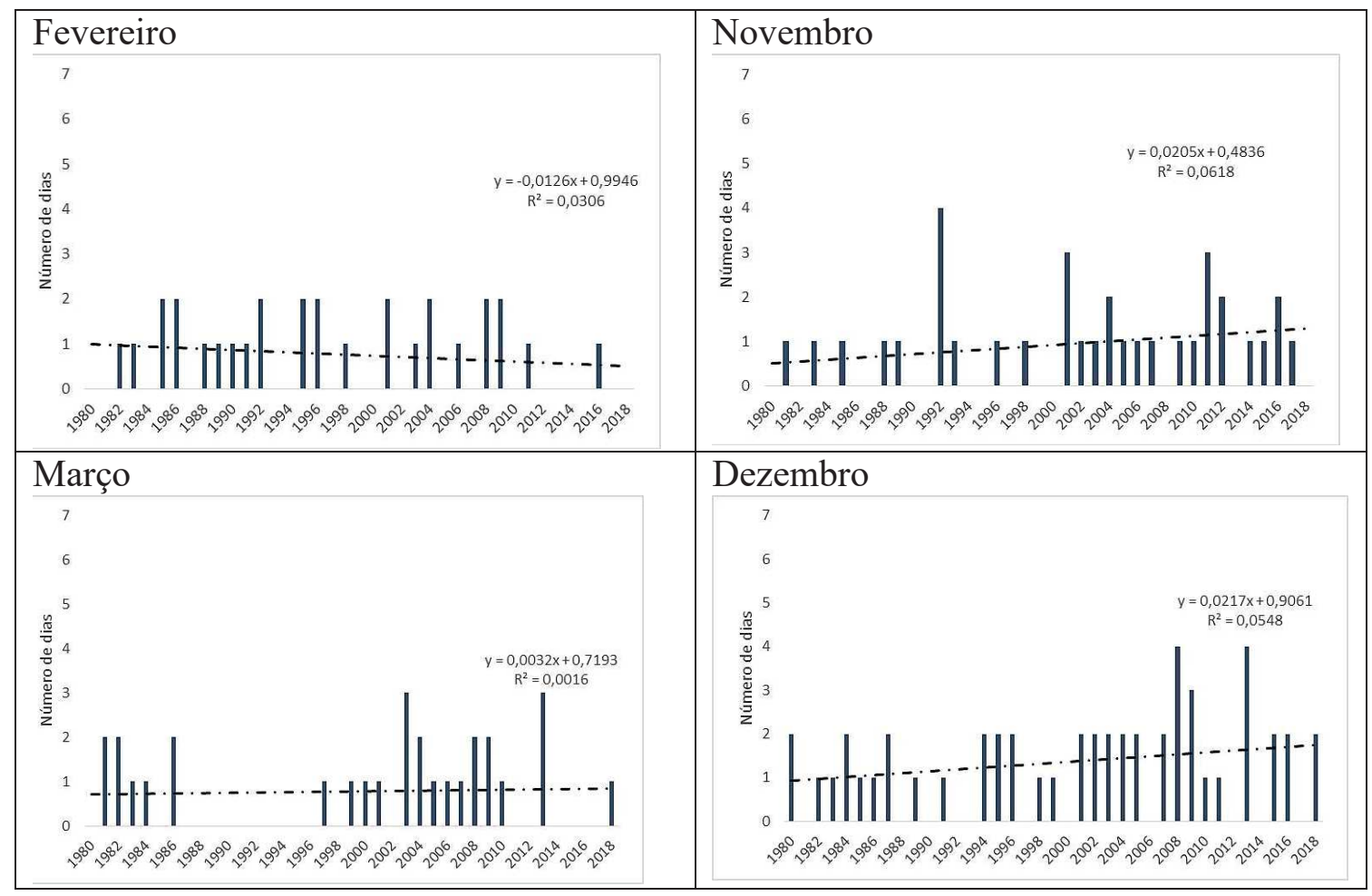

Fonte: Organizado pelo autor.

Quadro 29: Estatística de tendência para os dados mensais da estação chuvosa a partir do percentil 95.

\begin{tabular}{|c|c|c|c|c|}
\hline Mês & Tendência & Equação & $\mathrm{R}^{2}$ & Variação \\
\hline Janeiro & - & $-0,0144 \mathrm{x}+1,6721$ & 0,0129 & $-0,05$ \\
\hline Fevereiro & - & $-0,0126 \mathrm{x}+0,9946$ & 0,0306 & $-0,48$ \\
\hline Março & + & $0,0032 \mathrm{x}+0,7193$ & 0,0016 & 0,12 \\
\hline Outubro & - & $-0,0044 \mathrm{x}+0,3506$ & 0,0127 & $-0,16$ \\
\hline Novembro & + & $0,0205 \mathrm{x}+0,4836$ & 0,0618 & 0,76 \\
\hline Dezembro & + & $0,0217 \mathrm{x}+0,9061$ & 0,0548 & 0,80 \\
\hline
\end{tabular}

Fonte: Organizado pelo autor.

Nos percentis 95, nenhum dos meses tiveram tendências significativas as $95 \%$, no entanto os meses de Novembro e Dezembro, com tendência de aumento, apresentaram os maiores valores do score z, quadro 30. Cabe destacar que a elevação na frequência dos eventos nos meses de Novembro e Dezembro, podem desencadear uma intensificação nos impactos e nos episódios extremos em Juiz de Fora. 
Quadro 30: Estatística de Mann-Kendall aplicado ao percentil 95.

\begin{tabular}{|c|c|c|c|c|c|c|}
\hline \multicolumn{7}{|c|}{ Teste Mann-Kendall } \\
\hline MK & Janeiro & Fevereiro & Março & Outubro & Novembro & Dezembro \\
\hline $\mathrm{z}$ & $-0,64$ & $-1,08$ & 0,18 & $-0,67$ & 1,86 & 1,27 \\
\hline
\end{tabular}

Fonte: Organizado pelo autor.

\section{O percentil 99: a investigação mensal}

Os dados do percentil 99 indicaram que os meses de Janeiro e Fevereiro apresentaram tendência de redução, enquanto que os demais demonstraram tendência de aumento (Figura 53). Entretanto há um número reduzido de ocorrências mensais do percentil 99, sobretudo no mês de Outubro, que registrou apenas dois eventos ao longo da série, figura 53.

Figura 53: Gráficos de tendência mensal para os dados a partir do Percentil 99, na estação chuvosa

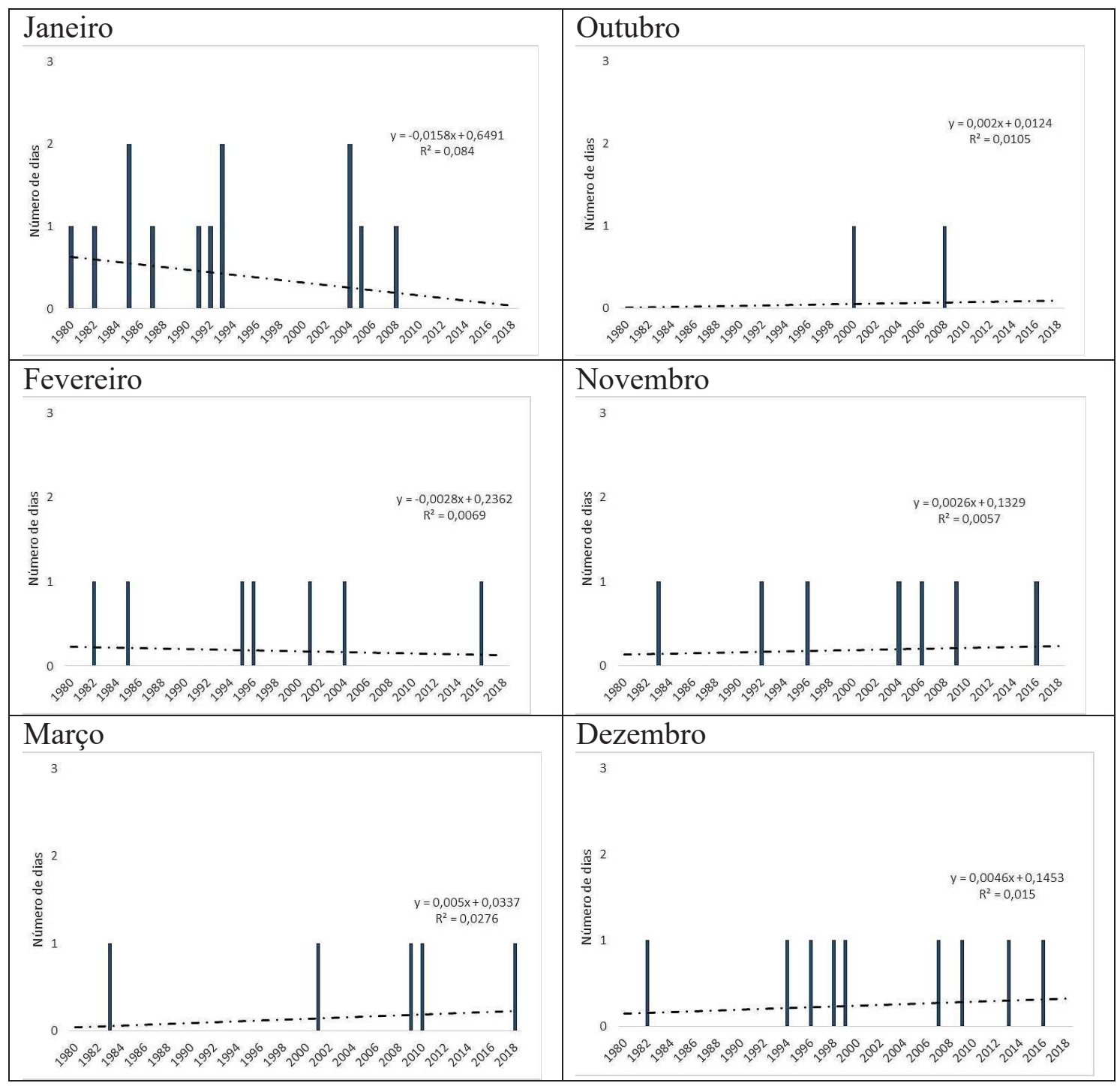


Fonte: Organizado pelo autor.

Avaliando os dados da tendência mensal apenas o mês de Janeiro teve um indício maior de alteração, com uma redução de 0,6 eventos durante o período analisado, com maior valor do score z no Teste Mann Kendall. Dentre os meses com tendência de elevação na frequência de eventos no percentil 99, Março, Outubro, Novembro e Dezembro, comparativamente, o mês de março tem maior inclinação na reta (Quadro 31).

Quadro 31: Estatística de tendência para os dados mensais da estação chuvosa a partir do percentil 99.

\begin{tabular}{|c|c|c|c|c|c|}
\hline Mês & Tendência & Equação & $\mathrm{R}^{2}$ & Variação & $\mathrm{MK}$ \\
\hline Janeiro & - & $-0,0158 \mathrm{x}+0,6491$ & 0,084 & $-0,60$ & $-1,94$ \\
\hline Fevereiro & - & $-0,0028 \mathrm{x}+0,2362$ & 0,0069 & $-0,11$ & $-0,49$ \\
\hline Março & + & $0,005 \mathrm{x}+0,0337$ & 0,0276 & 0,19 & 0,99 \\
\hline Outubro & + & $0,002 \mathrm{x}+0,0124$ & 0,0105 & 0,08 & 0,55 \\
\hline Novembro & + & $0,0026 \mathrm{x}+0,1329$ & 0,0057 & 0,10 & 0,45 \\
\hline Dezembro & + & $0,0046 \mathrm{x}+0,1453$ & 0,015 & 0,17 & 0,72 \\
\hline
\end{tabular}

Fonte: Organizado pelo autor.

\section{Técnicas Para A Identificação De Eventos Intensos e Extremos}

Paralelamente à utilização da técnica dos percentis, utilizada para a identificação dos eventos intensos e extremos, utilizou-se as técnicas das pêntadas e dos máximos de precipitação com o intuito de avaliar comparativamente a partir dos impactos qual recurso representaria de maneira mais precisa os episódios extremos em Juiz de Fora.

\section{A técnica das pêntadas}

Ao aplicar a técnica dos percentis para os dados agrupados em pêntadas pode-se visualizar as classes de intensidade para esta técnica. Os episódios superiores ao Percentil 90 congregaram acumulados que superaram os $81,3 \mathrm{~mm}$, o percentil 95 representa os totais superiores a $108,1 \mathrm{~mm}$ e o percentil 99 os totais pluviométricos superiores a 158,8 mm em cinco dias, (Quadro 32).

Quadro 32: Classes do percentil calculados para as pêntadas pluviométricas.

\begin{tabular}{l|l|l} 
Percentil & Classe & Intervalo \\
\hline
\end{tabular}




\begin{tabular}{|c|c|c|}
\hline$<$ P15 & $1 \mathrm{~mm}$ & $1-3,6 \mathrm{~mm}$ \\
\hline P15 & $3,7 \mathrm{~mm}$ & $3,7-11,4 \mathrm{~mm}$ \\
\hline P35 & $11,5 \mathrm{~mm}$ & $11,5-33,5 \mathrm{~mm}$ \\
\hline P65 & $33,6 \mathrm{~mm}$ & $33,6-65,9 \mathrm{~mm}$ \\
\hline P85 & $66 \mathrm{~mm}$ & $66-81,2 \mathrm{~mm}$ \\
\hline P90 & $81,3 \mathrm{~mm}$ & $81,3-108 \mathrm{~mm}$ \\
\hline P95 & $108,1 \mathrm{~mm}$ & $108,1-158,8 \mathrm{~mm}$ \\
\hline P99 & $158,9 \mathrm{~mm}$ & $>158,8 \mathrm{~mm}$ \\
\hline
\end{tabular}

Fonte: Organizado pelo autor

$\mathrm{Na}$ figura 54, demonstra a frequência anual de pêntadas superiores ao percentil 90, que ocorreram 181 vezes ao longo da série. Nos anos de 1983 e 2008 ocorreram as maiores frequências, com 11 eventos em cada. Além disso, o conjunto de dados revela uma leve tendência de aumento, sendo que no período de 2003 a 2011 pelo menos seis eventos/ano foram registrados.

Figura 54: Frequência anual de pêntadas pluviométricas superiores ao P90

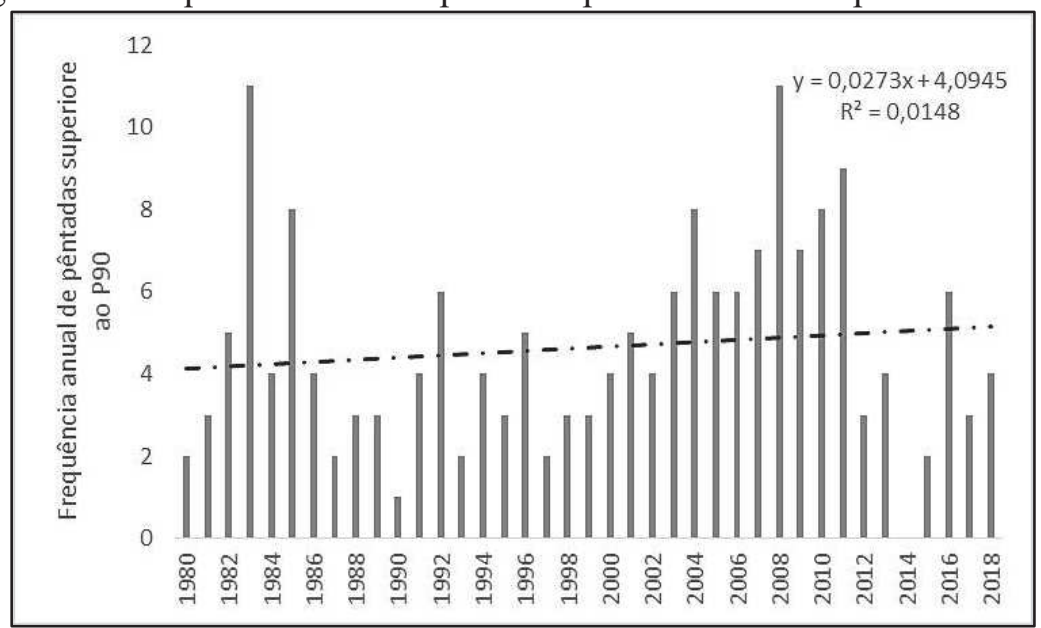

Fonte: Organizado pelo autor.

$\mathrm{Na}$ figura 55, estão os dados agrupados em pêntadas ao longo da série histórica, assim como nos dados diários, demonstraram a estacionalidade das chuvas em Juiz de Fora, bem como a ocorrência de eventos superiores aos percentis 90 em todos os anos da série. 


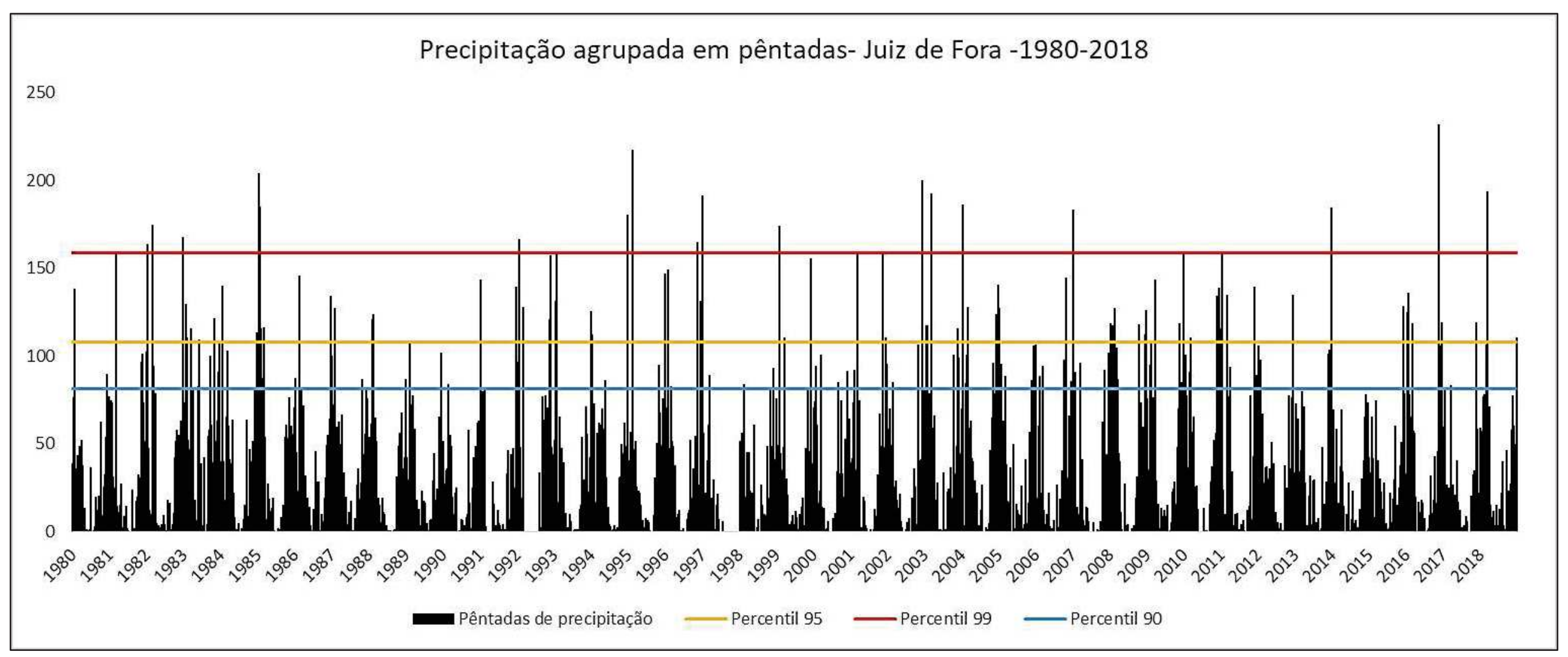

Figura 55: Precipitação agrupada em pêntadas e as faixas dos percentis 90, 95 e 99. Fonte: Organizado pelo autor. 
Avaliando a frequência nas classes dos percentis 90, 95 e 99, Figura 56, estes foram registrados 90, 71 e 29 vezes, respectivamente, ao longo do período. No caso do percentil 90, a tendência tem indicado elevação na frequência, com um $\mathrm{R}^{2}$ de 0,037 e um aumento de 0,96 eventos ao longo da série.

Figura 56: Frequência anual das pêntadas pluviométricas nas classes do percentil 90, 95 e 99

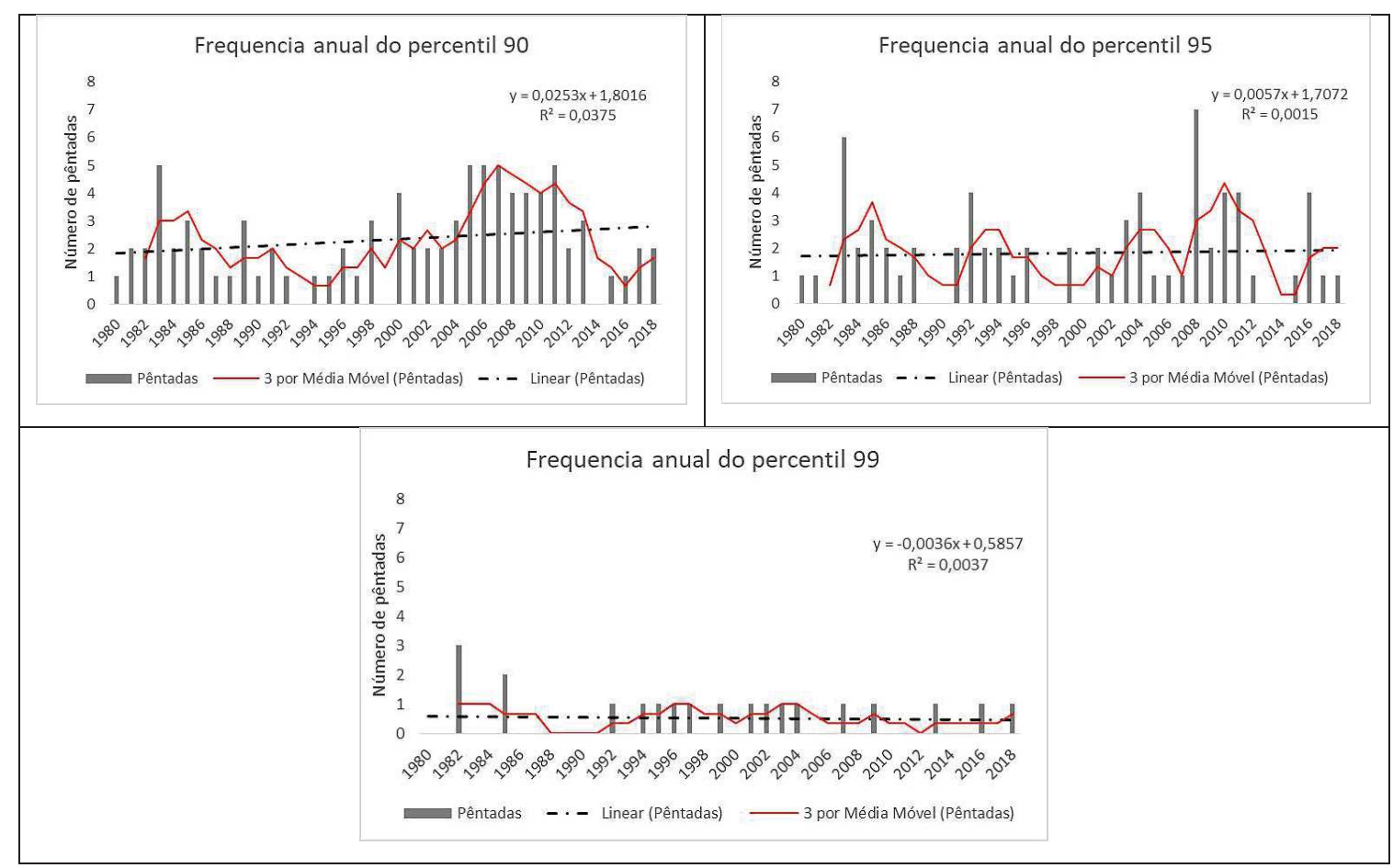

Fonte: Organizado pelo autor.

O percentil 95 apresentou uma inclinação muito baixa da reta, indicando pouca alteração nos dados com uma elevação de 0,2 ao longo da série e, por fim, no percentil 99, ocorrendo em uma baixa frequência, estes apresentaram uma tendência de redução, também muito pequena, com um decréscimo de 0,1 eventos ao longo do período (Quadro 33).

Quadro 33: Estatísticas de tendência aplicada aos percentis 90, 95 e 99 dos dados agrupados em pêntadas

\begin{tabular}{|c|c|c|c|c|}
\hline Percentil & Tendência & $\mathrm{R}^{2}$ & $\mathrm{MK}$ & Variação em função da reta \\
\hline Percentil 90 & + & 0,0375 & 1,12 & 0,96 \\
\hline Percentil 95 & + & 0,0015 & 0 & 0,22 \\
\hline Percentil 99 & - & 0,0037 & 0,38 & $-0,14$ \\
\hline
\end{tabular}

Fonte: Organizado pelo autor. 
A partir da média móvel, observa-se que as classes do percentil 90 e 95 (Figura 56) tiveram uma concentração de ocorrências no período de 2000 a 2011, que retraiu a partir de 2012, para um número menor de ocorrências. O percentil 99, com um menor número de ocorrências teve no período entre 1994 e 2004 a maior concentração de ocorrências.

Avaliando a frequência e o tempo de retorno das pêntadas pluviométricas, quadro 34, observa-se que os valores referentes aos percentis 90 e 95 ocorreram pelo menos uma vez ao ano, com um tempo de retorno de 5,3 e 6,7 meses, respectivamente, denotando a influência da estacionalidade das chuvas na cidade. Já o percentil 99, com os eventos superiores a 158,8mm, ocorreram com um tempo de retorno de 2 anos.

Quadro 34: Frequência e tempo de retorno para os dados agrupados em pêntadas

\begin{tabular}{|c|c|c|c|c|}
\hline \multicolumn{5}{|c|}{ Frequência e tempo de retorno } \\
\hline Intervalo (mm) & Frequência & Frequência relativa (\%) & Tempo de retorno (anos) & Tempo de retorno (Meses) \\
\hline $1-3,6$ & 270 & 0,09483667 & 0,1 & 1,8 \\
\hline $3,7-11,4$ & 360 & 0,126448894 & 0,1 & 1,3 \\
\hline $11,5-33,5$ & 573 & 0,201264489 & 0,1 & 0,8 \\
\hline $33,6-65,9$ & 361 & 0,12680014 & 0,1 & 1,3 \\
\hline $66-81,2$ & 90 & 0,031612223 & 0,4 & 5,3 \\
\hline $81,3-108$ & 90 & 0,031612223 & 0,4 & 5,3 \\
\hline $108,1-158,8$ & 71 & 0,024938532 & 0,5 & 6,7 \\
\hline$>158,8$ & 20 & 0,007024939 & 2,0 & 23,7 \\
\hline
\end{tabular}

Fonte: Organizado pelo autor

Dividindo os dados superiores ao percentil 99, ou seja, superiores a 158,8 mm, sabe-se que 17 deles foram inferiores a $200 \mathrm{~mm}$, sendo oito inferiores a $180 \mathrm{~mm}$ e nove no intervalo de 180-200mm, com relação ao tempo de retorno estes ficaram em 4,9 anos e 4,3, respectivamente. Três eventos superaram os $200 \mathrm{~mm}$, dois foram inferiores a $220 \mathrm{~mm}$ com um tempo de retorno de 19,5 anos e apenas um ultrapassou essa marca, sendo todos no período da estação chuvosa (Quadro 35).

Quadro 35: Frequência e tempo de retorno para os dados em pêntadas superiores ao P99

\begin{tabular}{|c|c|c|c|c|}
\hline \multicolumn{5}{|c|}{ Frequência e tempo de retorno } \\
\hline Intervalo (mm) & Frequência & Frequência relativa (\%) & Tempo de retorno (anos) & Tempo de retorno (Meses) \\
\hline $158,8-180$ & 8 & 0,002809975 & 4,9 & 59,3 \\
\hline $180,1-200$ & 9 & 0,003161222 & 4,3 & 52,7 \\
\hline $200,1-220$ & 2 & 0,000702494 & 19,5 & 237,3 \\
\hline$>220$ & 1 & 0,000351247 & 39,0 & 474,5 \\
\hline
\end{tabular}

Fonte: Organizado pelo autor

Os três eventos foram registrados em janeiro de 1985, na pêntada 4 com 203,9 mm entre os dias 16 e 20, o segundo foi registrado em fevereiro 1995, na pêntada 9 com 217,5mm entre os dias 10 e 14, e o terceiro evento foi registrado em novembro de 2016, com 231,7mm entre os dias 12 e 16 , quadro 36. 
Quadro 36: Maiores totais de pêntadas pluviométricas em Juiz de Fora

\begin{tabular}{|c|c|c|}
\hline Pêntada & Período & Prec. $(\mathrm{mm})$ \\
\hline 4 & $16-20 / 01 / 1985$ & 203,9 \\
\hline 9 & $10-14 / 02 / 1995$ & 217,5 \\
\hline 64 & $12-16 / 11 / 2016$ & 231,7 \\
\hline
\end{tabular}

Fonte: Organizado pelo autor

\section{A técnica dos máximos de precipitação}

A aplicação da técnica dos máximos de precipitação permite avaliar a partir de níveis a frequência que determinados eventos ocorrem na série, dando um enfoque nos eventos de maior intensidade, por sua capacidade de gerar impactos na cidade. Aplicada por Monteiro e Zanella (2012) que utilizaram um valor limiar para evento extremo de 50mm, pretende-se aqui substituílo pelo valor do percentil 95, 45,6mm (Quadro 37).

Nesse contexto, os dados demonstraram que eventos diários até $62,5 \mathrm{~mm}$ foram considerados normais a partir dessa técnica, uma vez que apresentaram uma frequência elevada ao longo do período. À medida em que a intensidade dos eventos se eleva, a sua frequência diminuiu, sendo que na intensidade máxima, IV, aconteceram apenas cinco vezes ao longo da série.

Quadro 37: Intensidades da precipitação diária calculada pela técnica dos máximos de precipitação.

\begin{tabular}{|c|c|c|}
\hline Intensidade & Intervalo & Número de eventos \\
\hline "Normal" & $45,6-62,5 \mathrm{~mm}$ & 135 \\
\hline Intensidade I & $62,6-79,8 \mathrm{~mm}$ & 47 \\
\hline Intensidade II & $79,9-97,1 \mathrm{~mm}$ & 20 \\
\hline Intensidade III & $97,2-114,4 \mathrm{~mm}$ & 7 \\
\hline Intensidade IV & $>114,4 \mathrm{~mm}$ & 5 \\
\hline
\end{tabular}

Fonte: Organizado pelo autor.

O tempo de retorno desses eventos demonstrou que as classes de intensidade "normal" e I, podem ocorrer em todos os anos, a classe de intensidade II tem o tempo de retorno em 23 meses, já as intensidades III e IV têm uma expectativa de retorno menor, de 5 e 7 anos, respectivamente, e representam 12 eventos ao longo da série de dados (Quadro 38). 
Quadro 38: Frequência e tempo de retorno para as classes dos máximos de precipitação.

\begin{tabular}{|c|c|c|c|c|}
\hline \multicolumn{5}{|c|}{ Frequência e tempo de retorno } \\
\hline Intervalo (mm) & Frequência & Frequência relativa (\%) & Tempo de retorno (anos) & Tempo de retorno (Meses/dias) \\
\hline $45,6-62,6$ & 135 & 0,00972973 & 0,3 & $3,42(103$ dias) \\
\hline $62,7-79,9$ & 47 & 0,003387387 & 0,8 & $9,84(295$ dias) \\
\hline $80-97,2$ & 20 & 0,001441441 & 1,9 & $23,12(694$ dias) \\
\hline $97,3-114,5$ & 7 & 0,000504505 & 5,4 & $66,07(1982$ dias) \\
\hline$>114,5$ & 5 & 0,00036036 & 7,6 & 92,5 (2775 dias) \\
\hline
\end{tabular}

Fonte: Organizado pelo autor.

A aplicação das referidas técnicas estatísticas demonstrou alguns pontos com relação aos considerados eventos extremos. Com relação aos percentis verificou-se que os valores dos Percentis 90, 95 e 99 tem um tempo de retorno inferior a 1 ano, o percentil 90 apresentou tendência de aumento, o Percentil 95 tem tendência de elevação da frequência ao longo do período, enquanto que o Percentil 99 tem mostrado redução na frequência.

Passando à investigação mensal dos eventos, nos meses da estação chuvosa, observouse que há uma variabilidade na tendência dos dados, tendo três meses, uma tendência de redução na frequência (Janeiro, Fevereiro e Outubro), enquanto que três tem apresentado elevação na frequência (Março, Novembro e Dezembro), sendo que Novembro e Dezembro apresentaram alterações mais abruptas, para os percentis 90 e 95.

Para os dados agrupados em pêntadas ocorreram tendências de elevação para os dados superiores ao Percentil 90 e tendência de redução para os superiores aos percentis 95 e 99. A técnica dos máximos de precipitação permitiu classificar os eventos extremos em cinco classes, estabelecidas a partir da intensidade do evento, sendo que a intensidade máxima foi marcada pelos totais pluviométricos superiores a $114,5 \mathrm{~mm} / 24 \mathrm{~h}$. Além disso, nessa técnica foi realizada uma alteração metodológica, substituindo o valor mínimo de $50 \mathrm{~mm} / 24 \mathrm{~h}$ pelo valor do percentil 95.

\section{Tendências dos dados a partir dos Índices de Extremos Climáticos-ETCDDI}

Em Juiz de Fora Oliveira et al (2019) investigaram os índices de extremos climáticos: Dias secos consecutivos - CDD; Dias úmidos consecutivos - CWD; Precipitação máxima em 1 dia- Rx1day; Índice Simples de Intensidade Diária- SDII; Precipitação superior a 50mmR50mm e apontaram que há tendência de redução no número de dias consecutivos secos e úmidos, elevação no índice simples de intensidade diária, bem como da frequência de eventos superiores a 50mm e redução no volume das precipitações máximas em um dia. 
Além dos índices já aplicados por Oliveira et al (2019) aplicou-se paralelamente os índices PRPCTOT - total anual de precipitação em dias úmidos, R10mm e R20, R40. Sendo que os percentis 95 e 99, que também são índices do ETCCDI já foram apresentados (Figura $57)$.

Figura 57: Índices de extremos climáticos aplicados aos dados de precipitação de Juiz de Fora.

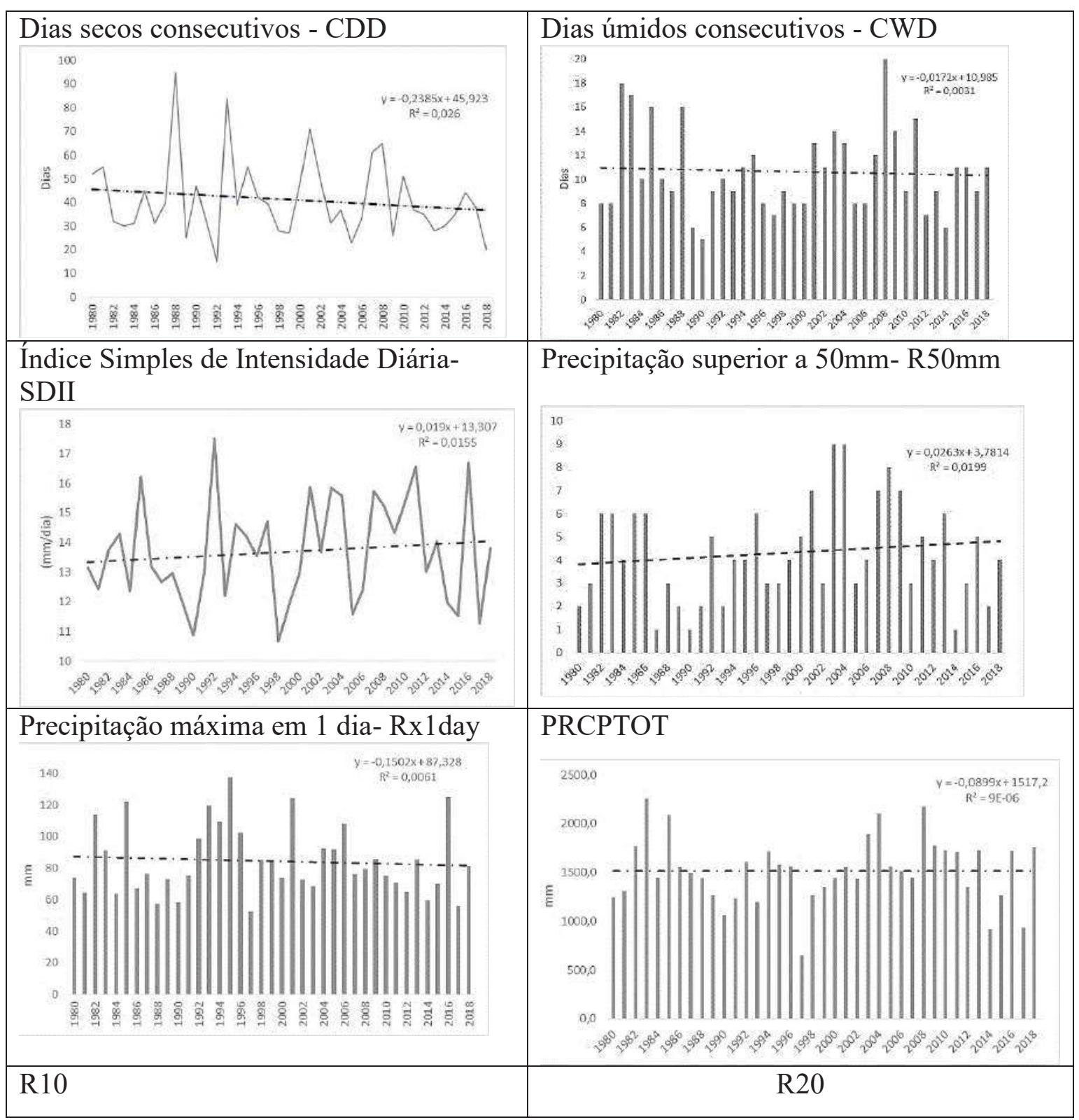




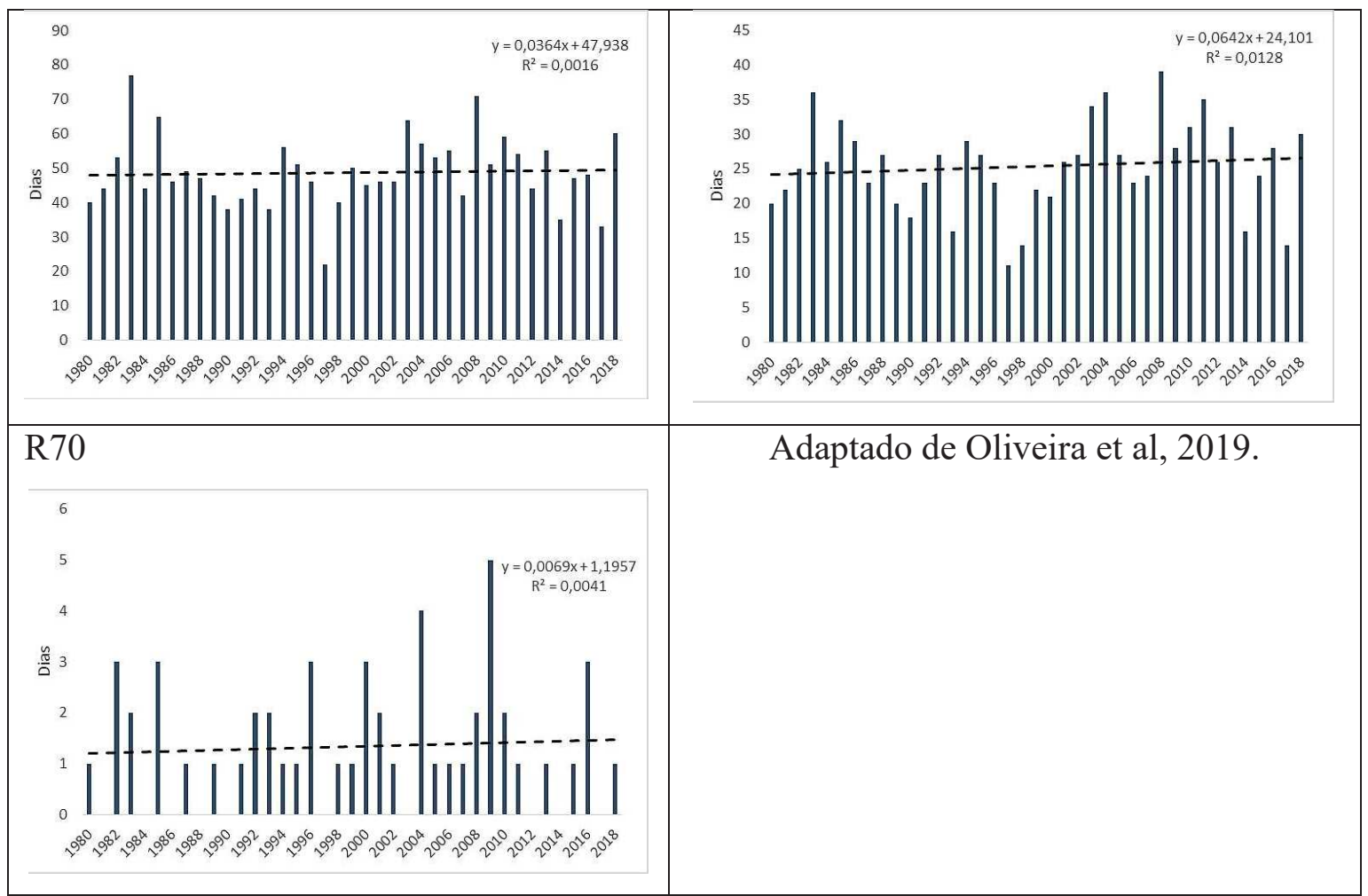

Fonte: Organizado pelo autor.

O índice PRPCTOT não apresenta nenhuma tendência de alteração ao longo do período, a reta mostra uma mínima tendência de redução, que representou um decréscimo de 1,6 mm ao longo da série. Os índices R10, 20 e 70 apresentam tendência de aumento, sendo que R20 apresentou maior elevação, de 2,4 eventos no final do período (Figura 57 e Quadro 39).

Quadro 39: Estatísticas de tendência aplicadas aos índices de extremos climáticos do ETCCDI.

\begin{tabular}{|c|c|c|c|c|}
\hline Índice & Tendência & Mann- Kendall & $\mathrm{R}^{2}$ & $\begin{array}{c}\text { Variação em } \\
\text { função da reta }\end{array}$ \\
\hline CDD & - & 0,95 & 0,026 & $-9,1$ dias \\
\hline CWD & - & 0,01 & 0,0031 & $-0,65$ dias \\
\hline SDII & + & 0,62 & 0,015 & $+0,7 \mathrm{~mm} /$ dia \\
\hline Rx1 day & - & 0,39 & 0,0061 & $-5,7 \mathrm{~mm}$ \\
\hline R10 & + & 0,90 & 0,0016 & $+1,38$ eventos \\
\hline R20 & + & 1,04 & 0,0128 & $+2,43$ eventos \\
\hline R50 & + & 0,019 & 0,019 & $+0,9$ eventos \\
\hline R70 & + & 0,28 & 0,0041 & $+0,26$ eventos \\
\hline PRPCTOT & - & 0,62 & $9 \mathrm{E}-06$ & $-1,6$ mm \\
\hline
\end{tabular}


Fonte: Organizado pelo autor.

O cálculo do tempo de retorno (Quadro 40) para as classes de $10 \mathrm{~mm}$ permite identificar que eventos até $70 \mathrm{~mm}$ ocorreram pelo menos uma vez por ano, sendo que os superiores a $50 \mathrm{~mm}$ ocorreram em um intervalo superior a seis meses, ou seja, estão concentrados na estação chuvosa.

Os eventos superiores a 70mm e inferiores a 80, 90 e $100 \mathrm{~mm}$ ocorreram com intervalos de retorno de 1,$9 ; 2,4 ; 5,4$ anos e os eventos superiores a 100 têm uma ocorrência mais rara, com apenas nove eventos e o tempo de retorno superior a dez anos.

Quadro 40: Frequência e tempo de retorno por classes de intensidade diária

\begin{tabular}{|c|c|c|c|c|}
\hline \multicolumn{7}{|c|}{ Cálculo da Frequência e Tempo de Retorno } \\
\hline Intervalo (mm) & Frequência & Frequência relativa (\%) & Tempo de retorno (anos) & Tempo de retorno (Meses/ dias) \\
\hline $10,1-20$ & 908 & 0,065441441 & 0,04 & 0,51 (15 dias) \\
\hline $20,1-30$ & 472 & 0,034018018 & 0,08 & $0,98(29$ dias) \\
\hline $30,1-40$ & 233 & 0,016792793 & 0,16 & $1,98(60$ dias) \\
\hline $40,1-50$ & 117 & 0,008432432 & 0,32 & $3,95(119$ dias) \\
\hline $50,1-60$ & 72 & 0,005189189 & 0,53 & $6,42(193$ dias $)$ \\
\hline $60,1-70$ & 44 & 0,003171171 & 0,86 & $23,12(694$ dias $)$ \\
\hline $70,1-80$ & 20 & 0,001441441 & 1,90 & $28,9(867$ dias $)$ \\
\hline $80,1-90$ & 16 & 0,001153153 & 2,38 & $66,07(1982$ dias $)$ \\
\hline $90,1-100$ & 7 & 0,000504505 & 5,43 & $154,16(4625$ dias $)$ \\
\hline $100,1-110$ & 3 & 0,000216216 & 12,67 & $231,25(6938$ dias) \\
\hline $110,1-120$ & 2 & 0,000144144 & 19,01 & $154,16(4625$ dias) \\
\hline $120,1-130$ & 3 & 0,000216216 & 12,67 & $462,5(13875$ dias) \\
\hline $130,1-140$ & 1 & 0,000072072 & 38,01 & \\
\hline
\end{tabular}

Fonte: Organizado pelo autor.

As técnicas dos índices climáticos do ETCCDI demonstram para uma redução nos índices CDD (Número de dias secos consecutivos) e CWD (Número de dias úmidos consecutivos), redução na intensidade dos eventos máximos em 1 dia (Rx1day), bem como na Precipitação total anual em dias úmidos (PRCPTOT), além disso, tendências de elevação foram identificadas nos R10, 20, 50 e 70, sendo mais intensa no R20, bem como no índice simples de intensidade diária (SDII) revelando que o total anual tem precipitado em um número menor de dias.

De certa maneira alguns eventos de intensidade elevada têm mostrado tendências de elevação na frequência dentre as técnicas utilizadas, como os percentis 90 e 95 para os dados diários, percentil 90 para os dados agrupados em pêntadas, os dados do SDII e dos R50 e 70, nos índices do ETCCDI, demonstrando que apesar de serem recortes diferentes do mesmo conjunto de dados, observa-se alguns indícios, ainda que pequenos, de alteração nas precipitações intensas. 


\section{Capítulo 6: Entre os elementos do risco: a suscetibilidade ambiental; vulnerabilidade social e os impactos das chuvas}

O município de Juiz de Fora, localizado no domínio dos “mares de morros” (Ab’ Sáber, 2003), com uma topografia típica de morros, que através destes drenam diversos canais fluviais em direção ao rio Paraibuna, tributário da bacia do rio Preto e Paraíba do Sul. No perímetro urbano são diversas as situações de sítio urbano que revelam condições de suscetibilidade ambiental à ocorrência de inundações e movimentos de massa.

Dessa forma, com relação à inundação, dos $51,7 \mathrm{~km}^{2}$ de áreas suscetíveis no perímetro urbano, 18,9 km² são ocupadas, ou seja, 36,6\% das áreas suscetíveis as inundações são de alguma forma ocupadas pela área urbana de Juiz de Fora (Quadro 41). Em função das classes de intensidade, as áreas com alta suscetibilidade têm a maior porcentagem de área ocupada, com $8,1 \%$, enquanto que as áreas de baixa e média suscetibilidade tem $6,0 \%$ e 5,8\%, respectivamente.

Quadro 41: Suscetibilidade a inundação por classe, no perímetro urbano de Juiz de Fora.

\begin{tabular}{|c|c|c|c|c|}
\hline \multicolumn{5}{|c|}{ Suscetiblidade a inundação } \\
\hline & \multicolumn{2}{|c|}{ Total } & \multicolumn{2}{c|}{ Edificada } \\
\cline { 2 - 5 } & $\mathrm{Km}^{2}$ & $\%$ & $\mathrm{Km}^{2}$ & $\%$ \\
\hline Área do perímetro urbano $\left(\mathrm{Km}^{2}\right)$ & 429,8 & 100 & 95,6 & 100,0 \\
\hline Baixa suscetibilidade & 9,2 & 2,1 & 5,7 & 6,0 \\
\hline Média suscetibilidade & 16,4 & 3,8 & 5,5 & 5,8 \\
\hline Alta suscetibilidade & 26,2 & 6,1 & 7,7 & 8,1 \\
\hline Área total suscetivel & 51,7 & 12,0 & 18,9 & 36,6 \\
\hline
\end{tabular}

Fonte: CPRM (2014) / Organizado pelo autor.

Além disso, a área total edificada no perímetro urbano de Juiz de Fora que corresponde a 95,6 km² apresenta 18,9 km² em áreas suscetíveis, em diferentes graus, a inundação. No entanto a suscetibilidade varia espacialmente dentro do perímetro urbano, com isso, cada região de planejamento (RP) terá um cenário deferente com relação à inundação (Figura 58).

Todos os cursos d'água no perímetro urbano apresentam suscetibilidade à inundação, mesmo com as diversas intervenções de traçado e calha, é comum que os córregos, quando demandados por altos totais de precipitação extravasem seus leitos impactando a circulação viária e os habitantes do entorno. Na sequência serão discutidos os casos para cada região de planejamento, com um maior detalhamento das informações. 
Figura 58: Carta de suscetibilidade a inundação no perímetro urbano de Juiz de Fora

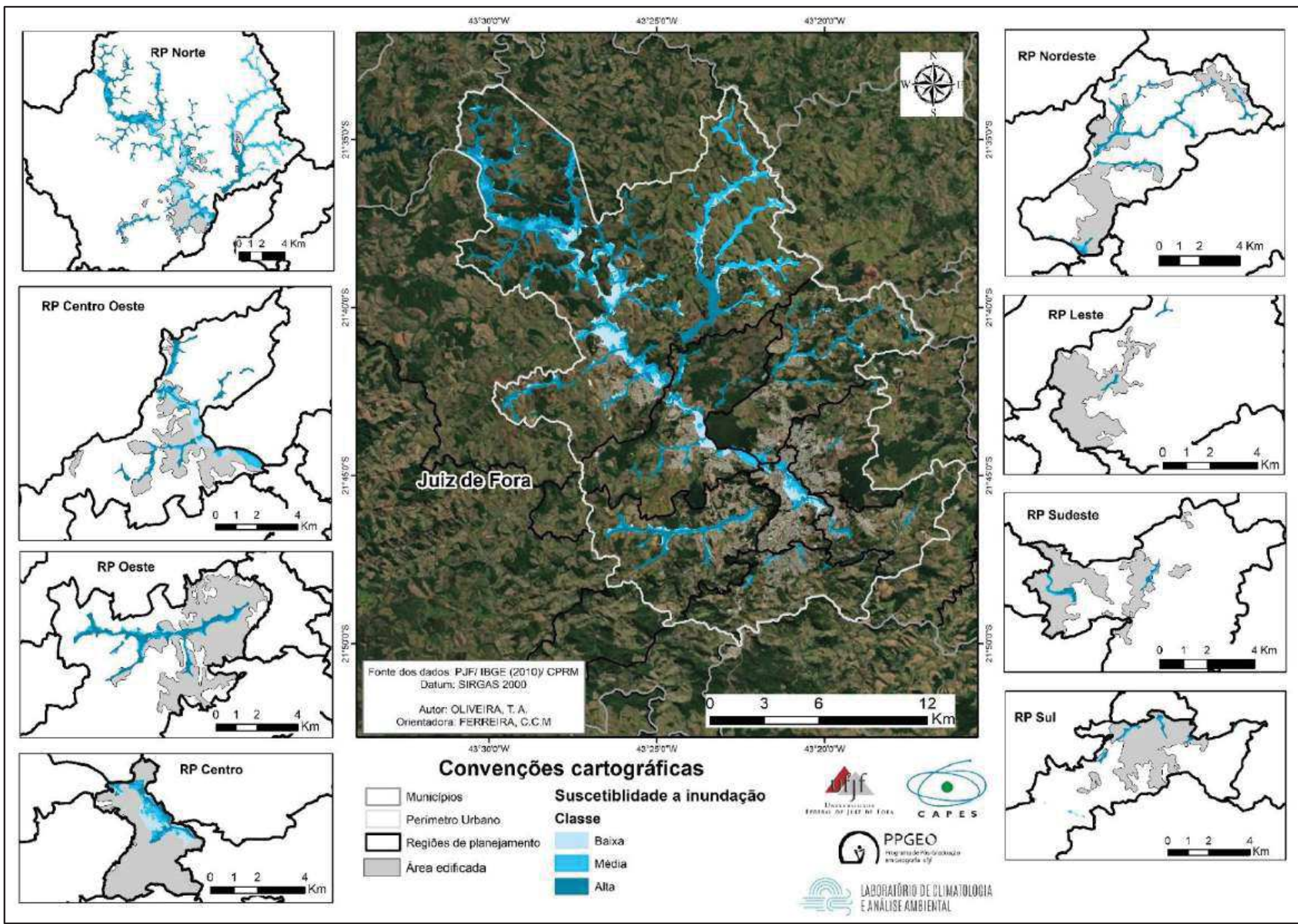


Fonte: Adaptado do CPRM, 2014.

Com relação aos movimentos de massa, toda área do perímetro urbano encontra-se de alguma forma suscetível a este tipo de evento, dessa forma toda área edificada foi considerada suscetível a movimentos de massa (Figura 59). Na área edificada, 51\% encontra-se em áreas de baixa suscetibilidade, $33,5 \%$ com média suscetibilidade e 15,5\% em áreas com alta suscetibilidade (Quadro 42). Considerando que as áreas com baixa suscetibilidade as ocorrências são praticamente desprezíveis (BITAR, 2014).

Quadro 42: Suscetibilidade a movimentos de massa, por classe, no perímetro urbano de Juiz de Fora.

\begin{tabular}{|c|c|c|c|c|}
\hline \multicolumn{5}{|c|}{ Suscetiblidade a movimentos de massa } \\
\hline & \multicolumn{2}{|c|}{ Total } & \multicolumn{2}{c|}{ Edificada } \\
\cline { 2 - 5 } & $\mathrm{Km}^{2}$ & $\%$ & $\mathrm{Km}^{2}$ & $\%$ \\
\hline Área do perímetro urbano $\left(\mathrm{Km}^{2}\right)$ & 429,8 & 100 & 95,6 & 100,0 \\
\hline Baixa suscetibilidade & 138,7 & 32,3 & 48,8 & 51,0 \\
\hline Média suscetibilidade & 148,8 & 34,6 & 32,0 & 33,5 \\
\hline Alta suscetibilidade & 142,4 & 33,1 & 14,8 & 15,5 \\
\hline Área total suscetivel & 429,8 & 100,0 & 95,6 & 22,2 \\
\hline
\end{tabular}

Fonte: CPRM (2014) / Organizado pelo autor.

Diversos trabalhos investigaram a suscetibilidade aos movimentos de massa na cidade de Juiz de Fora. Zaidan e Fernandes (2009) avaliaram a ocorrência de escorregamentos na bacia do córrego Independência; Pechincha (2014) avaliou a qualidade ambiental associada a movimentos de massa na bacia do córrego Matirumbide, na RP Leste; Menon Júnior (2016) estudou a bacia do córrego do Young; Costa (2019) avaliou a relação entre expansão urbana e suscetibilidade a escorregamentos na bacia do córrego Tapera.

Zaidan e Fernandes (2009) investigaram e modelaram a suscetibilidade a escorregamentos na bacia do córrego Independência, localizada na RP Centro, concluíram que 19,2\% da área localizam-se em situação de instabilidade. Estas áreas estão localizadas no setor Oeste (próximo ao morro do Imperador), sul (no morro do Teixeiras) e leste da bacia (na área da RU Granbery).

Pechincha (2014) avaliou as condições de qualidade ambiental e suscetibilidade a escorregamentos na bacia do córrego Matirumbide, localizada na RP Leste, e considerou que as áreas com maior número de atributos negativos observam alto risco a escorregamentos associados à alta densidade populacional, ausência de espaços livres e condições de baixa renda. 
Menon Junior (2016) modelou o risco a ocorrência de escorregamentos na bacia do córrego do Young, localizada na RP Leste da cidade, e destaca a partir de um levantamento histórico $(1968 ; 1983 ; 2010)$ que a ocupação tem aumentado nas áreas com declividade superior a $30^{\circ}$. Além disso a classe de alto risco a escorregamento aumentou ao longo dos levantamentos.

Costa (2019) avaliou a evolução da mancha urbana $(1968,1983,2000,2007)$ e a ocorrência de escorregamentos na bacia do córrego Tapera, localizada na RP Nordeste da cidade. Assim como Menon Júnior (2016), observou um aumento na ocupação de áreas com declividade superior a $30 \%$, e da mesma forma observa um aumento nas áreas classificadas com alto risco a escorregamento. 
Figura 59: Carta de suscetibilidade a movimentos de massa no perímetro urbano de Juiz de Fora.

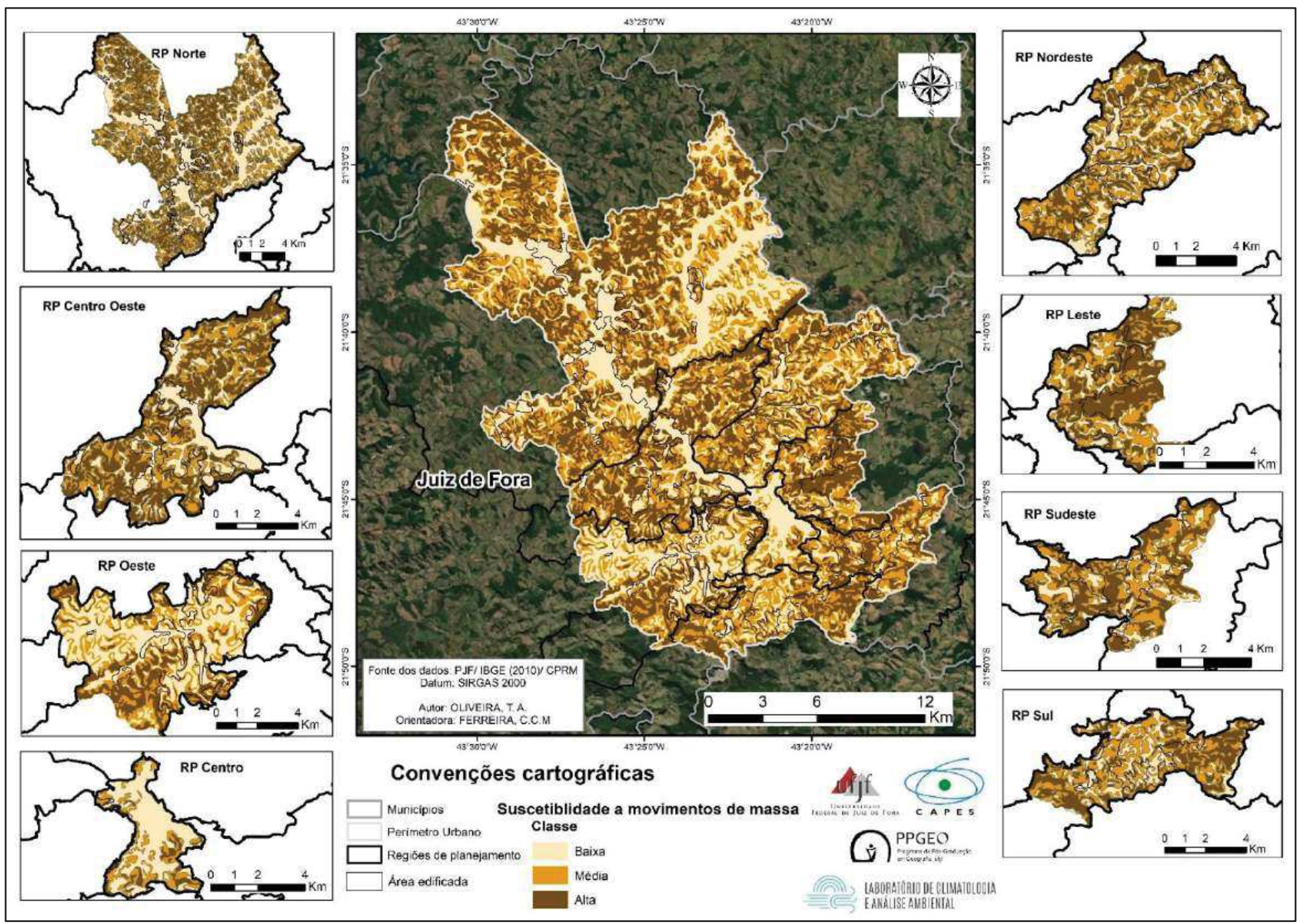


Fonte: Adaptado do CPRM, 2014.

A área edificada em situação de alta suscetibilidade aos movimentos de massa é maior nas RP Leste e Sudeste, onde superam os 20\% do total, seguida pela RP Nordeste com 17,8\%. As outras cinco RP tem uma menor proporção de ocupação nessa classe, sendo que nessas a ocupação é maior nas classes com baixa suscetibilidade (Quadro 43).

Quadro 43: Percentagem de área edificada por classe de suscetibilidade aos movimentos de massa, por região de planejamento

\begin{tabular}{|c|c|c|c|}
\hline \multicolumn{4}{|c|}{ Área Edificada (\%) x Classes de suscetibilidade } \\
\hline Região de Planejamento & Baixa & Média & Alta \\
\hline Norte & 67,7 & 21,8 & 10,5 \\
\hline Nordeste & 42,6 & 39,5 & 17,8 \\
\hline Centro- Oeste & 59,4 & 26,8 & 13,7 \\
\hline Leste & 23,2 & 39,9 & 36,7 \\
\hline Sudeste & 30,2 & 48,4 & 21,1 \\
\hline Sul & 39,0 & 47,4 & 13,5 \\
\hline Oeste & 55,2 & 32,9 & 11,8 \\
\hline Centro & 61,0 & 27,7 & 11,2 \\
\hline
\end{tabular}

Fonte: CPRM (2014) / Organizado pelo autor.

Em função das condições de suscetibilidade aos movimentos de massa e os processos históricos de ocupação do município, as áreas edificadas sempre estiveram próximas aos canais fluviais, que foram profundamente alterados por obras de engenharia, com isso as condições de alta suscetibilidade inundação são comuns em todas as RPs, com maior proporção na RP Norte e menor na RP Leste (Quadro 44).

Com isso, há que se considerar que normalmente as áreas com baixa suscetibilidade aos movimentos de massa estão associadas às áreas de planície e consequentemente com alguma suscetibilidade à inundação. 
Quadro 44: Percentagem de área edificada por classe de suscetibilidade à inundação, por região de planejamento

\begin{tabular}{|c|c|c|c|}
\hline \multicolumn{4}{|c|}{ Área Edificada (\%) x Classes de suscetibilidade } \\
\hline Região de Planejamento & Baixa & Média & Alta \\
\hline Norte & 12,4 & 15,7 & 45,2 \\
\hline Nordeste & 1,2 & 4,4 & 21,4 \\
\hline Centro- Oeste & 10,4 & 9,3 & 15,1 \\
\hline Leste & 0,0 & 0,0 & 1,2 \\
\hline Sudeste & 0,0 & 2,1 & 5,2 \\
\hline Sul & 0,0 & 1,3 & 4,7 \\
\hline Oeste & 0,7 & 2,6 & 16,2 \\
\hline Centro & 6,6 & 7,0 & 6,2 \\
\hline
\end{tabular}

Fonte: CPRM (2014) / Organizado pelo autor.

Volochko (2018) destaca a relação entre a natureza na/da cidade e a produção do espaço, sendo que cada vez mais esse aspecto configura um elemento de valor de troca na terra urbana, fazendo com que aspectos como a suscetibilidade sejam considerados na produção do espaço.

A relação entre a suscetibilidade aos movimentos de massa e vulnerabilidade nas RPs Leste e Sudeste é maior e também são estas que observam um maior número de setores com alta e altíssima vulnerabilidade social. Esta situação revela como a produção do espaço e a produção do risco são materializados na cidade.

\section{A produção do espaço e a vulnerabilidade social em Juiz de Fora}

Juiz de Fora, quarta cidade mais populosa do estado de Minas Gerais, revela profundas desigualdades sociais, que associadas a um quadro ambiental complexo produz diversos impactos associados aos eventos pluviométricos extremos.

A população de Juiz de Fora em 2010 era de 503443 na área urbana, sendo que as regiões urbanas mais populosas eram o Centro (55) e Benfica (3), além de outras RUs como Santa Cruz (4), Ipiranga (37), São Mateus (40), Progresso (73). As RUs com os menores totais populacionais no perímetro urbano são as Represa (2), Remonta (7), São Dimas (14), Nova Califórnia (30) e Salvaterra (33), com menos de 1000 habitantes (Figura 62).

A taxa de crescimento populacional por região de planejamento demonstra que o crescimento tem se direcionado para as RPs Oeste, Norte e Sul, principalmente, sendo que na RP Oeste a taxa de crescimento chega a 99\%, denotando um intenso crescimento populacional na "cidade alta" (Figura 60 e 62). 
Figura 60: Taxa de crescimento populacional (\%) no período de 1991-2010.

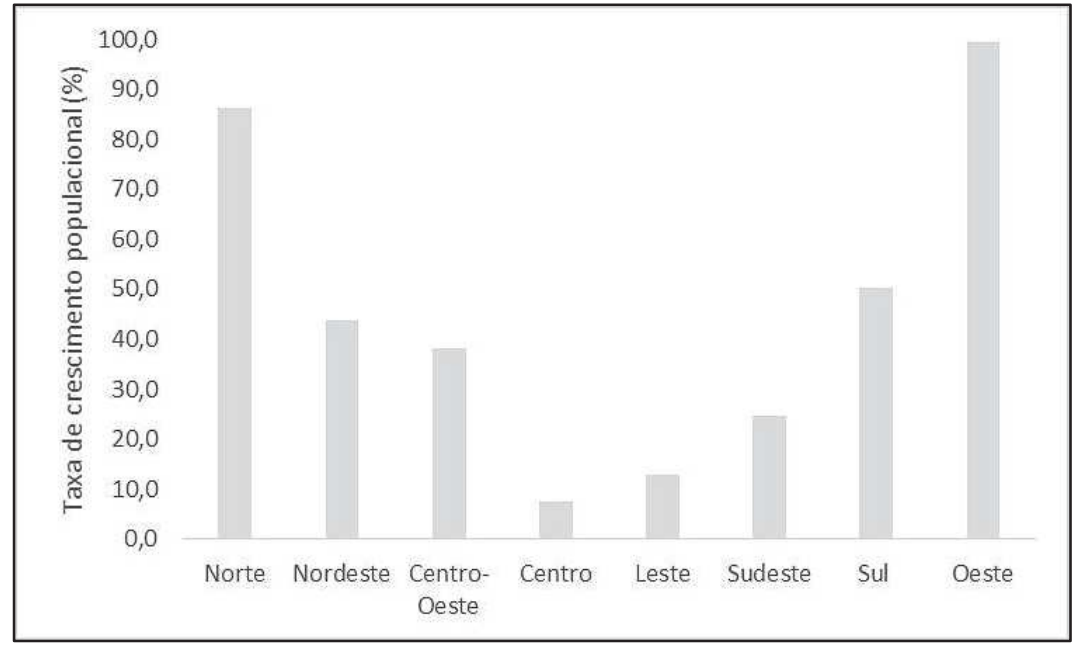

Fonte: IBGE/PJF.

As regiões urbanas com maior taxa de crescimento na RP Oeste são Morro do Imperador (23), Aeroporto (32), Martelos (27), São Pedro (28) e Novo Horizonte (31), sendo que em todas essas a taxa de crescimento supera os 100\%, e ultrapassa os 300\% nas RUs Morro do Imperador e Aeroporto.

O PDDU (2004) trazia dentre as proposições, o direcionamento de vetores de crescimento para os setores Norte, Nordeste, Oeste e Sul do perímetro urbano (Figura 61), o que de fato se consolidou, conforme já destacado, sendo que estas quatro regiões de planejamento observaram as maiores taxas de crescimento populacional no município.

Figura 61: Vetores de crescimento disposto no Plano Diretor

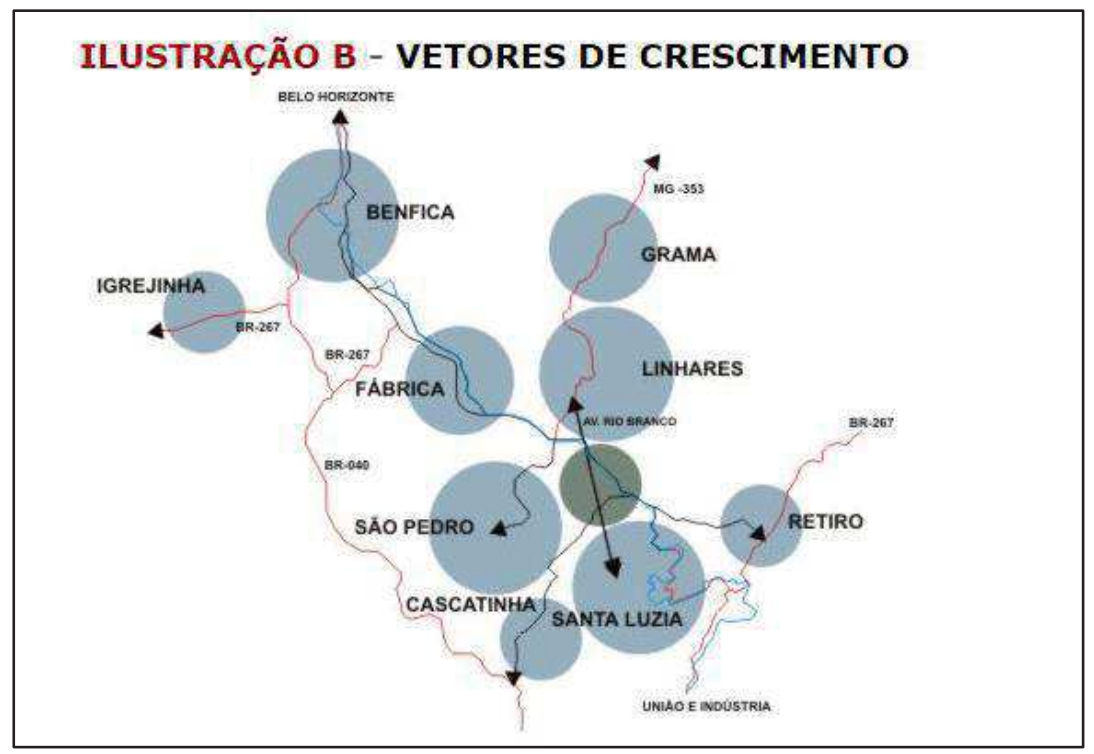

Fonte: PDDU, 2004.

Essa condição reforça o que já fora apontado por Rodrigues (2013), Geraldo (2011, 2014) com o crescimento da mancha urbana no setor oeste do município. Tasca (2010) 
argumenta que a rodovia BR 040, a UFJF, o Shopping Independência, dentre outros empreendimentos favoreceram e incentivaram o crescimento populacional na RP Oeste de Juiz de Fora.

Outros setores como o Norte e Nordeste se apresentam com a maior disponibilidade territorial do município (PDDU,2004), com as maiores proporções da área urbana municipal sem ocupação, ainda que boa parte sejam de áreas da União, utilizadas pelo Exército Brasileiro, na região urbana Remonta (7) (Figura 62). 
Figura 62: População total em Juiz de Fora- 1991-2010 e taxa de crescimento nesse período

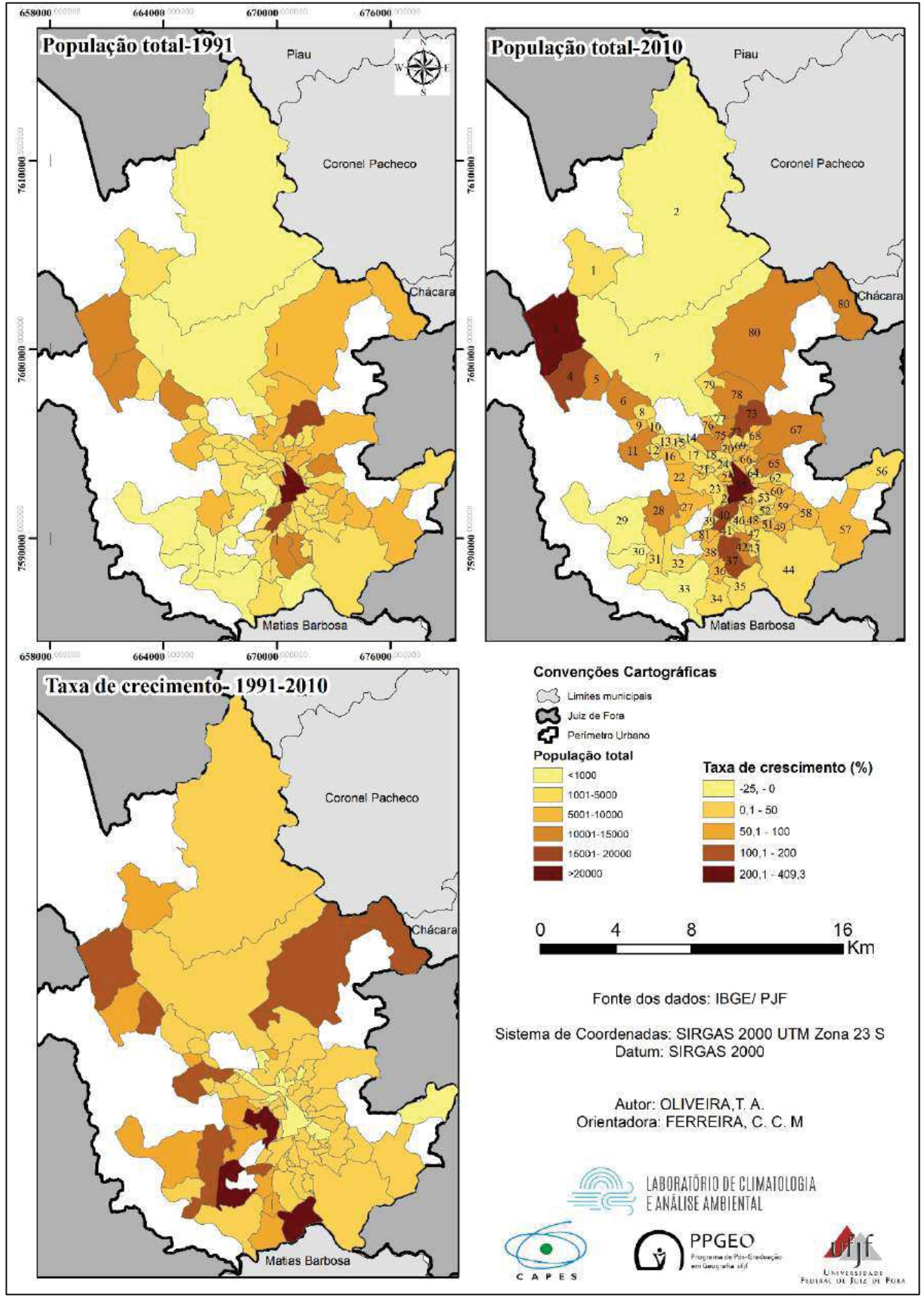

Fonte: Organizado pelo autor

Conforme coloca Rodrigues (2005), é necessário salientar que essa dinâmica de crescimento e produção do espaço na cidade não se dá de maneira aleatória, muito pelo 
contrário, está diretamente atrelada aos interesses de pessoas e instituições. Logo essa produção diferenciada do espaço é resultado de diversos conflitos de interesses.

Ainda de acordo com Rodrigues (2005) processos como o incentivo a ocupações de novas áreas, pelo poder público, através da instalação de infraestruturas que possibilitam a instalação de novos empreendimentos, ou mesmo quando esses investimentos ocorrem para a revitalização de determinado espaço, ocorre que "a congruência de todos esses fatores interfere no dinamismo e direcionamento dos fluxos migratórios internos e, por conseguinte, terá repercussões na demanda e preço do solo urbano" (RODRIGUES, 2005, p. 66).

Desde os anos 80, com a implementação da EMCASA, após o BNH, que fora extinto em 1986, diversos empreendimentos imobiliários foram alocados na cidade (SILVA, 2014), seguindo apenas os interesses imobiliários, expandiram a mancha urbana na cidade em busca de terrenos mais baratos.

Com isso, diversos conjuntos de habitação popular foram construídos, associados ao crescimento populacional nas RP Norte e Centro-Oeste, sendo considerado por Silva (2014) um cinturão habitacional, com onze unidades habitacionais. Essa condição "fortalece a tese em torno da questão da habitação, que a coloca como uma necessidade em conflito: entre a propriedade privada e o direito à cidade pelos grupos e classes sociais menos favorecidos" (SILVA, 2014, p. 65).

Geraldo (2014) discute o crescimento da cidade entorno do que Silva (2014) chama de Cinturão da BR-040, caracterizado pela implementação dos conjuntos habitacionais, "entre 1970 e 2010, constatamos que 55,12\% dos loteamentos foram situados nas cinco RPs que formam o cinturão urbano, sobretudo São Pedro (RP OESTE) e Benfica (RP NORTE) com 25,31\% e 23,67\% dos loteamentos do período, respectivamente" (GERALDO, 2014, p. 183).

A cidade de Juiz de Fora teve sobretudo a partir dos anos 1980-90, um espaço produzido através dos conjuntos habitacionais, sejam eles loteamentos fechados de alto padrão, que no caso se posicionam sobretudo na RP Oeste da cidade, sejam também os conjuntos habitacionais provenientes de políticas habitacionais que se posicionam nas franjas da cidade, sobretudo nas RPs Norte, Centro-Oeste e Sul.

Albertoni (2014) destaca o mosaico que tem se tornado a RP Oeste, com a conjugação de loteamentos de alto padrão, sobretudo nas RUs Morro do Imperador e Aeroporto. Nesse contato entre as RPs Oeste e Centro-Oeste, em áreas de baixa valorização dos terrenos tem se localizado diversos conjuntos habitacionais, como o Jardim Caiçaras, o loteamento Nova 
Germânia, Parque das Águas I e II. Esse cenário pode ser visualizado a partir do IVS (Índice de Vulnerabilidade Social), no qual revela esta desigualdade socioeconômica na RP Oeste.

Os loteamentos provenientes de políticas habitacionais, como o Jardim Caiçara, localizado na RU São Pedro, está localizado na borda de uma reserva ambiental municipal (Reserva Santa Cândida). Albertoni (2014) destaca que "há a instalação de conjuntos habitacionais sem infraestrutura básica e com a dotação precária, paulatina e desigual, perpetua as condições de desigualdades urbanas e segregação espacial” (ALBERTONI, 2014, p. 77).

Por outro lado loteamentos fechados de alto padrão contracenam com os loteamentos populares, divididos por muros altos. Além das técnicas construtivas diferenciadas nesses dois grupos, visualiza-se nos loteamentos fechados, uma preservação da cobertura vegetal, baixa densidade construtiva, o que repercute nas condições microclimáticas.

Estes exemplos reforçam a ideia colocada por Albertoni (2014)

O quanto o urbano é apropriado pelos agentes detentores do capital e, consequentemente, do solo urbano, o que gera intensa desigualdade na distribuição dos recursos e da população, onde as áreas que possuem maior valor, pela presença de infraestrutura ou de amenidades, são apropriadas e o processo de reprodução do espaço se dá de forma planejada e induzida pelos promotores imobiliários e pelo Estado. Nas áreas onde não há o interesse do capital, o valor do solo urbano é mais baixo e o processo de reprodução do espaço ocorre de forma espontânea (ALBERTONI, 2014, p. 85).

A partir do índice de vulnerabilidade social é possível ter um panorama de como essa desigualdade social se expressa espacialmente no perímetro urbano do município. Visualizando quantitativamente, em função do número de setores censitários, observa-se que em algumas regiões de planejamento, como a Norte, Sudeste e Sul, mais de $40 \%$ dos setores estão em condição de alta ou altíssima vulnerabilidade social. Sendo que o quadro se inverte nas regiões de planejamento Centro, Oeste e Nordeste, nas quais os indicadores demonstrem mais que 40\% dos setores como baixa ou baixíssima vulnerabilidade social (Figura 63).

A região de planejamento Centro apesar de apresentar mais de $80 \%$ de sua população em condições de baixíssima ou baixa vulnerabilidade social, ainda apresenta setores em condição se alta ou altíssima vulnerabilidade social, como nas regiões urbanas Santa Cecília (41) e Dom Bosco (39). Sendo que essas regiões urbanas estão alocadas em áreas de declividade mais elevada e com alta suscetibilidade a movimentos de massa. 
Figura 63: Percentual de setores por classe de vulnerabilidade social nas regiões de planejamento

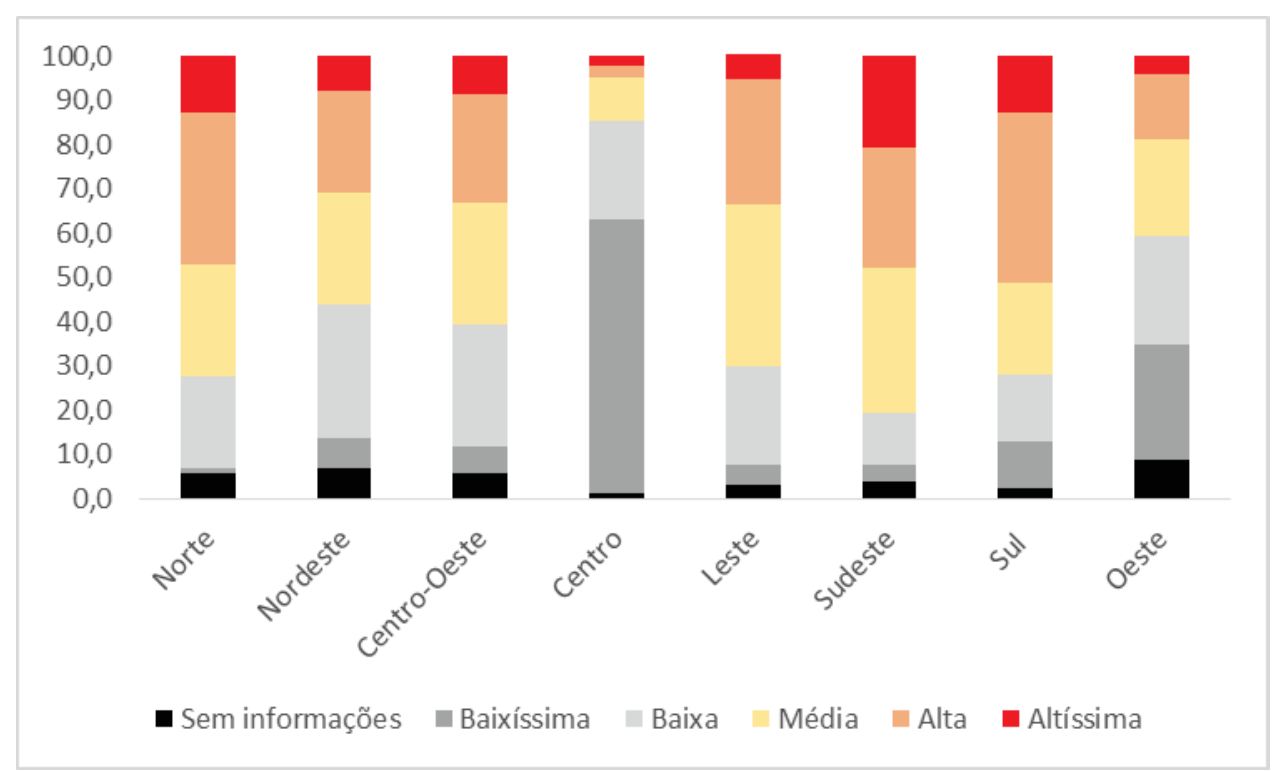

Fonte: Organizado pelo autor.

As outras RPs Norte, Leste, Sudeste, Sul, revelam uma maior proporção de setores com maior vulnerabilidade social, sendo que menos de $30 \%$ dos setores apresentam condições de baixa ou baixíssima vulnerabilidade social. Nessas RPs as áreas com baixa e baixíssima vulnerabilidade estão localizadas em setores de ocupação mais antiga e consolidada, sobretudo nas planícies dos córregos por onde a expansão se deu de maneira inicial (Figura 64).

A RP Nordeste tem uma condição de menor vulnerabilidade social nos setores mais próximos ao Centro, nas RUs Santa Terezinha (75) e Bandeirantes (78), no entanto destaca-se áreas de alta vulnerabilidade social nas RUs Grama (80), Granjas Bethânia (79). Na RP Centro Oeste, a situação se assemelha em que as RUs ocupadas no eixo das avenidas JK como a RU Francisco Bernardino (11), e outras que ocupam sobretudo áreas de maior declividade tem condição de alta e altíssima vulnerabilidade social, como na RU Jardim Natal (9).

Figura 64: Índice de vulnerabilidade social no perímetro urbano de Juiz de Fora. 

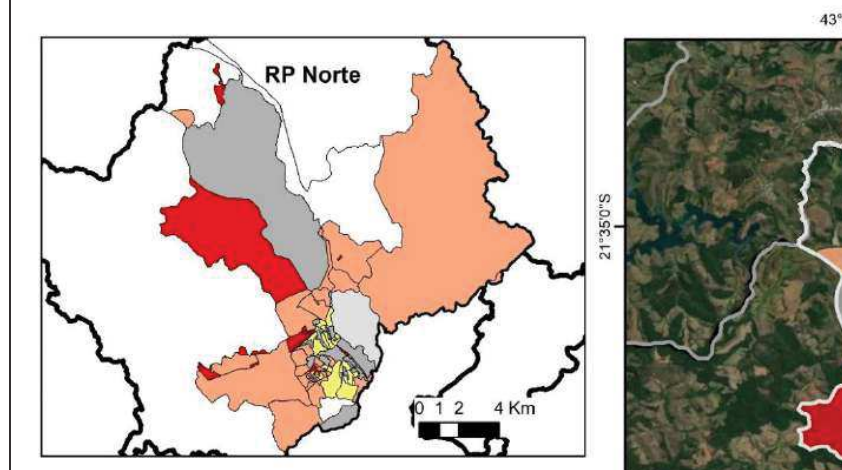

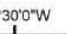

$4^{4} \cdot 200^{\circ} \mathrm{W}$
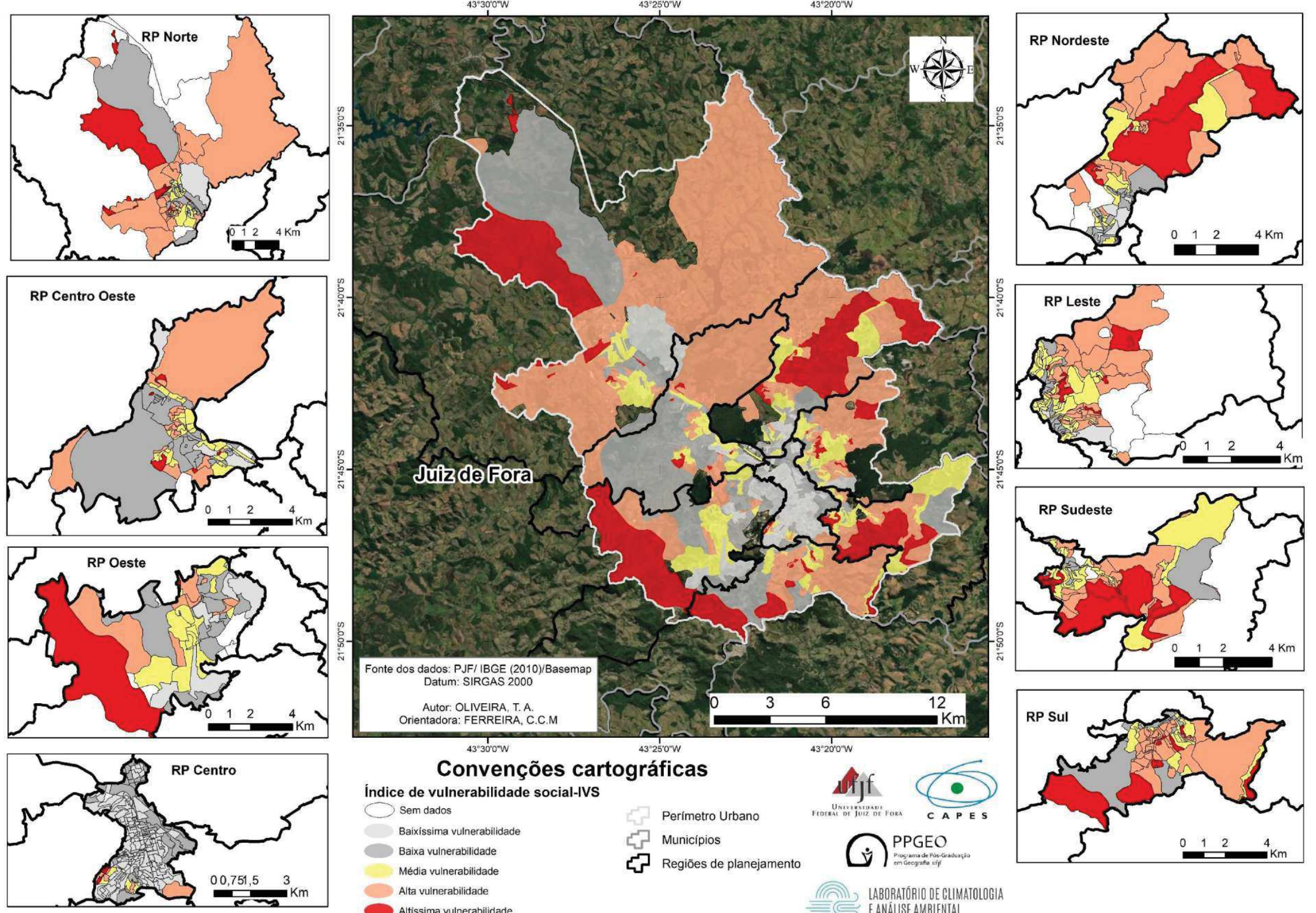

Média vulnerabilidace

Alta vulnerabilidade

Regiões de planejamento

LaboRatónII OE GLIMATOLOCIA

Fonte: Organizado pelo autor. 


\section{A suscetibilidade ambiental e as regiões de planejamento}

\section{A região de planejamento Sul}

Localizada no limite do município com Matias Barbosa e em contato com a RP Centro, a RP Sul tem uma ocupação antiga, tendo o bairro de Santa Luzia (42), considerado o mais importante da Região de Planejamento Sul (PDDU, 2004). Desenvolveu-se a partir do desmembramento de uma fazenda que havia na região, a Fazenda Cachoeirinha, daí em diante se consolida, principalmente como um bairro residencial e pelas atividades de comércio (Figura $65)$.

Figura 65: Bairro Santa Luzia em dois momentos, durante o loteamento na década de 1950 (a) e na atualidade (b)

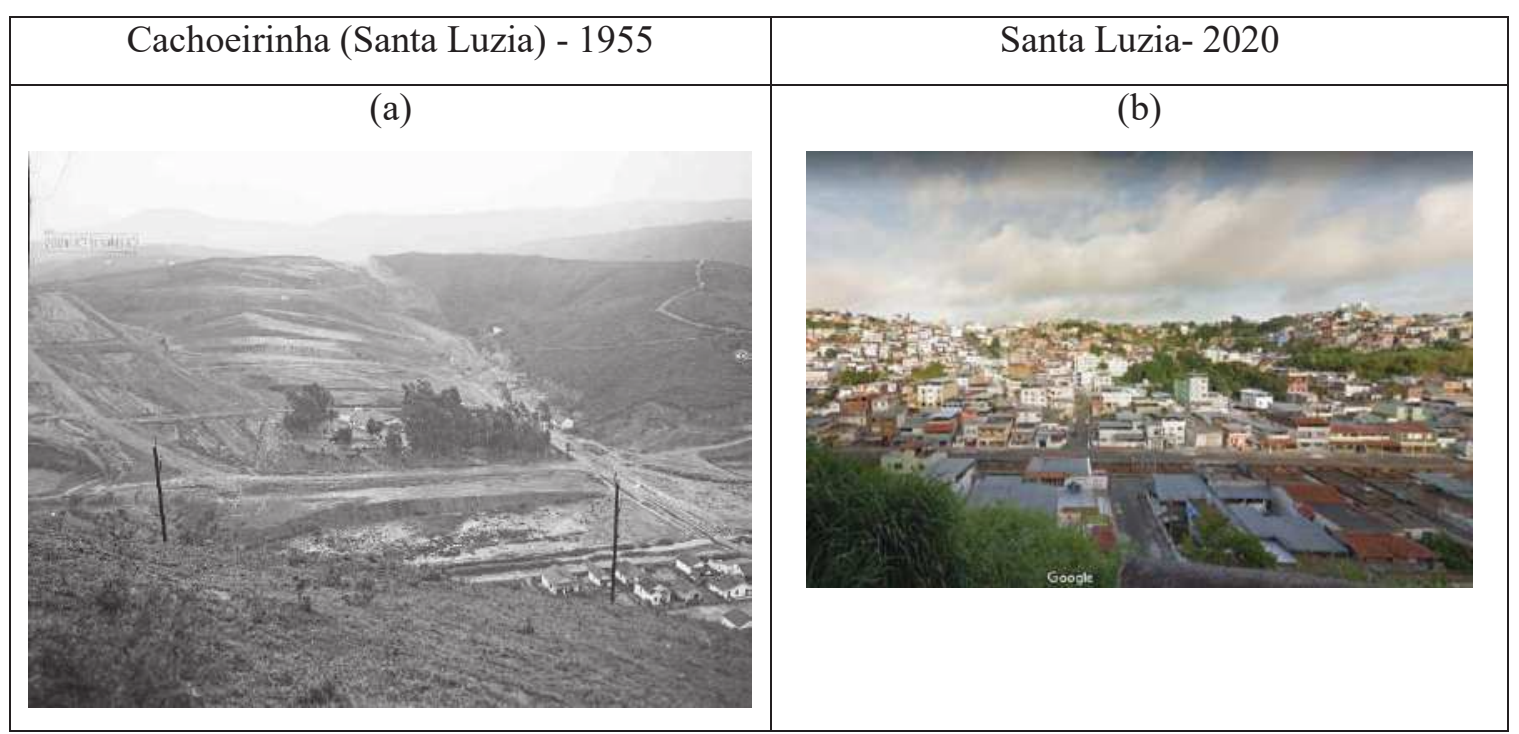

Fonte: Blog Maria do Resguardo e Google Maps Street View.

A partir do bairro Santa Luzia, outros se organizaram na RP Sul, principalmente para uso residencial, sendo este mais adensando quanto mais próximo ao centro, e mais rarefeito nos limites do município. Destaca-se o crescimento populacional da RP no período de 1991 a 2010 (Figura 66), de mais de 20 mil habitantes, com um aumento populacional de 50,3\%, nos últimos anos tem-se observado a ocupação associada ao programa habitacional do Minha Casa Minha Vida, impactando no aumento populacional da RP, sobretudo na região urbana São Geraldo (35).

O crescimento populacional se deu de maneira mais intensa nas RU's São Geraldo (35), Cascatinha (81) e Teixeiras (38), com 409,3\%, 129,9\% e 83,5\%, respectivamente (Figura 62). Na RU São Geraldo (35) os Conjuntos Habitacionais do programa Minha Casa Minha Vida 
refletem nesse incremento populacional, enquanto que nas RUs Cascatinha (81) e Teixeiras (38) o processo de verticalização intensificou a ocupação nessas RUs, associadas a setores com maiores rendimentos familiares.

Figura 66: População total na RP Sul- 1991-2010.

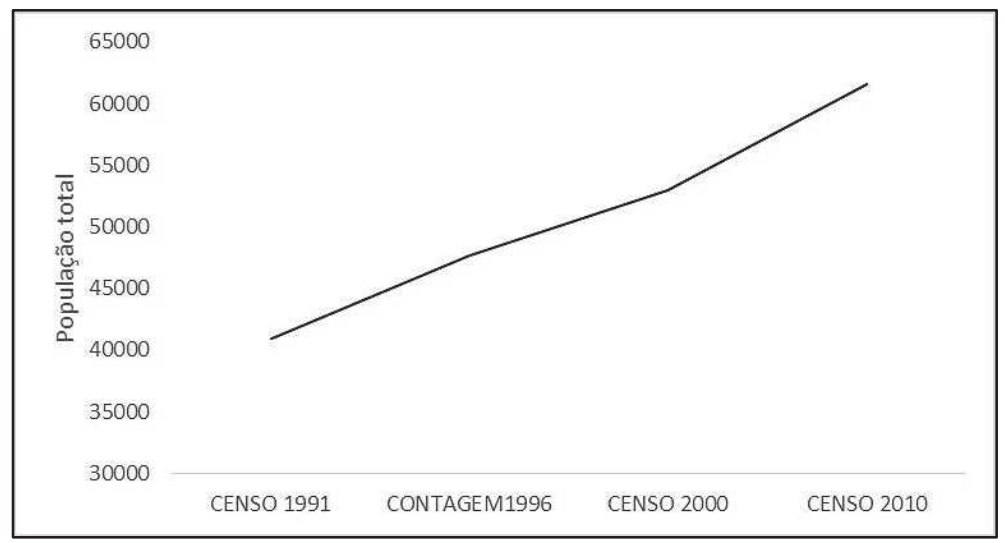

Fonte: PJF. Organizado pelo autor.

No setor dos bairros Cascatinha (81) e Teixeiras (38) a intensificação da ocupação se deu por motivos diferentes, sendo que o desenvolvimento da RP Oeste, no contato com estas regiões urbanas, e o eixo formado pelas avenidas Paulo Japiassu Coelho e Deusdeth Salgado influenciaram em um dinamismo econômico nessas regiões urbanas. A construção do Shopping Independência foi um fator importante para esse processo, como discutido por Rodrigues (2013).

De acordo com Tasca (2010) a população de baixa renda é majoritária na RP Sul, sendo que em 1991, 68,5\% dos chefes de família tinha rendimento inferior a 2 salários mínimos. Com base no Índice de vulnerabilidade social-IVS calculado para os dados de 2010, a RP ainda apresentava mais de $50 \%$ dos setores censitários em situação de alta ou altíssima vulnerabilidade social.

Com relação aos movimentos de massa, a carta de suscetibilidade apresenta que a maior área da RP Sul encontra-se na classe de média suscetibilidade, seguida pelas áreas de alta e baixa suscetibilidade. A área ocupada, nessa RP, encontra-se em maior proporção nas áreas de baixa e média suscetibilidade, no entanto $13,5 \%$ encontra-se em área de alta suscetibilidade (Figura 67 e Quadro 45). 
Quadro 45: Suscetibilidade a movimentos de massa, por classe, na região de planejamento Sul.

\begin{tabular}{|c|c|c|c|c|}
\hline \multicolumn{3}{|c|}{ Suscetiblidade a movimentos de massa } \\
\cline { 2 - 5 } & \multicolumn{2}{|c|}{ Total } & \multicolumn{2}{c|}{ Edificada } \\
\cline { 2 - 5 } & $\mathrm{Km}^{2}$ & $\%$ & $\mathrm{Km}^{2}$ & $\%$ \\
\hline Área da RP $\left(\mathrm{Km}^{2}\right)$ & 28,7 & 100 & 9,2 & 100 \\
\hline Baixa suscetibilidade & 7,3 & 25,5 & 3,6 & 39,0 \\
\hline Média suscetibilidade & 12,4 & 43,1 & 4,4 & 47,4 \\
\hline Alta suscetibilidade & 9,0 & 31,4 & 1,2 & 13,5 \\
\hline
\end{tabular}

Fonte: CPRM (2014) / Organizado pelo autor.

Com relação à taxa de ocupação visualiza-se que 49\% da área de baixa suscetibilidade é ocupada, seguida por 35,2\% nas áreas de média e 13,8\% nas áreas de alta suscetibilidade (Quadro 46). Há que se considerar que as áreas de baixa suscetibilidade a movimentos de massa estão associadas às planícies do córrego Ipiranga e com isso representam alta suscetibilidade às inundações (Figura 67).

Quadro 46: Percentagem das áreas suscetíveis a movimentos de massa ocupadas.

\begin{tabular}{|c|r|}
\hline \multicolumn{2}{|c|}{ Ocupação em áreas suscetíveis } \\
\hline Baixa suscetibilidade & 49,1 \\
\hline Média suscetibilidade & 35,2 \\
\hline Alta suscetibilidade & 13,8 \\
\hline
\end{tabular}

Fonte: CPRM (2014) / Organizado pelo autor.

A suscetibilidade à inundação na região de planejamento (RP) Sul está associada ao córrego Ipiranga, canalizado desde os anos 70, frequentemente figura em eventos de inundação nos bairros Ipiranga e Santa Luzia. As áreas suscetíveis às inundações correspondem a 2,5\% da área total da RP, sendo que 6\% da área edificada encontra-se em áreas suscetíveis (Quadro 47).

Quadro 47: Suscetibilidade a inundação por classe, na região de planejamento Sul

\begin{tabular}{|c|c|c|c|c|}
\hline \multicolumn{4}{|c|}{ Suscetiblidade a inundação } \\
\hline & \multicolumn{2}{|c|}{ Total } & \multicolumn{2}{c|}{ Edificada } \\
\cline { 2 - 5 } & $\mathrm{Km}^{2}$ & $\%$ & $\mathrm{Km}^{2}$ & $\%$ \\
\hline Área da RP $\left(\mathrm{Km}^{2}\right)$ & 28,7 & 100 & 9,2 & 100 \\
\hline Baixa suscetibilidade & 0,0 & 0,0 & 0,0 & 0,0 \\
\hline Média suscetibilidade & 0,20 & 0,7 & 0,12 & 1,3 \\
\hline Alta suscetibilidade & 0,51 & 1,8 & 0,43 & 4,7 \\
\hline
\end{tabular}

Fonte: CPRM (2014) / Organizado pelo autor. 
Figura 67: Carta de suscetibilidade a movimentos de massa e inundações, com base na CPRM (2014) na RP Sul

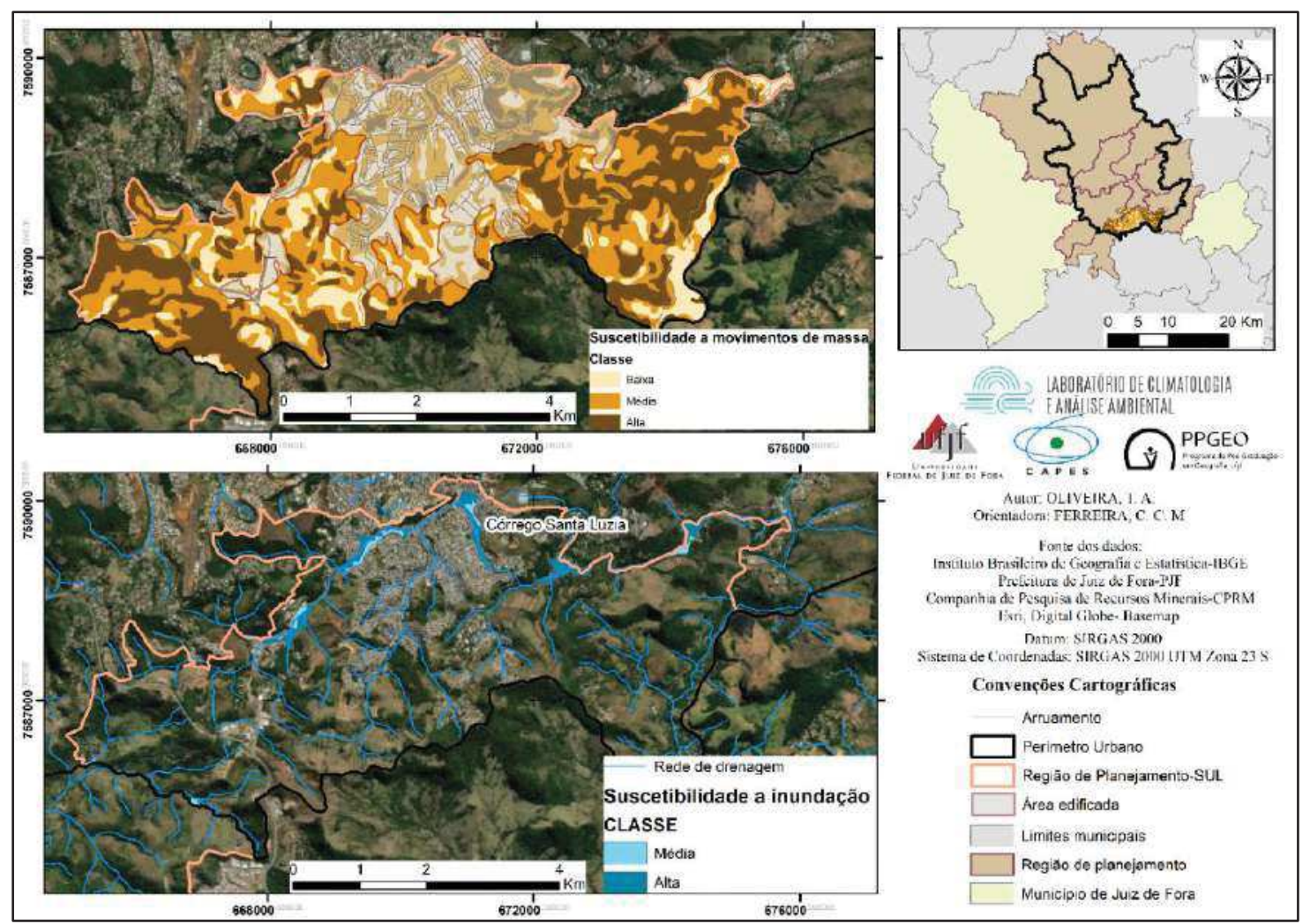

Fonte: CPRM (2014). Organizado pelo autor.

Com relação às áreas edificadas, observa-se que as áreas com alta suscetibilidade à inundação é $84 \%$ ocupada, já as áreas com média suscetibilidade têm $60 \%$ de sua área ocupada (Quadro 48). Dessa forma, a partir da figura 68, é possível observar que desde a canalização do córrego na década de 1980, a ocupação se intensificou nas margens do córrego, sobretudo nas áreas de alta suscetibilidade.

Quadro 48: Porcentagem das áreas suscetíveis a inundação, ocupadas.

\begin{tabular}{|c|c|}
\hline \multicolumn{2}{|c|}{ Ocupação em áreas suscetíveis (\%) } \\
\hline Baixa suscetibilidade & 0 \\
\hline Média Suscetibilidade & 60,0 \\
\hline Alta Suscetibilidade & 84,3 \\
\hline
\end{tabular}

Fonte: CPRM (2014) / Organizado pelo autor.

Exemplo da ocupação em áreas com alta suscetibilidade, observa-se a região urbana Santa Luzia (42), drenada pelo córrego Ipiranga, que fora canalizado ainda nos anos 70 e com a intensificação da ocupação no seu entorno figura como uma das áreas com alta suscetibilidade a inundação (Figura 68). 
Figura 68: Comparativo da ocupação no bairro Santa Luzia, às margens do córrego Ipiranga (indicado pela seta vermelha) em 1980-2020

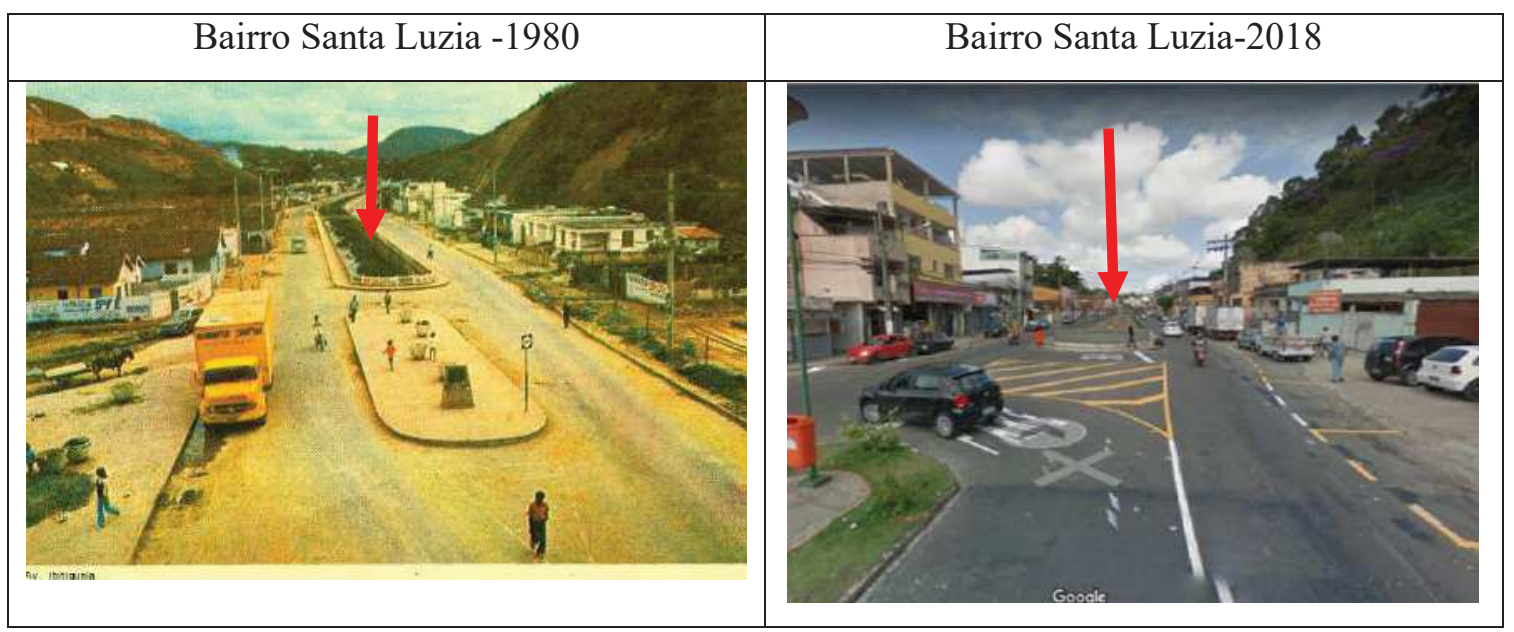

Fonte: Blog Maria do Resguardo/ Google Street View

\section{A região de planejamento Centro}

A região de planejamento Centro concentra dezenove regiões urbanas, com total populacional superior a 100 mil habitantes marca a porção de ocupação mais antiga do município. De acordo com o PDDU (2004) a partir dessa RP importantes vias de acesso interligam todos os pontos da cidade. Destaca-se as avenidas Brasil (que margeia rio Paraibuna), Barão do Rio Branco que liga o setor Nordeste ao setor Sul da Cidade, bem como a Av. Itamar Franco (antiga Av. Independência) que conecta o Centro à Cidade Alta (RP Oeste) onde se localiza o campus da UFJF.

Na RP Centro observa-se a menor taxa de crescimento populacional, dentre as RPs, tendo na RU Centro (55) e Poço Rico (53), um decréscimo populacional. Segundo Rodrigues (2005)

O centro urbano passa a desempenhar, cada vez mais, funções comerciais e de serviços, não só básicos, mas cada vez mais especializados e diversificados. Nos poucos terrenos disponíveis, erguem-se prédios somente para fins comerciais e de prestação de serviços, escritórios de empresas etc. (RODRIGUES, 2005, p. 78).

Com isso, cada vez mais são fomentadas atividades comerciais e de serviços na RP Centro, em detrimento dos usos residenciais. Ainda assim, algumas RUs que compõem a RP Centro observam crescimento populacional, os maiores no Paineiras (26), Grambery (54) e Bom Pastor (48), que estão associados ao processo de verticalização que estas RUs têm observado (Figuras 62 e 69). 
Figura 69: População total na RP Centro- 1991-2010.

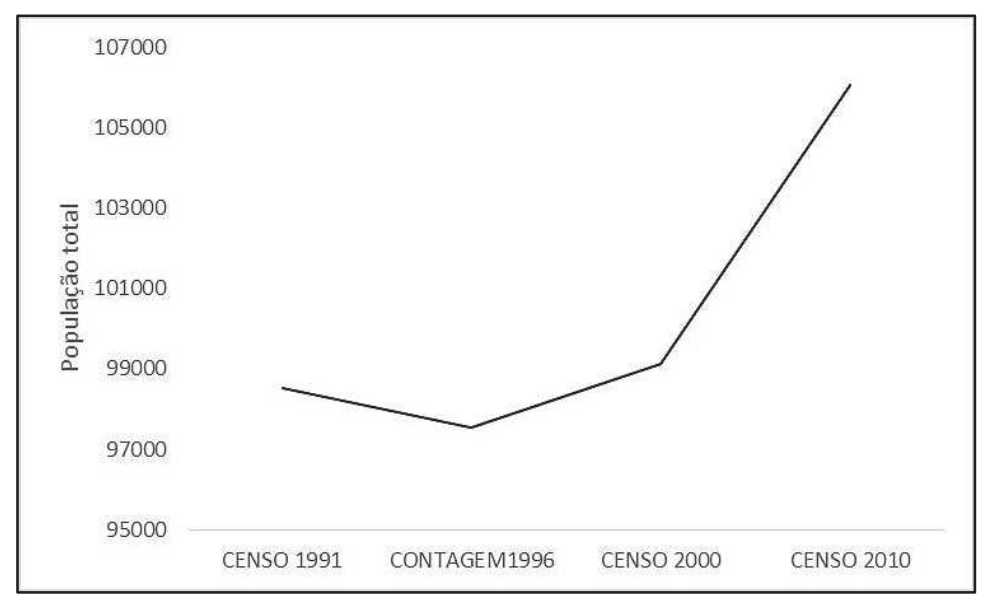

Fonte: PJF. Organizado pelo autor.

Nessa RP se concentram os mais diversos serviços públicos, comerciais e econômicos da cidade. Visto que a cidade se destaca pelas atividades comercias, é na região central que se distribui o comércio varejista, através das diversas ruas e galerias (PDDU, 2004).

A partir desses eixos de tráfego outras regiões urbanas despontam como subcentros a partir de suas atividades comerciais, com isso pode-se destacar as RU São Mateus (40) e Manoel Honório (70), (que se localiza na RP Leste, mas está no contato com o Centro), onde visualizase uma intensificação da verticalização, bem como da instalação de atividades comerciais (PDDU, 2004).

Além disso, na mesma RP é possível visualizar algumas regiões urbanas em condições de alta/altíssima vulnerabilidade social (Figura 64), exemplo das RU's Vila Ozanan (52), Dom Bosco (39) e Santa Cecília (41), com residências de baixo padrão construtivo, deficiências em diversos serviços essenciais. Por outro lado, bairros de baixa/baixíssima vulnerabilidade social, como Jardim Glória (24), Santa Helena (25), Bom Pastor (48), Grambery (54), Paineiras (26), dentre outros, figuram com forte tendência a verticalização e apresentam maior disponibilidade de serviços essenciais.

A região de planejamento Centro congrega a área mais densamente ocupada dentre as RPs. Com relação à suscetibilidade aos movimentos de massa, a maior proporção de área apresenta baixa suscetibilidade, com 59,6\%, enquanto a suscetibilidade média representou $27,8 \%$ da área e a alta suscetibilidade $12,4 \%$ da área (Quadro 49), em função de estar alojada na planície do rio Paraibuna. 
Em função de ser a área mais densamente ocupada, independentemente do grau de suscetibilidade, são amplamente ocupadas. A área edificada congrega praticamente os $100 \%$ da área total dessa região de planejamento, com $12,5 \mathrm{~km}^{2}$ dos $12,8 \mathrm{Km}^{2}$ totais.

Quadro 49: Suscetibilidade a movimentos de massa, por classe, na região de planejamento Centro.

\begin{tabular}{|c|c|c|c|c|}
\hline \multicolumn{4}{|c|}{ Suscetiblidade a movimentos de massa } \\
\hline & \multicolumn{2}{|c|}{ Total } & \multicolumn{2}{c|}{ Edificada } \\
\cline { 2 - 5 } & $\mathrm{Km}^{2}$ & $\%$ & $\mathrm{Km}^{2}$ & $\%$ \\
\hline Área da RP $\left(\mathrm{Km}^{2}\right)$ & 12,8 & 100 & 12,5 & 100 \\
\hline Baixa suscetibilidade & 7,7 & 59,6 & 7,6 & 61,0 \\
\hline Média suscetibilidade & 3,6 & 27,8 & 3,5 & 27,7 \\
\hline Alta suscetibilidade & 1,6 & 12,4 & 1,4 & 11,2 \\
\hline
\end{tabular}

Fonte: CPRM (2014) / Organizado pelo autor.

Com relação à ocupação em áreas suscetíveis, a ocupação é de mais de 95\% nas áreas com baixa e média suscetibilidade e de $88 \%$ nas áreas com alta suscetibilidade a movimentos de massa. As áreas de alta suscetibilidade estão associadas à escarpa do Morro do Imperador, que impediram a franca ocupação desse setor do relevo (Quadro 50).

Quadro 50: Porcentagem das áreas suscetíveis a movimentos de massa ocupadas, na RP Centro.

\begin{tabular}{|c|c|}
\hline \multicolumn{2}{|c|}{ Ocupação em áreas suscetíveis (\%) } \\
\hline Baixa suscetibilidade & 99,7 \\
\hline Média suscetibilidade & 96,9 \\
\hline Alta suscetibilidade & 88,1 \\
\hline
\end{tabular}

Fonte: CPRM (2014) / Organizado pelo autor.

No limite da RP Centro com a RP Oeste encontra-se o morro do Imperador, definido por uma tipologia de relevo escarpado, associada ao sistema horst-gráben do rio Paraibuna (EDUARDO, 2018), nesse setor de alta suscetibilidade aos movimentos de massa, sobretudo de queda de blocos, impossibilita a ocupação, como pode ser visualizado nas figuras 70 e71. 
Figura 70: Área de alta suscetibilidade a movimentos de massa na RP Centro, localizada no setor limítrofe à RP Oeste.

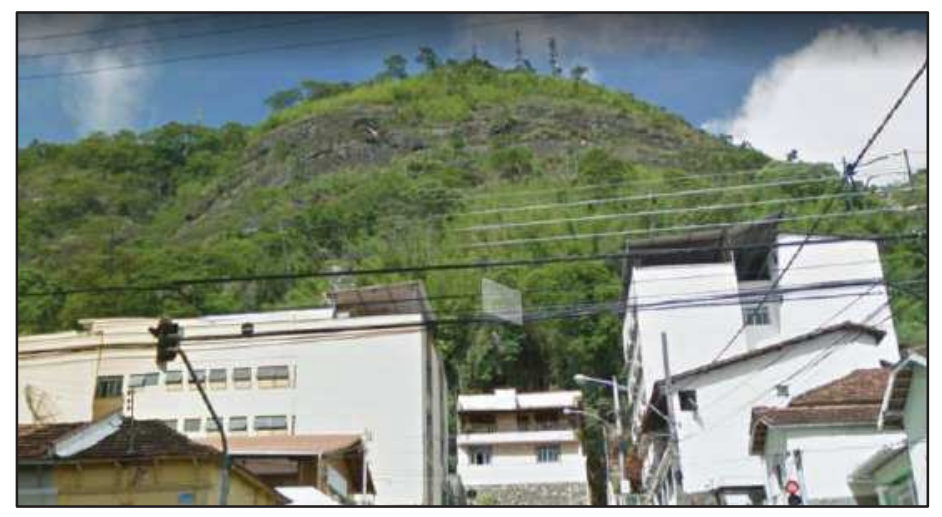

Fonte: Google Street View. Organizado pelo autor.

Figura 71: Carta de suscetibilidade a movimentos de massa e inundações, com base na CPRM (2014), na RP Centro.

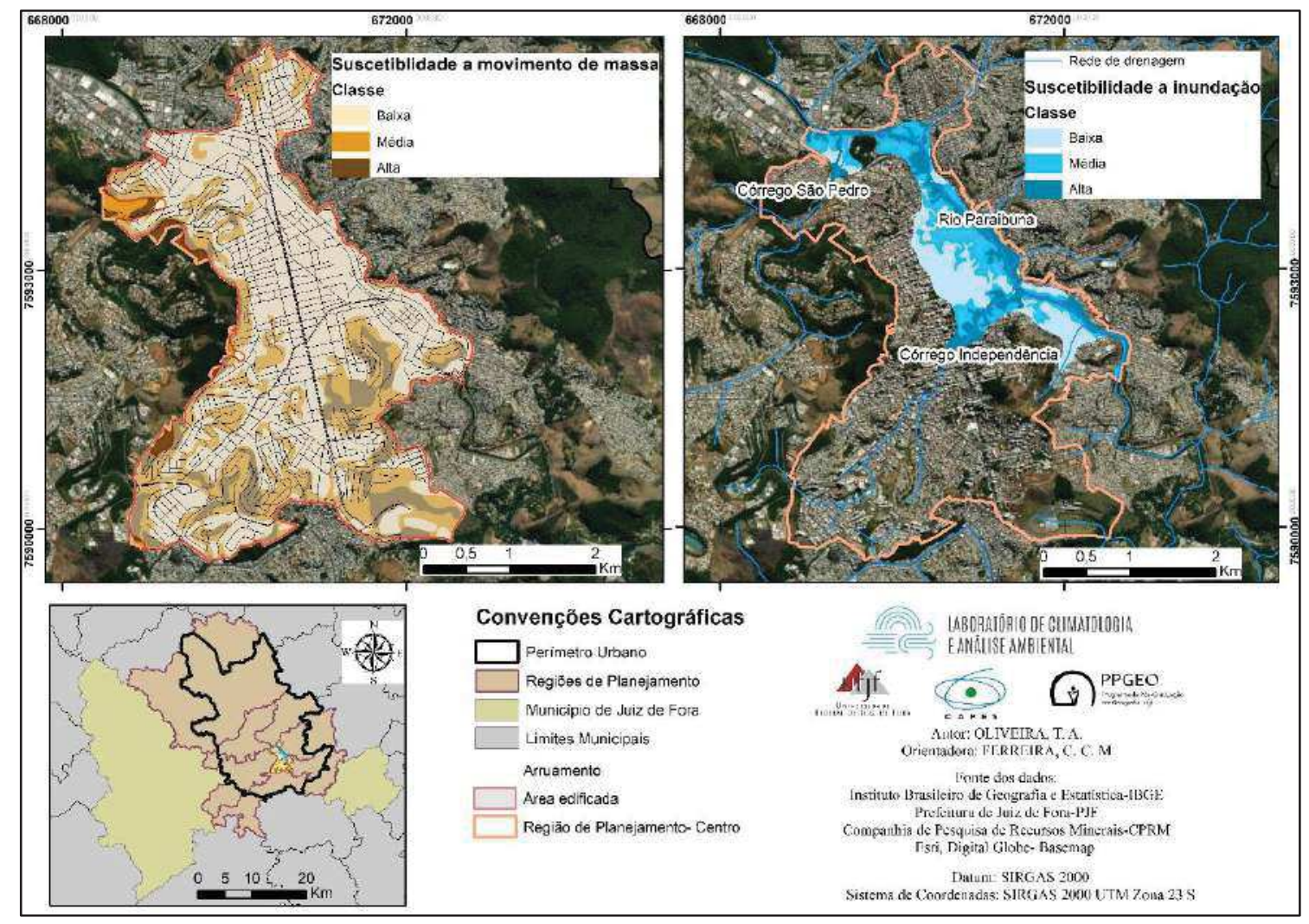

Fonte: CPRM (2014). Organizado pelo autor.

A suscetibilidade a inundação (Figura 71 e Quadro 51) nessa região de planejamento está associada ao córrego Independência que em 2015, segundo Machado (2016), tinha 76\% da área da bacia já urbanizada, e o córrego São Pedro que drena a região Oeste da cidade, 
conhecida como "Cidade Alta", e gera suscetibilidade a inundação na região central, sobretudo nas regiões urbanas Fábrica (17) e Mariano Procópio (18).

Quadro 51: Suscetibilidade a inundação por classe, na região de planejamento Centro

\begin{tabular}{|c|c|c|c|c|}
\hline \multicolumn{4}{|c|}{ Suscetiblidade a inundação } \\
\hline & \multicolumn{2}{|c|}{ Total } & \multicolumn{2}{c|}{ Edificada } \\
\cline { 2 - 5 } & $\mathrm{Km}^{2}$ & $\%$ & $\mathrm{Km}^{2}$ & $\%$ \\
\hline Área da RP $\left(\mathrm{Km}^{2}\right)$ & 12,8 & 100 & 12,5 & 100 \\
\hline Baixa suscetibilidade & 0,82 & 6,4 & 0,82 & 6,6 \\
\hline Média suscetibilidade & 0,87 & 6,8 & 0,87 & 7,0 \\
\hline Alta suscetibilidade & 0,77 & 6,0 & 0,77 & 6,2 \\
\hline
\end{tabular}

Fonte: CPRM (2014) / Organizado pelo autor.

Na região de planejamento Centro as áreas suscetíveis são todas completamente ocupadas, por ter uma ocupação mais antiga, dessa forma são comuns os impactos hidrológicos nessa região de planejamento. Localizando-se na planície do Rio Paraibuna, as águas escoam em direção a este, direcionando-se para o centro da cidade.

Quadro 52: Porcentagem das áreas suscetíveis a inundação, ocupadas, na RP Centro.

\begin{tabular}{|c|c|}
\hline \multicolumn{2}{|c|}{ Ocupação em áreas suscetíveis (\%) } \\
\hline Baixa suscetibilidade & 100 \\
\hline Média Suscetibilidade & 100 \\
\hline Alta Suscetibilidade & 100 \\
\hline
\end{tabular}

Fonte: CPRM (2014) / Organizado pelo autor.

O córrego Independência drena boa parte da RP Centro, e fora canalizado e retificado no trecho da Av. Itamar Franco (Antiga Av. Independência), sendo que o setor do canal, sobretudo nas RUs Centro e São Mateus figuram intensos impactos hidrológicos associados a inundações e alagamentos (Figura 72).

Figura 72: Avenida Independência (atual Itamar Franco) em dois momentos.

Avenida Independência-1970

Avenida Itamar Franco (Antiga Av. Independência) 2017 


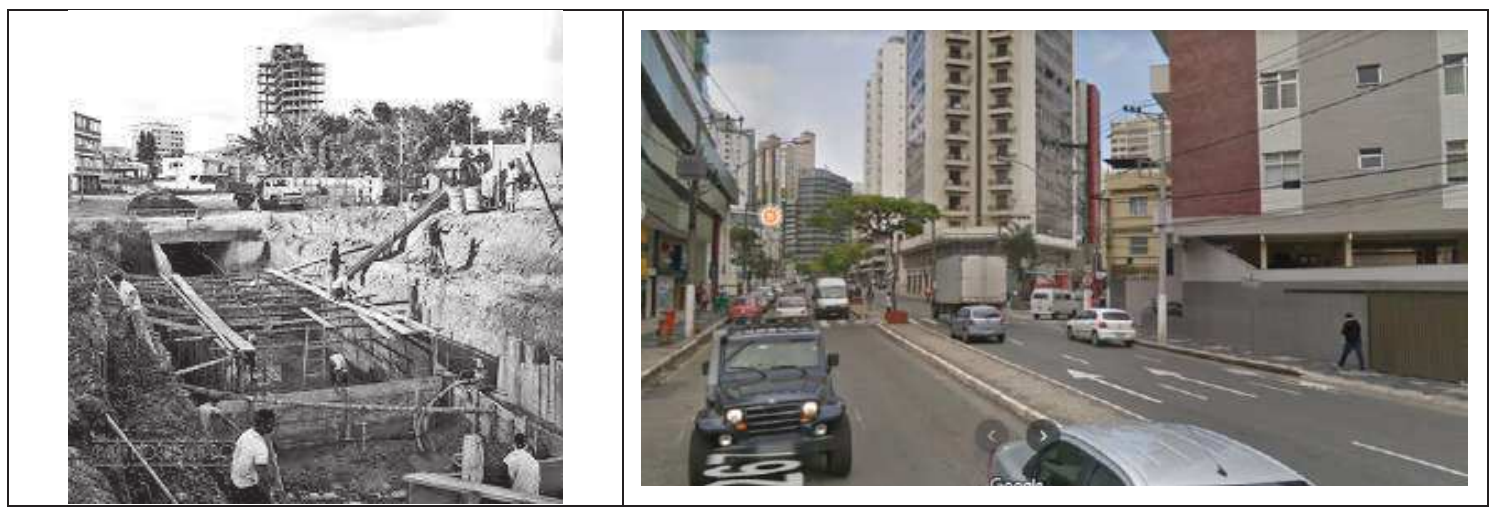

Fonte: Blog Maria do Resguardo e Google Street View (2017).

\section{A região de planejamento leste}

A RP Leste tem uma ocupação antiga e adensada ao longo das planícies do córrego do Young, tem nas margens do córrego seu principal vetor de crescimento,

Tem duas formas distintas de ocupação: de um lado, a ocupação mais antiga das áreas planas que foi se adensando, ao longo do tempo, deixando livres somente as encostas íngremes que caracterizam o seu perfil morfológico (bairros São Bernardo, Jardim do Sol, Grajaú); de outro lado, à medida que ocorre a consolidação desta ocupação, as camadas médias e baixas da população vão sendo afastadas, ocupando as encostas íngremes de forma intensa (Vitorino Braga, Linhares). (TASCA, 2010, p. 73)

A ocupação nessa RP é basicamente de uso residencial, sendo que ocorrem algumas atividades comerciais e pequenas empresas. "A vinculação com o Centro também se reflete em termos das atividades econômicas, pois nesta RP reside grande parte dos trabalhadores no comércio e os prestadores de serviço que lá trabalham" (PDDU, 2004, n.p.).

A RP Leste teve um crescimento de $12,9 \%$ na população no período de 1991 a 2010, de acordo com Menon Júnior e Zaidan (2016) esse crescimento populacional, e consequentemente, da área edificada se deu em direção a compartimentos do relevo proibitivos à ocupação urbana, com a declividade mais elevada (Figuras 62 e 73).

A região de planejamento Leste tinha em 1991, 62,2\% dos domicílios com rendimento inferior a 2 salários mínimos (PDDU, 2004), sendo que esta condição de desigualdade de renda segue, expressa pelo IVS utilizado, sendo que esta RP apresenta mais de 30\% dos setores censitários em condição de altíssima e alta vulnerabilidade social (Figura 63). 
Figura 73: População total na RP Leste- 1991-2010.

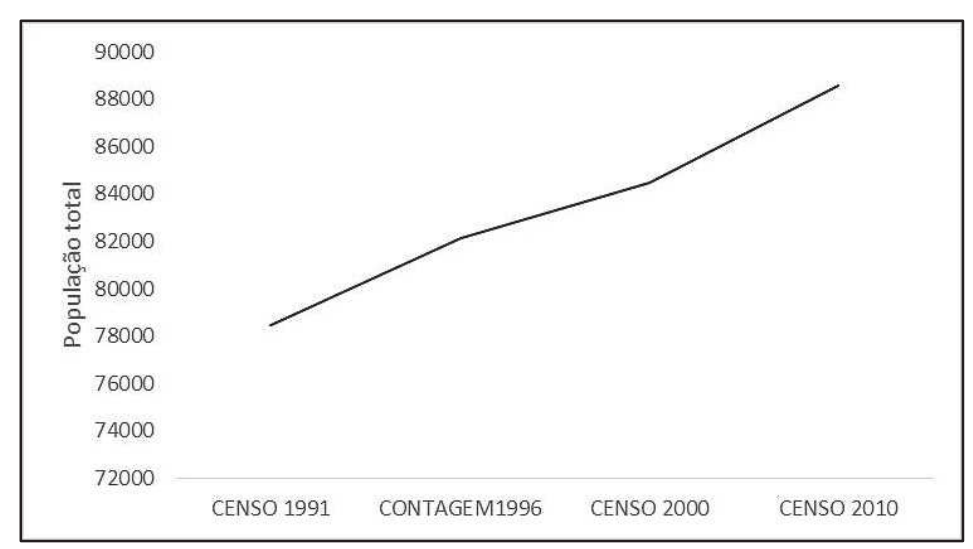

Fonte: PJF. Organizado pelo autor.

De acordo com Cassab e Pinto (2013, p. 6) a "região Leste caracterizada por uma ocupação antiga e bastante adensada, superada apenas pelo Centro. Também é nessa região que se localizam as maiores áreas de risco da cidade e o maior número de habitações subnormais".

A região de planejamento Leste apresenta menos da metade de sua área total ocupada (Quadro 53), tendo a maior proporção da sua área em alta suscetibilidade aos movimentos de massa, com 48,7\% da área total, e além disso a menor proporção de áreas com baixa suscetibilidade a movimentos de massa, com 15,3\% da área (Figura 74).

Quadro 53: Suscetibilidade a movimentos de massa, por classe, na região de planejamento Leste.

\begin{tabular}{|c|c|c|c|c|}
\hline \multicolumn{4}{|c|}{ Suscetiblidade a movimentos de massa } \\
\cline { 2 - 5 } & \multicolumn{2}{|c|}{ Total } & \multicolumn{2}{c|}{ Edificada } \\
\cline { 2 - 5 } & $\mathrm{Km}^{2}$ & $\%$ & $\mathrm{Km}^{2}$ & $\%$ \\
\hline Área da RP $\left(\mathrm{Km}^{2}\right)$ & 23,82 & 100 & 8,09 & 100 \\
\hline Baixa suscetibilidade & 3,65 & 15,3 & 1,88 & 23,2 \\
\hline Média suscetibilidade & 8,56 & 35,9 & 3,23 & 39,9 \\
\hline Alta suscetibilidade & 11,6 & 48,7 & 2,97 & 36,7 \\
\hline
\end{tabular}

Fonte: CPRM (2014) / Organizado pelo autor.

As áreas com baixa e média suscetibilidade aos movimentos de massa são as mais ocupadas, com $51,5 \%$ e $37,7 \%$, respectivamente e com $25,6 \%$ de ocupação se encontram em áreas de alta suscetibilidade à movimentos de massa (Figura 74 e Quadro 54).

Quadro 54: Porcentagem das áreas suscetíveis a movimentos de massa ocupadas, na RP Leste.

\begin{tabular}{|c|c|}
\hline \multicolumn{2}{|c|}{ Ocupação em áreas suscetíveis (\%) } \\
\hline Baixa suscetibilidade & 51,5 \\
\hline Média suscetibilidade & 37,7 \\
\hline Alta suscetibilidade & 25,6 \\
\hline
\end{tabular}


Fonte: CPRM (2014) / Organizado pelo autor.

Paralelamente aos impactos relacionados aos movimentos de massa, o córrego do Young que drena a região apresenta alguns pontos de alta suscetibilidade a inundação, sobretudo na RU Linhares (Figura 74).

Figura 74: Carta de suscetibilidade a movimentos de massa e inundações, com base na CPRM (2014), na RP Leste

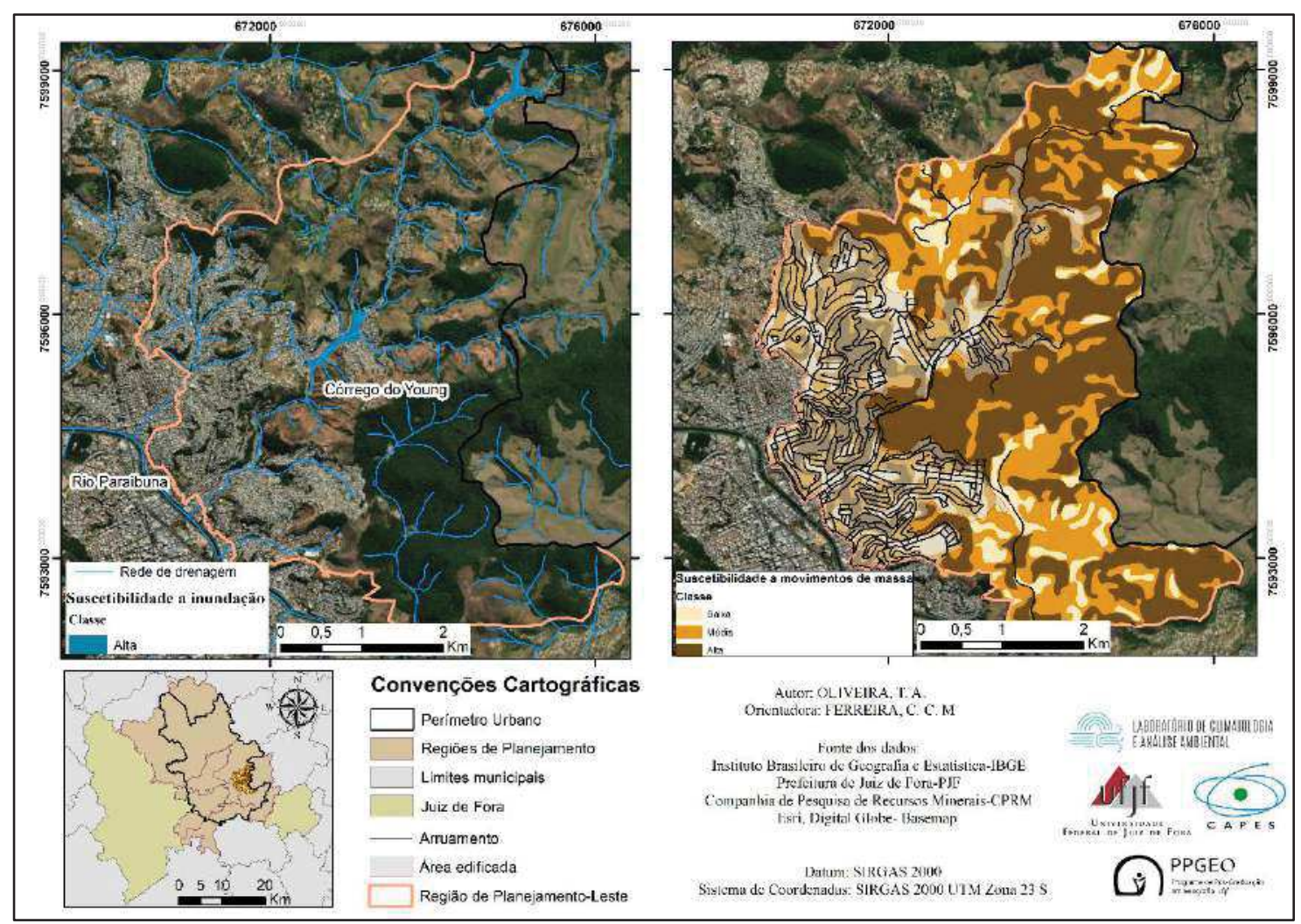

Fonte: CPRM (2014). Organizado pelo autor.

Com relação à suscetibilidade à inundação, esta RP apresenta a menor área de suscetível, correspondendo apenas $1,2 \%$ da área total, no entanto esta região vai figurar entre as mais impactadas por eventos hidrológicos, dentre as regiões de planejamento. As regiões urbanas Vitorino Braga e Linhares são frequentemente impactadas não apenas por eventos inundação, mas também alagamentos e enxurradas, associados à bacia do córrego do Young (Quadro 55). 
Quadro 55: Suscetibilidade a inundação por classe, na região de planejamento Leste

\begin{tabular}{|c|c|c|c|c|}
\hline \multicolumn{4}{|c|}{ Suscetiblidade a inundação } \\
\hline & \multicolumn{2}{|c|}{ Total } & \multicolumn{2}{c|}{ Edificada } \\
\cline { 2 - 5 } & $\mathrm{Km}^{2}$ & $\%$ & $\mathrm{Km}^{2}$ & $\%$ \\
\hline Área da RP $\left(\mathrm{Km}^{2}\right)$ & 23,82 & 100 & 8,09 & 100 \\
\hline Baixa suscetibilidade & 0 & 0,0 & 0 & 0,0 \\
\hline Média suscetibilidade & 0 & 0,0 & 0 & 0,0 \\
\hline Alta suscetibilidade & 0,20 & 0,8 & 0,10 & 1,2 \\
\hline
\end{tabular}

Fonte: CPRM (2014) / Organizado pelo autor.

Dessa forma o compartimento com alta suscetibilidade à inundação tem $50 \%$ de ocupação na área (Quadro 56). Diversas intervenções foram realizadas no córrego, como canalização, retificação, dentre outras atividades, uma vez que a ocupação na RP seguiu o vale do rio, onde se desenvolveu inicialmente, até ampliar a ocupação para as vertentes mais declivosas.

Quadro 56: Porcentagem das áreas suscetíveis a inundação, ocupadas, na RP Leste.

\begin{tabular}{|c|c|}
\hline \multicolumn{2}{|c|}{ Ocupação em áreas suscetíveis (\%) } \\
\hline Baixa suscetibilidade & 0 \\
\hline Média Suscetibilidade & 0 \\
\hline Alta Suscetibilidade & 50 \\
\hline
\end{tabular}

Fonte: CPRM (2014) / Organizado pelo autor.

\section{A região de planejamento Oeste}

A RP Oeste teve um crescimento populacional de quase 100\% no período de 1991 a 2010, embora tenha uma ocupação antiga, associada à colonização Alemã, foi a partir dos anos 90 que a expansão urbana se desenvolveu na região. Considerada como área para expansão urbana pelo PDDU (2004) a RP Oeste tem visualizado a expansão dos empreendimentos imobiliários, o que tem gerado uma recente verticalização na região (Figuras 62 e 75). 
Figura 75: População total na RP Oeste- 1991-2010.

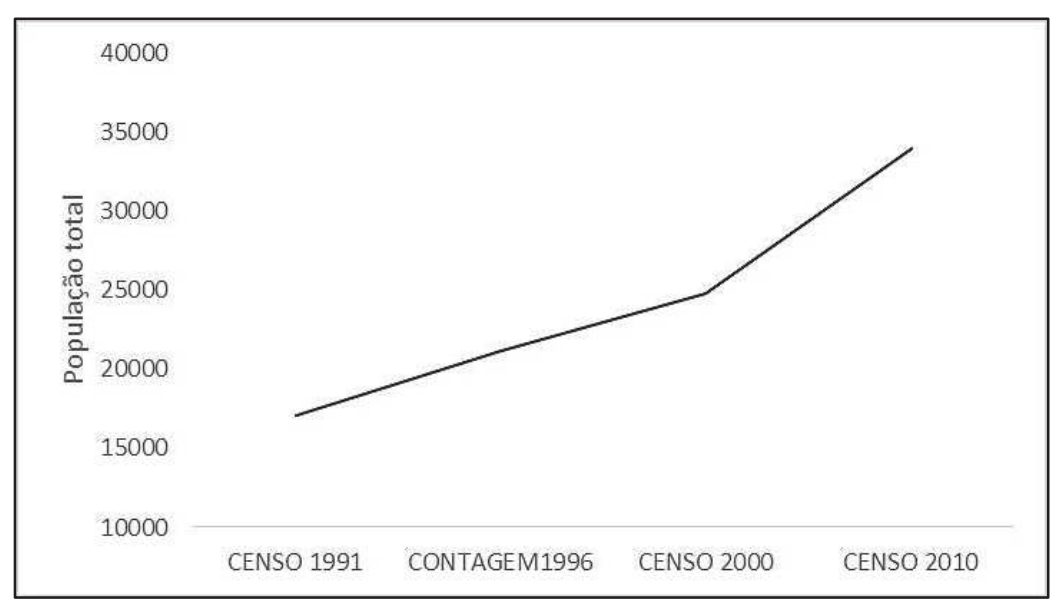

Fonte: PJF. Organizado pelo autor.

As atividades comerciais na região são bastante diversas, sobretudo nas RU's São Pedro (28) e Borboleta (22). Devido à presença da UFJF o setor imobiliário e de serviços de desenvolveu na região (CARMO, 2019). Esta condição vem se consolidando nos últimos anos (GERALDO, 2011; CARMO, 2019), no entanto algumas questões de infraestrutura e mobilidade urbana ainda são importantes a serem resolvidas na região.

A região de planejamento Oeste compreende a área da cidade conhecida como cidade alta. Com relação à suscetibilidade aos movimentos de massa a região apresenta maior percentagem de área em condições de baixa suscetibilidade, enquanto que as classes de média e alta suscetibilidade, juntas somam 57,5\% da área total (Figura 76 e Quadro 57).

Quadro 57: Suscetibilidade a movimentos de massa, por classe, na região de planejamento Oeste.

\begin{tabular}{|c|c|c|c|c|}
\hline \multicolumn{3}{|c|}{ Suscetiblidade a movimentos de massa } \\
\hline & \multicolumn{2}{|c|}{ Total } & \multicolumn{2}{c|}{ Edificada } \\
\cline { 2 - 5 } & $\mathrm{Km}^{2}$ & $\%$ & $\mathrm{Km}^{2}$ & $\%$ \\
\hline Área da RP $\left(\mathrm{Km}^{2}\right)$ & 43,9 & 100 & 15,6 & 100 \\
\hline Baixa suscetibilidade & 18,7 & 42,5 & 8,6 & 55,2 \\
\hline Média suscetibilidade & 14,2 & 32,4 & 5,1 & 32,9 \\
\hline Alta suscetibilidade & 11,0 & 25,0 & 1,8 & 11,8 \\
\hline
\end{tabular}

Fonte: CPRM (2014) / Organizado pelo autor.

A ocupação se dá principalmente nos compartimentos com baixa suscetibilidade, com $46 \%$ da área ocupada, no entanto esses espaços correspondem aos fundos de vale e, assim como nas outras RPs, estão suscetíveis à ocorrência de inundação. Ainda assim, 36\% dos setores do 
relevo com média suscetibilidade são ocupados, bem como $16,8 \%$ das áreas em alta suscetibilidade (Quadro 58).

Quadro 58: Porcentagem das áreas suscetíveis a movimentos de massa ocupadas, na RP Oeste.

\begin{tabular}{|c|c|}
\hline \multicolumn{2}{|c|}{ Ocupação em áreas suscetíveis (\%) } \\
\hline Baixa suscetibilidade & 46,1 \\
\hline Média suscetibilidade & 36,1 \\
\hline Alta suscetibilidade & 16,8 \\
\hline
\end{tabular}

Fonte: CPRM (2014) / Organizado pelo autor.

Figura 76: Carta de suscetibilidade a movimentos de massa e inundações, com base na CPRM (2014), na RP Oeste.

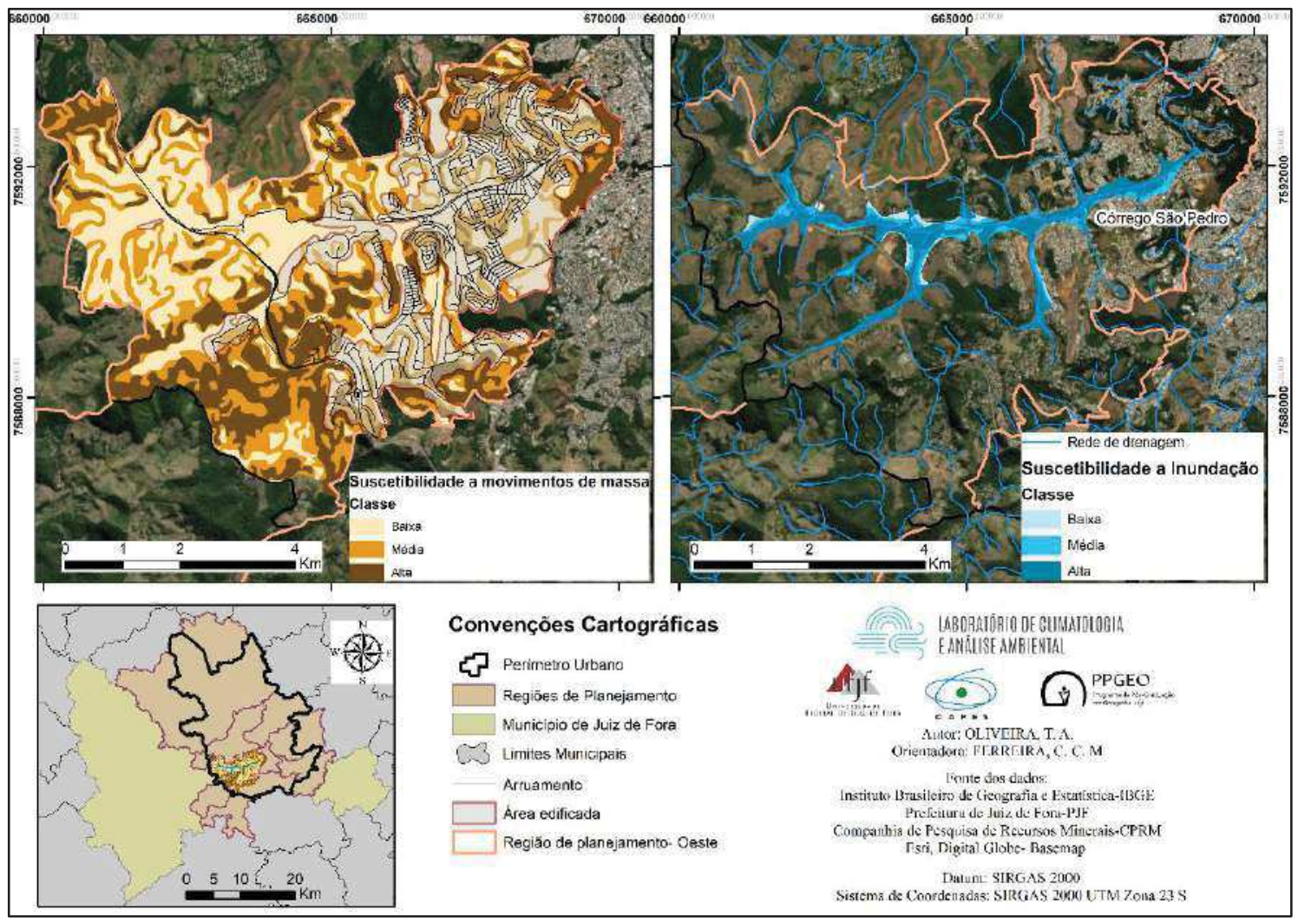

Fonte: CPRM (2014). Organizado pelo autor.

A região é drenada pela bacia do córrego São Pedro, com relação à suscetibilidade à inundação essa RP apresenta 7,9\% de sua área considerada suscetível a inundação, sendo que a maior parte revela uma alta suscetibilidade, em função das condições geomorfológicas. 
Quadro 59: Suscetibilidade a inundação por classe, na região de planejamento Oeste

\begin{tabular}{|c|c|c|c|c|}
\hline \multicolumn{4}{|c|}{ Suscetiblidade a inundação } \\
\hline & \multicolumn{2}{|c|}{ Total } & \multicolumn{2}{c|}{ Edificada } \\
\cline { 2 - 5 } & $\mathrm{Km}^{2}$ & $\%$ & $\mathrm{Km}^{2}$ & $\%$ \\
\hline Área da RP $\left(\mathrm{Km}^{2}\right)$ & 43,9 & 100 & 15,6 & 100 \\
\hline Baixa suscetibilidade & 0,2 & 0,5 & 0,1 & 0,7 \\
\hline Média suscetibilidade & 0,7 & 1,5 & 0,4 & 2,6 \\
\hline Alta suscetibilidade & 2,6 & 5,9 & 2,5 & 16,2 \\
\hline
\end{tabular}

Fonte: CPRM (2014) / Organizado pelo autor.

Com relação à ocupação de áreas suscetíveis, a maior parte das áreas suscetíveis encontra-se ocupada, sendo que os setores com alta suscetibilidade encontram-se 96,7\% ocupados. Enquanto pelo menos 50\% das áreas de média e baixa suscetibilidade a inundação também são ocupadas. Com isso a RP Oeste, em função de seu rápido crescimento e adensamento construtivo tem sofrido como impactos tanto hidrológicos como também geomorfológicos (Quadro 60), apesar de que algumas áreas com alta suscetibilidade têm sido ocupadas por loteamentos fechados, em que as técnicas construtivas minimizam possíveis impactos associados às inundações e movimentos de massa.

Quadro 60: Porcentagem das áreas suscetíveis a inundação, ocupadas, na RP Oeste.

\begin{tabular}{|c|c|}
\hline \multicolumn{2}{|c|}{ Ocupação em áreas suscetíveis (\%) } \\
\hline Baixa suscetibilidade & 50,0 \\
\hline Média Suscetibilidade & 58,8 \\
\hline Alta Suscetibilidade & 96,9 \\
\hline
\end{tabular}

Fonte: CPRM (2014) / Organizado pelo autor.

\section{A região de planejamento Sudeste}

A região de planejamento Sudeste é composta por oito regiões urbanas, está localizada no eixo cortado pela BR-267 que liga Juiz de Fora à BR-116 (Rio-Bahia). A população nessa região de planejamento teve um crescimento de 24\% no período de 1991 a 2010 (Figura 77). O tipo de uso é majoritariamente residencial, com alguns estabelecimentos comerciais que se concentram nas regiões urbanas Vila Ideal e Nossa Senhora de Lourdes (PDDU, 2004).

Algumas RUs apresentam alta densidade demográfica, como a Vila Olavo Costa (50) que em 1991 apresentava 156,3 hab./ha. (TASCA, 2010, p. 76), em 2010 apresentou 259,6 hab/ha, enquanto outras RU apresentam-se com uma baixa densidade demográfica, como 
Floresta (56) e Retiro (57), com 2,7 e 12,7 hab./ha, respectivamente. Situação que não se alterou desde 1991 (TASCA, 2010).

Figura 77: População total na RP Sudeste- 1991-2010.

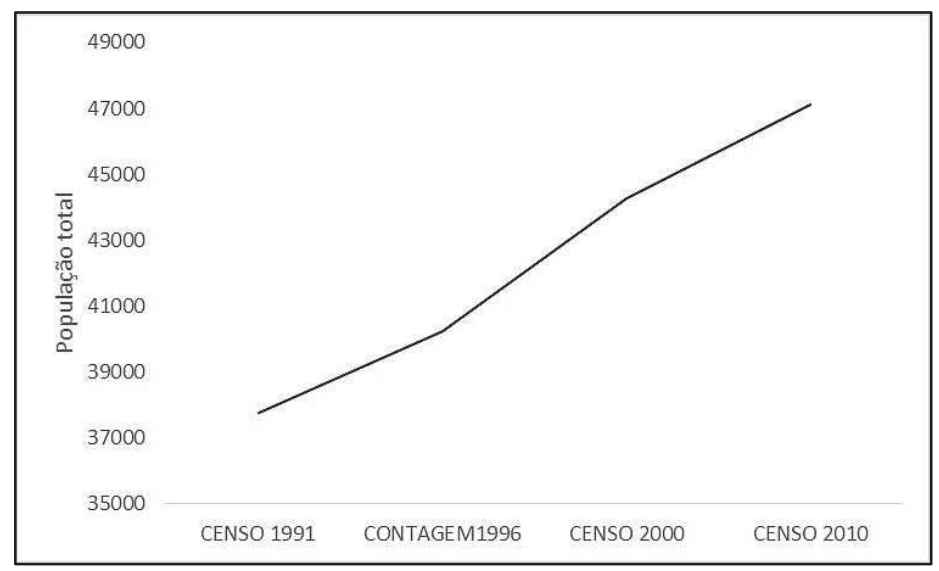

Fonte: PJF. Organizado pelo autor.

As questões sociais nessa RP são devéras complexas, uma vez que o número de domicilios com rendimento inferior a dois salários mínimos é elevado, "sendo os bairros com maior índice o Olavo Costa com 88,92\%, Santo Antônio com 72,71\% e Nossa Senhora de Lourdes, com 48,87\%" (TASCA, 2010, p. 77).

Esta condição pode ser ilustrada a partir do IVS aplicado com os dados de 2010, em que esta RP apresentou a maior proporção de setores com altíssima e alta vulnerabilidade social, bem como a menor proporção de setores nas classe de baixa e baixíssima vulnerabilidade (Figura 64).

A RU Vila Olavo Costa (Figura 78), que carrega o nome do prefeito na cidade entre 1951-1955, fora ocupada com a permissão do poder publico, sem que houvesse uma infraestrutura adequada para as ocupações. Em 1969, “o bairro era o que mais abrigava barracos e moradias da cidade, uma vez que foram distribuídos sem planejamento e divisões" (ROCHA, 2015).

Figura 78: Vista da RU Vila Olavo Costa- Juiz de Fora. 


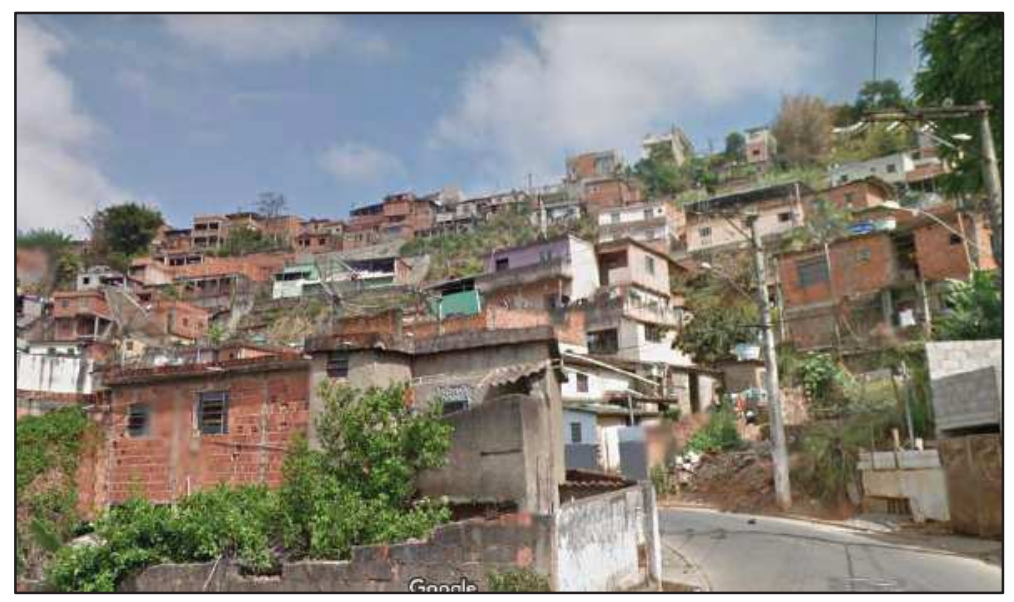

Fonte: Google Street View (2011). Organizado pelo autor.

A suscetibilidade aos movimentos de massa apresenta as maiores proporções de área nas classes de média e alta suscetibilidade, somando 79,2\% da área total da RP, enquanto outros $20,8 \%$ representam os compartimentos com baixa suscetibilidade a movimentos de massa (Quadro 61).

Quadro 61: Suscetibilidade a movimentos de massa, por classe, na região de planejamento Sudeste.

\begin{tabular}{|c|c|c|c|c|}
\hline \multirow{2}{*}{ Suscetiblidade a movimentos de massa } \\
\cline { 2 - 5 } & \multicolumn{2}{|c|}{ Total } & \multicolumn{2}{c|}{ Edificada } \\
\cline { 2 - 5 } & $\mathrm{Km}^{2}$ & $\%$ & $\mathrm{Km}^{2}$ & $\%$ \\
\hline Área da RP $\left(\mathrm{Km}^{2}\right)$ & 23,8 & 100 & 8,2 & 100 \\
\hline Baixa suscetibilidade & 5,0 & 20,8 & 2,5 & 30,2 \\
\hline Média suscetibilidade & 10,1 & 42,5 & 4,0 & 48,4 \\
\hline Alta suscetibilidade & 8,7 & 36,6 & 1,7 & 21,1 \\
\hline
\end{tabular}

Fonte: CPRM (2014) / Organizado pelo autor.

As áreas edificadas nessa RP encontram, a metade em áreas de baixa suscetibilidade, $39 \%$ em compartimentos de média suscetibilidade aos movimentos de massa e $20 \%$ com alta suscetibilidade (Quadro 62). No caso mais específico da Vila Olavo Costa (50) que ocupa os setores mais declivosos da RP existe uma relação entre altíssima vulnerabilidade social atrelada à alta suscetibilidade a movimentos de massa, que desencadeiam situações de risco, sobretudo no período chuvoso.

Quadro 62: Porcentagem das áreas suscetíveis aos movimentos de massa ocupadas, na RP Sudeste.

\begin{tabular}{|c|c|}
\hline \multicolumn{2}{|c|}{ Ocupação em áreas suscetíveis (\%) } \\
\hline Baixa suscetibilidade & 50,2 \\
\hline Média suscetibilidade & 39,3 \\
\hline Alta suscetibilidade & 20,0 \\
\hline
\end{tabular}

Fonte: CPRM (2014) / Organizado pelo autor. 
Figura 79: Carta de suscetibilidade a movimentos de massa e inundações, com base na CPRM (2014), na RP Sudeste.

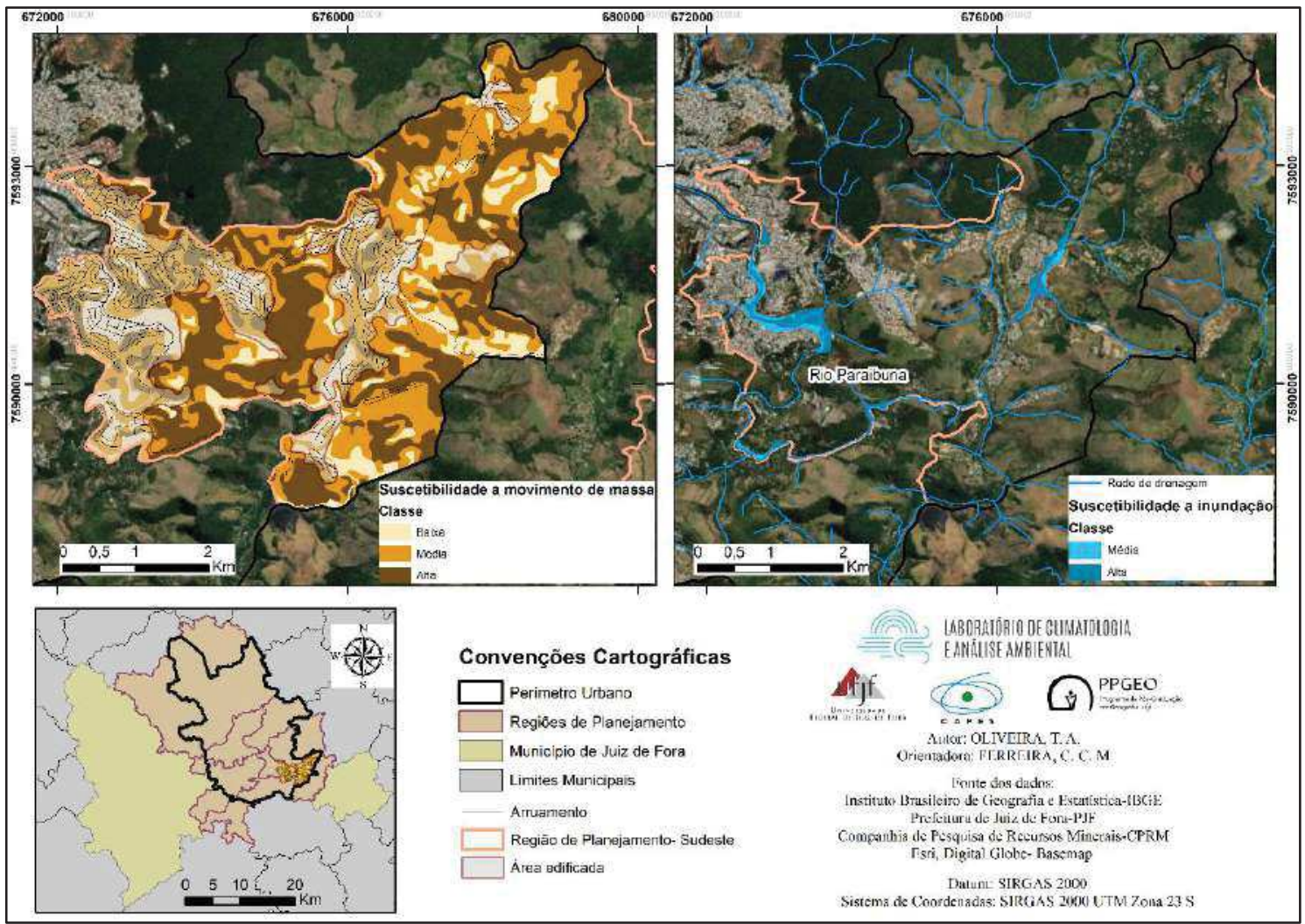

Fonte: CPRM (2014). Organizado pelo autor.

As áreas suscetíveis às inundações correspondem a menos de 3\% da área total da RP, com a maior área de alta suscetibilidade, associadas ao Rio Paraibuna e ao Ribeirão Floresta. Com relação à área edificada 7\% desta encontra-se nas áreas suscetíveis, sendo 5,2\% na área de alta suscetibilidade e 2,1\% com média suscetibilidade (Quadro 63).

Quadro 63: Suscetibilidade à inundação por classe, na região de planejamento Sudeste

\begin{tabular}{|c|c|c|c|c|}
\hline \multicolumn{4}{|c|}{ Suscetiblidade a inundação } \\
\hline & \multicolumn{2}{|c|}{ Total } & \multicolumn{2}{c|}{ Edificada } \\
\cline { 2 - 5 } & $\mathrm{Km}^{2}$ & $\%$ & $\mathrm{Km}^{2}$ & $\%$ \\
\hline Área da RP $\left(\mathrm{Km}^{2}\right)$ & 23,8 & 100 & 8,2 & 100 \\
\hline Baixa suscetibilidade & 0,0 & 0,0 & 0,0 & 0,0 \\
\hline Média suscetibilidade & 0,17 & 0,7 & 0,17 & 2,1 \\
\hline Alta suscetibilidade & 0,47 & 2,0 & 0,43 & 5,2 \\
\hline
\end{tabular}

Fonte: CPRM (2014) / Organizado pelo autor. 
As áreas suscetíveis nessa RP são quase que na sua totalidade ocupadas por edificações, sendo totalmente edificada nas áreas de média suscetibilidade e 91,5\% nos setores com alta suscetibilidade (Quadro 64).

Quadro 64: Percentagem das áreas suscetíveis a inundação, ocupadas, na RP Sudeste.

\begin{tabular}{|c|c|}
\hline \multicolumn{2}{|c|}{ Ocupação em áreas suscetíveis (\%) } \\
\hline Baixa suscetibilidade & 0 \\
\hline Média Suscetibilidade & 100,0 \\
\hline Alta Suscetibilidade & 91,5 \\
\hline
\end{tabular}

Fonte: CPRM (2014) / Organizado pelo autor.

\section{A região de planejamento Centro-Oeste}

Composta por 11 regiões urbanas a RP Centro Oeste tinha um total populacional de 52438 habitantes em 2010, sendo que este valor representa um aumento de $38 \%$ comparado ao total populacional de 1991 (Figura 80). Situada no eixo que segue o vale do rio Paraibuna, por onde se estabeleceram importantes vias de acesso, como a Av. JK; Brasil, bem como a rodovia BR 267.

O eixo que segue a Av. JK, a linha férrea e o próprio rio Paraibuna, na sua margem direita, é mais densamente ocupada. Já o setor mais a oeste da RP tem uma ocupação mais rarefeita, que tem se intensificado em função dos conjuntos habitacionais e loteamentos fechados, enquanto que no setor leste da RP encontra-se a área da RU Remonta (7), que controlada pelo Exército Brasileiro, tem uma ocupação inibida (Figura 79).

A região apresenta uma ocupação diversa, sendo tanto residencial, comercial e industrial. No setor econômico destaca-se o mini distrito industrial localizado no bairro Monte Castelo (16), onde aporta a empresa de equipamentos cirúrgicos, Becton Dickinson-BD.

Figura 80: População total na RP Centro Oeste- 1991-2010.

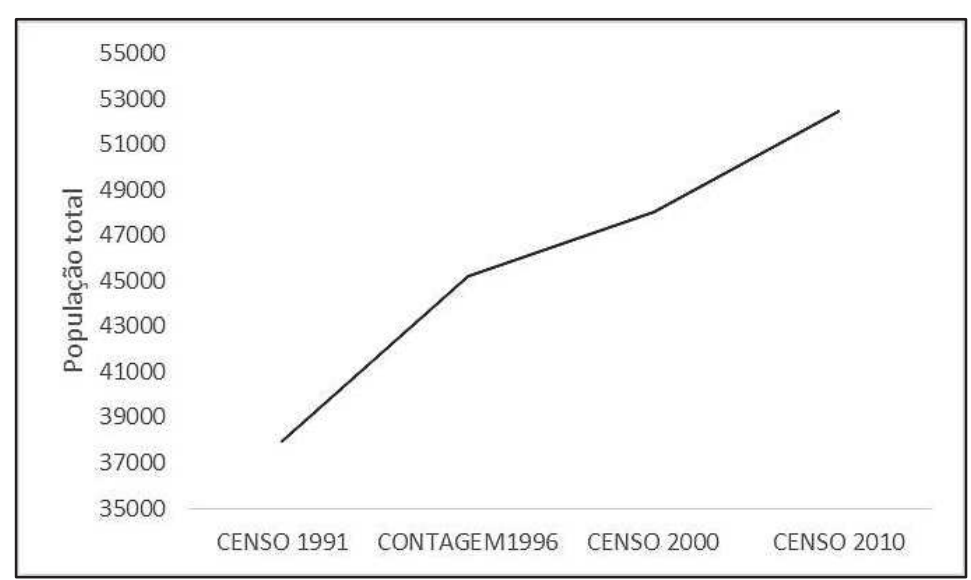


Fonte: PJF. Organizado pelo autor.

No PDDU (2004) era tida como uma das áreas para o crescimento urbano, em função das proximidades com as rodovias BR040 e 267 e com isso, nessa área de expansão urbana foram instalados conjuntos habitacionais do programa Minha Casa Minha Vida-MCMV, como Conjunto Parque das Águas I e II, com 565 residências, localizado na região urbana Monte Castelo (16), além de áreas de ocupação como no bairro Jardim Cachoeira (Figura 81).

Figura 81: Conjunto habitacional localizado na RU Monte Castelo- RP Centro-Oeste

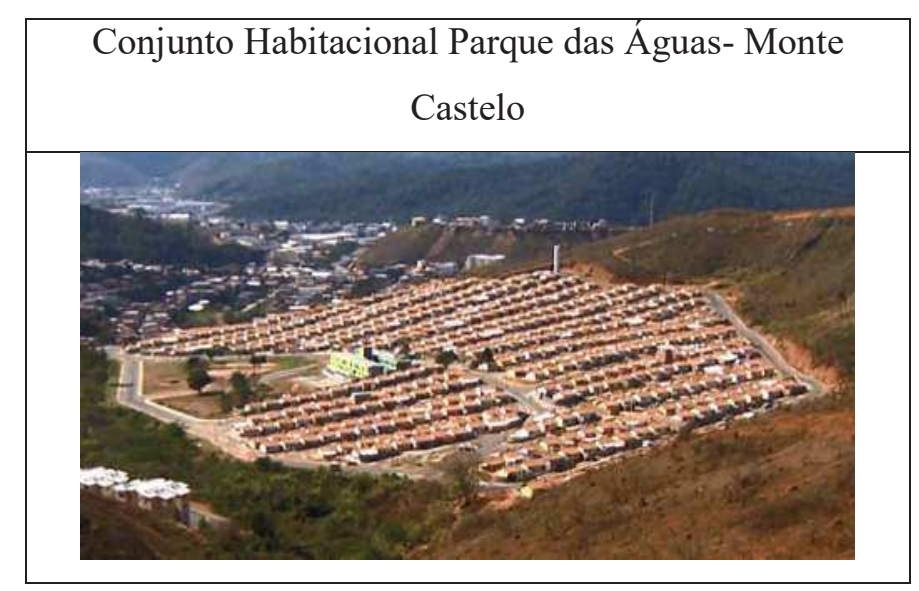

Fonte: Nugea/UFJF (2015).

É drenada pela bacia do córrego Humaitá e do ribeirão do Monte Castelo. Nessa RP a ocupação encontra-se majoritariamente em compartimentos com baixa suscetibilidade à ocorrência de movimentos de massa, com $59,4 \%$, sendo que outros $26,8 \%$ estão em áreas com média suscetibilidade e 13,7\% em áreas de alta suscetibilidade (Figura 82 e Quadro 65).

Quadro 65: Suscetibilidade a movimentos de massa, por classe, na região de planejamento CentroOeste.

\begin{tabular}{|c|c|c|c|c|}
\hline \multicolumn{4}{|c|}{ Suscetiblidade a movimentos de massa } \\
\cline { 2 - 5 } & \multicolumn{2}{|c|}{ Total } & \multicolumn{2}{c|}{ Edificada } \\
\cline { 2 - 5 } & $\mathrm{Km}^{2}$ & $\%$ & $\mathrm{Km}^{2}$ & $\%$ \\
\hline Área da RP $\left(\mathrm{Km}^{2}\right)$ & 50,9 & 100 & 11,4 & 100 \\
\hline Baixa suscetibilidade & 13,4 & 26,3 & 6,8 & 59,4 \\
\hline Média suscetibilidade & 16,7 & 32,8 & 3,1 & 26,8 \\
\hline Alta suscetibilidade & 20,7 & 40,7 & 1,6 & 13,7 \\
\hline
\end{tabular}

Fonte: CPRM (2014) / Organizado pelo autor.

As áreas com média e alta suscetibilidade a movimentos de massa tem apenas 18,3\% e $7,5 \%$, respectivamente, de suas áreas ocupadas, enquanto as áreas com baixa suscetibilidade 
registram 50,5\% de ocupação (Quadro 66). A ocupação se torna mais densa no baixo curso do córrego Humaitá, tendo assim os impactos associados a inundações e alagamentos, mais recorrentes (Figura 82).

Quadro 66: Percentagem das áreas suscetíveis a movimentos de massa ocupadas, na RP Centro-Oeste.

\begin{tabular}{|c|c|}
\hline \multicolumn{2}{|c|}{ Ocupação em áreas suscetíveis (\%) } \\
\hline Baixa suscetibilidade & 50,5 \\
\hline Média suscetibilidade & 18,3 \\
\hline Alta suscetibilidade & 7,5 \\
\hline
\end{tabular}

Fonte: CPRM (2014) / Organizado pelo autor.

Figura 82: Carta de suscetibilidade a movimentos de massa e inundações, com base na CPRM (2014), na RP Centro-Oeste.

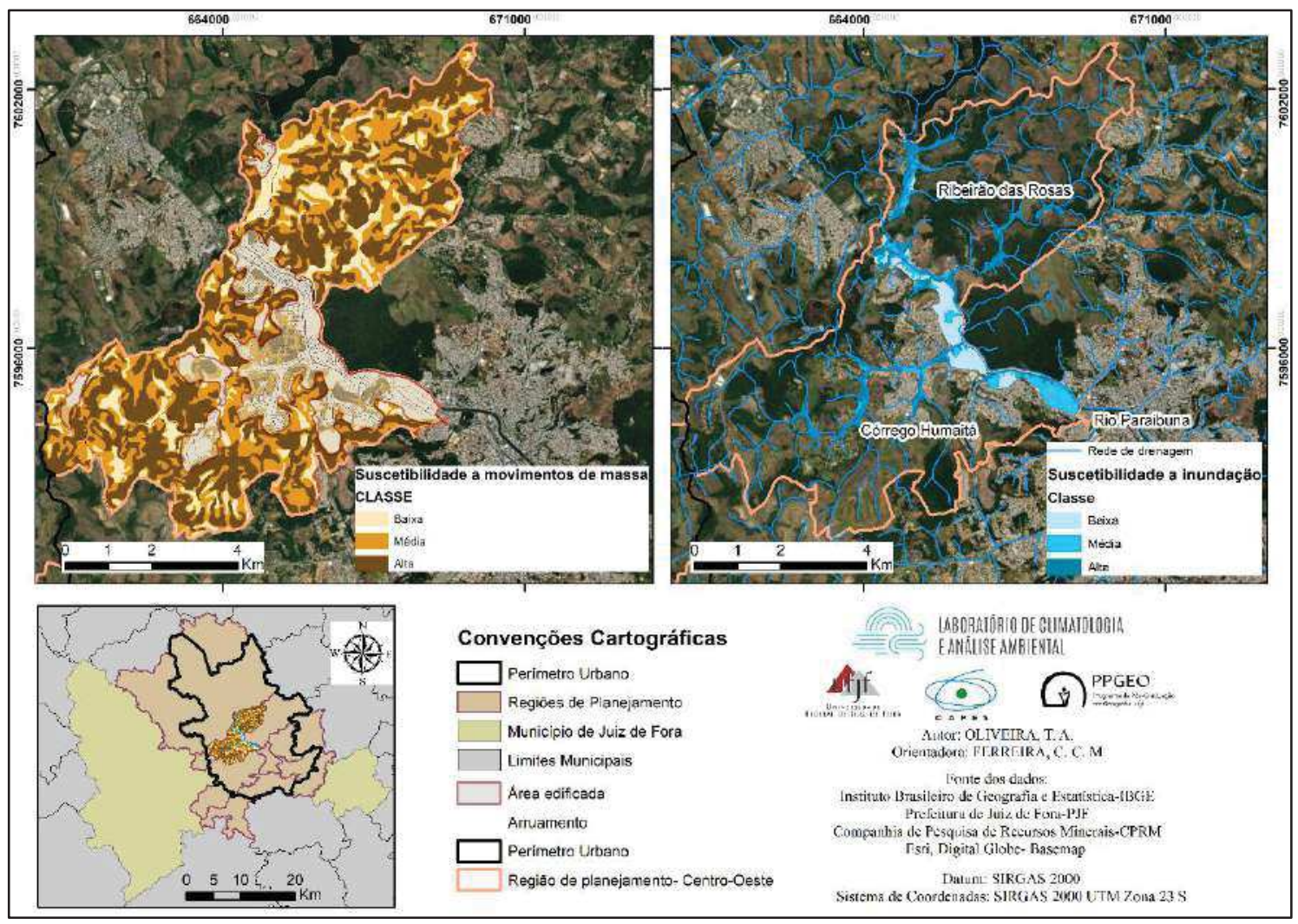

Fonte: CPRM (2014). Organizado pelo autor.

A suscetibilidade à inundação na RP Centro-Oeste representa $9 \%$ da área total, e ocorrem sobretudo ao longo do córrego Humaitá, bem como nas margens do rio Paraibuna (Quadro 67). Sendo assim historicamente esse eixo associado ao rio Paraibuna, a partir do Caminho Novo e as avenidas que por ali interligam a região norte da cidade ao centro, foi ocupada. 
Assim, 34\% da área edificada encontra-se em algum setor suscetível às inundações, sendo que $15,1 \%$ dessa área está em compartimentos de alta suscetibilidade à inundação, destaque para os bairros Industrial (10) e Cerâmica (13) (Quadro 67).

Quadro 67: Suscetibilidade a inundação por classe, na região de planejamento Centro-oeste

\begin{tabular}{|c|c|c|c|c|}
\hline \multicolumn{4}{|c|}{ Suscetiblidade a inundação } \\
\hline & \multicolumn{2}{|c|}{ Total } & \multicolumn{2}{c|}{ Edificada } \\
\cline { 2 - 5 } & $\mathrm{Km}^{2}$ & $\%$ & $\mathrm{Km}^{2}$ & $\%$ \\
\hline Área da RP $\left(\mathrm{Km}^{2}\right)$ & 50,9 & 100 & 11,4 & 100 \\
\hline Baixa suscetibilidade & 1,20 & 2,4 & 1,18 & 10,4 \\
\hline Média suscetibilidade & 1,17 & 2,3 & 1,06 & 9,3 \\
\hline Alta suscetibilidade & 2,19 & 4,3 & 1,72 & 15,1 \\
\hline
\end{tabular}

Fonte: CPRM (2014) / Organizado pelo autor.

As áreas suscetíveis às inundações estão amplamente ocupadas nessa RP, nas classes de baixa e média suscetibilidade essa ocupação supera os $90 \%$, enquanto que na classe de alta suscetibilidade a ocupação atingiu 78\% da área (Quadro 68). A margem esquerda do Rio Paraibuna e o baixo curso do ribeirão das rosas apresentam a suscetibilidade à inundação mas por estarem em áreas de proteção ambiental, como a Mata do Krambeck, e/ou controladas pelo Exército Brasileiro, não são ocupadas.

Quadro 68: Percentagem das áreas suscetíveis a inundação, ocupadas, na RP Centro-Oeste.

\begin{tabular}{|c|c|}
\hline \multicolumn{2}{|c|}{ Ocupação em áreas suscetíveis (\%) } \\
\hline Baixa suscetibilidade & 98,3 \\
\hline Média Suscetibilidade & 90,6 \\
\hline Alta Suscetibilidade & 78,5 \\
\hline
\end{tabular}

Fonte: CPRM (2014) / Organizado pelo autor.

O ponto historicamente marcado por inundações encontra-se no contato entre o córrego Humaitá e o rio Paraibuna, no bairro Industrial (10), este bairro localiza-se na planície de inundação. Quando o nível do rio Paraibuna se eleva, inviabiliza a entrada das águas do córrego Humaitá no mesmo, que se dá de forma perpendicular, ocorrendo as inundações (Figura 83).

Figura 83: Baixo curso do Córrego Humaitá na região urbana B. Industrial

\begin{tabular}{|c|c|}
\hline Córrego Humaitá no bairro Industrial (2011) & $\begin{array}{c}\text { Córrego Humaitá }(09 / 01 / 2012) \text { - Tribuna de } \\
\text { Minas }\end{array}$ \\
\hline
\end{tabular}




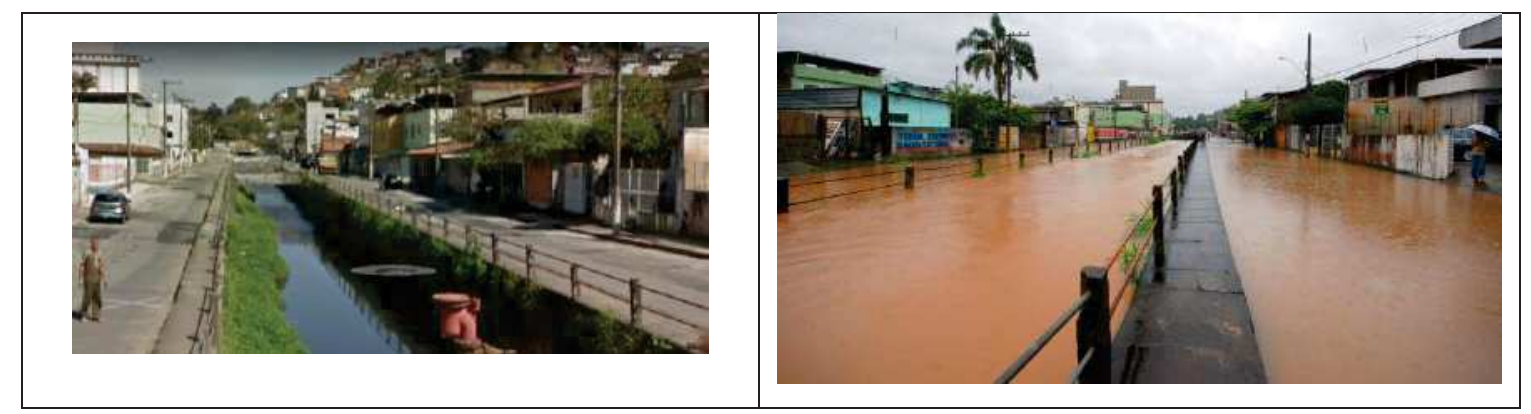

Fonte: Google Maps- Street View/ Tribuna de Minas.

\section{A região de planejamento Nordeste}

A região de planejamento Nordeste é composta por sete regiões urbanas, a RP Nordeste tinha 47648 habitantes em 2010, com uma elevação de 43\% se comparado ao total populacional de 1991 (Figura 84). Com um uso residencial a RP Nordeste se estrutura a partir da rodovia BR353 que faz a ligação de cidades da Zona da Mata (com Ubá, Visconde do Rio Branco, Viçosa, etc.) com a cidade de Juiz de Fora, além das capitais estaduais a partir da BR 040.

Figura 84: População total na RP Nordeste- 1991-2010.

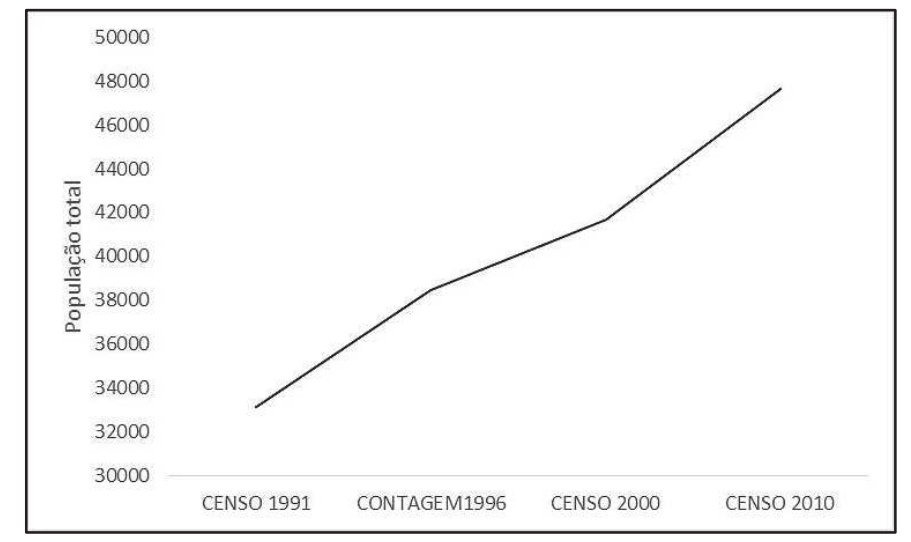

Fonte: PJF. Organizado pelo autor.

Apresenta um subcentro econômico representado pela RU Santa Terezinha (75) que "adquire maior importância por possibilitar, com o comércio e serviços locais, a redução dos deslocamentos de seus moradores para o Centro. Exerce influência sobre os bairros Eldorado (76), Nossa Senhora das Graças (75) e Mariano Procópio (18)" (PPDU, 2004). Além de instituições das Polícias Militar e Civil, dentre outras instituições.

A suscetibilidade aos movimentos de massa nessa RP, tem $28 \%$ de área com baixa suscetibilidade, 41,4\% com média suscetibilidade e 30,6\% em alta suscetibilidade, sendo que as maiores extensões ocupadas estão nas classes de baixa e média suscetibilidade. Ainda assim, 
17,8\% encontra-se em setores de alta suscetibilidade a movimentos de massa (Quadro 69 e figura 85).

Quadro 69: Suscetibilidade aos movimentos de massa, por classe, na região de planejamento Nordeste.

\begin{tabular}{|c|c|c|c|c|}
\hline \multicolumn{4}{|c|}{ Suscetiblidade a movimentos de massa } \\
\hline & \multicolumn{2}{|c|}{ Total } & \multicolumn{2}{c|}{ Edificada } \\
\cline { 2 - 5 } & $\mathrm{Km}^{2}$ & $\%$ & $\mathrm{Km}^{2}$ & $\%$ \\
\hline Área da RP $\left(\mathrm{Km}^{2}\right)$ & 49,7 & 100 & 11,7 & 100 \\
\hline Baixa suscetibilidade & 13,9 & 28,0 & 5,0 & 42,6 \\
\hline Média suscetibilidade & 20,6 & 41,4 & 4,6 & 39,5 \\
\hline Alta suscetibilidade & 15,2 & 30,6 & 2,1 & 17,8 \\
\hline
\end{tabular}

Fonte: CPRM (2014) / Organizado pelo autor.

A ocupação das áreas suscetíveis aos movimentos de massa atinge a maior proporção de área na classe de baixa suscetibilidade, com $35,9 \%$, enquanto $22,5 \%$ encontra-se na classe de média suscetibilidade e 13,7\% com alta suscetibilidade a movimentos de massa (Quadro 70 e Figura 85).

Quadro 70: Percentagem das áreas suscetíveis a movimentos de massa ocupadas, na RP Nordeste.

\begin{tabular}{|c|c|}
\hline \multicolumn{2}{|c|}{ Ocupação em áreas suscetíveis (\%) } \\
\hline Baixa suscetibilidade & 35,9 \\
\hline Média suscetibilidade & 22,5 \\
\hline Alta suscetibilidade & 13,7 \\
\hline
\end{tabular}

Fonte: CPRM (2014) / Organizado pelo autor.

A suscetibilidade às inundações representa 7\% da área dessa RP, sendo associadas à bacia do Ribeirão das Rosas, que tem seu baixo curso drenando na RP Centro-Oeste, mas seu alto curso engendra suscetibilidade à inundação na RU Grama (80). Além disso na bacia do córrego da Tapera a suscetibilidade à inundação ocorre nas RU's Bandeirantes (78) e Santa Terezinha (75) (Figura 85 e Quadro 71). 
Figura 85: Carta de suscetibilidade a movimentos de massa e inundações, com base na CPRM (2014), na RP Nordeste.

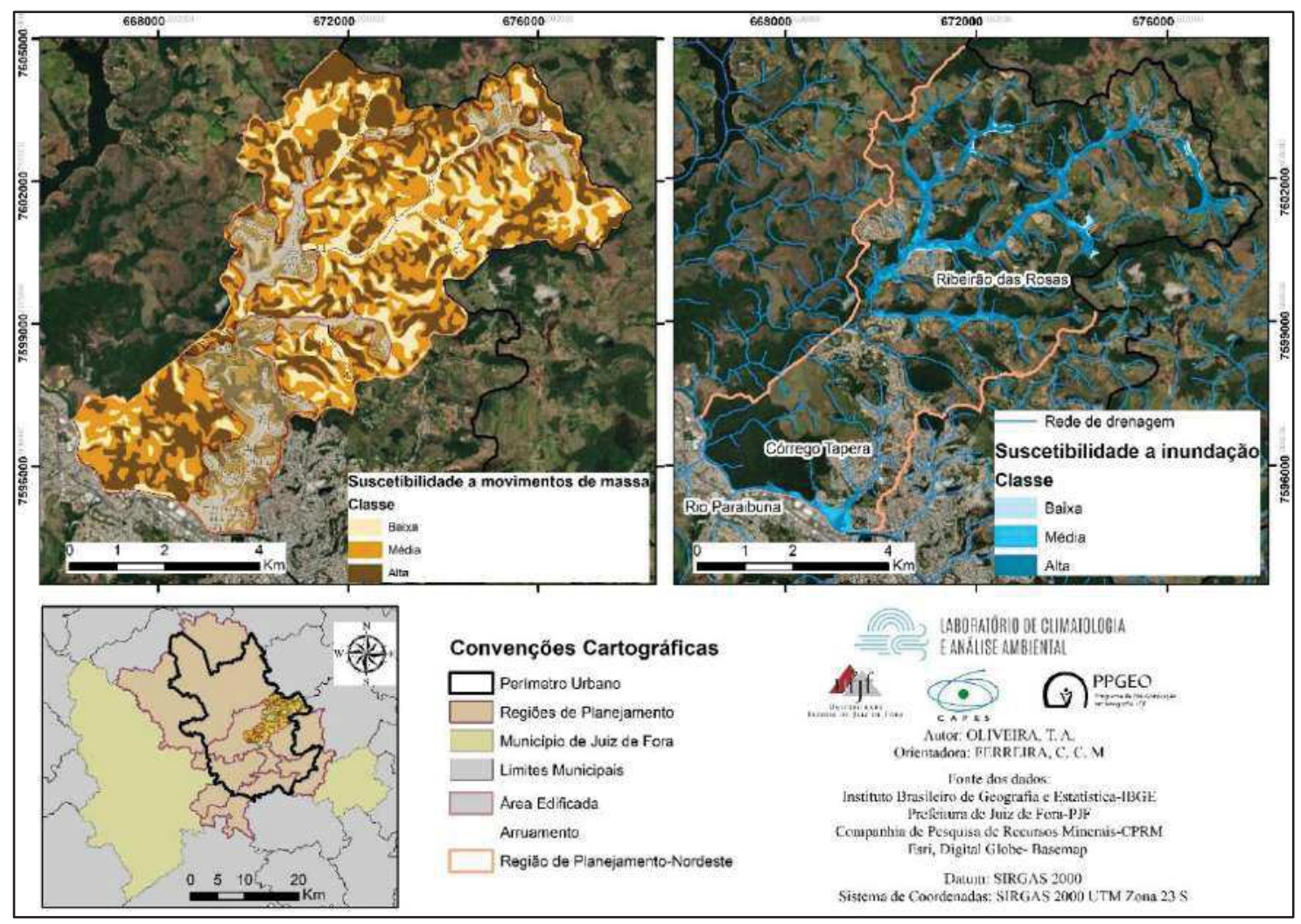

Fonte: CPRM (2014). Organizado pelo autor.

A área edificada nessa RP ocupa $27 \%$ das áreas suscetíveis, sendo que a classe de alta suscetibilidade tem a maior porcentagem de área edificada, com $21,4 \%$ da mancha edificada, sendo que isso representa $95,4 \%$ de todo compartimento com alta suscetibilidade a inundação.

Quadro 71: Suscetibilidade a inundação por classe, na região de planejamento Nordeste

\begin{tabular}{|c|c|c|c|c|}
\hline \multirow{2}{*}{ Suscetiblidade a inundação } \\
\cline { 2 - 5 } & \multicolumn{2}{|c|}{ Total } & \multicolumn{2}{c|}{ Edificada } \\
\cline { 2 - 5 } & $\mathrm{Km}^{2}$ & $\%$ & $\mathrm{Km}^{2}$ & $\%$ \\
\hline Área da RP $\left(\mathrm{Km}^{2}\right)$ & 49,7 & 100 & 11,7 & 100 \\
\hline Baixa suscetibilidade & 0,22 & 0,4 & 0,14 & 1,2 \\
\hline Média suscetibilidade & 0,67 & 1,3 & 0,52 & 4,4 \\
\hline Alta suscetibilidade & 2,62 & 5,3 & 2,50 & 21,4 \\
\hline
\end{tabular}

Fonte: CPRM (2014) / Organizado pelo autor.

Além disso, as áreas com baixa e média suscetibilidade a inundação apresentam menor extensão ocupada, se comparada com a alta suscetibilidade, com 63,6\% e 77,6\%, respectivamente. Embora esses valores ainda demonstrem uma elevada ocupação de áreas suscetíveis (Quadro 72). 
Quadro 72: Percentagem das áreas suscetíveis a inundação, ocupadas, na RP Nordeste.

\begin{tabular}{|c|c|}
\hline \multicolumn{2}{|c|}{ Ocupação em áreas suscetíveis (\%) } \\
\hline Baixa suscetibilidade & 63,6 \\
\hline Média Suscetibilidade & 77,6 \\
\hline Alta Suscetibilidade & 95,4 \\
\hline
\end{tabular}

Fonte: CPRM (2014) / Organizado pelo autor.

A ocupação na classe de alta suscetibilidade a inundações se dá, sobretudo, na RU Santa Terezinha (75), onde o córrego Tapera foi retificado no seu baixo curso, área na qual as ocorrências de inundação são frequentes (Figura 86). Na bacia do Ribeirão das Rosas a ocupação ainda tem se intensificado sobretudo a partir da RU Grama (80).

Figura 86: Córregos da Tapera e Ribeirão das Rosas na RP Nordeste.

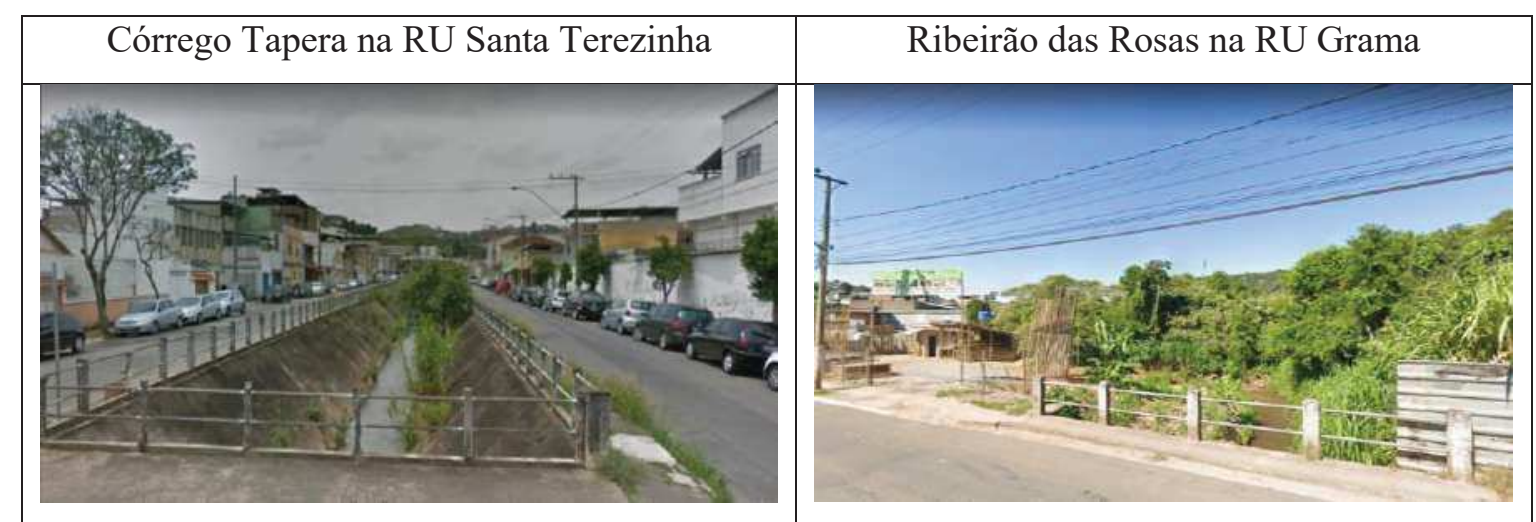

Fonte: Google Maps- Street View (2017 e 2018).

\section{A região de planejamento Norte}

A região de planejamento Norte é composta por cinco regiões urbanas e apresenta a maior área total dentre as RP's com $195 \mathrm{~km}^{2}$. A RP Norte tinha em 2010, 53917 habitantes, sendo que em 1991 o contingente populacional era de 28947 habitantes, o que representa uma elevação de $86 \%$ nesse período (Figura 87 ). 
Figura 87: População total na RP Norte- 1991-2010

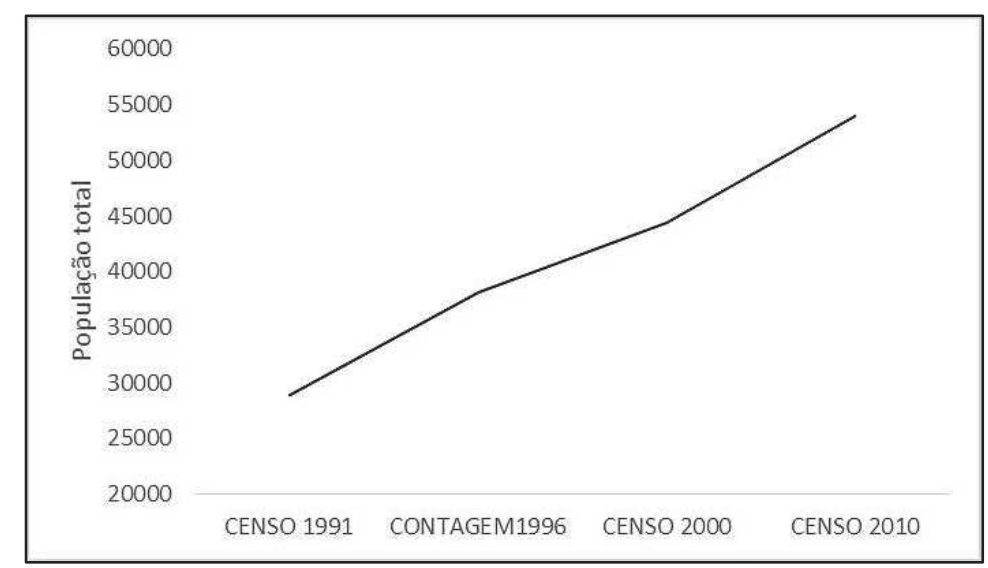

Fonte: PJF. Organizado pelo autor.

A ocupação na RP Norte se deu ainda no período de construção do caminho Novo, quando o Halfeld muda o traçado da estrada para a margem direita do Rio Paraibuna, desde então a ocupação tem se desenvolvido ao longo desse eixo que segue o próprio rio, mas que foram incentivados pela ferrovia, bem como a Avenida Juscelino Kubitschek.

Sua ocupação foi intensificada a partir de 1930 com a instalação da FEEA (Fábrica de Estojos e Espoletas da Artilharia, atual IMBEL- Indústria de Material Bélico do Brasil), que iniciou os serviços em 1937 (SILVA, 2015), e consequentemente instalação de vilas de trabalhadores.

Essa alteração rápida de um espaço agrário para uma área de vilas operárias repercutiu em um rápido crescimento populacional, sobretudo na RU Benfica (3), de acordo com Silva (2015), sendo que o impacto da construção da indústria direcionou a produção do espaço na região, sobretudo até os anos 1970.

Além disso, a implantação do Distrito Industrial (DI) do município, a partir da década de 1970, impulsionou o desenvolvimento viário na região, com vias de interligar o DI às rodovias do entorno. Dentre as indústrias que ali se alojaram destaca-se o setor automobilístico e de siderurgia (SILVA, 2015).

Desde então a região se consolida como um subcentro importante no município, esses movimentos que se desencadearam na região influenciaram em um crescimento populacional, bem como a instalação de diversos serviços imputam a essa RP uma condição de subcentro.

A expansão para a RP Norte fora também indicada pelo PDDU (2004) e com isso é necessário observar as condições de sítio e consequentemente a suscetibilidade ambiental na região. 
A suscetibilidade aos movimentos de massa tem $35,2 \%$ da área em condição de baixa suscetibilidade, $31,8 \%$ com média suscetibilidade e outros $32,9 \%$ da área em alta suscetibilidade, com relação a edificação da mancha urbana, a maior proporção de área encontra-se nas condições de baixa suscetibilidade com $67,7 \%$ da extensão edificada, $21,8 \%$ em compartimentos de média suscetibilidade e 10,5\% em setores com alta suscetibilidade (Quadro 73 e Figura 88).

Quadro 73: Suscetibilidade a movimentos de massa, por classe, na região de planejamento Norte.

\begin{tabular}{|c|c|c|c|c|}
\hline \multirow{2}{*}{ Suscetiblidade a movimentos de massa } \\
\cline { 2 - 5 } & \multicolumn{2}{|c|}{ Total } & \multicolumn{2}{c|}{ Edificada } \\
\cline { 2 - 5 } & $\mathrm{Km}^{2}$ & $\%$ & $\mathrm{Km}^{2}$ & $\%$ \\
\hline Área da RP $\left(\mathrm{Km}^{2}\right)$ & 195,0 & 100 & 18,9 & 100 \\
\hline Baixa suscetibilidade & 68,7 & 35,2 & 12,8 & 67,7 \\
\hline Média suscetibilidade & 62,1 & 31,8 & 4,1 & 21,8 \\
\hline Alta suscetibilidade & 64,2 & 32,9 & 2,0 & 10,5 \\
\hline
\end{tabular}

Fonte: CPRM (2014) / Organizado pelo autor.

A ocupação em áreas suscetíveis aos movimentos de massa nessa RP, conforme já colocado, encontra-se nas classes de baixa suscetibilidade a movimentos de massa, além de que outros $6,6 \%$ em situação de média suscetibilidade e 3,1\% em condição de alta suscetibilidade (Quadro 74). Com isso essa RP era tida como potencial à expansão da mancha urbana, de acordo com o PDDU (2004).

Quadro 74: Percentagem das áreas suscetíveis a movimentos de massa ocupadas, na RP Norte.

\begin{tabular}{|c|c|}
\hline \multicolumn{2}{|c|}{ Ocupação em áreas suscetíveis (\%) } \\
\hline Baixa suscetibilidade & 18,6 \\
\hline Média suscetibilidade & 6,6 \\
\hline Alta suscetibilidade & 3,1 \\
\hline
\end{tabular}

Fonte: CPRM (2014) / Organizado pelo autor. 
Figura 88: Carta de suscetibilidade a movimentos de massa e inundações, com base na CPRM (2014), na RP Norte.

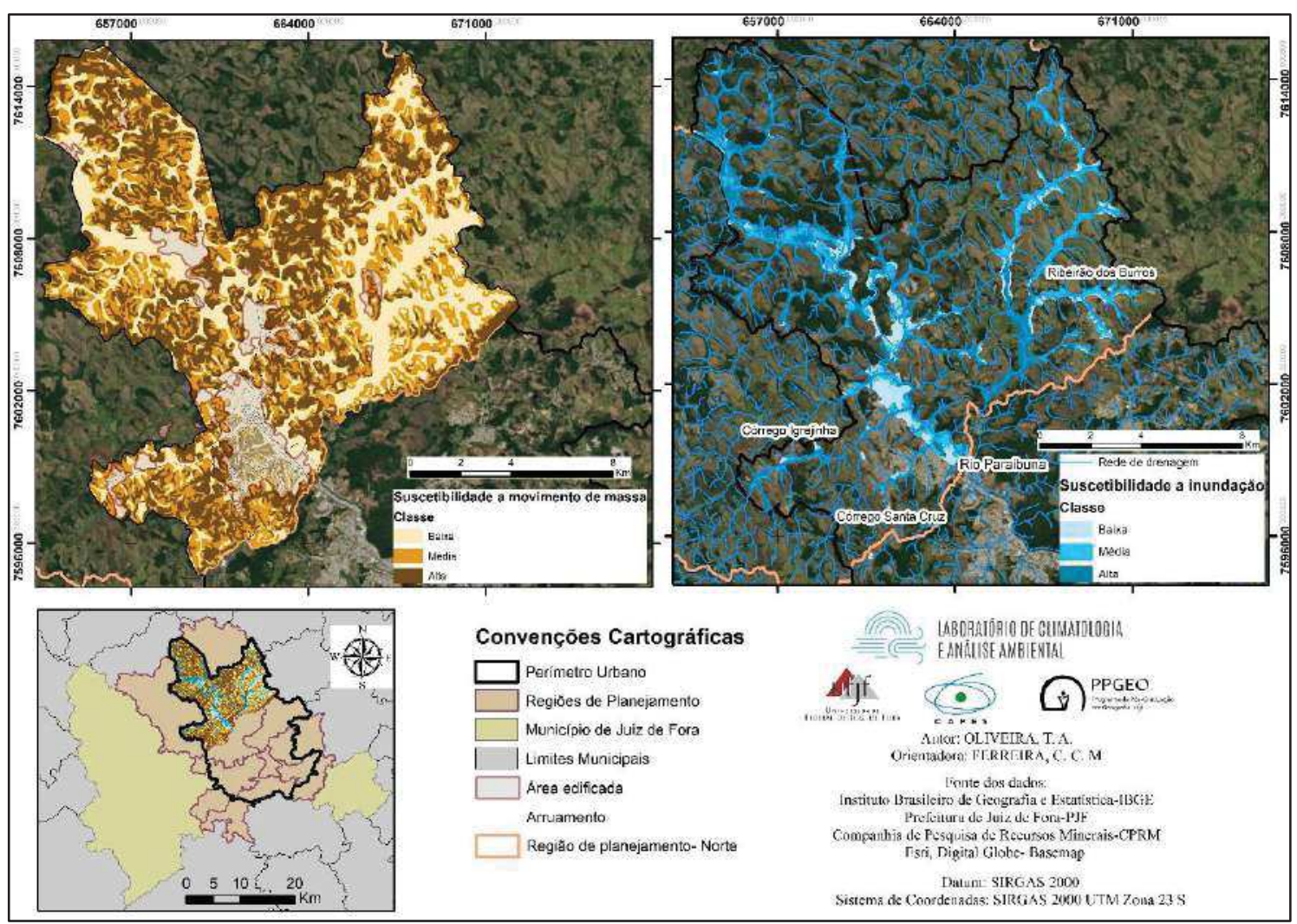

Fonte: CPRM (2014). Organizado pelo autor.

A suscetibilidade à inundação representa $18,5 \%$ da área total da RP, associada aos córregos do Santa Cruz e Igrejinha e ao próprio rio Paraibuna. Entretanto, as áreas suscetíveis às inundações foram amplamente ocupadas, sendo que mais de $86 \%$ da área edificada está alocada em setores com alta suscetibilidade à inundação (Quadro 75). 
Quadro 75: Suscetibilidade a inundação por classe, na região de planejamento Norte

\begin{tabular}{|c|c|c|c|c|}
\hline \multicolumn{3}{|c|}{ Suscetiblidade a inundação } \\
\hline & \multicolumn{2}{|c|}{ Total } & \multicolumn{2}{c|}{ Edificada } \\
\cline { 2 - 5 } & $\mathrm{Km}^{2}$ & $\%$ & $\mathrm{Km}^{2}$ & $\%$ \\
\hline Área da RP $\left(\mathrm{Km}^{2}\right)$ & 195,0 & 100 & 18,9 & 100 \\
\hline Baixa suscetibilidade & 6,6 & 3,4 & 4,46 & 23,7 \\
\hline Média suscetibilidade & 12,6 & 6,5 & 3,27 & 17,3 \\
\hline Alta suscetibilidade & 16,7 & 8,6 & 16,23 & 86,1 \\
\hline
\end{tabular}

Fonte: CPRM (2014) / Organizado pelo autor.

Com isso, as áreas com alta suscetibilidade encontram-se 97\% ocupadas, enquanto outros $67,4 \%$ estão em compartimentos de baixa suscetibilidade a inundação, os setores com média suscetibilidade são os menos ocupados, com 26\%. Apesar de ser tida como setor disponível para a expansão da mancha urbana, é necessário destacar os impactos oriundos da ocorrência de inundações e alagamentos tem sido recorrente nessa RP (Quadro 76).

Quadro 76: Percentagem das áreas suscetíveis a inundação, ocupadas, na RP Norte.

\begin{tabular}{|c|c|}
\hline \multicolumn{2}{|c|}{ Ocupação em áreas suscetíveis (\%) } \\
\hline Baixa suscetibilidade & 67,4 \\
\hline Média Suscetibilidade & 26,0 \\
\hline Alta Suscetibilidade & 97,0 \\
\hline
\end{tabular}

Fonte: CPRM (2014) / Organizado pelo autor.

\section{Os episódios extremos e os impactos das chuvas em Juiz de Fora}

Dentre os elementos levados a efeito para a análise do risco climático está a ocorrência dos episódios extremos, que revelam a integração entre o evento pluviométrico e os respectivos impactos por este deflagrados no espaço urbano, conforme descrito por Armond (2014). Com isso, a investigação dos impactos responde à ocorrência pluviométrica, mas também se associam às condições de suscetibilidade e vulnerabilidade que repercutem para a sua distribuição espacial na cidade.

A avaliação dos episódios extremos de precipitação permite visualizar a quantidade de dias por mês/período chuvoso em que ocorreram impactos em Juiz de Fora. Os episódios extremos então serão tratados como datas em que ocorreram qualquer tipo de impacto na cidade. 
Avaliando a partir dos dados anuais, visualiza-se uma tendência de elevação no número de episódios extremos. A ocorrência dos episódios está associada à própria variabilidade dos dados de precipitação, sendo que anos chuvosos como 1985, 1994, 2003,2004 observaram mais que 25 episódios extremos, no entanto, outros anos chuvosos como 1983, 2016 e 2018 o número foi inferior. Ainda que exista uma relação entre a variabilidade da precipitação, o número de episódios extremos, por vezes se relaciona e em outros momentos não (Figura 89).

Além disso, a média móvel de três períodos demonstra um período com maior ocorrência de episódios extremos, evento pluviométrico com impactos deflagrados, no período de 1991 a 2004 e no período mais recente (entre 2012 e 2018) o número de episódios fícou com um valor mais baixo, inferior a 15 episódios por ano.

Figura 89: Frequência anual de episódios extremos em Juiz de Fora- MG.

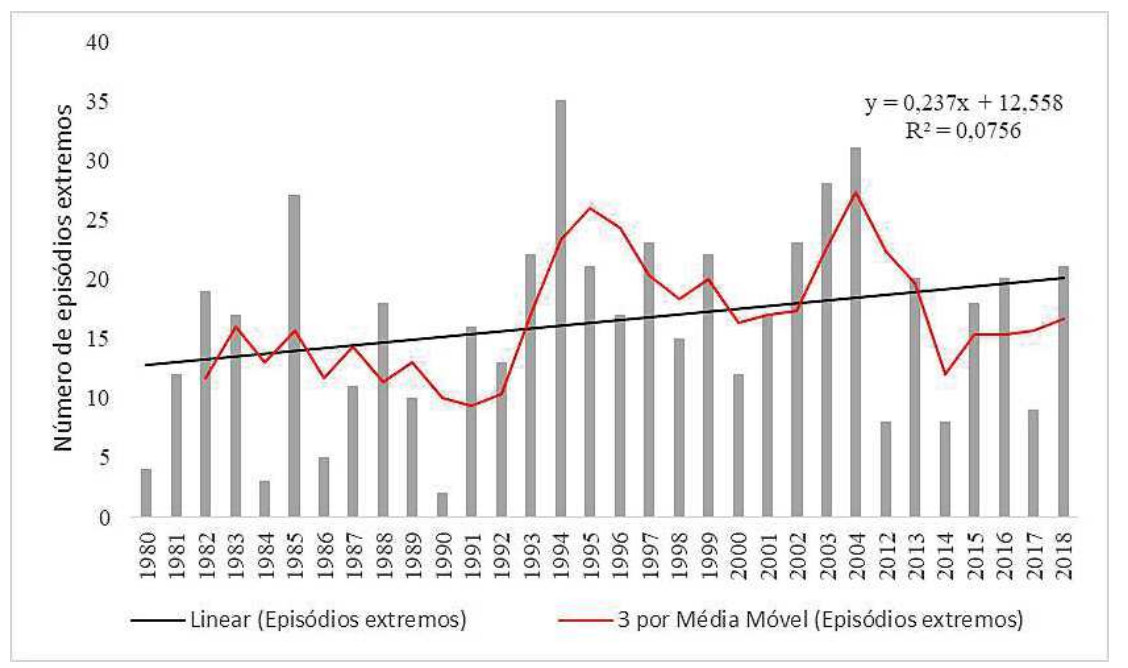

Fonte: Organizado pelo autor.

Os episódios extremos se concentram principalmente nos meses de Novembro, Dezembro e Janeiro, meses nos quais também registra-se um maior número de dias de chuva, conforme já colocado. Ainda assim, o mês de Janeiro tem, em média, o maior número de episódios extremos, sendo que o número de dias com precipitação superior ao percentil 90 é maior no mês de dezembro, que em média, tem um número de impactos menor (Figura 90).

Figura 90: Média mensal de episódios extremos em Juiz de Fora.

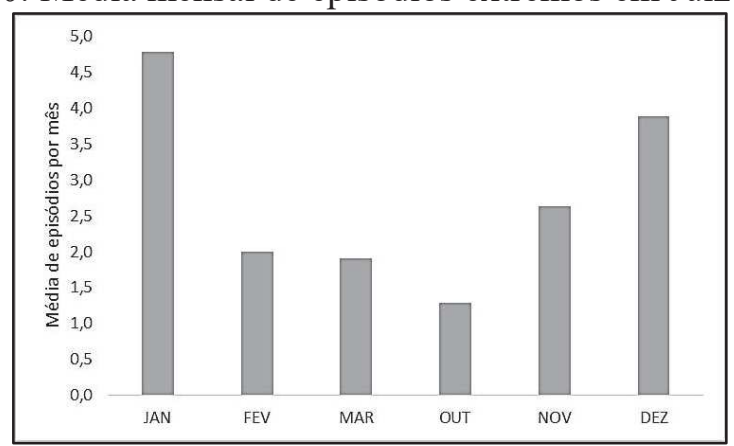


Fonte: Organizado pelo autor.

Ao longo dos anos, o número de episódios apresentou uma variabilidade, sendo que o mês de Janeiro jamais teve ausência de registro de episódios extremos, já os outros meses pelo menos uma vez não houveram ocorrências na cidade. O mês com o menor número de episódios extremos foi o mês de Outubro em que $75 \%$ da série esteve entre 0 e 2 ocorrências (Figura 91).

Figura 91: Variabilidade mensal da ocorrência de episódios extremos em Juiz de Fora

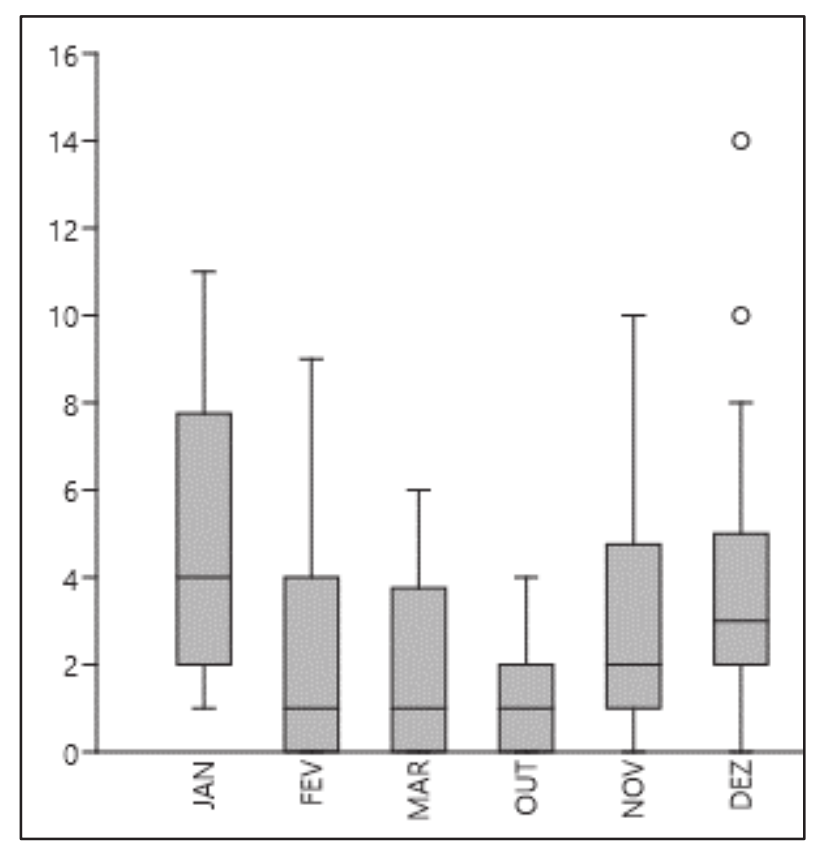

Fonte: Organizado pelo autor.

Os valores extremos de episódios estiveram associados a ocorrências de totais pluviométricos mais elevados. O valor extremo de Janeiro, com 11 episódios se deu no mês mais chuvoso da série em 1985 com $715 \mathrm{~mm}$; fevereiro teve extremo de 9 episódios observado em 1988 com 403,1 mm; março teve extremo de 6 episódios registrado em 1982, com 349mm; outubro o valor máximo foi de 4 episódios também em 1985, quando o valor mensal foi considerado habitual, com 157,4, sendo que o setembro anterior fora considerado chuvoso; novembro também teve seu valor máximo em um mês considerado habitual, em 1994 com 159,6mm; e dezembro que teve dois episódios fora da curva (outliers) um em 2013 com 14 episódios quando choveram 475,4mm e outro com 10 episódios em 2018, quando o total pluviométrico foi de $380,6 \mathrm{~mm}$, ambos foram considerados chuvosos.

Embora não seja uma relação direta entre os totais pluviométricos mensais e a ocorrência de episódios extremos, é comum que meses chuvosos representem um maior número 
de impactos na cidade, e consequentemente um maior número de episódios extremos, e o contrário disso também ocorre.

Outro elemento importante é o número de impactos que os episódios geraram na cidade, é possível visualizar que o total de impactos citados nos jornais tem aumentando ao longo dos anos, sendo que existe uma variabilidade que pode estar associada à própria variabilidade pluviométrica, mas no contexto geral os impactos têm se tornado mais frequentes (Figura 92). A partir da média móvel observa-se o período mais elevado entre 1991 e 2004 e no período mais recente o número de impactos tem aumentado, sobretudo a partir de 2016.

Figura 92: Frequência anual de impactos registrados em Juiz de Fora

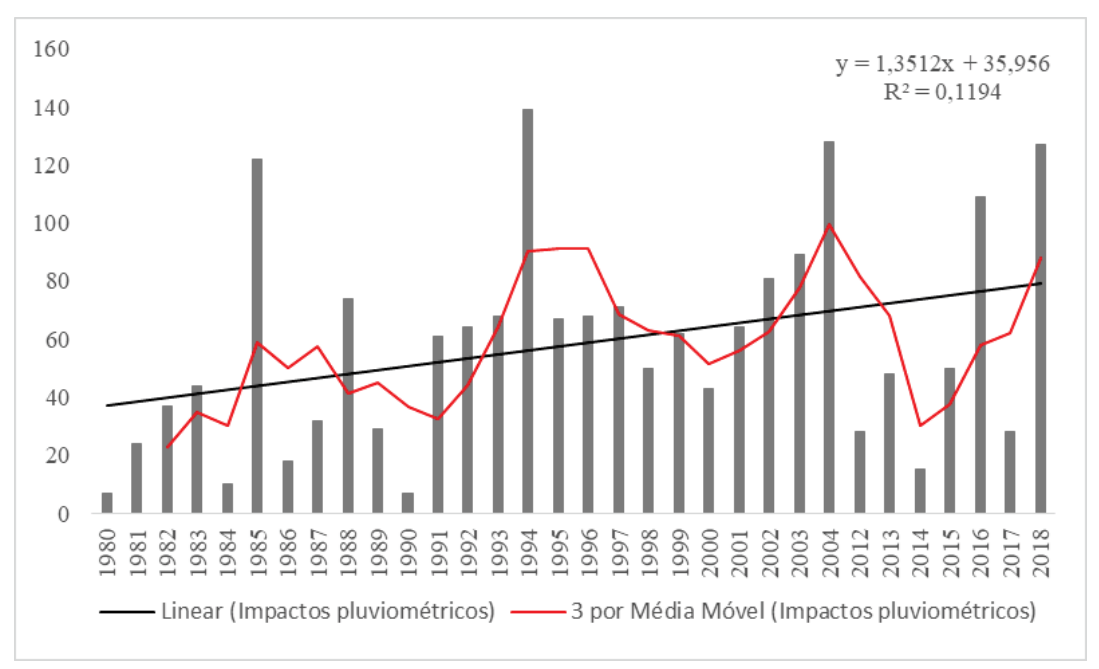

Fonte: Organizado pelo autor.

A primeira década (1980-1989) de levantamento o número de impactos foi o mais reduzido, com 397 citações, enquanto a segunda década (1990-1999) teve 657 citações e o terceiro período, entre 2000 e 2018 (lembrando a falha de dados entre 2005 e 2011), integrando assim 12 anos, teve 810 citações (Figura 93).

Figura 93: Somatório de impactos por período- 1980-89;1990-99; 2000-18.

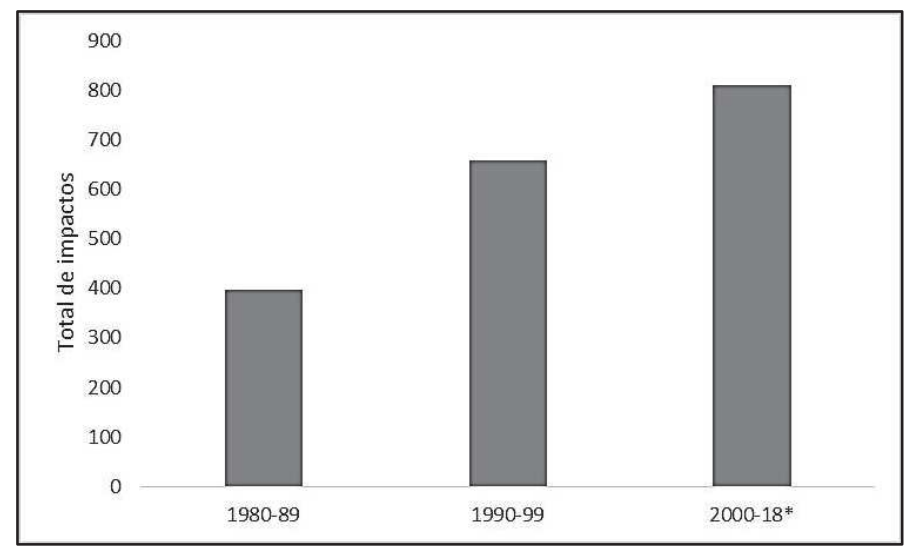


Fonte: Organizado pelo autor.

Essas informações demonstram que o número de impactos tem ficado mais frequente na cidade de Juiz de Fora. Apesar de serem observadas alguma elevação na frequência de eventos extremos, que podem indicar esse crescimento, a expansão da mancha urbana repercute nesses números, uma vez que só ocorre impacto na medida em que existe alguma ocupação humana.

A distribuição mensal dos impactos seguiu a mesma lógica dos episódios, sendo que os meses de Janeiro, Novembro e Dezembro são os que observam um maior número de impactos, enquanto que o mês de outubro tem valores mais baixos. O mês de Janeiro foi o único mês que em todos os anos registrou impactos, observando uma variabilidade que vai de $1(1981 ; 1982$; 1988 e 2013) impactos a 81, que ocorreram em 1985 mês mais chuvoso da série. Outro mês com um número elevado de impactos foi o mês de Dezembro, no entanto esse não apresentou impactos nos anos de 1985, 1990 e 2017 (Figura 94).

Figura 94: Box plot mensal dos impactos registrados em Juiz de Fora.

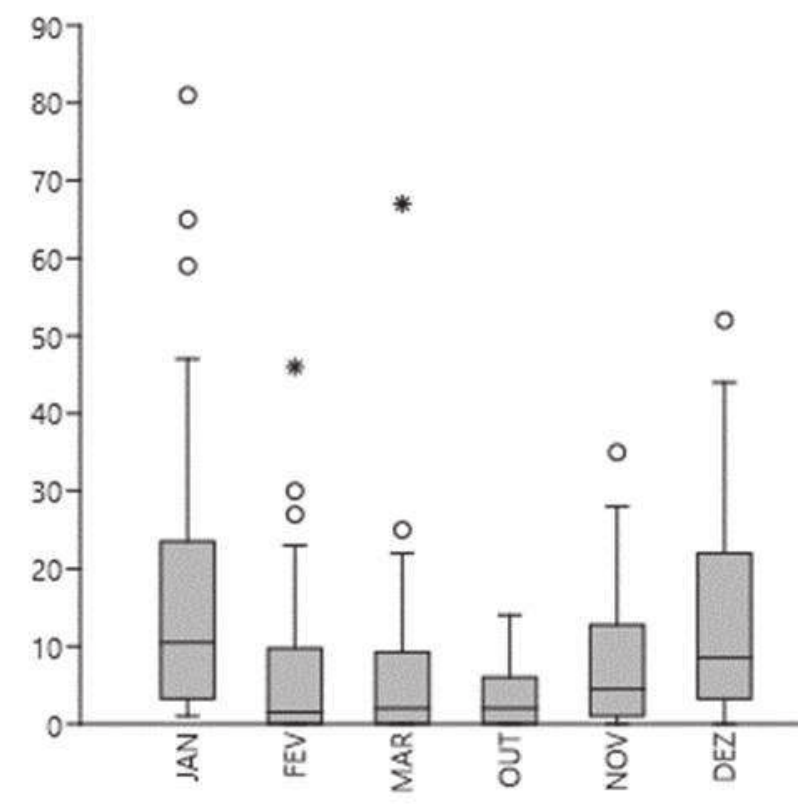

Fonte: Organizado pelo autor.

Os meses de Fevereiro, Março, Novembro apesar de terem valores mais baixos, registraram outliers que ultrapassaram os vinte impactos no mês. Fevereiro com a ocorrência de 27, 30 e 46 impactos nos anos de 2016, 1995, 1988, respectivamente; Março com 25 e 67 
impactos nos anos de 1999 e 2018 respectivamente e Novembro com 35 impactos em 2016. Outubro com um número menor de ocorrências teve o valor máximo de 14 impactos em 1985.

\section{Os impactos das chuvas em Juiz de Fora: e a sua espacialização no perímetro urbano}

As RPs com o maior número de impactos foram a Leste e a Centro, com mais de 300 impactos registrados no período analisado (1980-2018). A RP Leste tem um histórico já elevado de ocorrências, o que observa-se é que o cenário não se alterou ao longo dos anos, mantendose em totais elevados, que sempre superaram os 100 impactos nos três períodos. Com isso a variação entre o terceiro período (2000-2018) e a primeira década (1980-1989) foi de 22\% (Figura 95).

Figura 95: Distribuição dos impactos por região de planejamento e por período analisado.

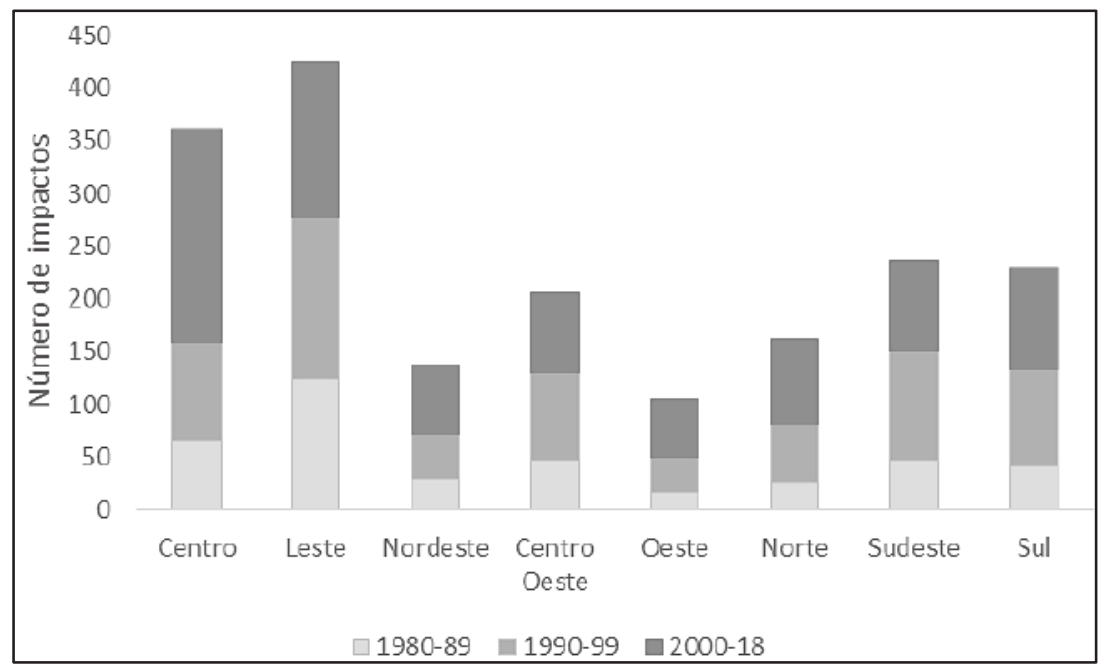

Fonte: Organizado pelo autor.

Já a RP Centro teve um crescimento elevado no último período e totaliza uma elevação de mais de $200 \%$ se comparado à primeira década (1980-1989). Apesar de não ter um crescimento populacional elevado, a intensificação da impermeabilização do solo nessa RP, associado à verticalização nas RUs Grambery (54) e Bom Pastor (48) repercutiram na elevação dos impactos hidrológicos, principalmente os alagamentos (Figura 96).

As RPs que observaram o maior crescimento no número de impactos na última década correspondem às que obtiveram o maior crescimento populacional, sobretudo nas RPs Oeste e Norte, Sul e Nordeste. A maior proporção se deu na RP Oeste em que o crescimento foi de 
$250 \%$ indicando que as formas pelas quais a ocupação se deu nessa RP não impediu que os impactos relacionados à precipitação passassem a atingi-la (Figura 96).

Figura 96: Variação no número de impactos entre o período 2000-18 e 1980-89.

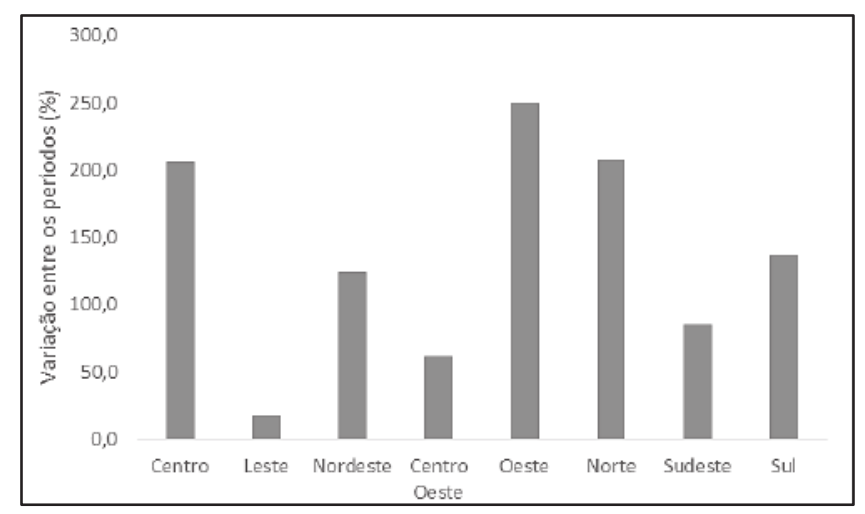

Fonte: Organizado pelo autor.

Esse processo revela a questão da cidade como produto e produtora de impactos, no sentido em que a expansão da mancha urbana ao longo das décadas repercutiu na intensificação dos impactos nas respectivas regiões de planejamento, sobretudo nas áreas de vulnerabilidade social mais elevada.

Os impactos na área urbana de Juiz de Fora foram somados no mapa de citações totais, com isso agrega-se as informações dos impactos hidrológicos e geomorfológicos. Com o intuito de identificar possíveis áreas que são impactadas pelas duas classes investigadas, ou mesmo por apenas uma delas.

As dez regiões urbanas mais impactadas encontram-se duas na RP Leste, Linhares (67) e Vitorino Braga (64), na RP Centro encontram-se o Centro (55) e São Mateus (40), outras duas RUs na RP Norte, Santa Cruz (4) e Benfica (3). A região urbana São Pedro aparece na RP Oeste (28), a RU Vila Olavo Costa aparece na RP Sudeste e duas regiões urbanas na RP Sul, Santa Luzia (42) e Ipiranga (37) (Figura 97).

Figura 97: Dez regiões urbanas mais citadas por impactos associados a chuva em Juiz de Fora 


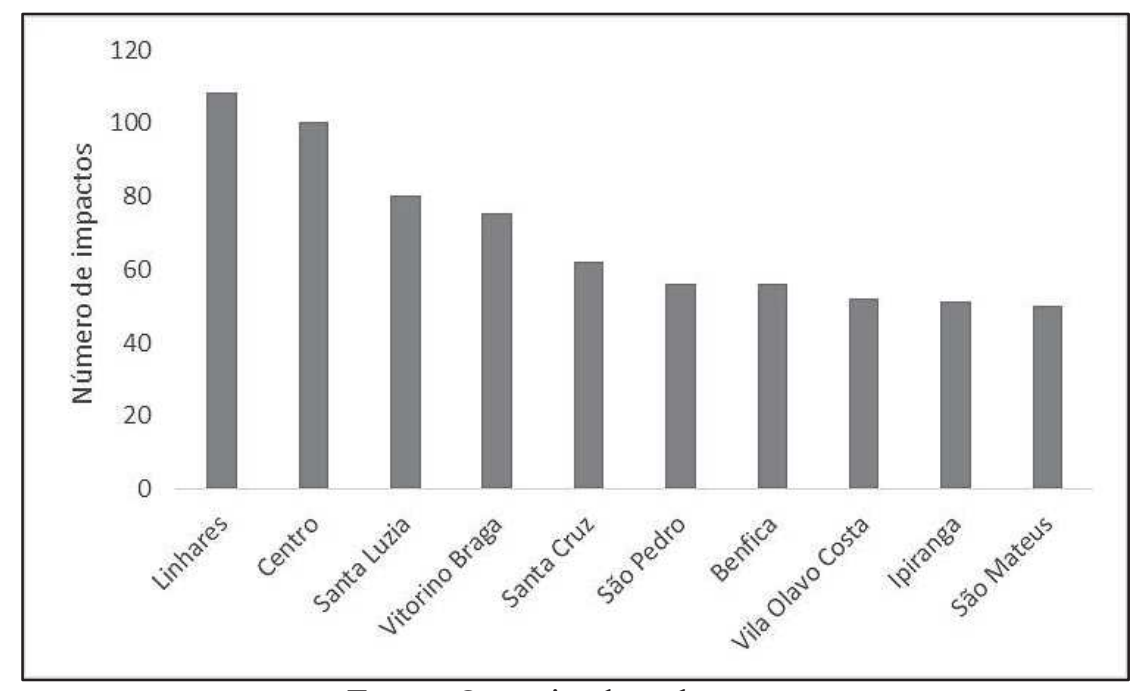

Fonte: Organizado pelo autor.

Nesse cenário, apenas as RP Centro-Oeste e Nordeste não apresentam nenhuma região urbana entre as dez mais impactadas. Dentre as RUs mais impactadas observa-se que em algumas delas existe uma concentração no número de ocorrências a uma determinada tipologia.

No quadro 77, apresenta-se a porcentagem de ocorrência dos impactos por região urbana, desconsiderando as ocorrências que foram apenas citadas (sem indicação de tipologia). Algumas RUs tem uma concentração de determinada tipologia, como a RU Centro (55) com 92,8\% das ocorrências de impactos hidrológicos, enquanto que na Vila Olavo Costa, ocorre o oposto, 95,3\% dos impactos são geomorfológicos. E nas outras RUs existe uma distribuição mais variável, sendo próxima nas RUs Vitorino Braga (64), Santa Luzia (42) e São Mateus (40), indicando ocorrências variadas nas áreas.

Quadro 77: Percentagem do tipo de impacto por região urbana

\begin{tabular}{|c|c|c|}
\hline Região Urbana & Impacto hidrológico & Impacto geomorfológico \\
\hline Linhares & 31,5 & 68,5 \\
\hline Centro & 92,8 & 7,2 \\
\hline Santa Luzia & 47,3 & 52,7 \\
\hline Vitorino Braga & 52,2 & 47,8 \\
\hline Santa Cruz & 30,2 & 69,8 \\
\hline São Pedro & 66,7 & 33,3 \\
\hline Benfica & 68,0 & 32,0 \\
\hline Vila Olavo Costa & 4,7 & 95,3 \\
\hline Ipiranga & 30,4 & 69,6 \\
\hline São Mateus & 56,5 & 43,5 \\
\hline
\end{tabular}

É possível visualizar a partir das décadas o deslocamento dos impactos para o setor Oeste do perímetro urbano. Na década de 1980-1989 eram poucos os impactos na RP Oeste, 
enquanto que nas décadas seguintes o número foi se intensificando, conforme já destacado como uma das RP como maior crescimento nesse indicador, bem como foi a que teve maior crescimento populacional.

Em um contexto geral é fato que todas as regiões urbanas já apresentaram pelo menos uma citação ao longo do período (Figura 98). As RUs com o menor número de citações, se localizam em áreas que ainda estão em processo de ocupação recente, ou são ocupadas por construções de alto padrão, ou loteamentos fechados como ocorre nas RUs Aeroporto (32) e Morro do Imperador (23), que tem as maiores taxas de crescimento populacional e figuram dentre as RUs com o menor número de impactos.

Esse processo exemplifica a seletividade espacial da cidade que irá repercutir na distribuição dos impactos associados à precipitação, pois mesmo que estejam em áreas com suscetibilidade à ocorrência de movimentos de massa, as técnicas construtivas mais sofisticadas permitem driblar essa situação.

Figura 98: Distribuição por região urbana dos impactos associados a chuvas em Juiz de Fora 


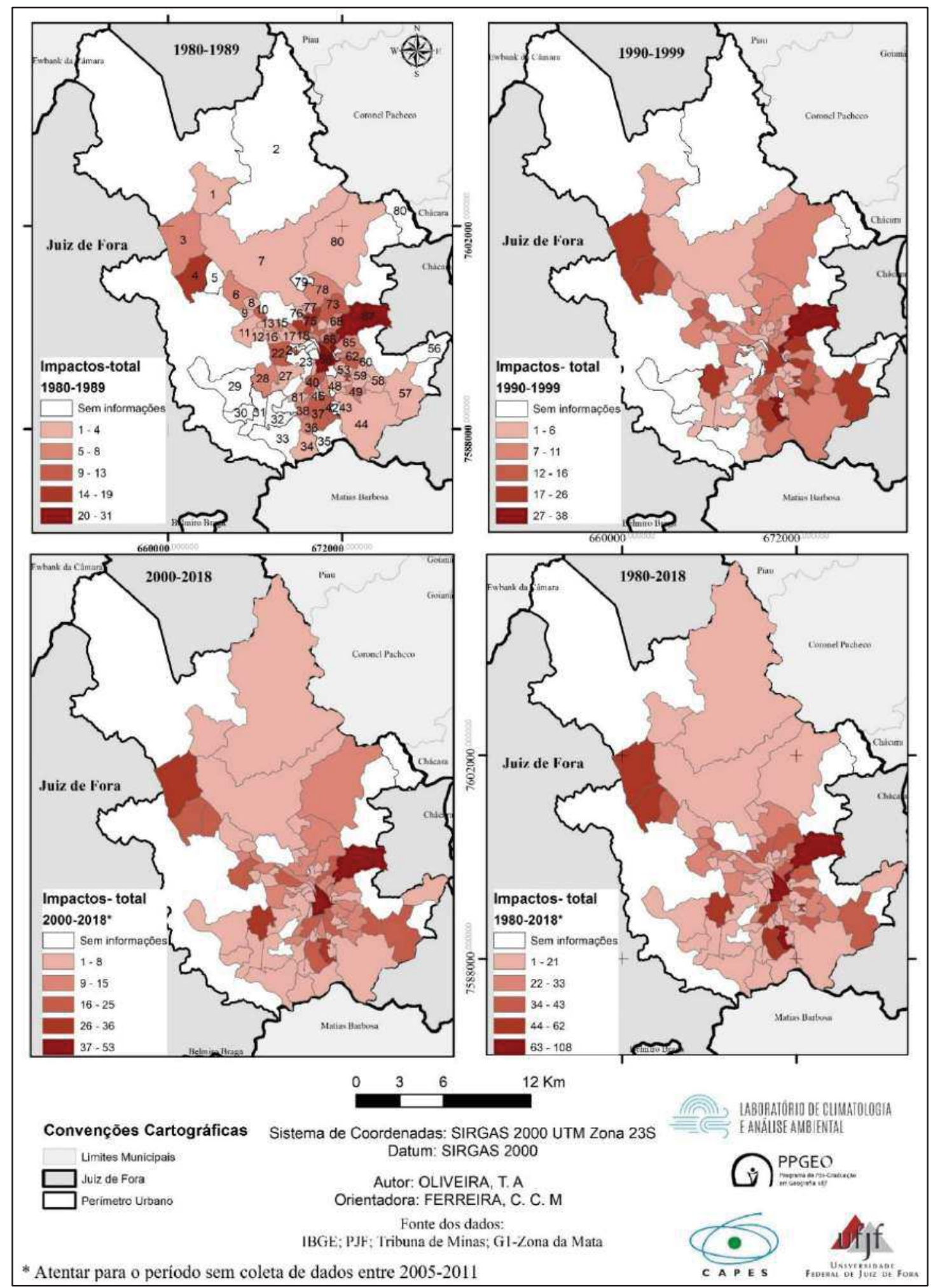

Fonte: Organizado pelo autor.

Com relação especificamente aos impactos geomorfológicos (Figura 99), que congregam os deslizamentos e os desabamentos, estes têm observado uma variabilidade ao longo do período analisado e com uma tendência insignificante de elevação. Os anos de 1985 e 1994 observaram o maior número desses impactos na cidade, com 68 e 89 registros, 
respectivamente. A partir da média móvel observa-se o período entre 1993 e 1996 e 2002-2004 com o número de impactos geomorfológicos mais elevados na série.

Figura 99: Frequência anual dos impactos geomorfológicos em Juiz de Fora.

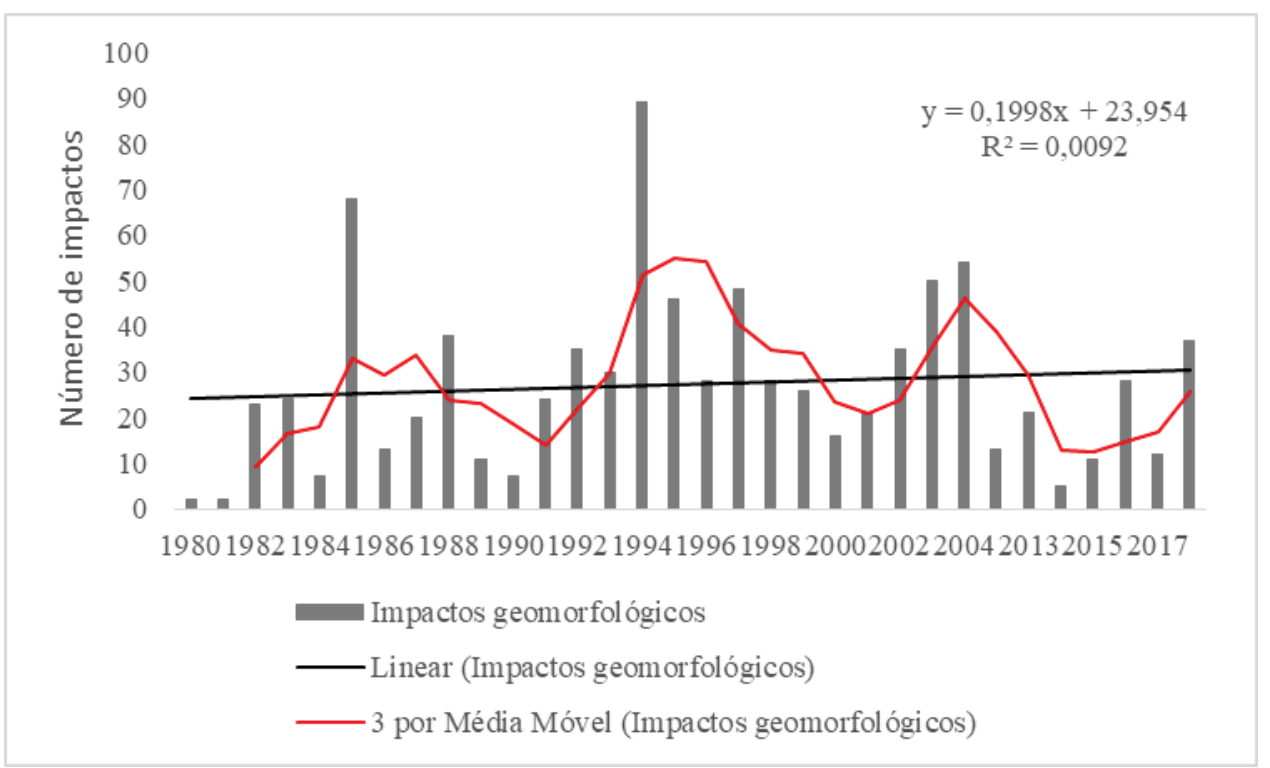

Fonte: Organizado pelo autor.

O balanço a partir das décadas permite visualizar que o número de ocorrências se elevou nos dois últimos períodos (1990-1999 e 2000-2018), quando comparado ao primeiro período (1980-1989), no entanto no último recorte (2000-2018) o número de impactos geomorfológicos teve uma pequena redução (Figura 100).

Figura 100: Somatório por décadas dos impactos geomorfológicos em Juiz de Fora.

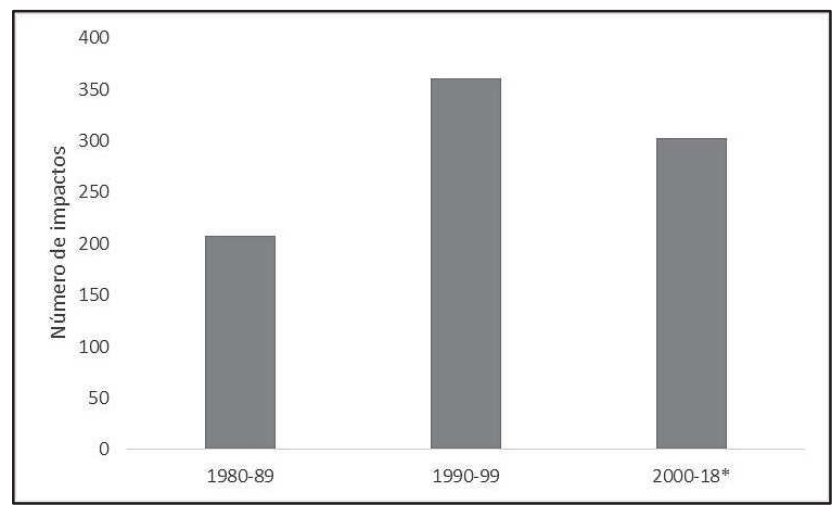

Fonte: Organizado pelo autor.

A região de planejamento com o maior número de impactos é a RP Leste, onde o número ultrapassa os 250 registros, no período de 1980-2018, nesta RP existe pouca variação entre as décadas. Outras RPs têm valores que se aproximam das 100 ocorrências, como a RP Centro, Sudeste e Sul (Figura 101). 
Figura 101: Distribuição dos impactos geomorfológicos por região de planejamento e por período analisado.

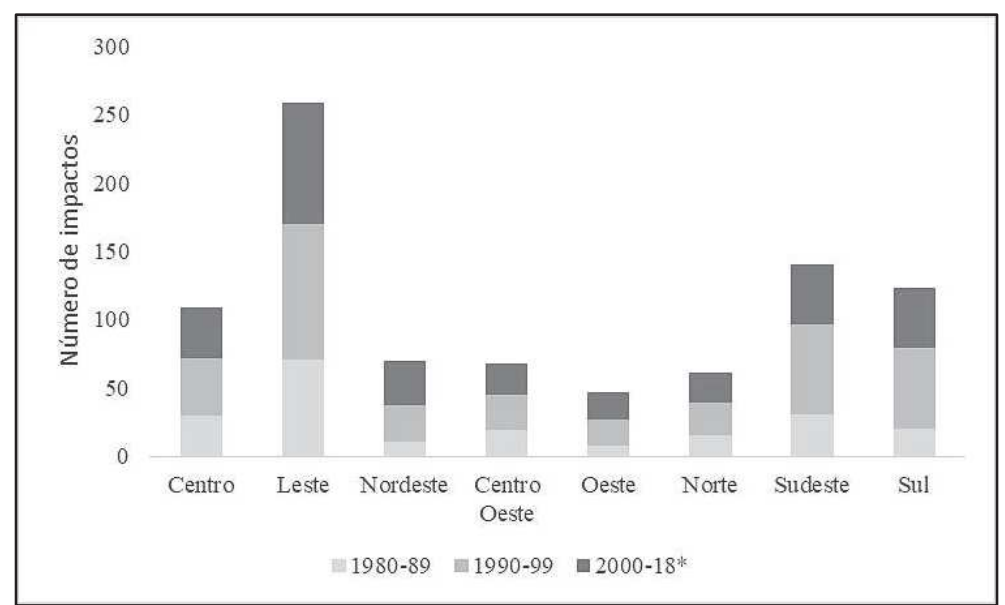

Fonte: Organizado pelo autor.

As maiores elevações na ocorrência de impactos geomorfológicos ocorrem nas RPs Nordeste, Oeste e Sul, que apesar de ainda serem baixos estes foram numerosos no último período (2000-2018). As RPs Nordeste e Oeste tiveram uma elevação superior a 100\% indicando uma profusa ocorrência dessa classe de impacto nos últimos anos. Costa (2019) também indicou uma elevação das áreas suscetíveis a escorregamentos na bacia do córrego Tapera, localizada na RP Nordeste (Figura 102).

Figura 102: Variação no número de impactos geomorfológicos entre o período 2000-18 e 1980-89.

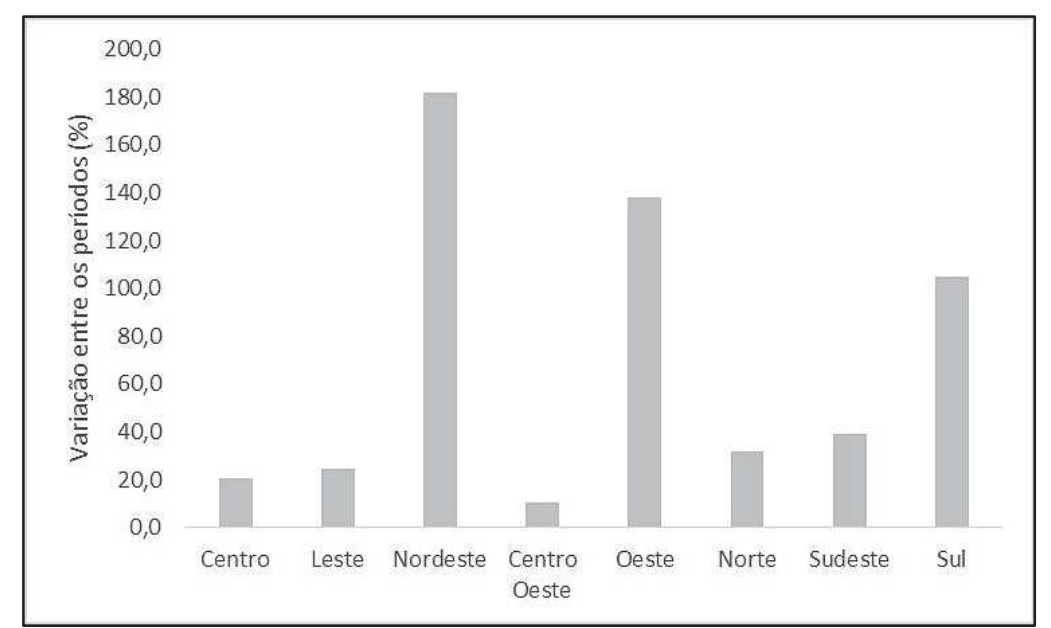

Fonte: Organizado pelo autor.

Dentre as regiões urbanas, as dez mais citadas por impactos geomorfológicos foram cinco da RP Leste, Linhares (67), Grajaú (66), Vitorino Braga (64), Santa Cândida (65) e N. S. Aparecida (69); duas na RP Sul, Santa Luzia (42) e Ipiranga (37); uma na RP Sudeste, Vila Olavo Costa (50); uma na RP Norte, Santa Cruz (4); e uma na RP Oeste, Borboleta (22). 
As dez RUs mais citadas tem um histórico de ocorrências ao longo de todo o período, sendo possível visualizá-las em destaque nos três períodos recortados. A região urbana Linhares(67) aparece sempre em destaque com o maior registro de ocorrências de impactos geomorfológicos na cidade (Figura 103).

Figura 103: Dez regiões urbanas mais citadas por impactos geomorfológicos em Juiz de Fora

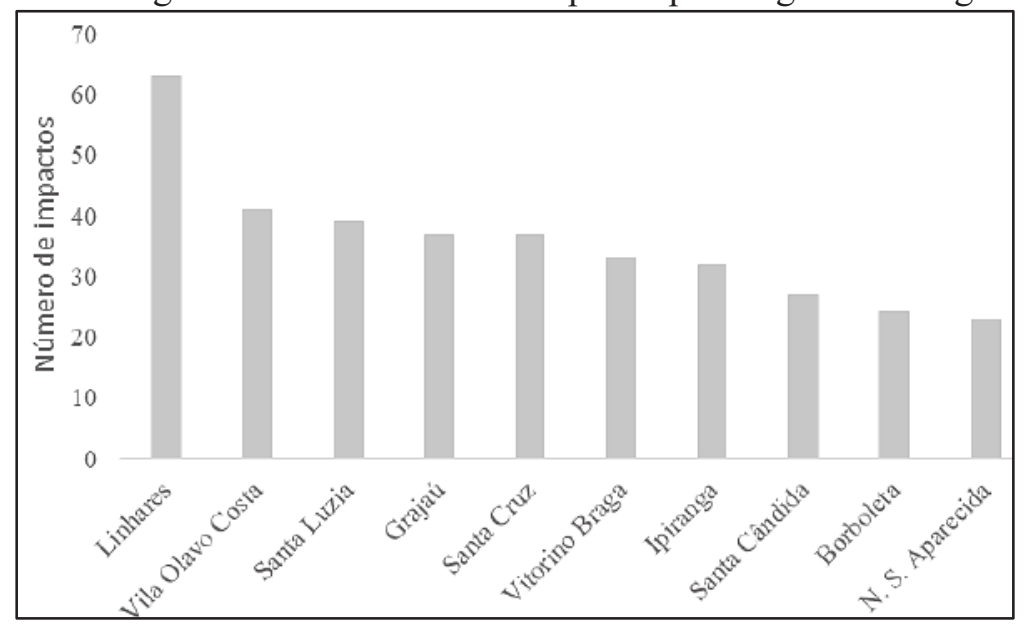

Fonte: Organizado pelo autor.

Dentre as 81 regiões urbanas, treze destas jamais registraram ocorrências de impactos geomorfológicos, algumas por estarem em áreas de planície como Represa (2), Bairro Industrial (10), São Dimas (14), em outras a ocupação se dá ainda de maneira rarefeita como Floresta (56), Salvaterra (33), e outras que apesar de apresentarem condições de elevada declividade não apresentaram ocorrências de deslizamento ou desabamento, como na região urbana Morro do Imperador e Morro da Glória (Figura 104).

Com isso, podemos vislumbrar que a ocorrência dos impactos geomorfológicos está profundamente associada a uma conjugação entre a suscetibilidade ambiental e a vulnerabilidade social, pois os recursos técnicos utilizados para a construção refletem nas condições de exposição à ocorrência dos deslizamentos.

Figura 104: Distribuição por região urbana dos impactos geomorfológicos em Juiz de Fora 


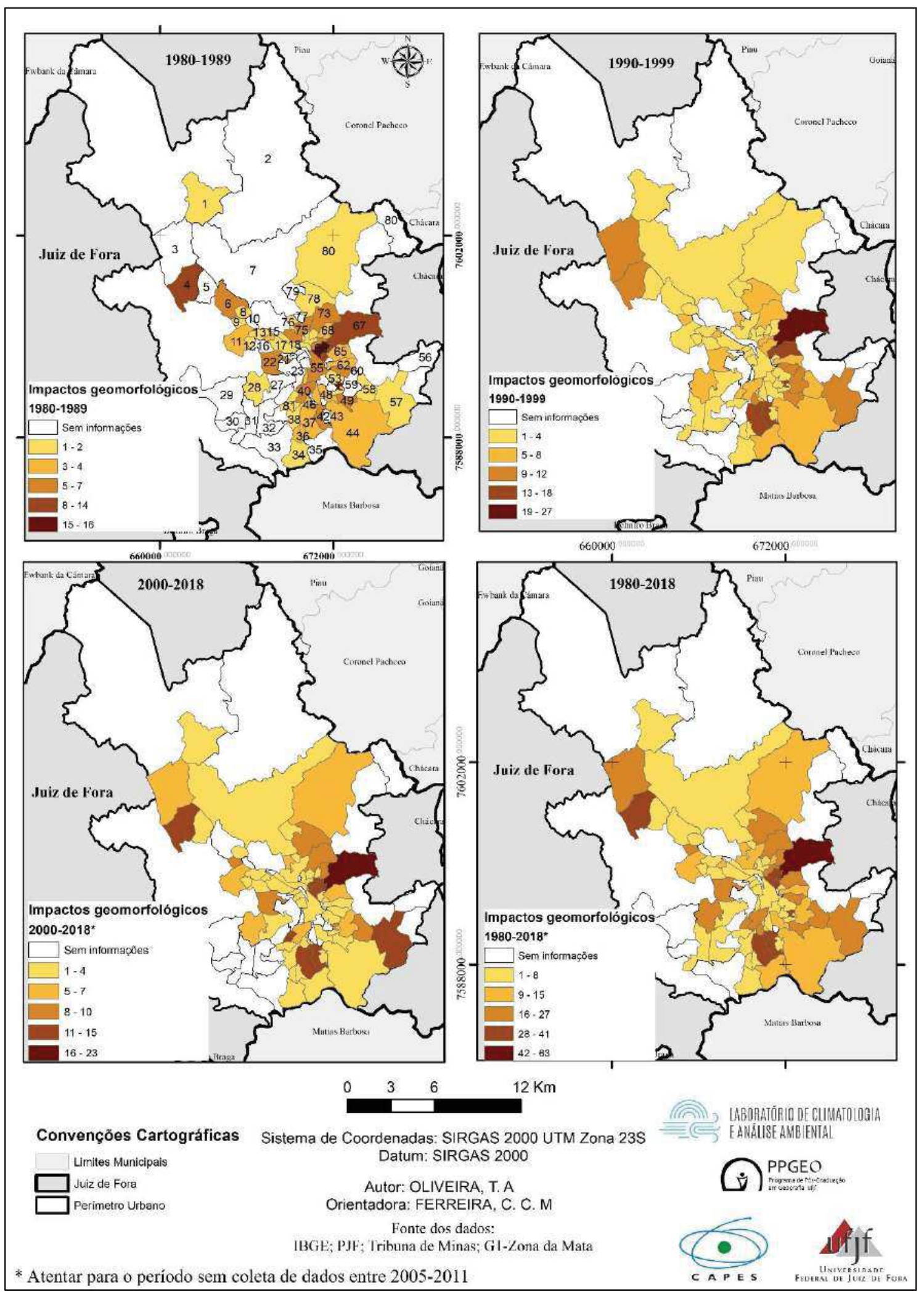

Fonte: Organizado pelo autor.

Os impactos geomorfológicos, também mapeados pontualmente, figura 105, foram contabilizados 608 pontos de deslizamentos/desabamentos, agrupados como impactos 
geomorfológicos, registrados ao longo dos 32 anos analisados. Distribuídos em todas as regiões de planejamento, sendo que é na RP Leste que ocorrem com maior frequência.

Figura 105: Distribuição por região urbana dos impactos geomorfológicos em Juiz de Fora, a partir dos pontos.

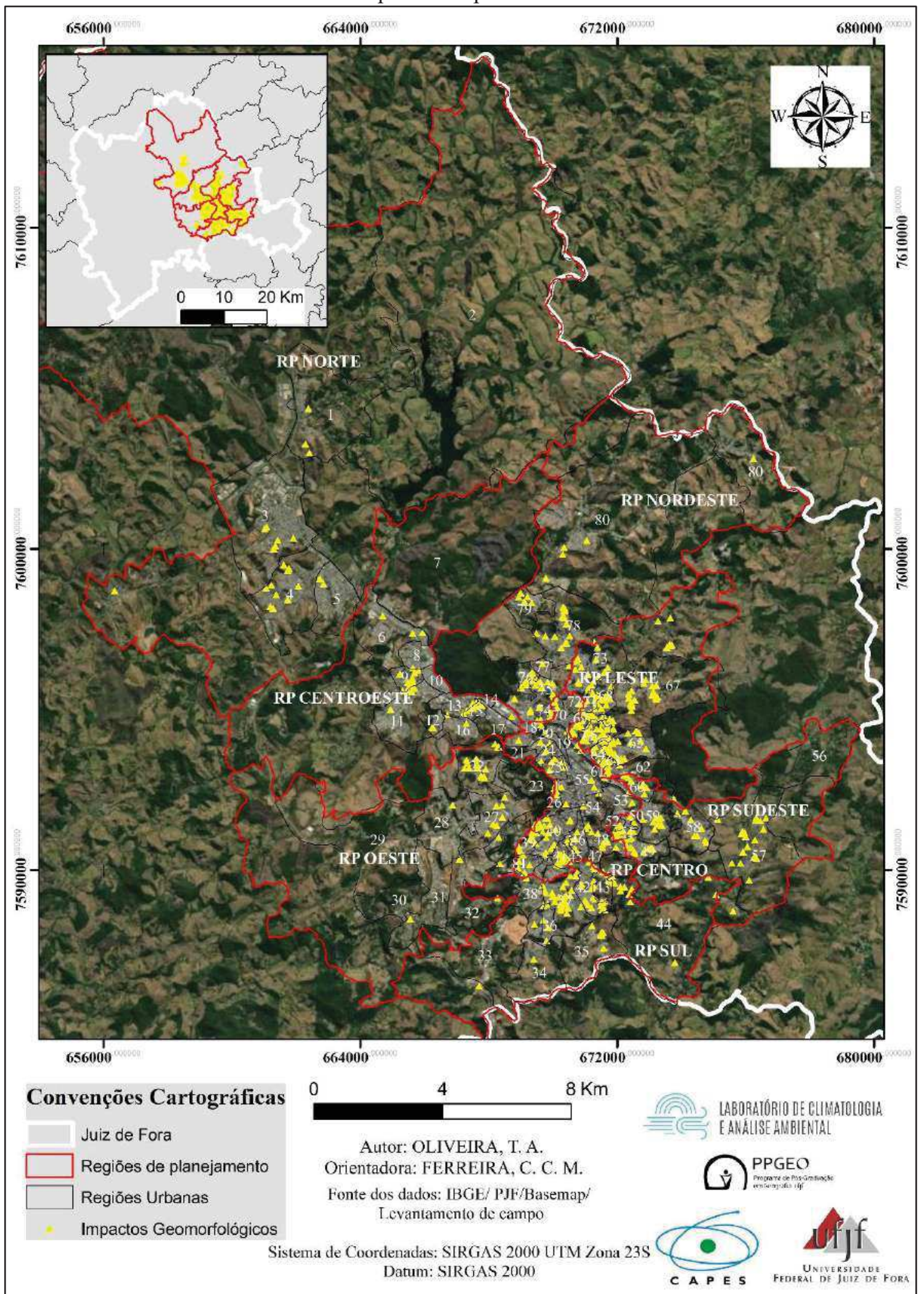

Fonte: Organizado pelo autor. 
Com o intuito de avaliar a espacialização dos impactos geomorfológicos foi aplicado o indicador de densidade de Kernel, a partir disso observa-se um agrupamento na RP Leste da cidade, caracterizando um hotspot, localizados nas RU's Santa Cândida (65), Vitorino Braga (64), Grajaú (66), Santa Rita (68) e Bonfim (71), (Figura 106).

Figura 106: Indicador de densidade de Kernel aplicado aos impactos geomorfológicos.

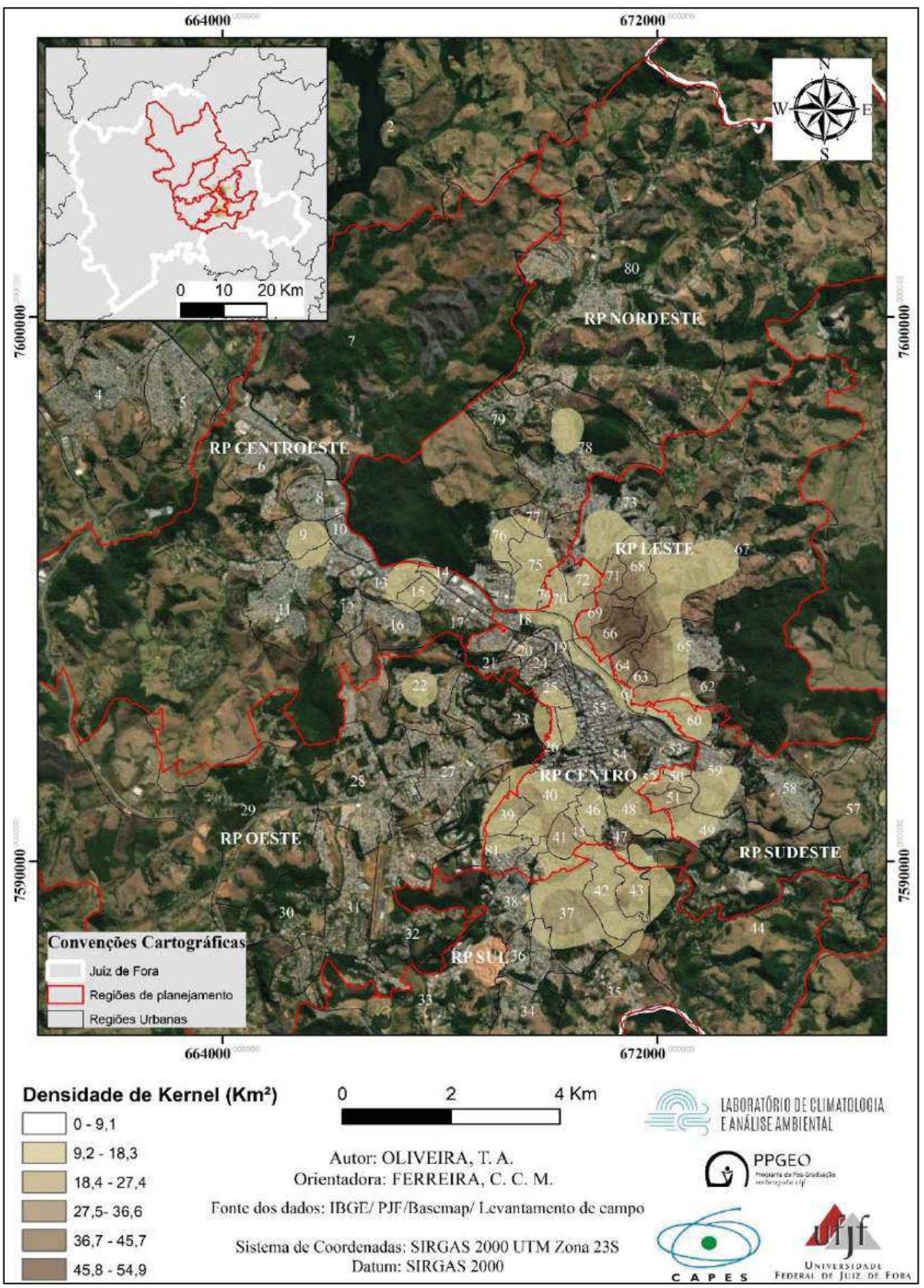

Fonte: Organizado pelo autor. 
Outro setor com ocorrências elevadas de impactos geomorfológicos encontra-se no contato entre as RP's Centro; Sudeste e Sul (Figura 106). Na região de planejamento Centro destaca-se as RU's Dom Bosco (39), Santa Cecília (41), São Mateus (40), Bom Pastor (48). A RP Sudeste tem as RU's Vila Olavo Costa (50), Vila Ideal (49) e Furtado de Menezes (51), bem como a RP Sul, com as RU's Cruzeiro do Sul (43), Santa Luzia (42) e Ipiranga (37).

Outras RU's aparecem como áreas com concentração de impactos geomorfológicos, como a RU Borboleta (22) na RP Oeste; Jardim Natal (9) e Espanada (15) na RP Centro Oeste; Santa Terezinha (75), Eldorado (76), Bom Clima (77) e Bandeirantes (78) na RP Nordeste. Além disso, na RP Centro concentram-se impactos também nas RUs Paineiras (25) e Santa Helena (26), associados à queda de blocos no Morro do Imperador.

Os impactos hidrológicos, diferentemente dos geomorfológicos, têm tido uma tendência de elevação ao longo do período. Ocorrências de alagamentos e inundações têm fícado mais recorrentes em Juiz de Fora, sendo que a partir de 1990 o número sempre ultrapassou pelo menos 10 ocorrências por ano, sendo mais baixo nos anos considerados secos, na série histórica, denotando uma relação com os totais pluviométricos (Figura 107). Na linha da média móvel o número de impactos demonstra que os impactos têm se elevado, tendo apenas um número mais baixo no ano de 2014, ano considerado super-seco.

Figura 107: Frequência anual dos impactos hidrológicos em Juiz de Fora

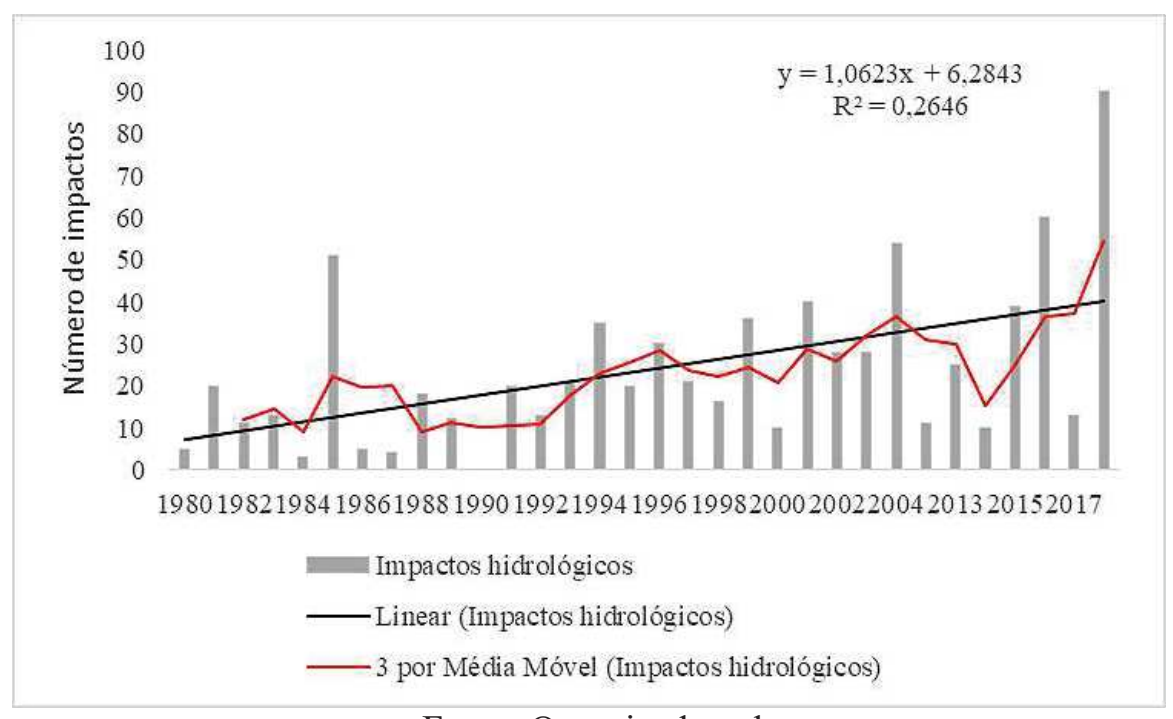

Fonte: Organizado pelo autor.

Avaliando a partir dos três recortes (1980-89; 1990-99; 2000-18*) os dados de impactos hidrológicos sempre se elevaram em detrimento do período anterior. No entanto, o terceiro período de 2000-18, com 12 anos, teve um aumento maior que o dobro do período de 1990-99, indicando que cada vez mais esses impactos têm proliferado na cidade (Figura 108). 
Figura 108: Somatório por décadas dos impactos hidrológicos em Juiz de Fora

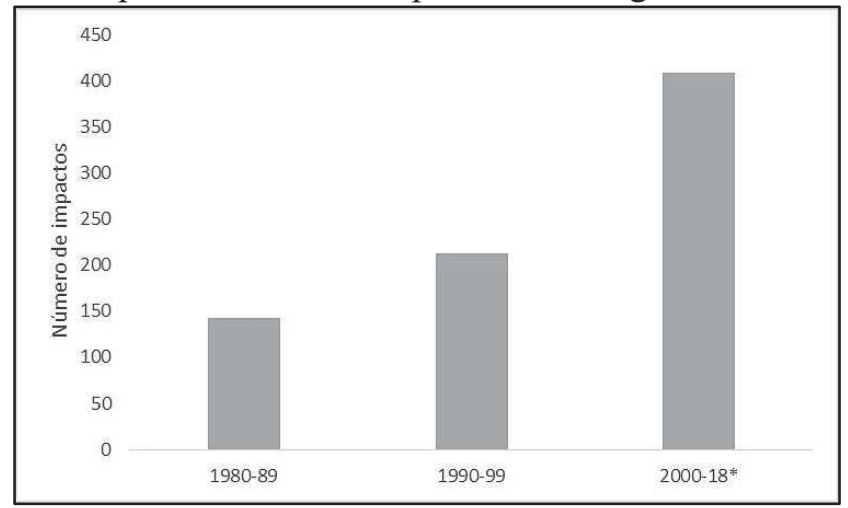

Fonte: Organizado pelos autores.

Os impactos hidrológicos se concentraram em maior número na RP Centro e Centro Oeste, Leste, Sul e Norte, outras com menor número são as Sudeste, Nordeste e Oeste, sendo que a Oeste tem tido uma elevação nas ocorrências. A RP Leste teve um número menor de ocorrências no período mais recente (2000-2018) se comparado ao período de 1980-89 (Figura 109).

Figura 109: Distribuição dos impactos hidrológicos por região de planejamento e por período analisado.

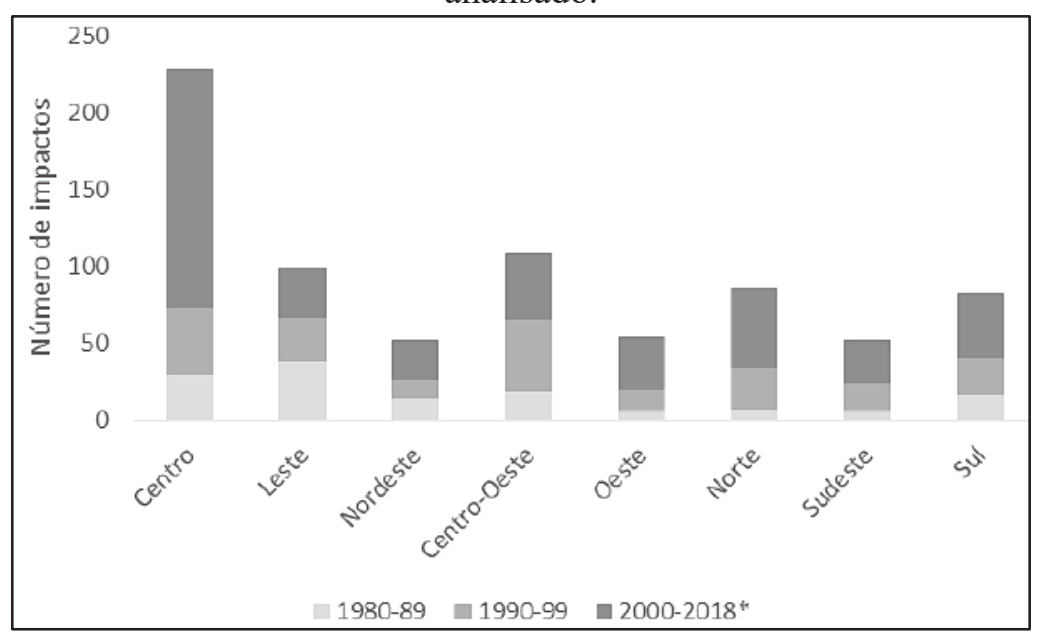

Fonte: Organizado pelo autor.

A variação no número de impactos ao longo da série indica que seis das oito regiões de planejamento tiveram aumento superior a 100\%, quando comparado o período de 2000-18 com a primeira década, 1980-89. As maiores elevações foram nas RPs Norte, Centro e Oeste, nas quais, conforme já destacado as RPs Oeste e Norte obtiveram maior crescimento populacional, o que engendra uma intensificação no uso da terra ocasionando maior impermeabilização (Figura 110). 
Figura 110: Variação no número de impactos hidrológicos entre o período 2000-18 e 1980-89.

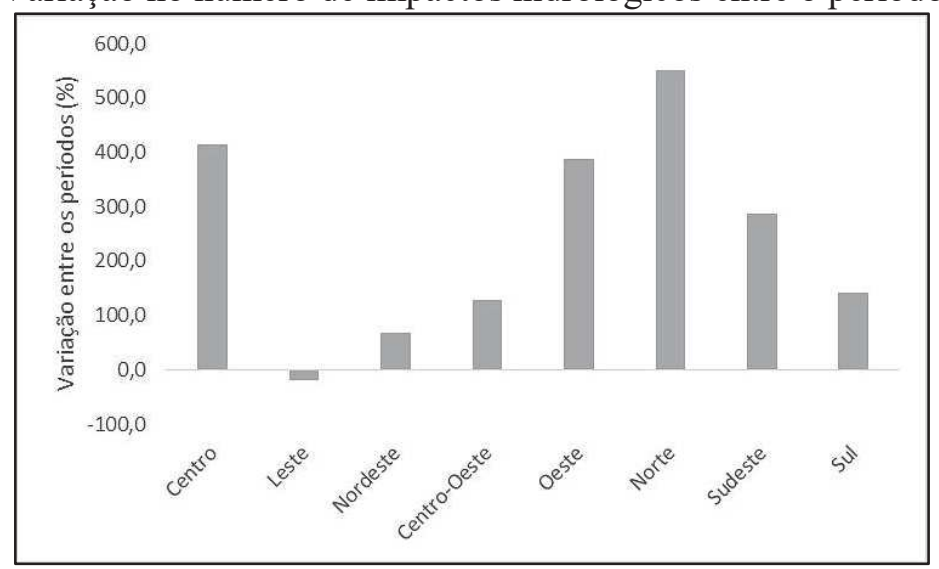

Fonte: Organizado pelo autor.

Na RP Centro, que tem quase 100\% de sua área edificada, processo associado a uma ocupação mais antiga, ocorrências como alagamentos são comuns, sobretudo nas RUs Grambery; Bom Pastor e São Mateus. Além do próprio Centro que historicamente registra alagamentos no trecho da avenida Rio Branco, conhecido como Mergulhão (Figura 111).

Figura 111: Ocorrência de impacto hidrológico na RP Centro

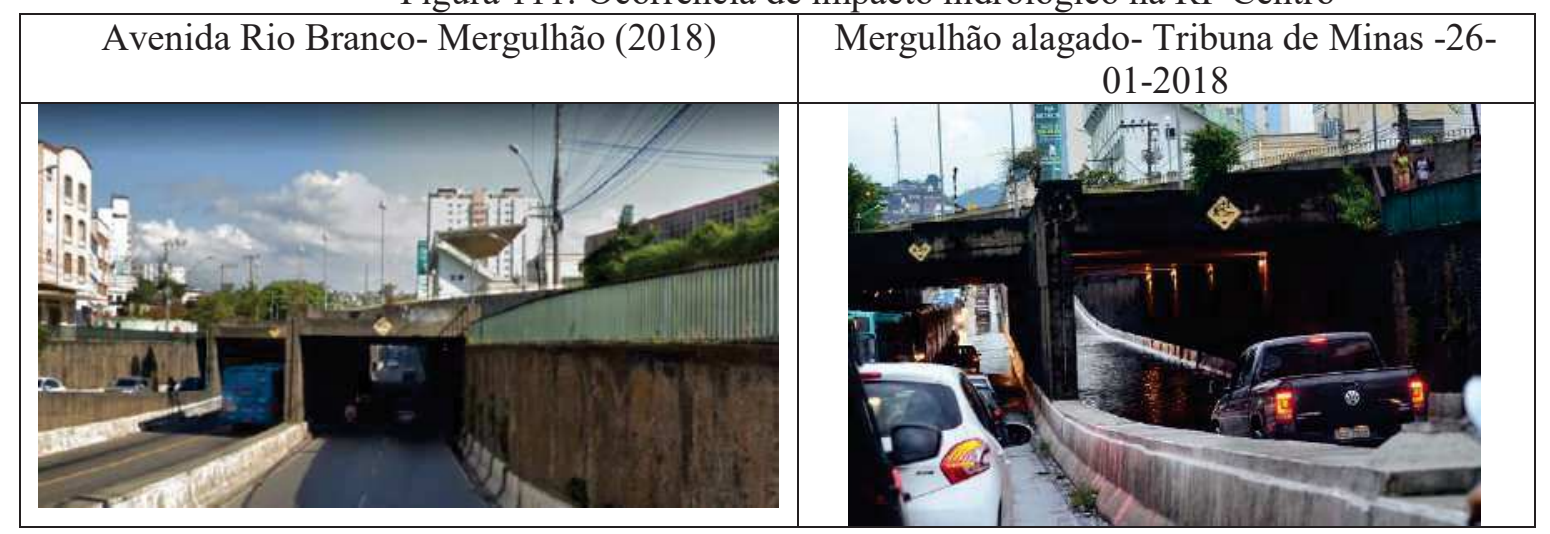

Fonte: Google Maps- Street View (2018) / Tribuna de Minas. Adaptado pelo autor.

Dentre as regiões urbanas mais impactadas, a RU Centro figura como a mais citada, atingindo 90 ocorrências. A partir dessa, aparecem Vitorino Braga e Linhares, na RP Leste; Bairro Industrial, na RP Centro Oeste; Santa Luzia, na RP Sul; Benfica e Nova Era na RP Norte; São Mateus na RP Centro e Santa Terezinha na RP Nordeste. Sete das Oito RPs têm pelo menos uma RU dentre as dez mais impactadas, apenas a RP Sudeste não apresentou nenhuma RU dentre as mais citadas (Figura 112). 
Figura 112: Dez regiões urbanas mais citadas por impactos hidrológicos em Juiz de Fora

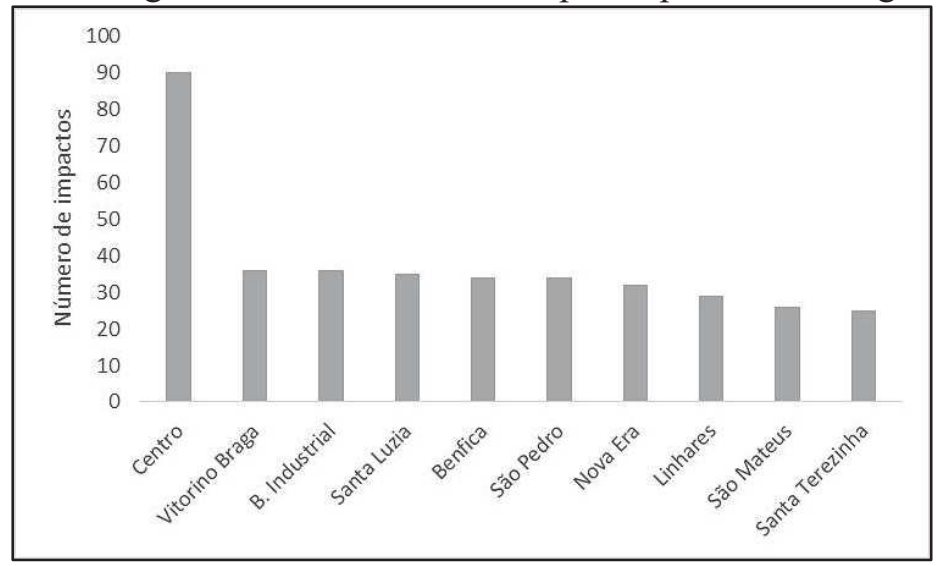

Fonte: Organizado pelo autor.

Ao longo dos anos é possível observar que a RP Centro esteve entre as mais citadas, sendo que ao longo das décadas os impactos foram se disseminando ao longo da mancha urbana. Isso indica que a expansão da mancha urbana associada à impermeabilização das superfícies, supressão das áreas permeáveis e de cobertura vegetal pode ter impactado nessa elevação das ocorrências, bem como na distribuição ao longo do perímetro urbano (Figuras 112 e 113).

Algumas RUs sempre estiveram entre as mais citadas, com Centro, Linhares, Santa Luzia, dentre outras, enquanto outras passaram a figurar a partir dos anos 1990, como Nova Era. Algumas RUs na RP Centro sempre tiveram ocorrências de impactos pluviométricos, porém foram intensificados a partir dos anos 1990, como São Mateus, Bom Pastor, Alto dos Passos, Grambery (Figura 113). 
Figura 113: Distribuição por região urbana dos impactos hidrológicos em Juiz de Fora

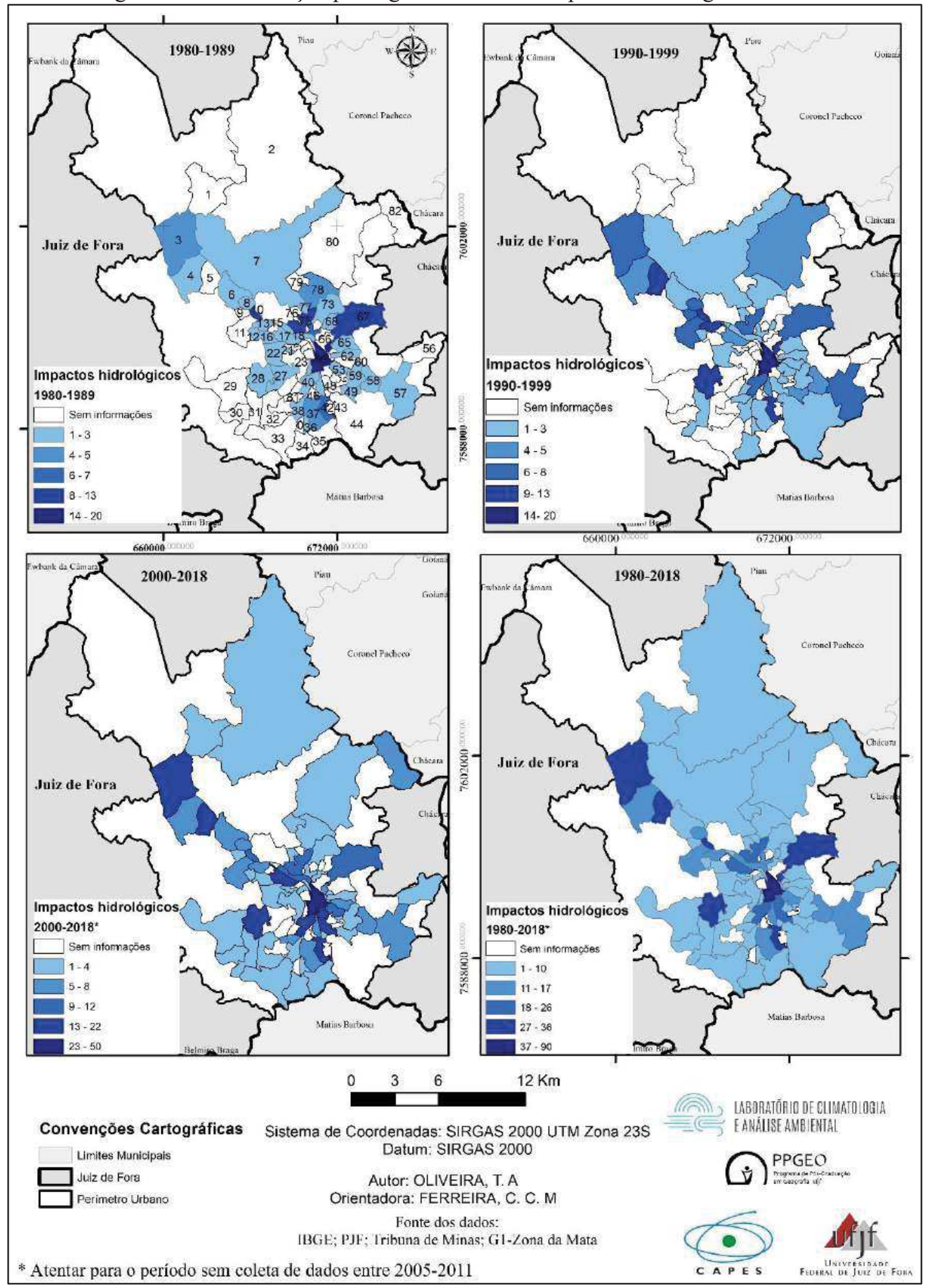

Fonte: Organizado pelo autor.

O mapeamento de pontos para os impactos hidrológicos agregou 621 pontos na área urbana de Juiz de Fora, sendo que nesse levantamento foram agregadas informações sobre 
inundação, enchente, alagamentos e enxurradas, uma vez que a imprecisão das informações das notícias do jornal não permitiu a utilização precisa das terminologias (Figura 114).

Figura 114: Distribuição por região urbana dos impactos hidrológicos em Juiz de Fora, a partir dos pontos.

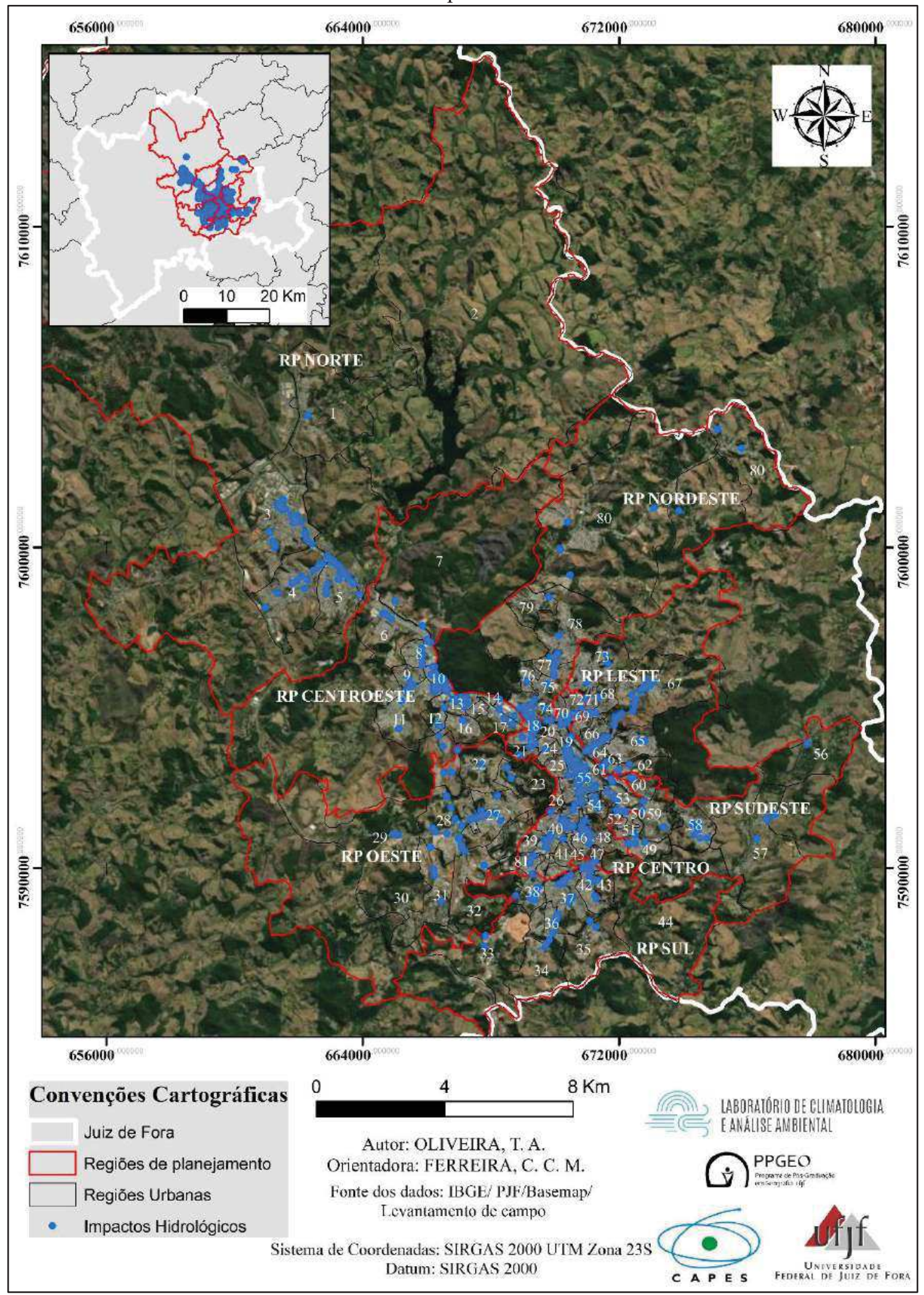


Fonte: Organizado pelo autor.

Com base no indicador de densidade de Kernel é possível visualizar uma condição de intensa ocorrência de impactos na RP Centro, em contato com a RP Sul. As Regiões urbanas Centro (55), Grambery (54), Bom Pastor (48), Alto dos Passos (46), Morro da Glória (19), Mariano Procópio (18) na RP Centro e as RU's Santa Luzia (42) e Ipiranga (37) na RP Sul figuram dentre as áreas, nas quais a concentração de pontos foi mais elevada (Figura 115).

Na RP Centro o ponto com maior concentração de pontos está na Av Rio Branco na altura do Mergulhão, conforme já destacado, bem como na Av dos Andradas no ponto chamado Largo do Riachuelo, local historicamente marcado por inundações/alagamentos. Além disso, esse hotspot se prolonga para a RP Leste, na qual as RUs Vitorino Braga (64) e Cesário Alvim (63) aparecem com uma elevada concentração de pontos de impactos hidrológicos (Figura 115).

Além dessa mancha principal nas RPs Centro, Sul e Leste outros cinco pontos despontam com uma concentração de pontos mais elevada, dois pontos na RP Norte, nas RUs Nova Era (5) e Benfica (3); um ponto na RP Centro Oeste, na RU Bairro Industrial (10) e Cerâmica (13); outro ponto na RP Oeste nas RUs Martelos (27) e São Pedro (28); e outro ponto na RP Leste porém na região urbana Linhares (67). 
Figura 115: Indicador de densidade de Kernel aplicado aos impactos hidrológicos

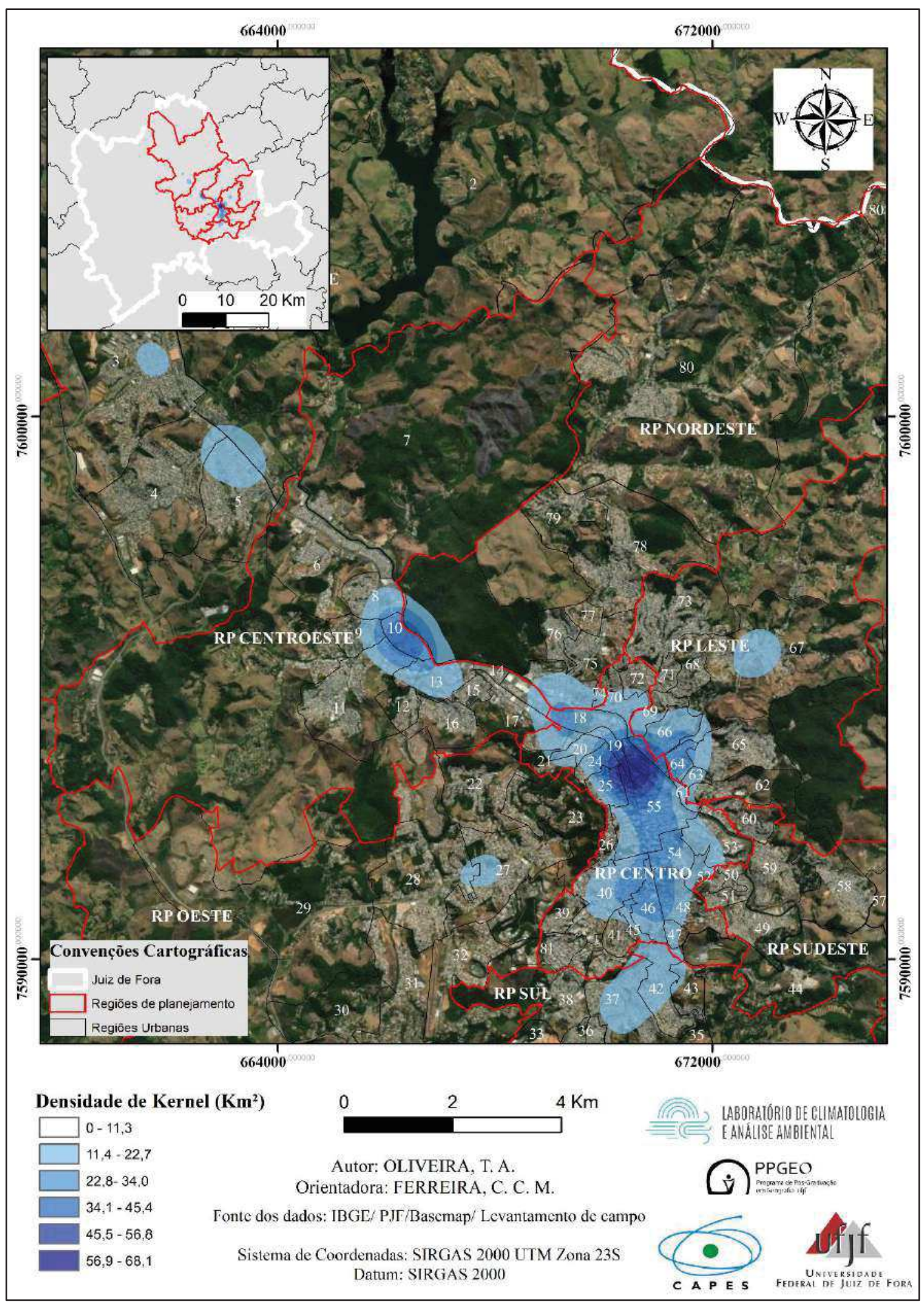

Fonte: Organizado pelo autor. 


\section{Capítulo 7: O Clima Urbano como risco climático e os episódios extremos em Juiz de Fora}

\section{Os riscos aos impactos geomorfológicos}

Ao longo da construção da análise do clima urbano dentro da perspectiva do risco climático buscou-se a conjugação dos elementos suscetibilidade ambiental, vulnerabilidade social e histórico de ocorrências. A construção da modelagem reuniu a carta de suscetibilidade da CPRM (BITAR, 2014), o índice de vulnerabilidade social-IVS (TEOBALDO NETO, 2019; GOUDARD, 2019), bem como o levantamento das informações das reportagens de jornal.

Assim, quanto maior a pontuação obtida na modelagem proposta, maior o risco aos impactos geomorfológicos. A verificação do modelo proposto teve como base os pontos, nos quais as informações sobre os impactos foram precisamente descritas na reportagem, diferentemente do mapa de citações.

As classes de risco a impactos geomorfológicos no perímetro urbano de Juiz de Fora indicam que a maior proporção encontra-se em situação de médio risco, com 38,1\% da área total, seguida pelas condições de baixo risco com 31,7\% da área. As classes de baixíssimo, alto e altíssimo risco aparecem com menor proporção de área com 12,1\%,16,4\% e 1,5\%, respectivamente.

Quadro 78: Classes de risco a impactos geomorfológicos no perímetro urbano de Juiz de Fora

\begin{tabular}{|c|c|c|}
\hline Classes & Área $\left(\mathrm{km}^{2}\right)$ & Área $(\%)$ \\
\hline Baixíssimo risco & 51,8 & 12,1 \\
\hline Baixo risco & 135,5 & 31,7 \\
\hline Médio risco & 162,7 & 38,1 \\
\hline Alto risco & 70,1 & 16,4 \\
\hline Altíssimo risco & 6,2 & 1,5 \\
\hline Sem informação & 0,51 & 0,1 \\
\hline
\end{tabular}

Fonte: Organizado pelo autor.

Dentro do processo de avaliação da modelagem de risco a impactos geomorfológicos, observa-se que a maior parte dos pontos se localizaram na classe de médio risco, com $36,3 \%$, além disso, as classes de alto e altíssimo risco registraram outros $42,1 \%$ dos pontos, apesar de representarem apenas $17,9 \%$ da área do perímetro urbano. Outros $21,7 \%$ dos pontos ocorreram nas classes de baixo e baixíssimo risco, que correspondem a $43,8 \%$ do perímetro urbano. 
Quadro 79: Distribuição dos pontos por classe de risco no perímetro urbano de Juiz de Fora

\begin{tabular}{|c|c|c|}
\hline Classe & $\mathrm{N}^{\circ}$ de pontos & $\%$ \\
\hline Baixíssimo risco & 19 & 3,1 \\
\hline Baixo risco & 113 & 18,6 \\
\hline Médio risco & 220 & 36,2 \\
\hline Alto risco & 217 & 35,7 \\
\hline Altíssimo risco & 39 & 6,4 \\
\hline
\end{tabular}

Fonte: Organizado pelo autor.

Observa-se que mesmo com uma área menor o número de ocorrências nas áreas de alto risco foi $17,1 \%$ maior que nas áreas de baixo risco. As áreas de alto e altíssimo risco representam $17,9 \%$ da área total do perímetro urbano com $42,7 \%$ das ocorrências, e o contrário ocorre com as classes de baixo e baixíssimo risco que ocupam $43,8 \%$ da área total e observaram $21,7 \%$ das ocorrências dos impactos geomorfológicos.

Com isso, considera-se que os aspectos como a suscetibilidade ambiental e a vulnerabilidade social estabelecem relação com a ocorrência dos impactos geomorfológicos. Nas classes de alto e altíssimo risco é possível visualizar, em diferentes níveis, a conjugação dos três que foram conjugados para a análise do risco, histórico de ocorrências, vulnerabilidade e suscetibilidade, e totalizam a maior percentagem dos pontos, com $42,1 \%$.

$\mathrm{Na}$ classe de médio risco observa-se a baixa influência de algum dos elementos do risco, seja a suscetibilidade, vulnerabilidade ou um histórico de ocorrências, com isso entende-se que estes fatores atuam de maneira conjugada mas também de maneira isolada, consubstanciando nas classes de médio risco.

A classe de baixo e baixíssimo risco representa a menor quantidade de pontos, ainda assim, registrou $21,7 \%$ dos pontos mapeados, indicando que mesmo em condição de baixa influência à ocorrência dos impactos, estes ainda ocorrem nessas áreas, de maneira aleatória. 
Figura 116: Risco climático a impactos geomorfológicos no perímetro urbano de Juiz de Fora.

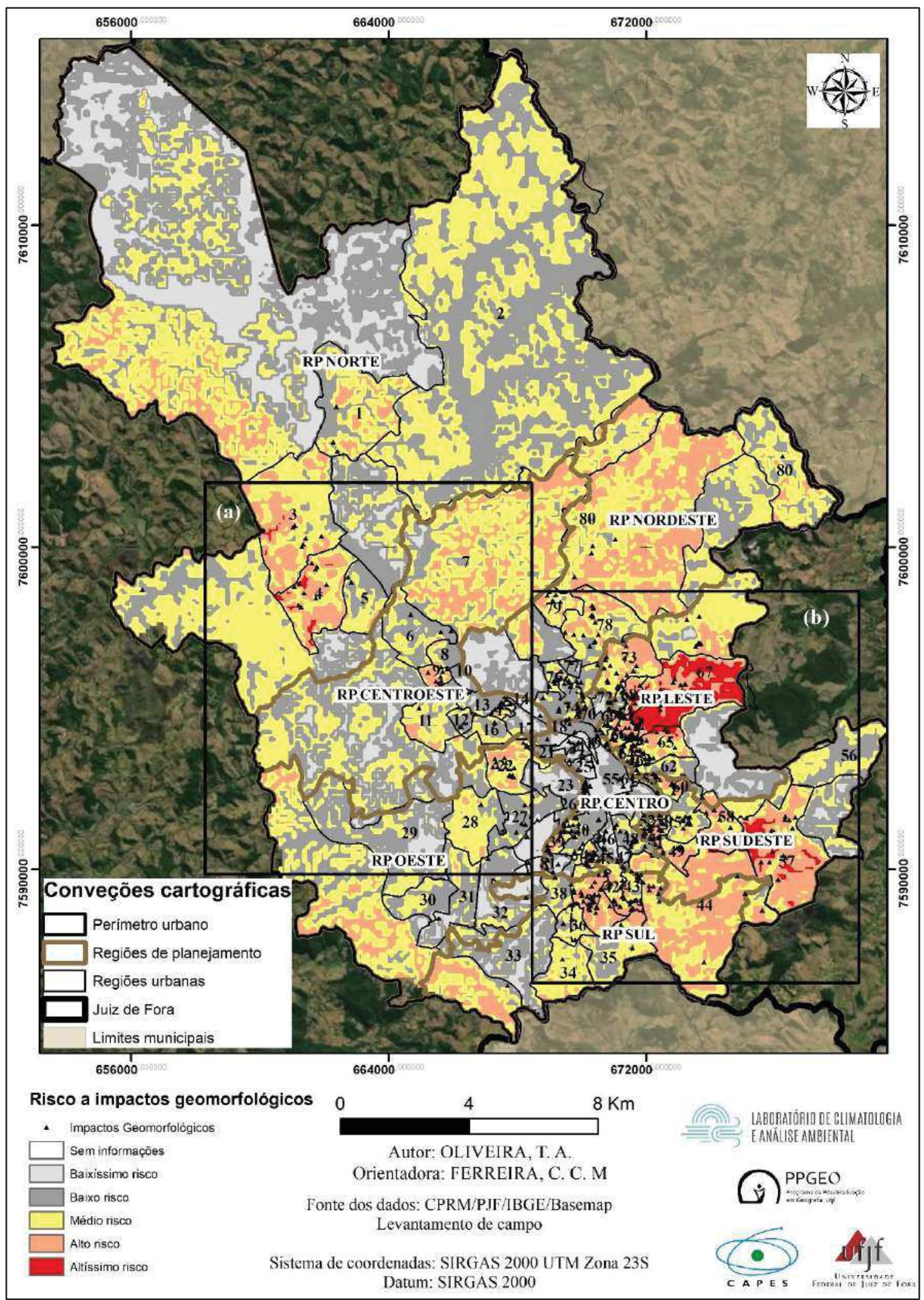

Fonte: Organizado pelo autor.

Dentre as regiões de planejamento, as regiões de planeamento Nordeste, Leste, Sudeste e Sul apresentam mais de $70 \%$ de sua área total em áreas de médio, alto e altíssimo risco a 
impactos geomorfológicos, enquanto a RP Centro apresentou 74,8\% de sua área nas classes de baixíssimo e baixo risco (Figura 117).

Figura 117: Percentagem de área por região de planejamento.

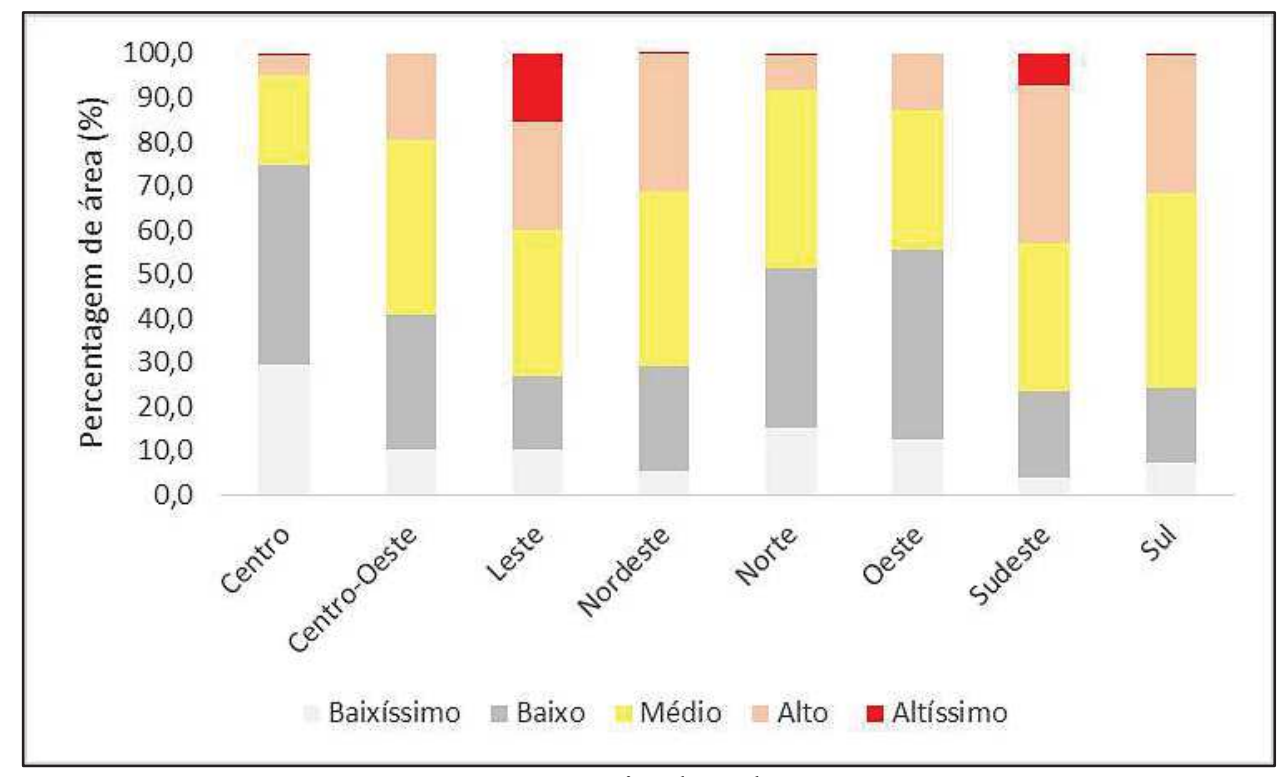

Fonte: Organizado pelo autor.

As regiões de planejamento com maior percentagem de área em condição de alto e altíssimo risco são as RPs Leste e Sudeste, sendo estas as que apresentam as condições mais complexas com relação aos impactos geomorfológicos, visualizados a partir do indicador de densidade de kernel como um hotspot. Além disso, três regiões de planejamento Centro-Oeste, Oeste e Nordeste, não apresentaram condições de altíssimo risco.

De acordo com Santos (2012b) às áreas com as condições mais elevadas de risco deveriam ser desocupadas na medida em que intervenções de correção seriam insuficientes nesses setores. No caso de Juiz de Fora, as áreas de altíssimo risco correspondem a 23,8\% da área do perímetro urbano, sendo 15,6\% e 7,1\% nas RPs Leste e Sudeste, respectivamente.

As outras RPs que apresentam áreas menores e/ou inexistentes deveriam ter uma legislação que assegurasse a impossibilidade de ocupação dessas áreas, entretanto as duas RPs com a maior ocupação de áreas com altíssimo risco climático, assim o são pela conjugação dos elementos suscetibilidade x vulnerabilidade x histórico, esses elementos também repercutem no preço da terra e consequentemente direcionam os sujeitos em condição de vulnerabilidade a ocuparem esses setores da cidade.

No setor "a" do município de Juiz de Fora, observa-se algumas regiões urbanas com áreas de alto e altíssimo risco a impactos geomorfológicos, como as RUs Benfica (03), Santa Cruz (04), na RP Norte; Jardim Natal (09) e Esplanada (15) na RP Centro-Oeste; além da RU Borboleta (22) na RP Oeste. 
$\mathrm{Na}$ RU Benfica (3) as áreas de alto risco à ocorrência de impactos estão nos bairros Vila Esperança I e II (Figura 118), que observaram diversas ocorrências de deslizamentos e desabamentos ao longo da série, com um total de 16 ocorrências, sendo que o maior número ocorreu em 1994, com 4 ocorrências.

Figura 118: Ocorrência de deslizamento na Vila Esperança, RU Benfica (3)

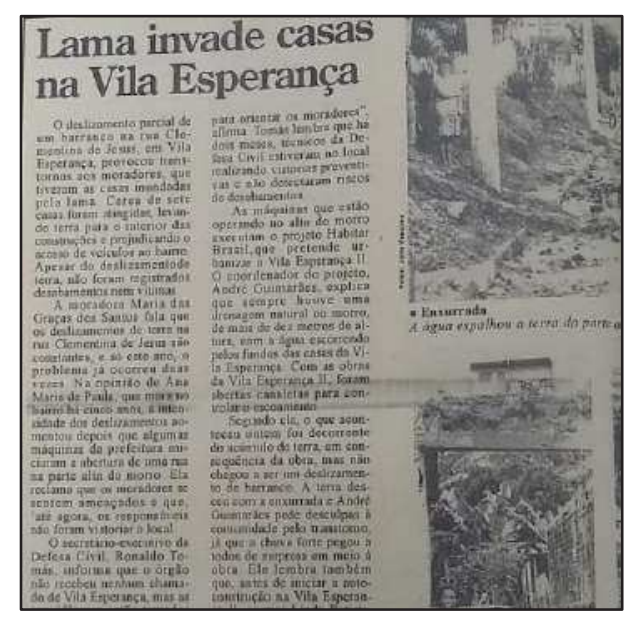

Fonte: Tribuna de Minas (04/03/1994, p.8).

Na RU Santa Cruz encontra-se áreas historicamente afetadas pelos deslizamentos, como na Vila Melo Reis, cujos a percepção ao risco fora estudada por Souza (2006), esta RU figura dentre as dez que mais registrou ocorrências de impactos geomorfológicos na cidade.

Já na RP Centro Oeste pode-se observar na RU Jardim Natal (9) outra área de alto risco a impactos geomorfológicos, com um total de 16 ocorrências, 15 destas registradas a partir dos anos 90. No caso destacado, ocorrido em 2013, um óbito foi registrado no desabamento da residência (Figura 119).

Figura 119: Desabamento registrado na RU Jardim Natal em 25/12/2013.

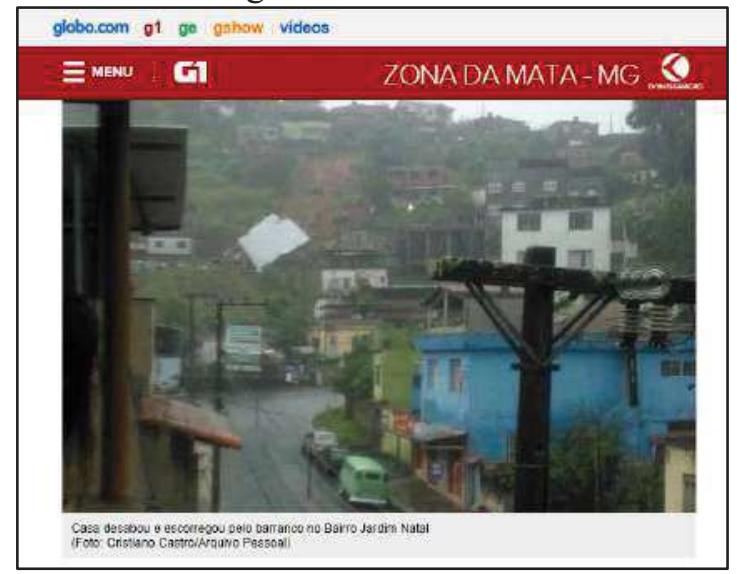

Fonte: G1-Zona da Mata. Adaptado pelo autor. 
Ainda na RP Centro Oeste, observa-se a RU Esplanada (15) que registrou 11 ocorrências ao longo da série, também aparece nas áreas de médio/alto risco. Nessa RU, apesar de um número de ocorrências mais baixo, as condições de vulnerabilidade social e de alta suscetibilidade a movimentos de massa reforçam as condições de risco (Figura 120).

Figura 120: Ocorrência de deslizamentos na RU Esplanada.

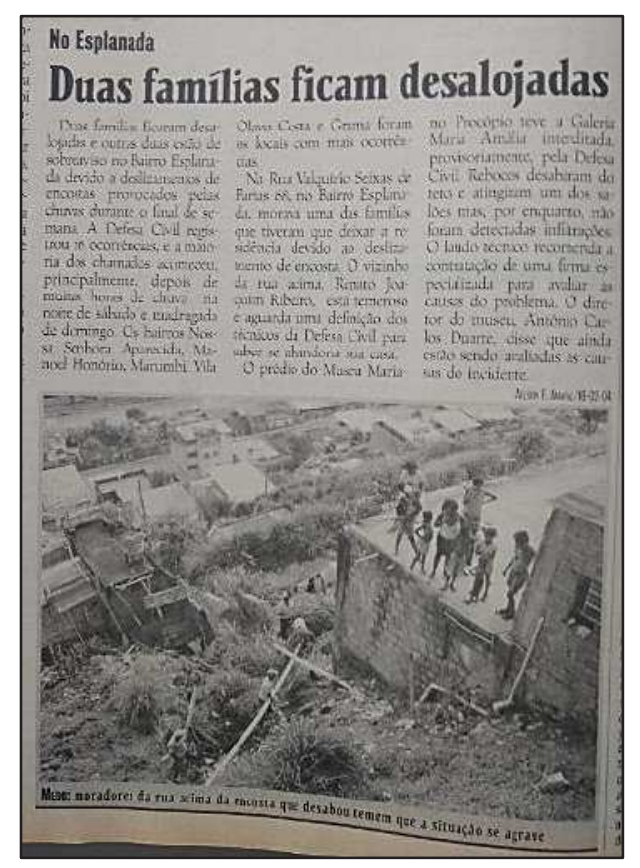

Fonte: Jornal Tribuna de Minas (17/02/2004, p. 4).

$\mathrm{Na}$ RP Oeste, a região urbana Borboleta (22) aparece com o maior número de ocorrências de impactos geomorfológicos, sendo uma das dez RUs mais citadas na cidade, com 24 ocorrências, sendo que nos anos de 1982 e 2004 foram registradas 4 ocorrências no bairro (Figura 121).

Figura 121: Ocorrência de deslizamento na RU Borboleta

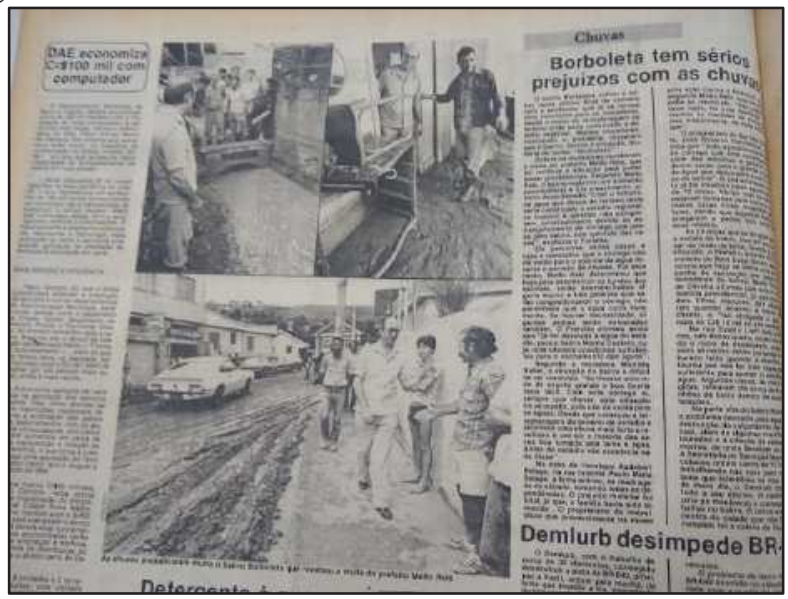

Fonte: Jornal Diário da Tarde (02/03/1982, p. 2). 
Figura 122: Risco climático a ocorrência de impactos geomorfológicos no setor "a" do perímetro urbano.

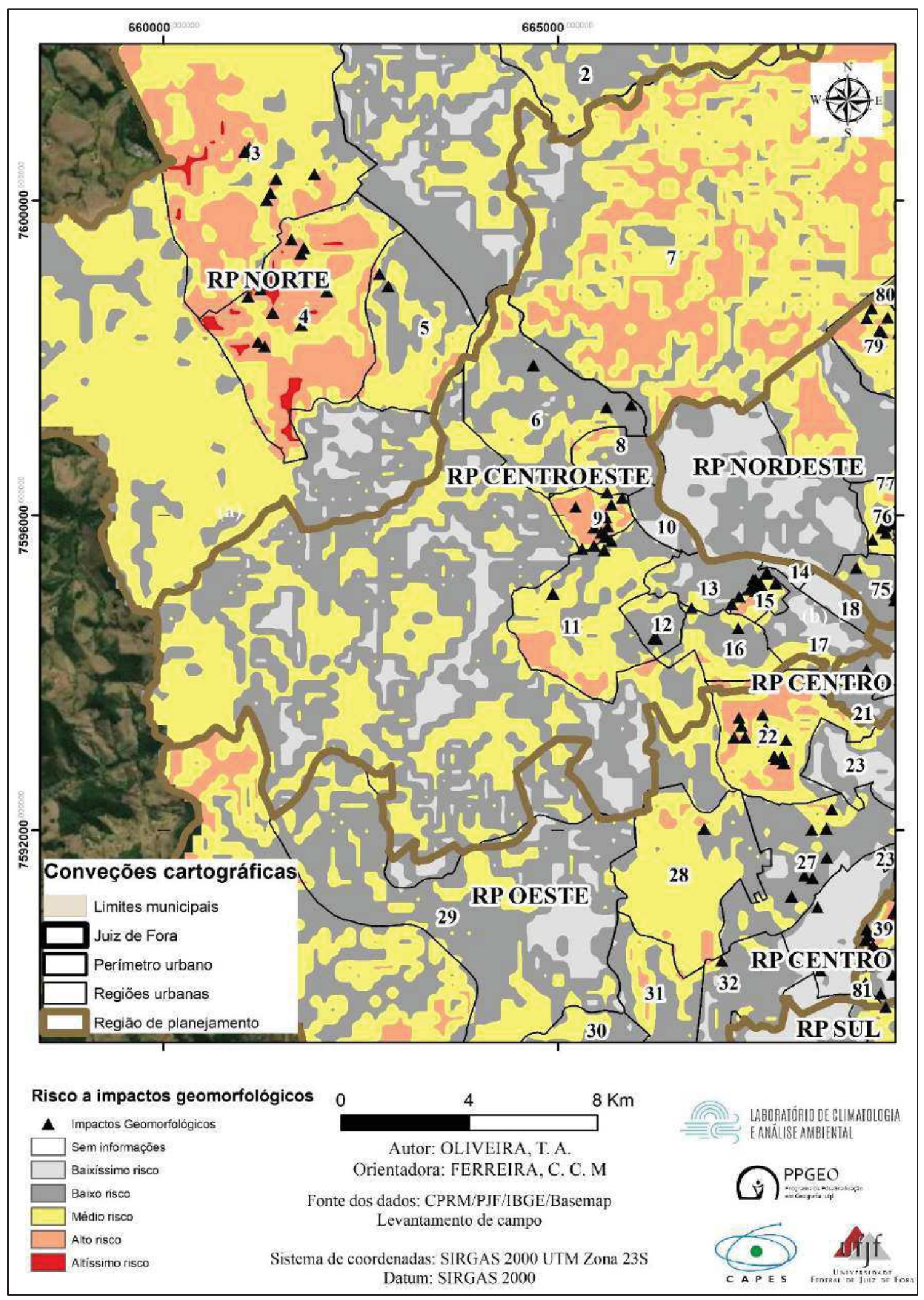

Fonte: Organizado pelo autor. 
No outro setor destacado, "b”, (Figura 124), que reflete as RPs Nordeste, Leste, Centro, Sudeste e Sul, localizam-se as maiores áreas de altíssimo risco a impactos geomorfológicos. Sendo que na RP Leste a condição é mais pronunciada, sobretudo nas RUs Grajaú (66), Linhares (67), Santa Cândida (65) e Vitorino Braga (64).

Na região de planejamento Centro, apesar de um predomínio das classes de baixíssimo e baixo risco, algumas áreas figuram em condições de alto risco a impactos geomorfológicos. Nas regiões urbanas Dom Bosco (39) e Santa Cecília (41) essa situação ocorre, justamente por serem, também, áreas com alta/altíssima vulnerabilidade social, ocupando setores com alta suscetibilidade a movimentos de massa. As regiões urbanas Dom Bosco e Santa Cecília registraram 19 e 17 ocorrências de impactos geomorfológicos, respectivamente (Figura 123).

Figura 123: Desabamento ocorrido na RU Santa Cecília vitimando uma criança

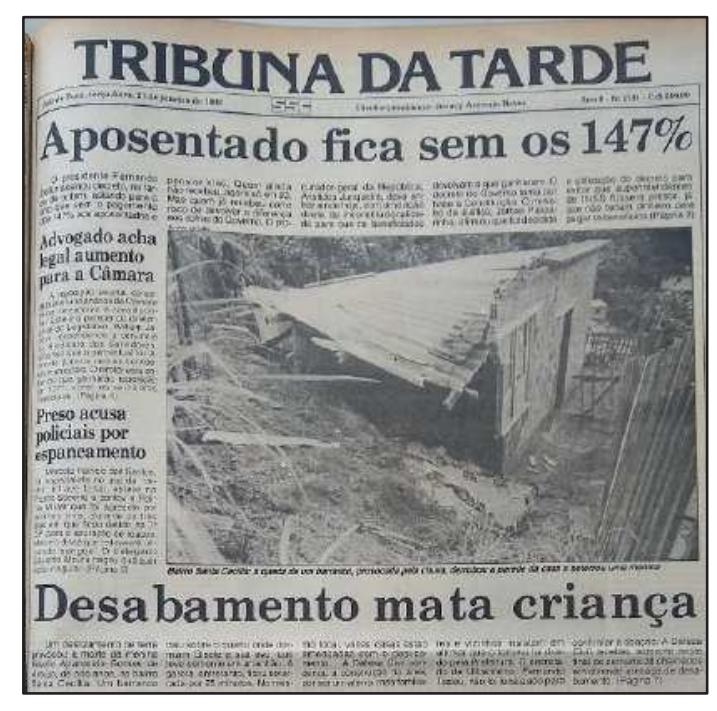

Fonte: Tribuna da Tarde (21/01/1992, p. 1)

Na RP Sudeste as áreas de alto risco ocorrem nas regiões urbanas Vila Ideal (49), Vila Olavo Costa (50), Santo Antônio (58) e Retiro (57) e Costa Carvalho (60) sendo que esta RP é a segunda no número de ocorrências de impactos geomorfológicos, bem como a que observa o maior número de setores em condição de altíssima vulnerabilidade social, em áreas com declividade elevada, alta suscetibilidade a movimentos de massa. 
Figura 124: Risco climático a ocorrência de impactos geomorfológicos no setor "b" do perímetro urbano.

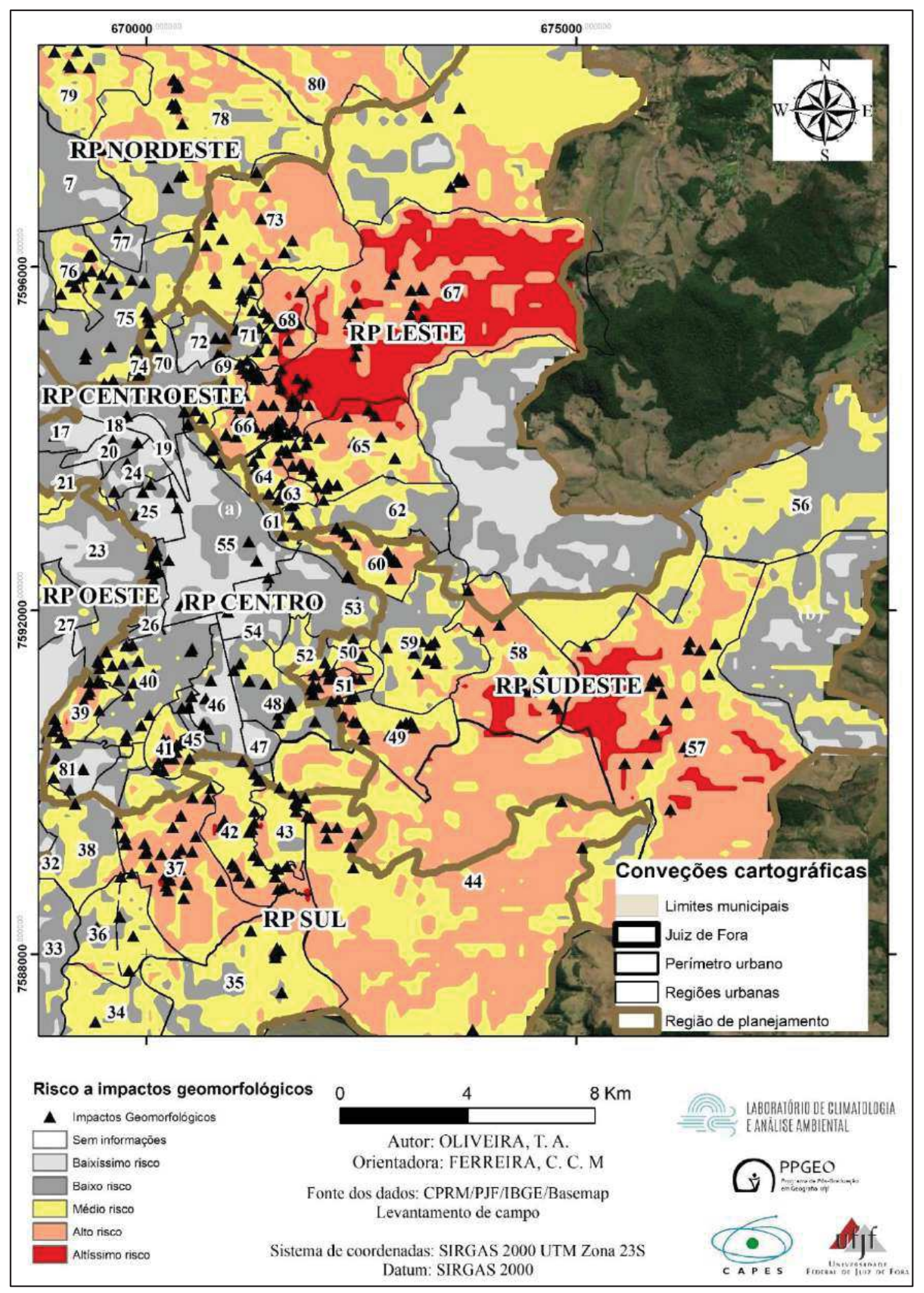

Fonte: Organizado pelo autor. 
A Vila Olavo Costa (50) teve o maior número de ocorrências, com 40, seguida pela Retiro (57) com 22 ocorrências, Vila Ideal (49) e Costa Carvalho (60) com 20 ocorrências e Santo Antônio (58) com 16. A Vila Olavo Costa (Figura 125) é a segunda RU com maior número de ocorrências, ficando atrás apenas da RU Linhares (67) na RP Leste.

Figura 125: Deslizamento ameaça famílias na Vila Olavo Costa

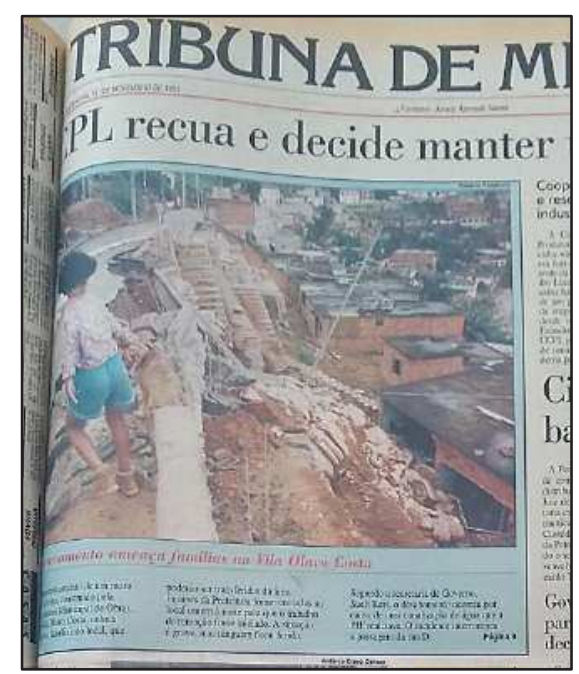

Fonte: Tribuna de Minas (17/11/1995, p. 1).

Na região de planejamento Sul também possui algumas regiões urbanas que apresentam condições de alto e altíssimo risco a impactos geomorfológicos, são elas Santa Luzia (42), Ipiranga (37) e Graminha (44), com 39, 32 e 13 ocorrências, respectivamente (Figura 126).

Figura 126: Ocorrência de desabamento no Graminha, com três vítimas fatais

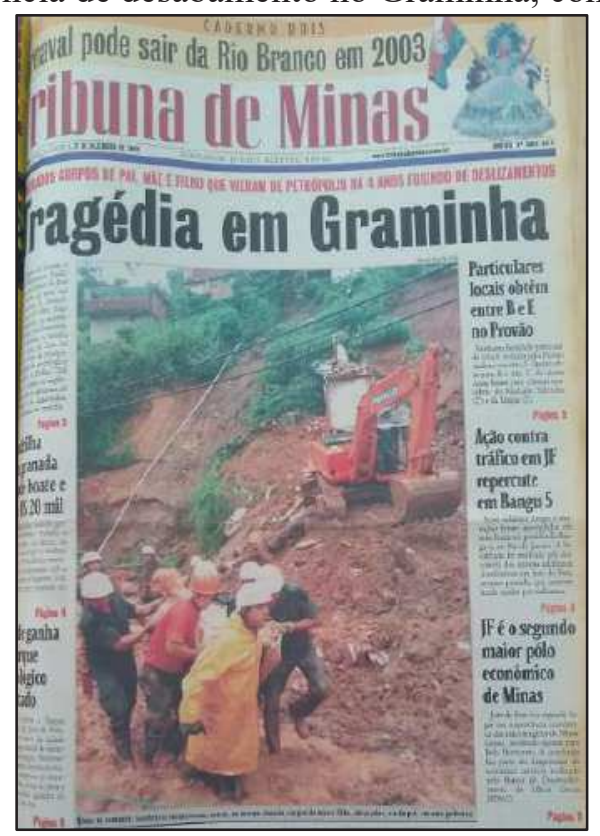

Fonte: Tribuna de Minas (17/12/2002, p. 1). 
Na região de planejamento Leste estão as maiores áreas com altíssimo risco, sobretudo na RU Linhares (67), e condições de médio e alto risco, refletindo como a região de planejamento com o maior número de impactos geomorfológicos na cidade (Figura 127), além da RU Linhares, outras como Vitorino Braga (64), Grajaú (66), N S Aparecida (69), Santa Rita de Cássia (68), também tem um número elevado de ocorrências.

Figura 127: Ocorrência de deslizamento no bairro Três Moinhos- RU Linhares

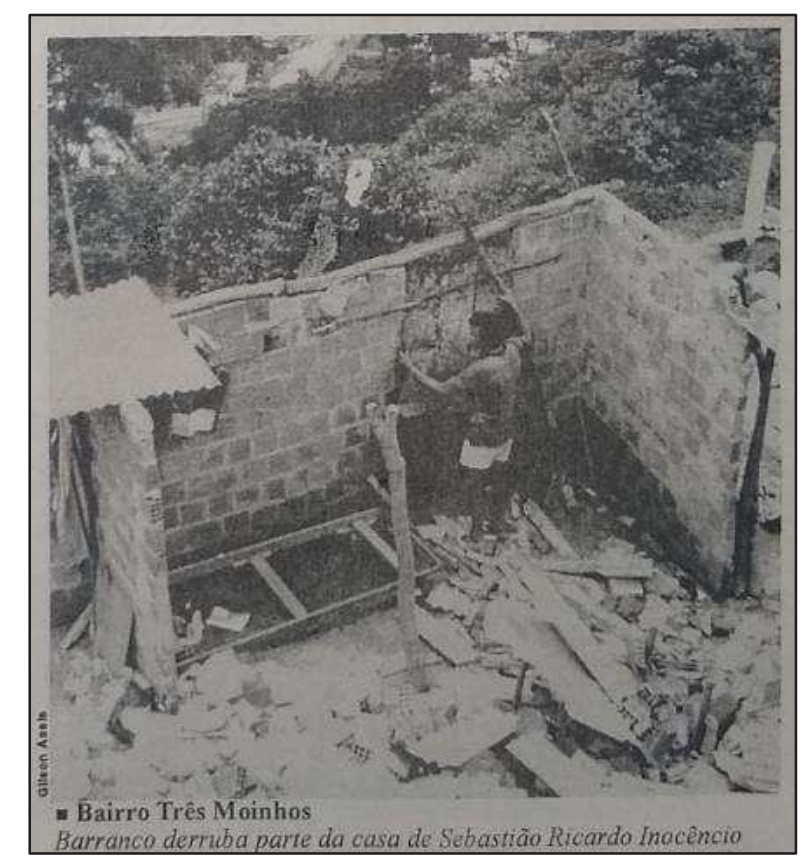

Fonte: Tribuna de Minas (04/01/1994, p. 9).

Além das áreas já apontadas com as condições de maior risco aos impactos geomorfológicos, é fato que estes também ocorreram nas áreas com baixo ou baixíssimo risco, totalizando $21,7 \%$ dos pontos. Na figura 122 pode-se observar algumas ocorrências nas regiões urbanas Santa Helena (25) e Paineiras (26), Santa Terezinha (75), Bom Pastor (48), Alto dos Passos (46), apesar de estarem em condições de menor risco.

A região urbana Bom Pastor (48) apresenta boa parte de sua área com alta suscetibilidade a impactos geomorfológicos, no entanto a baixa vulnerabilidade social observada na RU permite condições de adaptação e enfrentamento à ocorrência dos impactos. Nessa região urbana apesar do predomínio de condições de baixo risco, ainda ocorrem situações de médio risco.

No caso observado na região urbana Bom Pastor (48), figura 128, os moradores do prédio foram direcionados a hotéis da cidade após o ocorrido, diferentemente do que ocorre em 
áreas de maior vulnerabilidade social, que são comumente direcionados a abrigos em escolas ou igrejas.

Figura 128: Ocorrência de deslizamento na RU Bom Pastor.

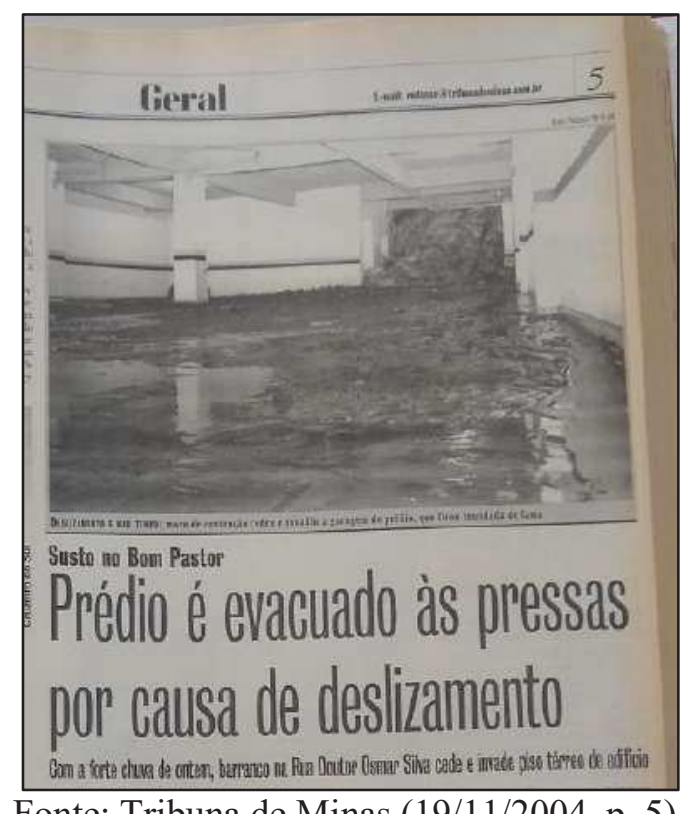

Apesar do impacto ocorrer em toda a cidade, a experiência dos sujeitos e as medidas corretivas após o impacto normalmente são muito diferenciadas nas áreas de maior risco, e associada a uma maior vulnerabilidade, do que em outras de menor risco, com condições de baixa vulnerabilidade social.

Souza (2006) estudou a percepção ao risco na Vila Melo Reis, localizada na RU Santa Cruz (4), em uma área considerada de alto e altíssimo risco, revela que o maior número dos entrevistados destacou ter mudado para o bairro em busca da casa própria, deixando assim os aluguéis.

Com isso, pode-se vislumbrar que as condições sociais são importantes para a discussão da ocupação das áreas de risco, bem como nos aspectos de exposição e enfrentamento aos impactos, disparados por episódios extremos de precipitação, mas vivenciados de maneira diferenciada no espaço.

Sant'Anna Neto (2011, p. 47) destaca que “população vulnerável sofre consequências que podem variar em grau de intensidade, em função de sua capacidade em enfrentar os desastres". E esta condição pode ser visualizada ao investigar os impactos associados à precipitação em Juiz de Fora, uma vez que a ocupação das áreas de risco se dá muitas das vezes por uma necessidade de moradia, que ultrapassa a percepção do risco, como identificou Souza (2006), e com isso os impactos são experimentados de forma muito diferenciada no espaço em 
função dessa multiplicidade de situações que ocorrem no espaço urbano e das condições de vulnerabilidade social.

\section{Os riscos aos impactos hidrológicos}

Apesar de não ter aplicado a técnica de integralização das informações para as ocorrências de impactos hidrológicos, em função das diferentes nomenclaturas utilizadas pelos veículos de imprensa e sem a precisão técnica necessária, algumas das áreas mais impactadas por impactos hidrológicos serão aqui destacadas.

Da mesma forma que os impactos geomorfológicos, é necessário destacar que os impactos hidrológicos ocorrem nos diversos pontos da cidade, sendo que na região de planejamento Centro estes ocorrem de maneira mais profusa, conforme visualizado no mapa de pontos (Figuras 113, 114 e 115).

As alterações processadas ao longo da história, e que ainda estão em curso, favoreceram e favorecem a intensificação dos impactos hidrológicos na RU Centro. Aterros, canalizações, retificações foram realizadas nos cursos hídricos da região central, e com a intensificação do uso da terra nas regiões adjacentes favorece a ocorrência de alagamentos e inundações nesta RP.

Na RP Centro, que apresenta condição de baixa e/ou baixíssima vulnerabilidade social, em sua maior parte, ao ser atingida pelos impactos hidrológicos provoca diversos reflexos na circulação de veículos e pessoas, atingindo o comércio, transporte coletivo, com isso, as consequências desses impactos se proliferam para outros pontos da cidade na medida em que as pessoas têm sua circulação limitada.

Esta região de planejamento, tem mais de $95 \%$ de sua área já ocupada e passando por um processo de intensificação de seu uso em algumas regiões urbanas, sobretudo São Mateus, Grambery e Bom Pastor, o que eleva a demanda nos sistemas de drenagem que foram construídos ainda nos anos 1970/80. Dessa forma, as condições de sítio associada a uma intensificação do uso da terra repercutem nesse processo.

\section{Os impactos hidrológicos associados aos canais fluviais}

As regiões urbanas com os maiores registros de impactos hidrológicos em áreas próximas a canais fluviais são as RUs Bairro Industrial (RP Centro-Oeste), São Pedro (RP Oeste), Santa Luzia (RP Sul), Vitorino Braga (RP Leste), Linhares (RP Leste) e Santa Terezinha 
(RP Nordeste). Nessas regiões urbanas figuram os córregos Humaitá, São Pedro, Ipiranga, Young e Tapera, respectivamente.

Na RP Centro Oeste, drenada pelo córrego Humaitá apresenta diversas condições entre a vulnerabilidade social e a suscetibilidade a inundação (Figura 129), na margem esquerda predominam as condições de média vulnerabilidade e na margem direita as condições de baixa vulnerabilidade social.

Figura 129: Condições de suscetibilidade a inundação e vulnerabilidade social na RP Centro- Oeste.

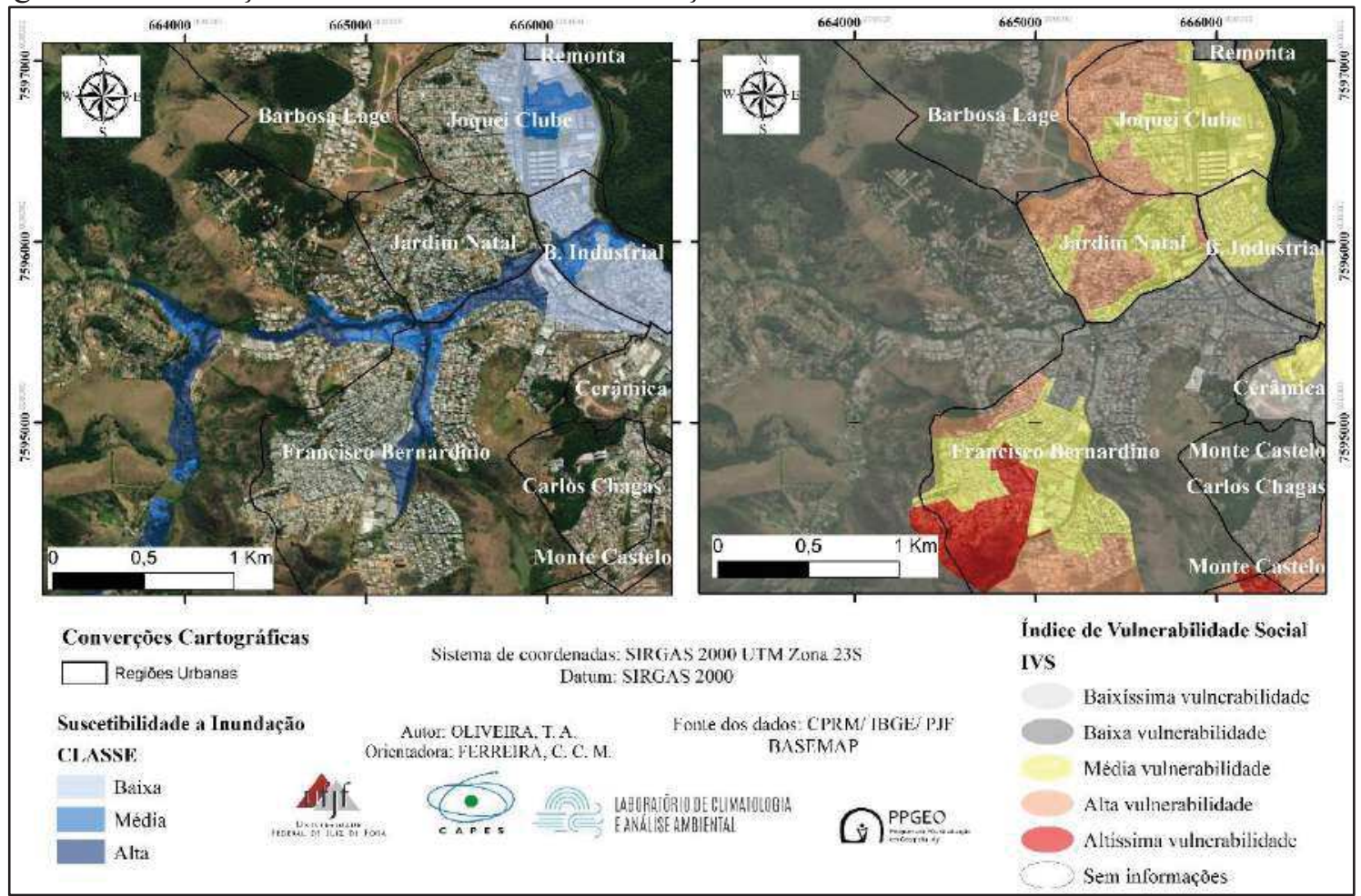

Fonte: Organizado pelo autor.

A região urbana Industrial está entre as que mais tem ocorrências de impactos hidrológicos, com 36 ocorrências e localizada no baixo curso do córrego Humaitá. O bairro congrega condições de suscetibilidade à inundação em toda sua extensão, bem como condições de baixa a média vulnerabilidade social, repercutindo em uma das áreas de risco a impactos hidrológicos no perímetro urbano de Juiz de Fora (Figura 130).

Figura 130: Inundação no bairro Industrial em 11/03/2018

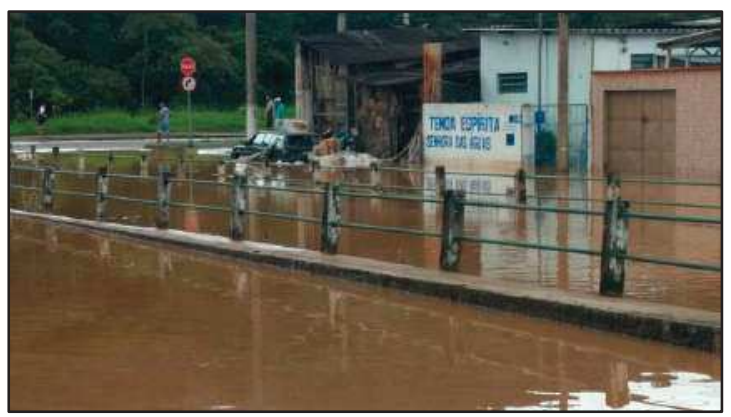


Fonte: Jornal Tribuna de Minas, 11/03/2018.

Ainda na RP Centro Oeste, no contato com a RP Norte, existem situações em que ocorrem ocupação em áreas de alta suscetibilidade a inundação às margens do rio Paraibuna no bairro Parque das Torres (Figura 131), na RU Barbosa Lage (6), nos limites com a RU Remonta. No Parque das Torres a condição é de alta e altíssima vulnerabilidade social, indicando também uma condição de risco a impacto hidrológico.

Figura 131: Condições de suscetibilidade a inundação e vulnerabilidade social na RP Centro- Oeste/

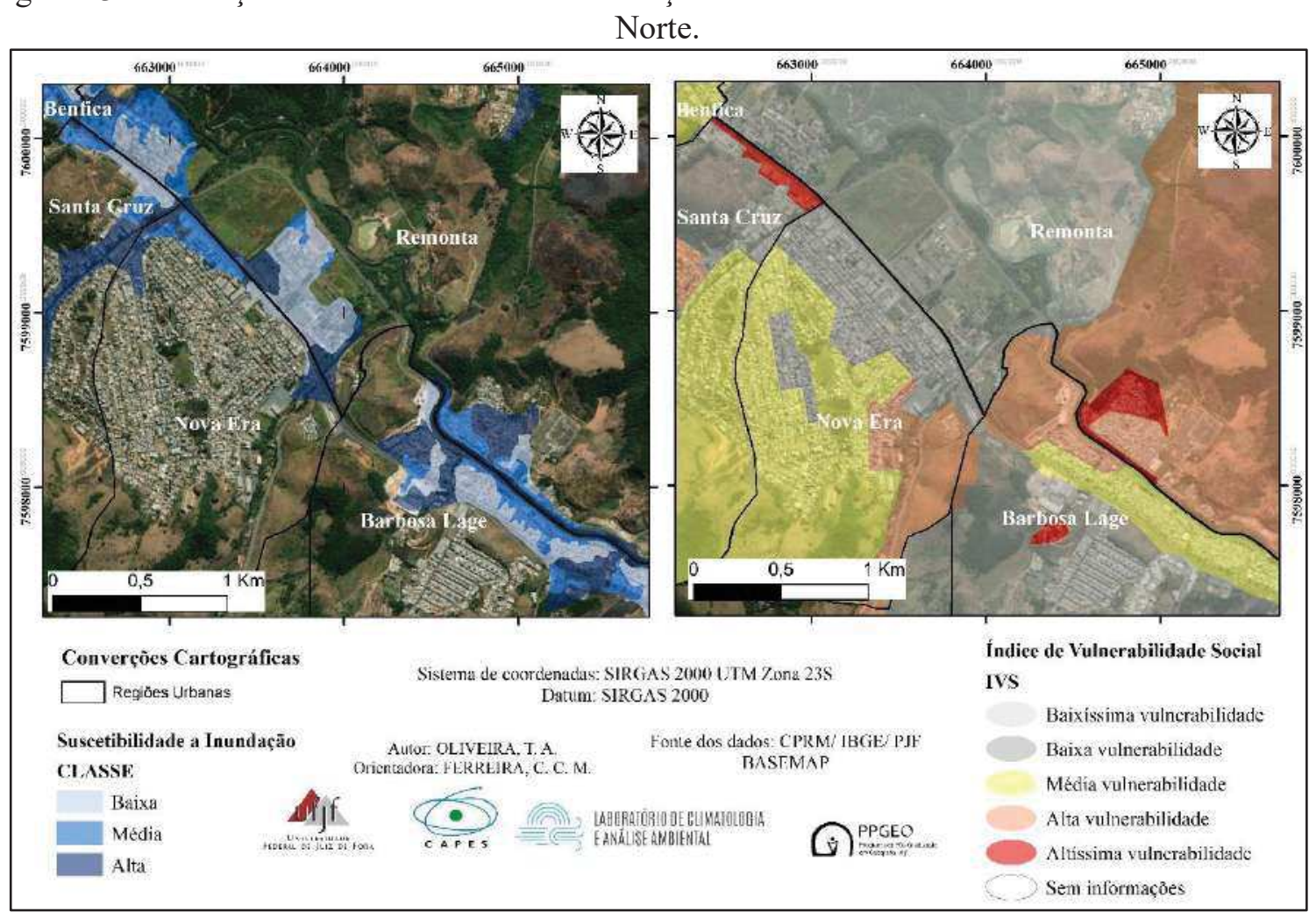

Fonte: Organizado pelo autor.

Na figura 132, observa-se a ocupação em condição de altíssima vulnerabilidade social às margens do Rio Paraibuna, no bairro Parque das Torres (RU Barbosa Lage). Ao longo da série de dados foram registradas 10 ocorrências de impactos hidrológicos na RU Barbosa Lage, sendo que em 2001 foram dois registros no Parque das Torres. 
Figura 132: Bairro Parque das Torres

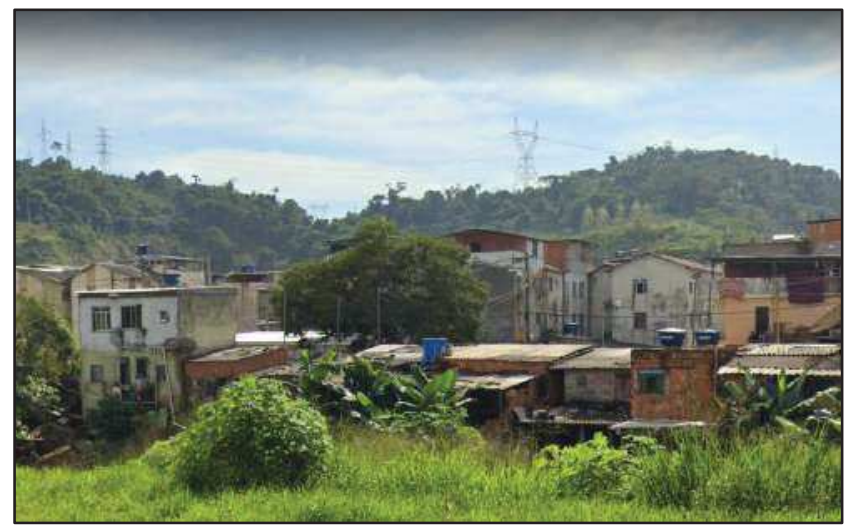

Fonte: Google Maps/ Street View (2019).

$\mathrm{Na}$ "Cidade Alta" (RP Oeste) diversas são as condições sociais às margens do córrego São Pedro, nos últimos anos tem se elevado o número de impactos hidrológicos nesta região (Figura 133). A RP Oeste registrou um crescimento no número de ocorrências superior a 300\% quando comparado o período de 2000-2018 (2000-2004;2012-2018) ao período 1980-89, indicando que as situações de risco a impactos hidrológicos têm aumentado nessa RP.

Figura 133: Condições de suscetibilidade a inundação e vulnerabilidade social na RP Oeste.

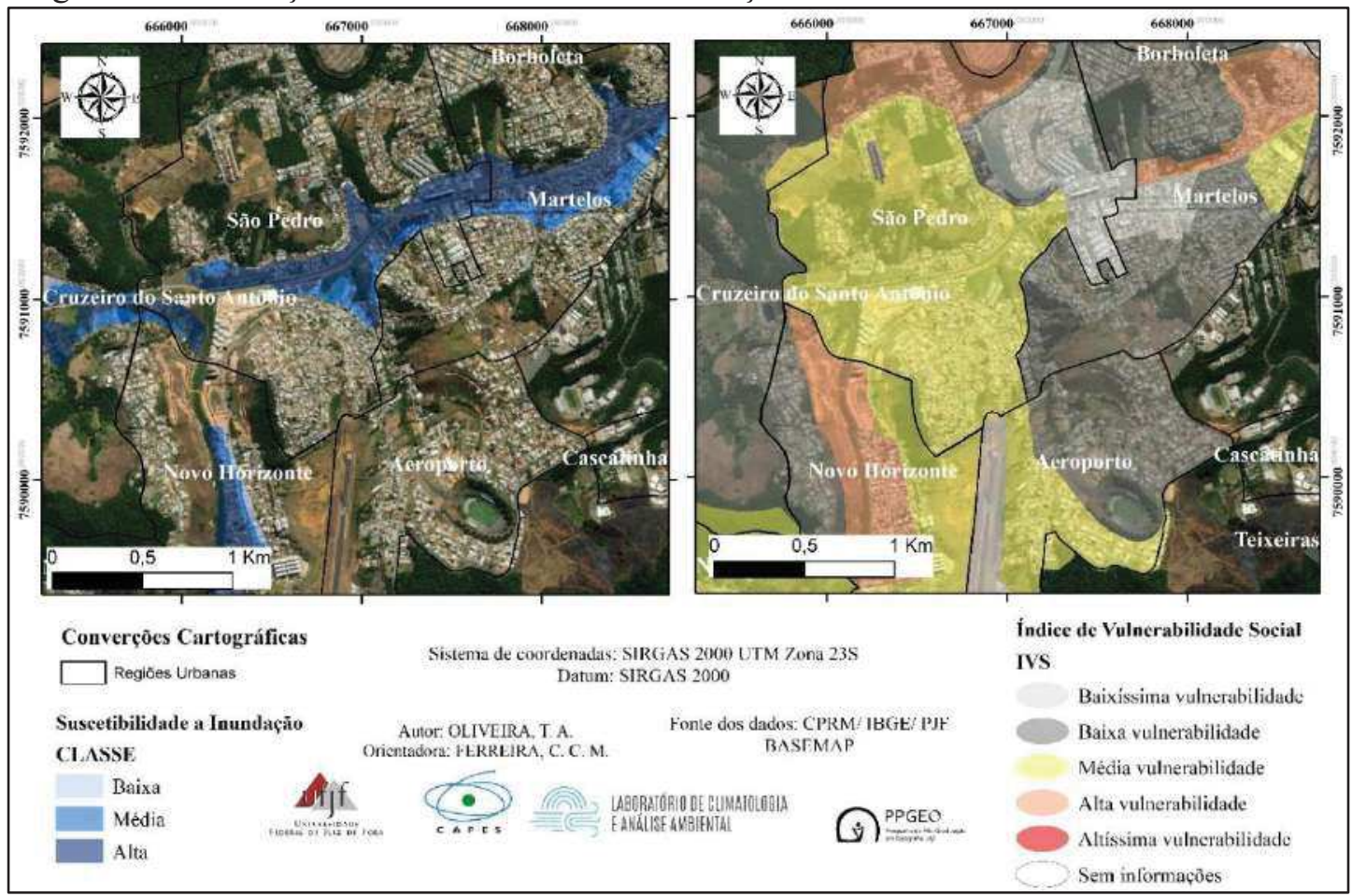

Fonte: Organzado pelo autor.

Nas RUs São Pedro, Martelos e Novo Horizonte, são diversas as condições de vulnerabilidade social às margens do córrego São Pedro, indicando que os diversos setores sociais são impactados pelos eventos hidrológicos, no entanto, na RU Martelos, no bairro 
Adolfo Vireque as condições de alta vulnerabilidade social e alta suscetibilidade a inundação denotam uma condição de risco a impactos hidrológicos (Figura 134).

Figura 134: Trecho canalizado do córrego São Pedro em um setor de alta vulnerabilidade social na RU Martelos

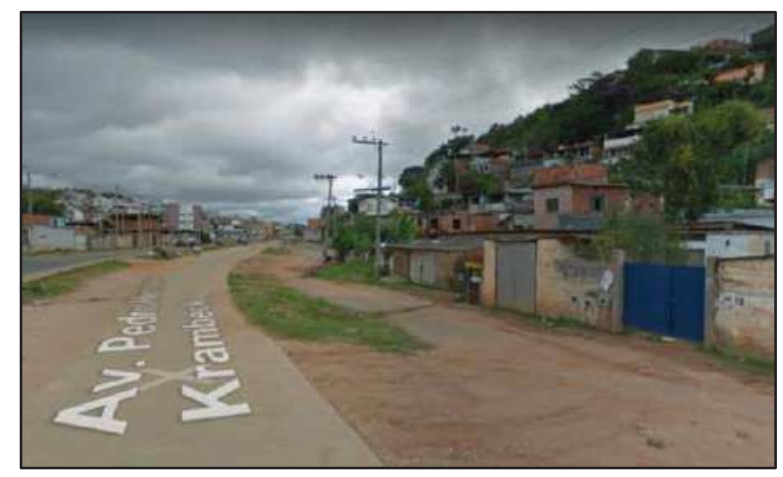

Fonte: Google Street View (2015).

Na região de planejamento Sul os impactos hidrológicos ocorreram de maneira mais concentrada na RU Santa Luzia, área do médio/baixo curso do córrego Ipiranga. O bairro Santa Luzia está entre as dez mais citadas por impactos hidrológicos na cidade, sendo que as ocorrências ocorreram ao longo de todo o período (Figura 135).

Figura 135: Condições de suscetibilidade a inundação e vulnerabilidade social na RP Sul.

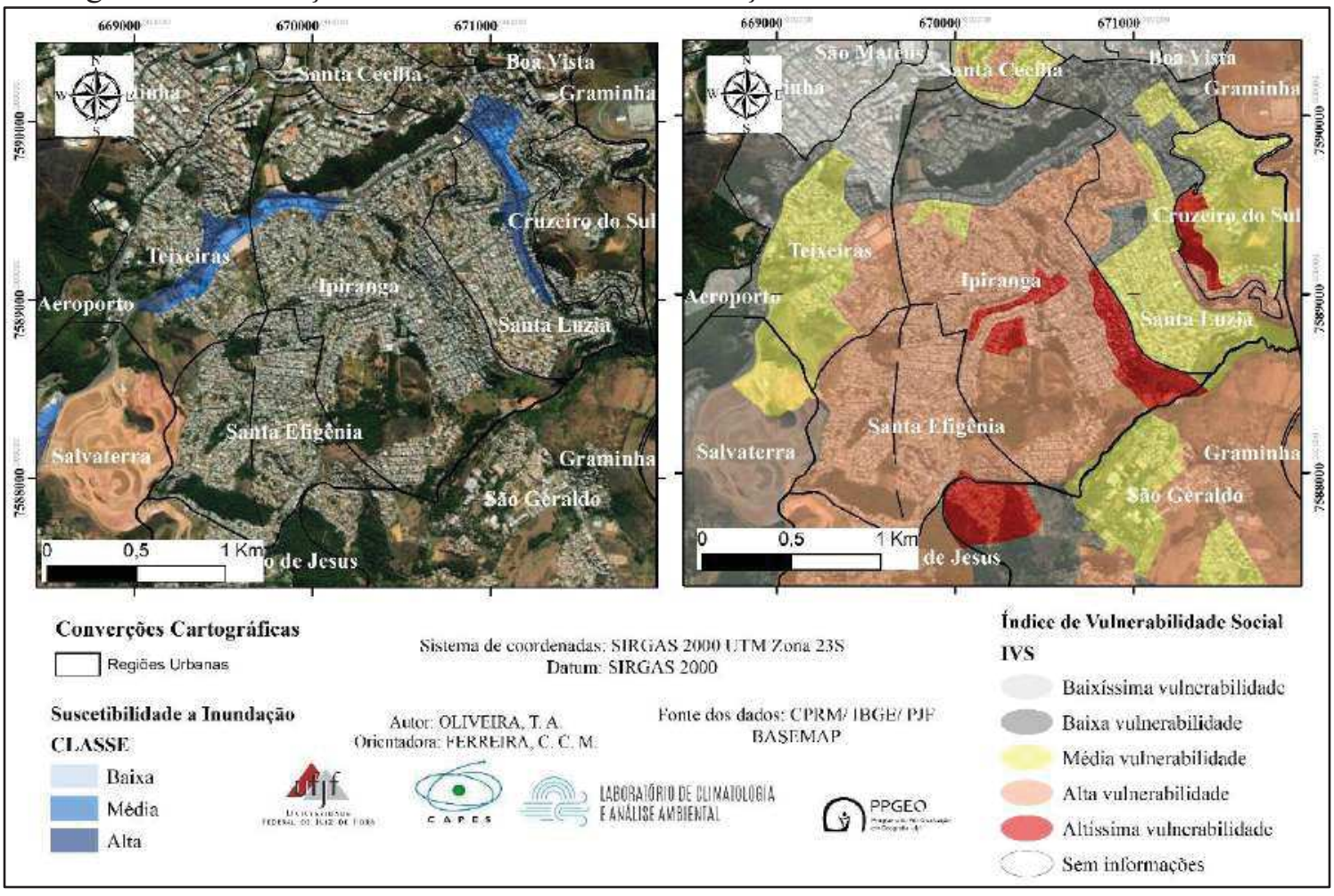

Fonte: Organizado pelo autor. 
Ao longo da região urbana Santa Luzia, diversas são as condições de vulnerabilidade social às margens do córrego, sendo que nos setores de ocupação mais antiga, as atividades comerciais predominam e as condições de vulnerabilidade social são baixas (Figura 136). À medida em que se afasta dessa região central da região urbana, em direção ao baixo curso as condições de vulnerabilidade social vão se diferenciando, e com isso, os impactos das inundações do córrego são diferenciados ao longo da região urbana.

Figura 136: Diferenças nos tipos de uso e na vulnerabilidade social em relação à suscetibilidade a inundação na RU Santa Luzia

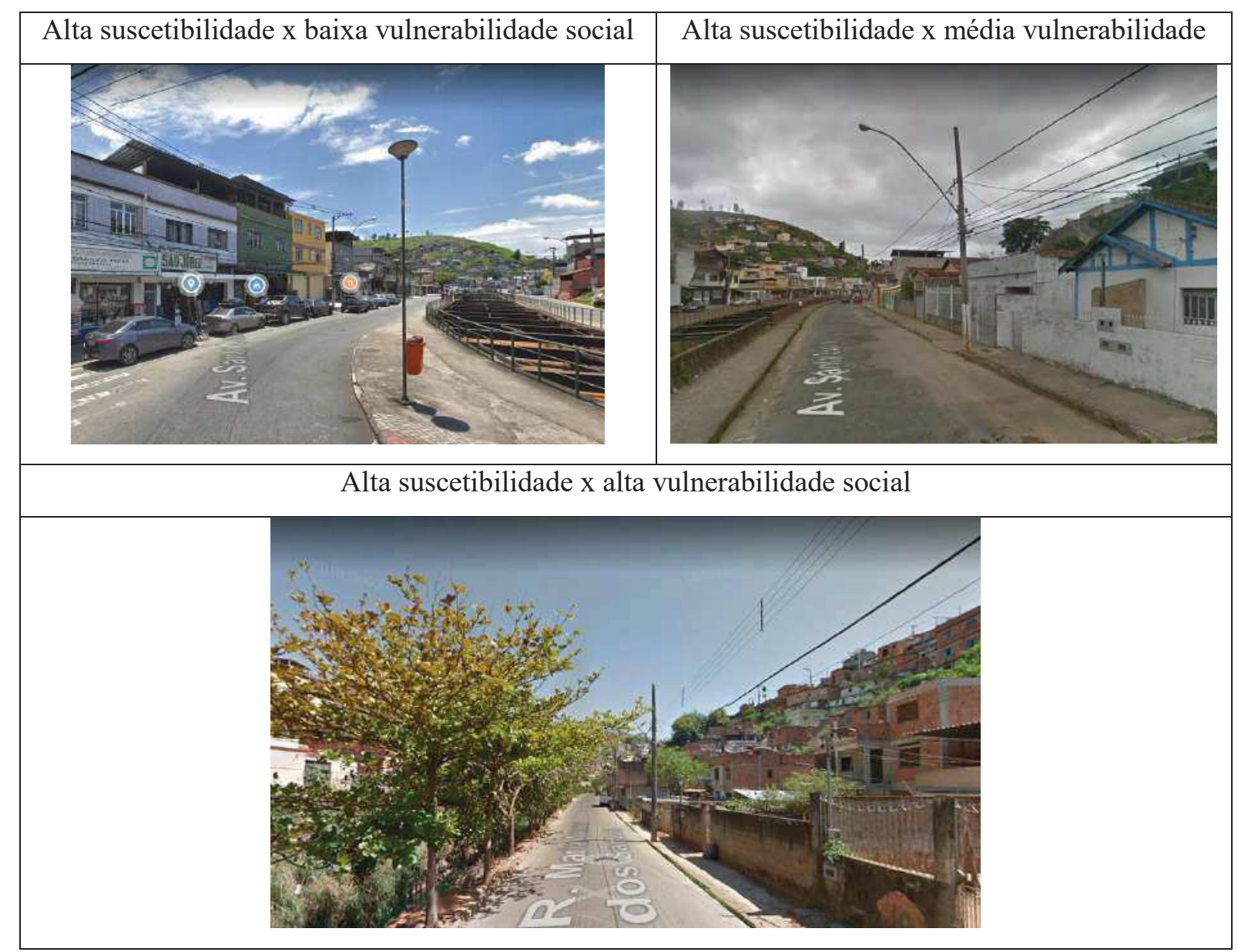

Fonte: Google Street View (2018).

Na região de planejamento Leste (Figura 137) duas regiões urbanas estão entre as mais citadas por ocorrências dos impactos hidrológicos, Vitorino Braga e Linhares. Além disso, as condições de vulnerabilidade social nessa RP são no médio e alto curso do córrego Young de média, alta e altíssima vulnerabilidade social. 
Figura 137: Condições de suscetibilidade a inundação e vulnerabilidade social na RP Leste

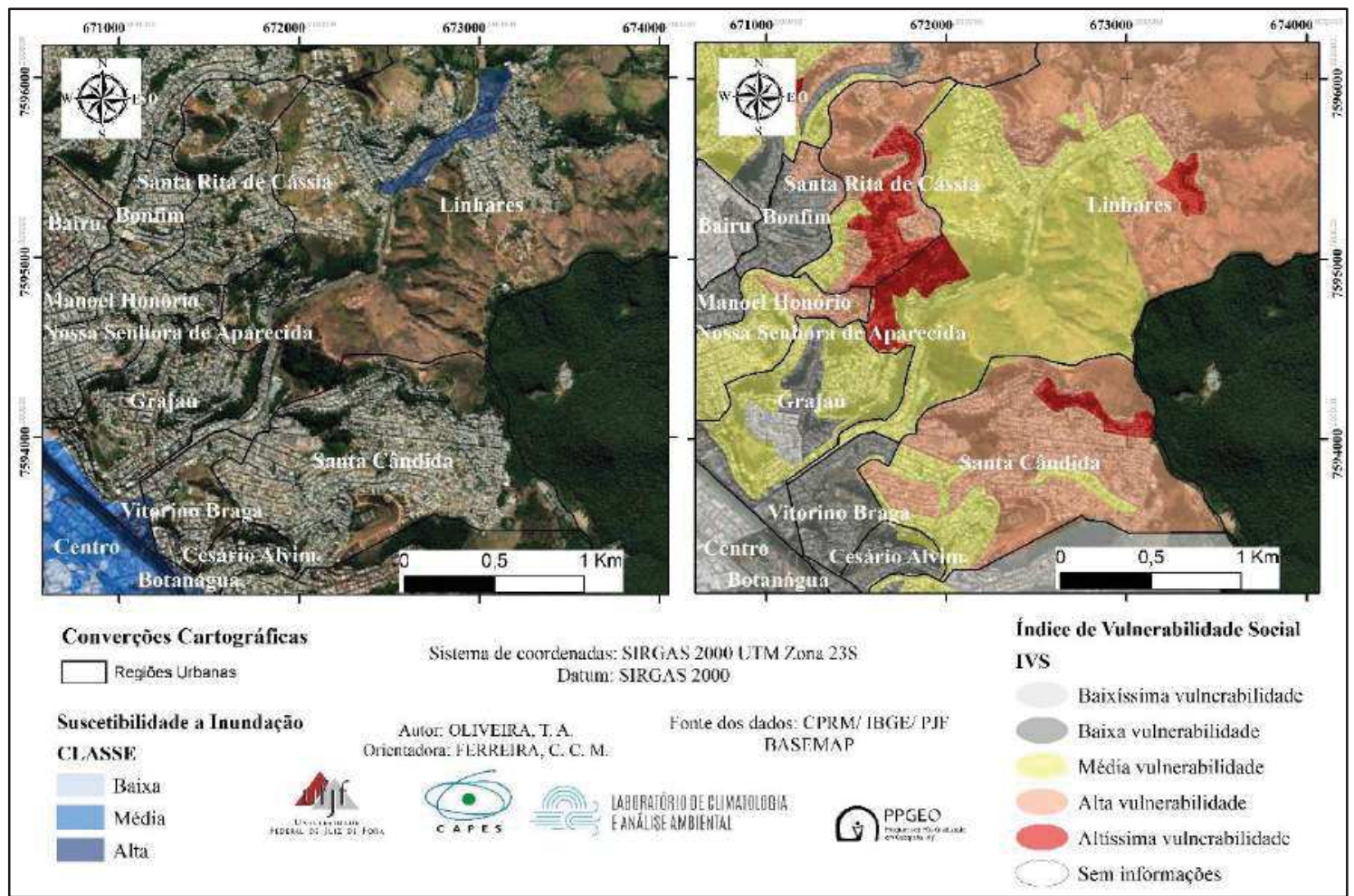

Fonte: Organizado pelo autor.

O córrego Young é canalizado no setor que drena a região de planejamento Vitorino Braga, nessa RU as ocorrências de alagamentos e inundações ocorrem ao longo do bairro, sendo o mais citado da RP, com 36 ocorrências ao longo do período. No ano de 2018 o bairro foi amplamente impactado no dia 24/12, com diversas ocorrências e 1 óbito por afogamento (Figura 138).

Figura 138: Impactos hidrológicos na RU Vitorino Braga em Dezembro de 2018

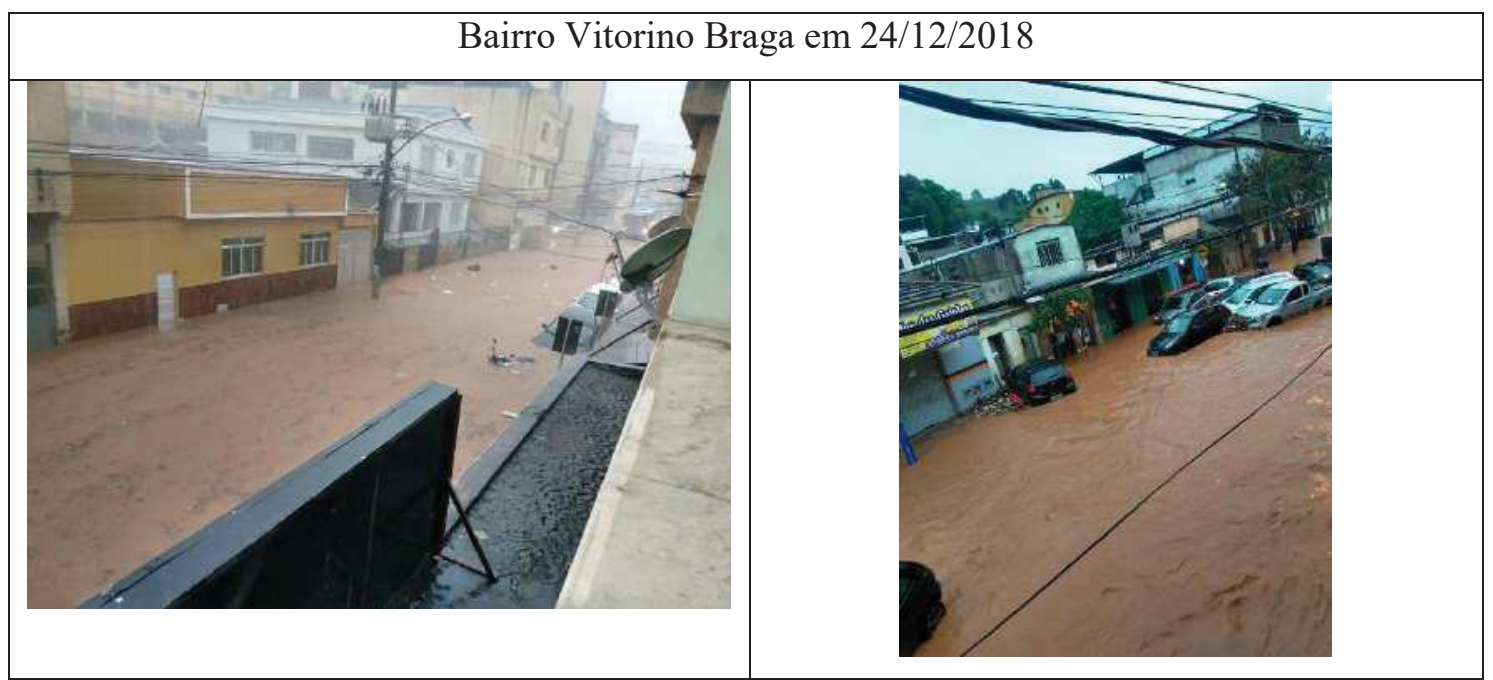

Fonte: G1 Zona da Mata. 
$\mathrm{Na}$ RP Leste, os vales historicamente foram ocupados de maneira inicial e posteriormente as encostas foram ocupadadas.Com isso, no vales desenvolveram-se os setores comerciais e as condições sociais são melhores, como pode ser observado na figura 139, no bairro Vitorino Braga, com as residências de melhor padrão construtivo na planície e nas encostas pequenas residências e de menor padrão construtivo.

Figura 139: Vista do bairro Vitorino Braga em 1971

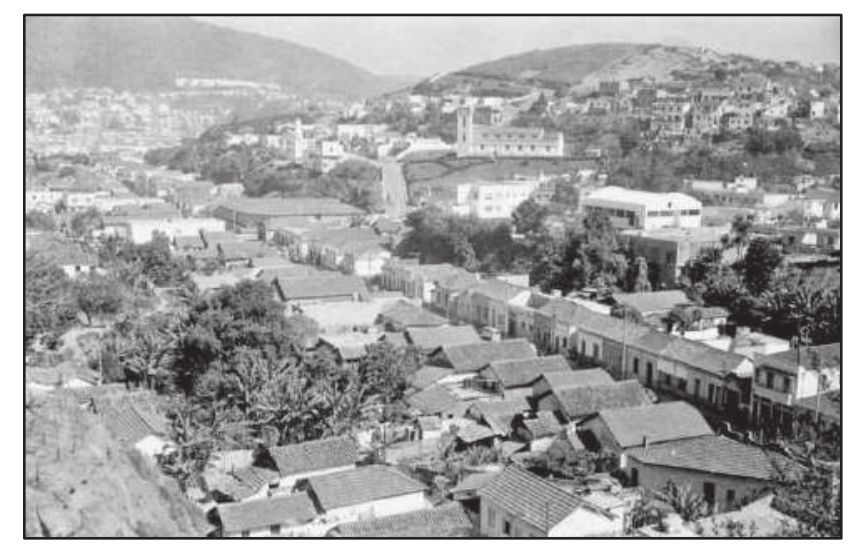

Fonte: Blog Maria do Resguardo.

Na região urbana Linhares os impactos hidrológicos estão associados às inundações do córrego do Young, ao longo do período investigado foram 29 registros no bairro. Na RU Linhares a suscetibilidade a inundações, associadas a condições de média e alta vulnerabilidade social, bem como um histórico elevado de ocorrências engendra uma condição de alto risco a impactos hidrológicos (Figura 140).

Figura 140: Inundação no bairro Linhares

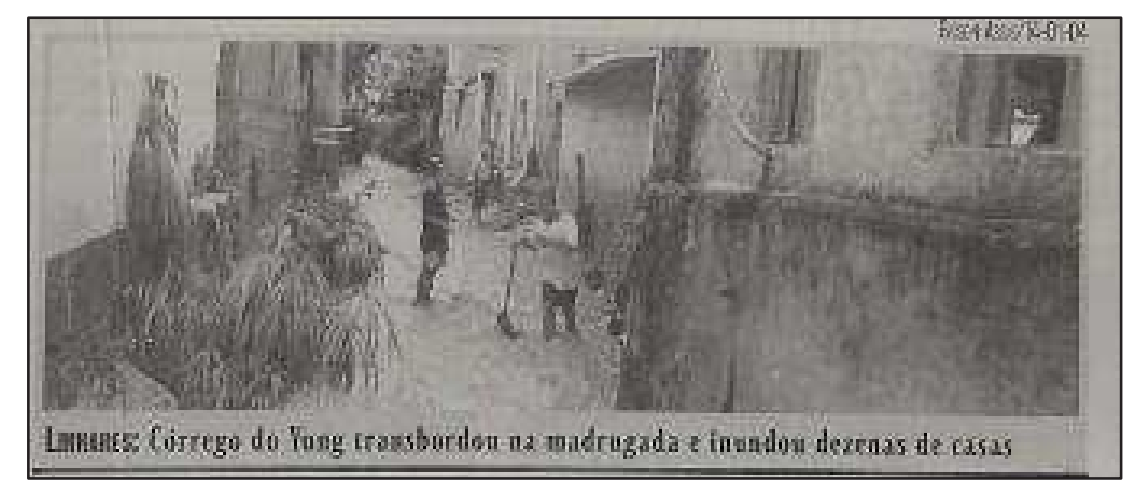

Fonte: Jornal Tribuna de Minas, 15/01/2004, p. 3.

Nas regiões urbanas Santa Terezinha, Mariano Procópio e Fábrica, que pertencem para as RPs Centro e Nordeste (Figura 141), as ocorrências de impactos hidrológicos são recorrentes, sendo que a RU Santa Terezinha está entre as dez mais citadas no perímetro urbano de Juiz de Fora. Nesses setores as condições de vulnerabilidade estão nas classes baixíssima e baixa. 
Figura 141: Condições de suscetibilidade a inundação e vulnerabilidade social na RP Centro/Nordeste.

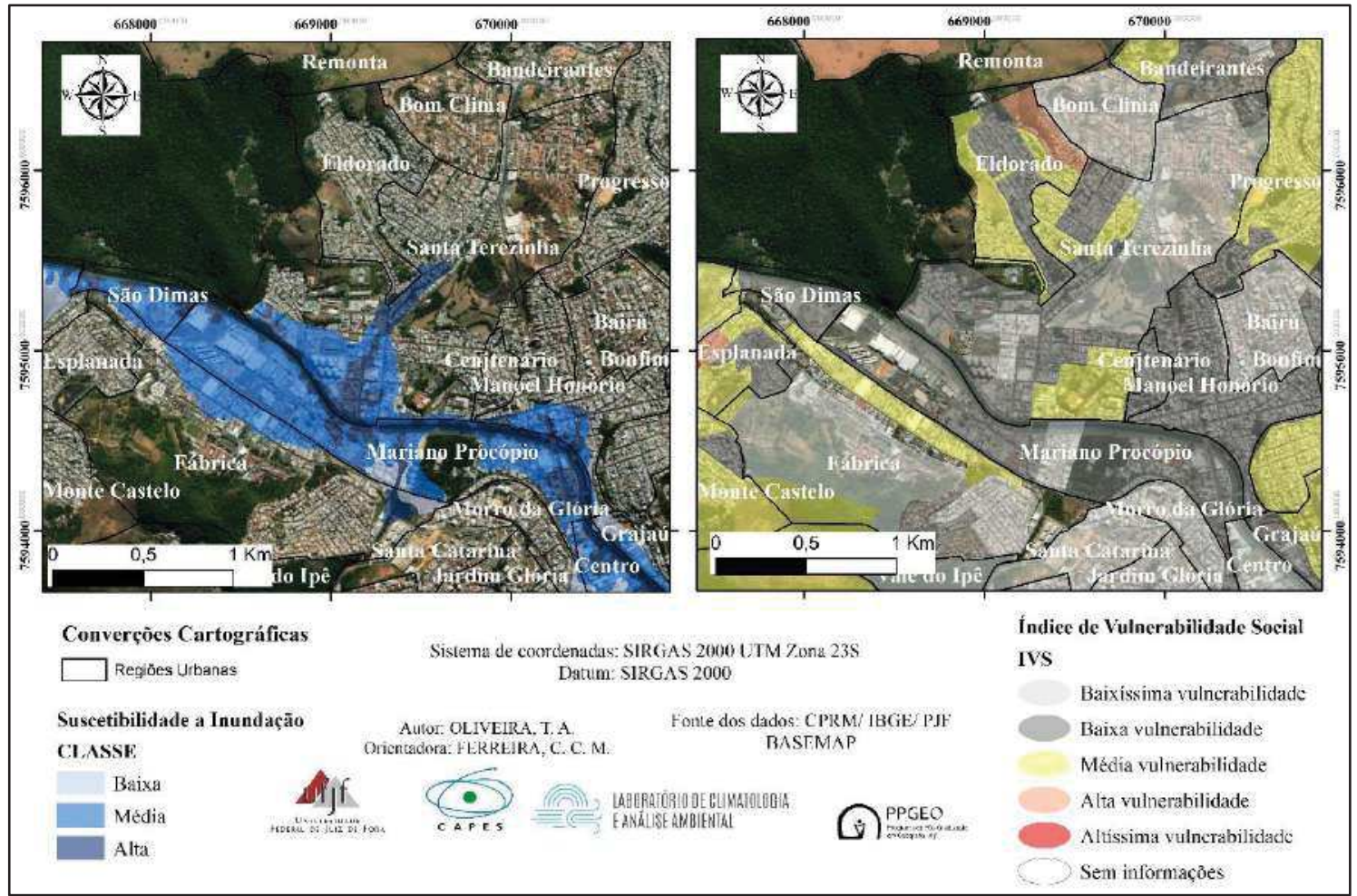

Fonte: Organizado pelo autor.

Na RU Fábrica, o bairro Democrata é impactado pelas inundações do córrego São Pedro, bem como na Favela do Rato na RU Santa Terezinha em que as inundações do rio Paraibuna (Figura 142) e um sistema de drenagem deficitário revelam diversos impactos hidrológicos nessas RUs.

Figura 142: Impactos hidrológicos nas regiões urbanas Fábrica e Santa Terezinha

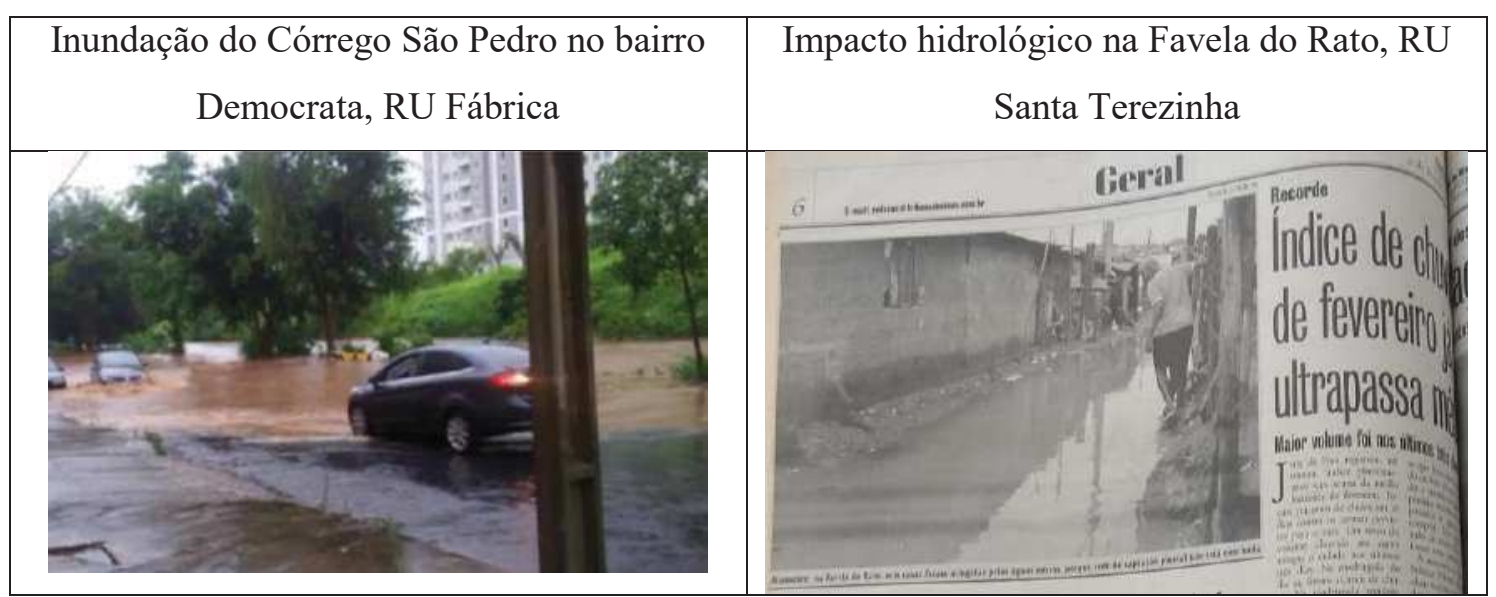

Fonte: G1 Zona da Mata, 10/12/2016 e Jornal Tribuna de Minas, 27/02/2004, p. 6. 


\section{Os eventos/episódios extremos em Juiz de Fora e os meses padrão}

A análise comparativa dos episódios nos meses padrão seco, habitual e chuvoso, poderia ter se dado em qualquer um dos meses da estação chuvosa, no entanto o mês de Janeiro foi selecionado em função de alguns critérios. Dentre os seis meses da estação chuvosa, Janeiro e Dezembro apresentam os maiores totais pluviométricos e se localizam no meio da estação chuvosa, além disso a Janeiro apresentou em média o maior número de impactos e os maiores valores extremos de ocorrências na cidade, por isso foi selecionado para a comparação.

A análise sinótica dos três meses padrão selecionados, 1985 (chuvoso), 1990 (seco) e 2012 (habitual), permitiram visualizar a frequência de determinados sistemas atmosféricos. Em um primeiro balanço é possível visualizar que os dias chuvosos estão associados à atuação de sistemas como os frontais, sejam frentes frias e estacionárias, linhas de instabilidade, como também à Zona de Convergência do Atlântico Sul (ZCAS).

Nos episódios visualizados nos anos de 1985 e 1990, em função da representação então utilizada, a simbologia da ZCAS utilizada atualmente ainda não era empregada, dessa forma, ficaria difícil estabelecer vínculos comparativos com os dados de 2012. Entretanto, Oliveira (2016) utiliza a representação de sequências de células de baixa pressão orientadas no sentido NW-SE na América do Sul, como um indicativo da ocorrência da ZCAS, além disso, foram utilizados os dados CHIRPS como um indicativo de ocorrência desse sistema.

Como pode ser visualizado na carta sinótica de 15/01/1985 uma frente estacionária localizada no Sudeste do Brasil e dois centros de baixa pressão localizados no Centro-Oeste e Norte do país (Figura 143), indicam, possivelmente, a convergência de umidade proveniente da região Norte, característica do período.

Figura 143: Carta sinótica de 15/01/1985.

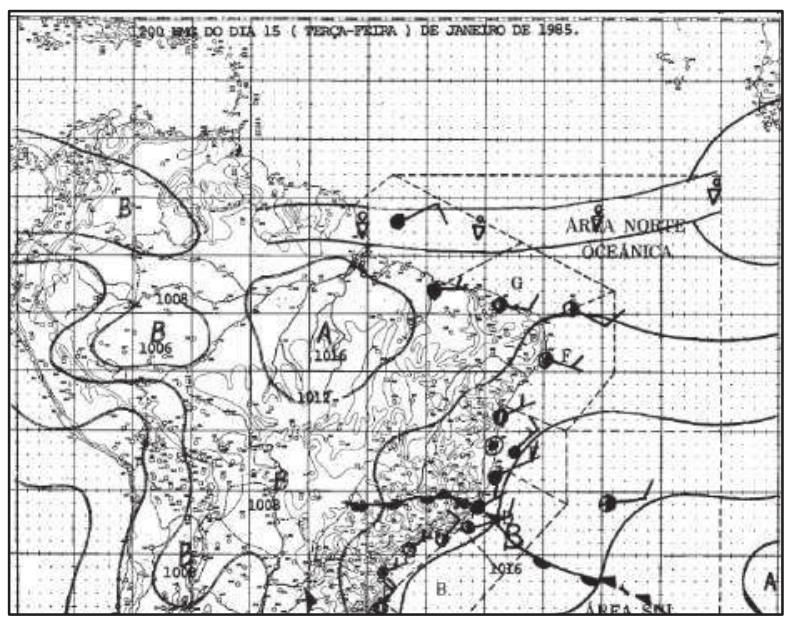

Fonte: Marinha do Brasil. 
Nos três meses analisados houveram algumas diferenças na frequência dos sistemas atmosféricos, no ano chuvoso de 1985 a recorrência de sistemas produtores de precipitação, como a ZCOU/ZCAS, refletem o elevado total pluviométrico observado. No ano habitual e seco verifica-se uma atuação maior de sistemas de alta pressão, como a massa Tropical atlântica, atuando como bloqueio atmosférico na região impedindo o avanço dos sistemas frontais, bem como a formação da Zona de Convergência do Atlântico Sul-ZCAS.

Figura 144: Comparativo da atuação dos sistemas atmosféricos nos meses analisados

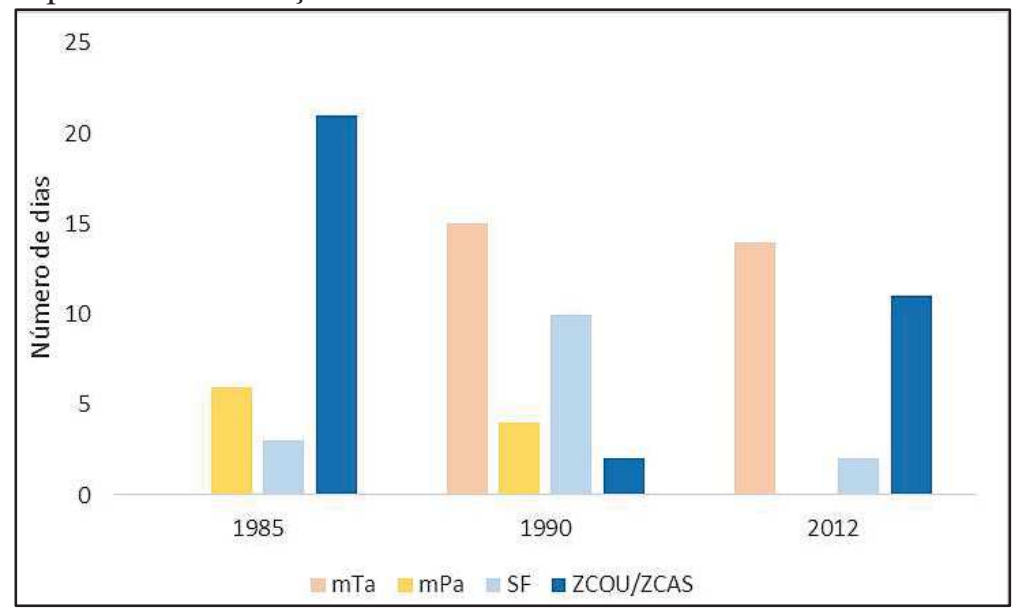

Fonte: Cartas Sinóticas- Marinha do Brasil. Organizado pelo autor.

A diferença entre os anos habitual e seco está associada à maior atuação de sistemas atmosféricos com características de alta pressão, como a massa Tropical Atlântica e a massa Polar Atlântica. Além disso, apesar de terem apresentado uma frequência parecida de ocorrência da massa Tropical Atlântica, no mês padrão seco de 1990 esta foi intercalada por sistemas frontais, que nessa ocasião passaram mais rápidos na região, provocando baixos totais pluviométricos.

No mês padrão habitual de janeiro de 2012, a prevalência da massa Tropical Atlântica se deu entre os dias 14 e 25 de Janeiro, sendo que no início e no fim do mês episódios de ZCAS produziram totais pluviométricos mais elevados na cidade.

\section{O mês padrão chuvoso de Janeiro 1985}

Janeiro de 1985 foi o mês mais chuvoso nos registros pluviométricos da cidade, em qualquer um dos meses do ano, o total de $715 \mathrm{~mm}$ de chuva caíram em 24 dias daquele mês, quase que ininterruptamente. Do ponto de vista sinótico a prevalência de sistemas frontais 
estacionários, indicando uma profunda convecção na região indicam a gênese desses elevados totais pluviométricos.

Figura 145: Precipitação na América do Sul nas pêntadas 1 e 2 de Janeiro de 1985, estimandos pelo CHIRPS.

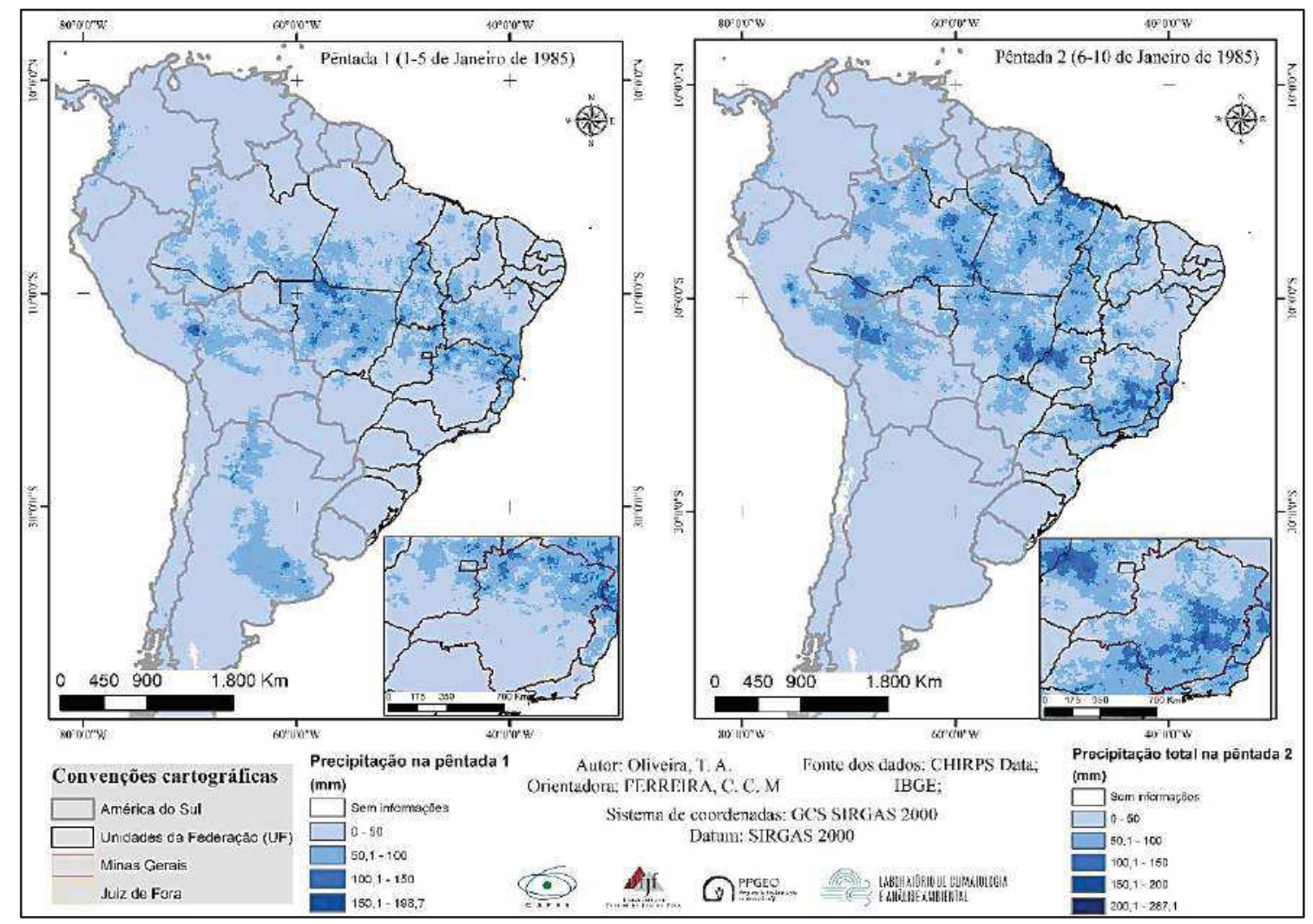

Fonte: Organizado pelo autor.

Na primeira pêntada de Janeiro de 1985 os totais pluviométricos registrados na cidade de Juiz de Fora foram de 16,9 mm, associados à passagem rápida de um sistema frontal, que ficara estacionário na região do norte de Minas Gerais e Espírito Santo e sul da Bahia. Na segunda pêntada a precipitação foi mais elevada com $88,3 \mathrm{~mm}$, estando associada a outro sistema frontal, que ficou estacionário na região do sudeste brasileiro, impactando a cidade nos dias 6,7 e 8 de Janeiro (Figura 145).

$\mathrm{Na}$ terceira pêntada o sistema frontal que persistia nos dias anteriores se deslocou para Nordeste, até que no dia 13 de Janeiro de 1985 outro sistema frontal atingiu a região, fazendo com que registrasse $105 \mathrm{~mm}$ no período de 11 a 15 de Janeiro, sendo que 98,5mm foram registrados nos dias 13 e 14/01/1985 (Figura 146).

$\mathrm{Na}$ quarta pêntada o sistema frontal se deslocou dando lugar rapidamente a outra frente fria no dia 17/01, e daí em diante se comportou de maneira estacionária na região, totalizando 203,9 mm no período entre 16-20 de Janeiro de 1985, indicando a formação de uma Zona de 
Convergência do Atlântico Sul. Nesse período ocorreu um evento de 122,4mm no dia 17/01/1985 (Figura 146).

Figura 146: Precipitação na América do Sul nas pêntadas 3 e 4 de Janeiro de 1985 estimandos pelo CHIRPS.

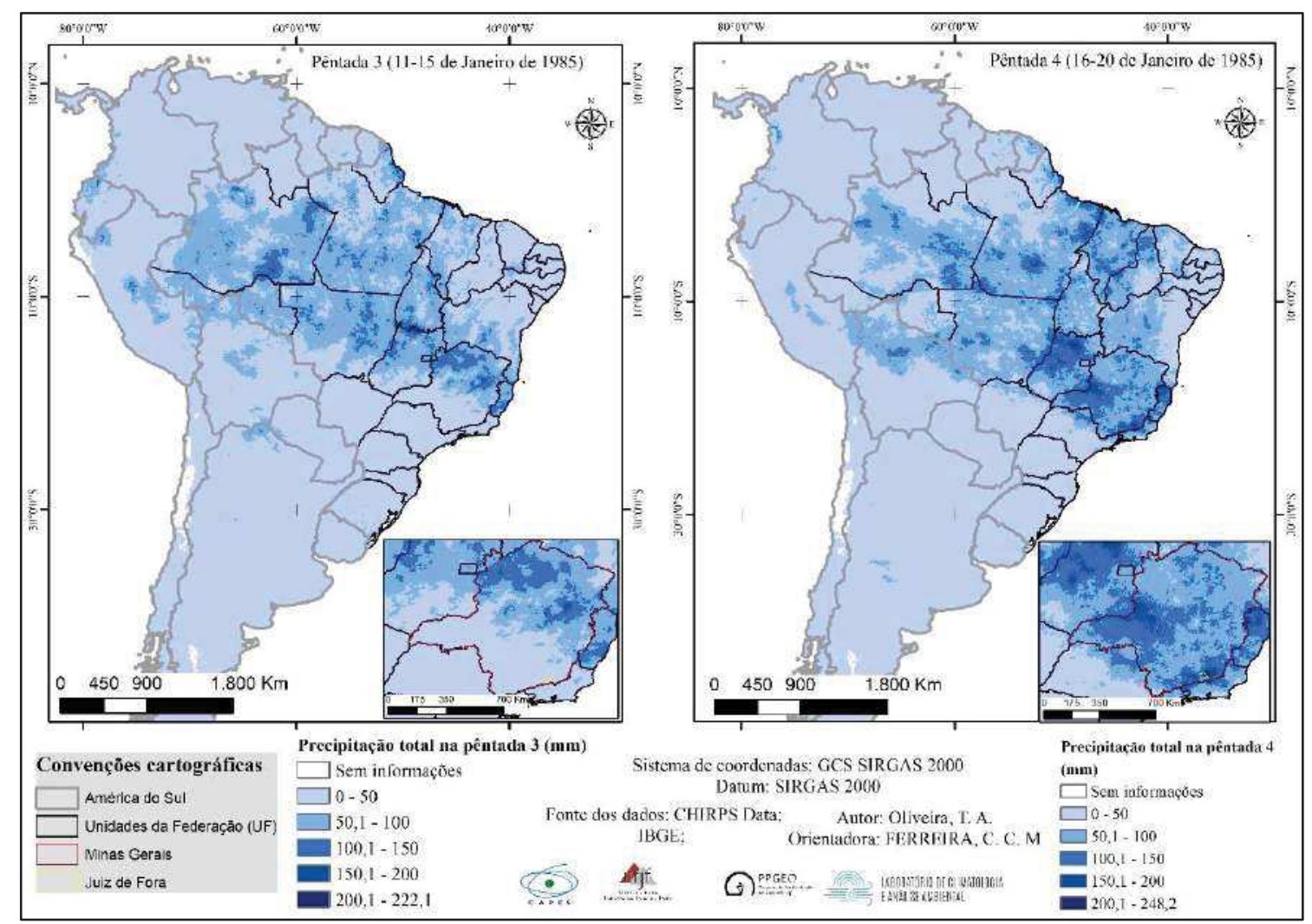

Fonte: Organizado pelo autor.

A partir da quarta pêntada (Figuras 146, 147 e 148), no dia 16/01 de 1985, foram $504,8 \mathrm{~mm}$ nesses 16 dias finais do Janeiro de 1985. Esse elevado total pluviométrico registrado esteve associado à frente estacionária que figurou no sudeste brasileiro. Nas estimativas de precipitação CHIRPS é possível visualizar os elevados totais pluviométricos no eixo NW-SE denotando a ocorrência de uma Zona de Convergência do Atlântico Sul. 
Figura 147: Cartas sinóticas nos dias 18 e 24 de Janeiro de 1985.

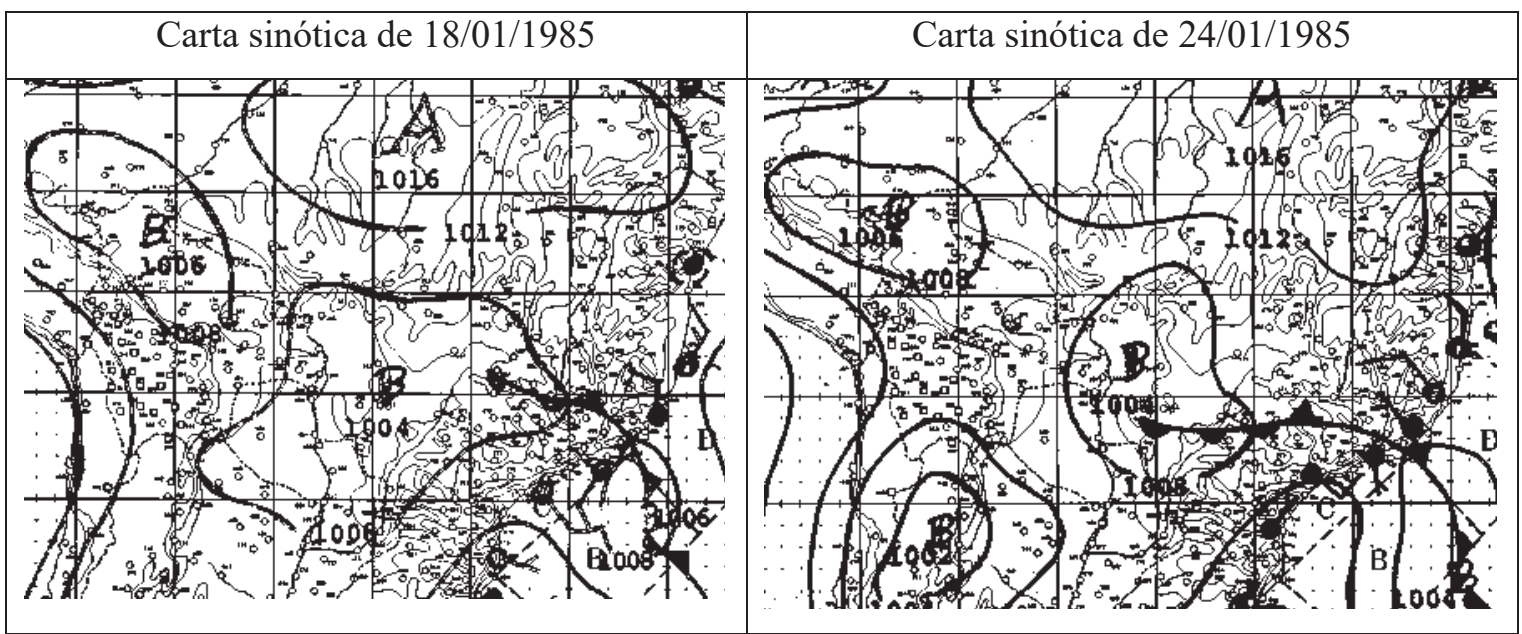

Fonte: Marinha do Brasil

Figura 148: Precipitação na América do Sul nas pêntadas 5 e 6 de Janeiro de 1985 estimandos pelo CHIRPS.

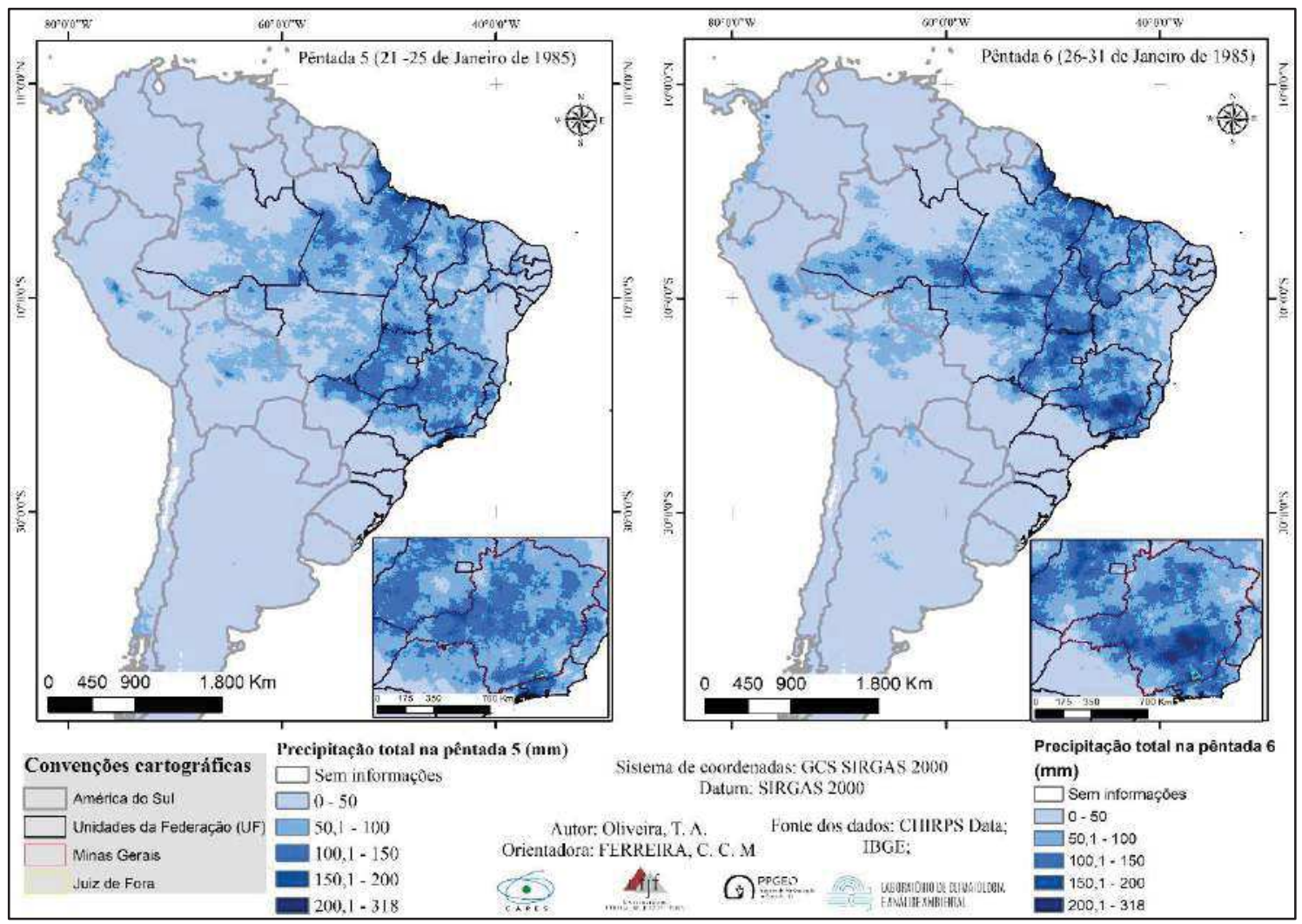

Fonte: Organizado pelo autor.

\section{O mês padrão chuvoso e os eventos/episódios extremos}

A figura 149 demonstra os totais pluviométricos diários para Janeiro de 1985 e a relação destes com as técnicas utilizadas para a identificação dos eventos extremos, bem como os 
episódios extremos. Nesse mês foram registrados 81 impactos na cidade, sendo o mês com o maior número de registros.

A técnica dos percentis indicou que 7 eventos foram superiores ao percentil 90, 6 foram superiores ao percentil 95, eventos intensos, e 2 superaram o percentil 99, eventos extremos, nos dias 17 e 24 de Janeiro. Com base na técnica dos máximos de precipitação observou-se seis eventos nesse mês que se enquadraram em quatro dos cinco níveis estabelecidos pela técnica, sendo que foram dois eventos normais, um evento de nível I e um evento de nível IV, o total de 122,4 (Figura 149).

Em todos os eventos extremos foram observados impactos na cidade, sendo que os maiores totais pluviométricos, corresponderam ao maior número de impactos. No entanto, em 11 dias foram registrados impactos na cidade, sejam eles associados a determinado evento pluviométrico ou decorrentes de um mesmo evento. 
Figura 149: Dados de precipitação total diária de Janeiro de 1985 e número de impactos (a); dados de precipitação e os percentis 90,95 e 99 (b); dados de precipitação e os níveis de máximos de precipitação (c); dados agrupados em pêntadas (d)

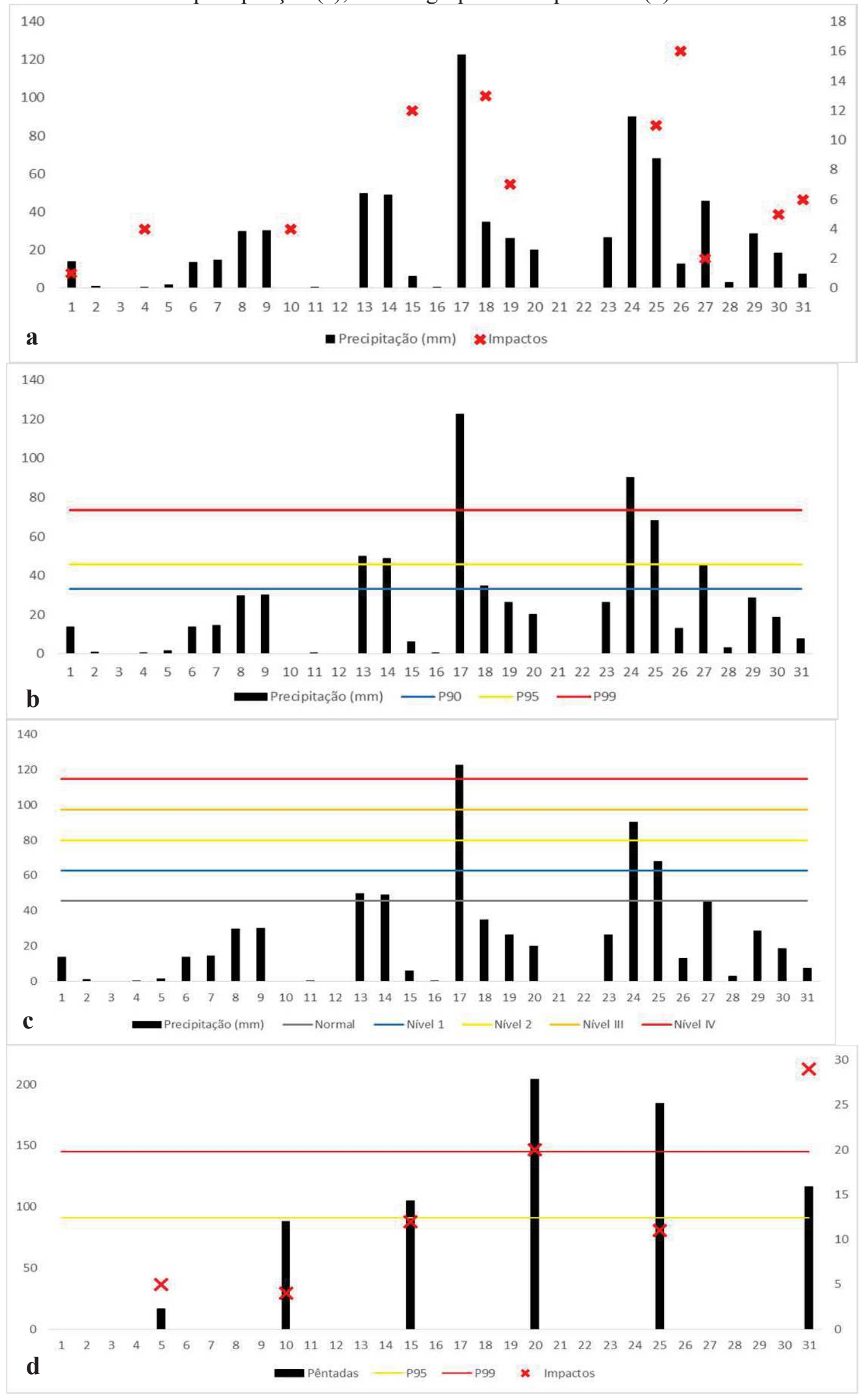


Fonte: Organizado pelo autor.

A técnica das pêntadas indicou que quatro das seis superaram o percentil 95, nestas quatro o número de impactos na cidade foi mais elevado, sendo maior na última pêntada, também em função do acumulado mensal gerado nos períodos anteriores. O período entre 16 e 25 de Janeiro de 1985, totalizou 388,5mm (Figura 149).

Alguns episódios extremos observados estiveram associados a acumulados diários de precipitação inferiores aos estabelecidos nas técnicas, no entanto quando acumulados, repercutiram em impactos na cidade. Exemplo disso pode ser observado no dia 9 de Janeiro, quando 4 impactos foram registrados, porém associados a totais pluviométricos inferiores aos valores indicados pelas técnicas estatísticas para a identificação dos eventos extremos.

\section{Os impactos das chuvas no mês padrão chuvoso de Janeiro 1985}

O mês de Janeiro de 1985 foi o que teve o maior número de impactos, dentre os analisados, foram 81, localizados no perímetro urbano de Juiz de Fora. Neste mês, com o elevado número de impactos observados na cidade, todas as regiões de planejamento observaram alguma ocorrência.

As Regiões Urbanas com o maior número de registros foram a RU Vitorino Braga (64), Centro (55), Ipiranga (37), RUs que historicamente estão entre as mais citadas por impactos na cidade. Além disso, os impactos se distribuíram por toda a área urbana da cidade, atentando para o fato de que nesse período a mancha urbana era mais reduzida (Figura 150).

Com relação aos impactos geomorfológicos estes representaram 42 registros, com maior número de ocorrências nas RUs Grajaú (66) e Santa Cruz (4). Na região Central também foram visualizados impactos geomorfológicos, além dos recorrentes alagamentos e inundações, nas RUs São Mateus (40), Dom Bosco (39) e Paineiras (26) e Centro (55). Nas Regiões Urbanas Centro e Paineiras as ocorrências estiveram associadas às quedas de blocos provenientes do Morro do Cristo (Figura 151). 
Figura 150: Total de impactos por região urbana em Janeiro de 1985.

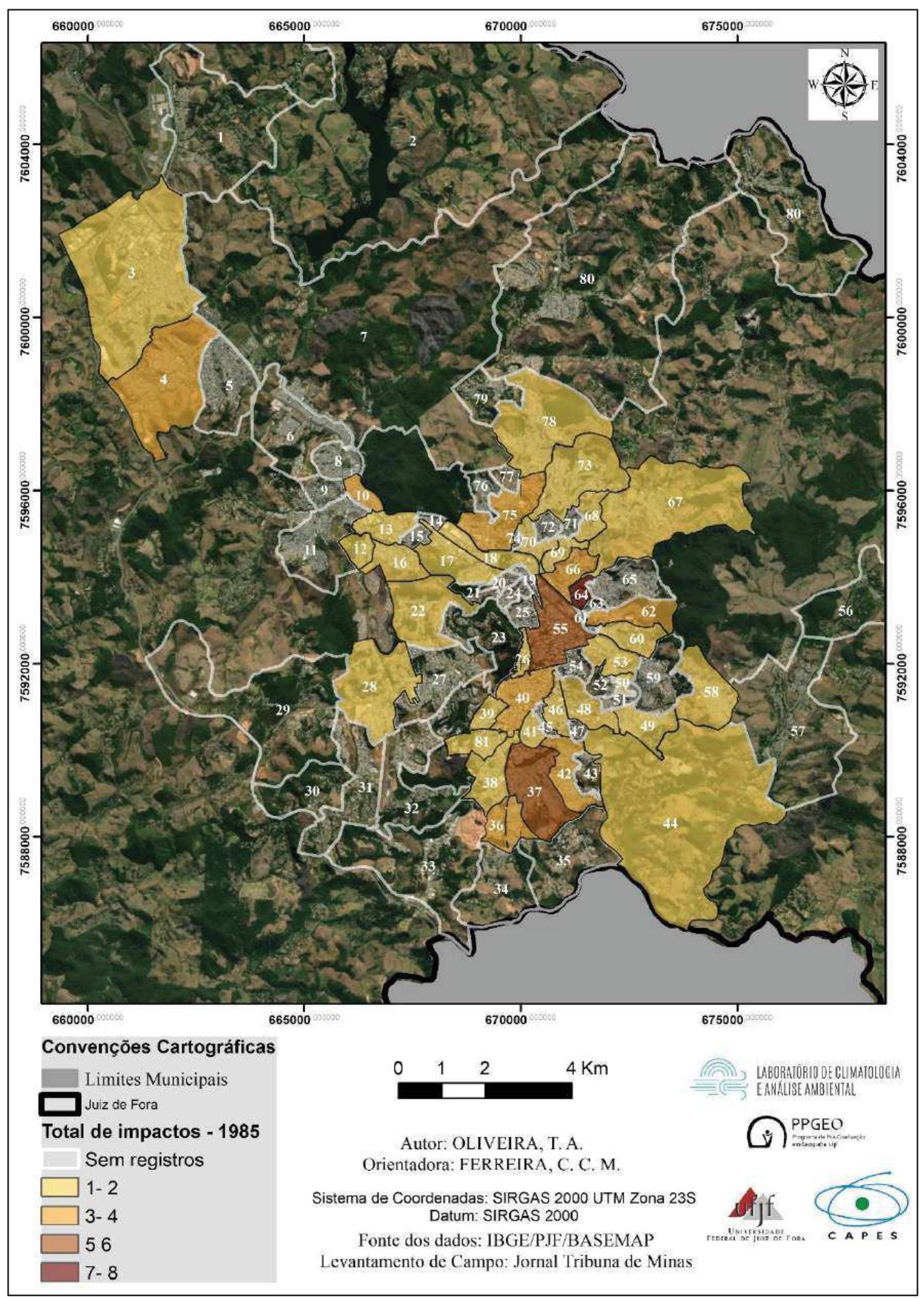

Fonte: Organizado pelo autor. 
Figura 151: Impactos geomorfológicos registrados em Janeiro de 1985.

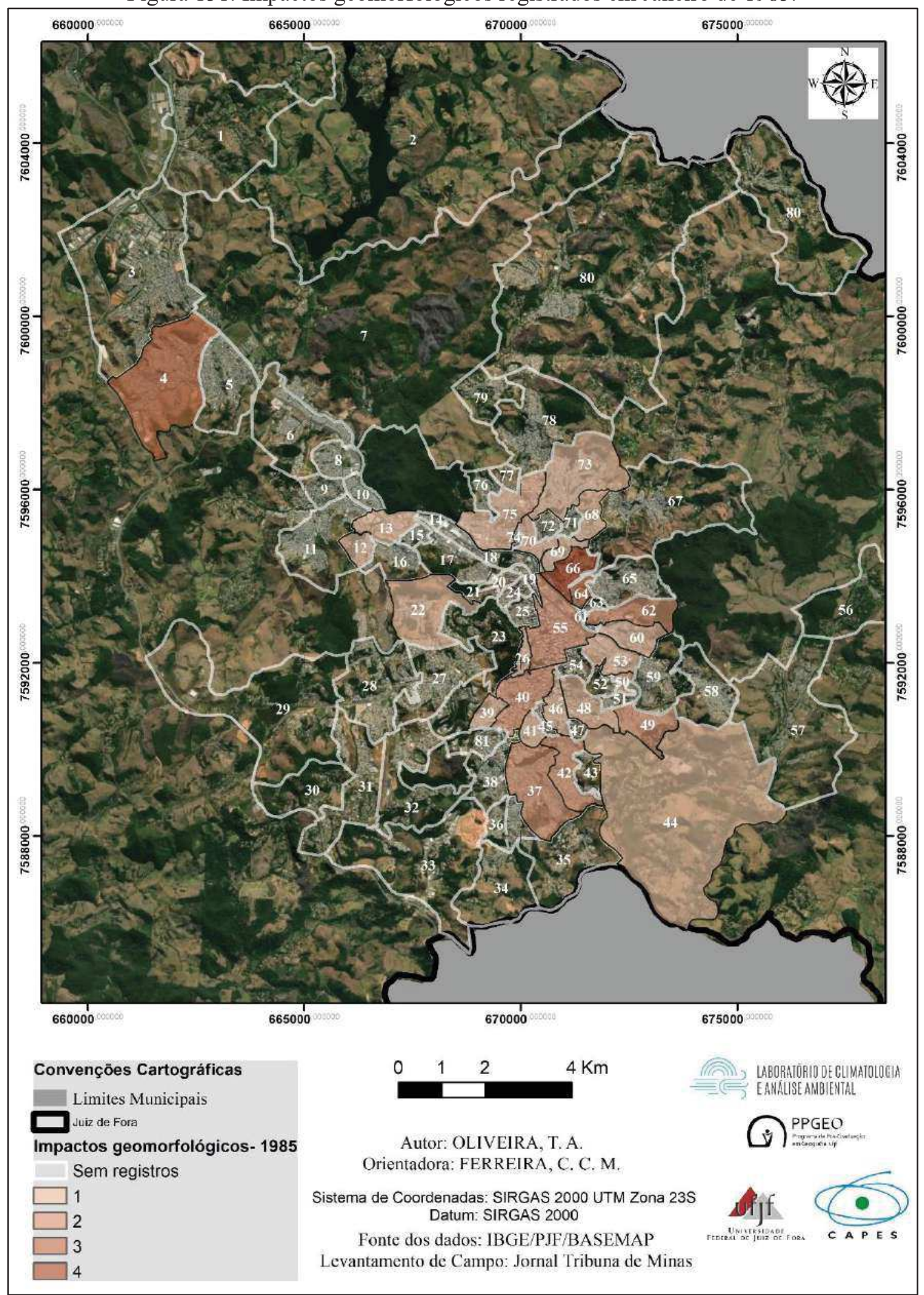

Fonte: Organizado pelo autor. 
Nos bairros mais citados com relação aos impactos geomorfológicos, observa-se as ocorrências nas Regiões Urbanas Grajaú (66) e Santa Cruz (4), na primeira ocorreram 5 óbitos no dia 26/01/1985, e na RU Santa Cruz, na Vila Melo Reis um deslizamento provocou o desabamento de três residências (Figura 152).

Figura 152: Ocorrências registradas em Janeiro de 1985.

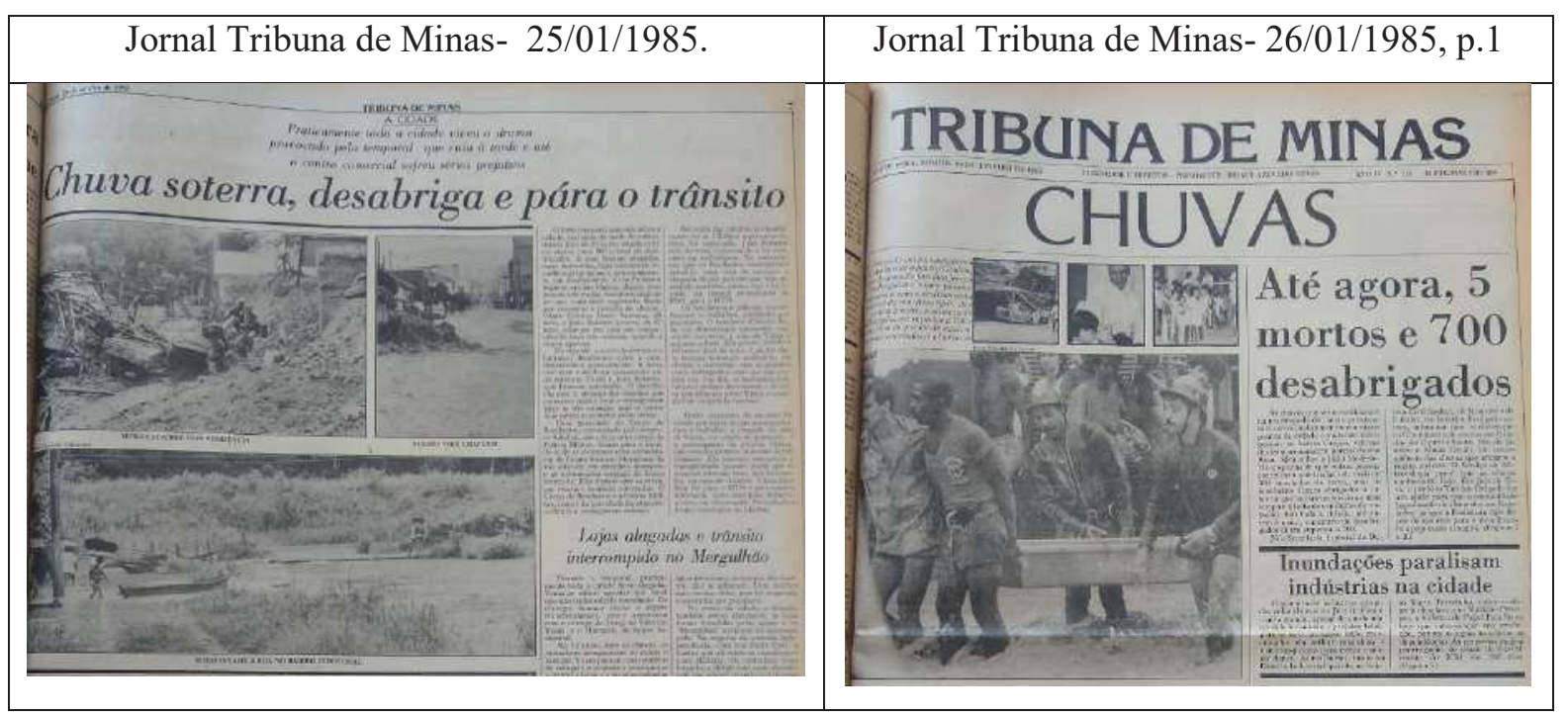

Fonte: Jornal Tribuna de Minas.

Os impactos hidrológicos neste mês ocorreram em todas as regiões de planejamento da cidade, e se concentraram nas regiões urbanas Vitorino Braga (64), Centro (55), Bairro Industrial (10), Ipiranga (37) e Santa Efigênia (36). As RUs, Vitorino Braga, Centro e Bairro Industrial já aparecem dentre as mais citadas ao longo da série, Ipiranga e Santa Efigênia apareceram dentre as mais citadas nesse ano especificamente (Figura 153 e 154).

Figura 153: Impactos na região urbana Centro

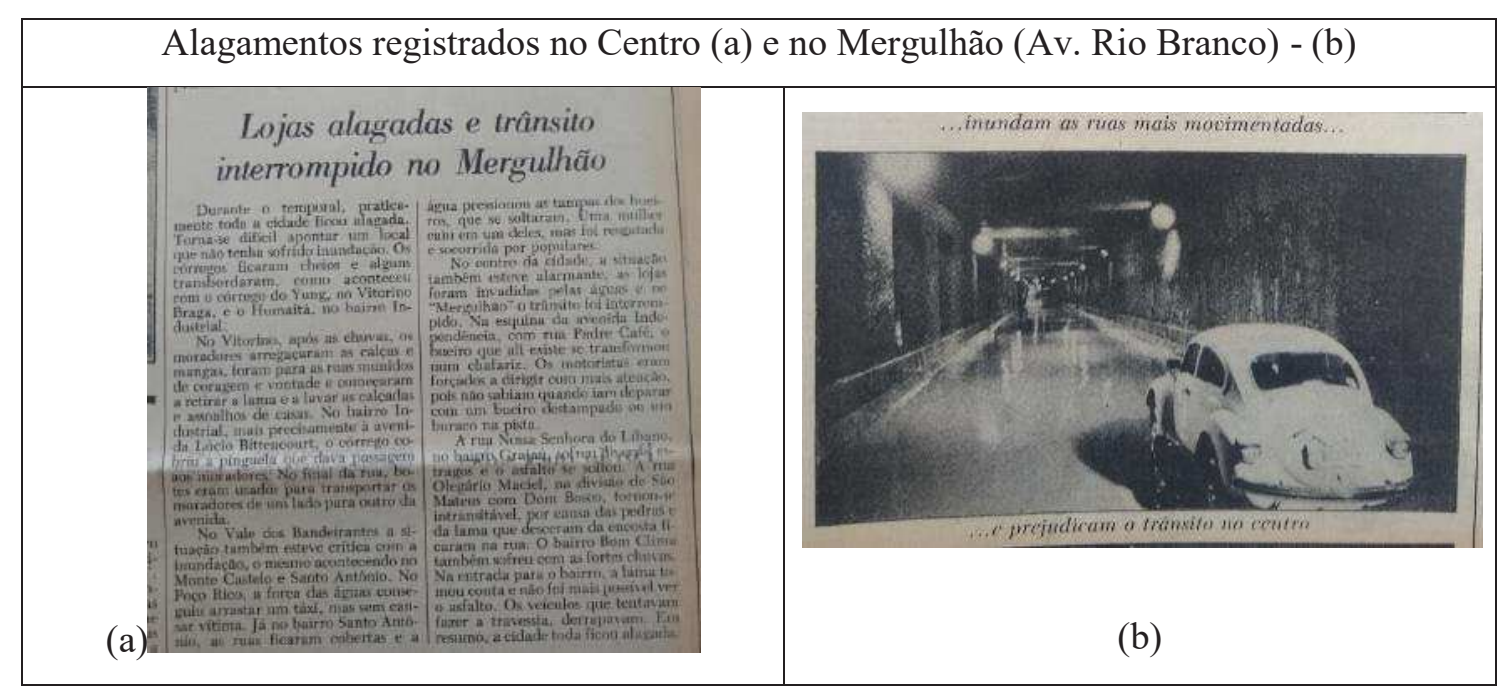

Fonte: Jornal Tribuna de Minas- 25/01/1985. 
Figura 154: Impactos hidrológicos registrados em Janeiro de 1985.

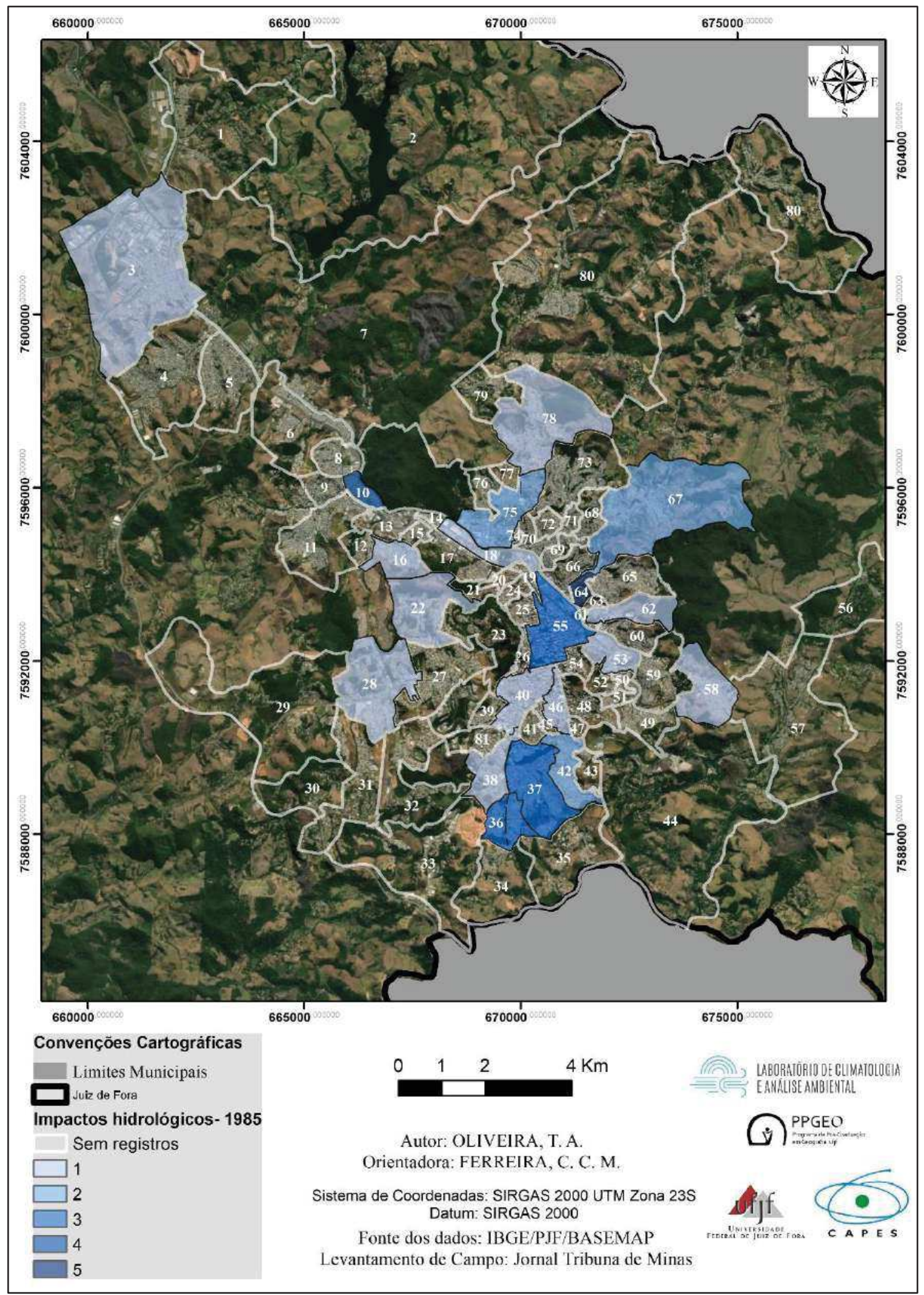

Fonte: Organizado pelo autor 
Além disso, outras regiões urbanas também foram impactadas por eventos hidrológicos nesse mês, como as RUs Santa Terezinha (75), Linhares (67), Santa Luzia (42), com duas ocorrências cada. Com apenas uma ocorrência 12 regiões urbanas foram registradas, Alto dos Passos (46), Bandeirantes (78), Borboleta (22), Benfica (3), Mariano Procópio (18), Monte Castelo (16), Poço Rico (53), Santo Antônio (58), São Bernardo (62), São Mateus (40), São Pedro (28) e Teixeiras (38).

$\mathrm{Na}$ Região Urbana Santa Terezinha (75) as inundações do Rio Paraibuna atingiram uma área conhecida como "Favela do Rato" (Figura 155). Em algumas regiões urbanas os impactos ocorreram em áreas de risco a impactos hidrológicos, como na RU Santa Luzia, Linhares, Industrial, São Bernardo, São Pedro setores em que as condições de vulnerabilidade social são de média a alta às margens dos córregos.

Figura 155: Inundação do Paraibuna na Favela do Rato

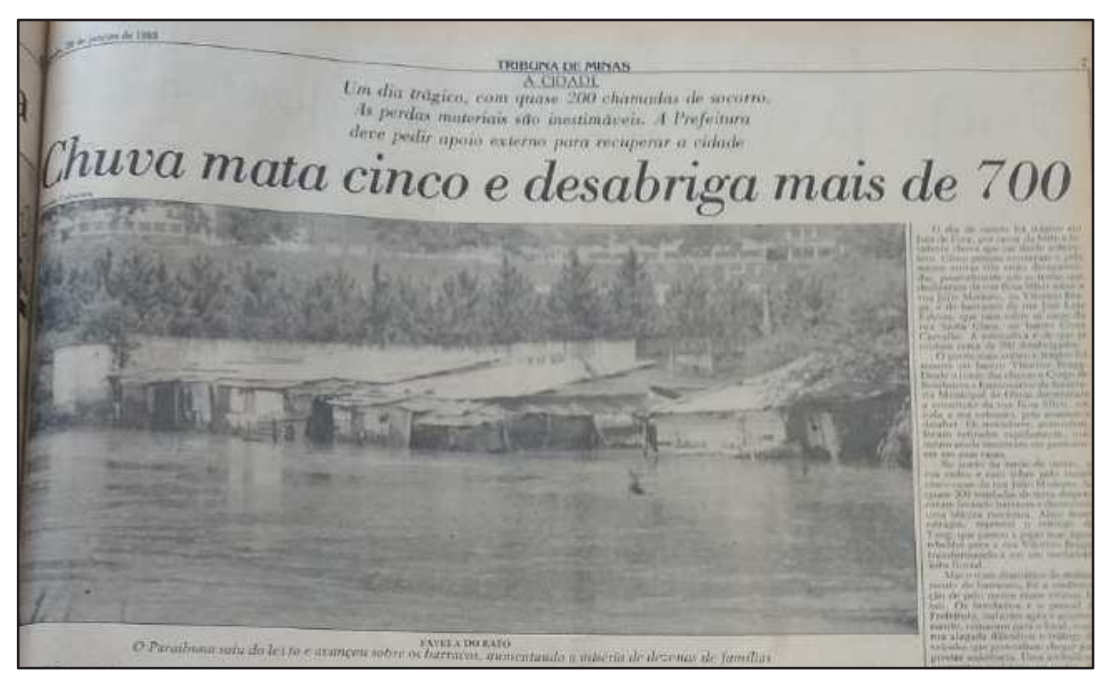

Fonte: Jornal Tribuna de Minas, 26/01/1985, p. 7.

Assim, observa-se que no ano padrão chuvoso e com elevados totais pluviométricos diários, todas as regiões de planejamento da cidade registraram impactos durantes os episódios extremos. Com isso, nesse caso, as áreas já suscetíveis a inundações ou áreas de risco a impactos geomorfológicos são as mais impactadas, no entanto outras áreas que apresentam condições de menor risco acabaram sendo também impactadas em função dos elevados totais pluviométricos. 


\section{O mês padrão seco de Janeiro 1990}

O janeiro de 1990 registrou um total de 97,7 mm distribuídos em 10 dias de chuva. O estabelecimento de uma massa Tropical Atlântica por 14 dias consecutivos em uma condição de bloqueio atmosférico, bem como a passagem rápida dos sistemas frontais, engendrou os baixos totais pluviométricos para este mês.

No início do mês, devido à atuação de uma Zona de Convergência do Atlântico Sul, até o dia 4 de Janeiro produziu o período de precipitação acumulada mais elevada na cidade. Já na segunda pêntada a precipitação se concentra no sul do Brasil, uma vez que no sudeste brasileiro, exceto o estado de São Paulo, já estava sob influência da atuação da massa Tropical Atlântica (Figura 156).

Figura 156: Precipitação na América do Sul nas pêntadas 1 e 2 de Janeiro de 1990, estimandos pelo CHIRPS.

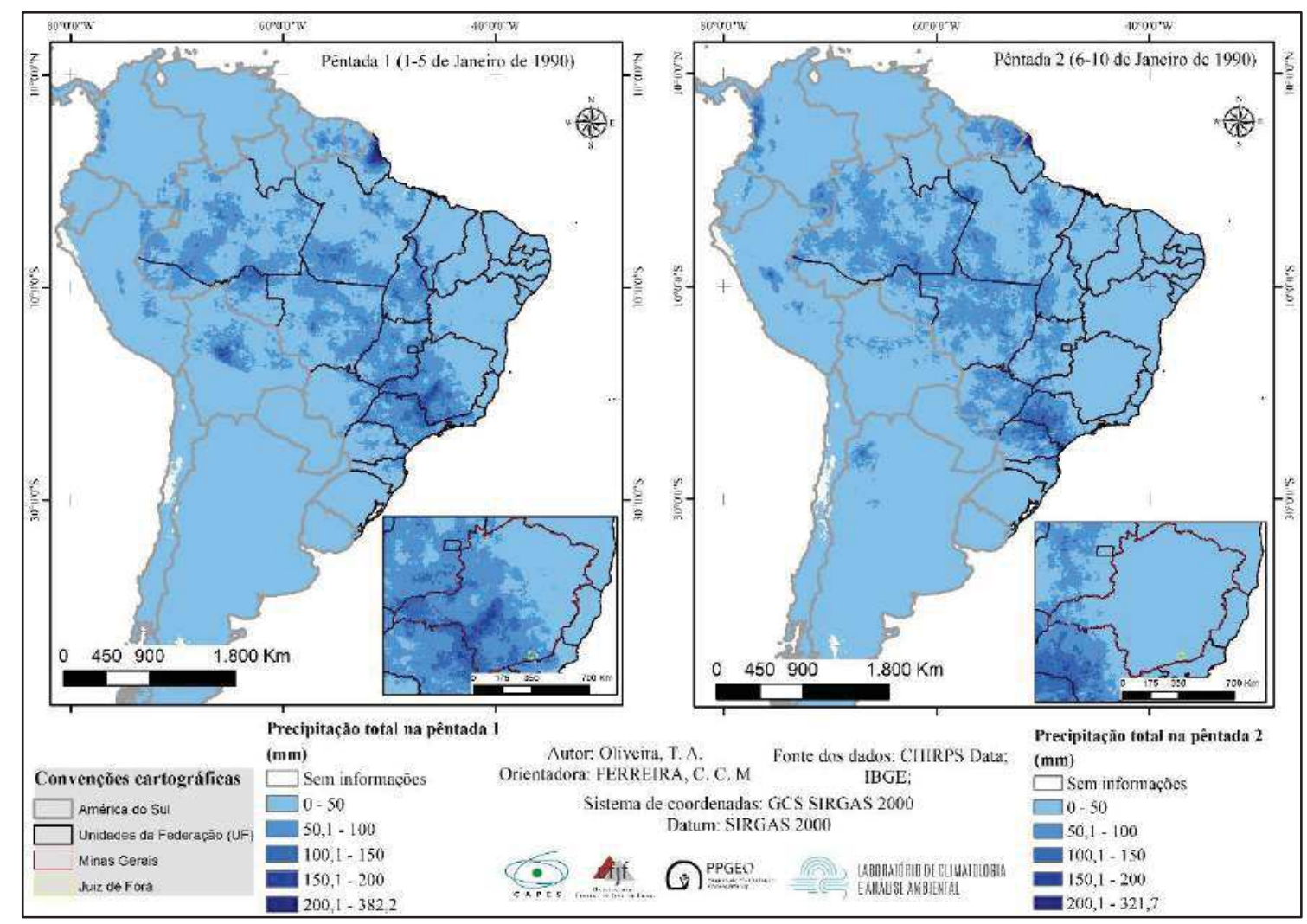

Fonte: Organizado pelo autor.

A partir das cartas sinóticas é possível observar o centro de alta pressão, associado ao anticiclone semifixo do Atlântico Sul-ASAS, localizado sob o oceano Atlântico, indicando a ocorrência da massa Tropical Atlântica-mTa (Figura 157). 
Figura 157: Cartas sinóticas de 07 e 10 de Janeiro de 1990.

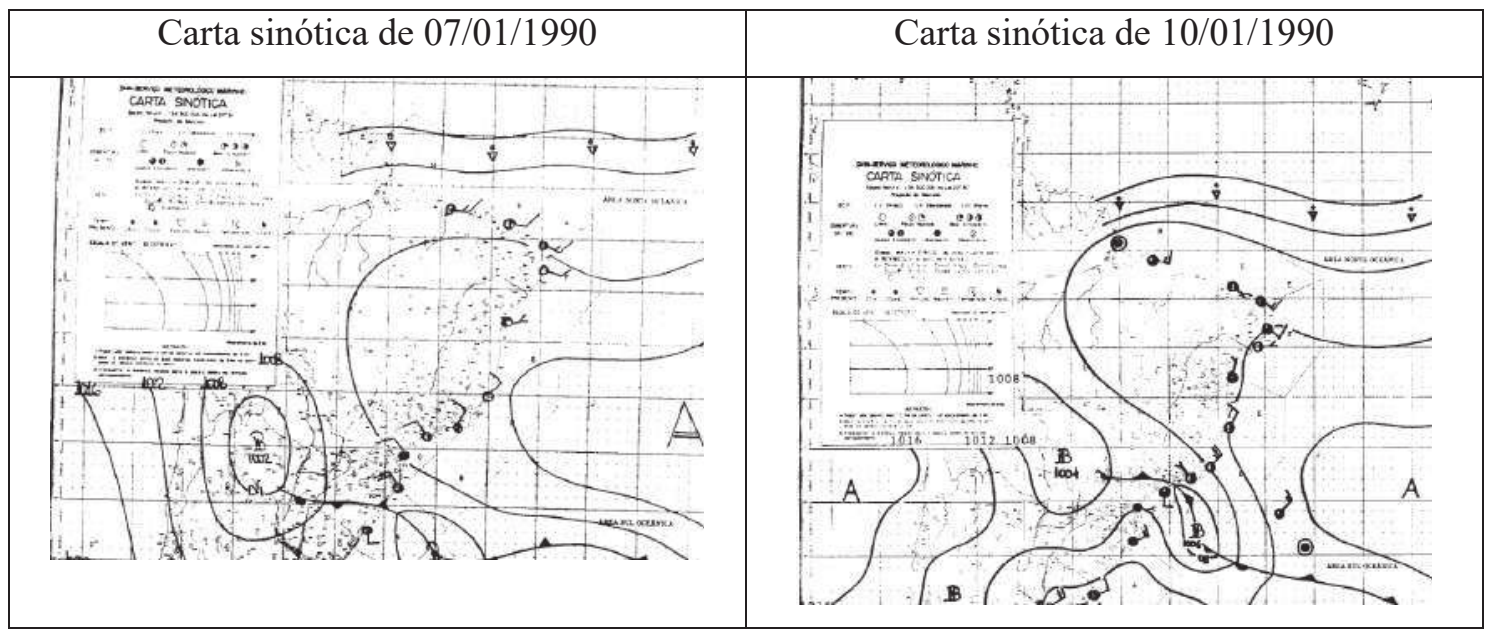

Fonte: Marinha do Brasil.

No dia 10 de Janeiro um sistema frontal avançou na região Sudeste do Brasil, provocando totais pluviométricos muito baixos, e rapidamente, a partir do dia 12 de Janeiro, a situação de estabilidade atmosférica retoma, com a atuação da massa Tropical Atlântica que persistiu até o dia 20 de Janeiro (Figura 158 e 159).

Figura 158: Precipitação na América do Sul nas pêntadas 3 e 4 de Janeiro de 1990 estimadas pelo CHIRPS

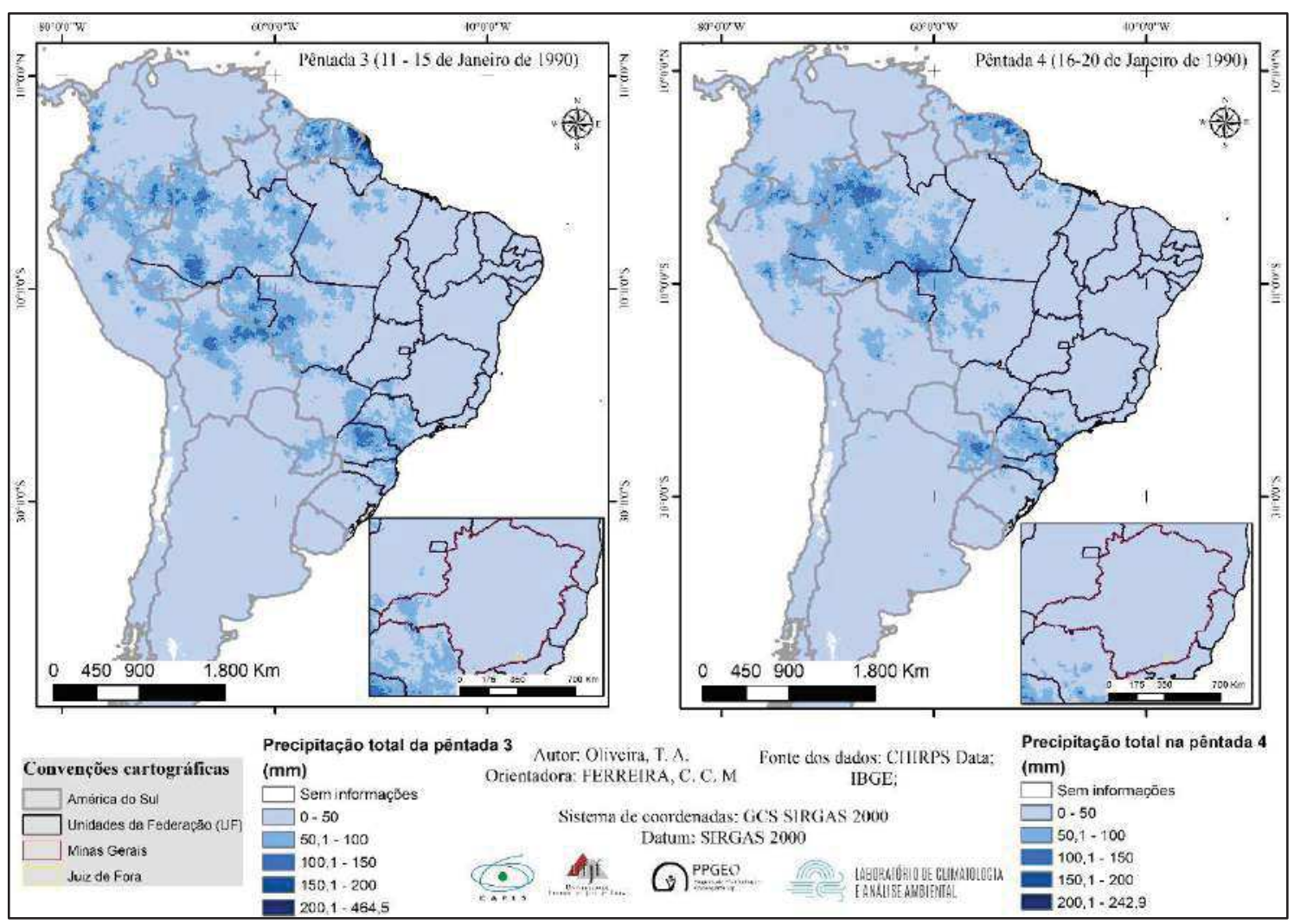

Fonte: Organizado pelo autor. 
Figura 159: Cartas sinóticas de 20 e 24 de Janeiro de 1990.

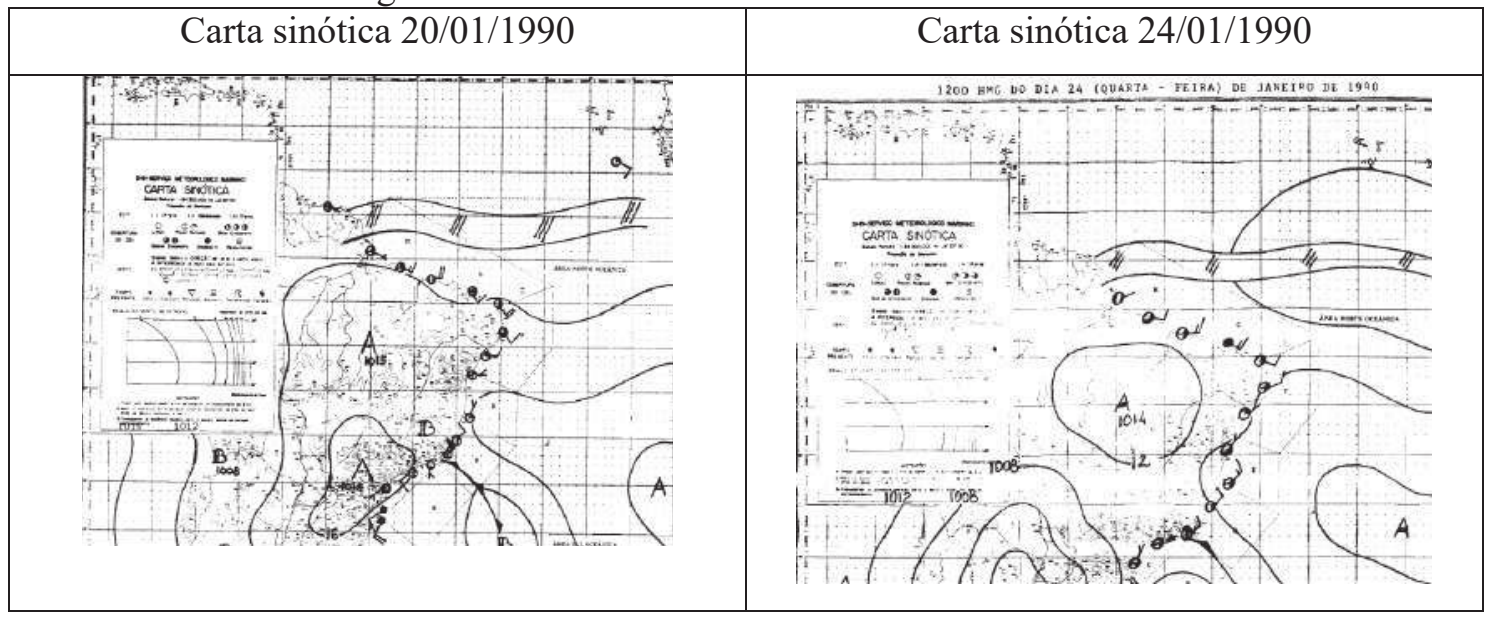

Fonte: Marinha do Brasil.

Na quinta e sexta pêntada os dias com precipitação ocorreram entre os dias 21 e 24 de Janeiro e nos dias 26 e 27, associados a passagem de outro sistema frontal, no entanto os totais pluviométricos registrados foram baixos, conforme já destacado (Figura 160).

Figura 160: Precipitação na América do Sul nas pêntadas 5 e 6 de Janeiro de 1990 estimadas pelo CHIRPS

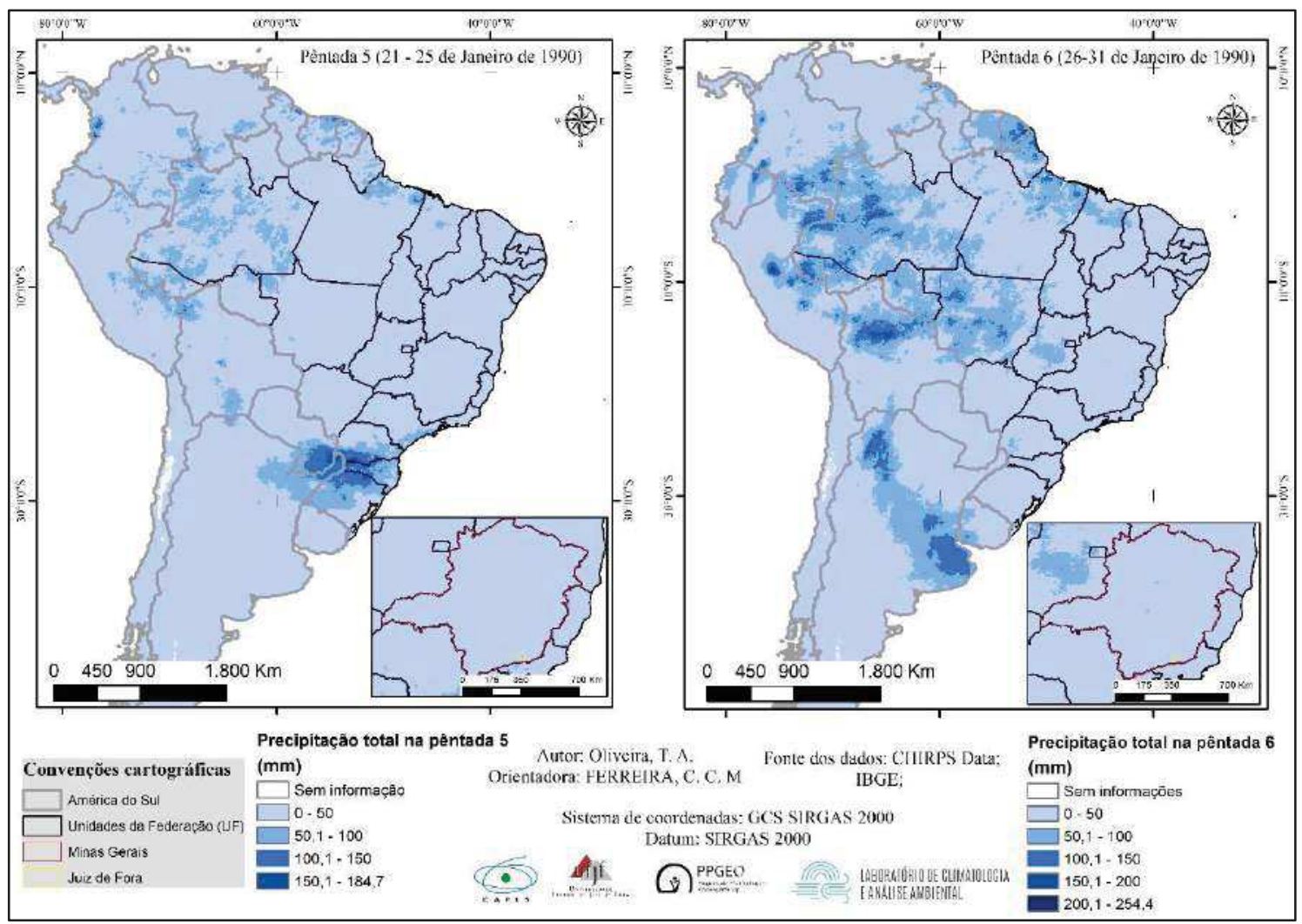

Fonte: Organizado pelo autor. 


\section{O mês padrão seco e os eventos/episódios extremos}

Com relação aos dados de precipitação no mês padrão seco de 1990, observa-se que dentre os dez dias com precipitação registrada na cidade, nenhum dos casos ultrapassou os 25 $\mathrm{mm}$. Avaliando a partir das técnicas estatísticas nenhum dos dias foi considerado evento intenso e ou extremo (Figura 162).

Com relação aos impactos ocorridos na cidade (Figura 161 e 162), ainda que não fosse observado evento extremo na cidade, dois episódios foram identificados um no dia 5 de Janeiro com seis locais impactados e outro no dia 27 de janeiro com 1 impacto registrado. Com isso observa-se que mesmo com um número baixo de precipitação diária nesse mês, os acumulados de alguns dias, como na pêntada 1 , de 51,3mm, desencadeou episódio extremo na cidade.

Figura 161: Impactos registrados no dia 05/01/1990

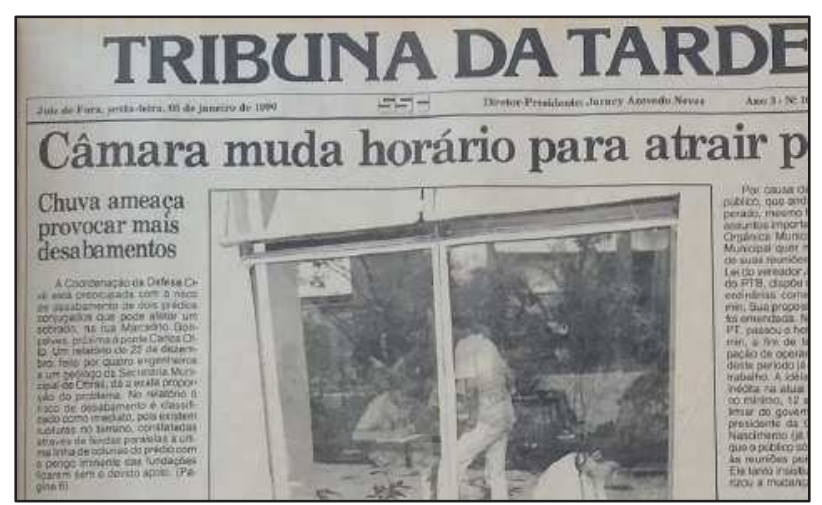

Fonte: Jornal Tribuna da Tarde- 05/01/1990, p. 1. 
Figura 162: Dados de precipitação total diária de Janeiro de 1990 e número de impactos (a); dados de precipitação e os percentis 90,95 e 99 (b); dados de precipitação e os níveis de máximos de precipitação (c); dados agrupados em pêntadas (d)

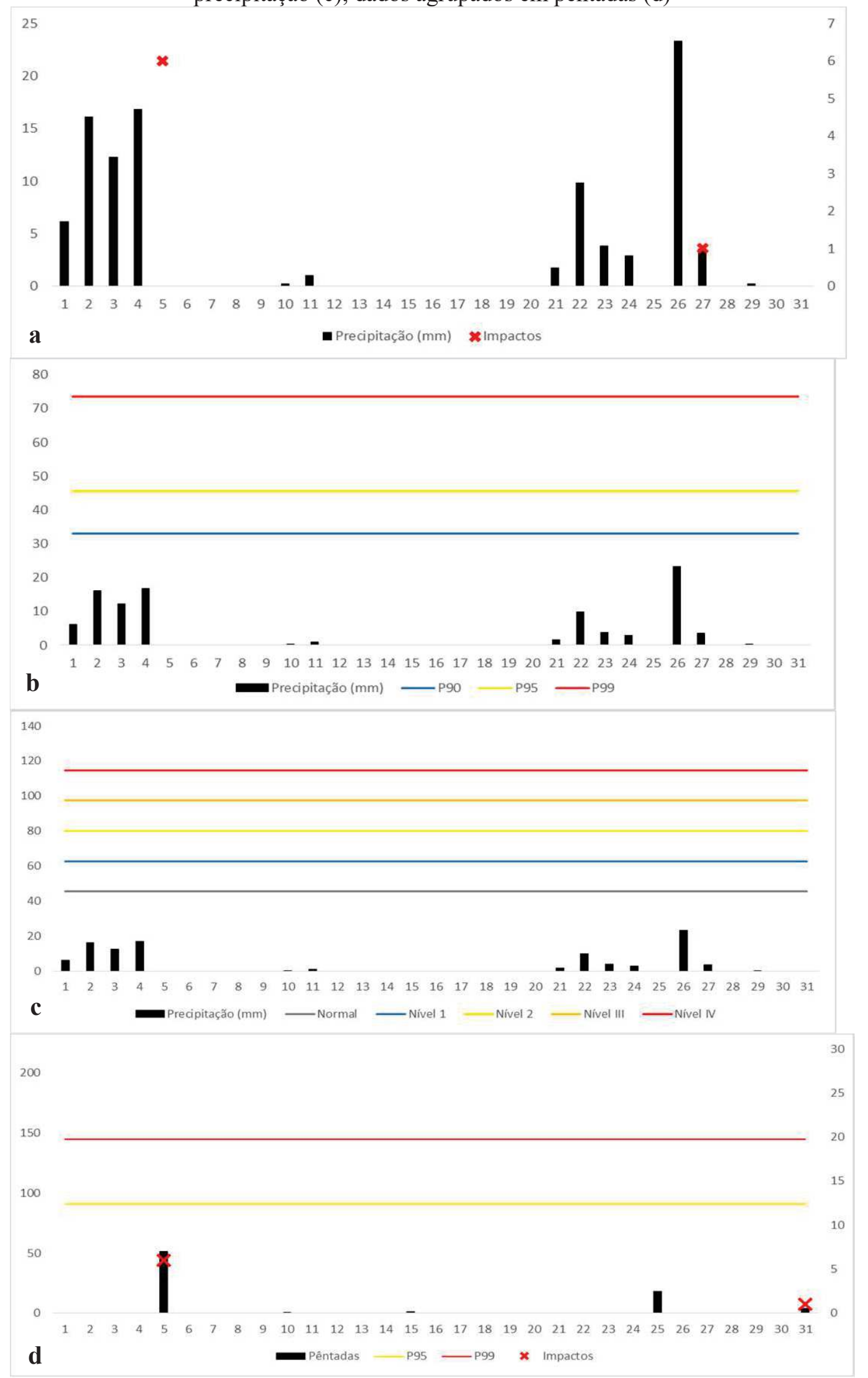

Fonte: Organizado pelo autor. 


\section{Os impactos das chuvas no mês padrão seco-1990}

Em Janeiro de 1990 foram observados sete impactos na cidade, localizados em seis regiões urbanas, dois impactos na Santa Cândida (65), e um no Santa Cruz (4), Santa Cecília (41), Vila Ideal (49), Santa Luzia (42) e Ipiranga (37). Nesse mês ocorreram apenas dois episódios extremos, e foram registradas apenas ocorrências de impactos geomorfológicos, ou seja, deslizamentos e desabamentos (Figura 163).

Figura 163: Impactos geomorfológicos em Janeiro de 1990

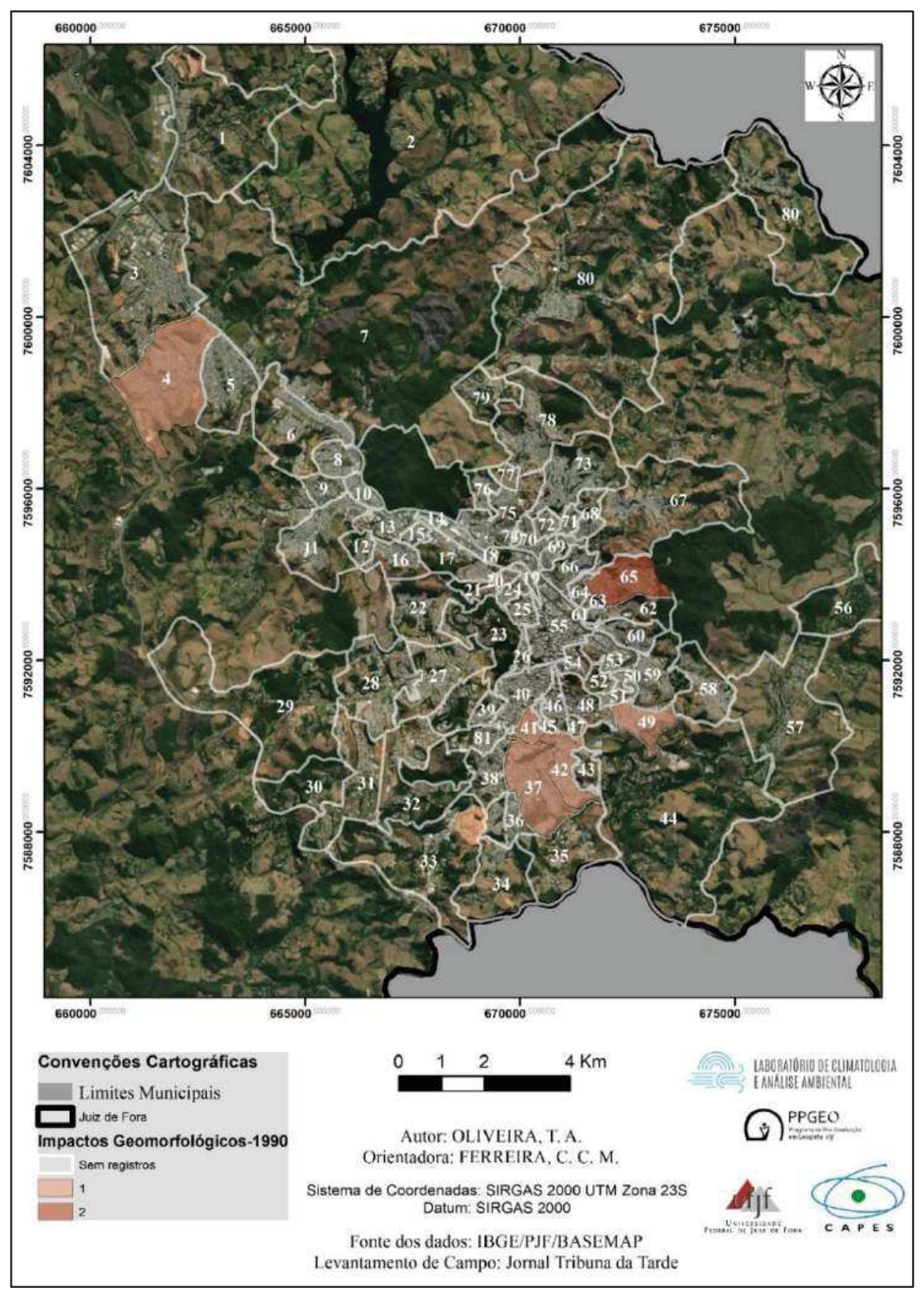

Fonte: Organizado pelo autor. 
Pode-se considerar que em função dos baixos totais pluviométricos diários registrados nesse mês, as ocorrências de deslizamentos e desabamentos estejam associadas ao acumulado de mais de um dia de chuva. Com isso, as ocorrências de impactos hidrológicos, que demandam totais pluviométricos concentrados em espaços curtos de tempo, não ocorreriam em função dos totais de precipitação mais baixos.

Além disso, as regiões urbanas impactadas nesse mês padrão seco foram caracterizadas como áreas de alto e altíssimo risco a impactos geomorfológicos, dessa forma, é possível visualizar que as condições de risco apresentadas nessas áreas consubstanciam em impactos mesmo com baixos totais pluviométricos, ou independentemente da ocorrência de eventos intensos e ou extremos de precipitação.

\section{O mês padrão habitual de Janeiro 2012}

O mês padrão habitual de Janeiro de 2012, teve um total de $275 \mathrm{~mm}$, que foram distribuídos em 16 dias de chuva. Nesse mês a atuação de uma Zona de Convergência do Atlântico Sul-ZCAS e de uma linha de instabilidade- Li estavam associados à gênese das chuvas na primeira quinzena do mês (Figura 164).

Figura 164: Precipitação na América do Sul nas pêntadas 1 e 2 de Janeiro de 2012 estimadas pelo CHIRPS

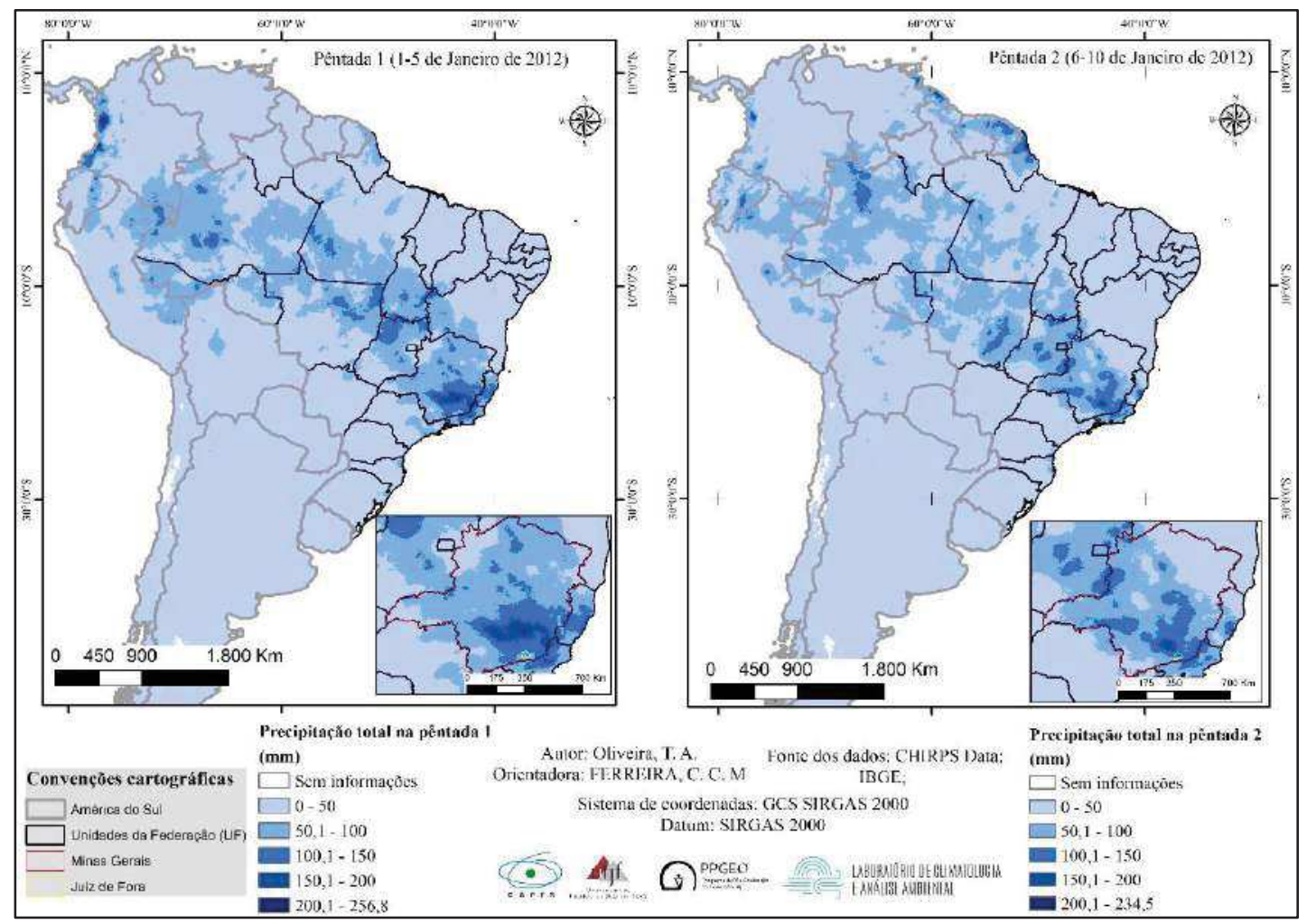

Fonte: Organizado pelo autor. 
A partir do dia 12 de Janeiro um sistema de alta pressão associado à massa Tropical Atlântica se aproximou do continente e repercutiu em um período seco que se estendeu até o dia 25 de Janeiro (Figura 165), quando outro sistema frontal avançou pela região formando linhas de instabilidade e um outro episódio de Zona de Convergência do Atlântico Sul-ZCAS na região.

Figura 165: Carta sinótica de 14/01/2012

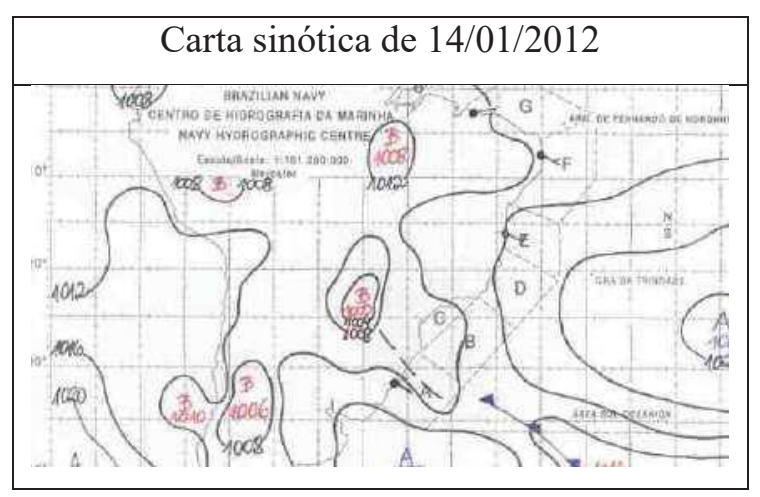

Fonte: Marinha do Brasil

No período entre 12 e 26 de Janeiro os totais pluviométricos em Juiz de Fora foram reduzidos, em função da atuação da massa Tropical atlântica que atuou como um bloqueio atmosférico, impedindo o avanço dos sistemas frontais na região. Nesse período a precipitação ficou concentrada nas regiões Centro Oeste e Sul do Brasil, em função do estabelecimento de uma linha de instabilidade (Figura 166).

Figura 166: Precipitação na América do Sul nas pêntadas 3 e 4 de Janeiro de 2012 estimadas pelo CHIRPS

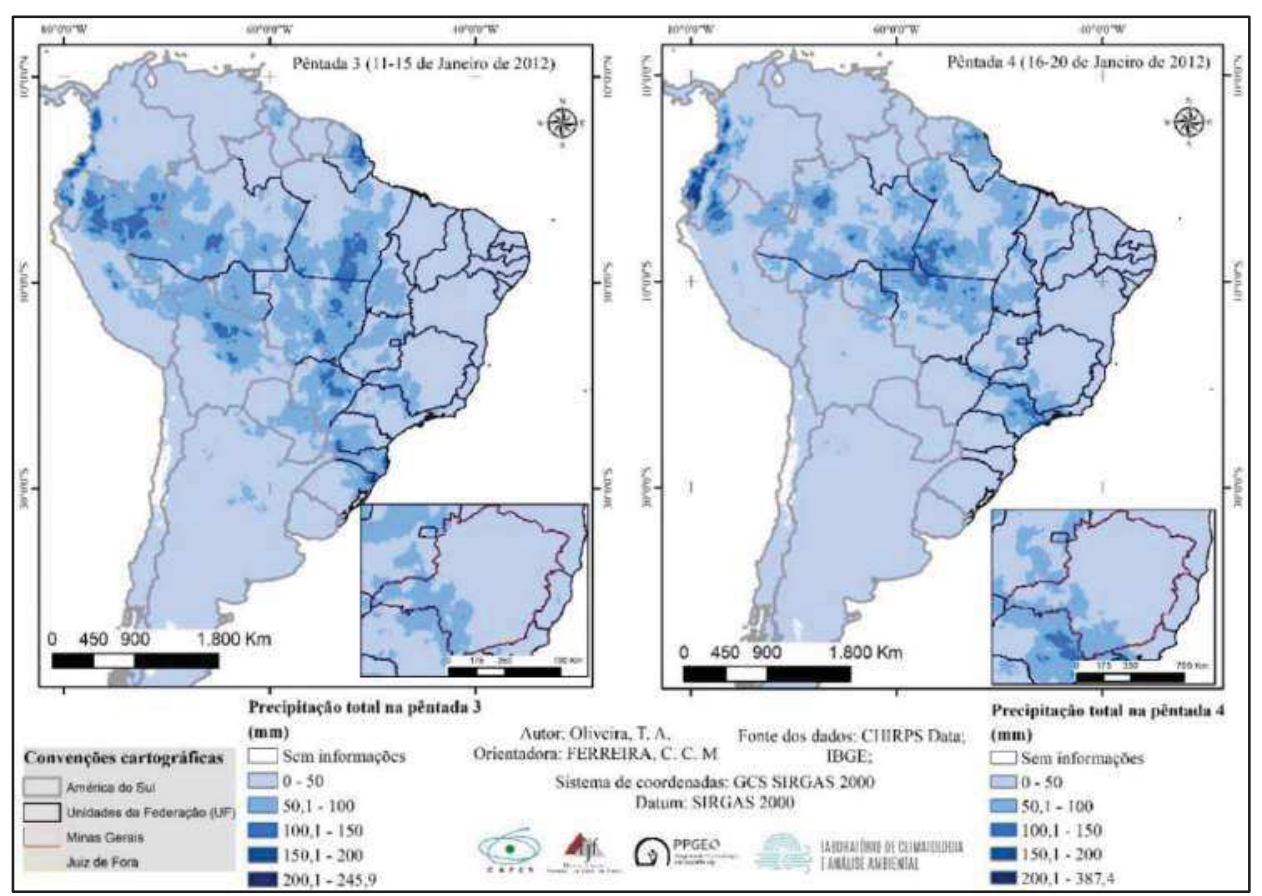


Fonte: Organizado pelo autor.

Os baixos totais pluviométricos seguiram na pêntada 5 , associada ainda à condição de bloqueio atmosférico. Sendo que os totais pluviométricos voltariam a cair de maneira mais volumosa na cidade a partir do dia 25/26 de Janeiro, quando um sistema frontal avança pela região e posteriormente formando uma Zona de Convergência do Atlântico Sul-ZCAS, produzindo eventos extremos de precipitação na cidade nos últimos dias desse mês (Figura 167 e 168).

Figura 167: Cartas sinóticas de 23 e 26 de Janeiro de 2012

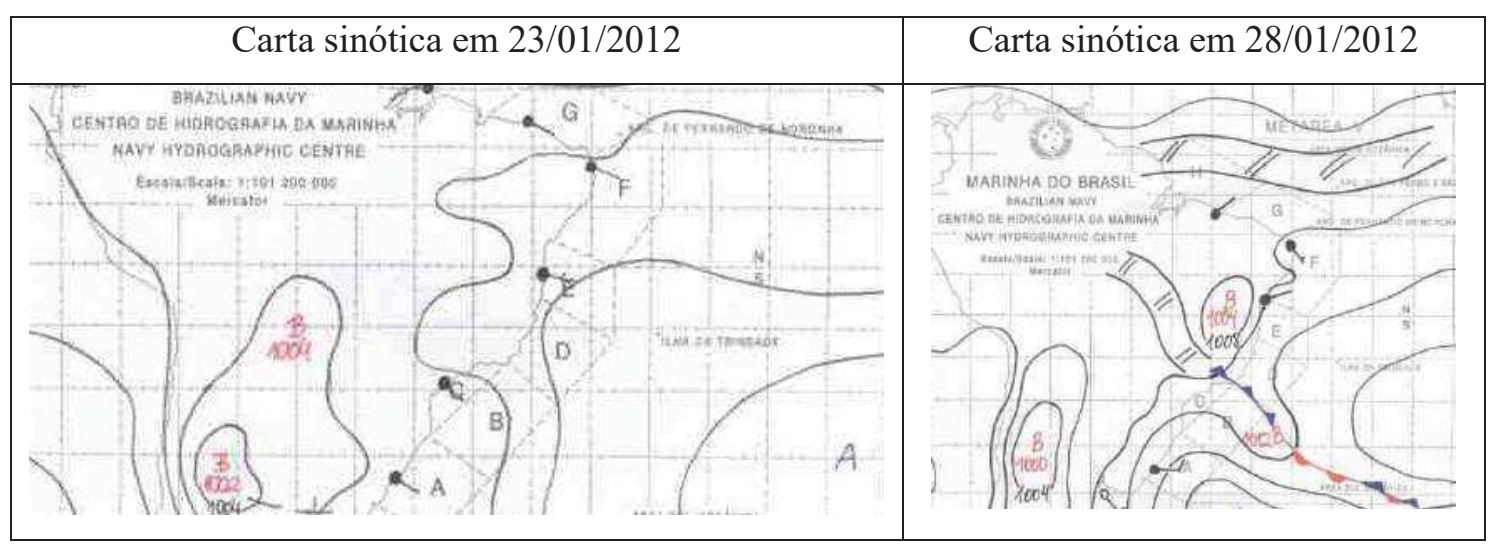

Fonte: Marinha do Brasil

Figura 168: Precipitação na América do Sul nas pêntadas 5 e 6 de Janeiro de 2012 estimadas pelo CHIRPS

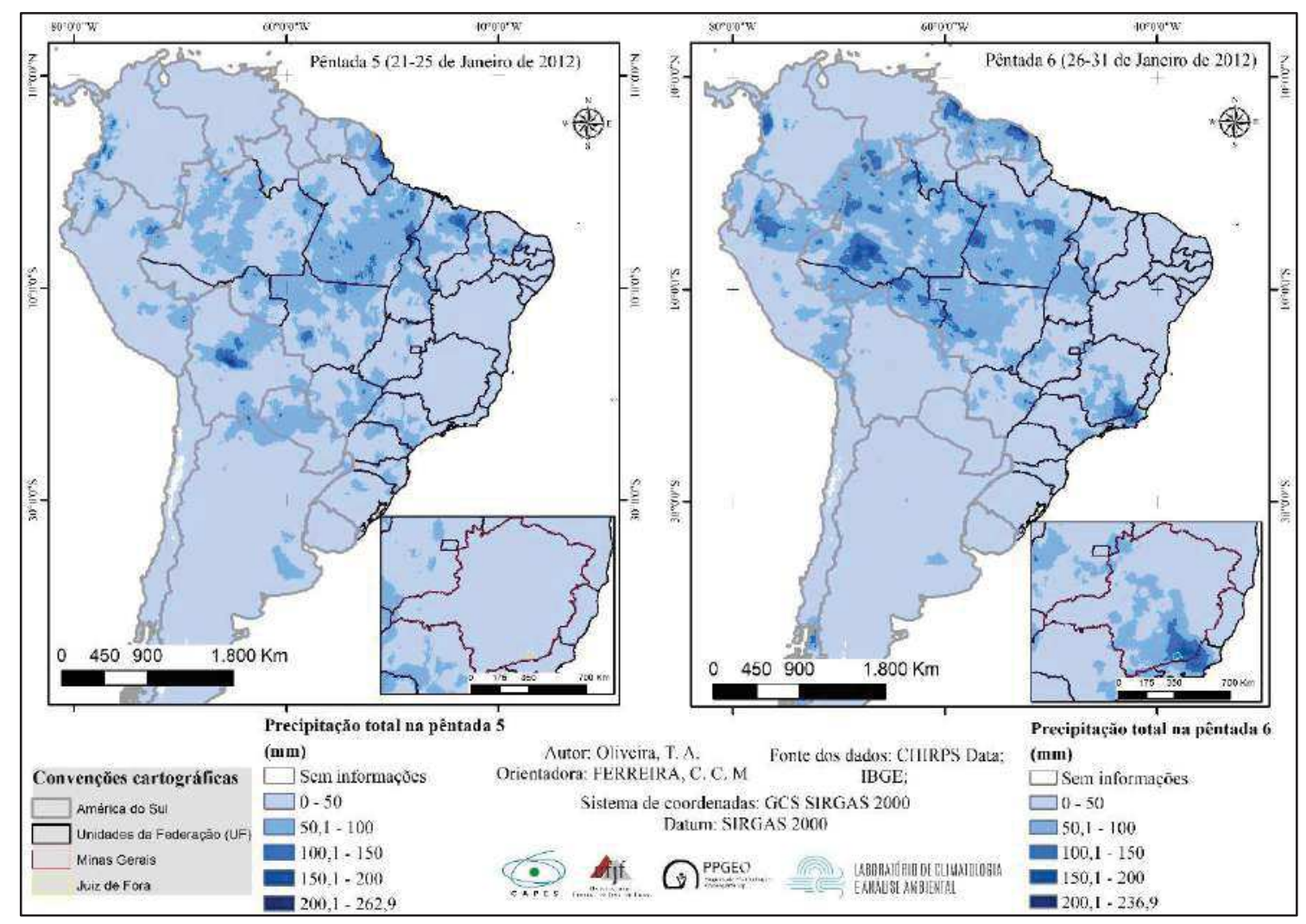


Fonte: Organizado pelo autor.

\section{O mês padrão habitual e os eventos/episódios extremos}

Com relação aos eventos/ episódios extremos o mês de Janeiro de 2012 teve dois eventos que ultrapassaram o percentil 95 e nenhum ultrapassou o percentil 99. De acordo com a técnica dos máximos de precipitação, também houveram dois eventos extremos, sendo um normal e outro de nível I (Figura 169).

Quando observados os impactos, existe uma relação entre o número de impactos e o evento extremo de nível I, consubstanciando assim um episódio extremo. No entanto, no início do mês o outro evento intenso observado no dia 1, repercutiu em impactos apenas no dia cinco, quando somado a outros totais pluviométricos ocasionaram 5 impactos na cidade (Figura 169).

Além disso, outros impactos foram observados em datas em que os totais pluviométricos dos dias anteriores estiveram abaixo dos valores tidos como limiares para a ocorrência de eventos extremos. Dessa forma, foram observados episódios extremos sem que houvesse ocorrido algum evento intenso/extremo, como, por exemplo, no dia 9 de Janeiro de 2012.

Com relação às pêntadas, nas três pêntadas que observaram totais pluviométricos superiores a 50mm, foram registrados impactos na cidade, ainda que não ultrapassaram o valor dos percentis 95 e 99. Esse fato demonstra que são observados episódios extremos na cidade, mesmo não associados a eventos intensos e extremos de precipitação (Figura 169). 
Figura 169: Dados de precipitação total diária de Janeiro de 2012 e número de impactos (a); dados de precipitação e os percentis 90,95 e 99 (b); dados de precipitação e os níveis de máximos de precipitação (c); dados agrupados em pêntadas (d)

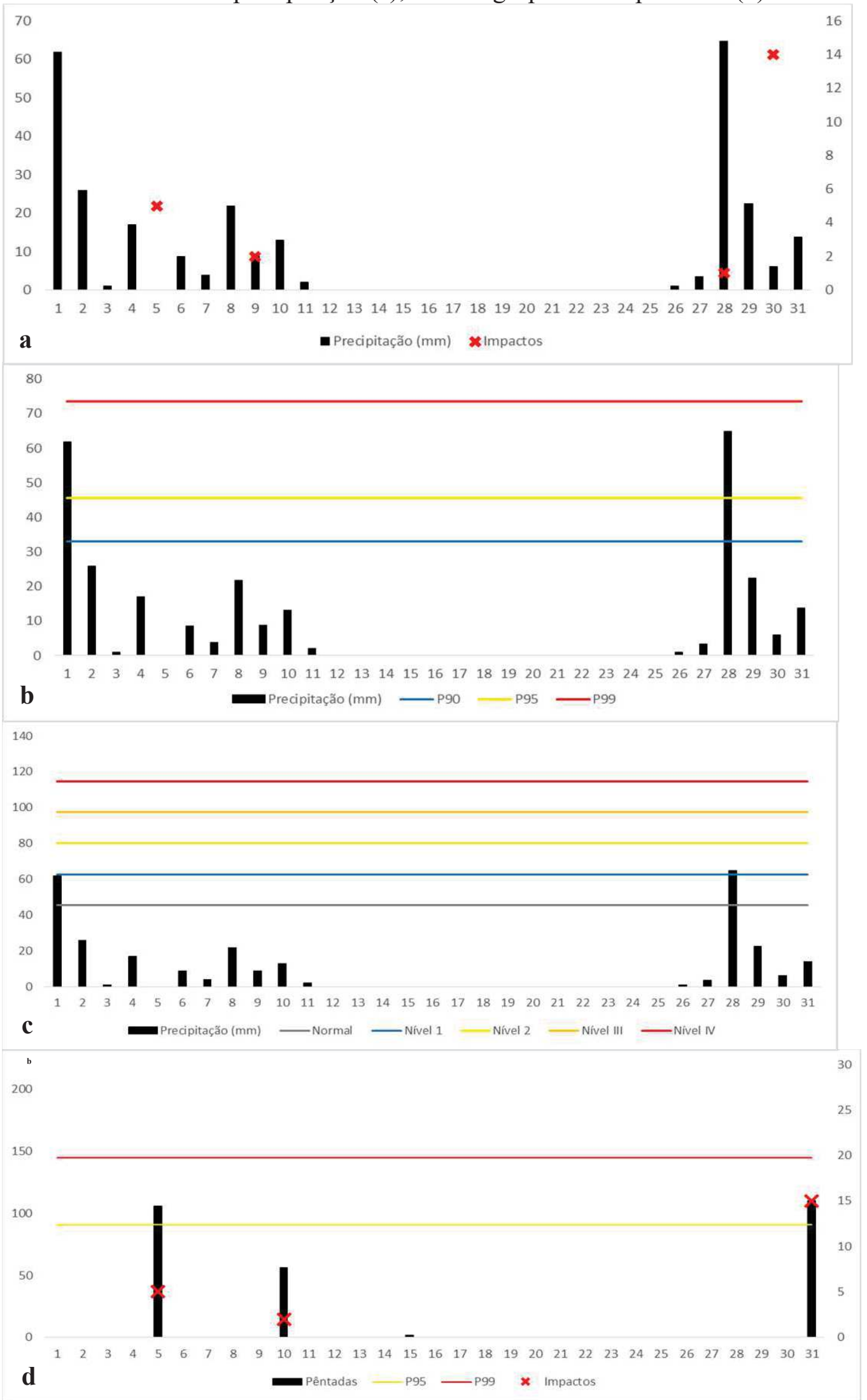

Fonte: Organizado pelo autor. 


\section{Os impactos das chuvas em Janeiro de 2012}

Em Janeiro de 2012 foram registrados 22 impactos no perímetro urbano de Juiz de Fora Figura 171), sendo que desses 7 foram hidrológicos e 11 geomorfológicos, além de 4 que não tiveram uma descrição exata. Estes 22 impactos foram distribuídos em 4 episódios extremos e o maior número foi registrado no dia 30 de Janeiro de 2012 com 14 impactos (Figura 170).

Figura 170: Reportagem no site do Jornal Tribuna de Minas- 30/01/2012

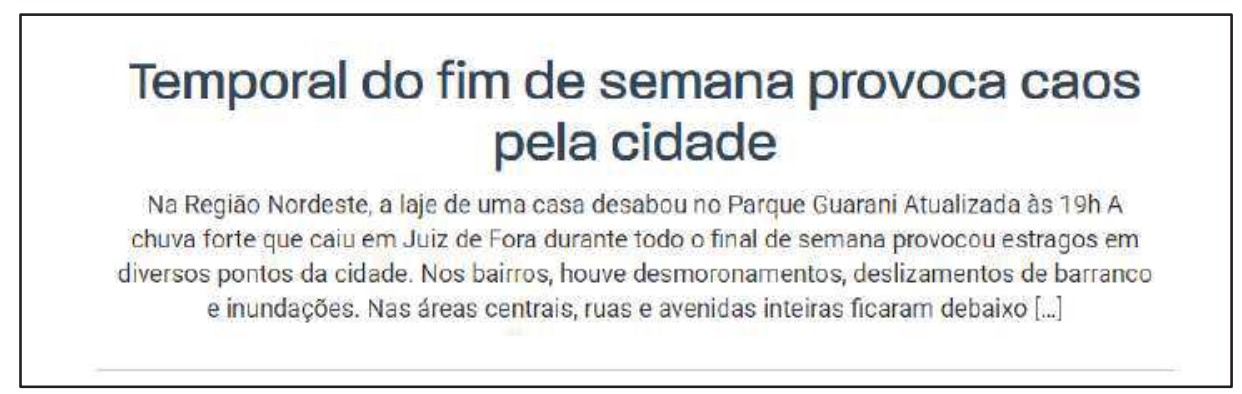

Fonte: Jornal Tribuna de Minas.

No mês de Janeiro de 2012, dentre as RU's mais citadas, estiveram o Linhares (67), o Progresso (73), Retiro (57) e São Mateus (40), ao todo 17 regiões urbanas foram citadas em função dos impactos ocorridos nesse mês.

Com relação aos impactos geomorfológicos (Figura 172), estes se concentraram nas RPs Leste e Nordeste, nas regiões urbanas Granjas Betânia (79), Bandeirantes (78), Progresso (73), Grajaú (66), Vitorino Braga (64), Manoel Honório (70). Além disso, ocorrências foram registradas no Centro (55), Retiro (57) e no Santa Luzia (42).

Nas RUs Granjas Betânia, Bandeirantes, Progresso, Linhares, Grajaú, Vitorino Braga, Manoel Honório, Retiro, Santa Luzia, as ocorrências se deram em áreas consideradas de médio a alto risco a impactos geomorfológicos (Figura 123). Indicando que a conjugação dos fatores vulnerabilidade social, suscetibilidade ambiental e histórico de ocorrências, quando demandada por totais pluviométricos dentro de uma normalidade engendram a ocorrência dos impactos.

Nas Regiões Urbanas Centro e Manoel Honório os impactos ocorreram em função de uma elevada suscetibilidade a movimentos de massa nos locais dos registros, indicando que os totais pluviométricos precipitados foram suficientes para dinamizar a ocorrência dos escorregamentos nessas áreas. 
Figura 171: Total de registros de impactos em janeiro de 2012

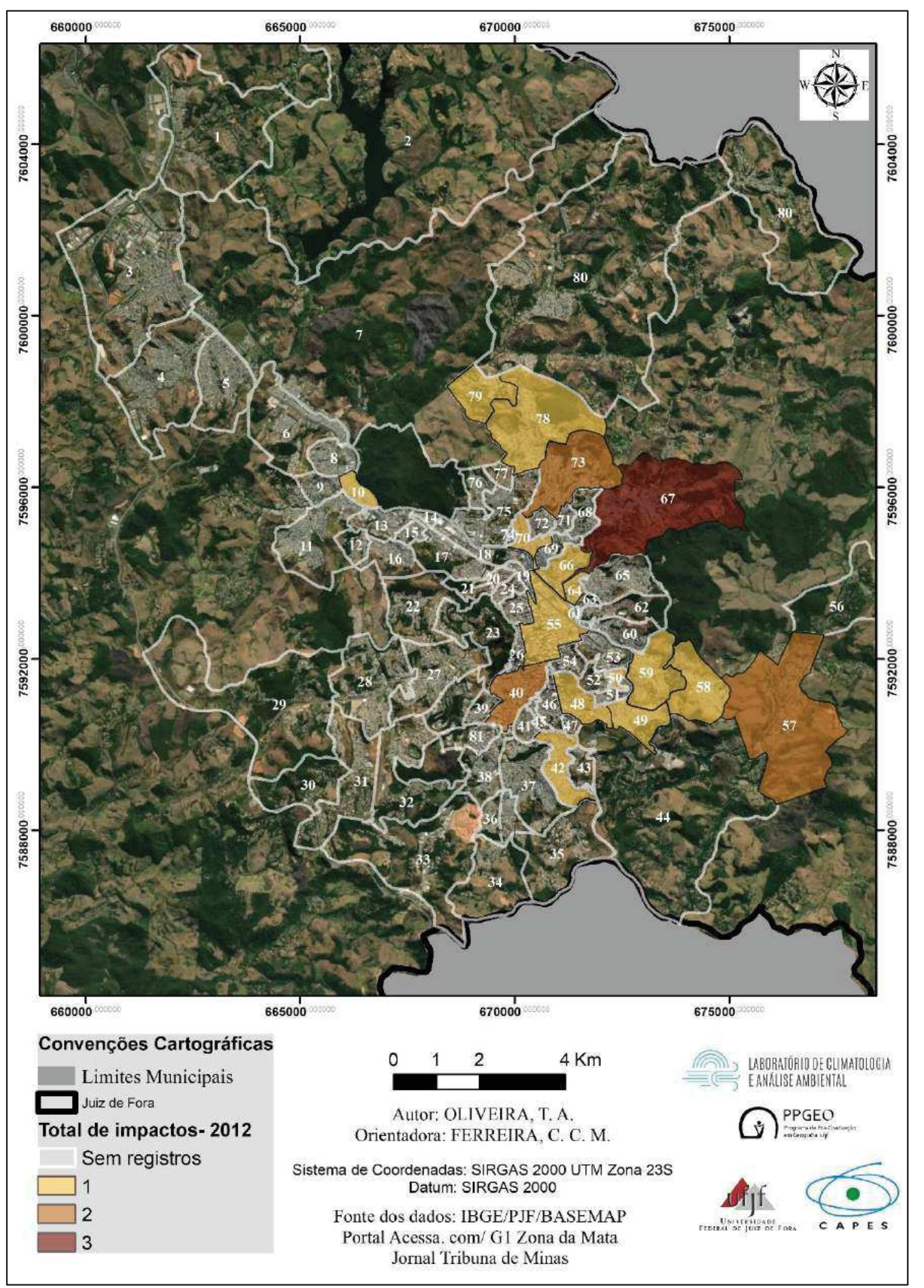

Fonte: Organizado pelo autor. 
Figura 172: Impactos geomorfológicos registrados em Janeiro de 2012

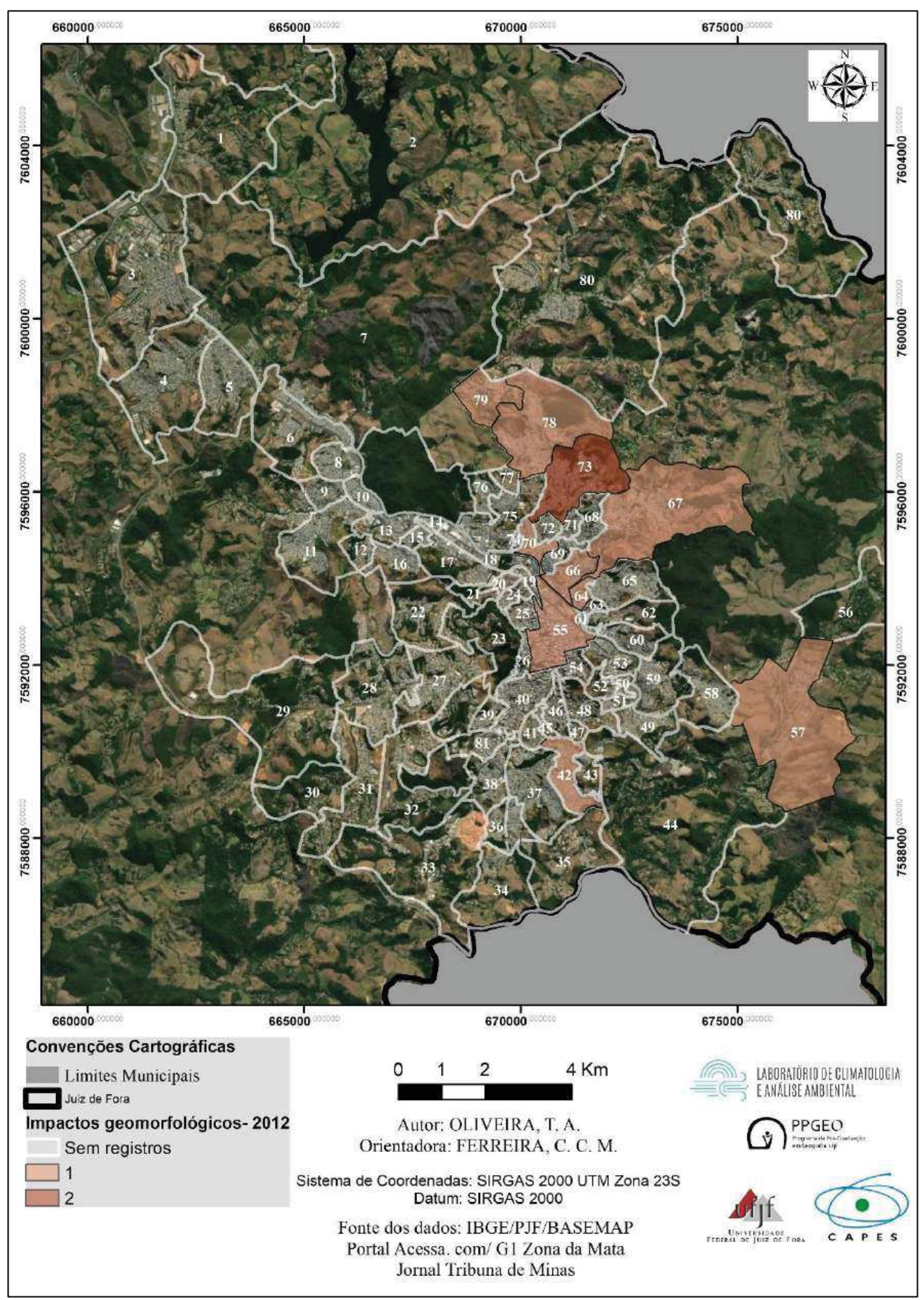

Fonte: Organizado pelo autor.

Os impactos hidrológicos (Figura 173) ocorreram em cinco regiões urbanas, no bairro Industrial (10), São Mateus (40), Bom Pastor (48), Linhares (67) e Retiro (57). No Linhares e 
no São Mateus foram duas ocorrências, e nas outras três regiões urbanas foi registrada apenas uma ocorrência.

Figura 173: Impactos hidrológicos registrados em Janeiro de 2012

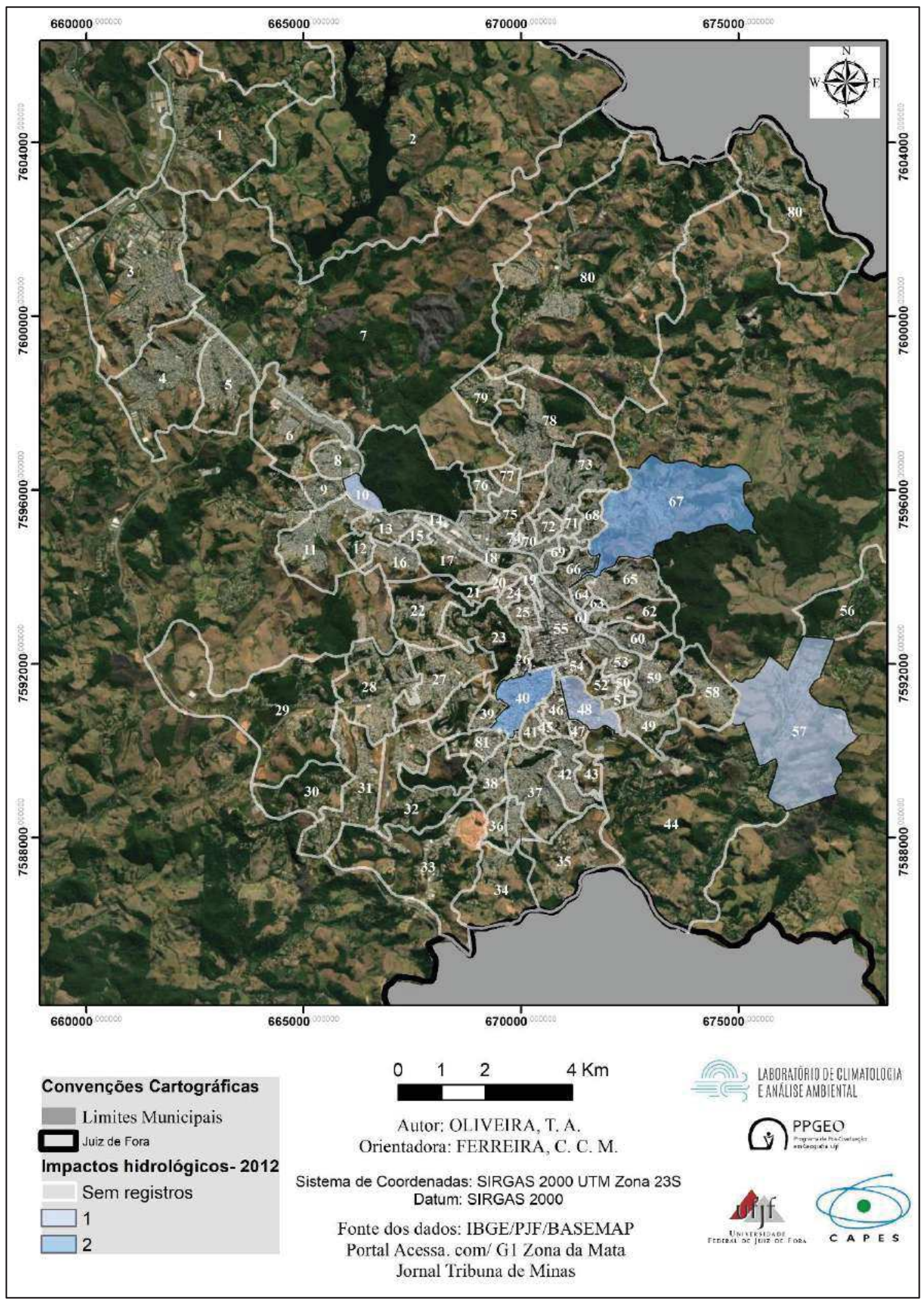

Fonte: Organizado pelo autor. 
Os impactos hidrológicos em Janeiro de 2012, (Figura 173), ocorreram em áreas historicamente associadas aos riscos a impactos hidrológicos como as RUs Industrial (10), Linhares (67) e Retiro (57), locais em que as condições de suscetibilidade, vulnerabilidade e histórico de ocorrências denotam uma condição de maior risco a esses eventos.

As outras regiões urbanas que foram citadas, São Mateus (40) e Bom Pastor (48) as ocorrências foram associadas a alagamentos, mesmo que sejam áreas de baixa vulnerabilidade social, em função da impermeabilização do solo, bem como as intervenções em superfície, favorecem a ocorrência desses impactos.

\section{Os episódios extremos: gênese, impactos e riscos na cidade de Juiz de Fora.}

A partir desse comparativo realizado a partir dos meses padrão seco, habitual e chuvoso, extraídos a partir da técnica do box plot aplicado à série de dados de 1910-2018, foram identificados o mês chuvoso de Janeiro de 1985, o mês seco de Janeiro de 1990 e o mês normal/habitual de Janeiro de 2012.

Os eventos intensos e extremos chuvosos estiveram associados a eventos da Zona de Convergência do Atlântico Sul (ZSAS), bem como de sistema frontais, que nesse período favorecem o desenvolvimento das nuvens de chuva, bem como das precipitações volumosas. $\mathrm{O}$ mês padrão chuvoso, em janeiro de 1985, teve um elevado número de dias com a ocorrência da Zona de Convergência do Atlântico Sul, atuando em 21 dias, o que proporcionou a precipitação de 504,8 mm de chuva em 15 dias ou 715 mm nos 31 dias daquele mês.

O mês padrão seco de 1990 foi caracterizado pela prevalência da massa Tropical atlântica-mTa em uma condição de bloqueio atmosférico, bem como pela passagem rápida dos sistemas frontais repercutindo em baixos totais pluviométricos nesse mês. $\mathrm{O}$ mês padrão habitual de janeiro de 2012, assim como em 1990, teve um elevado número de dias com a atuação também da mTa (15 dias em 1990 e 14 dias em 2012), no entanto, a ocorrência de episódios de Zona de Convergência do Atlântico Sul (ZCAS) em alguns dias desse mês elevaram os totais pluviométricos mensais, bem como engendraram a ocorrência de eventos intensos de precipitação.

Dito isso, é possível destacar que as ocorrências dos eventos mais elevados de precipitação estiveram associadas à ocorrência da ZCAS, bem como a ocorrência de sistemas frontais estacionários, como foi visualizado em janeiro de 1985. O contrário disso, os meses 
secos, são influenciados pela baixa atuação da ZCAS, bem como a ocorrência, por consecutivos dias, da massa Tropical atlântica, conforme já destacado por Oliveira (2016).

Nos casos investigados o mês padrão habitual, demonstrou que esta ocorrência está associada à uma participação mais "equitativa" dos sistemas atmosféricos, sendo que foram 11 dias com atuação da ZCAS, 14 dias com atuação da mTa, por exemplo. Dessa forma sistemas que fornecem precipitação e sistemas que a inibem se distribuíram nesse mês, refletindo em um total pluviométrico mensal considerado habitual ao longo do período.

Nos meses padrão analisados, os impactos de uma forma geral seguiram o padrão histórico de espacialização na cidade. Os impactos geomorfológicos, deslizamentos e desabamentos, ocorreram de maneira mais profusa na RP Leste, onde as condições de risco são mais elevadas.

No mês padrão seco, 01/1990, os impactos ocorreram apenas nas áreas de alto e altíssimo risco, indicando que as ocorrências nesse mês, independeram de elevados totais pluviométricos para sua consubstanciação. Nos meses chuvoso (01/1985) e habitual (01/2012) as ocorrências foram mais numerosas nas áreas de alto e altíssimo risco, mas também ocorreram em áreas de médio, baixo e baixíssimo risco, denotando que os totais pluviométricos foram determinantes para suas respectivas ocorrências.

Da mesma forma que os impactos geomorfológicos, os hidrológicos ocorreram de maneira mais numerosa nas áreas consideradas de risco a impactos hidrológicos, na região Central da cidade que nos meses chuvoso (01/1985) e habitual (01/2012) teve o maior número de impactos, as condições de vulnerabilidade nesses setores são baixas, no entanto o número de impactos tem se elevado com o passar dos anos.

Alguns córregos quando foram demandados por elevados totais pluviométricos revelaram diversas inundações na cidade, como o córrego Humaitá na RU Industrial, córrego São Pedro nas RUs São Pedro, Fábrica e Mariano Procópio, córrego do Young nas RUs Linhares e Vitorino Braga.

Nesses pontos são diversas as formas de ocupação, haja visto que as ocupações mais antigas dos bairros na cidade estão associadas aos fundos de vale, dessa forma os impactos nessas bacias atingem os diversos setores sociais. Com isso, deve-se considerar as condições de resposta aos impactos que serão diferencias nessas regiões urbanas, em função das condições socioeconômicas que precedem aos impactos.

Dessa forma, no perímetro urbano de Juiz de Fora as áreas de médio e alto risco a impactos geomorfológicos observaram ocorrências nos meses seco, habitual e chuvoso, 
denotando que nessas áreas o elemento pluviométrico não foi completamente determinante nos meses analisados. Entretanto nos meses mais chuvosos o número de impactos foi, obviamente, mais elevado.

Com relação aos impactos hidrológicos, em Juiz de Fora existem as inundações associadas aos canais fluviais. A ocupação nas margens dos canais fluviais por setores sociais em condição de vulnerabilidade denota condições de risco a impactos hidrológicos na cidade.

Essa distribuição espacial dos impactos em função dos episódios reforça e corrobora com as colocações levadas a efeito por Sant'Anna Neto (2001; 2008); Armond (2014); Nascimento Júnior (2018) de que existe uma seletividade espacial dos impactos pluviométricos no espaço urbano da cidade de Juiz de Fora. 


\section{Considerações finais}

Inicialmente cumpre salientar que boa parte do desenvolvimento desse trabalho se deu durante uma pandemia, associada ao Coronavírus (COVID-19), por razão das medidas sanitárias de isolamento social impostas por estas condições este trabalho teve de passar por algumas alterações metodológicas que foram necessárias. Com isso pode-se apontar para futuramente, quando as condições permitirem, prosseguir o levantamento de dados para a complementação das informações coletadas, apesar de que o conjunto de dados coletado permitiu ainda assim discutir o objeto de estudo.

A abordagem do clima urbano a partir da perspectiva do risco permitiu discutir a relação complexa entre clima e cidade (natureza x sociedade), (NASCIMENTO JÚNIOR, 2018), favorecendo a integração entre elementos de ordem natural, no caso a chuva e os eventos extremos, perigos, e a cidade que para além das questões de sítio, suscetibilidade, apresenta uma complexidade social, inerente à própria produção capitalista do espaço que engendra condições de vulnerabilidade social.

Do ponto de vista atmosférico, climático, apoiando-se na proposta do Sistema Clima Urbano, preconizada por Monteiro (1976), visualizou-se a interescalaridade inerente à dinâmica dos elementos climáticos, que repercutem na sua variabilidade tanto temporal como espacial. A variabilidade temporal da precipitação permite discutir o clima urbano e no caso os riscos embutidos pelos eventos extremos de precipitação a um recorte sazonal, uma vez que a sua concentração se dá ao longo da estação chuvosa (Outubro a Março), no caso de Juiz de ForaMG.

Com base nos pressupostos de Monteiro (1971; 1976) foi possível elencar períodos padrão para uma investigação comparativa, no caso foram selecionados três meses de Janeiro, um seco, um habitual e outro chuvoso, para investigar a ocorrência dos eventos e episódios extremos nesses meses.

O mês de Janeiro foi selecionado por estar numa condição central da estação chuvosa, junto com Dezembro, mas ao longo do período analisado foi no mês de Janeiro que, em média, os impactos foram mais numerosos na cidade. O mês padrão chuvoso, Janeiro de 1985, foi caracterizado pelo maior número de eventos e episódios extremos, e consequentemente mais impactos, sendo o maior de toda série, com 81 impactos.

O mês padrão seco, Janeiro 1990, não observou nenhum evento considerado intenso/extremos pelas técnicas estatísticas e ainda assim ocorreram sete impactos 
geomorfológicos na cidade, distribuídos em dois episódios extremos. O mês padrão habitual de Janeiro de 2012 apresentou dois eventos intensos de precipitação e quatro episódios extremos que provocaram 22 impactos na cidade.

Com relação aos sistemas atmosféricos observados nesses meses em questão, existiram diferenças fundamentais para a ocorrência de dias com chuva, os dias chuvosos sempre estiveram associados a sistemas frontais e à Zona de Convergência do Atlântico Sul-ZCAS, sendo que nessa última os totais pluviométricos ocorreram de forma mais elevados, caracterizando-se como eventos intensos e extremos. A baixa frequência desses sistemas atmosféricos provocou períodos de estiagem e baixos totais pluviométricos como observado no mês de Janeiro de 1990.

Além disso, deve-se considerar as teleconexões e as inter-relações oceano-atmosfera que reverberam na variabilidade temporo-espacial das chuvas e com isso alteram a frequência e a intensidade dos eventos de precipitação na cidade. É fato que estudos mais detalhados sobre essa questão necessitam ser levados a efeito para a discussão com maior propriedade sobre a temática, haja visto a diferença na frequência de determinados sistemas atmosféricos nos estudos de caso realizados.

As discussões desenvolvidas por Sant'Anna Neto (2001; 2008; 2011) permitiram visualizar os impactos das chuvas na cidade de Juiz de Fora com uma lente que observasse o clima urbano e os impactos das chuvas como produtos da própria precipitação, mas também produzidos pela própria cidade, na medida em que é produzida pela própria expansão da mancha urbana da cidade.

Na cidade de Juiz de Fora os impactos, sobretudo hidrológicos, tem aumentado com o passar dos anos, em função da própria intensificação da impermeabilização do solo demandando maior vazão dos sistemas de drenagem que já se encontram defasados. Além disso as regiões de planejamento com maior crescimento populacional também observam as maiores percentagens de aumento no número de impactos ao longo do período.

O crescimento urbano da cidade, dessa forma, repercutiu para um aumento no número de impactos deflagrados. É fato que só ocorrem impactos quando há algum tipo de ocupação humana no espaço, no entanto, essa questão permite discutir que o crescimento da cidade foi desacompanhado de políticas de planejamento e gestão urbana capazes de minimizar a ocorrência dos impactos.

Com base no referencial teórico utilizado destaca-se a utilização de técnicas estatísticas, bem como de geoprocessamento, que permitiram organizar, testar, avaliar e modelar as 
informações utilizadas, correspondendo como ferramentas fundamentais para a aplicação e reflexão prática acerca dos pressupostos teóricos apontados.

Com relação às técnicas estatísticas utilizadas para a identificação dos eventos intensos e extremos (Percentis, Máximos de precipitação, pêntadas) observou-se que estas representaram bem os episódios extremos de maior magnitude, no entanto houveram episódios que as técnicas não identificaram.

O mês de Janeiro de 1990 não teve nenhum evento intenso ou extremo identificado, mas dois episódios extremos ocorreram naquele mês. Com isso, observa-se que as técnicas identificam os eventos/episódios mais significativos numericamente ao longo da série, porém podem ocorrer episódios em que os valores não são considerados extremos porém deflagraram impactos.

Nos casos observados, os episódios que não foram identificados como eventos extremos estiveram associados a totais pluviométricos acumulados em vários dias e que deflagraram, na maior parte dos casos, impactos geomorfológicos. Dessa forma, revela-se que as técnicas apontando para eventos de maior magnitude acabam sendo incapazes de diagnosticar alguns episódios.

A aplicação das técnicas dos percentis, máximos de precipitação e pêntadas foram importantes para a delimitação estatística dos eventos considerados intensos e extremos. Dessa forma, pode-se futuramente com base nessas informações discutir a partir de estudos de caso mais profundos a dinâmica dos sistemas atmosféricos associados à ocorrência dos eventos em cada nível estabelecido.

As análises de tendência para os dados diários de precipitação a partir dos índices de extremos climáticos do ETCCDI, observou-se que nenhum dos indicadores apresentou tendência significativa estatisticamente para alteração de comportamento, quando aplicados ao conjunto de dados anual. O único indicador que apresentou tendência de elevação foi o R90p, quando aplicado mensalmente, teve uma tendência significativa de elevação no mês de Novembro.

O indicador de vulnerabilidade social utilizado foi baseado nas propostas de Dantas et al (2017); Goudard (2019) e Teobaldo Neto (2019), com isso foram avaliados os indicadores empregados e que foram indicados por estes autores, bem como foram avaliados empiricamente a partir da realidade juiz-forana.

O mapeamento do risco climático na cidade de Juiz de Fora perpassou uma investigação sazonal, na medida em que os levantamentos de informações sobre os impactos deflagrados 
foram realizados no período de Outubro a Março, período da estação chuvosa, haja visto que a ocorrência de eventos pluviométricos elevados na estação seca é rara.

A técnica empregada para a integralização dos dados permitiu nos impactos geomorfológicos uma conjugação entre os elementos do risco, possibilitando uma interpretação mais integrada entre os elementos. As áreas com alto e altíssimo risco a impactos geomorfológicos responderam a 42,7\% dos pontos de impactos, mesmo com uma área de 17,9\% do perímetro urbano.

O mapeamento das áreas de risco a impactos geomorfológicos demonstrou que 17,9\% do perímetro urbano de Juiz de Fora está alocado nas classes de alto e altíssimo risco, indicando que esses setores merecem intervenção de políticas públicas, na medida em que apresentam condição de alta suscetibilidade à ocorrência de escorregamentos, bem como altíssima vulnerabilidade social e uma recorrência na ocorrência dos impactos.

Observou-se com isso que a conjugação dos três planos de informação apontou para a maioria dos pontos de ocorrências. Nas classes de baixo e baixíssimo risco apresentou 21,7\% dos pontos e os outros $36,2 \%$ dos pontos ocorreram em áreas de médio risco a impactos geomorfológicos.

Dentre as regiões de planejamento deve-se destacar a RP Leste e Sudeste que apresentam mais de $40 \%$ de sua área total em situação de alto ou altíssimo risco, indicando que são setores com necessidade de assistência das políticas públicas, uma vez que são ocupadas por sujeitos em condições de alta/altíssima vulnerabilidade social.

Durante os meses de Janeiro analisados, as áreas consideradas de alto e altíssimo risco foram as mais impactadas durante os episódios extremos. O Janeiro de 1990 que não observou nenhum evento intenso ou extremo de precipitação teve 7 impactos geomorfológicos deflagrados todos nas áreas de alto/altíssimo risco. Nesses pontos a ocorrência dos impactos ocorreu mesmo com baixos totais pluviométricos. Nos outros meses, janeiro de 1985 e 2012, os impactos ocorreram de maneira mais numerosa nas áreas de alto/ altíssimo risco, mas também foram deflagrados em outros pontos da cidade.

Com relação aos impactos hidrológicos observou-se que algumas bacias compreendem situações de risco aos episódios, algumas regiões urbanas como Industrial, Santa Luzia, São Pedro, Vitorino Braga, Mariano Procópio, Fábrica, Linhares, foram citadas nos diversos episódios extremos associadas a ocorrência das inundações, por estarem próximas a canais fluviais. Bem como as regiões urbanas Centro, São Mateus, Bom Pastor, Grambery, foram as mais citadas no caso dos impactos hidrológicos na região de planejamento Centro. 
Por fim, a partir das questões colocadas no início da pesquisa observou-se que a partir das técnicas estatísticas utilizadas os eventos intensos e extremos de precipitação não tem se elevado, no entanto o número de impactos vem aumentando ao longo do período. Desse modo, a expansão da mancha urbana da cidade repercutiu para que um maior número de episódios ocorresse e com maior intensidade.

Dentre as áreas mais afetadas constatou-se que ocorre uma conjugação dos fatores investigados (vulnerabilidade x suscetibilidade) refletindo no histórico de ocorrências em determinados bairros/regiões urbanas. Com isso, as condições "naturais" associadas a uma necessidade de moradia, bem como questões de ordem econômica e social determinam a situação nas áreas de alto/altíssimo risco.

Como perspectivas de trabalhos futuros observa-se a possibilidade de visualizar especificamente as relações dos eventos extremos de precipitação e os modos de variabilidade de larga escala (ENOS, ODP, OAA, Dipolo do Atlântico) e visualizar como esses processos interagem favorecendo ou inibindo a ocorrência de situações sinóticas e os eventos extremos. 


\section{Referências bibliográficas}

AB'SÁBER, A. Os domínios de natureza do Brasil. São Paulo: Ateliê Editorial, 2013.

AB'SÁBER, A. Geomorfologia do sítio urbano de São Paulo. Tese de doutorado (em Geografia), Faculdade de Filosofia, Ciências e Letras, Universidade de São Paulo, 1956.

ABDALLA, G. Juiz de Fora: evolução urbana de uma cidade industrial desde o século XIX. In: Seminário de História da Cidade e do Urbanismo, $6^{\circ}$ ed., 2000. Natal. Anais... p.1-15.

ALBERTONI, F. P. A ação dos sujeitos sociais na urbanização da região de São Pedro em Juiz de Fora-MG. Dissertação de Mestrado (em Serviço Social), Programa de Pós Graduação em Serviço Social, Faculdade de Serviço Social, Universidade Federal de Juiz de Fora, 2014.

ALMEIDA, L. Q. Vulnerabilidades socioambientais de rios urbanos. Tese de Doutorado (em Geografia), Programa de Pós-Graduação em Geografia, Instituto de Geociências e Ciências Exatas, Universidade Estadual Paulista- Campus Rio Claro, 2010.

ALMEIDA, H. A. Climatologia Aplicada à Geografia. Campina Grande: EDUEPB, 2016

ALVAREZ, I. P. A produção e reprodução da cidade como negócio e segregação. In: CARlos, A. F. A.; VOlOCHKO, D.; AlVAREZ, I. P. (Orgs.) A cidade como negócio. São Paulo: Contexto, 2018.

ALVAREZ, O. R.; SINGH, V. P.; MEDINA, J. E.; CAPURATA, R. E. O.; SANTOS, A. C. Observed trends in daily Precipitation extreme indices in Aguascalientes, México.

Meteorological Applications, 2019.

ALVES, R. S. O campo térmico de Alvinópolis-MG em situação sazonal de verão e inverno: uma contribuição aos estudos de clima urbano em cidades de pequeno porte. Dissertação de Mestrado (em Geografia), Programa de Pós-Graduação em Geografia, Universidade Federal de Juiz de Fora, 2019.

ARMOND, N. B. Entre eventos e episódios: As excepcionalidades das chuvas e os alagamentos no espaço urbano do Rio de Janeiro, Dissertação de mestrado (em geografia) Faculdade de ciências e tecnologias, Universidade Estadual Paulista, Presidente Prudente, 2014.

ARMOND, N. B. Dinâmica climática, excepcionalidades e vulnerabilidade: contribuições para uma classificação geográfica do clima do estado do Rio de Janeiro. Tese de Doutorado (em geografia) Faculdade de ciências e tecnologias, Universidade Estadual Paulista, Presidente Prudente, 2018.

ASSIS, D. C. $O$ comporto térmico associado às variáveis de cobertura da terra na região central de Juiz de Fora-MG. Dissertação de mestrado (em Geografia), Programa de PósGraduação em Geografia da Universidade Federal de Juiz de Fora, 2016. 
AUGUSTO FILHO, O. Caracterização geológico-geotécnica voltada à estabilização de encostas: uma proposta metodológica. In: Conferência Brasileira sobre Estabilidade de Encostas, 1, Rio de Janeiro. Anais... Rio de Janeiro: ABMS/ABGE/PUCRJ, 1992, v.2, p.721733.

BARBOSA, Y. A. Pequena Geografia Histórica de Juiz de Fora: O processo urbano do Caminho Novo ao início do século XX. FUNALFA, Curitiba: CRV, 2017.

BARCELOS, S. S. M. A Geografia Urbana na Revista Brasileira de Geografia (19391995). Dissertação de Mestrado (em Geografia), Programa de Pós-Graduação em Geografia, Instituto de Geociências, Universidade Federal do Rio de Janeiro, 2010.

BARRY, R. G.; CHORLEY, R. J. Atmosfera, Tempo e Clima. Porto Alegre: Bookman, 2013

BITAR, O. Y. Cartas de suscetibilidade a movimentos gravitacionais de massa e inundações: nota técnica explicativa. Brasília, DF: CPRM- Serviço Geológico do Brasil, 2014.

BLAIN, G.C. Detecção de tendências monótonas em série mensais de precipitação pluvial do Estado de São Paulo. Bragantia, Campinas, v. 69, n. 4, p1027-1033, 2010.

BORSATO, V. A dinâmica climática do Brasil e massas de ares. Curitiba-PR:CRV, 2016.

BOTELHO, R. G. M. Bacias Hidrográficas Urbanas. In: GUERRA, A. J. T. Geomorfologia Urbana. Rio de Janeiro: Bertrand Brasil, 2011.

CAMPOS, T. L. O. B.; MOTA, M. A. S.; SANTOS, S. R. Q. Eventos extremos de precipitação em Belém-PA: uma revisão de notícias históricas de jornais. Revista Ambiente e Água. V. 10. N. 1. P. 182-194, 2015.

CARLOS A. F. A. Da organização à produção do espaço no movimento do pensamento geográfico. In: A produção do espaço urbano: agentes e processos, escalas e desafios. São Paulo: Contexto; 2011.

CARLOS, A. F. A. A cidade. São Paulo: Contexto, 2013

CARMO, J. G. S. Centralidades no bairro São Pedro em Juiz de Fora (MG): Uma análise a partir das avenidas Presidente Costa e Silva e Senhor dos Passos. Trabalho de Conclusão de Curso (em Geografia), Departamento de Geociências, Instituto de Ciências Humanas, Universidade Federal de Juiz de Fora, 2019.

CASSAB, C.; PINTO, M. B. O lugar dos pobres na cidade de Juiz de Fora: O programa MCMV e os nos padrões de espacialização da pobreza em JF. Revista de Geografia, v. 3, n. $1,2013$.

CASTELLANO, M. S. Inundações em Campinas (SP) entre 1958 e 2007: tendências socioespaciais e as ações do poder público. Dissertação de mestrado (em Geografia), Pós- 
Graduação em Geografia, Instituto de Geociências, Universidade Estadual de Campinas, 2010.

CASTRO, J. M. G. Pluviosidade e movimentos de massa nas encostas de Ouro Preto. Dissertação de Mestrado (em Engenharia Civil), Programa de Pós-Graduação em Engenharia Civil, Departamento de Engenharia Civil, Universidade Federal de Ouro Preto, 2006.

CAVALCANTI, I. F. A. Large scale and synoptic associated with extreme precipitation over South America: a review and case studies for the first decade the $21^{\text {st }}$ century. Atmospheric Research, 118, p. 27-40, 2012.

CAVALCANTI, I.F.A.; FERREIRA, N.J.; DA SILVA, M.G.A.J.; SILVA DIAS, M.A.F. Tempo e Clima no Brasil. São Paulo: Oficina de Textos, 2009.

CERIGATTO, M. P.; CASARIM, H. C. S. As mídias como fonte de informação: aspectos para uma avaliação crítica. Revista Brasileira de Biblioteconomia e Documentação, v. 13, n. especial, p. 155-176, 2017.

CHANDLER, T. J. The Climate of London. Hutchinson of London, 1965.

COLÂNGELO, A. C. Sobre os modelos de magnitude-frequência e de estabilidade de vertentes. Revista do Departamento de Geografia. V. 16, p. 11-23, 2005.

COLLISCHONN, E. Inundações em Venâncio Aires/RS: Interações entre as dinâmicas natural e social na formação de riscos socioambientais urbanos. Tese de Doutorado (em Geografia), Programa de Pós-Graduação em Geografia, Universidade Federal de Santa Catarina-UFSC, Florianópolis, 2009.

CORREA, R. L. O espaço urbano. São Paulo: Ática, 1989.

COSTA, R. M. Ação antropogênica sobre o relevo e sua influência na modelagem de predição de escorregamentos e de risco na bacia hidrográfica do córrego Tapera, Juiz de Fora-MG. Dissertação de Mestrado (em Geografia), Programa de Pós-Graduação em Geografia, Instituto de Ciências Humana, Universidade Federal de Juiz de Fora-UFJF, 2019.

CUNICO, C. Do Risco à Adaptação: A identificação da vulnerabilidade socioambiental de Curitiba - PR, Tese de Doutorado (em Geografia), Programa de Pós-Graduação em Geografia, Setor de Ciências da Terra, Universidade Federal do Paraná, Curitiba, 2013.

CUTTER, S. A ciência da vulnerabilidade: modelos, métodos e indicadores. Revista Crítica de Ciências Sociais, 93, 2011, p. 59-69.

DANTAS, E. W. C.; COSTA, M. C. L.; ZANELLA, M. E. Vulnerabilidade socioambiental e qualidade de vida em Fortaleza. Fortaleza: Imprensa Universitária, 2017.

EDUARDO, C. C. Cartografia geomorfológica comparada: aplicações no município de Juiz de Fora-MG como subsidio ao planejamento. Dissertação de Mestrado (em Geografia), Instituto de Ciências Humanas- ICH, Universidade Federal de Juiz de Fora, Juiz de Fora, 2018. 
ELY, D. F. Eventos climáticos e mídia impressa em Londrina (PR): construindo uma abordagem a partir da análise do discurso. In: Simpósio Brasileiro de Climatologia Geográfica. 2008, Alto Caparaó, anais, p 138- 151.

FERNANDES, N. F.; AMARAL, C. P. Movimentos de massa: uma abordagem geológicogeomorfológica. In: GUERRA, A. J. T.; CUNHA, S. B. (Orgs.) Geomorfologia e Meio Ambiente, $3^{\circ}$ ed. Rio de Janeiro: Bertrand Brasil, 2000.

FERNANDES, N. F.; GUIMARÃES, R. F.; GOMES, R. A. T.; VIEIRA, B. C.; MONTGOMERY, D. R.; GREENBERG, H. Condicionantes geomorfológicos dos deslizamentos de encostas: Avaliação de metodologias e aplicação de modelo de previsão de áreas susceptíveis. Revista Brasileira de Geomorfologia. V. 2, n. 1, p. 51-71, 2001.

FERREIRA, C.C.M. Estudo do comportamento do período chuvoso em Juiz de Fora-MG. Revista Geonorte. UFAM, V.1, N.5, 2012, p. 953-963.

FERREIRA, C. C. M. Modelo para análise das variáveis de cobertura da terra e a identificação de microclimas, em centros urbanos. Revista Brasileira de Climatologia, V.14, p.50-75, 2014.

FERREIRA, P. S.; GOMES, V. P.; GALVÍNCIO, J. D.; SANTOS, A. M.; SOUZA, W. M. Avaliação da tendência espaço-temporal da precipitação pluviométrica em uma região semiárida do estado de Pernambuco. Revista Brasileira de Climatologia. Ano 13, v. 21, p. 113-134, 2017.

FISCH, G. Caracterização climática e balanço hídrico em Taubaté. Revista Biociências, v. 1, n. 1, p.81-90, 1995

FISCH, G. Distribuição da precipitação em Taubaté, Vale do Paraíba (SP). Revista Biociências, v. 5, n. 2, p.7-11, 1999.

FONSECA, L. A, M.; LANI, J. L.; FERNANDES FILHO, E. I.; FERREIRA, W. P. M.; VIANNA, Y. C. G.; MAGALHÃES, B. L. Áreas de risco a deslizamentos de terra em Juiz de Fora, Minas Gerias. Revista de Geografia, v. 7, n. 2, p. 181-193, 2017.

FONTÃO, P. A. B. Variações no ritmo pluvial na região metropolitana de São Paulo: reflexos no armazenamento hídrico e impactos no abastecimento urbano. Tese de Doutorado (em Geografia). Instituto de Geociências e Ciências Exatas, Universidade Estadual Paulista, Rio Claro, 2018.

FUNK, C.; PETERSON, P.; LANDSFELD, M.; PEDREROS, D.; VERDIN, J.;SHUKLA, S; HUSAK, G.; ROWLAND, J.; HARRISON, L.; HOELL, A.;MICHAELSEN, J. The climate hazards infrared precipitation with stations-a new environmental record for monitoring extremes, Scientific data, v. 2, p. 150066, 2015

GALVANI, E. e AZEVEDO, T.R. A Frente Polar Atlântica e as características de tempo associadas: Estudo de caso. Textos do Laboratório de Climatologia e Biogeografia Departamento de Geografia / FFLCH / USP - Série TA - Tex to 018 disponível em: http://www.geografia.fflch.usp.br/inferior/laboratorios/lcb/az/TA018. pdf, 2012. 
GALVANI, E; LUCHIARI, A. Critérios para classificação de anos com regime pluviométrico normal, seco e úmido. In: VI Simpósio Brasileiro de Climatologia Geográfica, Aracajú, 2004, anais ..., p. 20-29.

GAN, M.; RODRIGUES, L. R.; RAO, V. B. Monção na América do Sul. In: CAVALCANTI, I.F.A.; FERREIRA, N.J.; DA SILVA, M.G.A.J.; SILVA DIAS, M.A.F. Tempo e Clima no Brasil. São Paulo: Oficina de Textos, 2009.

GERALDO, W. M. J. Novas dinâmicas socioespaciais na "cidade alta" de Juiz de ForaMG. Trabalho de Conclusão de Curso (em Geografia), Departamento de Geociências, Instituto de Ciências Humanas, Universidade Federal de Juiz de Fora, 2011.

GERALDO, W. M. J. A reestruturação urbana pós-fordista de Juiz de Fora. Dissertação (Mestrado em Geografia), Universidade Federal Fluminense, Instituto de Geociências, Niterói, 271 f, 2014.

GERHEIM, D. K. M. Alagamentos, Enxurradas e Inundações na área urbana de Juiz de Fora: Um olhar sobre as bacias hidrográficas dos córregos São Pedro e Ipiranga. Trabalho de Conclusão de Curso (em Geografia), Departamento de Geociências, Instituto de Ciências Humanas, Universidade Federal de Juiz de Fora, 2016.

GONÇALVES, N. M. S. Impactos pluviais e desorganização do espaço urbano em Salvador-BA. Tese de Doutorado (em Geografia), Curso de Pós-Graduação em Geografia, Departamento de Geografia, Faculdade de Filosofia, Letras e Ciências Humanas, Universidade de São Paulo, 1992.

GONÇALVES, N. M. S. Impactos pluviais e desorganização do espaço urbano em Salvador. In: Monteiro, C. A. F; Mendonça, F. (Orgs) Clima Urbano. São Paulo: Contexto, 2013. p. 69-91. 2.ed., $1^{\circ}$ reimp.

GONÇALVES, L. F. H.; Guerra, A. J. T. Movimentos de massa na cidade de Petrópolis (Rio de Janeiro). In: Guerra, A, J. T.; Cunha, S. B (Orgs.). Impactos ambientais urbanos no Brasil. Rio de Janeiro: Bertrand Brasil, $4^{\circ}$ ed., 2006.

GOUDARD, G. Eventos naturais extremos e riscos hidrometeorológicos híbridos na bacia do Alto Iguaçu. Dissertação de Mestrado (em Geografia), Programa de Pós-Graduação em Geografia, Setor de Ciências da Terra, Universidade Federal do Paraná, 2019.

HAMMER, Ø.; HARPER, D.A.T.; RYAN, P.D. Paleontological Statistics Software Package for Education and Data Analysis. Palaeontologia Electronica 4(1): 9pp 2001.

HINKLE, D. E. Statistics for Social and Behavioral Sciences, Boston: Houghton Mifflin, 2003.

INSTITUTO BRASILEIRO DE GEOGRAFIA E ESTATÍSTICA-IBGE. Censo demográfico de 2010. Disponível em: < https://censo2010.ibge.gov.br/resultados.html >. Acessado em 23/09/2019 
IPCC. Climate Change - The Physical Science Basis. Summary for Policymakers -Technical Summary, Intergovernmental Panel on Climate Change, 2013. 222p. Disponível em: https://archive.ipcc.ch/publications_and_data/publications_and_data_reports.shtmlAcesso em: Fevereiro, 2020.

LANDSBERG, H. E. The Urban Climate. International Geophysics series, 1981.

LAVE, R.; WILSON, M. W.; BARRON, E. S. Intervenção: Geografia Física Crítica. Revista Espaço Aberto. v. 9, n. 1, p. 77-94, 2019.

LESSA, J. Juiz de Fora e seus pioneiros: do caminho novo à proclamação. Juiz de Fora: Universidade Federal de Juiz de Fora, 1985.

LIMA, A. P. Análise dos impactos associados à precipitação na cidade de São Carlos-SP. 177f. Dissertação de Mestrado (em geografia), Programa de Pós-Graduação em Geografia da FCT/Unesp, Universidade Estadual Paulista, Presidente Prudente, 2012.

LIMA, N. R.; PINHEIRO, G. M.; MENDONÇA, F. Clima Urbano no Brasil: análise e contribuição da metodologia de Carlos Augusto de Figueiredo Monteiro. Revista Geonorte. V. 2, n. 5, p. 626-638, 2012.

LOUREIRO, R. S.; SARAIVA, J. M.; SARAIVA, I.; SENNA, R. C.; FREDÓ, A. S. Estudo dos eventos extremos de precipitação ocorridos em 2009 no estado do Pará. Revista Brasileira de Meteorologia, v. 29, n. especial, p. 83-94, 2014.

LUCAS, T. P. B. Chuvas persistentes e ação da Zona de Convergência do Atlântico Sul na região metropolitana de Belo Horizonte. Dissertação de Mestrado (em Geografia), Programa de Pós-Graduação do Departamento de Geografia, Universidade Federal de Minas Gerais, 2007.

LUCENA, A. J. O campo térmico na Zona Oeste do Rio de Janeiro/RJ: uma contribuição ao estudo do clima urbano. 2005. 154f. Dissertação (Mestrado em Geografia). Instituto de Geografia. Universidade do Estado do Rio de Janeiro, 2005;

MACHADO, P. J. O.; RAIMUNDO, C. S.; MARQUES, V. Juiz de Fora e a urbanização do Paraibuna. Revista de Geografia, v. 6, n. 1, p. 23-34, 2016.

MACHADO, P. J. O. Evolução demográfica do município de Juiz de Fora/MG, no período de 1850/1920: População, café e território. In: Gomes, I. A. (Org.). A Geografia na

Contemporaneidade. Ponta Grossa: Atena Editora, 2018.

MARANDOLA JR., E; HOGAN, D. J. O risco em perspectiva: tendências e abordagens. Revista Geosul, v. 19, n. 38, p. 25-58, 2004.

MARENGO, J.A. Mudanças climáticas globais e seus efeitos sobre a biodiversidade: caracterização do clima atual e definição das alterações climáticas para o território brasileiro ao longo do século XXI - Brasília: MMA, 2007. 2a edição. 
MARENGO, J. A.; SCHAEFFER, R.; PINTO, H. S.; ZEE, D. M. W. Mudanças climáticas e eventos extremos no Brasil. Fundo Nacional do Desenvolvimento Social, Rio de Janeiro, 2009.

MARENGO, J. A.; ALVES, L. M.; AMBRIZZI, T.; YOUNG, A.; BARRETO, N. J. C.; RAMOS, A. M. Trends in extreme rainfall and hydrogeometeorological disaster in the Metropolitan Area of São Paulo: a review. Annals of the New York Academy of Sciences. 2020.

MARQUES NETO, R.; SILVA, F. P.; FERNANDES, B. J.; BARRETO, J. C.; EDUARDO, C. C. A espacialidade do relevo em paisagens transformadas e sua representação: mapeamento geomorfológico da bacia do Rio Paraibuna, sudeste de Minas Gerais. Revista Ra'e Ga, v. 42, p. 65-81, 2017.

MENDONÇA, F. O estudo do clima urbano no Brasil: Evolução, tendências e alguns desafios. In: Monteiro, C. A. F; Mendonça, F. (Orgs) Clima Urbano. São Paulo: Contexto, p. 69-91, 2003.

MENDONÇA, F. Geografia e Meio Ambiente. São Paulo: Contexto, 2004a.

MENDONÇA, F. A. S. A.U.- Sistema Socioambiental Urbano: uma abordagem dos problemas socioambientais da cidade. In: Mendonça, F. (Org.). Impactos Socioambientais urbanos. Curitiba: Editora UFPR, 2004b.

MENDONÇA, F.A. Riscos e Vulnerabilidades socioambientais urbanos a contingência climática. Mercator, v 9, n.1, p.153-163, dez/2010.

MENDONÇA, F.; DANNI-OLIVEIRA. Climatologia: noções básicas e climas do Brasil. São Paulo: Oficina dos Textos, 2007.

MENEZES, M. L. P. Juiz de Fora e a moradia popular: o Alto Santo Antônio. Barcelona: Universidad de Barcelona, 2003. Disponível em: $<$ http://www.ub.edu/geocrit/sn/sn146(133).htm>. Acesso em: 01/03/2016.

MENON JÚNIOR, W. Evolução temporal das áreas de risco à ocorrência de escorregamentos na bacia hidrográfica do córrego do Young- Juiz de Fora/MG entre 1968 e 2010. Dissertação de Mestrado (em Geografia), Programa de Pós-Graduação em Geografia, Instituto de Ciências Humanas, Universidade Federal de Juiz de Fora, 2016).

MICHAELIS. Dicionário online Michaelis.2019 Disponível em: < https://michaelis.uol.com.br/>. Acesso em: 25/08/2019.

MINISTÉRIO DAS CIDADES. Mapeamento de risco em encostas e margem de rios. Instituto de Pesquisas Tecnológicas-IPT, 2007.

MIYAZAKI, V. K. Estruturação da cidade e morfologia urbana: um estudo sobre as cidades de porte médio da rede urbana paulista, Tese de Doutorado (em Geografia), Programa de Pós-Graduação em Geografia, Faculdade de Ciências e tecnologia, Universidade Estadual Paulista, 2013. 
MONTEIRO, C. A. F. Análise rítmica em climatologia. São Paulo: USP/ Instituto de Geografia, 1971.

MONTEIRO, C. A. F. Teoria e Clima Urbano. IG06- USP, 1976. (Série Teses e Monografias n. 25).

MONTEIRO, C. A. F. A cidade como processo derivador ambiental e a geração de um clima urbano: Estratégias na Abordagem Geográfica, Revista Geosul, n. 09, p. 75-107, 1991.

MONTEIRO, C. A. F. Clima e excepcionalismo: conjecturas sobre o desempenho da atmosfera como fenômeno geográfico. Florianópolis: Editora da UFSC, 1991.

MONTEIRO, C. A. F. O estudo geográfico do clima. Cadernos Geográficos, Departamento de Geografia, Centro de Filosofia e Ciências Humanas, Universidade Federal de Santa Catarina Florianópolis, 1999.

MONTEIRO, A. As cidades e a precipitação: uma relação demasiado briguenta. Revista Brasileira de Climatologia, v. 5, p. 7-25, 2009.

MONTEIRO, C. A. F. Teoria e Clima Urbano. In: MONTEIRO, C. A. F; MENDONÇA, F. A. (Orgs) Clima Urbano. São Paulo: Contexto, 2013. p. 9-68. 2.ed., $1^{\circ}$ reimp.

MONTEIRO, J. B. Desastres naturais no estado do Ceará: uma análise de episódios pluviométricos extremos. Tese de Doutorado (em Geografia), Programa de Pós-Graduação do Departamento de Geografia. Universidade Federal do Ceará- UFC, 2016.

MONTEIRO, J. B.; ZANELLA, M. E. A metodologia dos máximos de precipitação aplicada ao estudo de eventos extremos diários nos municípios de Crato, Fortaleza e Sobral-CE.

Revista Geotextos, v. 13, n. 2, p. 135-159, 2017.

MUKAKA, M. M. A guide to appropriate use of correlation coefficient in medical research. Malawi Medical Journal, v. 24, n. 3, p. 69-71, 2012.

MURARA, P. G. Adaptação às inundações urbanas em Rio do Sul, Santa Catarina. Tese de Doutorado (em Geografia), Programa de Pós-Graduação, Universidade Federal de Santa Catarina, 2016.

NASCIMENTO JÚNIOR, L. As chuvas no Paraná: variabilidade, teleconexões e impactos dos eventos extremos. Dissertação de Mestrado (em Geografia), Programa de Pós-Graduação em Geografia, Universidade Estadual Paulista- Campus Presidente Prudente, 2013.

NASCIMENTO JÚNIOR. L. Clima urbano, risco climático e vulnerabilidade em cidades costeiras de clima tropical: estudo comparado entre Santos (Brasil), Maputo (Moçambique) e Brisbane (Austrália). Tese de Doutorado (em Geografia), Programa de Pós-Graduação em Geografia, Universidade Estadual Paulista- Campus Presidente Prudente, 2018.

NASCIMENTO JÚNIOR, L. O clima urbano como risco climático. Revista GeoUERJ, n. 34, 2019. 
NERY, J. T.; CARFAN, A. C. Glossário de termos técnicos em Meteorologia e Climatologia. Jundiaí: Paco Editorial, 2013.

NEW, M.; HEWITSON, B.; STEPHENSON, D. B.; TSIGA, A.; KRUGER, A.; MANHIQUE, A.; GOMEZ, B.; COELHO, C. A.S.; MASIKI, N.; KULULANGA, E.; MBAMBALALA, E.; ADESINA, F.; SALEH, H.; KANYANGA, J.; ADOSI, J.; BULANE, L.; FORTUNATA, L.; MDOKA, M. L.; LAJOIE, R. Evidence of trends in daily Climate extremes over Southern and West Africa. Journal of Geophisical research. V. 111, p. 1-11, 2006.

NUNES, L. H. O papel da mídia na difusão da informação climática: o El Niño de 1997-98. Revista Geografia- Rio Claro, v. 32, n. 1, p. 29-50, 2007.

NUNES, L. H. Urbanização e desastres naturais. São Paulo: Oficina dos textos, 2015.

OKE, T. R. Review of urban climatology (1973-1976). Technical note, n. 169, 1979.

OKE, T. R. Boundary Layer Climates, $2^{\circ}$ ed. 1988.

OLIVEIRA, M. R. Juiz de Fora: vivendo a história. Juiz de Fora: EDUFJF, 1994.

OLIVEIRA, E. V. Meteorologia Aplicada. Recife: IFPE, 2014.

OLIVEIRA, D. E. Participação dos sistemas atmosféricos na gênese e ritmos das chuvas na bacia hidrográfica do Rio Preto MG/RJ. Dissertação de mestrado (em geografia), Instituto de Ciências Humanas- ICH, Universidade Federal de Juiz de Fora, Juiz de Fora, 2016.

OLIVEIRA, T. A.; OLIVEIRA, D. E.; FERREIRA, C. C. M. Sistemas atmosféricos atuantes no inverno de Juiz de Fora-MG: estudo de caso para o ano padrão habitual de 2012. In: II Simpósio Mineiro de Geografia: Geografia e Contemporaneidades, Juiz de Fora, anais ..., p. 1405- 1418, 2016.

OLIVEIRA, T. A.; TAVARES, C. M. G. FERREIRA, C. C. M. Tendências das chuvas mensais no município de Juiz de Fora-MG. In: Simpósio Brasileiro de Climatologia Geográfica, 2018, Juiz de Fora, anais, p 1168- 1177.

OLIVEIRA, T. A.; TAVARES, C. M. G.; FERREIRA, C. C. M.; SANCHES, F. Aplicação dos índices de extremos pluviométricos em Juiz de Fora-MG. In: VII Seminário de PósGraduação em Geografia: “A Geografia e os desafios contemporâneos”, Juiz de Fora, anais ..., p. 419- 429, 2019.

OLIVEIRA, T. A.; TAVARES, C. M. G.; SANCHES, F.; FERREIRA, C. C. M. Variabilidade pluviométrica no município de Juiz de Fora no período de 1910-2018: investigação a partir da técnica do Box plot. Revista Brasileira de Climatologia, v. 26, 2020, p. 457-478.

OSCAR JÚNIOR, A. C. S. Extremos atmosféricos e desastres hidrometeorológicos em Duque de Caxias (RJ). Revista Brasileira de Climatologia, Ano 11, v. 17, p. 189-205, 2015. 
PAULA, R. Z. A. E do Caminho Novo das Minas dos Matos Gerais emerge a 'Manchester Mineira' que se transformou num "baú de ossos": História de Juiz de Fora: da vanguarda de Minas Gerais à "industrialização periférica". Tese de Doutorado (em Economia), Instituto de Economia, Universidade Estadual de Campinas, 2006.

PAULA, R. Z. A. Estrutura e dinâmica da indústria de Juiz de Fora no contexto da industrialização brasileira - 1930/1985. Revista de História Econômica \& Economia Regional Aplicada - Vol. 3. No 4, 2008.

PAZ, C. M. V.; SANCHES, F. O.; FERREIRA, R. V. Chuvas em Uberaba: em estudo sobre a ocorrência de eventos extremos. Revista Entre- Lugar, v. 10 , nº 20, 2019.

PECHINCHA, M. G. H. Qualidade ambiental a partir do zoneamento de risco a ocorrência de escorregamentos na bacia do córrego Matirumbide, Juiz de Fora/MG. Dissertação de Mestrado (em Geografia), Programa de Pós-Graduação em Geografia da Universidade Federal de Juiz de Fora, 2014.

PIMENTEL, F. O. Clima Urbano: o uso de modelos geoespaciais na investigação do conforto térmico em Juiz de Fora-MG. Dissertação de mestrado (em Geografia), Programa de Pós-Graduação em Geografia da Universidade Federal de Juiz de Fora, 2017.

PINHEIRO, G. M. Variabilidade têmporo-espacial da pluviosidade na bacia do Alto Iguaçu. Tese de Doutorado (em Geografia), Curso de Pós-Graduação em Geografia, Setor de Ciências da Terra, Universidade Federal do Paraná, 2016.

PIRES, A. J. Capital Agrário, investimentos e crise na cafeicultura de Juiz de Fora1870/1930. Dissertação de Mestrado (em História), Instituto de Ciências Humanas e Filosofia, Universidade Federal Fluminense, 1993.

POPOV, T.; GNJATO, S.; TRBIĆ, G. Analysis of extreme Precipitation over the Peripannonian region of Bosnia Hercegovina. Quarterly Journal of the Hungarian Meteorological Service, v. 122, n. 4., p. 433-452, 2018.

PRISTO, M. V. J.; DERECZYNSKI, C. P.; SOUZA, P. R.; MENEZES, W. F. Climatologia das chuvas extremas no município do Rio de Janeiro. Revista Brasileira de Meteorologia. V. 33. V. 2, p. 615-630, 2018.

PREFEITURA DE JUIZ DE FORA. Juiz de Fora Sempre: Plano Diretor de Desenvolvimento Urbano de Juiz de Fora. Juiz de Fora, MG: FUNALFA Edições, 2004.

REBOITA, M. S.; RODRIGUES, M.; SILVA, L. F.; ALVES, M. A. Aspectos climáticos do estado de Minas Gerais. Revista Brasileira de Climatologia, V. 17, Ano 11, p. 206-226, 2015 .

ROCHA, G. C.; LATUF, M. O.; CARMO, L. F. Z. Mapeamento de riscos ambientais à escorregamentos na área urbana de Juiz de Fora, MG. Revista Geografia, v. 12, n. 1, 2003. 
ROCHA, C. H. B. Inundações na cidade alta e baixo curso do córrego São Pedro, Juiz de Fora (MG). In: VII Seminário de Pós-Graduação em Geografia: “A Geografia e os desafios contemporâneos”, Juiz de Fora, anais ..., p. 440- 450, 2019.

ROCHA, N. A. Observação social sistemática: Estudo de caso em duas regiões urbanas de Juiz de Fora- MG. Dissertação de mestrado (Ambiente Construído), Programa de Pós Graduação em Ambiente Construído, Faculdade de Engenharia, Universidade Federal de Juiz de Fora, 2015.

RODRIGUES, A. S. R. Atuais dinâmicas socioespaciais: a habitação em Juiz de ForaMG. Dissertação de mestrado (em Geografia), Programa de Pós Graduação em Geografia, Instituto de Geociências, Universidade Federal do Rio de Janeiro, 2005.

RODRIGUES, A. S. R. A produção do espaço urbano de Juiz de Fora-MG: Dinâmicas imobiliárias e novas centralidades. Tese de Doutorado (em Geografia), Programa de PósGraduação em Geografia, Universidade Federal de Minas Gerais- UFMG, Belo Horizonte, 2013.

RODRIGUES, A. M. Produção e consumo do e no espaço: Problemática ambiental urbana. Editora Hucitec, 1998.

RODRIGUEZ, J. M. M; SILVA, E. V. Teoria dos Geossistemas- o legado de V. B.

Sochava: Volume 1 Fundamentos teórico-metodológicos. Fortaleza: Edições UFC, 2019.

ROMERO, H.; MENDONÇA, M. Ameaças Naturais e Avaliação Subjetiva na construção da Vulnerabilidade Social diante de Desastres Naturais no Chile e Brasil. Revista Internacioanl Interdisciplinar INTERthesis, Florianópolis, v.9, n.1, p.127-180, 2012.

SALVIANO, M. F.; GROPPO, J. D.; PELLEGRINO, G. Q. Análise de tendências em dados de precipitação e temperatura no Brasil. Revista Brasileira de Meteorologia. V.31, N.31, p. 64-73, 2016.

SAMPAIO, T. V. M. Diretrizes e procedimentos metodológicos para a cartografia de síntese com atributos quantitativos via álgebra de mapas e análise multicritério. Boletim de

Geografia de Maringá, v. 30, n. 1, p. 121-131, 2012.

SANCHES, F. O.; VERDUM, R.; FISCH, G. Estudo de tendência de chuvas de longo prazo. Revista Ambiente e Água, v.8, n.3. p.214-228, $2013 \mathrm{a}$.

SANCHES, F. Os areais do sudoeste do Rio Grande do Sul: estudo sobre as chuvas no século XX e um possível cenário para o século XXI. Tese de Doutorado (em Geografia), Programa de Pós Graduação em Geografia, Universidade Federal do Rio Grande do Sul, $2013 b$.

SANCHES, F. O.; BALEN, D. S.; SILVA, R. V.; ROSA, K. K.; RADÜNZ, A. Chuvas no Rio Grande do Sul: um estudo sobre as precipitações acumuladas intensas no Alto Uruguai Gaúcho. Revista Brasileira de Climatologia, V. 15, Ano 10, p. 143-162, 2014. 
SANT'ANNA NETO, J. L. Por uma geografia do clima: antecedente históricos, paradigmas contemporâneos e uma nova razão para um novo conhecimento. Revista Terra Livre. n. 17, p. 49-62, 2001.

SANT'ANNA NETO, J. L. Decálogo de climatologia do Sudeste Brasileiro. Revista Brasileira de Climatologia, V. 1, N. 1, p. 43- 60, 2005.

SANT'ANNA NETO, J. L. Da Climatologia Geográfica à Geografia do Clima: Gênese, paradigmas e aplicações do clima como fenômeno geográfico. Revista da ANPEGE, V. 4. p. 51-72, 2008.

SANT'ANNA NETO, J. L. O clima urbano como construção social: Da vulnerabilidade polissêmica das cidades enfermas ao sofisma utópico das cidades saudáveis. Revista Brasileira de Climatologia. V. 8. , n. 7, p. 45- 60, 2011

SANTOS, A. R. Enchentes e deslizamentos: causas e soluções. São Paulo: Pini, 2012b.

SANTOS, M. Metamorfoses do espaço habitado: Fundamentos teóricos e metodológicos da geografia. São Paulo: Edusp. 2012 (a). 6 ed. 1 reimp.

SANTOS, M. A urbanização Brasileira. São Paulo: Editora da Universidade de São Paulo, 2018. $5^{\circ}$ ed. $4^{\circ}$ reimp.

SANTOS, V. J.; FIALHO, E. S. Zona de convergência do Atlântico Sul (ZCAS) e impactos pluviais intensos: o caso da cidade de Ubá-MG. Revista Brasileira de Climatologia, V. 19, Ano 12, p. 218-238, 2016.

SANTOS, B. C.; SANCHES, R. G.; SILVA, M. S. D.; KAYANO, T. Y. K.; SOUZA, P. H.; TECH, A. R. B. Análise do efeito orográfico por meio da interpolação dos índices climáticos. Revista de Geografia- PPGEO-UFJF, v. 8, n. 2, p. 114-132, 2018.

SANTOS, D. L.; FRAGOSO JÚNIOR, C. R.; SOUZA, V. C. B. Limiar de precipitação com potencial de gerar deslizamentos nos complexos de risco em uma zona urbana. Revista Rega, v. 16, 2019.

SILVA, R. A. S. Geografia e habitação social: A política habitacional e os expedientes da (re) produção da cidade capitalista em Juiz de Fora- MG. Dissertação de mestrado (em Geografia), Programa de Pós Graduação em Geografia, Instituto de Ciências Humanas, Universidade Federal de Juiz de Fora, 2014.

SILVA, R. F. R. Benfica: subúrbio ferroviário, industrial, militar e operário. Dissertação de mestrado (em Geografia), Programa de Pós Graduação em Geografia, Instituto de Geociências, Universidade Federal Fluminense, 2015.

SILVA, C. B.; SILVA, M. E. S.; AMBRIZZI, T.; TOMMASELLI, J. T. G.; PATUCCI, N. N.; MATAVELI, G. A.V.; LIMA, B. M.; CORREA, W. C. Precipitação na América do Suldados obtidos por dados de estações automáticas e sistemas orbitais. Revista Brasileira de Climatologia. N.15, V. 25, 2019. 
SILVESTRE, M. R. Técnicas estatísticas utilizadas em Climatologia Geográfica: diagnósticos e propostas. Tese de Doutorado (em Geografia) - Programa de Pós-Graduação em Geografia, Universidade Estadual de São Paulo, Presidente Prudente, 2016.

SOUZA, L. B. Chuvas e escorregamentos na região noroeste da área urbana de Juiz de Fora-MG: uma abordagem genética em Climatologia. Dissertação de Mestrado (em Geografia), Programa de Pós-Graduação em Geografia, Universidade Estadual PaulistaUNESP- Campus Rio Claro, Rio Claro, 2003.

SOUZA, L. B. Percepção dos riscos de escorregamentos na Vila Mello Reis, Juiz de Fora (MG): contribuição ao planejamento e à gestão urbanos. Tese de Doutorado (em Geografia), Programa de Pós-Graduação em Geografia, Universidade Estadual Paulista-UNESP- Campus Rio Claro, Rio Claro, 2006.

SOUZA, L. A. A hipérbole mercantil da expansão urbana e suas implicações ambientais. Revista Mercator. V. 14, n. 4, p. 159-180, 2015.

SOUZA, L. A. A produção desigual do espaço urbano de Juiz de Fora: a ocupação vila Barroso. Dissertação de mestrado (em Geografia), Programa de Pós Graduação em Geografia, Instituto de Ciências Humanas, Universidade Federal de Juiz de Fora, 2016.

SOUZA, E. B; AMBRIZZI, T. Precipitação Climatológica Pentadal sobre o Brasil e os mecanismos atmosféricos associados: Resultados Preliminares. In: XII Congresso Brasileiro de Meteorologia, anais, p. 561-572, Foz do Iguaçu, 2002.

SOUZA, P. H.; SANCHES, R. G.; SANTOS, B. C. Índices climáticos e chuvas intensas no município de Alfenas/MG no período de 1984-2016. Revista Brasileira de Climatologia. Ano 14, Edição especial Dossiê Climatologia de Minas Gerais, p. 320-341, 2018.

STABILE, R. A.; COLÂNGELO, A. C. Estudo pluviométrico dos escorregamentos deflagrados no verão de 2009/2010 no Planalto do Paraitinga (SP). In: PEREZ FILHO, A.; AMORIM, R. R. (Orgs.). Os desafios da Geografia Física na fronteira do conhecimento. Campinas: Instituto de Geociências- UNICAMP, 2017.

STEPHENSON, D. B. Definition, diagnosis and origin of extreme weather and climate events. In: DIAZ, H.F e MURNANE, R. J (org.). Climate Extremes and Society, Cambridge University Press, p. 11-23, 2008.

SUERTEGARAY, D. M. A. Geografia e Ambiente: Desafios ou novos olhares. Revista Mato-Grossense de Geografia, v. 17, n. 1, p. 3-14, 2014.

SUN, W; MU, X.; SONG, X.; WU, D.; CHENG, A.; QIU, B. Changes in extremes temperature and precipitation events in the Loess Plateau (China) during 1960-2013 under global warning. Atmospheric Research, 168, p. 33-48, 2016.

TASCA L. As Contradições e Complementaridades nas Leis Urbanas de Juiz de Fora: dos planos aos projetos de intervenções. Tese de Doutorado (em Planejamento urbano e 
regional), Programa de Pós Graduação em Planejamento Urbano e Regional, Universidade Federal do Rio de Janeiro, Rio de Janeiro, 2010.

TAVARES, R. Imbricações entre os ritmos do clima e os ritmos da urbanização na formação de risco e vulnerabilidade socioambientais a deslizamentos de terra na Serra do Mar- Ubatuba/SP. Tese de Doutorado (em Geografia), Programa de Pós-Graduação em Geografia, Universidade Federal do Paraná-UFPR, Curitiba, 2010.

TAVARES, R; MENDONÇA, F. Ritmo climático e ritmo social: pluviosidade e deslizamentos de terra na serra do mar- Ubatuba/SP. In: MENDONÇA, F. (Org.), Riscos climáticos: vulnerabilidades e resiliência associados. Jundiaí: Paco editorial, 2014.

TEOBALDO NETO. A. A geografia do risco e da vulnerabilidade ao calor em espaços urbanos da zona tropical: o caso Cuiabá-MT. Tese de Doutorado (em Geografia), Programa de Pós-Graduação em Geografia, Faculdade de Ciências e Tecnologia, Universidade Estadual Paulista "Júlio de Mesquita Filho"- Campus Presidente Prudente, 2019.

TOMINAGA, L. K. Escorregamentos. In: TOMINAGA, L. K.; SANTORO, J.; AMARAL, R. Desastres Naturais: conhecer para prevenir. $3^{\circ}$ ed., São Paulo: Instituto Geológico, 2015.

TUCCI, C.E.M. Hidrologia: ciência e aplicação. 2.ed.; 2.reimpr. - Porto Alegre: Ed. Universidade/UFRGS: ABRH, 2002.

UGEDA JÚNIOR, J. C. Clima e Planejamento Urbano na cidade de Jales- SP. Tese de Doutorado. Tese de Doutorado (em Geografia), Programa de Pós Graduação em Geografia da Faculdade de Ciência e Tecnologias. Presidente Prudente, 2011.

UGEDA JÚNIOR, J. C.; AMORIM, M. C. C. T. Reflexões Acerca Do Sistema Clima Urbano E Sua Aplicabilidade: Pressupostos Teórico-Metodológicos E Inovações Técnicas. Revista do Departamento de Geografia, volume especial, p. 160-173, 2016.

VALVERDE, M. C.; CARDOSO, A. O.; BRAMBILA, R. O padrão de chuvas na região do ABC Paulista: os extremos e seus impactos. Revista Brasileira de Climatologia, V. 22, Ano 14, p. 165-187, 2018.

VAREJÃO- SILVA, M. A. Climatologia e Meteorologia. Recife: UFPE, 2006.

VEYRET, Y. Os riscos: o homem como agressor e vítima do meio ambiente. $2^{\circ}$ ed., $1^{\circ}$ reimp, São Paulo: Contexto, 2019.

VIANNA, Y. C. G. Modelagem e identificação de ilhas de calor em Ubá. Dissertação de Mestrado (em Geografia), Programa de Pós-Graduação em Geografia da Universidade Federal de Juiz de Fora, 2018.

VICENTE, A. K. Eventos extremos de precipitação na Região Metropolitana de Campinas. Dissertação de Mestrado (em Geografia), Pós- Graduação em Geografia, Universidade Estadual de Campinas, Campinas, 2005. 
VIEIRA, T. C. M. Efeitos dos extremos pluviométricos na cidade de Belo Horizonte no período de 2000 a 2016. Dissertação de Mestrado (em Geografia), Tratamento da Informação Espacial, Pontifícia Universidade Católica de Minas Gerais, 2018.

VOLOCHKO, D. Conflitos socioespaciais, socioambientais e representações: dimensões da análise urbana. In: CARLOS, A. F. A.; SANTOS, C. S.; ALVAREZ, I. P. Geografia urbana crítica: teoria e método. São Paulo: Contexto, 2018.

WANDERLEI, L. S. A.; NOBREGA, R. S.; MOREIRA, A. B.; ANJOS, R. S.; ALMEIDA, C. A. P. As Chuvas na cidade do Recife: uma climatologia dos extremos. Revista Brasileira de Climatologia, V. 22, Ano 14, p. 149-164, 2018.

YNOUE, R. Y.; REBOITA, M. S.; AMBRIZZI, T.; SILVA, G. A. M. Meteorologia: noções básicas. São Paulo: Oficina dos Textos, 2017.

ZAIDAN, R. T.; FERNANDES, N. F. Zoneamento de suscetibilidade a escorregamentos em encostas aplicado à bacia de drenagem urbana do córrego do Independência- Juiz de ForaMG, Revista Brasileira de Geomorfologia, v. 10, n. 2, 2009.

ZANELLA, M. E. Inundações urbanas em Curitiba/PR: Impactos, riscos e vulnerabilidade socioambiental no bairro Cajuru. Tese de Doutorado (em Geografia). Programa de PósGraduação em Meio Ambiente e Desenvolvimento. Universidade Federal do Paraná-UFPR, Curitiba, 2006.

ZANELLA, M. E.; SALES, M. C. L.; ABREU, N. J. A. Análise das precipitações diárias intensas e impactos gerados em Fortaleza, CE. Revista GeoUSP, n. 25, p. 53-68, 2009.

ZHANG, X.; YANG, F. RClimDex (1.0) User Guide. Climate Research Branch, Environment Canada: Downsview, Ontario, Canada, 2004.

\section{Sites:}

- Laboratório de Climatologia e Análise Ambiental- LabCAA-

$<$ http://www.ufjf.br/labcaa/>; Acesso em: 02/05/2019;

- Agência Nacional de Águas- ANA < http://www.snirh.gov.br/hidroweb/apresentacao >; Acesso em: 10/06/2019;

- Empresa Brasileira de Pesquisa Agropecuária- EMBRAPA $<$ https://www.cnpm.embrapa.br/projetos/relevobr/download/>; Acesso em:

27/10/2019;

- Centro Nacional de Monitoramento e Alerta de Desastres Naturais- CEMADEN

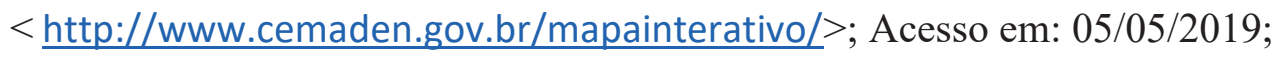

- Climate Hazards Center- UC Santa Bárbara.

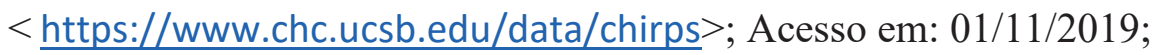

- Prefeitura de Juiz de Fora. < https://www.pjf.mg.gov.br/\#popup21>; Acesso em: 01/08/2019 